\title{
Szabó Tamás
}

Magyar-román államközi viszony és az RMDSZ

kapcsolatrendszere a rendszerváltástól a könnyített honosítási

eljárás bevezetéséig 
Nemzetközi Tanulmányok Intézet

Témavezető:

Dr. Békés Csaba János, egyetemi tanár, DSc 


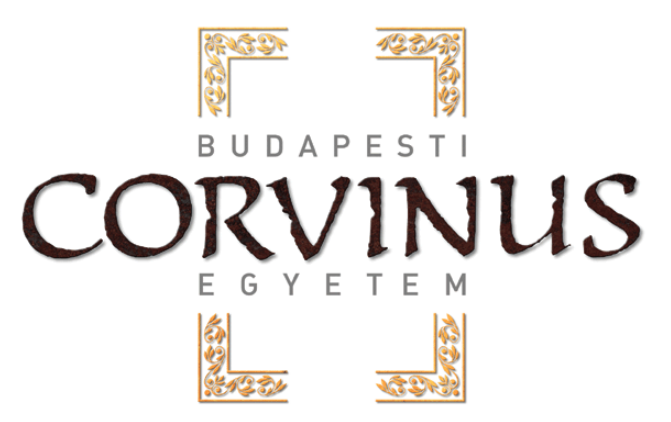

Budapesti Corvinus Egyetem Nemzetközi Kapcsolatok

Multidiszciplináris Doktori Iskola

Nemzetközi és biztonsági

tanulmányok alprogram

Magyar-román államközi viszony és az RMDSZ kapcsolatrendszere a rendszerváltástól a könnyített honosítási eljárás bevezetéséig

PHD ÉRTEKEZÉS

Szabó Tamás

Budapest, 2019 



\section{TARTALOMJEGYZÉK}

TÁBLÁZATOK ÉS ÁBRÁK JEGYZÉKE …...............................................................3

RÖVIDÍTÉSEK JEGYZÉKE ................................................................................... 4

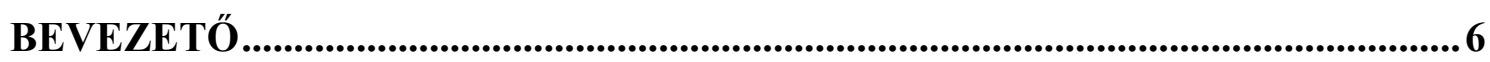

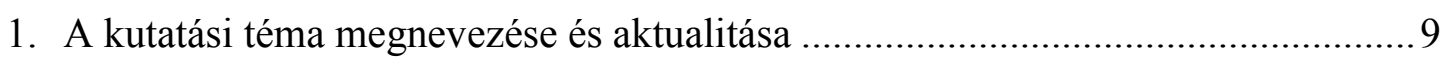

2. A dolgozat fontosabb állításai és kutatási kérdései ........................................... 11

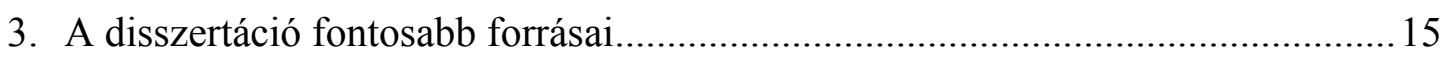

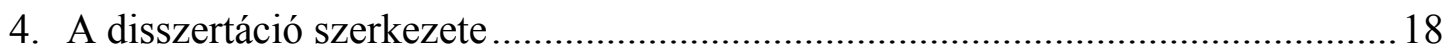

I. ÁLLAMOK ÉS KISEBBSÉGI KÖZÖSSÉGEK. A MAGYAR-ROMÁN ÁLLAMKÖZI VISZONY ÉS AZ ERDÉLYI MAGYARSÁG KAPCSOLATÁT ELEMZÖ IRODALOM ÁTTEKINTÉSE..................................................................20

II. ELMÉLETI KIINDULÓPONTOK ÉS LEHETSÉGES ÉRTELMEZÉSI

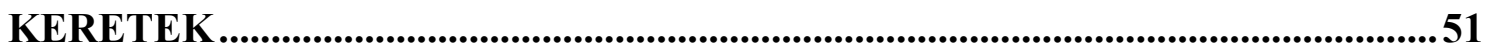

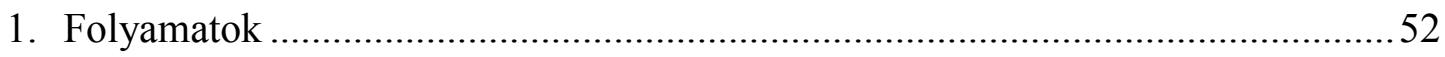

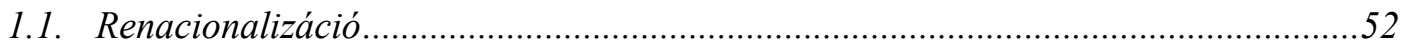

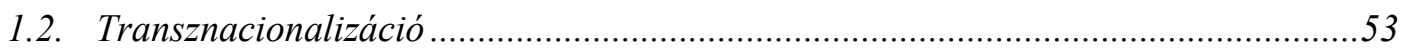

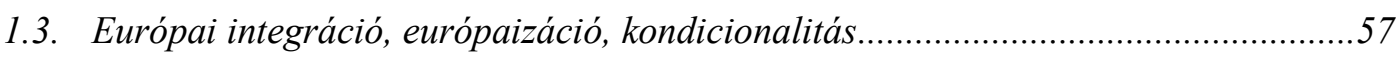

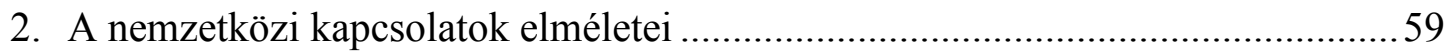

2.1. Az államközi kapcsolatok realista értelmezése ......................................................61

2.2. A liberalizmus és a liberális institucionalizmus...................................................65

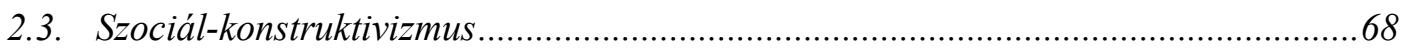

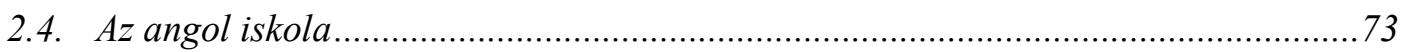

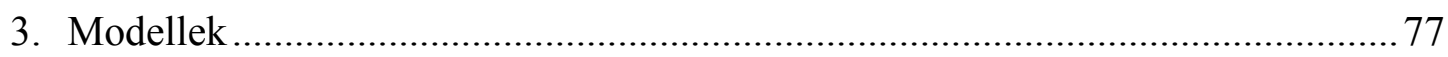

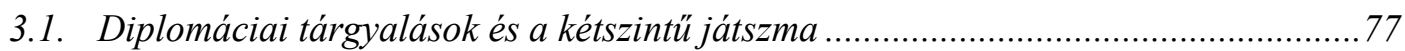

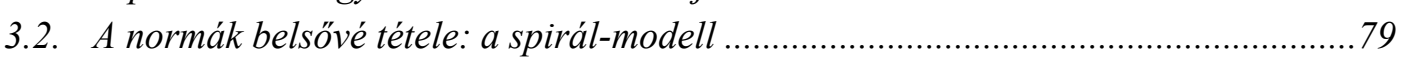

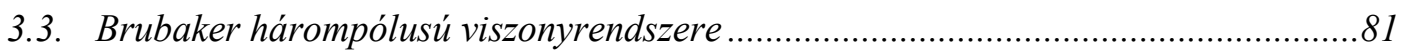

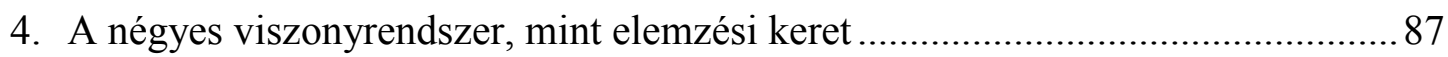

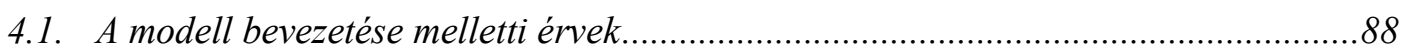

4.2. A négyes viszonyrendszert ért birálatok ...............................................................91

4.3. A dolgozatban alkalmazott négyes viszonyrendszer értelmezése .............................92

III. A KUTATÁS MÓDSZERTANA ...............................................................96

IV. A MAGYAR-ROMÁN ÁLLAMKÖZI VISZONY ÉS AZ ERDÉLYI MAGYARSÁG KAPCSOLATRENDSZERE. TÖRTÉNETI ÁTTEKINTÉS.....102

1. A rendszerváltás előtti időszak: az 1970-es és '80-as évek viszonyai.................. 103

2. A rendszerváltás és az átmenet első évei ........................................................ 112

V. A MAGYAR-ROMÁN ALAPSZERZŐDÉS TÁRGYALÁSAI ......................123

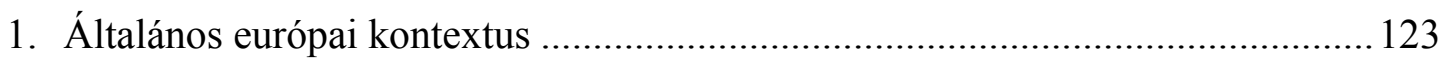

2. A magyar-román alapszerződés tárgyalásának folyamata ................................ 128

2.1. A tárgyalások elökészületei és a javaslatok ismertetése .......................................130

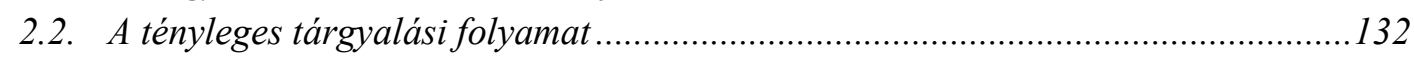

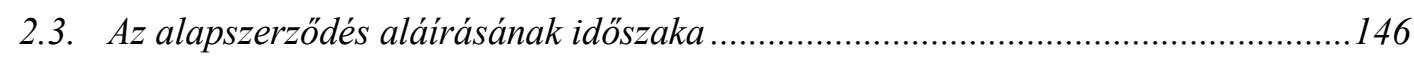

3. A nemzeti parlamentekben lefolytatott viták tanulságai ................................... 152

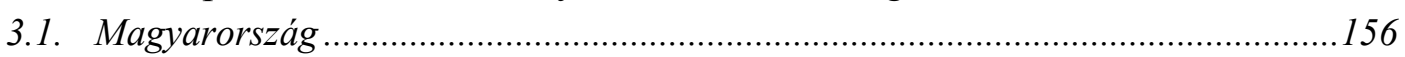

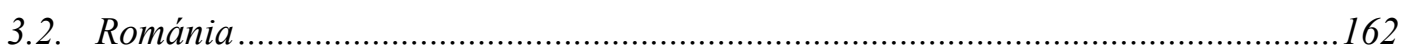


3.3. A pártok közötti megosztottság jellemzői és a pártok pozíciói ................................ 167

3.4. Fö témák, érvrendszerek és stratégiák a vitában.................................................... 169

4. Az alapszerződés hatásvizsgálata .................................................................. 176

\section{A STÁTUSTÖRVÉNY ÉS A MAGYAR-ROMÁN ÁLLAMKÖZI VISZONY} 183

1. A határon túli nemzettársak kedvezményes elbánására vonatkozó alkotmányos rendelkezések és politikák

2. A szomszédos államokban élő magyarokról szóló törvény kidolgozása és elfogadása

2.1. Kormányváltás és a nemzetpolitika felértékelődése .............................................. 188

2.2. A státustörvény megjelenése a politika napirendjén ............................................. 193

2.3. A státustörvény vitája az államközi kapcsolatokban és az európai fórumok elött... 203

3. A nemzeti parlamentekben lefolytatott viták................................................2. 217

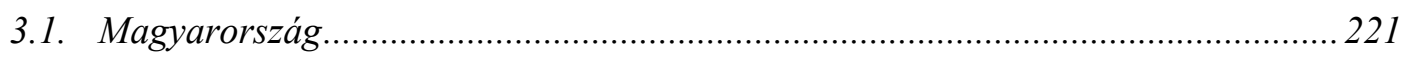

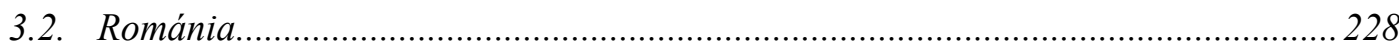

3.3. A pártok közötti megosztottság jellemzői és a pártok pozíciói ................................ 233

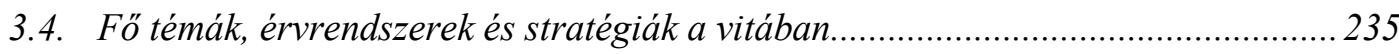

4. A státustörvény módosítása és hatásvizsgálata ..................................................24

\section{A KETTŐS ÁLLAMPOLGÁRSÁG KÉRDÉSE A MAGYAR-ROMÁN}

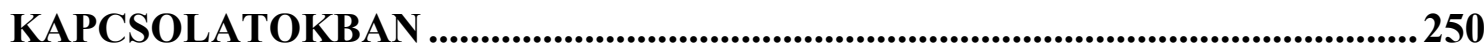

1. Kettős állampolgárság és szavazati jog - európai kitekintés..............................251

2. A magyar és a román állampolgársággal kapcsolatos viták ...............................2262

2.1. A magyar és a román állampolgárság-politika a '90-es években ...........................2262

2.2. A kettös állampolgárságról szóló magyarországi népszavazás.............................206

1.1. A román állampolgársági törvény módositása és a román-moldáv viták ................273

3. A kedvezményes honosítás és az állampolgárság kiterjesztése a parlamenti

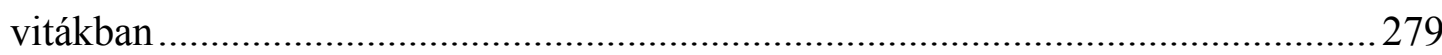

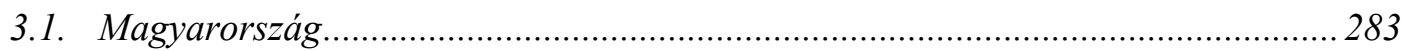

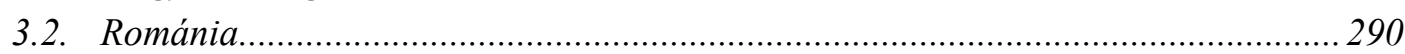

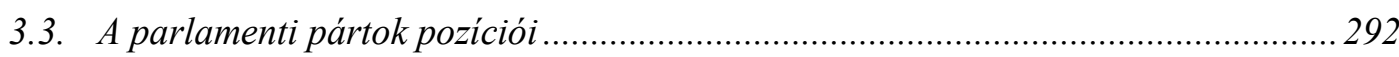

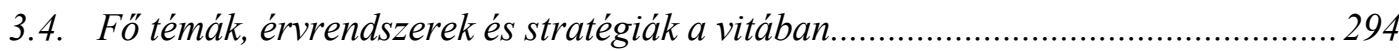

4. Az állampolgársági törvény módosításának következményei és a magyar-magyar kapcsolatok „újraértelmeződése”.

5. A kisebbségben levő közösségek védelmétől az állampolgárok egyéni

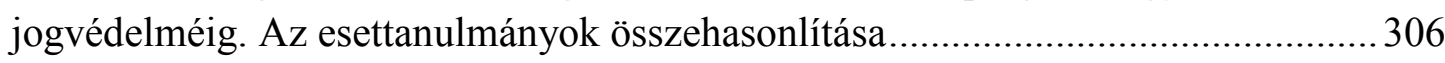

KÖVETKEZTETÉSEK .........................................................................................3 317

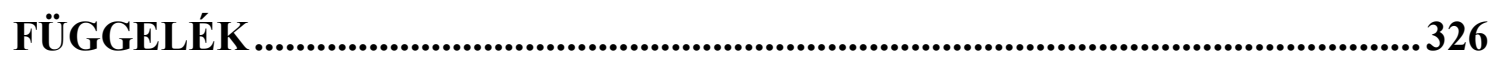

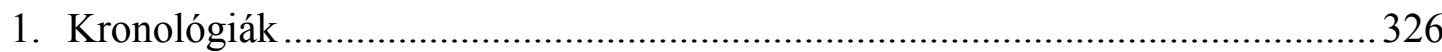

2. Érvényben levő magyar-román államközi megállapodások és nemzetközi

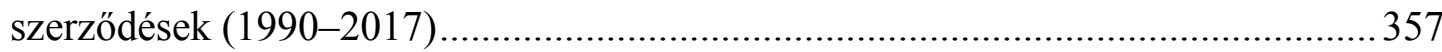

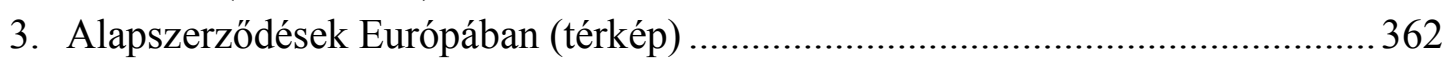

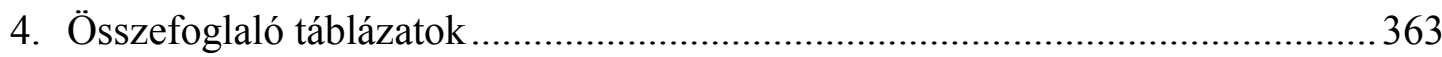

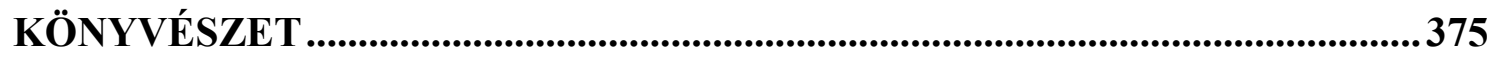

A doktori értekezés témájában született publikációk..............................................406 


\section{TÁBLÁZATOK ÉS ÁBRÁK JEGYZÉKE}

1. sz. ábra: Államközpontú (hagyományos) és transznacionális kapcsolatrendszerek ................54

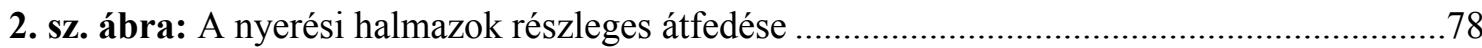

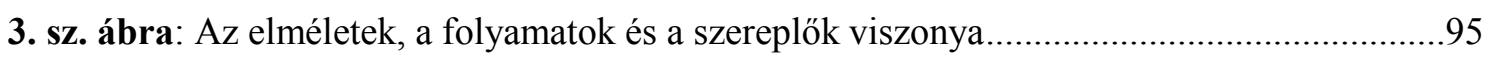

4. sz. ábra: Az európai biztonság és kisebbségvédelem összefüggései: az alapszerződés aláírása

5. sz. ábra: A pártok pozíciói az alapszerződés vitájában. 169

6. sz. ábra: Alapszerződés: szereplők, folyamatok, funkciók .................................................173

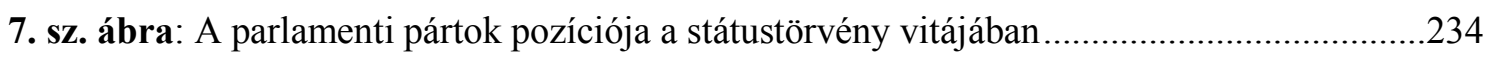

8. sz. ábra: A státustörvény és az egyetértési nyilatkozat: szereplők, folyamatok, funkciók ...238

9. sz. ábra: A magyar-román viszony megítélése 2000-2002 között.......................................247

10. sz. ábra: A parlamenti pártok pozíciói a kettős állampolgárság vitájában..........................293

11. sz. ábra: A nemzetpolitikára fordított források 2009-2017 között (milliárd Ft) .................304

1. sz. táblázat: A transznacionális szervezetek egy lehetséges csoportosítása ...........................56

2. sz. táblázat: A vizsgálat általános kerete, elemzési szintjei és forrásai ................................101

3. sz. táblázat: Érvek és ellenérvek az RMDSZ alapszerződésben való részvételéről...............137

4. sz. táblázat: Románia és Magyarország csatlakozása az európai fórumokhoz.....................139

5. sz. táblázat: Az alapszerződésről szóló viták általános jellemzői........................................153

6. sz. táblázat: Alapszerződés: kategóriák a magyar és román vitában ...................................155

7. sz. táblázat: Az alapszerződés értelmezései, jelentésváltozatai a magyar vitában ................156

8. sz. táblázat: Az alapszerződés értelmezései, jelentésváltozatai a román vitában .................163

9. sz. táblázat: Uralkodó témák és stratégiák az alapszerződés vitájában ..............................172

10. sz. táblázat: A 2001. évi LXII. törvény alapján nyújtott támogatások és kedvezmények ..202

11. sz. táblázat: A státustörvényről szóló viták általános jellemzői ........................................218

12. sz. táblázat: Kategóriák a státustörvény vitájában ........................................................220

13. sz. táblázat: A státustörvény értelmezése és jelentésváltozatai a magyar vitában ...............221

14. sz. táblázat: A státustörvény és a memorandum értelmezése a román vitában...................228

15. sz. táblázat: Uralkodó témák és alkalmazott stratégiák a státustörvény vitájában...............237

16. sz. táblázat: Regisztrált kérelmek száma éves bontásban (2002-2007) .............................246

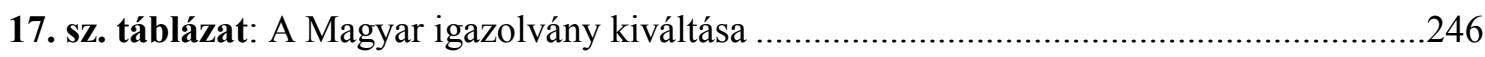

18. sz. táblázat: A magyar állampolgárság odaítélésének feltételei (1993. évi LV. törvény) ..265

19. sz. táblázat: A román állampolgársági törvény fontosabb módosításai..............................274

20. sz. táblázat: A honosítási eljárásró1/ kettős állampolgárságról szóló viták jellemzői.........280

21. sz. táblázat: Kategóriák a kettős állampolgárság vitájában .............................................228

22. sz. táblázat: Uralkodó témák és alkalmazott stratégiák a státustörvény vitájában .............296

23. sz. táblázat: Honosítási kérelmek és az „új magyar állampolgárok” számának alakulása 297 2011-2018 között

24. sz. táblázat: A román közvélemény viszonya a román állampolgársághoz 300 


\section{RÖVIDÍTÉSEK JEGYZÉKE}

CDR Convenția Democratică Română - Román Demokratikus Konvenció

EBESZ Európai Biztonsági és Együttmüködési Szervezet

ENSZ Egyesült Nemzetek Szervezete

ESE Európai Stabilitási Egyezmény

ET Európa Tanács

ET PKGY Európa Tanács Parlamenti Közgyülése

EU Európai Unió

FIDESZ-MPP Fiatal Demokraták Szövetsége - Magyar Polgári Párt

FKgP Független Kisgazda Párt

HHRF Hungarian Human Rights Foundation; Magyar Emberi Jogok Alapítvány

HTMH Határon Túli Magyarok Hivatala

KDNP Kereszténydemokrata Néppárt

KKE Közép-Kelet-Európa

PL '93-PAC Partidul Liberal '93-Partidul Alianței Civice; Liberális Párt '93-Polgári

Szövetség Pártja

MÁÉRT Magyar Állandó Értekezlet

MDF Magyar Demokrata Fórum

MDNP Magyar Demokrata Néppárt

MSZP Magyar Szocialista Párt

MVSZ Magyarok Világszövetsége

NATO Észak-atlanti Szerződés Szervezete

NEIT Nemzeti Egység Ideiglenes Tanácsa

NMF Nemzeti Megmentési Front

PNȚCD-PER Partidul Naţional Țărănesc Creștin Democrat-Partidul Ecologist

Român; Kereszténydemokrata Nemzeti Parasztpárt-Román

Környezetvédő Párt

PD Partidul Democrat; Demokrata Párt

PDSR Partidul Democraţiei Sociale din România; Társadalmi Demokrácia Romániai Pártja

PRM Partidul România Mare; Nagy-Románia Párt

PUNR Partidul Unităţii Națiunii Române; Román Nemzeti Egységpárt

RMDSZ Romániai Magyar Demokrata Szövetség

RMSZ Romániai Magyar Szó

SZDSZ Szabad Demokraták Szövetsége

TÜK iratok A magyar Külügyminisztérium titkos ügykezelésű iratai 


\section{Köszönetnyilvánítás}

Ez a dolgozat többéves kutatómunka után készült el egy szélesebb intézményi együttmüködésnek köszönhetően. A Budapesti Corvinus Egyetem Társadalomtudományi és Nemzetközi Kapcsolatok Kar Nemzetközi Kapcsolatok Multidiszciplináris Doktori Iskola a PhD-képzés intézményes hátterét biztosították, míg oktatói tevékenységet 2011 óta a Babeș-Bolyai Tudományegyetemen müködő Politika-, Közigazgatás- és Kommunikációtudományi Kar Politikatudományi Intézet magyar tagozatán folytattam.

A dolgozat elkészítésében nyújtott segítségért, az építő jellegü javaslatokért köszönettel tartozom témavezetőmnek, Békés Csaba tanár úrnak, aki doktori tanulmányaim alatt figyelemmel kísérte elörehaladásomat és az elkészült fejezetekhez érdemi javaslatokat fogalmazott meg. Hálával tartozom Salat Leventének, akinek meghatározó szerepe van szakmai fejlődésemben. Baráti tanácsai és módszertani megjegyzései rendkívül inspirálónak bizonyultak a disszertációírás során, a dolgozat kéziratához füzött rendkívül alapos kritikai észrevételei pedig nagymértékben javították a dolgozat tartalmi részének hiányosságait. Köszönöm Bárdi Nándornak a segítségét, aki a magyar-román alapszerződés vizsgálatára ösztönzött és több kéziratomat is véleményezte, valamint Kiss J. Lászlónak, Székely István Gergőnek és Toró Tibornak a szakmai tanácsokat, útmutatásokat. Tanulmányaim alatt folyamatosan számíthattam a doktori iskola alprogramjának vezetőjére, dr. Kardosné Kaponyi Erzsébet tanárnő támogatására. Segítségét ez úton is köszönöm! A kutatás során több döntéshozó is segítségemre volt: a velük készült interjúk és személyes beszélgetések sokat segítettek abban, hogy árnyaltabb képet kapjak a korabeli viszonyokról, az egyes döntések hátteréről és a szereplők vélt vagy valós érdekeiről.

Végezetül köszönetemet szeretném kifejezni szüleimnek önzetlen támogatásukért, feleségemnek pedig, hogy végig mellettem állt és türelemmel, megértéssel viselte a disszertációírás minden mozzanatát. 


\section{BEVEZETŐ}

A kommunizmus bukása és a rendszerváltást megteremtő politikai-, gazdasági- és társadalmi átmenet kezdeti időszakában a kelet-közép-európai államok tényleges szuverenitásuk visszaszerzése után a külpolitikai függetlenség, az önálló külpolitika megteremtését is célul tűzték ki (Kiss J. 2004, pp. 45-78), amellyel nyílt vagy burkolt módon az eltérő nemzeti érdekek és nemzetépítési stratégiák is megfogalmazódtak. A gyakran egymással szemben álló nemzeti érdekek és nemzetépítési stratégiáknak volt azonban egy közös pontjuk, amely eltérő formában és súlyponttal, de jelen volt a rendszerváltó elitek programjában: az európai fórumokhoz és a nyugat-európai államokhoz való közeledés, valamint a különböző szintű és szakpolitikákra kiterjedő együttmüködések javítása.

A térség államainak nyugati orientációja a demokratizálódás kezdeti időszakában mind az államközi kapcsolatokban, mind pedig a kisebbség-többség viszonyában jelentős változásokat hozott, amely a jövőre nézve két főbb alternatívát kínált. A fejlemények egyfelől magukban hordozták annak a lehetőségét, hogy a kisebbségekre ne mint valamilyen belpolitikai veszélyforrásra - amolyan ötödik hadosztályra - tekintsenek, hanem államalkotó tényezőre, és az államalkotó többség érdekelt legyen egy olyan kisebbségpolitikai berendezkedés megteremtésében, amely a kisebbségek helyzetének intézmények útján történő rendezését feltételezné. Másfelől viszont a többség és a kisebbség közötti konfliktus eszkalálódásának lehetőségével is számolni lehetett. Figyelembe véve a térség államainak növekvő külpolitikai aktivitását és anyaországként való önmeghatározásukat és fellépésüket, a nacionalizmus erősödését, a kisebbségi közösségek párhuzamos nemzetépítési stratégiáinak megvalósítására tett erőfeszítéseket, továbbá egyéb tényezők egyidejű előfordulását, reális esély mutatkozott az államközi és az államon belüli interetnikus konfliktusok kialakulására is. Nem alaptalanul jutottak tehát a térséggel foglalkozó szakértők és elemzők - tekintettel a felsorolt tényezőkre -, arra a következtetésre, hogy a kommunizmus bukása nem feltétlenül a Fukuyama által megfogalmazott liberális demokráciák elterjedéséhez fog elvezetni (Fukuyama 1989). Minden kétséget kizáróan a balkáni események - jugoszláv tagköztársaságok függetlenségi törekvései - csak erősítették az erre irányuló feltételezéseket. 
A helyzet a magyar-román viszony tekintetében sem volt ígéretesebb, számos külföldi szakértő, köztük a nemzetközi kapcsolatok avatott képviselöi és biztonságpolitikai elemzők a két állam rendszerváltást követő, közvetlen időszakának fejleményeire alapozva a magyar-román konfliktus kiéleződésétől tartottak, míg mások éppen amellett érveltek, hogy az erősödő nyugat-európai integráció megelőzheti a térség államai közötti konfliktus kialakulását. ${ }^{1} \mathrm{Az}$ elörejelzések több helyen, így a magyar-román viszony tekintetében pontatlannak bizonyultak és annak ellenére, hogy 1996 novemberéig a magyar kisebbség képviseletét ellátó szervezet, az RMDSZ a román pártrendszer marginalizált szereplője volt, az államközi kapcsolatok látványos fejlődésnek indultak: a kezdeti védelmi és biztonságpolitikai együttmüködés más szakterületekre - oktatás és kultúra - is kiterjedt, új dimenziókat nyitva a két állam kapcsolatrendszerében. Ennek eredményeként, mára az államközi kapcsolatokat több tucat szerződés, egyezmény és megállapodás szabályozza ${ }^{2}$, és noha nem beszélhetünk történelmi megbékélésröl a két nép között, kormányzati szinten nyoma sincs a kezdeti bizalmatlanságnak. Eltekintve az államközi kapcsolatok szintjén időközönként mindkét részről elhangzó élesebb hangvételü nyilatkozatoktól, megállapítható, hogy a két állam viszonya alapvetően stabilnak mondható, mi több, mind Románia, mind pedig Magyarország stratégiai partnerként tekint egymásra.

Magyarország és Románia viszonyának utóbbi 25 éve azonban nem értelmezhető az európai és nemzetközi politika szintjén bekövetkező változások, így a globalizáció és a regionális együttműködési formák, továbbá a politika transznacionalizációja nélkül. Noha úgy tünt, hogy a rendszerváltás utáni időszak a nemzeti érdek újrafogalmazásával a nemzetállam megerősödését hozta magával, két párhuzamosan zajló folyamat is kikezdte a nemzetállami kereteket, amelynek során a hagyományos értelemben vett területelvüség és területi igazgatás, a szuverenitás, a belügyekbe való beavatkozás és az ezzel összefüggésben álló joghatóság, de a klasszikus értelemben vett állampolgárság fogalma és tartalma is újabb kihívásoknak és változásoknak lett kitéve.

Az alulról jövő változások főként a regionalizmus és a többszintű kormányzás (multi-level governance) fogalmával írhatók körül, melynek következtében az alulról

\footnotetext{
${ }^{1}$ Lásd az erről szóló vitát az International Security 1990/1-3. számaiban, amelyre a későbbiekben bővebben kitérek. A vita részletes, magyar és angol nyelvü ismertetését Salat Levente végezte el (Salat 2009, pp. 347-352), valamint (Salat 2013, pp. 655-690).

${ }^{2}$ Magyarország és Románia között kötött kétoldalú dokumentumokról nehéz teljes képet alkotni. A Magyarország Külügyminisztériumának szerződéstára alapján 51, a román külügy szerződéstárában ennél kevesebb dokumentumot azonosítottam. A Külgazdasági és Külügyminisztériumhoz eljutatott adatigénylésemre egy 50 tételből álló listát kaptam, ebből jelenleg 45 van érvényben. Az érvényben levő államközi szerződésekről lásd a dolgozat 2. számú függelékét.
} 
építkező területi egységek, az önkormányzatok, valamint a régiók a szubszidiaritás és a decentralizáció elve alapján egyre több feladatot és döntési kompetenciát vettek át a központi kormányzattól. Ebben fontos szerepet játszott az az európai szintü elképzelés, amely a régiók Európáját állította a szakmai és politikai viták középpontjába. Az elképzelést nemcsak a regionális kormányzás hatékonyságába vetett hit, hanem a gazdasági fejlődéssel összefüggő tényezők is alátámasztották, amelyben a sajátos gazdasági, kulturális identitással rendelkező, nemzeti és őshonos kisebbségek által lakott régiók érdekei is hangsúlyosabban artikulálódtak (McGarry-Keating 2006).

A másik folyamat az európai fórumok (ET, EU, NATO, EBESZ) tevékenységéhez köthető, akik az átmenet időszakában mindvégig normaalkotó és irányadó szereplőkként léptek fel. Ennek következtében a kelet-közép-európai államok arra irányuló elképzelése, hogy „visszatérjenek Európába” csakis integrációs folyamat révén vált megvalósíthatóvá, a meghatározott feltételek teljesítésével. A legösszetettebb feltételrendszert az Európai Unió állította fel: a tagjelölt államoknak elsőként eleget kellett tenniük a koppenhágai kritériumoknak, másodsorban harmonizálniuk kellett a belső jogrendjüket a közösségi joggal, végül pedig a csatlakozással bizonyos mértékű szuverenitás-átruházásra is sor került, amely nemcsak az egyes szakpolitikákat alakítását, hanem a külpolitikai döntéshozatal bizonyos aspektusait is érintette (Sedelmeier 2005, pp. 401-427). E két irányból - alulról és felülről - érkező hatások állandó kihívások elé állították a hagyományos értelemben konszolidáltnak és stabilnak tekintett nemzetállamokat. Ezzel kapcsolatban Andrew Linklater már a politikai közösségek átalakulásáról beszélt, amelyben a hagyományos értelemben vett területelvűség, a szuverenitás és az állampolgárság intézménye a poszt-vesztfáliai korban fontos változásoknak van kitéve (Linklater 1998).

A nemzetállamok átalakulásának és megerősödésének folyamatát két, a közelmúltban bekövetkezett fejlemény is alakította, egyrészt az európai államokat mélyen érintő 2008-as pénzügyi válság nyomán megjelenő „„öbb Európáról” szóló elképzelések, másrészt pedig a Közel-Kelet irányából, valamint az afrikai országokból áramló menekültek, az úgynevezett migrációs válság. Figyelembe véve e két válságjelenségre adott tagállami válaszokat és az európai szintű szolidaritás hiányát, megállapítható, hogy a korábbiakban idézett, Linklater által felvázolt trendekkel ellentétes folyamatok indultak be. A magyarországi és lengyelországi fejlemények, valamint az Egyesült Királyságban lezajlott népszavazás eredménye arra engednek következtetni, hogy a nemzeti érdek újrafogalmazásának, a nemzetállam megerösödésének vagyunk tanúi, amely a kisebbségi közösségek perspektívájából 
számos problémát felvet. E folyamat következményei - melyet akár „visszarendeződésként” is értelmezhetünk - már rövidtávon érzékelhetőek, elsőként az EU tagállamok viszonyrendszerének szélesebb kontextusában, másrészt pedig az államközi kapcsolatok tekintetében is.

\section{A kutatási téma megnevezése és aktualitása}

Szem előtt tartva a közép-kelet-európai és a tágabb értelemben vett európai államokat ért kihívásokat és az utóbbi negyedszázad globális és regionális szintű változásait, továbbá a nemzetközi kapcsolatok és az etnopolitika iránti érdeklődésemet, a magyar-román államközi viszony és az erdélyi magyarság rendszerváltás utáni kapcsolatrendszerének vizsgálatát választottam doktori értekezésem témájául. Ebben a viszonyrendszerben, melyet az európai fórumok és más nem állami szereplők is befolyásoltak ${ }^{3}$, azoknak a folyamatoknak és döntéseknek szenteltem kiemelt figyelmet, amelyek a nemzetpolitika szempontjából relevanciával bírnak, következményei pedig mind az államközi kapcsolatokban, mind pedig a belpolitikai viták szintjén meghatározóak voltak.

Az utóbbi két és fél évtizedben három olyan fejlemény határozta meg a magyar-román kapcsolatokat, amely relevanciával bírhat kutatásom szempontjából. Elsőként a két állam közötti alapszerződés előkészítő tárgyalásai hozták felszínre azokat az eltérő elképzeléseket, áthidalhatatlan szakadéknak tűnő képzeteket, amely egyrészt a szuverenitás és a területi integritás, másfelől a nemzeti kisebbségek védelmével kapcsolatos eltérő értelmezésekből adódtak. Noha magyar oldalon ebben a vitában is felvetődött a kérdés, hogy kik a magyar nemzet tagjai, ez mégis a státustörvényről szóló vitában csúcsosodott $\mathrm{ki}$, amely a nemzet határainak kulturális értelemben vett kiterjesztéséről szólt. Az ebböl adódó reakciók az államközi kapcsolatokban is komoly vitákat eredményeztek, másfelől hozzájárultak az anyaország (kin-state) szerepének jobb megértéséhez, végső soron pedig előkészítették - az általam is vizsgált harmadik döntés -, a könnyített honosítási eljárás bevezetését. A jogszabály, amely a határon túli magyarság számára is lehetővé tette a magyar állampolgárság megszerzését, jogi viszonyt létesített Magyarország és a külhoni magyarság között. Dolgozatomban e döntések mögött meghúzódó érdekekre, a szereplök érdekérvényesítési lehetőségeire, valamint a következményekre próbálok rávilágítani.

\footnotetext{
3 A Brubaker által bevezetett hármas viszonyrendszer (nemzeti kisebbség, nemzetiesítő állam és anyaország) alapvető kiindulópont kutatásom szempontjából, amelyhez, mint azt a továbbiakban látni fogjuk, az európai fórumok, valamint számos állami és nem állami szereplő is kapcsolódni fog.
} 
A kutatási téma aktualitását az adja, hogy a rendszerváltást követő két és fél évtizedben számos olyan bel- és külpolitikai döntés született Magyarországon, amely közvetve vagy közvetlenül hatott a külhoni magyarságra, azon belül az erdélyi magyarságra. A két állami szereplő és a magyar kisebbségi közösség kapcsolatrendszerét éppen e döntések eredményeként nehéz objektív módon elemezni és értékelni, ugyanis a néha ,jó”, máskor „megromlott” vagy „,feszült” jelzővel illetett kapcsolatoknak nem alakulhatott ki egy mindkét fél által elfogadott, közös értékelési mechanizmusa. Az értékelést tovább bonyolítja az a mód is, ahogyan a két ország egymás kisebbségpolitikai és nemzetpolitikai lépéseit az évek során megítélte, illetve, ahogyan erről kommunikált. Ebben az értelmezési keretben pedig meghatározónak bizonyult az, hogy (1) Románia milyen kisebbségpolitikát folytatott, (2) a budapesti kormányzatok milyen nemzetpolitikai törekvéseket fogalmaztak meg, végül pedig (3) az erdélyi magyarság e két, többnyire ellentétes törekvéshez, hogyan viszonyult, milyen stratégiát követett az évek során?

Az államközi kapcsolatok rendszerváltás utáni időszakáról elmondható, hogy a két állam viszonyában a fent megnevezett nemzetpolitikai fordulatok összetett problémaként jelentkeztek. Az tény, hogy mindkét állam ,érzékeny” kérdésként kezelte a másik állam nemzetpolitikai célkitüzéseit, nemcsak a megoldatlan történelmi sérelmekre, hanem a kulturális, illetve a politikai nemzeteszmén alapuló politikák kizárólagosságára visszavezethetően. Ugyanis, míg belpolitikai összefüggésekben mindkét állam a politikai nemzeteszmén alapuló politikát folytatnak és korlátozzák a kisebbségi jogok bővítésére irányuló törekvéseket, addig kifele a kulturális nemzeteszmén alapuló politikát folytatva etnokulturálisan határozzák meg magukat, és támogatják a külhoni nemzettársakat (Kántor 2014, pp. 9-11; 65-66). Ennek megfelelően, nemzetállami perspektívából szemlélve, a román törekvések is legitimnek tekinthetők: a román alkotmány az államot homogén nemzetállamként határozza meg és de facto az ortodox egyházat teszi meg államegyházzá. Noha biztosított a kisebbségek parlamenti képviselete, az elmúlt negyed évszázadban számtalan politikai vita éppen a kisebbségi jogok bővítése körül alakult ki, ami számos esetben megterhelte a magyar-román államközi viszonyt. ${ }^{4}$

\footnotetext{
${ }^{4}$ Amikor tehát Románia a külhoni románok érdekében lép fel, akkor a kulturális nemzeteszmén alapuló politikát folytat. Ebben a kontextusban értelmezhető Romániának a fellépése Szerbiával szemben, az EUtagjelölti státusának elnyerése előtt (2012), valamint legutóbb az ukrán nyelvtörvény elfogadását követően (2017).
} 


\section{A dolgozat fontosabb állításai és kutatási kérdései}

A dolgozat fó állítása az, hogy a román-magyar viszony normalizálódása és a többség-kisebbség viszonyának intézményes rendeződése nem Románia és Magyarország közötti történelmi megbékélés következménye, hanem Románia nyugati integrációs elköteleződésének és a Romániai Magyar Demokrata Szövetség kormányzati pozícióba való kooptálásának az eredménye. Ennek az állításnak az alátámasztására a román külpolitika európaizálódási folyamatával és a román kormány kisebbségekkel szembeni politikájával kapcsolatos érvek is felhozhatók. Egyrészt a nemzetközi közvéleménnyel Románia sikeresen elfogadtatta - a nyugati integrációs elköteleződést bizonyító lépéseinek köszönhetően - az integrációs szervezetek és a nyugati államok képviselőivel azt, hogy a kisebbségi jogok a legmagasabb európai normák szerint biztosítottak. Románia ez irányú törekvése ebben a tekintetben nem maradt visszhangtalan, ugyanis a nemzetközi szervezetek és a nyugati államok képviselői számos esetben visszaigazolták a román törekvéseket, modell-értékünek nevezve a román kisebbségpolitikát. ${ }^{5}$ Ennek alapján elmondható, hogy a román külpolitika egy jelentős eredménye éppen Románia kisebbségpolitikájának látványos külügyi reprezentációja: mialatt a nyugati partnerekkel és az európai fórumokkal sikerült elfogadtatni azt, hogy az ország milyen példásan biztosítja a kisebbségi jogok érvényesülését, addig a belpolitika szintjén, a kisebbségi jogokat jelentős megkötésekkel ültette gyakorlatba (nyelvi jogok, oktatási és közigazgatási törvény); e jogosítványok többségének legitimitását pedig a többség folyamatosan megkérdőjelezi.

Két és fél évtized távlatából elmondható, hogy a magyar kisebbséget képviselő politikai szervezet, az RMDSZ kormányzati pozícióba való jutása minden kétséget kizáróan pozitív hatást gyakorolt mind az interetnikus, mind az államközi kapcsolatokra. Ettől kezdődően a többség-kisebbség viszonyában beszélhetünk egyfajta közeledésről, az ellenségképek fokozatos lebontásáról, amit az etnikumközi viszonyokról készült felmérések és publikációk is alátámasztanak. ${ }^{6}$ A kormányzati

\footnotetext{
${ }^{5} \mathrm{Az}$ európai fórumok közül elsőként az EBESZ Kisebbségi Főbiztosa (Max van der Stoel) szólt elismerően a román kisebbségpolitikáról, amikor 1993 nyarán - az ET-tagfelvételt megelőzően találkozott a Nemzeti Kisebbségi Tanács tagjaival. A román kisebbségpolitikáról az integráció időszakában az EU és az ET különbözö intézményei is pozitívan vélekedtek. Legutóbb a Velencei Bizottság elnöke, Gianni Buquicchio méltatta a román kisebbségpolitika eredményeit a Keretegyezmény Románia által történő aláírásának húsz éves évfordulója alkalmából szervezett kolozsvári konferencián (Buquicchio 2016, pp. 14-19).

6 Lásd bővebben az Etnikumközi Viszonyok Kutatóközpontjának (CCRIT), az Etnokulturális Kisebbségek Forrásközpontjának (EDRC), valamint a Nemzeti Kisebbségkutató Intézet (ISPMN) kutatásait, kiadványait. Az interetnikus viszonyok helyzetének javulásához hozzájárulhatott Frunda György 1996-os államfőjelölti kampánya, majd az RMDSZ kormányra kerülésével a különböző
} 
részvételnek volt egy további, az RMDSZ szempontjából lényeges következménye, nevezetesen az, hogy a Szövetség fokozatosan felhagyott a kisebbségi sérelmeket a nemzetközi fórumokon megjelenítő, külügyi érdekérvényesítő tevékenységével, és, akarva-akaratlanul, a nyugati közvélemény előtt legitimálta a román kisebbségpolitikai rezsimet.

A dolgozat másik állítása az erdélyi magyarság parlamenti képviseletét ellátó szervezet, az RMDSZ által az államközi kapcsolatok szintjén betöltött szereplehetőségére vonatkozik. A nemzetközi kapcsolatok jelenleg is uralkodó államközpontú felfogása, valamint a nemzetközi jog alapján az RMDSZ, mint etnikai párt, nem értelmezhető tényező, abban az értelemben, hogy jogalanyisággal nem rendelkező szereplő. Ennek alapján arra a következtetésre juthatunk, hogy az RMDSZ nem jöhet szóba mérvadó tényezőként az államközi kapcsolatokban sem. Ha azonban a két állam viszonyának alakulását és az RMDSZ szereplehetőségét helyezzük az elemzés fókuszába, akkor a fenti állítás árnyalásra szorul. Jóllehet a Szövetség tárgyaló félként nem vett részt a magyar-román kapcsolatok alakításában, de konzultatív minőségben számos alkalommal hozzájárult az államközi kapcsolatok alakításához, mi több, kezdeményező és közvetítő szerepet töltött be a napirenden szereplő vitás kérdések megoldásában, és több alkalommal tájékoztatta az európai fórumokat és a nyugateurópai államokat az erdélyi magyarság helyzetéről.

Dolgozatom fó állításaihoz több kutatási kérdést is megfogalmaztam, amelyekre a disszertáció megírása során válaszolok. Elsősorban az érdekelt, hogy (1) mennyire alkalmasak a rendelkezésre álló elméleti keretek a kétoldalú kapcsolatok, ezen belül pedig a magyar-román viszony 1989 utáni alakulásának értelmezésére. Feltételezésem az, hogy sem a nemzetközi kapcsolatok elmélete (itt az egyes iskolák közötti vetélkedésekről beszélhetünk), sem más rokon társadalomtudományok nem dolgoztak ki precíz elméleteket, amelyek kielégítő magyarázattal szolgálnának az államközi kapcsolatokban a hidegháború végét követően bekövetkezett fejlemények vonatkozásában, esetenként pedig előre jeleznék az államközi kapcsolatok alakulását.

Noha az államok viszonyának vizsgálatában a nemzetközi kapcsolatok uralkodó irányzatai (realizmus, liberalizmus, szociál-konstruktivizmus) érvényes megállapításokat tettek, az általam vizsgált jelenség egyik megkerülhetetlen magyarázata abban áll, hogy sem Magyarország, sem pedig Románia nem tekinthető „késznek” abban az értelemben, ahogy a főbb elméleti iskolák az államokra - mint a

végrehajtói szervekben megjelenő magyar miniszterek, államtitkárok és vezető pozíciót betöltő személyek. 
nemzetközi kapcsolatok meghatározó szereplőire - tekintenek. A két állam és a romániai magyar kisebbség viszonyrendszerének megértéséhez - a fentebb említett irányzatokon túlmenően egy újabb irányzat, az angol iskola értelmezését is fontosnak tartottam, mert lényegesen árnyalta a realizmus, a liberalizmus és a szociálkonstruktivizmus által nyújtott értelmezéseket. ${ }^{7}$

A szakirodalomban számos kísérlet ismert, amelyek különböző perspektívából kiindulva - pl. a történelmi örökség, az elitek viselkedése, az átmenet és a demokratizálódás, a nacionalizmuselméletek, az európai fórumok befolyásának értékelése, stb. - vizsgálta a kétoldalú kapcsolatok alakulását, azonban egy összefüggő elméleti keret kidolgozása még vára magára. További problémát jelent, hogy bizonyos, a nemzetközi kapcsolatok szakirodalmában használt fogalmak nem elég precízek és megalapozottak, gondoljunk csak a hatalom és a konfliktus, az együttmüködés vagy a normák fogalmaira.

Másodsorban, elemezve a két állam viszonyának szempontjából releváns döntéseket, választ szeretnék adni a kérdésre, hogy (2) melyek azok a szereplők és intézmények, amelyek az államközi kapcsolatok utóbbi negyedszázadát alakították? Kik és milyen mechanizmusok révén müködtetik az államközi kapcsolatokat? Másként fogalmazva, a „müködtetők világa” érdekelt elsősorban, a döntéshozatalban részt vevő szereplők pozíciói, döntésbefolyásolási képessége. Foglalkoztatott végül a kérdés, hogy mennyiben tárható fel a döntések meghozatalának mechanizmusa: a tárgyalási mandátumok kialakítása, döntés-előkészítés, a döntések meghozatalának részletei. Noha a nemzetközi kapcsolatokban a külpolitikai döntéshozatalra vonatkozó szakirodalom alapján viszonylag elfogadott képünk van azon intézményekről és szereplőkről, melyek a külpolitikai döntéshozatalért felelősek, arra voltam kíváncsi, hogy ezek az intézmények és döntéshozatali módszerek miként érvényesülnek két olyan állam viszonyában, amelyek a nemzetközi kapcsolatok szempontjából nem tekinthetők fontos vagy befolyásos államoknak. A külpolitikai döntéshozatal részleteinek a feltárása főként Románia esetében bizonyult problematikusnak, ugyanis a fél-prezidenciális rendszer egyik következményeként viszonylag nehéz volt a külpolitika vonatkozásában a különböző hatáskörökkel felruházott intézmények, egyrészt az államfö, másrészt a kormányfő és a külügyminiszter közötti, rendszerint konfliktusos viszony alakulásában a döntő mozzanatokat megragadni.

\footnotetext{
${ }^{7}$ Köszönöm Salat Leventének, hogy e lényeges kiegészítésre felhívta a figyelmem.
} 
A kutatás további kérdésfelvetése az, hogy (3) a jelenlegi nemzetközi rend perspektívájából, amelynek kizárólagos szereplői a nemzetállamok, egy kisebbségi közösség és ennek politikai képviselete, esetünkben az RMDSZ milyen szereppel és érdekérvényesítési lehetőségekkel rendelkezik a külpolitika, ezen belül pedig a kétoldalú kapcsolatok szintjén? Az RMDSZ kormányzati teljesítményét és érdekérvényesítő tevékenységét elemző szakértők között konszenzus mutatkozik arra nézve, hogy az RMDSZ külügyi tevékenységének egy jelentős része arra irányult, hogy az államközi kapcsolatok szintjén tárgyaló félként jelenjen meg, a magyar és a román féllel folytatott egyeztetések során pedig napirenden tartsa a magyar kisebbség problémáit. A dolgozatban arra próbálok választ adni, hogy a Szövetség a vizsgált döntések során mennyiben tudta alakítani az államközi kapcsolatokat, illetve milyen stratégiákat követett e célkitűzések megvalósítása érdekében.

Noha a külpolitikai érdekérvényesítés korlátaival az RMDSZ már Románia ETtagfelvételi kérelme során szembesült, azonban csak az alapszerződés tárgyalásai során, a részvételi kérelmét elutasító román válasz követően vált nyilvánvalóvá a szervezet vezetői számára az a tény, hogy a Szövetség jelentős erőfeszítései ellenére sem tud államközi szinten tárgyaló félként megjelenni. Ennek ellenére, a vizsgált időszakban számos további lehetőség adódott arra - akár kormányzati vagy ellenzéki pozícióból -, hogy pozitív irányba mozdítsa elő az államközi kapcsolatok alakulását, befolyásolva ezzel a többség-kisebbség viszonyát.

Végül megfogalmazható az a kérdés, hogy (4) hosszabb távon, milyen keretek között beszélhetünk történelmi megegyezésről, megbékélésről, illetve a két nép közeledéséről, amikor az erdélyi magyarság részvételét, ennek legitim politikai képviseletét nélkülözik a román-magyar viszony rendezésére irányuló folyamatokban, valamint a két állam közötti fontosabb szerződések és dokumentumok kidolgozása során, amelyek közvetve vagy közvetlenül érintik a magyar kisebbséget? Azt gondolom, hogy az államközi kapcsolatokban a kisebbségi közösségek részvétele formálisan azért nem volt biztosított, mert ez ütközött a román fél érdekeivel, a belpolitika szintjén pedig felértékelte volna az RMDSZ pozícióját. Noha mindkét részről adott volt a konzultációs lehetőség, és a Szövetség képviselői számos egyeztetésen részt is vettek - főként az alapszerződést előkészítő tárgyalások időszakában -, egy olyan diplomáciai játéknak lettek résztvevői, amelyet számos bel- és külpolitikai tényező meghatározott, ennek következtében pedig a Szövetség érdekérvényesítései lehetőségei mindvégig korlátozottak maradtak. 
A dolgozat állításait és kutatási kérdéseit szem előtt tartva a következő kutatási célokat fogalmaztam meg munkám során:

$\mathrm{C}_{1}$ : Az államközi kapcsolatok, ezen belül pedig a magyar-román kapcsolatok értelmezésében megjelenő fogalmak tisztázása.

$\mathrm{C}_{2}$ : A nemzetközi kapcsolatok elméletéből kiindulva olyan elméleti keret kidolgozása, amelyben értelmezhetőek a rendszerváltás utáni magyar-román államközi kapcsolatok és az erdélyi magyarság viszonyrendszere.

$\mathrm{C}_{3}$ : $\mathrm{Az}$ államközi kapcsolatok müködtetőinek és folyamatainak elemzése: szereplök, intézmények, döntéshozatali mechanizmusok és stratégiák azonosítása.

$\mathrm{C}_{4}$ : Az államközi kapcsolatok napirendjén szereplő, nemzetpolitikai relevanciával bíró döntések mögötti érdekek feltárása, a szereplök pozícióinak azonosítása, a döntések hatáselemzése.

$\mathrm{C}_{5}$ : Az RMDSZ szerepének értelmezése az államközi kapcsolatokban, a külügyi érdekérvényesítési lehetőségeinek feltárása.

$\mathrm{C}_{6}$ : $\mathrm{Az}$ európai fórumok stratégiáinak azonosítása és a magyar-román viszonyt befolyásoló képességének értékelése.

$\mathrm{C}_{7}$ : A magyar-román államközi kapcsolatok alakulására vonatkozó alternatívák felvázolása, tekintettel az európai folyamatokra és a két állam belpolitikájára.

Dolgozatom, a szó hagyományos értelmében véve nem történeti munka. Noha a két ország viszonyában meghatározó a történelmi örökség, nem történelmi szempontból közelítek a problémához. A történeti és a diplomáciatörténeti perspektíva abban az esetben kerül majd előtérbe, amikor (1) segít megalapozni az államközi viszonyokról felállított értelmezési keretet; (2) a diplomáciatörténet szempontjából is fontos hozadékkal szolgál a kétoldalú kapcsolatokra vonatkozóan; (3) hozzájárul a szakpolitikai folyamatok és döntések, a fennálló összefüggések mélyebb megértéséhez és elemzéséhez. A dolgozat tudományrendszeri szempontból mindenekelőtt a politikatudomány és ezen belül a nemzetköz kapcsolatok meghatározó elméleteinek és módszertanának eszköztárát, illetve eredményeit hasznosítja. A dolgozatra ugyanakkor hangsúlyosan jellemző az interdiszciplinaritás, ugyanis más tudományterületek, így a külpolitikai elemzés és az etnopolitika, továbbá a nemzetközi jog és a diplomáciatörténet nézőpontja és módszertana is lényeges pontokon egészíti ki, illetve árnyalja az elemzést.

\section{A disszertáció fontosabb forrásai}

A kutatás során rendszereztem és feldolgoztam a témához kapcsolódó elsődleges és másodlagos forrásanyagokat. A kutatás egyik legfontosabb újdonsága, hogy korábban feltáratlan levéltári anyagokra, az 1989-1996 közötti időszakra vonatkozó külügyminiszteri iratokra támaszkodik, amit a Magyar Nemzeti Levéltárban folytatott kutatómunkám során tártam fel. A Külügyminisztérium titkos ügykezelésű iratai (TÜK 
iratok, továbbiakban külügyminisztériumi iratok) között az államközi kapcsolatok, valamint a magyar kormány és az RMDSZ kapcsolatainak dokumentumai lelhetők fel: szerződések, nyilatkozatok, külügyminiszteri és miniszteri találkozókról készült beszámolók, emlékeztetők, témavázlatok, interjúk, nagyköveti és konzuli beszámolók, tárgyalásokról készült feljegyzések és jegyzőkönyvek, munkatervek és hivatalos levelek. A dokumentumok rendszerezését és feldolgozását a kutatás következő fázisában végeztem el, amelynek eredményeként több mint ezer, többségében magyar, de jelentős román és angol nyelvű dokumentumot sikerült azonosítanom, aminek alapján - eddigi ismereteinkhez képest - pontosabban meghatározható a felek viszonyrendszere, ugyanakkor a tárgyalási mandátumok ismeretében a külpolitikai döntéshozatal folyamatába is betekintést nyerhetünk.

Magyarország és Románia kapcsolataiban az egyes kormányzati időszakok elemzése, valamint ezek összehasonlítása is hozzájárulhat a felek viszonyainak alaposabb megismeréséhez. Ebben a tekintetben a kormányprogramok, a felsőszintü találkozók és emlékeztetők, valamint a kormányközi vegyesbizottságok kisebbségi szakbizottságainak dokumentumai további adalékokkal szolgálhatnak az államközi kapcsolatok napirendjén megjelenő kisebbségi kérdések elemzésében. E dokumentumok mellett, az egyes döntések meghozatalának elemzésében a parlamenti viták alakulása a belpolitikai erőviszonyok egyik lehetséges indikátorát képezhetik.

A kutatási témámhoz kapcsolódóan számos dokumentumot találtam a kormányzati weboldalakon, a nemzetközi szervezetek és európai fórumok, valamint a nem állami szereplők honlapján. Szintén elsődleges forrásanyagként használtam fel a memoárokat és visszaemlékezéseket, az általam készített félig strukturált interjúkat, nyilatkozatokat, a parlamenti viták és felszólalások anyagait. Dolgozatom megírásában fontos forrásnak bizonyulnak az RMDSZ belső dokumentumai és állásfoglalásai (Közlöny), továbbá belső tájékoztatói (Tájékoztató), végül pedig a Magyar Külügyminisztérium Évkönyve (2012-ig).

A szakirodalom áttekintéséhez és a dolgozat elméleti megalapozásához magyar, angol, román és német nyelvü monográfiákat, szakkönyveket, tanulmányokat és szakcikkeket dolgoztam fel, továbbá nemzetközi és regionális szervezetek jelentéseit. Hasznos forrásnak bizonyultak Kuszálik Péter és Udvardy Frigyes sajtókronológiái, valamint az MTI 1988 utáni hírarchívuma, végül a magyarországi és romániai sajtótermékek. A források következő csoportját azon közvéleménykutatások és felmérések képezik, melyek az interetnikus viszony felmérésére készültek (Etnikumközi Viszonyok Kutatóközpontja - CCRIT, Nemzeti Kisebbségkutató Intézet - ISPMN). Ide 
sorolhatók azok a szakértői és civil kezdeményezések, kutatások és javaslatcsomagok is, melyek a magyar-román viszony rendezésének bizonyos aspektusaival foglalkoztak.

A dolgozat megírásához felhasznált források szerteágazó és egymást számos tekintetben kiegészítő jellege ellenére említést kell tennem egy fontos hiányosságról, amellyel a forrásfeltárás során szembesültem. A kutatás szempontjából egy objektív szemléletmód kialakítása azt feltételezte volna, hogy az államközi viszonyok elemzésénél mindkét fél vonatkozásában hasonló jellegü és fajsúlyú dokumentumokat használjak fel. Ennek az elvárásnak csak részben tudtam megfelelni: míg a magyar levéltárakban a kilencvenes évek második feléig kutathatók a külügyminisztériumi iratok, addig a román levéltárakban a rendszerváltás utáni külügyi iratok nem kutathatók, tudomásom szerint az illetékes szervek 1982-vel bezárólag oldották fel az iratok titkosítását. Ezt a problémát igyekeztem úgy áthidalni, hogy nagyobb figyelmet szenteltem a magyar külügyi iratokban szereplő román feljegyzéseknek, román forrásoknak és dokumentumoknak. Az így nyert képet korabeli sajtóanyagokkal, kormányzati nyilatkozatokkal, visszaemlékezésekkel és a sajtóban megjelent interjúkkal egészítettem ki.

A rendelkezésemre álló források és bő ismeretanyag ellenére a forrásfeltárásból következő hiányosság egy további aspektusáról is említést kell tennem, amely bizonyos tekintetben kisebb aránytalansághoz vezetett az esettanulmányok elkészítésében. Míg az alapszerződésről folytatott tárgyalások diplomáciai dokumentumai rendelkezésemre álltak - ezek döntő többségét budapesti kutatásaim alatt tártam fel -, addig a státustörvény és a könnyített honosítás esetében ilyen jellegü alapokkal nem rendelkeztem. A korabeli sajtóanyagok, nyilatkozatok, szaktanulmányok és egyéb kiadványok alapján azonban követni lehet a státustörvényről és a kettős állampolgárságról folytatott vitákat, valamint a könnyített honosítási eljárás folyamatát is. Ezen kívül nagyszámú szaktanulmány, publikáció és elemzés, a sajtóban megjelent interjúk és nyilatkozatok is a rendelkezésemre álltak, valamint a parlamenti jegyzőkönyvek anyagai, amelyre a kutatásaim során támaszkodhattam.

A disszertációban nem vállalkoztam az RMDSZ szélesebb nemzetközi tevékenységének bemutatására és a szervezeten belül a külpolitikai intézményesülés folyamatára. ${ }^{8}$ Noha a '90-es évek első felében megítélésem szerint a Szövetség jelentős erőforrásokat fektetett az erdélyi magyarság problémáinak európai és nemzetközi szintű megjelenítésére és az erre irányuló tevékenységét az utóbbi években újra aktivizálta, a

\footnotetext{
${ }^{8}$ Ezekkel a kérdéssel részletesen foglalkoztam: (Szabó 2015b).
} 
dolgozatban a külügyi érdekérvényesítés kérdéseivel és az RMDSZ pozíciójával csak annyiban foglalkozom, amennyiben az szervesen kapcsolódik az alapszerződés, a státustörvény, illetve a könnyített honosítási eljárás bevezetéséhez.

\section{A disszertáció szerkezete}

A disszertáció első részében a kutatási témához kapcsolódó szakirodalom áttekintésére teszek kísérletet, elsőként a magyar-román államközi viszony perspektívájából majd pedig a többség-kisebbség és a magyar-magyar kapcsolatok szempontjából. Az fejezet végén a szakirodalom tükrében az európai fórumok befolyását, az államközi kapcsolatok alakulására gyakorolt szerepét értékelem.

Az elméleti keret megalkotása képezi dolgozatom következő fejezetét, amely három komponensböl áll. Elsőként a KKE-i államok rendszerváltását meghatározó folyamatokat vázolom fel, majd a nemzetközi kapcsolatok uralkodó elméletének perspektívájából értelmezem az államközi kapcsolatokat, végül pedig azon modellek kritikai értékelésére teszek kísérletet, amelyek hozzásegítenek a felek közötti viszonyok értelmezéséhez.

A harmadik fejezetben a kutatás módszertanát foglaltam össze. Itt részleteztem egyrészt a dokumentumok és sajtóanyagok, másrészt a tárgyalási kronológiák szerepét, végül pedig a parlamenti viták feldolgozásának módszerét. Szintén ebben a fejezetben vázoltam fel a három nemzetpolitikai relevanciával bíró döntés szerkezetét és az elemzési szintek szerepét a dolgozatomban.

A módszertani részt követő három esettanulmány képezi a dolgozat empirikus részét, amelyben a magyar-román alapszerződés aláírásának körülményeit, a státustörvényről kialakult államközi vitát, valamint a kettős állampolgárság és a könnyített honosítási eljárás bevezetését vizsgálom. Az esettanulmányokban a kialakult probléma európai kontextusának ismertetését követően a viták folyamatát, valamint a felek pozícióját, érvrendszerét és érdekérvényesítési lehetőségét tekintem át. Az egyes fejezetek végén az illető döntés hatásvizsgálatát végzem el, és arra próbálok válaszolni, hogy a vita miként befolyásolta a felek viszonyrendszerét. A jórészt hasonló szerkezetü esettanulmányok módszertanilag lehetővé tették az összehasonlítást, amely során a döntések közötti föbb hasonlóságokat, különbségeket és a fontosabbnak vélt változásokat mutattam be.

A disszertáció tartalmi részének záró fejezetében megválaszolom a kutatási kérdéseket, összegezve a dolgozat legfontosabb következtetéseit és tanulságait, végül 
pedig néhány lehetségesnek vélt alternatívát vázolok fel az államközi kapcsolatok alakulására vonatkozóan.

A disszertáció utolsó részében helyeztem el a függeléket és az irodalomjegyzéket. Míg a függelék a dolgozat fontosabb tartozékait tartalmazza: nagyobb terjedelmü táblázatok, tárgyalási kronológiák, valamint az érvényben levő államközi szerződések és megállapodások, addig a bibliográfiai jegyzékbe a hivatkozott dokumentumok és jogszabályok, valamint a szakirodalmi tételek kerültek. 


\section{I. ÁLLAMOK ÉS KISEBBSÉGI KÖZÖSSÉGEK. A MAGYAR-ROMÁN ÁLLAMKÖZI VISZONY ÉS AZ ERDÉLYI MAGYARSÁG KAPCSOLATÁT ELEMZŐ IRODALOM ÁTTEKINTÉSE}

A magyar-román viszony és az erdélyi magyarság kapcsolatának kutatása nem képezi sem a hazai, sem a magyarországi vizsgálatok mainstream irányzatát, azonban a jelentősebb eseményekre és folyamatokra, a vázolt viszonyrendszerre vonatkozó szakértői reflexiók és elemzések nemcsak tanulmánykötetekben, hanem szakfolyóiratokban is megjelentek. Ez az állítás nemzetközi szakirodalomban fellelhető forrásokra vonatkozóan is érvényes, ugyanis a szakértők figyelme azokban az években irányult a KKE-i államok viszonyára, amikor geopolitikai szempontból lényeges változások következtek be a térségben. Figyelembe véve a térségben bekövetkező változásokat három időszak különíthető el: (1) a rendszerváltás és az átmenet kezdeti évei; (2) az integrációs előkészületek és a befogadó államközi szervezetek által támasztott feltételek teljesítése (ET, NATO, EU); (3) az integráció utáni időszak kihívásai. Az államközi kapcsolatok és az erdélyi magyarság viszonyrendszerének szintjén, noha irányadó lehet ez a hármas periodizáció, a kormányzati szintü, nemzetpolitikai relevanciával bíró döntések eredményeként sokkal árnyaltabb kép tárul elénk.

Noha már a bevezető részben említést tettem arról, hogy az elemzés nem függetleníthető az európai kontextustól, szükségesnek tartottam újra kiemelni, hogy a dolgozat kilép a Brubaker által felvázolt, referenciának tekinthető triadikus viszonyként meghatározott elemzési keretből (Brubaker 2006b), melynek nyomán a nemzetiesítő állam, az anyaország, valamint a kisebbségi közösség további kapcsolati szintekkel egészült ki. Ennek alapján a „hármas viszonyrendszer” az európai fórumokkal euroatlanti dimenziót kap, amelyben megjelenik az ET, a NATO, az EBESZ Kisebbségi Főbiztosa, az EU, valamint néhány nyugati állam és nemzetközi nem-kormányzati szervezet is. ${ }^{9}$ A „,kibővített” négyes viszonyrendszer, mint elemzési keret, némileg a szakirodalmi áttekintésben is tükröződik, azonban nem törekszem az aktorközpontú áttekintésre. A továbbiakban a magyar-román államközi viszony és az erdélyi magyarságra vonatkozó szakirodalom azon részeinek bemutatására teszek kísérletet, amelyek kapcsolódnak a kutatás célkitüzéseihez. Struktúráját tekintve, a fejezet a

\footnotetext{
${ }^{9}$ David J. Smith tanulmányában számos ponton vitatja Brubaker megállapítását: noha elfogadja a hármas viszonyrendszert, mint értelemzési keretet, szerinte az euro-atlanti dimenzió nélkül (négyes viszonyrendszer) nem értelmezhető a kelet-közép-európai és balti államok, valamint az itt élő nemzeti kisebbségek viszonyrendszere (Smith 2002, pp. 3-16).
} 
szakirodalomban megjelenő problémák és kérdésfelvetések összesítő elemzésére, a különböző vizsgálatok módszertanára, és fogalmi eszköztárára, valamint az ezekből levont következtetések összegzésére és ütköztetésére vállalkozik.

Már a kutatás első fázisában nyilvánvalóvá vált számomra, hogy a két állam kapcsolatrendszerében - amint azt számos társadalomkutató hangsúlyozza -, meghatározó a kölcsönös sérelmekkel telített múlt, a rendszerváltás előtti évek időszaka $^{10}$, valamint a kommunizmus történelmi öröksége is. ${ }^{11}$ Ebből a feltételezésből kiindulva a történelmi örökség, mint változó az államközi kapcsolatok megértését is elösegítheti. Erre tesz kísérletet Ruxandra Ivan, aki a két állam rendszerváltás utáni másfél évtizedének fejleményeit a külpolitika-elemzés perspektívájából vizsgálta, nagy hangsúlyt fektetve a történelmi örökség kérdésére, mint a két állam viszonyát meghatározó magyarázó változóra. Áttekintve Magyarország és Románia közelmúltig terjedő történelmét - hangsúlyosan kitérve a Trianon előtti nemzetiségi kérdésre, a kommunizmus éveire, majd a rendszerváltást követő időszakra - Ruxandra Ivan arra a következtetésre jut, hogy a történelmi örökség nagy fontossággal bírt a két állam viszonyának 1990-1994 közötti időszakában (Ivan 2010, pp. 394-417).

Állítását a szerző azzal támasztja alá, hogy a rendszerváltás első éveiben az alakuló nemzetközi rend paraméterei még nem voltak tisztázottak, sem a NATO, sem az EU nem hozott döntést a bővítésről és a román külügyi doktrína sem kristályosodott ki teljességgel (ibid, p. 415). Mivel a külügyi apparátus felkészültsége nem volt megfelelö, a „kölcsönös tudatlanság” arra ösztönözte a diplomatákat, hogy a történelemkönyvekböl szerzett ismeretekre hagyatkozzanak, így pedig az államközi kapcsolatok múltjáról alkotott percepciók fontos szerepet játszottak a döntéshozók opcióinak meghatározásában, (ibid. p. 395; 415).

A kommunizmus öröksége, mint magyarázó változó, a többség-kisebbség viszonyát is meghatározta. Salat Levente és Novák Csaba Zoltán, a román kisebbségpolitikai rezsimről szóló tanulmányukban - hivatkozva Karl Cordell, Timofey Agarin, and Alexander Osipov által szerkesztett tanulmánykötetre - a nemzetépítés sajátos párhuzamára hívták fel a figyelmet. Míg a kommunizmus időszakában a tituláris nemzet jogai elsőbbséget élveztek a nemzeti kisebbségek jogaival szemben, addig

\footnotetext{
${ }^{10}$ Földes György, aki a két állam kapcsolatrendszerét a nemzetiségi kérdés perspektívájából vizsgálta, többször utalt az államközi kapcsolatok rendszerváltás előtti konfliktusos, feszült viszonyára. Ennek legfontosabb következményei között megemlíthető a két állam viszonyának elhidegülése és a diplomáciai kapcsolatok mélypontra zuhanása (Földes 2007).

${ }^{11}$ A kommunizmus történelmi örökségéröl több átfogó munka jelent meg, melyek esettanulmány formájában a fogalom minél precízebb konceptualizálására törekedtek (Beissinger-Kotkin 2014; Wittenberg 2015).
} 
poszt-kommunista időszakban a nemzet és az állam egybeesése, valamint a tituláris nemzet (esetünkben a románok) szerepének a hangsúlyozása a nemzetépítés fô tézisei maradtak (Salat-Novák 2015, p. 65). Ennek következtében - mondják a szerzők -, azok a törekvések, melyek újabb kisebbségvédelmi mechanizmusok elfogadását kezdeményezték, a domináns csoport szempontjából nem képezhette a tárgyalások alapját, mint például a fennálló berendezkedés kérdése; mi több azok, akik megkérdőjelezték az állam meghatározását, vagy a „tituláris” nemzeti státus konzekvenciáit, informálisan vagy akár törvényes eszközökkel is büntethetőkké váltak (ibid).

A kommunizmus öröksége azonban, mint magyarázó változó, számos kérdésre nem tudott magyarázattal szolgálni, nevezetesen azokra a rendszerszintű fejleményekre, melyek a Szovjetunió felbomlása után következtek be. A lehetséges jövőképeket illetően a szakirodalomban két uralkodó szemlélet alakult ki: a pesszimisták vagy realisták képviselői a nacionalizmus és az etnikai törésvonalakból eredő helyi és államközi konfliktusok kialakulását vetítették előre, míg az optimisták vagy utópisták elhatárolódtak az „apokaliptikus előrejelzésektől” és a biztonsági garanciák vállalásában, valamint az együttműködés különböző módozataira alapozva képzelték el a hidegháború utáni időszakot. ${ }^{12}$ A konfliktusnak, illetve az együttmüködésnek a perspektívája a magyar-román államközi viszony irodalmában is tükröződik: ezzel kapcsolatban elsőként az államközi és interetnikus konfliktus lehetősége melletti érveket mutatom be, majd azokat a tényezőket, amelyek megakadályozták a konfliktus kialakulását. Az áttekintés második részében a szakirodalom azon részeit emelem ki, melyek együttműködés különböző módozataira, valamint a felmerülő vitákra vonatkoznak: elöbb államközi szinten, majd pedig a többség-kisebbség viszonyában.

Annak ellenére, hogy a nemzetközi kapcsolatok szempontjából a térség országai nem tekinthetők meghatározó szereplőknek, a rendszerváltás időszakában élénk figyelem irányult a volt szovjet tagköztársaságok és a KKE-i államok viszonyára, így a magyar-román viszonyra is. Elsőként Zbigniew Brzezinski, a nacionalizmus feléledéséről szóló elemzésében beszél a két állam viszonyáról. Véleménye szerint „súlyos és potenciálisan robbanékony a nyíltan ellenséges” magyar-román viszony, Erdély vitatott státusa, valamint a domináns románok által elnyomott magyarok miatt (Brzezinski 1989, pp. 4-5). A szerző a szerb-albán konfliktus mellett a magyar-román szembenállást emelte ki, mint biztonságpolitikai veszélyforrást. Brzezinski mellett

\footnotetext{
${ }^{12}$ Lásd bővebben (Griffiths 1993, pp. 1-3; Snyder 1990, p. 5; Baylis 1998, pp. 14-27).
} 
számos neves kutatót foglalkoztatta a térségben bekövetkezett fejlemények: az ebből kialakuló vitákat Salat Levente két - egy magyar és egy angol nyelvü - publikációban foglalta össze, a nemzetközi kapcsolatok elméletének (NKE) perspektívájából vizsgálva a kérdést (Salat 2009; 2013, pp. 655-690). A Salat által idézett John Mearsheimer - akit a neorealizmus egyik legfontosabb képviselőjeként tartanak számon -, arra hívta fel a figyelmet 1990 első hónapjaiban, hogy Magyarország és Románia között elkerülhetetlennek látszik a konfliktus (Salat 2009, p. 347). Magyarázatként a szerző a Mearsheimer által felhozott érveket ismerteti: (1) a Szovjetunió felbomlásával eltűnt a regionális stabilitást szavatoló hegemón; (2) államközi szinten arra hivatkozik, hogy a magyar állam képviselői „európai megoldást” szorgalmaznak az erdélyi magyarság helyzetének rendezésében, (3) a többség-kisebbség viszonyában a marosvásárhelyi eseményeket emeli ki, mint egy lehetséges konfliktus kirobbanásához vezető okot (Mearsheimer 1990, pp. 33-34, idézi Salat 2013, pp. 656-657).

Mearsheimer tanulmánya jelentős vitát generált, amelyre a nemzetközi kapcsolatok neoliberális és liberális institucionalista iskoláinak képviselői is reagáltak, elvetvén a konfliktus kialakulásának lehetőségét, valamint olyan tényezők figyelembe vételét javasolták többek között, mint a belpolitikai változások, döntéshozók szerepe, valamint a nemzetközi szervezetek és európai fórumok befolyása (ibid. pp. 657-659). A rendszerváltást követő években - ahogyan Salat is megjegyzi - Mearsheimer konfliktusra vonatkozó elképzeléseit több szerző is osztotta, ami alapján elmondható, hogy az értelmezésekben meghatározó volt a konfliktus-diskurzus, amiről neves intézeti kiadványok és a különféle szaklapokban megjelenő elemzések sokasága tanúskodik.

Számos szerző - mint az előbb idézett Brzezinski -, a két állam viszonyában fennálló magas konfliktuspotenciált a rendszerváltást követő (etno)nacionalizmus térnyerésének tulajdonította (Nelson 1991, p. 137), a közel kétmilliós magyarság pedig jelentős államközi konfliktus potenciális forrásaként jelent meg, melyet olyan magyarellenes szervezetek, mint a Vatra Româneasca is igyekeztek kiaknázni (Nelson 1992). A magyar kisebbséggel szembeni bánásmód további szerzőknél is egy lehetséges konfliktus kiindulópontjaként jelenik meg. Az European Security hasábjain C. J. Dick, J. F. Dunn, és J. B. K. Lough (1993) kiemelte, hogy a román többség és a magyar kisebbség közötti viszony annak következtében feszült, hogy a magyarok alulreprezentáltak a különböző intézményekben, és zaklatásnak, illetve megfélemlítésnek vannak kitéve. A szerzőhármas szerint Bukarest ellenségesen viszonyul a kulturális autonómiára vonatkozó magyar követelésekhez, mi több, tagadja a kisebbségi kérdés létét is, ennek alapján, vélik a szerzők, a kétoldalú kapcsolatokban 
feléledő konfliktusról (quickening conflict) lehet beszélni (ibid. p. 394). Tekintettel a magyar kisebbség helyzetére, több szerző Magyarország, mint anyaország szerepének aktivizálódását emelte ki (Van Oudenaren 1998, pp. 239-256). A két állam közötti konfliktus kialakulása annak betudhatóan is valószínűnek látszott, ahogyan a Nemzeti Megmentési Front által alakított kormány a kisebbségi kérdéshez viszonyult: az anyanyelvü oktatás kiszélesítésének az akadályoztatása a többség-kisebbség közötti törésvonalak mélyülését eredményezte, ami Marosvásárhelyen 1990 márciusában nyílt konfliktusba torkollt (Kostecki 2002, pp. 16-18).

Az a mód, ahogyan a magyar kormány a határon túli magyar közösségek jogait az EBEÉ találkozókon megjelenítette, arra késztette a szomszédos államokat, jegyzi meg a Stockholmi Békekutató Intézet keretében készült tanulmány, hogy legyenek „éberek” (Griffiths 1993, p. 22). Magyarország fokozottabb szerepvállalásaként értelmezhetők a kormányzati nyilatkozatok, amelyek olykor félreértésre adhattak okot. Erre példa Antall József miniszterelnökké való megválasztása utáni nyilatkozata, miszerint „lélekben, érzésben tizenötmillió magyar miniszterelnöke kívánok lenni”. ${ }^{13} \mathrm{~A}$ magas szintű nyilatkozatok és a magyar kormánynak a határon túli magyarok iránti felelősségvállalásra vonatkozó kijelentések a magyar revizionizmus vádjának a megfogalmazódását vonták maguk után, főként a szomszéd országok hatóságainak a részéről. Thomas Abrosio elemzésében - Magyarország történelmi magatartására utalva - arra a megállapításra jut, hogy az anyaországnak a határon túli magyarok sorsa iránti aggodalmát a szomszédos államok „kibontakozó irredentizmusként értékelték” (Griffiths 1993, p. 22).

A két állam viszonyának kérdése Jack Snydernél is megjelent, aki az International Security folyóiratban az államközi kapcsolatok biztonságpolitikai dimenzióját emelte ki. Tanulmányában a katonai kihívásokat vizsgálva arra a megállapításra jutott, hogy kívánatos, hogy azon országok, „melyek területi igényekkel lépnek fel, katonai szempontból ne legyenek erösebbek, mint a szomszéd államok" (Snyder 1990, p. 33). Összegezve álláspontját, Snyder tényként állapította meg, hogy katonailag Magyarország gyengébb, mint Románia és célszerü, hogy az is maradjon, mert az „megakadályozza az Erdélyre irányuló területi törekvéseit” (ibid).

Az idézett szerzők állításai és a viták tartalma kapcsán két észrevétel fogalmazható meg: egyrészt látható, hogy a fentiekben hivatkozott szerzők többsége korlátozott terepismerettel rendelkezett, ebből következően pedig csak azokat az

${ }^{13}$ A kijelentés 1990. június 2-án, az MDF III. országos gyülésén hangzott el (Jeszenszky 2005a). 
eseményeket vették figyelembe, melyek az előzetes feltételezéseket, valamint a térség viszonyaira vonatkozó következtetéseket erősítették. Másfelöl kevés, a térséget behatóbban ismerő szakértő munkáját sikerült beazonosítani. Ezek közül megemlíthető Valki László, az ELTE nemzetközi jogász-professzora, aki a KKE-i változásokról az előbbiekben idézett szerzőkhöz képest jóval optimistább hangot ütött meg. A European Security folyóiratban, főként a román oldalról érkező revizionista vádakra reagálva elmondta, hogy Bukarest az államközi kapcsolatokban több társadalmi-politikai realitást is figyelmen kívül hagyott, nevezetesen azt, hogy (1) Erdélyt, tekintettel a történelmi adottságokra, nem lehet Magyarországhoz csatolni, (2) az erdélyi magyarság nagy része sem érdekelt ebben; (3) Magyarország irányából jövő bármilyen területi igény az ország európai integrációját veszélyeztetné, és végül (4) néhány nacionalista nyilatkozatától eltekintve a magyar kormány semmilyen lépést nem tett ez irányba (Valki 1992, p. 7).

Noha a két állam viszonyára vonatkozó pesszimista, a konfliktus valószínűségét hangoztató elörejelzéseknek a felsorakoztatott érvek alapján - a történelmi örökség, az erősödő nacionalizmus, a magyar kisebbség helyzete, valamint Magyarország szerepének növekedése - lehetett valóságalapja, mégsem alakult ki konfliktus a felek között. Annak ellenére, hogy az utóbbi 25 évben számos vita jellemezte az államközi kapcsolatokat, a két fél között látványosnak mondható együttműködés alakult ki. Erre alapozva teszi fel a kérdést Salat Levente a már idézett tanulmányában, hogy mivel magyarázható a két állam viszonyának alakulása, valamint milyen tényezőknek betudhatóan maradt el a fegyveres konfliktus?

A szakirodalomból Salat Levente három választ ismertet, elsőként Donald Linden álláspontját, aki a két ország viszonyát a nemzetközi kapcsolatok elméletének várakozásaira alapozva vizsgálta (Linden 2000, idézi Salat 2013, pp. 664-666). Linden tanulmányában kifejti, hogy noha a realisták által előre jelzett konfliktus kialakulásához számos tényező adott volt, a belpolitikai és külpolitikai változások a konfliktus elmaradását eredményezték, éppen azért, mert a politikai elitek az európai csatlakozási szándék kinyilvánításával mindkét országban az európai fórumok által felállított követelményrendszert is elfogadták, ami a nemzeti érdek átalakulását, végső soron pedig Románia és Magyarország együttmüködését eredményezték.

A konfliktus elmaradására vonatkozóan Salat szerint Constantin Iordachi szolgál újabb magyarázattal, aki a biztonságpolitika egyik központi fogalmával, a „,biztonsági komplexum" segítségével értelmezi az államközi szinten bekövetkezett fejleményeket (Iordachi 2001 idézi Salat pp. 666-669). Noha az európai fórumoknak is fontos szerepük volt a két állam viszonyának javulásában, mégis a belső átalakulás volt 
meghatározó, ugyanis a politikai elit felismerte, hogy a két ország biztonsága elválaszthatatlan egymástól: ennek nyomán pedig lépésről-lépésre olyan biztonsági közösség jött létre, amelynek mindkét ország része lett (ibid). Az elemzés azért is fontos lehet szempontunkból, mert felveti az RMDSZ pozícióját az államközi kapcsolatokban. Ezzel kapcsolatosan arra a következtetésre jut a szerző, hogy a magyar-román biztonsági komplexum nem teljes, mert az eddigi kétoldalú tárgyalásokban nem kapott helyet az erdélyi magyarság képviselete (ibid).

A Salat által idézett harmadik álláspont újabb érveket vonultat fel az elmaradt konfliktus okainak a megvilágítására. Andrew K. Milton és Patrick H. O’Neil szerint a realizmus és a liberális institucionalizmus képviselőinek azért nem sikerült magyarázatot adnia a térségben bekövetkező változásoknak, mert figyelmen hagyták azt a tényt, hogy a kommunista rezsim olyan racionalizált és bürokratikus állami intézményrendszert hozott létre, amelynek képviselői a rendszerváltást követően is az intézményi status quo fenntartására törekedtek: ennek következtében jött létre a „konzervatív béke” övezete, amely megakadályozta a konfliktus kialakulását (MiltonO’Neil 2002, idézi Salat, pp. 671-673). A szerzőpáros szerint ennek tudható be az is, hogy míg a rendszerváltást követően az államközi kapcsolatok napirendjét több probléma terhelte, addig az intézményesült bürokráciák fenntartották a kapcsolatokat és az államközi viszony javításán dolgoztak - erre irányuló igyekezetük leglátványosabb eredményei a védelmi és katonai együttmüködés területén mutatkoztak meg (MiltonO’Neil, p. 306).

A szakirodalomban a többség-kisebbség közötti konfliktus elmaradására belpolitikai magyarázatokat is találunk. Mihaela Mihailescu amellett érvel egyik tanulmányában, hogy a legalapvetőbb demokratikus intézmények megalapítása, a pártok létrehozása és a választásokon való részvétel - tehát a politikai rendszerbe való betagozódás - megelőzheti a konfliktus kialakulását, amennyiben „,a kisebbségek részvétele a demokratikus folyamatokban akár kormányzati, akár ellenzéki pozícióban biztosított" (Mihailescu 2005). A szerző azt állítja, hogy az intézmények által megteremtett „stratégiai környezet” ösztönözte a többségi ellenzéki pártok és az RMDSZ együttmüködését. Ezt a pozitív fejleményt három tényező befolyásolta: (1) az ellenzékben levő többségi elit a belpolitika szintjén nem jelentett komolyabb veszélyt a kormány tevékenységére nézve; (2) a demokratikus ellenzék gyenge és megosztott volt; valamint (3) a magyar kisebbséget képviselő politikai szervezet magas koalícióképességgel bírt (ibid. p. 41). A felsorolt érvek alapján levonható a következtetés, hogy a többség-kisebbségi közötti konfliktus azért nem következett be, 
mert az RMDSZ parlamenti részvétele biztosított volt, annak ellenére, hogy etnikai pártként és a demokratikus ellenzék tagjaként 1996-ig marginális szerepet töltött be a román pártrendszerben. A Szövetség parlamenti pozíciójától függetlenül államközi szinten - több vitás kérdés ellenére - javultak a kapcsolatok és egyre több területen látványosnak mondható együttmüködés alakult ki a felek között.

Ebben a tekintetben meghatározó volt a védelmi és katonai együttmüködés. ${ }^{14}$ Tom Gallagher a magyar-román viszony kapcsán a konfliktus elmaradását a katonai fenyegetés hiányának tulajdonította: helyzetértékelése szerint mindkét állam katonai ereje gyengének mondható az állomány, a képzés, valamint a felszereltség tekintetében (Gallagher 1997, p. 3). Mi több, az államközi kapcsolatok napirendjét terhelő problémák ellenére gyors ütemben javultak a katonai kapcsolatok: Kárpáti Ferenc magyar honvédelmi miniszter visszaemlékezése arra enged következtetni, hogy a 89-es romániai események és az azt követő időszakban is intenzív volt a felek közötti kapcsolattartás (Kárpáti 2000, pp. 26-29), ami minden bizonnyal hozzájárult ahhoz, hogy a két védelmi tárca között elinduljanak a tárgyalások a nyitott égbolt megállapodásról.

A fentiekből megállapítható, hogy Magyarország és Románia viszonyára vonatkozó szakirodalom erőteljes „,konfliktus-dimenziója” a '90-es évek első felében a regionális, az államközi, valamint a belpolitika szintjén bekövetkezett fejleményeknek betudhatóan megváltozott. Ennek következtében a két állam viszonyát, valamint az államközi kapcsolatokat befolyásoló szereplök viszonyrendszerét az együttmüködés fogalomkörének a segítségével értelmezhetjük, annak ellenére, hogy az utóbbi negyedszázadban az államközi kapcsolatok napirendjét számos vita terhelte. A továbbiakban arra teszek kísérletet, hogy az együttmüködés legfontosabb jellemzőit, a különböző elképzeléseket, a fontosabb viták tanulságait a szakirodalom alapján összefoglaljam, elsőként (1) a két állam viszonyában, majd (2) a többség-kisebbség, (3) a magyar-magyar, végül pedig (4) az európai fórumok és nyugati államok perspektívájából.

A rendszerváltást követően a két állam viszonyában kiemelhető néhány fontosabb esemény, amely fordulópontként értelmezhető, annak alapján, hogy a bekövetkező fejlemény elősegítette vagy éppen akadályozta a felek együttmüködését. A szakirodalomban hivatkozott szerzők többsége a két állam viszonyában a következő fordulópontokat emeli ki: míg a márciusi események és a státustörvény elfogadása körül

\footnotetext{
${ }^{14}$ Az államközi viszony javulásában a katonai együttmüködés fontosságát több szerző is hangsúlyozza: (Salat 2009, p. 349; Iordachi 2001; Dunay 2000, p. 158).
} 
kialakult viták következtében romlottak, addig az alapszerződés aláírása, valamint a közös kormányülések nagymértékben javították a két állam viszonyát. ${ }^{15} \mathrm{Az}$ államközi kapcsolatokban bekövetkező fordulópontok minden esetben visszavezethetőek a belpolitikai folyamatokra és az erdélyi magyarság helyzetére, érdekérvényesítési lehetőségeire is. Ez a feltételezés összecseng Ruxandra Ivan a korábbiakban már idézett megállapításával, miszerint a belpolitikai tényezők - a kormányon levő pártkoalíciók, valamint a külpolitikai döntéshozatalt befolyásoló szereplők - meghatározó szereppel bírtak a rendszerváltást követő időszak államközi kapcsolataiban (Ivan 2010, pp. 405509). Az idézett szerző helyesen állapítja meg, hogy e két változó közül az első a meghatározó, ugyanis az államközi kapcsolatok napirendjét a kormányon levő magyarországi politikai pártok és a szomszédos országokban élö magyarok viszonya határozta meg (ibid. p. 415). Ebből kifolyólag az államközi kapcsolatokban az 1994-es, majd az 1998-as magyarországi kormányváltás sokkal jelentősebb szereppel bírt, mind az 1996-os romániai kormányváltás. ${ }^{16}$

Az államközi kapcsolatok fentebb felsorolt fejleményei alapján megállapíthatjuk, hogy a két állam együttmüködésében az igazi áttörést az alapszerződésről szóló tárgyalások jelentették, amelyek, változó dinamikájuk ellenére, rendszeressé tették a szakértői tárgyalásokat, a minisztériumok és kormányzati intézmények együttműködését, valamint a felsőszintű találkozókat. Noha a szerződés aláíását mindkét államban komoly belpolitikai viták előzték meg, a dokumentum mint referenciapont jelent meg az államközi kapcsolatokban, egyes - fóként román értelmezések szerint pedig az aláírással létrejött a két állam közötti „várva-várt” történelmi megbékélés is.

A magyar-román államközi viszonnyal foglalkozó irodalomban a történelmi megbékélés kérdése egy központi problémaként jelent meg, maga a fogalom és ennek tartalma az eltérő értelmezéseknek betudhatón nem pontosan definiált. A történelmi megbékélésre vonatkozóan a szakirodalomban több kérdés is felmerült, amely érintette egyrészt a fogalom jelentéstartalmát, másrészt a követendő modellt, végül pedig az eddig elért eredményeket és a további lépéseket. A legátfogóbb kutatás, amely a felsorolt problémák megválaszolására kísérletet tett az a kolozsvári Etnokulturális

\footnotetext{
${ }^{15}$ Lásd erről Bárdi Nándor, Dunay Pál, Jeszenszky Géza, Kántor Zoltán, valamint Salat Levente idevágó munkáit, amelyekre a későbbiekben hivatkozom. A román szerzők közül Mihai-Romulus Vădean egy doktori értekezésben vázolta fel a két állam viszonyának fontosabb - a rendszerváltást követő fejleményeit (Vădean 2011).

${ }^{16} \mathrm{Az}$ államközi kapcsolatok alakulásában a magyarországi kormányváltást Ivan is jelentősebb fejleményként értékeli, azonban magyarázatában nem fejti ki az egyes kormányok nemzetpolitikai stratégiáit és célkitüzéseit.
} 
Kisebbségek Forrásközpontja és a marosvásárhelyi Pro Európa Liga együttműködésével a 2000-es évek első felében zajlott le. A kezdeményezés „az államközi kapcsolatok állapotáról és jövőbeli kilátásairól” kívánt képet adni, felkérvén a két állam magas beosztású tisztségviselőit, vezető politikusait, valamint véleményformálóit egy ankétban való részvételre (Salat-Enache 2004, p. 13). A megfogalmazott kérdések érintették többek között, (1) a két ország közeledésében bekövetkező várakozások teljesülését, (2) a magyar-román kapcsolatok és a francia-német megbékélés közötti párhuzam lehetőségét, (3) a magyar-román viszony dinamikussá tétele melletti érveket, valamint (4) a két állam közötti kapcsolatok fejlődését gátoló akadályokat (ibid. p. 32). Az ankétra beérkezett válaszokban az akadályok mellett azok a kezdeményezések és lehetőségek is megfogalmazódtak, amelyek előmozdítanák az államközi kapcsolatok fejlődését. Mindazonáltal a kutatás fó megállapítása a két modell közötti párhuzamra, valamint az ebben rejlő lehetőségekre vonatkozott. Ennek kapcsán Salat Levente arra a megállapításra jutott, hogy míg magyar oldalon a válaszadók többsége tiltakozik vagy legalábbis bizalmatlan a párhuzammal szemben, addig román oldalon a megbékélés folyamatát „lezárult, befejezett tényként” értékelték (Salat 2004, pp. 470-471). A kötet végkövetkeztetésében a szerző arra hívja fel a figyelmet, hogy francia-német Együttmüködési Szerződés aláírásával nem zárult le a megbékélés: a mai napig tartó, több évtizedes munka tulajdonképpen a Német-Francia Ifjúsági Iroda megalapításával kezdődött, és „fiatalok egymást követő generációinak szemléletét befolyásolta”. Ebből kiindulva, Salat egy hasonló ifjúsági iroda megalapítását javasolta a magyar és román döntéshozóknak (ibid).

Noha az ankétban a történelmi megbékélés fogalmára, annak tartalmára konkrétan nem kérdeztek rá, a válaszokból kirajzolódott a fogalom értelmezése, amelynek „felszínes” és „mély” változata különböztethető meg. A megbékélés „felszínes” változata a rendszerváltást követően a két állam közötti politikai és gazdasági együttműködésén alapszik, amelyet a felsőszintű találkozók és a diplomáciai tárgyalások tettek lehetővé. A megbékélés e változatának kiváló indikátorait képezik az államközi szerződések, és főként a román állam részéről a nyugati államok irányába megfogalmazott üzenetek, valamint a két állam viszonyáról készült felmérések is mind román, mind pedig magyar oldalon.

Az államközi kapcsolatok alakulásának a két ország közvéleményében bekövetkező változásairól nem rendelkezünk idősoros elemzésekkel, annak ellenére, hogy a közvélemény szerepét a külpolitika elemzés fontos változóként tartja számon. A bukaresti Közpolitikai Intézet 2005-ben lezajlott kutatásában az állampolgárok 
külpolitikára és nemzetközi kapcsolatokra vonatkozó percepcióit mérték, melynek keretében a Magyarországhoz való viszony is megjelent. A kutatás szomszédsági kapcsolatokra vonatkozó fejezetéböl kiderült, hogy a válaszadók 18\%-a szerint Romániának nagyobb figyelmet kell fordítania Magyarországra. ${ }^{17}$ Ennek ellenére a szomszédos Magyarországhoz a válaszadók 41\%-a semleges érzelmekkel viszonyul, aminek alapján Magyarország a „közepesen rokonszenves” országok csoportjába tartozik (ibid. pp. 69-70).

A közelmúltban közreadott felmérés az államközi kapcsolatok pozitív irányba történő alakulásáról tanúskodik. A Nézőpont Intézet a Charta XXI Megbékélési mozgalom megrendelésére végzett magyarországi reprezentatív mintán Magyarország és a környező államok kapcsolatainak javulását mutatta ki. Míg 2016-ban a válaszadókat megosztotta a két állam viszonya (35\% inkább jónak, míg 37\% inkább rossznak értékelte jónak a két állam viszonyát), addig a 2017-re ez az arány 43\%-ra emelkedett, és valamelyest csökkent, azoknak az aránya is, akik inkább rossz véleménnyel vannak a kapcsolatok alakulásáról. ${ }^{18}$ Noha a két kutatás megállapításaiból messzemenő következtetéseket nem tudunk levonni, az mégis elmondható, hogy kisebb mértékben ugyan, de a közvélemény is „érzékeli” a külpolitikai döntések egyes aspektusait: míg a 2005-ös vizsgálatot megelőzően stagnáltak a magyar-román államközi kapcsolatok, addig az elmúlt években lezajlott külügyminiszteri találkozók újabb lendületet adtak a két állam viszonyának. A két felmérés eredményeinek ismertetése, valamint az államközi kapcsolatok alakulásáról szóló ankétban megjelenő, többnyire a román politikusok és értelmiségiek részéről érkező válaszok a megbékélés felszínes jelentéstartalmának elfogadásáról tanúskodnak.

A megbékélés „mély” változatában az államközi kapcsolatok mellett a két nép, a többség-kisebbség viszonyrendszerének megnyugtató rendezése jelenik meg, ebben a tekintetben az Etnokulturális Kisebbségek Forrásközpontjának keretében zajlott kutatásban - föként az magyar válaszoknak betudhatóan - már nem ennyire pozitív a kép. Minden bizonnyal igaza van Gabriel Andreescunak, aki egyik tanulmányában amellett érvel, hogy a megbékélés egyik fontos lépése az RMDSZ kormányzati részvételében, míg a második, a román politikai erők által elfogadott, nemzeti kisebbségek védelmére vonatkozó jogszabályokban érhető tetten (Andreescu 1998, pp.

\footnotetext{
${ }^{17}$ („Percepţia opiniei publice din România asupra politicii externe” 2005, p. 47) A kérdésre válaszolók közel egyharmada szerint Románia egyetlen szomszédos államra sem kellene figyelmet fordítson, míg egynegyede a Moldova Köztársasággal való kapcsolatok erösítését jelölte meg. A felmérésböl tehát az derül ki, hogy Románia szomszédságpolitikájában Moldova után Magyarország kell prioritást élvezzen.

18 („Magyarország megítélése a szomszéd államokban. Nézőpont Intézet, 2017. január). A közvéleménykutatás 2017. január közepén zajlott 1000 fö megkérdezésével.
} 
55-56). Ez azonban szükséges, de nem elégséges feltétele a megbékélésnek, ugyanis Iordachi, áttekintve a '90-es évek államközi kapcsolataiban bekövetkező változásokat, úgy látja, hogy a felek közötti politikai megbékélés hosszú távon csak úgy biztosítható, ha ezt a kulturális megbékélés folyamata kíséri (Iordachi 2004, p. 125). ${ }^{19}$

Az említett szerzőkkel ellentétben Salat azon a véleményen van, hogy ez idő szerint nem beszélhetünk teljes értékü magyar-román megbékélésről, mert mind a magyar, mind a román közgondolkodást, és ebből kifolyólag a közéletet „egymásnak ellentmondó mentális struktúrák" befolyásolják, amelyek beazonosíthatók a mindennapi életben $^{20}$, illetve rendre visszaköszönnek a '90-es évek közepével kezdődően több hullámban elvégzett közvéleménykutatások eredményeiből (Salat 2009, pp. 351-352). Salat megállapításait a későbbi felmérések is igazolták. Az 1995-2014 között 9 országos felmérésre alapozva Kiss Tamás tanulmányában többek között azt vizsgálta, hogy a román közvélemény hogyan ítéli meg a magyarok etnopolitikai követeléseit Romániában. A kisebbségi jogok és az etnopolitikai célkitűzése különböző szintjeit (hivatalos nyelvhasználat, anyanyelvü oktatás, TV- és rádió stb.) elemezve arra a következtetésre jut, hogy a román többség részéről a létező jogosítványok támogatottsága igen alacsony (Kiss 2015a, p. 19). Mi több, a felmérések összehasonlító vizsgálata Kiss szerint arra enged következtetni, hogy nem tartható az a narratíva, miszerint az RMDSZ kormányzati részvétele következtében ,aa román közvélemény egyre pozitívabban viszonyulna a magyarok (mérsékelt) etnopolitikai célkitűzéseihez és politikai szerepvállásához" (ibid).

Ahhoz, hogy megértsük a létező kisebbségi jogosítványok elfogadottsága körüli problémákat, valamint az erdélyi magyarok és a többségi románok többnyire egymással ellentétes etnopolitikai célkitüzéseit, előbb a többség-kisebbség viszonyrendszerét kell áttekintenünk, amely leginkább a kisebbségpolitikai rezsim keretrendszerében értelmezhető. ${ }^{21} \mathrm{E}$ tekintetben kiindulópont, hogy az államhatalom milyen mértékben ismeri el a kulturális megosztottságot, illetve milyen modellek segítségével írható körül e viszony? Székely István Gergő és Horváth István (2014, pp. 433-434) elemzésükben

\footnotetext{
19 A szerző példaként az aradi Szabadság-szobor felállítása kapcsán lefolytatott vitákat részletezi, az eltérő történelem-értelmezéseket, valamint a szimbolikus politizálás fontosságát emeli ki a két állam viszonyában, mint a megbékélés előtt tornyosuló akadályokat (ibid. pp. 137-147).

20 Brubaker és munkatársainak Kolozsváron végzett kutatása azt vizsgálta, hogy a politikai diskurzusokban és nemzeti igényekben megjelenő etnikai és nemzeti mivolt hogyan fejeződik ki a mindennapi életben, az intézményes formákban valamint az interakciós helyzetekben. (Brubaker és mtsai. 2011).

21 Salat és Novák a kisebbségpolitikai rezsimet olyan “normák, intézmények és közpolitikák összességeként határozták meg, amely megkísérli kezelni az etnikai és nyelvi megosztottságot és elősegíti többség-kisebbség közötti fenntartható és intézményesített kapcsolatok kialakítását." (Salat-Novák 2015, p. 64).
} 
rámutatnak arra, hogy ebben a tekintetben Románia „mono- vagy domináns etnikai modell” kategóriába sorolható, mert noha a kisebbségi közösségek gyakorlatilag elismertek, az alkotmány nem kodifikálja jogi státusukat. A kodifikáció hiányából azonban nem következik a politikai részvétel megtiltása, sőt - ahogy Kiss Tamás a fentebb idézett tanulmányában megjegyzi -, a választási törvény arányos jellegéből kifolyólag támogatja az etnikai pártszerveződést (Kiss 2015a, pp. 11-13), amelynek eredményeként az erdélyi magyarság politikai képviseletét ellátó szervezet, az RMDSZ, a román pártrendszer egyik legstabilabb szereplőjének mondható. Megállapítható tehát, hogy a rendszerváltás után Románia kisebbségpolitikáját egy sajátos modell jellemzi, amelyben egyrészt előtérbe kerül az állam „mono- vagy domináns” jellege, másrészt pedig a rezsim az etnikai pártok aktivizálódását is támogatja, melyet Kiss aszimmetrikus akkomodációnak nevez (Kiss 2015b, p. 53; Kiss és mtsai 2018).

A romániai kisebbségpolitika kettősségének legalább két gyakorlati következményét érdemes a dolgozat szempontjából kiemelni. Az egyik az RMDSZ és a román politikai pártokkal való folyamatos együttmüködésben nyilvánul meg, amelynek eredményeképpen a Szövetség több alkalommal volt a kormánykoalíció tagja, vagy formális együttmüködésnek köszönhetően támogatta az éppen kormányzó politikai alakulato(ka)t. A másik gyakorlati következmény éppen a kormánypártokkal való együttmüködés jellegéből adódik, ugyanis a többség-kisebbség aszimmetrikus viszonyának betudhatóan a felek közötti együttmüködés nem irányulhatott a román állam intézményes keretének a megreformálására - például a hatalommegosztás módozataira, az autonómia különböző formáinak kodifikációjára, vagy a regionalizációs reform során egy magyar többségü régió létrehozására (ibid. p. 55). A Szövetség pozíciója - jegyzi meg Kiss - kizárólag aktuális alkufolyamatokon alapul, amelyet a kontroll-kooptáció fogalmával írhatunk körül (ibid). A fogalmat elsőként Horváth István $^{22}$, majd Narcisa Medianu használta többségi és kisebbségi elitek szintjén létrejövő alkuk természetének a megragadására, amely olyan politikai alkufolyamatot vagy stratégiát jelent, ami egyrészt arra irányul, hogy bevonja a magyar kisebbség képviselőit a döntéshozásba, másrészt pedig a kormányzati részvétel és a forrásallokáció segítségével bizonyos kontrollt is gyakorol felette (pl. a külpolitika, autonómiaküzdelem, korrupció-ellenes harc tekintetében). A román modellt elemezve Medianu következtetése összecseng a fentiekben idézett Kiss Tamás megállapításával, miszerint

\footnotetext{
${ }^{22}$ Horváth a fogalmat a Magyar Autonóm Tartomány megszünése utáni megyerendszerben különböző vezető funkciót betöltő magyar vezetői elitre alkalmazza elsőként, akik - pozíciójukból kifolyólag kisebb gesztusokkal kielégítették a helyi lakosságot (Horváth 2002, p. 80).
} 
a kontroll-kooptáció során úgy mérséklödnek a kisebbségi követelések, hogy közben a nemzetállam radikális újraértelmezésére nem kerül sor (Medianu 2002, p. 31).

A többség-kisebbség közötti alkufolyamatok kérdése Bakk Miklósnál is megjelent, a jelenség leírására azonban a fentiekhez képest más fogalmi apparátust használt. Szerinte a román kisebbségi modell a nemzeti közösségek képviselőit „etnikai ügyintézőkké” alakította át, melyben kihangsúlyozza a kapcsolat „tranzakcionális” jellegét, ugyanis a többség-kisebbség közötti ,ügyintézés keretében nem szolid keretegyezmények" hanem - ahogy fentebb Kiss is megjegyzi -, alkalmi megegyezések születtek (Bakk 2004b, pp. 2-3). Noha hiba lenne az alkalmi, többnyire a nyilvánosságtól elzárt tárgyalások eredményeit figyelmen kívül hagyni, a megegyezéshez mindkét fél részéről a „bizonytalanság képzete társult”, mert a magyar kisebbség által megszerzett jogok legitim voltáról, e jogok indokoltságáról a román többséget rendszerint senki sem győzi meg. E bizonytalanság Bakk értékelésében a román kisebbségpolitikai rezsim másik eleméhez vezet, melyet „határozatlansági modellnek” vagy „stratégiai határozatlanságnak” nevez (ibid. p. 2). Ez a határozatlanság leginkább akkor érhető tetten, amikor a román politikai elit a „romániai társadalom kulturális megosztottságát, távlatait politikai értelemben is megfogalmazza" (ibid). Ebben a kérdésben a román állam illetékes szervei leginkább kivárnak, ami nem teszi lehetővé azt sem, hogy intézményes úton rendeződjön a többség-kisebbség viszonya, nincs hosszú távú stratégia, egyszóval „hiányzanak a nagyobb távlatra szóló koncepcionális elképzelések" - vonja le Bakk a román kisebbségpolitikai rezsimre vonatkozó következtetéseit (ibid).

A román kisebbségvédelmi rezsim elemzésében és a különböző szakpolitikák értékelésének számbavételében a közpolitikai elemzés újabb perspektívákat kínált. A fentebb már említett Etnokulturális Kisebbségek Forrásközpontja és a kolozsvári Nemzeti Kisebbségkutató Intézet kutatása a politikai képviselet, az oktatás- és nyelvpolitikák elemzését alapozták meg a közpolitikai elemzés módszertanának vizsgálatával, amely olyan értékelési szempontokat helyezett a kutatás előtérbe mint a döntéshozatal kritériumai, az alkalmazás végigkövetése, hatásvizsgálat (Salat 2008, p. 10). A kötetben foglalt tanulmányok eredményei több szempontból is tanulságosak, egyrészt azért, mert több helyen rámutatnak a jogszabályi környezet és a gyakorlatba ültetés közötti ellentmondásra, másrészt azért, mert javaslatokat és ajánlásokat 
fogalmaznak meg a kisebbségi jogok hatékonyabb gyakorlatba ültetésére vonatkozóan. $^{23}$

Salat és Novák korábban hivatkozott tanulmánya is fontos megállapításokat tesz arra vonatkozóan, hogy a román kisebbségpolitika eredményei negyedszázados távlatból visszatekintve meglehetősen vitatott képet mutatnak (Salat-Novák 2015, p. 63). A román kisebbségpolitikai rezsim - jegyzik meg a szerzők - egyfelől látványos eredményeket mutat fel (nemzetközi kötelezettségek, kisebbségvédelmi elöírásokat tartalmazó jogszabályok, az intézményhálózat, valamint a magyar kisebbség részvétele a kormánykoalícióban), másrészt azonban, a meghozott intézkedések nem bizonyultak teljes mértékben eredményesnek, mivel az etnikai törésvonalak továbbra is fontos elemei a politikai és mindennapi életnek, valamint a „magyarok úgy érzik, hogy identitásuk megörzése bizonytalan” (ibid. p. 68). Ez a „bizonytalanság” annak ellenére létezik, hogy (1) több mint 900 jogszabályban találunk kisebbségvédelmi előírásokat ${ }^{24}$, (2) a magyar kulturális és oktatási intézményrendszer fenntartásában az állam kulcsszerepet vállal; (3) a kisebbségi érdekvédelmi szervezetek, így az RMDSZ is állami támogatásban részesül, valamint (4) a parlamenti képviselet mellett a megyei és helyi önkormányzatokban is jelentős a magyar képviselettel rendelkezik a Szövetség.

A kisebbségpolitikai rezsim látványosnak mondható eredményei ellenére többen amellett érvelnek, hogy a többség-kisebbség viszonya mindezidáig rendezetlen, ugyanis hiányoznak azok az intézményes megoldások, amelyek a romániai magyar kisebbség fennmaradását, kulturális újratermelődését hosszútávon biztosítanák. Az utóbbi negyedszázadban erre vonatkozóan számtalan elképzelés látott napvilágot, mint pl. államalkotó nemzet, társnemzeti státus (Borbély 1991), illetve az ezredforduló környékén a konszociációs demokrácia-modell ${ }^{25}$, melynek Románián belüli

\footnotetext{
${ }^{23}$ A tanulságokat levonva a kötet szerzői szerint a kisebbségi jogokra vonatkozó problémákra három intézkedés jelentene reális megoldást: egyrészt szükséges volna a meglévő kisebbségi jogokat és ennek elöírásait népszerüsíteni, másrészt növelni az alkalmazásban rejlő hatékonyságot, harmadrészt pedig a létező jogszabályok egységes keretbe történő foglalása - egy kisebbségi törvény elfogadása - tényleges elörelépést jelentene (Bogdán és mtsai. 2008, p. 261). A kutatás eredményeit összefoglaló kötet teljes fordításban a Magyar Kisebbség folyóiratban jelent meg: (,A romániai nemzeti kisebbségek integrációját célzó állampolitikák" 2008).

${ }^{24}$ Lásd erről a Kolozsvári Nemzeti Kisebbségkutató Intézet (ISPMN) projektjét: („Kisebbségi vonatkozású romániai jogszabályok - MinLex” 2011).

${ }^{25}$ A konszociációs demokrácia fogalma a '60-as évek végén föként Arend Lijphart holland és Gerhard Lembruch német politológus kutatásainak eredményeként került be a politikatudomány szakirodalmába, akik arra keresték a választ, hogy miként biztosítható a stabilitás a plurális vagy megosztott politikai kultúrájú társadalmakban. Lijphart szerint a konszociációs demokráciákban a „plurális társadalmakban rejlő centrifugális irányzatokat a lakosság különböző szegmenseit vezető kooperatív elitek magatartása és viselkedése ellensúlyozza." (Lijphart 1977) 1. Az elitek együttmüködése mellett Lijphart a modell további négy feltételét hangsúlyozza: (1) a csoportok vagy szegmensek elitjei által fenntartott nagykoalíció; (2) kölcsönös vétó a döntéshozatalban; (3) a csoportok arányos képviselete; (4) szegmentális autonómia és föderalizmus (ibid. pp. 25-47).
} 
kialakulásának lehetősége, valamint a modell alkalmazhatósága rövid ideig a szakmai érdeklődés középpontjába került. A Lijphart által kidolgozott modellről elsőként a magyar és román értelmiségü csoportosulás által müködtetett Provincia folyóirat 20002001 között megjelenő számaiban folyt érdemi vita, melynek főbb tézisei a fentebb idézett Medianunál (2002, pp. 28-30) is megjelentek, azonban a vita összegzését legutóbb Székely István Gergő (2011, pp. 157-162) végezte el.

A konszociációs demokráciáról szóló vitában két nagyobb, tematikailag is különböző blokkot különíthetünk el egymástól. A vita egyik része arról folyt, hogy Erdélyben beazonosíthatók-e a modell müködését elősegítő feltételek, mint pl. a megosztott (plurális/szegmentális) társadalom, a meghatározó szegmensek (szubkultúrák) intézményesültsége, valamint az eliteket jellemző készség az együttműködésre? A vita kezdeményezője Molnár Gusztáv volt, aki Erdélyt négy meghatározó szegmenssel bíró plurális társadalomként képzelte el, melyek kiindulópontként szolgálhatnak a modell kialakulása szempontjából. ${ }^{26}$ Felvetését a csoport több tagja is elvetette, mondván, hogy az erdélyi társadalmat alkotó szegmensek (pillérek) nem reálisak, a törésvonalak nem elég mélyek, következésképpen nem képezhetik egy konszociációs modell alapjait. ${ }^{27}$

A konszociációs modellel kapcsolatos elképzelések másik része a román politikában bekövetkező változásokhoz köthető, mivel 2000-től az RMDSZ egy formális együttmüködés keretében támogatta a szociáldemokrata kormányt, amit több elemző a konszociációs berendezkedés irányába tartó folyamatként értelmezett. Kántor Zoltán például a Szövetség és a kormányzó román pártok együttműködését „konszociációs jellegü politikai alkunak” nevezi (Kántor 2001, p. 7), amely a modell egyik követelményének a teljesítéseként is értelmezhető. ${ }^{28}$ A konszociációs berendezkedés lehetősége Salat Leventénél is megjelenik, aki a Szövetség hatalomból való részesedésének tapasztalataira vonatkoztatva sommásan állapítja meg, hogy abban nem az együttműködés szabályai, hanem az „eseti alkuk” érvényesültek (Salat 2003, p. 564). Azonban, a törvényhozói és a politikai döntésekből való részesedés nem elégséges az RMDSZ céljainak megvalósításához - véli Salat -, ugyanis „a törvények

\footnotetext{
${ }^{26}$ A Molnár által feltételezett szegmensek: 1. a transzszilvanista magyar, 2. a transzszilvanista román, 3. az unitarista, antitranszszilvanista román, és 4. az antitranszszilvanista magyar (Molnár 2000, idézi Székely p. 158).

${ }^{27}$ A vitában Borbély Zsolt Attila, Kántor Zoltán és Szász A. Zoltán is reagált Molnár elképzeléseire.

28 A konszociációs demokrácia és a politikai alkukra vonatkozó feltételezések a nemzetközi szakirodalomban is visszaköszönnek. Urlich Schneckener, az etnopolitikai konfliktusok kezelésről szóló munkájában úgy látja, hogy a konszociációs demokrácia intézményének építőkövei formális, tehát törvényben rögzített jogszabályokon, továbbá informális, írott és íratlan megállapodásokon is alapulhatnak (Schneckener 2002, p. 240).
} 
végrehajtása és az eredmények felmutatása érdekében rá kell épülnie a román kormánypártok klientúra-építő folyamataira:” ezzel pedig egy olyan elitszerkezetet támogat, amely hosszabbtávon akadályozza a konszociatív berendezkedést (ibid. p. $565)$.

A modell további elméleti feltételeinek a teljesülése - az arányos képviselet, valamint a kisebbségi vétó - csak kormányzati részvétel esetén jöhet szóba. Noha nincsenek pontos felmérések arra vonatkozóan, hogy számarányukhoz képest milyen mértékben alulreprezentáltak a romániai magyarok a központi közigazgatás intézményeiben, az megállapítható, hogy a Szövetség csak kormányzati pozícióból tudja ezt az aránytalanságot valamelyest csökkenteni. A másik feltétel, a kisebbségi vétó szintén kormányzati részvétel esetén bírhat csak - és akkor is korlátozott relevanciával. Székely Medianura hivatkozva megjegyezte, hogy a kisebbségi vétó jogával csak abban az esetben élhet a Szövetség, ha kilép az aktuális kormánykoalícióból, aminek számos következménye van: egyrészt előidézheti a kormány bukását (Medianu 2002, idézi Székely 2011, p. 163), másrészt egy ilyen lépéssel a szervezet gyakorlatilag lemond a kormányzati erőforrásokhoz való hozzáférésről. Összefoglalásként megállapítható, hogy Romániában a 2000-es évek elején nem voltak meg a konszociációs demokrácia kialakulásának a feltételei, az utóbbi évek változásai pedig a klientúra-építést erősítették, mind a román pártok, mind az RMDSZ esetében. ${ }^{29}$

Noha a konszociációs demokráciáról szóló viták érdekes „színfoltját” képezték a két fél viszonyának alakulásával kapcsolatos elképzeléseknek, az utóbbi 25 évben a többség-kisebbség viszonyának intézményes rendeződésére irányuló elképzeléseket, valamint a magyar kisebbség hosszú távú fennmaradását biztosító berendezkedés alapjait döntő mértékben az autonómiáról folyó diskurzus határozta meg. Az 1989-es rendszerváltást követően elkészült tervezetek (Bognár 2006) időről-időre tematizálták a politika napirendjét, heves vitákat generálva egyfelöl a többség-kisebbség viszonyában, másfelől az erdélyi magyarság politikai képviseletét ellátó pártok és szervezetek között (RMDSZ, EMNP, MPP, valamint SZNT). ${ }^{30}$ Az autonómia, mint a magyar kisebbség

\footnotetext{
${ }^{29}$ Ezt a kérdést vizsgálja behatóbban (Kiss-Barna-Székely, 2013).

${ }^{30}$ A 2000-es évek elejére egyre nagyobb ellentét alakult ki az RMDSZ és annak egyik meghatározó platformja a Reform Tömörülés között (belső választások elodázása, az RT fokozatos marginalizálódása, Tőkés László elleni támadások). A 2003-as szatmári kongresszus a tiszteletbeli elnöki tisztség megszüntetéséröl döntött, amelyre válaszul Tökés László, a RT tagjai és az belső ellenzék tagjai kivonultak a kongresszusról és az Erdélyi Magyar Nemzeti Tanács megalakításáról döntöttek. Az EMNTből 2003 nyarán különvált a Székely Nemzeti Tanács, amely a Székelyföl autonóm közigazgatási régió létrehozása érdekében szervezett helyi népszavazásokat.
} 
Romániába történő integrációjának egyik lehetséges eszköze Bakk Miklós szerint egyrészt elválaszthatatlan a Szövetségen belüli ('90-es évek), másrészt pedig a Szövetségen kívüli (2003-tól kezdődően) vitáktól, valamint a bel- és külpolitikai kihívásokra adott válaszoktól (Bakk 2004a).

Figyelembe véve az elkészült tervezeteket, kevés érdemi előrelépésről beszélhetünk, aminek az autonómia kérdésével foglalkozó szakértők szerint számos oka van. Nemzetközi szinten elmondható, hogy a tágabb értelemben vett kisebbségvédelem fejlődése megrekedt, ugyanis az utóbbi évek fejleményei nem mutattak jelentős előrelépést a 2000-es évek első feléhez képest. Az államközi kapcsolatok szintjén az autonómia kérdése a magyar-román alapszerződés tárgyalásait kivéve nem szerepelt meghatározó napirendi pontként, noha történelmi példákra visszatekintve elmondható, hogy az autonómia elismerésében fontos szerep hárult nemzetközi államközösségre, valamint az anyaország-nemzetiesítő állam viszonyára. Mivel sem a nemzetközi kontextus, sem az államközi kapcsolatok alakulása nem volt kedvezett az autonómiatörekvéseknek, az erdélyi magyarság törekvései főként a belpolitika szintjén jelentek meg (Salat 2014, pp. 131-34).

Bognár Zoltán szerint alapjában véve nem a belpolitikai komponens jelenti a legfőbb problémát az autonómia-küzdelem alakulásában, hanem az, hogy ez csakis magyar kérdésként, „magyar ügyként tematizálódik” a közbeszédben, a román partnerek hiányában pedig nehéz közpolitikai problémaként megfogalmazni (Bognár 2006, p. 110). Éppen emiatt, az autonómia-küzdelem fontos eszköze Salat szerint a román többséggel folytatott dialógus megteremtése (stratégiai üzenetek eljuttatása körültekintően kiválasztott pillanatokban), valamint az erdélyi magyarság tájékoztatása kellene legyen, arra vonatkozóan, hogy a különböző autonómia-formák milyen hatást gyakorolnak a mindennapi életre, ez pedig mit követelne meg a különleges státussal felruházott közösség tagjaitól (Salat 2014, p. 137). Az autonómia-tervezetek tartalmi elemzése során Bognár is hangsúlyozta az autonómia gyakorlati megvalósulása terén jelentkező - a hatáskörökkel, az intézményrendszer fenntarthatóságával és költségvetés

Az EMNT több alkalommal napirendre tüzte Székelyföld terület-közigazgatási autonómiájának kérdését, azonban a párt bejegyzése 2008-ig elhúzódott. A Magyar Polgári Párt (MPP) sikeres bejegyzése után, Szász Jenő pártelnök és az EMNT vezetése között további viták alakultak ki a 2009-es EP választásokat megelőzően az RMDSZ-szel folytatott együttmüködésről, aminek következtében egy új párt (Erdélyi Magyar Néppárt) bejegyzéséről született döntés. Az autonómiáról szóló vita legutóbb 2014 folyamán került napirendre, miután az Erdélyi Magyar Néppárt szakértői kidolgozták „Székelyföld Autonómia Statútumát”. A dokumentum megjelenésével komoly nyomás nehezedett az RMDSZ vezetőségére, hogy a Szövetség is bocsássa közvitára a dokumentumot, amelyre az év szeptemberében került sor „A romániai Székelyföld autonómia statútuma" címmel. Az RMDSZ-ellenzék intézményesülésének részletesebb elemzését adja (Toró 2013, pp. 121-28) 
bevételi oldalával kapcsolatos - problémákat (Bognár 2006, pp. 110-111). További fontos problémaként jelenik meg az autonómia-küzdelemben a „müködtetők világa”. Egyed Péter tanulmányában áttekintve a '90-es évek tervezeteit sommásan állapította meg, hogy az autonómia kérdése, továbbra is „politikai létünk tétje”, azonban hiányoznak azok a szervek, melyek ezt a „tevékenységet” folyamatosan müködtetnék (Egyed 2000, p. 43).

Az elkészült tervezetek száma egy további lényeges problémára világítanak rá, nevezetesen a minimális konszenzus hiányára, mert az egymással rivalizáló tervezetek és szervezetek aligha teremthetik meg az elörelépés lehetőségét. Ebből a felismerésből Bakk arra a következtetésre jut, hogy az elmúlt időszak „,erdélyi magyar politikai szerveződésformái nem voltak alkalmasak a konszenzus kialakítására” (Bakk 2004a, p. 55), tehát az autonómiát célként megfogalmazó, de többnyire csak eszközként használó szervezetek nem tudtak egy olyan platformot létrehozni és müködtetni, amely az autonómia megvalósítása szempontjából megkerülhetetlennek vélt kérdésekben elősegítette volna az együttműködést. Végül pedig, az RMDSZ autonómiához való viszonyulása is problematikusnak tekinthető: míg az autonómia formálisan része az RMDSZ programjának, a 2000-es évektől folyamatosan a választók mobilizációjának eszközévé vált, azonban megmaradt a kampányretorika szintjén, addig a román partnerekkel folytatott alkufolyamatokban - tulajdonképpen azokkal, akikkel a megvalósítás részleteiről kellene tárgyalni - meg sem jelenik (Kiss-Barna-Székely 2013, p. 28).

Magyarország és a határon túli magyarság viszonyrendszerének szakirodalma további fontos táppontokkal szolgálhat az államközi kapcsolatok megértésére nézve. A magyar-magyar kapcsolatoknak az anyaország határon túli magyar közösségek iránti felelősségvállalása ad kitüntetett szerepet. E különleges viszonyban meghatározó egyrészt a történelmi felelösség, amely a trianoni békeszerződés következményeire vezethető vissza, nevezetesen arra, hogy a létrejövő új államok joghatósága alá jelentős magyar kisebbség került, másrészt pedig az erre megfogalmazott válasz, amely az alkotmányos felelősségvállalásban érhető tetten. ${ }^{31} \mathrm{E}$ felelősségvállalás legfontosabb megnyilvánulása a budapesti kormányzatok magyarságpolitikája (vagy nemzetpolitika),

\footnotetext{
31 „Magyarország az egységes magyar nemzet összetartozását szem előtt tartva felelősséget visel a határain kívül élő magyarok sorsáért, elősegíti közösségeik fennmaradását és fejlődését, támogatja magyarságuk megörzésére irányuló törekvéseiket, egyéni és közösségi jogaik érvényesítését, közösségi önkormányzataik létrehozását, a szülőföldön való boldogulásukat, valamint előmozdítja együttműködésüket egymással és Magyarországgal.” („Magyarország Alaptörvénye”, 2011).
} 
amely szorosan, néha elválaszthatatlanul egybefonódott a magyar külpolitika célkitüzéseivel.

A magyar külpolitikát alakító személyek és elemzők megállapították, hogy a rendszerváltás után hivatalba lépő Antall-kormány külpolitikájának stratégiai céljairól a parlamenti pártok között kialakult egy minimális konszenzus, az egymást váltó kormányok ugyanis alapjaiban véve elfogadták az így létrejött hárompilléres struktúrát. $^{32}$ Az úgynevezett ,külpolitikai triád” elemei a következők voltak: (1) a nyugati politikai, gazdasági és katonai szervezetekbe történő integráció; (2) a jószomszédi viszonyok és a regionális együttmüködés; (3) a határon túli magyarok jogainak érvényesítése, a kisebbségi jogokért való kiállás (Jeszenszky 2012, 2015, p. 59). Annak ellenére, hogy a három prioritás között szoros kapcsolat áll fenn, az egymást váltó konzervatív és szociálliberális kormányzatok külpolitikai tevékenysége megosztó vitákat eredményezett, abból fakadóan, hogy más-más hangsúllyal kezelték e célkitüzéseket, ami leginkább a nemzetpolitikai prioritásokban nyilvánult meg. Míg a nemzeti-konzervatív kormányok az egységes magyar nemzet meghatározásából indultak ki, nagyobb hangsúlyt fektettek a nemzetpolitikai kérdésekre, és a szomszédos államokkal kapcsolatos viszonyt az ott élő magyarok helyzetétől tették függővé (Antalldoktrína), addig a szociálliberális kormányzatok külpolitikájában az integráció élvezett prioritást, a határon túli magyarság helyzetének rendezését pedig elsősorban a jószomszédi viszonyok megvalósítása után tartották elképzelhetőnek (Bárdi 2013, 2004, pp. 131-47; Kiss 2004).

Az egyes kormányzatok (nemzeti-konzervatív vs. szocialista) közötti ellentétek kiindulópontját az anyaország felelősségének kérdése és a határon túli magyarokhoz való viszony képezte (Bárdi 2013, pp. 40-79). Kiss J. László (2004 pp. 56-66) elemzésében az egymást váltó kormányzatok külpolitikájában megjelenő ellentétet a nemzetpolitika és integrációpolitika folyamatos vívódására vezeti vissza: érvelésében megjegyzi, hogy a konzervatív kormányok alatt a nemzetpolitika a külpolitika részévé vált (duális külpolitika), addig a szocialista kormányzatok alatt a nemzetpolitika az integációpolitikának rendelődött alá. Ebben a kontextusban pedig a határon túli magyar közösségek szerepe is átértékelődött.

A szakirodalomban több helyen találunk utalásokat arra nézve, hogy a határon túli magyar közösségek kisebb vagy nagyobb mértékben a magyar külpolitika

\footnotetext{
${ }^{32}$ Lásd erről Jeszenszky Géza, Dunay Pál, Kiss J. László, Kántor Zoltán és Terényi János idevágó elemzéseit, amelyekre a későbbiekben hivatkozom. Jeszenszky Géza, Németh Zsolt és Szent-Iványi István a velük készült interjúkban is megerősítették, hogy a három célkitüzésben alapvetően egyetértés volt a pártok között.
} 
befolyásoló és alakító tényezői lennének. Mindez abból a tényből vezethető le, hogy az Antall-kormány felértékelte a kisebbségek szerepét, képviselőiket tárgyaló félként igyekezett elfogadtatni az államközi kapcsolatokban. Dunay Pál, a magyar külpolitika egy neves szakértője, a magyar kisebbségek szervezeteinek „beleszólási jogát” emeli ki, Bába Ivánra hivatkozva pedig egyenesen a bel- és külpolitikai kérdésekben megnyilvánuló vétójogról beszélt, amely a szocialisták integrációpolitikájában értelemszerüen visszaszorult (Zellner-Dunay 1998, p. 217).

A 2000-es évek első felében a határon túli magyarság szerepe a magyar külpolitikában egy szakmai vita kapcsán újra az érdeklődés középpontjába került, annak nyomán, hogy Jeszenszky Géza, az Antall-kormány külügyminisztere, néhány pontosító megjegyzést füzött Dunay Pál „Az átmenet magyar külpolitikája” c. tanulmányához (Dunay 2004, pp. 221-43). A bírálatból élénk vita alakult ki a Külügyi Szemle 2005-ös, két egymást követő számában Jeszenszky Géza és Dunay Pál. ${ }^{33}$

A vita egyik kiindulópontja Dunay értékelésére vezethető vissza, miszerint a konzervatív kormányok a határon túli magyarság kérdésének kezelését „de facto nemzetközi prioritásként” kezelték (Dunay 2004, p. 238). Válaszában Jeszenszky amellett érvel, hogy az Antall-kormány időszaka alatt megkötött alapszerződések éppen azt cáfolják, hogy a ,külpolitikai prioritásokon belül a határon túli magyarok ügye szuperprioritás” lett volna (Jeszenszky 2005b, p. 281). E felértékelődött szerepet többen - föként a sajtó képviselői, de korábban idézett munkájában Dunay is - vétójogként értelmezték. A vitában, felidézve a kormány és a határon túli magyarság képviselői közötti rendszeres találkozókat, Jeszenszky tagadja, hogy a határon túli magyarok „vétójogot kaptak volna a szomszédi kapcsolatokban,” amire véleménye szerint nem is lett volna szükség, mivel ,alapvetően nézetazonosság állt fönn köztük és a magyar kormány között."34 A vétójog kérdése Horváth Istvánnál (2002, p. 54) és Kiss J. Lászlónál (2004, p. 63) is megjelenik, akik úgy látják, hogy az Antall-kormány alatti „de facto” vétójog a Horn-kormányzat alatt fokozatosan visszaszorult. Ezzel szemben Bárdi Nándor, az Antall-kormány nemzetpolitikáját elemezve arra a megállapításra jut, hogy a határon túli magyarok véleményének meghallgatása magyarságpolitikai kérdésekben nem jelentett vétójogot (Bárdi 2013, p. 141).

\footnotetext{
33 A vita részletei a Külügyi Szemle 2005-ös számaiban lelhetők fel: (Jeszenszky 2005a, pp. 274-90; Dunay 2005, pp. 281-89; Jeszenszky 2005b, pp. 290-93). Köszönettel tartozom Kiss J. Lászlónak, aki felhívta a figyelmem a vita néhány aspektusára.

34 (Jeszenszky 2005, p. 277). A volt külügyminiszter a határon túli magyarok vétójogát több helyen is cáfolja, vélhetően azért, hogy a további személye és az Antall-kormány elleni támadásokat elkerülje. Mindezzel ellentétben egy személyes beszélgetés során kiemelte, hogy a határon túli magyaroknak az őket érintő kérdésekben vétójoguk kellene legyen.
} 
A felsorakoztatott érvekből, ez utóbbit érzem leginkább elfogadhatónak, ugyanis az Antall-kormánynak a határon túli magyarok képviselőivel folytatott rendszeres egyeztetését joggal értékelhetjük „,kitüntetett” vagy megnövekedett szerepként, azonban a vétójog a külpolitikai döntéshozatalban való aktív részvételt, végeredményben pedig azt feltételezné, hogy a határon túli magyarság kezében összpontosulna a külpolitikai döntéshozatal öket érintő része. Erre véleményem szerint, még ha egyes döntések meghozatalát befolyásolták is a határon túli magyarok képviselői, egyetlen kormányzati időszakban sem kerülhetett sor.

A Jeszenszky-Dunay vitának egy további fontos eleme a szomszédsági (államközi) kapcsolatokra vonatkozik. Ebben a viszonyrendszerben Jeszenszky az „Antall-doktrínát” tekinti kiindulópontnak, ami a „szomszédokkal fennálló jó kapcsolat előfeltételének tekinti a magyar kisebbségekkel szembeni korrekt politikát” (ibid. p. 277). A határon túli magyarok támogatását Dunay is fontosnak tartja, ő sokkal inkább a szocialista kormányzatok „eszközrendszerét” fogadja el, a határon túli magyarok támogatását a többségi nemzet és a kisebbségnek otthont adó kormányzat viszonyától teszi függővé (Dunay 2005, pp. 281-289). Jeszenszkytől eltérően tehát Dunay úgy látja, hogy előbb a kétoldalú kapcsolatokban kell eredményeket elérni, amely végső soron a többség-kisebbség viszonyának javulását eredményezi. E szempontrendszerek ütközésének gyakorlati, politikai következményei nagyban befolyásolták a két állam és az erdélyi magyarság viszonyrendszerét: míg a konzervatív kormányzatok konfliktusokat felvállalva a nemzetközi jogi keretek tágítására törekedtek, addig a szociálliberális kormányzatok minden ilyen lépésben szükségtelen konfliktusok veszélyét látták (Kiss J. 2004, p. 64).

A vitában megjelenő érvek alapján megállapítható, hogy a külpolitika hármas célrendszere a látszólagos konszenzus ellenére törékeny lábakon állott, ugyanis a hármas prioritás egyidejü, hasonló súllyal való képviselete komoly kihívások elé állította a külpolitika kivitelezőit. A Jeszenszky-Dunay vitában megjelenő szemléletbeli különbségek világosan jelzik a hármas prioritással kapcsolatos problémákat. Kiss J. László Dunayra hivatkozva a magyar külpolitika „célstruktúrájának” ellentmondásos jellegére hívta fel a figyelmet, tekintettel arra, hogy a hármas prioritás „különböző módszerek alkalmazását követelte meg” a külügy vezetésétől (Zellner-Dunay 1998, p. 46, idézi Kiss J., p. 54). Az eltérő külpolitikai célkitűzések a nemzetközi kapcsolatok elméleteinek perspektívájából is megvizsgálható. Az elöbbiekben idézett Kiss J. az egymást váltó kormányok közötti ellentétet abban látja, hogy míg a konzervatív kormányok külpolitikai célkitüzései a nemzetközi kapcsolatok realista felfogásával 
azonosíthatók leginkább (nemzeti önérdek megfogalmazása, konfliktus felvállalása), addig a szocialista-liberális kormányok külpolitikája a neoliberális-konstruktivista elmélet (nemzetközi és európai normák feltétlen követése, együttmüködés) alapvetéseihez állnak közelebb (ibid. p. 65).

A két elméleti irányzatnak megfelelő külpolitikai orientáció a '90-es évek közepétől kezdődően kibékíthetetlennek tűnő ellentétetek eredményezett a kormány és az ellenzéki pártok között, amely egyrészt látványosan kiéleződött a parlamenti vitákban ${ }^{35}$, másrészt pedig meghatározónak bizonyult az egymást váltó kormányzatok főként a Horn-, az Orbán- és a Medgyessy kormányok - szomszédságpolitikájában és a határon túli magyarokkal kapcsolatos politikájában. Míg a magyar kormányzatok szomszédsági kapcsolatainak központi kérdése az volt, hogy milyen cél- és eszközrendszerrel biztosítható egyidőben a kapcsolatok rendezése és az ott élő magyar kisebbség helyzete, addig a magyar-magyar kapcsolatok alapvető kérdése az volt, hogy a kormány mely határon túli magyar szervezetekkel és csoportokkal keresse az együttműködést és mire helyezze a támogatáspolitika súlypontját. ${ }^{36}$

A határon túli magyarok iránti felelősségvállalás intézményesülésének a kormányzati (külpolitikai) célkitüzések mellett van egy gyakorlati megvalósulása, amely a támogatáspolitika eszközrendszerében érhető tetten. Számos - a kérdéssel foglalkozó - szakember véleménye szerint a magyar-magyar kapcsolatoknak a támogatáspolitika, ennek rendszerváltás után kialakított kormányzati és alapítványi rendszere ad kitüntetett szerepet. Bárdi Nándor szerint a magyar állam kezdeti elképzelése az volt, hogy „segédkezik” a rendszerváltás utáni intézmények újjáalakításában, az ily módon kiépült rendszereket pedig a kisebbségi társadalom fogja müködtetni (Bárdi 2013b, p. 212). Ez, mint utóbb kiderült, nem így történt - mondja Bárdi -, mert a „magyar intézményrendszert döntően magyarországi támogatásokból próbálják működtetni”, amely számos problémát eredményezett. ${ }^{37}$ A támogatáspolitika

\footnotetext{
35 Tóth Judit az 1989-1999 közötti parlamenti jegyzőkönyvek, valamint a diaszpórapolitika meghatározó politikusaival készült interjúk elemzését követően a magyar kormányzatok diaszpórapolitikájának kutatásában két folyamatot emel ki: egyrészt az diaszpórapolitika intézményesülését, másrészt az egyes kormányok különböző orientációs pontokhoz igazodó politikáját, amely az „érzelmi alapoktól” a „,pragmatikus megközelítésig” terjedő dimenziók között értelmezhető (Tóth 2000b).

36 A Horn-, az Orbán- és a Medgyessy kormányok magyarságpolitikájának főbb jegyeit az esettanulmányokban, az egyes döntések elemzésekor részletesebben ismertetem. Itt csupán azon dimenziókat emeltem ki, melyek jelentős különbségeket és változásokat eredményeztek az egymást váltó kormányzatok között. A rendszerváltást követő kormányok magyarságpolitikájáról Bárdi Nándor (2004, 2013) készített mértékadó elemzéseket.

${ }^{37}$ Ibid. p. 213. A kisebbségi közösségek támogatásáról Bárdi Nándor és Misovicz Tibor írt összefoglaló tanulmányt, melyben ismertetik a támogatáspolitika megvalósításáért felelős intézményeket, alapítványokat, valamint az egyes kormányok támogatáspolitikájának jellemzőit, stratégiáit. A rendszerváltás utáni támogatáspolitika rendszerét vizsgálva, a következő változásokat tartották
} 
kialakítása és a határon túli magyar érdekeltségű intézmények megerősítése nemzetépítési stratégiaként is értelmezhető. Ennek kapcsán Csergő Zsuzsa és James Goldgeier „transzszuverén nacionalizmusról” beszél, amelynek lényege az, hogy a „nemzeti központ olyan intézményeket hoz létre, amelyek fenntartják és újratermelik a nemzetet a fennálló államhatárokon túl” (Csergő-Goldgeier 2004, p. 26). A szerzők által felvázolt transzszuverén stratégiának a társadalmi és gazdasági intézményrendszer megerősítése mellett van egy további eleme, amely szorosan kapcsolódik a határon túli magyarok kisebbségi követeléseihez, nevezetesen az autonómia különböző formáinak a támogatásához, amely a magyar-magyar viszony egyik kiemelt napirendi pontját képezi (ibid. 27).

A rendszerváltás utáni időszakban a kisebbségi követelések megjelenítése az etnikai alkuk (ethnic bargaining) folyamatában is értelmezhető. Magyarország és a kisebbség-többség viszonyának alakulását vizsgálva Erin Jennét az a kérdés foglalkoztatta, hogy mivel magyarázható a „,kisebbségek vezetői által megfogalmazott követelések intenzitásának gyors időbeli változása, míg sérelmeik viszonylag állandóak" (Jenne 2007, p. 2). A Brubaker-i triadikus viszony alapján kidolgozott modell fő hipotézise az, hogy a kisebbségek vezetői leginkább akkor radikalizálódnak, amikor egy külső szereplő beavatkozási szándéka hitelesnek tekinthető. A szlovákiai és romániai viszonyokat elemezve Jenne megállapította, hogy a primordalista, etnikai vállalkozókra és biztonsági kérdésekre alapozott elméletekkel szemben az etnikai alkuk modellje alkalmasabb a történtek értelmezésére, két tekintetben is. Elsőként 1992-től kezdődően az alapszerződésről szóló tárgyalások alatt, a magyarországi lobbinak betudhatóan az erdélyi magyarok követelése radikalizálódott, ami hozzájárult ahhoz, hogy megfogalmazták a területi autonómiára vonatkozó elképzelésüket (ibid. pp. 109-120; 122-123). A modell második előrejelzése is helytállónak bizonyult, az 1996ot követő időszakra vonatkozóan, amikor a koalíciós részvételnek betudhatóan mérséklődtek a magyar követelések, ebben az időszakban Magyarország közbenjárása is visszafogottabb (ibid).

Annak ellenére, hogy a szerző az európai fórumoknak szerepét is fontosnak tartja az államközi és interetnikus viszony alakításában, az értelmezési modell számos problémát fölvet. Elsősorban relativizál bizonyos időszakokat, például az átmenet kezdeti éveit, amelyre nézve alulértékeli Magyarország befolyását. Ebből ered egy

meghatározónak: (1) a támogatási összegek folyamatos növelése iránti igény; (2) az elosztásért felelős intézmények/személyek közötti erőviszonyok alakulása; (3) kedvezményezettek körének folyamatos bővülése; valamint (4) a határon túli magyar pártok befolyásának növekedése a források elosztásában (Bárdi-Misovicz 2010). 
további probléma, nevezetesen az, hogy az elemezni kívánt időszak nem illeszkedik az elöre kidolgozott elemzési keretbe, a 2003-ig terjedő időszakot ugyanis, amikor a státustörvény körüli viták a legintenzívebbek voltak, nem értékelhetjük úgy, hogy Magyarország nem avatkozott be a határon túli magyarok és a szomszédos államok ügyeibe.

Az alkotmányos felelősségvállalás harmadik aspektusa a magyar-magyar kapcsolatok intézményesüléséhez, a magyar kormány és a határon túli politikai szervezetek közötti rendszeres, intézményes együttmüködéséhez köthető, ami viszonylag későn, a Magyar Állandó Értekezlet (MÁÉRT) megalakításával a '90-es évek végén intézményesült. A magyar kormányzatok kül- és nemzetpolitikájában uralkodó „hangsúlyeltolódások” a magyar-magyar viszonyban, a MÁÉRT, majd a későbbiekben a KMKF (Kárpát-medencei Magyar Képviselők Fóruma) munkájában is tetten érhetők, főként, ami a státustörvényről, majd a kettős állampolgárságról szóló vitákat illeti. $^{38}$

A magyar-magyar kapcsolatok dinamikájának van egy további lehetséges értelmezése is, amely nem illeszkedik a felelősségvállalás keretrendszerébe. Magyarország és a határon túli magyarok kapcsolatát elemezve Myra A. Waterbury úgy látja, hogy alapvetően nem az etnikai kötődés (ethnic ties) számlájára írható, hanem a politikai elitek versengésének tulajdonítható a határon túli magyarokkal kapcsolatos kötelezettségek növekedése (Waterbury 2010). Meglátása szerint a magyarságpolitikának (ő a „diaszpórapolitika” fogalmát használja) politikai és stratégiai céljai egyaránt beazonosíthatóak, ugyanis a politikai elit egyik fontos célkitüzése az volt, hogy hozzáférjenek a határon túli magyarok által képviselt - materiális, kulturális-nyelvi és politikai - forrásokhoz, ami végső soron az anyaországi elit legitimitását erősítette volna (ibid. 6).

A határon túli magyarokról szóló viták már a '90-es évek első felétől - a szomszédos államokkal megkötetett alapszerződésekkel kezdődően - a politikai pártok közötti versengés egyik meghatározó terepét jelentették, azonban e vitáknak egyre meghatározóbbak lettek a belpolitikai következményei. A kettős állampolgárságról folytatott vitáról több szakértő - köztük Bárdi is - megállapította, hogy az már nem a határon túli magyarokról szólt, hanem sokkal inkább az új kormányfó és az ellenzék

\footnotetext{
${ }^{38}$ A MÁÉRT szerepe igazán a státustörvényröl folytatott egyeztetések során vált fontossá, fő feladata pedig a magyar kormány által meghozott nemzetpolitikai döntések legitimációja lett. Kántor Zoltán a státustörvényről folyó egyeztetések kapcsán kiemeli, hogy a MÁÉRT „puszta léte, szimbolikus volta, legitimáló szerepe sokkal fontosabb, mint tényleges politikai súlya” (Kántor 2014, p. 141).
} 
vezére közötti pártpolitikai vitaként értelmezhető, amelyet leginkább a ,jóléti nacionalizmus" felerősödése jellemzett (Bárdi 2004, p. 73, 2013a, p. 60).

Magyarország NATO és EU-integrációjával a három pillérre épülő külpolitika célrendszerében jelentős változás állt be, ugyanis a csatlakozás után az integrációs szervezetekben gyakorolható érdekérvényesítés vált meghatározóvá. Ennek következtében napirendre került a külpolitikai stratégia átdolgozása, melyre Magyarország EU-csatlakozása után két alkalommal került sor. Elsőként Göncz Kinga külügyminiszter kezdeményezte a külkapcsolati stratégia újragondolását 2006-ban, melynek előkészítésében több kutatóintézettel együtt az MTA Etnikai-Nemzeti Kisebbségkutató Intézete vett részt (Szarka 2006, pp. 7-10). Magyarország és a határon túli magyarság kapcsolatának szempontjából a négy témában megírt előtanulmányok érdemelnek figyelmet - nemzetfogalom, nemzetpolitika és EU-tagság, autonómiák helyzete valamint média és oktatás helyzetkép ${ }^{39}$-, amelyek a munka volumenéhez képest kisebb mértékben tükröződtek a végleges dokumentumban. A külpolitikai és nemzetpolitikai prioritások újragondolására az uniós elnökség utáni időszak adott újabb alkalmat, amelyből két dokumentum, a „Magyar külpolitika az uniós elnökség után”40, valamint a „Magyar nemzetpolitika - A nemzetpolitikai stratégiai kerete” emelhető ki. ${ }^{41}$ A magyar-magyar viszony szempontjából ez utóbbi a legfontosabb, amely egységes keretrendszerbe foglalja és - kisebb módosításoktól eltekintve - a mai napig meghatározza a kormány nemzetpolitikáját.

A szakirodalomban konszenzus van arra vonatkozóan, hogy Magyarország és Románia viszonyának javulásában - egyben pedig a konfliktus elkerülésében - az európai fórumok (EBESZ, ET, NATO és EU) és a nyugati államoknak is nagy szerepük volt, abból tényből kiindulva, hogy a rendszerváltás után jelenlétükkel nyomon követték a térség államaiban a demokratikus intézményrendszer kiépítését, az integrációs perspektíva „lebegtetésével” pedig olyan normatív értékeket, elvárásokat, valamint szakpolitikai ajánlásokat fogalmaztak meg, amelyek mindkét állam esetében módosították a bel- és külpolitikai célkitüzéseket, végső soron pedig elősegítették a két

\footnotetext{
39 A Magyar Kisebbség folyóirat egy teljes számot szentelt a külkapcsolati stratégia előmunkálatairól készült tanulmányok bemutatására. Lásd bővebben: („Az új magyar külkapcsolati stratégia előmunkálatai” 2006). A tanulmányokhoz többek között hozzászólt: Bakk Miklós, Csernicskó István, K. Lengyel Zsolt, Losoncz Alpár, Petőcz Kálmán, Öllös László és Salat Levente.

40 Külügyminisztérium által készített stratégiában a külpolitikai és a nemzetpolitikai célkitüzések „szétválaszthatatlanul összefüggnek egymással.”A dokumentum a külpolitika „kibővített” értelmezését adja, miszerint a „magyar külpolitika nemcsak Magyarország, hanem egyszersmind a magyar nemzet külpolitikája is” („Magyar külpolitika az uniós elnökség után” 2011, p. 13).

41 („Magyar nemzetpolitika. A nemzetpolitikai stratégiai kerete” 2011).
} 
fél együttműködését. ${ }^{42} \mathrm{~A}$ két állam viszonyában az európai fórumok befolyása azt követően növekedett, hogy a román politikai elit az integrációt követendö célkitüzésként fogalmazta meg, másrészt pedig a tagsági kritériumok is megfogalmazódtak. ${ }^{43}$

Az EBESZ Kisebbségi Főbiztos romániai tevékenységét több szerző is értékelte. A Walter A. Kemp által szerkesztett kötet egy áttekintő képet nyújt az intézményi háttérről (megalakulás körülményei, alkalmazott stratégiák, szakterületek) és húsz államra vonatkozóan - köztük Romániára is - felelevenítette a Főbiztos fontosabb tárgyalásait és vázolta a találkozók legfontosabb eredményeit (W. A. Kemp 2001). Románia esetében a Főbiztos tevékenységét az anyanyelvű oktatás területén emeli ki, ezen belül pedig az egyetemi oktatás kérdését, amely a többség-kisebbség viszonylatában komoly vitákat eredményezett (ibid. pp. 199-205).

A Kemp által szerkesztett kötethez képest a Főbiztos intézményéről jóval átfogóbb, és módszertanilag is innovatív a Wolfgang Zellner által vezetett kutatási program, amely a hamburgi Institut für Frieden und Sicherheitspolitik (IFSH) égisze alatt valósult meg. ${ }^{44}$ A kutatás keretében a Főbiztos romániai tevékenységét, az ajánlások hatékonyságának vizsgálatát Horváth István végezte el, aki a többség-kisebbség kapcsolatát a Brubaker-i hármas viszonyrendszerben értelmezte (Horváth 2002, p. 13). Áttekintve a rendszerváltás utáni időszak főbb etnopolitikai fejleményeit és a kisebbségi rezsim intézményesülését, arra a következtetésre jutott, hogy a Föbiztosnak nagy szerepe volt az interetnikus együttmüködés kialakulásában, amely a kisebbségi jogokkal kapcsolatos viták következtében nem vált konfliktusmentes kapcsolattá (ibid. p 117). Horváth a Főbiztos ajánlásait az oktatási és nyelvi jogok terén tartja kiemelkedőnek, mert két vitában (az oktatási törvény 1995-ös végrehajtása, valamint a Babeș-Bolyai Tudományegyetemen kialakult helyzet) közvetítői szerepéből

\footnotetext{
${ }^{42}$ Mindamellett azonban, hogy az európai fórumoknak és más nem állami szereplőknek nagy szerepet tulajdonítunk, meg kell jegyezni, hogy a rendszerváltás kezdeti éveiben kevés befolyással bírtak az államközi kapcsolatokra, amely leginkább Románia külpolitikájának „határozatlanságával magyarázható”. McMahon azt állítja, hogy az európai fórumok figyelme 1993-tól irányult a két államra többnyire a balkáni eseményeknek betudhatóan - az államközi kapcsolatok konfliktussal terhelt területeire, valamint a többség-kisebbség viszonyára (McMahon 2007, pp. 108-112).

${ }^{43}$ Ivan tanulmányában amellett érvel, hogy az államközi kapcsolatokban a külső szereplök 1994 után bírnak magyarázó erővel, miután bekövetkezik a külpolitikai irányváltás és a taggá válás feltételei is nyilvánvalóvá váltak (2010, pp. 414-15).

${ }^{44}$ A kutatás az EBESZ kisebbségi rezsim hatékonyságát vizsgálta, a Kisebbségi Főbiztos 1993-2000 között tett ajánlásainak fényében, az észtországi, lettországi és ukrajnai orosz, a macedóniai albán, valamint a romániai és szlovákiai magyar kisebbségek perspektívájából (Zellner 1999, p. 31). A Zellner által felállított elméleti modell részletesebb ismertetését lásd (Salat 2001, pp. 48-52).
} 
kilépve aktív, kezdeményező szerepet vállalt, hozzájárulva a többség-kisebbség kapcsolatának javulásához. ${ }^{45}$

Az európai fórumok szerepének értékelése a többség-kisebbség perspektívájából más szerzőknél is megjelenik. Judith Kelley az EBESZ, az ET és az EU szerepét a kisebbségekre vonatkozó jogszabályok tükrében elemezte. Könyvében arra keresi a választ, hogy az európai fórumok stratégiái - melyek egyben a kutatás magyarázó változói: a normatív nyomásgyakorlás és a tagfelvétellel járó feltételrendszerek (kondicionalitás) - hogyan befolyásolták a lett, litván, a szlovák és a román kormányt abban, hogy a kisebbségekre vonatkozó jogszabályokat fogadjanak el (Kelley 2010, pp. 2-3). Romániára vonatkozóan 11 kisebbségekkel kapcsolatos jogszabály elfogadását és módosítását elemezte, a rendszerváltás időszakától 1999-ig. ${ }^{46}$ Az európai fórumok által gyakorolt hatás szempontjából a kutatásnak két fontosabb megállapítását emelhetjük ki: (1) abban az időszakban, amikor az európai fórumok nem voltak jelen az országban, vagy csak normatív ösztönzőket alkalmaztak, a kisebbségek számára kedvezőtlen jogszabályok születtek; (2) az európai fórumok szempontjából sokkal sikeresebbnek bizonyult, ha mindkét stratégiát alkalmazták (normatív ösztönzők, tagsággal járó feltételek). Ellenben, ha a tagság kapcsán bizonytalanság merült fel (az ET és az EU csatlakozást megelőző évek), a nyugati nyomásgyakorlás egymagában nem vezetett eredményre (ibid. pp. 140-162; 174-195).

Az idézett munkákhoz kapcsolódik Patrice C. McMahon kutatása, aki két esetre (Románia és Lettország) vonatkoztatva vizsgálta a többség-kisebbség együttmüködését. Megközelítése aktorközpontú, tehát a szereplők stratégiái és befolyása foglalkoztatta őt is, azonban az eddig idézett munkákhoz képest tovább megy, és amellett érvel, hogy az európai fórumok mellett számos további állam kormányzata, valamint nemkormányzatiszervezetek, alapítványok is szerepet játszottak a KKE-i átalakulás folyamataiban (McMahon 2007, p. 2). Annak ellenére, hogy az állami és nem állami szereplők eltérő stratégiákat alkalmaztak, közös célokat követtek, melynek eredményeként olyan transznacionális hálózat jött létre, ami együttmüködésre késztette a feleket (ibid. p. 9). A transznacionális hálózatok romániai tevékenységét döntőnek tartja a kisebbségek

\footnotetext{
${ }^{45}$ Horváth szerint a Főbiztos ajánlásainak értékelése és ennek hatása a többség-kisebbség viszonyára három tényező mentén végezhető el: (1) operacionális hatékonyság: a többségi és kisebbségi szereplők közötti kommunikáció intézményesítése; krízismenedzsment; (2) normatív hatékonyság: a nemzetközi normák és standardok közvetítése; (3) érdemi javaslatok és ajánlások megfogalmazása, valamint ezek nyomon követése (ibid. pp. 118-123).

${ }^{46}$ A Kelley által elkülönített esetek a következők: kétnyelvü feliratok (1992-1996 és 1997-1999); nemzeti kisebbségekről szóló törvény (1990-1991 és 1996-1997); anyanyelvhasználat a közintézményekben (1992-1996 és 1997-1999); oktatási reform, prefektusok kinevezése, magyar-román alapszerződés aláírása.
} 
akkomodációja szempontjából, melyben a belpolitikai változások, a vezetők döntései, a nemzetközi/regionális körülmények, valamint az RMDSZ kormányzati részvétele is nagy fontossággal bírtak (ibid. pp. 103-139).

A többség-kisebbség viszonyának kezelésében az EU szerepe a csatlakozási tárgyalások megindulásával válik fontossá, aminek következtében a kisebbségi problémák az európaizáció kontextusában értelmeződnek és megfogalmazódik az a kérdés, hogy az európaizáció folyamata mennyiben befolyásolja a kisebbségekre vonatkozó politikák kialakítását Romániában. Ana-Maria Dobre az EU monitoring rendszerét tartja meghatározónak, mert ez alakította a belpolitikai aktorok identitását, ami intézményi és szakpolitikai változásokat eredményezett. ${ }^{47} \mathrm{~A}$ tanulmány végkövetkeztetése az, hogy 1989 után Románia kisebbségpolitikája jelentős változásokon ment át: ez annak a szakpolitikai és identitásválasztásnak tulajdonítható, melyet a külső szereplők - köztük az EU-idéztek elő (Dobre 2003, p. 76).

Az európaizáció a többségi szereplők mellett a kisebbségek politikai képviseletét ellátó szereplőkre, így az RMDSZ-re is nagy hatást gyakorolt. Annak ellenére, hogy Románia EU-csatlakozásával a Szövetség számára az EU intézményei újabb arénát jelentettek, amelyek keretet és lehetőséget biztosítanak arra, hogy megfogalmazzák igényeiket és tematizálják a magyar közösséget érintő problémákat (Waterbury 2016), azonban lényegesebb eredményeket - kizárólagos tagállami kompetenciára hivatkozva - nem sikerült elérni. A legújabb vizsgálatok és összehasonlító tanulmányok arra mutattak rá, hogy a legtöbb európai kisebbségi szervezet továbbra is „strukturális hátrányban” van a többségi szereplőkkel szemben (Csergő-Regelmann 2017).

Az európai fórumok szocializációs szerepe, amely az általuk közvetített normák és jogszabályok elfogadását feltételezte, a KKE államok integrációjának egyik központi kérdését jelentette, amelynek nyomán a kisebbségi jogok kérdése szorosan összefüggött a belső demokratikus intézményrendszer kiépítésével. Egy összehasonlító kutatás keretében, Frank Schimmelfennig munkatársaival az európaizáció folyamatát vizsgálták, arra keresve a választ, hogy az európai fórumok milyen hatást gyakoroltak a közép és kelet-európai államok belső átalakulására, és milyen mértékben feleltek meg a követelményeknek (Schimmelfennig-Engert-Knobel 2006). A szerzők úgy értékelik,

\footnotetext{
${ }^{47}$ Noha a kormányzó Szociáldemokrata Párt eltávolodása a szélsőséges Nagy-Románia Párttól és az együttműködési megállapodás megkötése az RMDSZ-szel értelmezhető igazodási kényszerként, a Dobre által hangsúlyozott „,identitásváltásról” véleményem szerint nem beszélhetünk. Az együttmüködés mögött a pártpolitikai megfontolások mérvadóak: a kormányzó pártnak egyrészt szüksége volt a Szövetség parlamenti támogatására, másrészt a külügyi kommunikációban is „hasznos” volt a magyar érdekképviselet, mert a nyugati partnerek szemében jó példaként jelent meg, mi több erősítette a kormánypárt integráció iránti elköteleződését is.
} 
hogy Románia 1996-ig kismértékben tett eleget és felelt meg (compliance) az európai fórumok elvárásainak, annak ellenére, hogy 1993-tól kezdődően erős volt a demokratikus átalakulásra és a kisebbségi jogokra vonatkozó ösztönzés (incentives) (ibid. pp. 132-150). Románia jó példája annak - érvelnek a szerzők -, hogy a megváltozott európai kontextushoz a politikai elit is igazodott, tehát Iliescu elnöki mandátuma alatt is folytatódtak a reformok, ami igazolja azt a feltételezést, miszerint ,a megfelelés leginkább a belpolitikai költségekre alapozott számításoktól, a hiteles tagfelvétellel járó feltételrendszerektől és a felajánlott, meglehetősen magas anyagi ösztönzőktől függött” (ibid. p. 150).

$\mathrm{Az}$ európai fórumok szerepe az államközi kapcsolatok rendezésében az előbbiekben több ízben idézett Ivan tanulmányban is visszaköszönt. Magyarország és Románia viszonyának javulását a szerző két tényezőre vezeti vissza: az első, melyet reálpolitikai felismerésnek is nevezhetünk, arra vonatkozik, hogy a külügyi vezetésben is tudatosult, hogy az államközi kapcsolatok javulása feltétele a NATO-hoz és az EUhoz való csatlakozásnak. A második tényező a Schimmelfennig által is leírt európaizáció fogalmával írható körül. Ennek kapcsán a szerző amellett érvel, hogy a román döntéshozók átvették az európai fórumok által közvetített normák egy részét tehát nem egyszerüen a nyugati szereplőknek való megfelelésről van szó -, melyek idővel a belső jogrend részévé váltak (Ivan 2010, p. 414).

Szükségesnek érezem jelezni, hogy a szerző következtetéseivel csak részben tudok egyetérteni, ugyanis, amint azt a későbbiekben látni fogjuk, a külügyi apparátus jelentős energiát fordított arra, hogy javítsa Románia romló nemzetközi megítélését, főként a '90-es évek első felében, az esetek többségében arra visszavezethetően, hogy az európai fórumok által közvetített normákkal ellentétes szellemü jogszabályok születtek, amelyek az esetek többségében hátrányosan érintették az erdélyi magyarságot. ${ }^{48}$

A magyar-román államközi viszony szakirodalmának összefoglalása során áttekintett munkák számos tanulsággal szolgálnak kutatásomra vonatkozóan. Elsőként elmondható, hogy a két állam viszonya nem elemezhető a szük értelemben vett államközi perspektívában, amelyre a Rogers Brubaker által kidolgozott triadikus viszonyrendszer jó kiindulópontként szolgált. A hármas viszonyrendszerben megjelenő

\footnotetext{
48 A román nyelvü szakirodalomban további „,narratívákat” találunk arra nézve, hogy miért nem sikerült az európai fórumok ajánlásait és tagfelvételi feltételeket időben teljesíteni. Dragoș Zaharia doktori értekezésében Románia külpolitikai irányváltása körül kialakult problémáknak, a külpolitikai döntéshozatalban rivalizáló intézményeknek és személyeknek tulajdonítja az európai normák elfogadásával kapcsolatos problémákat (Zaharia 2014).
} 
anyaország, a nemzetiesítő állam, valamint az erdélyi magyarság kapcsolata az európai fórumok, a nyugati államok és egyéb nemzetközi nem-kormányzati szervezetek befolyásának betudhatóan egy kibővített „,négyes viszonyrendszerben” ragadható meg leginkább: az ennek eredményeként létrejövő, különböző kapcsolati szinteken lejátszódó „többszintű játék” kifejtésére a dolgozat elméleti részében kerül sor. A szakirodalmi áttekintés egy további megállapítása az, hogy rendszerváltás időszakában a térségben bekövetkező változások a bel- és külpolitikai fejleményeknek betudhatóan az ismertetett szerzők egy erőteljes konfliktusdimenziót vizionáltak a magyar-román államközi viszonyban és a többség-kisebbség viszonyrendszerében. Számos tényező egyidejü előfordulása azonban rácáfolt a konfliktusok várható kirobbanására vonatkozó elörejelzésekre, és annak ellenére, hogy a két állam és a többség-kisebbség viszonya a mai napig nem problémamentes, a szereplők viselkedését az utóbbi két és fél évtizedben leginkább a kooperáció, a kölcsönös együttmüködésre való hajlam jellemezte. 


\section{ELMÉLETI KIINDULÓPONTOK ÉS LEHETSÉGES ÉRTELMEZÉSI KERETEK}

A dolgozat szakirodalmi áttekintését követően azokra az elméleti kérdésekre és problémákra helyeztem a hangsúlyt, melyek reményeim szerint újabb elemzési szempontokkal és értelmezési lehetőségekkel szolgálhatnak a magyar-román államközi viszony és az erdélyi magyarság kapcsolatrendszerének utóbbi két és fél évtizedes folyamatára vonatkozóan.

Az elméleti keret első komponensét azokat a folyamatok képezik, melyek meghatározó jelleggel bírtak az általam vizsgált kapcsolatrendszerek elemzésénél. Véleményem szerint a rendszerváltást követően a KKE-i államok viszonyrendszerének alakulását a renacionalizáció, a transznacionalizáció és az európai integráció (európaizáció és kondicionalitás) folyamata alapvető módon meghatározta. Annak ellenére, hogy Románia és Magyarország, az RMDSZ, valamint a nem állami szereplők érdekérvényesítési lehetőségire a felsorolt folyamatok más-más hatással voltak, mégsem értelmezhetők egymástól függetlenül, mivel összefüggő, egy időben ható jelenségekről beszélünk. Az elméleti keret második részében a nemzetközi kapcsolatok elméleteinek perspektívájából tekintek a kutatásomra. A négy iskola (realizmus, liberális institucionalizmus, szociál-konstruktivizmus és angol iskola) rövid bemutatása után (fogalmak, alaptételek) azt vizsgálom, hogy az elméleti irányzatok szempontjából, hogyan értelmezhetők a szereplők viszonyrendszere.

$\mathrm{Az}$ elméleti keret harmadik komponensét három olyan modell bemutatása képezi (kétszintű játszma, spirál modell, hármas viszonyrendszer), amely további magyarázatokkal szolgálhat a felek stratégiáit illetően, valamint az érdekérvényesítésben és a döntéshozatalt befolyásoló szereplök tevékenységeinek értékelésében. A három modell kritikai értékelésével rámutatok azonban arra, hogy önmagában egyik modell sem nyújt kielégítő magyarázatot az általam vizsgált folyamatok és szereplők érdekérvényesítési stratégiáinak értékelésében. Ebből kifolyólag a szakirodalomban alkalmazott négyes viszonyrendszer bevezetése mellett érvelek, amely alkalmas keretnek bizonyult Magyarország, Románia, az RMDSZ és az európai fórumok viszonyrendszerének vizsgálatában. 


\section{Folyamatok}

KKE államainak politikai-, gazdasági- és társadalmi fejlődését a rendszerváltást követően legalább három egyidejü, azonban eltérő intenzitású folyamat, a renacionalizáció, az európaizáció és a transznacionalizáció érintette. A három folyamat a két állam és az erdélyi magyarság viszonyrendszerének elemzésében is fontossággal bír, mivel alapvető módon alakították és befolyásolták a felek egymáshoz füződő viszonyát.

\subsection{Renacionalizáció}

A szakirodalom alapján elmondható, hogy a renacionalizációt, a transznacionalizáció és az európai integráció folyamatával összevetve, lényegesen kevesebb szakmai érdeklődés övezte az utóbbi negyedszázadban. Ennek egyik okát leginkább abban látom, hogy noha a jelenség számos dimenzióját, megjelenési formáját elemezték a kutatók, a fogalmat nem operacionalizálták elég pontosan, következésképpen a renacionalizáció jelentéstartama viszonylag széles, melyben a biztonságot, gazdaságot, valamint a nemzeti integrációt érintő kérdések is helyet kapnak. A másik okot abban látom, hogy a jelenség többnyire KKE-i viszonyok között értelmezhető, az átmenettel, majd később az európai integrációs folyamattal pedig jelentősen háttérbe szorult. ${ }^{49}$

A fogalom jelentéstartamának áttekintése előtt a renacionalizáció két hullámáról érdemes említést tenni. A renacionalizáció első hulláma a kelet-nyugat konfliktus vége és a hidegháború utáni változásokkal hozható összefüggésbe. Wilfried von Bredow tanulmányában kiemeli, hogy a szövetségi rendszerek felbomlásával az államok „egy olyan környezetben tervezték újra pozícióikat és nemzeti érdeküket, ahol minden állam ugyanezt tette" (von Bredow 2001, p. 26). Ebben a környezetben - fejti ki a szerző - a politikai folyamatok és ebből adódóan a katonai magatartás is renacionalizálódott. A második hullám az EU válságához, nevezetesen a 2008-as pénzügyi és gazdasági, valamint az európai nyilvánosságot jelenleg is uraló migrációs válsághoz köthető, melyekben világosan kirajzolódtak közösségi szolidaritást felülíró, egymásnak akár ellentmondó tagállami érdekek, melyek mögött a rövidtávú politikai megfontolásokon túl alig találunk közép- és hosszú távú megoldási lehetőségeket felvonultató stratégiákat.

A renacionalizáció jelensége számos formában megjelent a magyar szakirodalomban is. A bevezetőben már hivatkozott Kiss J. László, ugyan nem említi szó szerint a renacionalizáció folyamatát, azonban értelmezésünkben „a tényleges

\footnotetext{
49 A renacionalizáció nem kizárólag a KKE államaira ható jelenség: a '90-es évek közepén az olasz külpolitika irányáról szóló vitákban is jelen volt (Aliboni-Greco 1996).
} 
szuverenitás visszaszerzése” és „az önálló külpolitika megteremtése” a jelenség egyik jelentéseként értelmezhető. A renacionalizáció a biztonság- és védelempolitika területét is érintette. Dunay Pál tanulmányában kifejti, hogy a kelet-nyugati szembenállás végével a térség államai előtt két opció lebegett: katonai ügyekben saját forrásokra támaszkodni, vagy csatlakozni a nyugati katonai-biztonsági szervezetekhez (Dunay 1995, p. 41). A szerző úgy értékelte, hogy mivel az utóbbi kísérlet nem vezetett volna korai sikerekhez - sem Magyarország sem Románia számára nem nyílt meg a gyors csatlakozás esélye -, következésképpen a térségben elkerülhetetlenné vált a biztonság „államosítása” (ibid).

A fogalom legszélesebb értelmezését - beleértve a jelenség biztonságpolitikai vetületét is - Tálas Péternél találjuk. A szerző szerint a renacionalizáció fogalmán „,a nemzeti érdekek újrafogalmazását a piaci alapú nemzetgazdaság megteremtését, a külés biztonságpolitikák nemzeti alapra való helyezését, a nemzeti társadalmak megerősítését és integrálását értjük" (Tálas 2008, p. 69). A fogalom értelmezését Tálas tovább szélesíti, amikor a renacionalizációt a nemzeti integrációval hozza összefüggésbe, melynek következményei a térség államai között fellelhető asszimetriákban nyilvánul meg, az államjogi helyzetre, társadalmi berendezkedésére, demokratikus politikai hagyományokra, gazdasági nyitottságra vonatkozóan(Tálas 2008a). ${ }^{50}$ E meghatározásból kiindulva elmondhatjuk, hogy a renacionalizáció minkét hulláma jelentősen befolyásolta a térség államait: míg a rendszerváltás után hasonló mintázatok figyelhetők meg Magyarország és Románia között (nemzeti érdek újrafogalmazása, piacgazdaság, belső integráció), addig az EU-t sújtó kettős válságra Magyarország fokozottabb renacionalizációs törekvésekkel, Románia pedig a nyugatnak való megfelelés stratégiájával válaszolt.

\subsection{Transznacionalizáció}

Kutatásom szempontjából egy további meghatározó folyamat a politika transznacionalizációja, amely James Rosenau meghatározásában azt a globális folyamatot jelöli, melyben az államok által alakított nemzetközi kapcsolatokban egyre nagyobb szerephez jutnak az egyének, különböző csoportok és társadalmak közötti kapcsolatok, és e jelenségnek fontos következményei vannak a nemzetközi politikára nézve (Rosenau 1980, p. 1 idézi Jackson-Sørensen 2013, p. 103). A transznacionális

\footnotetext{
${ }^{50}$ A nemzeti integrációból adódó különbségek, mint azt a magyar-szlovák viszony példáján szemlélteti a szerző - megemlítvén a magyar-román viszonyt is -, számos problémához vezetett és vezet jelenleg is az államközi kapcsolatokban
} 
politika tehát az új szereplők (a politikai pártok, nemzetközi szervezetek, társadalmi hálózatok, nem-kormányzati szervezetek, agytrösztök) határokat átlépő érdekérvényesítési tevékenységét jelöli, és azt vizsgálja, hogy a transznacionális szereplők interakciói milyen mértékben befolyásolják az államok bel- és külpolitikai magatartását. A politika transznacionalizációja és a transznacionális szereplők befolyásának vizsgálata a '60-as évek végén, a ’70-es évek elején jelent meg a nemzetközi kapcsolatok napirendjén ${ }^{51}$, melynek szakirodalmáról Thomas Risse (2013) készített egy alapos áttekintést.

Elsőként Karl Kaiser hívta fel a figyelmet arra, hogy a nemzetközi politikában egyre több olyan folyamat és esemény érhető tetten, amely nem magyarázható a hagyományos államközi és államközpontú modellekben (Kaiser 1969), majd két évre rá az International Organization Joseph S. Nye és Robert Keohane szerkesztésében a folyóirat egy teljes számot szentel a transznacionális kapcsolatoknak (Nye-Keohane 1971a). A szám szerkesztőinek meghatározása szerint a transznacionális kapcsolatok a transznacionális szereplők olyan „határokon átnyúló kapcsolatait, koalícióit és interakcióit jelenti”, melyet nem ellenőriznek a kormány különböző szervei (Nye-Keohane 1971b, p. 331). Transznacionálisnak pedig az a határon átnyúló állandó kapcsolat tekinthető, amelyben az egyik résztvevő nem állami szereplő (ibid. p. 335).

1. sz. ábra: Államközpontú (hagyományos) és transznacionális kapcsolatrendszerek

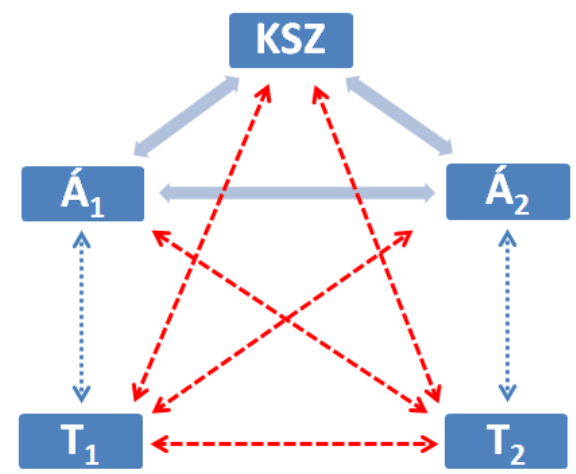

$$
\begin{aligned}
& \longleftrightarrow \text { Hagyományos államközpontú kapcsolatok } \\
& \longleftrightarrow \ldots . . \rightarrow \text { Belpolitika } \\
& \leftarrow---\rightarrow \text { Transznacionális kapcsolatok }
\end{aligned}
$$

Forrás: Nye-Keohane, p. 334.

\footnotetext{
${ }^{51}$ A transznacionális kapcsolatok mögötti élénk érdeklődésre többfajta magyarázat adható: elsőként a hatvanas évek gazdasági fellendülése és a határokon átnyúló, az üzleti kapcsolatokat lehetővé tevő kommunikáció fejlődése, az együttmüködési formák kialakulása kelet és nyugat között, továbbá a nemzetközi szereplők pluralizálódása és a közöttük kialakuló együttmüködések alapjában véve kérdőjelezték meg az államközpontú külpolitikáról alkotott elképzeléseket. Lásd bővebben: (Kiss J. 2009, p. 111). Mindazonáltal a transznacionális politika nem tekinthetô új jelenségnek a nemzetközi kapcsolatokban, ugyanis az integrációs elméletek - lásd funkcionalizmus - már az '50-es évektől kiemelt figyelemmel kísérték a nemzetállam és a regionális szervezetek viszonyát.
} 
Az ábrán látható államközpontú kapcsolatrendszerek az állam (Á) és a kormányközi szervezetek (KSZ) között jönnek létre, és nincs alapvető kapcsolat a társadalom (T) és a kormányközi szervezetek, illetve más államok és társadalmak között. Ezzel szemben a transznacionális kapcsolatrendszerek kilépnek ebből a keretből, és kapcsolataik hálózatszerüen összekötik az állami, nem állami és kormányközi szervezeteket, ezzel pedig létrejön az állami és nem állami szereplök közötti transznacionális kapcsolatok egyre növekvő rendszere. ${ }^{52}$

A folyóiratban megjelenő tanulmányokban, illetve a későbbi, a transznacionális kapcsolatokról szóló irodalomban (Huntington 1973) többnyire két közös vezérfonalat lehet végigkövetni. Az első feltételezés a nemzetközi kapcsolatokban uralkodó tételt igyekezett megkérdőjelezni, miszerint nem az államok az egyedüli meghatározói a világpolitikának, mellettük a transznacionális szereplők is egyre nagyobb jelentőséggel bírnak. A második kutatási irány arra próbált válaszolni, hogy a transznacionális szereplők térnyerése következtében az államok vagy az új szereplők befolyása érvényesül-e a jövőben a nemzetközi politikában. ${ }^{53}$

A nyolcvanas évek végén a világpolitikában és a szakmai körökben bekövetkező változások következtében a transznacionális kapcsolatok újra a figyelem középpontjába kerültek. Elsőként a kelet-nyugat szembenállás végével és a kommunista blokk felbomlásával az állami és nem állami szereplők egyre intenzívebb, határokat átívelő kapcsolatépítése indult meg. Egy másik, szakmai körökből érkező kihívás - a konstruktivizmus - a nemzetközi kapcsolatok uralkodó elméleteit kérdőjelezte meg. ${ }^{54}$ Végül a harmadik tényező a globalizáció irodalmához kapcsolható, amely valóságos új „,iparágat” teremtett a társadalomtudományokban; a gazdasági szereplők mellett a nonprofit szektor és a tudásalapú társadalmak (epistemic communities) szervezetei is megjelennek, mint új, transznacionális szereplők (Haas 1992).

Ezen változások megteremtették azokat a feltételeket, melyek a transznacionális kapcsolatokat új megvilágításba helyezte. Ezen munkák közül kiemelkedik a Thomas Risse-Kappen által szerkesztett kötet, amelyben a szerző arra hívja fel a figyelmet, hogy

\footnotetext{
52 Néhány empirikus adat a transznacionális kapcsolatokról: 207 állami szereplő (World Factbook) mellett a világban 37.000 aktív nemzetközi szervezet (The Yearbook of International Organizations) és 43.000 transznacionális vállalat (Global Issue) tevékenykedik a világban.

${ }^{53}$ Míg a transznacionális kapcsolatok első hullámának irodalma a nemzetközi szervezetek növekvő szerepének felismerésével új kutatási irányokat nyitott, addig a második kutatási irányban nem jutott tovább azon a felismerésen, hogy vajon az államközpontú (state-dominated) világ helyét mennyiben tudja felváltani és átvenni a társadalomközpontú (society-centered), a transznacionális kapcsolatokra épülő világ.

${ }^{54} \mathrm{Az}$ Alexander Wendt által képviselt konstruktivista irányzat arra helyezte a hangsúlyt, hogy a nemzetközi politikában a társadalmi struktúráknak és normáknak, az identitásnak és végül, de nem utolsó sorban a kultúrának is meghatározó szerepe van (Wendt 1999).
} 
a transznacionális kapcsolatokról szóló vita első részét idejekorán zárták le, és tévesnek bizonyult az a kérdésfelvetés is, miszerint az államközpontú világot felváltja-e a nem állami szereplők által dominált világ. Risse-Kappen úgy látja, hogy sokkal eredményesebbnek bizonyult volna az a kérdésfelvetés, hogy miként hatnak egymásra az állami és nem állami szereplők, interakcióikat milyen bel- és külpolitikai körülmények befolyásolhatják (Risse-Kappen 1995, p. 5). A felvázolt szakirodalom alapján a dolgozatban amellett érvelek, hogy a transznacionális szereplők - amelyek csoportosítására alább teszek kísérletet -, eltérő intenzitással alakítói és befolyásoló tényezői lehetnek az államközi kapcsolatoknak.

1. sz. táblázat: A transznacionális szervezetek egy lehetséges csoportosítása

\begin{tabular}{|c|c|c|}
\hline $\begin{array}{c}\text { A csoportosítás } \\
\text { alapja }\end{array}$ & A szervezetek/szereplők jellege & Példák \\
\hline \multirow{2}{*}{ Struktúra } & Formális szervezetek & $\begin{array}{l}\text { Multinacionális vállalatok, nemzetközi nem- } \\
\text { kormányzati szervezetek }\end{array}$ \\
\hline & Hálózatok, egyének csoportosulása & $\begin{array}{l}\text { Önkéntességen alapuló szervezetek, képviseleti } \\
\text { hálózatok (advocacy networks) }\end{array}$ \\
\hline \multirow[b]{2}{*}{$\begin{array}{l}\text { Célkitűzés és belső } \\
\text { motiváció }\end{array}$} & $\begin{array}{l}\text { Profitorientált (anyagi, materiális) } \\
\text { célokért küzdő szervezetek }\end{array}$ & Multinacionális vállalatok \\
\hline & Nem profitorientált szervezetek & $\begin{array}{l}\text { Nemzetközi nem-kormányzati } \text { szervezetek, } \\
\text { tudásalapú közösségek, kisebbségi és ellenzéki } \\
\text { csoportok }\end{array}$ \\
\hline \multirow{4}{*}{ Tevékenység } & \multirow[t]{2}{*}{ Territoriális szereplők } & $\begin{array}{l}\text { Államot, vagy az államhoz hasonló területi bázist } \\
\text { használ fel céljaik elérésére: politikai-katonai } \\
\text { szervezetek, állam nélküli nemzetek }\end{array}$ \\
\hline & & $\begin{array}{l}\text { Állam alatti egységek (városok, régiók, szövetségi } \\
\text { államok }\end{array}$ \\
\hline & $\begin{array}{l}\text { Egy kérdésterület mögé szerveződő } \\
\text { ideológiai-kulturális szereplők }\end{array}$ & $\begin{array}{l}\text { Egyházak, internacionálék, emberi jogok védelmét } \\
\text { hirdető szervezetek, politikai pártok, tudás-alapú } \\
\text { közösségek, alapítványok. }\end{array}$ \\
\hline & Gazdasági szereplők & Multinacionális vállalatok, médiaóriások \\
\hline
\end{tabular}

Forrás: saját szerkesztés (Kiss J. 2009, pp. 116-122), (Risse-Kappen 1995, pp. 7-13), valamint (Hill 2016, pp. 204-215) alapján.

A transznacionális szervezetek osztályozását azért tartottam fontosnak, mert a csoportosítás segíthet abban, hogy elhelyezzem az RMDSZ-t, mint erdélyi magyarság képviseletét ellátó szervezetet a transznacionális szereplők rendszerében. Az RMDSZ azért tekinthető transznacionális szereplőnek, mert (1) a kilencvenes évek első felétől kezdődően, a hagyományos nemzetállami kereteket átlépve a külpolitika szintjén több állami és nem állami szereplővel alakított ki és tartott fenn kapcsolatokat, másrészt pedig (2) megfelel a transznacionális szereplökre vonatkozó kritériumoknak is. A tipológia alapján a Szövetség belső struktúráját tekintve formális (pártokra jellemző 
szervezeti struktúra), célkitüzéseiben immateriális (elsősorban nem profitszerzésben érdekelt, azonban az állami támogatásoknak betudhatóan jelentős forrás-elosztóvá válhat), valamint tevékenységei mentén érdekvédelmi (egy nemzeti kisebbség politikai képviseletét ellátó) szervezet (Szabó 2015, pp. 124-25)

\subsection{Európai integráció, európaizáció, kondicionalitás}

A térség államainak viszonyát és egyben az államközi kapcsolatok alakulásában meghatározó volt az európai integráció folyamata, aminek kapcsán a szakirodalomban két fontosabb fogalom - az európaizáció és a kondicionalitás - jelenik meg.

Az európaizáció fogalmának vizsgálatában kiemelkedő Kevin Fatherstone kutatása, aki az europaizáció négy dimenzióját különítette el: (1) az europaizáció mint történelmi folyamat az európai uralmi formák és normák elterjedéséhez, valamint a gyarmati és birodalmi hagyományokhoz kapcsolódik; (2) európaizáció, mint a kulturális normák, eszmék és identitások elterjedése; (3) az európaizáció leggyakrabban használt értelmezése az EU-s tagságból eredő közvetett vagy közvetlen intézményi alkalmazkodásban, a politikai és gazdasági szereplők értékeinek változásaiban érhető tetten; (4) a szakpolitikák és döntéshozatali mechanizmusok átvétele, valamint az EU-s intézmények döntéshozatalában való részvétel az európaizáció újabb értelmezésére utal (Featherstone 2003). A szerző megjegyzi, hogy míg az európaizáció első két dimenziója nem köthető teljesen az EU-integrációhoz, addig az utolsó két értelmezés már szorosan az EU müködéséhez kapcsolódik (ibid. p.5).

Fatherstone-val szemben Johan P. Olsen az EU jövőjéről folyó viták kontextusában értelmezi az európaizáció fogalmát és az európai integráció folyamatában öt típusú változást azonosít be (Olsen 2002, pp. 923-943). Az EU bővítésével - fejti ki a szerző - elsőként a határok minősége változik meg, amelynek fontos területi dimenziója van, ugyanis ,a kontinens egyetlen politikai térré változik” (ibid. p. 923). A változás második és harmadik szintje a kormányzati intézmények fejlődéséhez, valamint a szubnacionális és többszintű kormányzás intézményeihez köthetők, ahogyan az európai szintű politikákba illeszkednek. Az európaizáció negyedik értelmezése az EU intézményi és kormányzati formáinak elterjesztését (exportálását) jelenti, többségében nem európai államokba. Az ötödik értelmezés szerint az európaizáció egy egységesítő politikai projekt, amelynek végcélja az, hogy az EU egy minél egységesebb és erősebb politikai entitássá váljon (ibid, pp. 923-943)

Fatherstone és Olsen megközelítése számos hasonlóságot mutat, mi több kiegészítik egymást, azonban az európaizáció fogalmának az értelmezésében egy fontos 
hiányosság jellemzi mindkettőt, nevezetesen az, hogy nem azonosítja be az európaizáció „,irányát”. Amint arra Tanja A. Börzel és Thomas Risse sokat hivatkozott munkájukban rámutatnak, az európai integrációval kapcsolatosan sokáig a „lentről felfele”, tehát a tagállamoktól az európai intézmények irányába történő változások voltak irányadóak (uploading), azonban a 2000-es évektől egyre több kutatás ennek fordítottját, tehát az EU-s intézmények tagállamokra gyakorolt hatásait helyezte (downloading) vizsgálatuk középpontjába (Börzel-Risse 2000, p. 2). A szerzőpáros által jelzett szakirodalmi fordulat az EU keleti bővítésével áll összefüggésben, mivel a korábbi bővítési hullámokhoz képest a keleti bővítésben mutatkoztak a legnagyobb különbségek az EU-s normák és a tagállami gyakorlatok között. Ennek következtében a '90-es évek második felétől előbb a politikai diskurzus szintjén, majd pedig a bővítés konkrét lépéseinek meghatározásával az EU különböző intézményeinek befolyása KKE államaira - mind az intézményi változások, mind pedig a szakpolitikák alakításában - példanélkülinek bizonyult. $^{55}$

Az európaizációval jelentős mértékü belpolitikai változásoknak lehettünk tanúi, amelyek KKE államai esetében azon kérdések megfogalmazását teszik indokolttá, hogy a tagjelölt államok milyen ösztönzők és kényszerek eredményeképpen fogadják el az EU intézményrendszere által közvetített formális és nem-formális normákat, jogszabályokat, irányelveket, gyakorlatokat. A szakirodalomban EU-kondicionalitásként megjelenő fogalom az EU által támasztott feltételrendszerre utal, vagyis azoknak az eszközöknek és technikáknak az összességére, amellyel a tagjelölt-államoknak biztosított előnyöket vagy a megítélt források folyósítását konkrét feltételekhez köti (koppenhágai kritériumok). A tagjelölt-államokkal szemben támasztott feltételeknek két csoportját különböztethetjük meg: az első a pénzügyi támogatásra vonatkozik (előcsatlakozási alapok, technikai segítségnyújtás, kereskedelmi és gazdasági előnyök a közöz piacra történő belépéssel), míg a második a társadalmi, ,immateriális jutalomra” vonatkozik, amely a feltételek teljesítésével gyakorlatilag elismeri az adott tagállam európai és demokratikus voltát (Schimmelfennig-Engert-Knobel 2003, pp. 321-322).

Schimmelfennig, Engert és Sedelmeier kutatási eredményeire támaszkodva elmondható, hogy az EU a csatlakozási tárgyalásokban felállított feltételrendszer teljesítését jutalmazta, míg a feltételek teljesítésének elmaradását, esetleges megszegését nem büntette, mivelhogy erre vonatkozóan nem rendelkezett eszközökkel, hanem

\footnotetext{
${ }^{55}$ A KKE-i államok európaizációjának irányára vonatkozóan Heather Grabbe megjegyzi, hogy ebben leginkább az EU intézményeinek hatása érvényesült, annak az aszimmetrikus hatalmi viszonynak betudhatóan, amely egyfelől az EU, másfelől a térség államai között fennállt (Grabbe 2006, p. 4).
} 
visszatartotta a materiális vagy egyéb jellegü jutalmakat (Schimmelfennig-Sedelmeier 2004, pp. 661-79). A térség államainak csatlakozásában az EU által alkalmazott kondicionalitás kisebb kivételektől eltekintve sikeresnek mondható, tudniillik a jutalmazás sokkal hatékonyabb eszköznek bizonyult, mint a javak visszatartása. Epstein, Sedelmeier és Schimmelfennig amellett érvelnek, hogy a kondicionalitás eszközrendszere ott bizonyult különösen sikeresnek, ahol a tagállamok hitelesnek tekintették az EU-s tagsággal járó ösztönzőket, valamint a kormányzó politikai erők meg voltak győződve afelől, hogy az EU-nak való megfeleléssel járó belpolitikai költségek nem veszélyeztetik hatalmuk megtartását (Epstein-Sedelmeier 2008; Schimmelfennig 2005).

A nemzetközi normák elfogadásának és gyakorlatba ültetésének kérdése újabb kutatási irányokat nyitott a konstruktivizmus és az európai integráció szakirodalmában, amely a normák hatásvizsgálatának értékelésére vonatkozóan számos megválaszolatlan kérdést tartalmaz. Mindazonáltal az európaizáció és a kondicionalitás szakirodalmának néhány fontos kérdése rávilágított arra, hogy a normák elfogadása nagyban függ a normaalkotó szervezet által alkalmazott stratégiától, másfelől pedig a tagállamok kormányainak, mint mintakövetőknek a költség-haszon számításaitól, amely a csatlakozási folyamatban egy összetett játékként értelmezhető.

\section{A nemzetközi kapcsolatok elméletei}

A nemzetközi kapcsolatok elmélete nem rendelkezik koherens elméleti kerettel az államközi kapcsolatok elemzésére vonatkozóan, azonban a szakirodalomban számtalan példát találunk arra, hogy az államközi kapcsolatok, valamint egyes államok külpolitikai irányváltásának (foreign policy change) folyamatát a NK elméletének perspektívájából értelmezték. A térség államairól az utóbbi időszakban több fontos mértékadó munka és tanulmánykötet jelent meg, amelyből a teljesség igénye nélkül kiemelhető a német külpolitika rendszerváltás utáni időszakáról készült monográfia (Rittberger 2001), valamint Németország kétoldalú kapcsolatait, a német-francia (Krotz-Schild 2013b), a német-olasz (Dinger 2013), a német-lengyel (Sommer 2015) és a német-cseh kapcsolatokat elemző munkák (Cordell-Wolff 2005). A hivatkozott munkák egyik közös vonása abban áll, hogy a bel- és a külpolitika szintjén lezajlott folyamatokra az elméleti irányzatok (iskolák) által adott magyarázatokat helyezik előtérbe.

Kutatásomban a NK elméletének perspektívájából igyekeztem magyarázatot találni a felek viszonyrendszerének alakulására, annak ellenére, hogy a korábbiakban már történt egy kísérlet, melynek során Ronald H. Linden - akire a szakirodalmi 
áttekintés során már történt hivatkozás -, a NK elméletének várakozásaira alapozva elemezte a magyar-román államközi viszony fejleményeit (Linden 2000). A szerzőt elsősorban az foglalkoztata, hogy minek tudható be a két állam közötti - a realisták által előrejelzett - konfliktus elmaradása, és milyen tényezőknek tudható be a felek közeledése és együttmüködése. Áttakintve a realizmus, a liberális institucionalizmus és a konstruktivizmus irányzatainak fontosabb megállapításait a magyar-román kapcsolatokra nézve arra a megállapításra jut, hogy önmagában egyik irányzat sem szolgál kellő magyarázattal a felek között létrejött együttműködésre. A két állam közeledésében az európai fórumok bővítési stratégiájának - konkrétan a NATO csatlakozás feltételeinek megjelenése 1995 szeptemberében - kulcsszerepe volt, ami Linden szerint a nemzeti érdek újraértelmezését, és ezzel a belpolitikai konfliktus felvállalását is jelentette (ibid. pp. 134-137).

Mindazonáltal a bő szakirodalmi hivatkozásokra épülő tanulmánynak több hiányosságát érdemes kiemelni, ami arra késztetett, hogy újragondoljam elméleti fejtegetését, több okból is. Elsősorban kiemelném, hogy a szerző realizmus értelmezése csak a konfliktus kialakulásának a lehetőségére korlátozódik - hasonlóan az előző fejezetben hivatkozott szerzőkhöz -, aminek eredményeként egy redukcionista realizmus-kép tárul elénk. A hatalomra törekvő államok viselkedése nem biztos, hogy csak a konfliktusdimenzióban érhető tetten: a keleti hegemón eltűnése - a Szovjetunió felbomlása - után Magyarország és Románia tényleges szuverenitásuk visszaszerzésére, a térségbeli befolyásuk növelésére és a külpolitikai döntéshozatalban nagyobb autonómia megszerzésére törekedett. E célkitűzéseket akár a nemzeti érdek újrafogalmazásaként is felfoghatjuk, amely kezdetben korlátozott, majd folyamatosan bővülő együttmüködést kívánt meg a két állam részéről, relatív nyereséget remélve az együttműködésből.

Másodsorban Linden elemzése megítélésem szerint túl államközpontú: annak ellenére, hogy helyén kezeli az európai fórumok szerepét és térségre gyakorolt befolyását, nem tekint kellő fontosságot az ellenzéki csoportoknak és pártoknak, a térségben tevékenykedő nem-kormányzati szervezeteknek, valamint a magyarság képviseletét ellátó RMDSZ-nek, amely számos alkalommal közvetített Budapest és Bukarest között. Az elemzés további hiányossága a NK elméletének konstruktivista iskolájához köthető. Linden a magyar-román viszony konstruktivista olvasatában helyesen - a normák identitásalakító szerepét emelte ki, azonban arról már kevés szó esik, hogy az integráció folyamatában ezek a normák hogyan és mennyiben befolyásolták a két állam identitását. Végül pedig megválaszolatlan marad még egy 
további probléma, nevezetesen az, hogy az egyéni, állami és európai szinten meghozott döntések között milyen kölcsönhatások fedezhetők fel, ezek pedig milyen mértékben befolyásolták a külpolitikai döntéshozatalt, végső soron pedig a kétoldalú kapcsolatokat.

A soron következőkben a fontosabb iskolák rövid áttekintésére teszek kísérletet, melyek megítélésem szerint közelebb visznek a magyar-román államközi kapcsolatok mélyebb megértéséhez, a szereplők közötti dinamikák és érdekérvényesítési lehetőségek feltárásához.

\subsection{Az államközi kapcsolatok realista értelmezése}

A nemzetközi kapcsolatok realista elmélete Kiss J. László szerint azért meghatározó szakirodalomban, mert egyrészt a szakértők jelentős részének, de a gyakorló politikusok számára is az elsődleges kiindulópont, mely a nemzetközi viszonyokról a „legmeggyőzőbb magyarázattal szolgál”, másrészt pedig a realizmus a „legvitatottabb elméleti tradíció a politikaelméletben”, amely a hidegháborút követően a globalizáció, a politika transznacionalizációja és a hatalom átalakulásának időszakában számos kihívással szembesült (Kiss J. 2009, p. 220). E kihívások jelentős változásokhoz és hangsúlyeltolódáshoz vezettek az elméleti irányzaton belül, aminek következtében megnehezítik egy egységes definíció vagy realizmus kép felvázolását. ${ }^{56}$

A realizmus elméletében a hatalom fogalma meghatározó jelentőséggel bír, ugyanis Hans J. Morgenthau (1948) szerint a nemzetközi kapcsolatokat a hatalomért folytatott harc (struggle for power) jellemzi, így az államok közötti kapcsolatok legföbb jellemzője a hatalomközpontúság, ami két tényezőre vezethető vissza. Egyrészt a hatalomért folytatott folytonos harc következtében az államok között a versengés és az együttműködés különböző formái lelhetők fel, ugyanis minden államot sajátos önérdeke és túlélése vezérel, annak érdekében, hogy hatalmukat maximalizálják és a rendelkezésre álló erőforrások birtokában, minél nagyobb befolyást szerezzenek meg. Másrészt pedig a hatalomközpontúság a nemzetközi politika rendszerszintü jellemzőjéből is következik. Kenneth Waltz a Theory of International Politics c. múvében kifejti, hogy a rendszer rendező elve két típusú lehet: míg az államok szintjén a politikai rendszerek centralizáltak és hierarchikusak, addig a nemzetközi rendszer ennek éppen az ellentéte: decentralizált és anarchikus (Waltz 1979, p. 88). A rendszer anarchikus - világkormány nélküli - jellegéből adódóan az államok elsődleges

\footnotetext{
${ }^{56}$ Jack Donnelly a realizmus elméletéről szóló munkájában a realista szerzők munkáira alapozva az elméleti irányzat több mint 50 jelentésváltozatát, reprezentatív meghatározását mutatta be (Donnelly 2000, pp. 7-11).
} 
célkitüzése a nemzetközi rendszerben saját túlélésük (survival) biztosítása és hatalmuk maximalizálása. Azonban, az államoknak arra vonatkozó célkitüzése, hogy biztonságukat szavatolják, más államok részéről bizonytalansághoz vezethet, nemzetbiztonsági kockázatként értékelve a másik állam megerősödését. ${ }^{57}$

A realisták között egyetértés van abban, hogy a nemzetközi politika legfontosabb aktorai az államok, melyek funkciójukat tekintve hasonlóak: noha politikai és intézményrendszerüket tekintve vannak közöttük különbségek, területük felett joghatósággal rendelkeznek és mind a bel-, mind a külpolitikában szuverénnek tekinthetők. Waltz szerint az államok közötti különbségek leginkább a hatalmi képességek tekintetében érhetők tetten, azonban a hatalom fogalmának nincs egy általánosan elfogadott meghatározása. ${ }^{58}$

A nemzeti hatalom elemeinek a beazonosítására több kísérlet ismert, a legtöbb szerző a katonai, gazdasági és a technikai képességek különböző formáit emelték ki. ${ }^{59}$ Morgenthauhoz és Waltzhoz képest Joseph S. Nye a kemény hatalom (katonai, gazdasági hatalom) valamint a puha hatalom (politikai eszmék, kultúra, márka, oktatás, sport, tudomány) eszközrendszerének különbségeire hívta fel a figyelmet: míg az előbbi konkrét ösztönzőkkel, többnyire fenyegetéssel fejtheti ki hatását, addig az utóbbi alapja a meggyőző erő lehet (Nye 1990, pp. 153-171). A hatalomról szóló újabb munkájában Nye azt emeli ki, hogy egyetlen állam külügyi vezetése sem támaszkodhat a hatalom egyik vagy másik dimenziójának érvényesítésére. Ehelyett a döntéshozók - mutat rá a szerző - a kemény és a puha hatalom eszközeinek ötvözésére kell törekedniük, melyet okos hatalomnak (smart power) nevez (Nye 2012, p. 121; 235).

A realisták képviselőinek többsége elismeri ugyan, hogy az államok nem az egyetlen szereplői a nemzetközi politikának. Az államok mellett megjelenő más szereplők - nemzetközi és regionális szervezetek, nemzetközi nem-kormányzati szervezetek, transznacionális vállalatok, agytrösztök - is befolyásolhatják a nemzetközi kapcsolatokat, főként regionális és globális problémákat jelenítve meg a nemzetközi politika napirendjén: azonban szerepük, az erős államok - nagyhatalmak - befolyása

\footnotetext{
${ }^{57}$ A külpolitikai célkitüzések félreértelmezését követően alakul ki a biztonsági dilemma, ennek pedig egyik legfontosabb megnyilvánulási formája a fegyverkezési verseny, amely a fegyveres konfliktusok kialakulásának legalapvetőbb okozója. A biztonsági dilemma fogalmáról lásd: (Herz 1950, pp. 157-180).

${ }^{58}$ David A. Baldwin például a hatalom meghatározásának két változatát hangsúlyozta: míg az első a nemzeti hatalom elemeinek a felleltározását jelentette, addig a második a hatalom fogalmának viszonylagosságára hívta fel a figyelmet, ez utóbbi a más államokhoz való kapcsolatokban értelmezhető (Baldwin 2013).

59 Morgenthau a nemzeti hatalom nyolc elemét különböztette meg (földrajzi helyzet, természeti erőforrások, ipari kapacitás, haderő, lakosság, nemzeti jelleg, nemzeti morál, valamint a diplomácia minősége), míg Waltz hét elemet sorol fel: lakosság és a terület nagysága, erőforrások, gazdasági képességek, katonai erő, politikai stabilitás (Baumann-Rittberger-Wagner 1999, p. 255).
} 
nélkül mindvégig korlátozott marad (Waltz 1979, p. 88; Ripsman-Taliaferro-Lobell 2016, p. 35). Ebből következik egy további vita az elméleti irányzat képviselői között, nevezetesen az, hogy a rendszerszintű tényezők, avagy a belpolitikai tényezők meghatározók a külpolitikai döntéshozatalban. A kérdésre a neoklasszikus realizmus képviselőitől érkezett a legfigyelemreméltóbb válasz (Rose 1998), akik amellett érvelnek, hogy a döntéshozók a rendszerszintü hatásokra adandó külpolitikai döntések meghozatalakor esetenként több opció közül választhatnak, azonban a megfelelő szakpolitika kiválasztásának folyamatát az állam szintjén nagymértékben meghatározzák a közbeeső változók (intervening variable), mint pl. a vezető személyisége, az állam-társadalom, valamint az alkotmányos berendezkedés (Ripsman-Taliaferro-Lobell 2016, pp. 61-79). A közbeeső változók árnyalják az államok viselkedését meghatározó rendszerszintü tényezőket, következésképpen a döntéshozók azon szakpolitikai lehetőségek közül választanak, melyek a külső tényezők és az állam szintjén létrejött döntéshozatal eredményeként születnek (ibid. p. 34).

A hatalomért folytatott harc és a hatalomra törekvés az államok kül- és szomszédságpolitikai magatartásában és stratégiájában is meghatározó lehet. A realista elmélet két magatartásmódot különböztet meg, melynek segítségével az államok meglévő hatalmi képességeiket arra használják fel, hogy érdekeiket a lehető leghatékonyabb módon érvényesítsék. Rittberger és szerzőtársai szerint az autonómiairányultságú külpolitikai magatartás legfontosabb célkitűzése a szuverenitásból eredő függetlenség visszaszerzése és más államokkal vagy nemzetközi szervezetekkel szembeni függetlenségének megtartása, illetve megerősítése (Baumann-Rittberger-Wagner 1999, pp. 257-258). A szerzők szerint az autonómiairányultságú külpolitika megnyilvánulási formája lehet többek között az, amikor (1) egy állam nem teljesíti az államközi- és többoldalú megállapodásokból eredő kötelezettségeit vagy (2) visszautasítja az erre vonatkozó újabb kötelezettségeket (ibid p. 258, idézi Kiss J. 2009, pp. 260-261), esetenként (3) formálisan, saját politikai érdekei mentén szelektíven értelmezi vállalásait. Ezzel szemben a befolyásirányultságú külpolitikai magatartás arra irányul, hogy az adott állam igyekszik más államokra, nemzetközi szervezeteke befolyást gyakorolni, és megteremteni azt a keretet, melyben sajátos érdekeit érvényesítheti (ibid. p. 259). E külpolitikai stratégia legfontosabb terei a 
nemzetközi, valamint a regionális szervezetek lehetnek, ahol az érdekérvényesítési lehetőségeket az államok relatív hatalma határozza meg. ${ }^{60}$

A nemzetközi kapcsolatokban Magyarország és Románia kis, illetve közepes államoknak tekinthetők, a hatalmi képességek realista értelmezését figyelembe véve nem léphetnek fel nemzetközi szintéren olyan „nagy stratégiával”, amely a nemzetközi politika, illetve a nemzetközi rendszer struktúráját alapvetően befolyásolhatná. Mi több a 90-es évek első felében mindkét állam katonai és védelmi szempontból is gyengének bizonyult, amely belső strukturális válsággal is párosult, ami kizárta egy esetleges konfliktus kialakulásának a lehetőségét. Mindazonáltal a realizmus elméletének kiindulópontját képező hatalomközpontúság alapján mindkét állam külpolitikai érdekérvényesítése az utóbbi két és fél évtizedben arra irányult, hogy a diplomácia eszköztárával hatalmát és befolyását növelje, a szomszédos államokkal szemben pedig megőrizze relatív hatalmát.

A rendszerváltás időszakában Magyarország és Románia külpolitikai magatartása az autonómiairányultságú külpolitika fogalmi keretében értelmezhető, ami az integráció kontextusában befolyásirányultságú magatartássá alakult át, azzal az előre kijelölt célkitűzéssel, hogy az elnyert tagság által legitimálják a bel- és külpolitika napirendjén szereplő döntéseket, valamint befolyást szerezzenek az európai fórumok szervezeti keretei között. E két külpolitikai stratégia váltakozása az államközi kapcsolatok jelentősebb momentumaiban is kimutathatók, ugyanis míg a magyar diplomácia jelentős erőforrásokat fordított a határon túli magyarság problémáinak tematizálására az európai fórumok előtt, addig az érintett felek - így Szlovákia és Románia - többnyire tagadták e problémák létét és formálisan, a belpolitikai megkötöttségek figyelembe vételével értelmezték az emberi jogokra és a kisebbségekre vonatkozó normákat.

A két állam viszonyának vizsgálatában a konfliktus elmaradásával ugyan csökken a realista elmélet magyarázó ereje, azonban külpolitikai magatartásformák arra engednek következtetni, hogy külpolitikai érdekérvényesítésükben fellelhető egy lappangó/rejtett realista stratégia, amely arra irányult, hogy az átalakuló globális és regionális viszonyok közepette megtartsák, és ha a lehetőségek engedik, erősítsék pozícióikat. Ez különösen igaz azokra az államközi vitákra, melyek jelentősen befolyásolták a romániai magyarság helyzetét és az RMDSZ érdekérvényesítési

\footnotetext{
${ }^{60}$ Rittberger és munkatársai elemzésükben megjegyzik, hogy mind a kisállamok, mind a nagyhatalmak törekedhetnek e két típusú magatartásból következő külpolitika folytatására, azonban az utóbbiak jóval nagyobb eséllyel valósíthatják meg erre irányuló célkitúzéseiket (ibid. p. 260).
} 
potenciálját, annak ellenére, hogy az elméleti irányzat nem számol a kisebbségek képviseletét ellátó politikai szervezetekkel.

\subsection{A liberalizmus és a liberális institucionalizmus}

A NK liberális elmélete a realizmussal szemben határozza meg önmagát, mert egyrészt nem osztja a realisták anarchiára épülő, pesszimista világképét, másrészt pedig a konfliktus hangsúlyozása mellett, az együttmüködés eltérő módozataira helyezik a hangsúlyt. Az elmélet képviselöi hangsúlyozzák, hogy a nemzetközi kapcsolatokban elképzelhető a „fejlődés”, ugyanis a demokratikus berendezkedés terjedésével csökken a konfliktus kialakulásának a lehetősége, továbbá előtérbe kerülnek azok a felfogások, melyek az állam jogi alapjának és a jog uralmának (Rechtsstaat) a megteremtésére irányulnak, szemben az állam, mint a hatalom (Machtstaat) megtestesítőjére vonatkozó elképzelésekkel (Jackson-Sørensen 2013, p. 101).

A hatalom-központúsággal és anarchiával szemben a liberalizmus egyik központi fogalma az államok és a nem állami szereplők közötti együttmüködés, legyen annak az alapja a közös érdekek és problémák felismerése, a kölcsönös függőségből eredő nyereség, vagy éppen a kényszer. Együttműködés akkor jön létre, állítja Robert O. Keohane, amikor „egy politikai koordináció folyamatán keresztül a szereplők viselkedésüket más szereplők tényleges vagy várható preferenciáihoz igazítják" (Keohane 1984, p. 51). Ebből kiindulva a szerző az együttműködés fogalmának három változatával operál: (1) harmónia: amikor az egyik szereplő célkitüzése automatikusan elősegíti a másik állam preferenciáját; (2) viszálykodás: az egyik fél által megfogalmazott célkitüzések a másik fél politikai céljait hátráltatják és fordítva; (3) konkrét együttműködés: a felek között fennáll a konfliktus bizonyos formája, azonban valamilyen belső vagy külső tényező hatására változnak a viselkedési mintázatok (patterns of behavior) (ibid. pp. 52-53).

A két elméleti irányzat közötti lényeges különbség a nemzetközi szervezetek szerepére vonatkozik. A NK liberális elmélete a realizmussal szemben nemcsak hogy elfogadja a nemzetközi rendszer pluralitását, hanem azt állítja, hogy a nemzetállamok mellett a nem állami szereplők és a transznacionális szervezetek is alakító tényezői a nemzetközi politikának. Andrew Moravcsik például amellett érvel, hogy a liberális elmélet szempontjából az államok, a társadalmi szereplök és a transznacionális szervezetek egyaránt lényeges, azonban az állam külpolitikai preferenciáinak kialakításában elsősorban a társadalmi szereplök és az intézményrendszer közötti érdekközvetítés válik meghatározóvá (Moravcsik 1997, pp. 516-517). Ebben a 
folyamatban Moravcsik a „transzmissziós szíjak” létét feltételezi, az állam és a társadalmi érdekek között olyan közvetítő intézmények és mechanizmusok meglétét, mint pl. politikai pártok, választási rendszer, NGO-k, köz- és államigazgatás rendszere, melyek interakciói nyomán kialakulnak az állam által képviselt külpolitikai preferenciák (ibid. p. 518). E preferenciák összessége Moravcsik szerint a nemzetközi rendszer alapvető eleme, amely attól függően, hogy a konfliktust vagy az együttmüködés bizonyos formáit részesíti előnyben, eltérő hatást gyakorol az állam külpolitikájára.

Moravcsik és a liberalizmus további képviselőinek álláspontja alapján elmondhatjuk, hogy az elméleti irányzat gyakorlatilag az államot nem tekinti egységes, fekete doboznak, hanem sokkal inkább olyan szereplőnek, amelynek magatartását, külpolitikájának alakulását mind belső (pl. politikai intézmények, döntéshozatali mechanizmusok, koalícióépítés, maga a közvélemény vagy a társadalom percepciói), mind pedig a külső tényezők (interdependencia, nemzetközi szervezetek) befolyásolják. Ez utóbbi felfogás egy nagyon fontos szemléletbeli különbséget is jelent a realizmushoz képest, mert a liberálisok az alulról-felfele vagy a bentről-kifele megközelítéseket helyezik előtérbe, és meggyőzően érvelnek amellett, hogy az államon belüli viszonyok és folyamatok határozzák meg az állami és nem állami szereplők együttmüködésének alakulását (Burchill 2005, p. 57).

A NK liberális elméleti iskolája több ponton is hozzásegíthet az államközi kapcsolatok megértéséhez, főként az együttmüködés elősegítésében vagy akadályoztatásában részt vevő szereplők érdekeinek és motivációnak feltárásában. A realizmussal ellentétben, a liberalizmus együttműködés-értelmezése nem a relatív előnyökre, hanem olyan kedvezőbb helyzetre fókuszál, melyben mindkét fél győztes pozícióban (win-win situation) találja magát. ${ }^{61}$ Ennek következtében az együttmüködés fenntartása és mélyítése mindkét fél elemi érdekév válik.

A kommunizmus bukása és térségünkben bekövetkező rendszerváltás lehetővé tette a liberális konszenzusra épülő politikai és gazdasági berendezkedés kiépítését és a nyugat-európai biztonsági és gazdasági szervezetekbe való betagozódást, ami növelte a NK liberális elméletének magyarázóerejét. A KKE-i államok együttműködésében az európai integráció fontos hajtótényezőnek bizonyult, amit ugyan különböző

\footnotetext{
${ }^{61}$ A neorealisták által követett relatív előnyökre épülő stratégia számtalan alkalommal megakadályozta az együttmüködést. Amint azt Reus-Smit is kifejti, azok az államok, melyek relatív előnyük megtartásában érdekeltek, inkább lemondanak az együttmüködésről, ha kiderül, hogy a másik állam relatív előnyre tehet szert. Érvelését a szerző két állam közötti kereskedelmi együttműködés lehetőségével szemlélteti: ha az A államnak 100 millió dollár, míg a B államnak 200 millió dollár nyereséget hozhatna az együttmüködés, az A állam kész elállni az együttmüködéstől, mivel ő nem az abszolút (mindkét fél nyerhet), hanem a relatív előny megszerzésében érdekelt. Ebben a modellben pedig, egy esetleges együttműködés során az A állammal szemben a B állam relatív elönye növekedne (Reus-Smit 2005, pp. 191-92).
} 
időpontokban, de a térség politikai elitjei stratégiai célkitüzésként fogadtak el. Az európai integráció folyamata a magyar-román államközi kapcsolatokban és a külpolitikai érdekérvényesítésben is változásokat eredményezett, aminek legalább két következményét érdemes kiemelni. Egyrészt azt, hogy az európai fórumok által megfogalmazott elvárások és viselkedési minták a politikai napirend részévé váltak, másrészt pedig azt, hogy a kormányzati-politikai döntések meghozatala, illetve ennek alakítása kikerült a kormány-ellenzék dimenziójából, és a döntéshozatal bizonyos szintjein más aktorok - társadalmi szereplök, közvetítő intézmények, valamint az európai fórumok különböző intézményei - jelentek meg az állam külpolitikai-európai preferenciáinak alakításának igényével. A teljesség igénye nélkül említést érdemelnek a meghatározó politikusok és véleményformálók, a pártok és érdekcsoportok, a kisebbségek érdekvédelmi szervezetei, a nem kormányzati szervezetek, amelyek sajátos érdekérvényesítési stratégiákkal léptek fel, annak érdekében, hogy erősítsék a politikai, gazdasági és más jellegü pozícióikat. ${ }^{62}$ Ez a megközelítés szakít a realisták által vallott egységes, racionális állam modelljével, és olyan államon belüli és államon kívüli intézmények és szervezetek egyidejü létét feltételezi, akik eltérő érdekek és preferenciák alapján cselekednek.

A liberális elmélet a két állam között fellelhető együttmüködés megértését is elösegítheti, mert választ adhat olyan kérdésekre is, mint pl. milyen területeken figyelhető meg a felek közötti kölcsönös függés és az együttmüködés milyen formái jöttek létre az államközi kapcsolatokban. A rendszerváltást követő két és fél évtizedben Magyarország és Románia viszonyát számos olyan kérdés terhelte, amely a bel- és külpolitikai fejlemények függvényében a „viszály” és konkrét együttmüködés jelentéstartományában értelmezhető. A disszertáció második részét alkotó három esettanulmányban foglalkozom a külpolitikai döntéshozatalban részt vevő intézmények döntéshozatalban játszott szerepével, a feltárt mechanizmusok pedig hozzásegíthetnek a magyar-román kapcsolatok dinamikájának és a különböző szintű együttműködések jellegének jobb megértéséhez. Igyekszem továbbá arra is válaszolni, hogy mivel magyarázható a két állam közötti harmónia a katonai és védelmi kérdésekben, míg más területeken - így a magyarság helyzetéről és a kisebbségi jogok biztosításáról - jelentős viták alakultak ki a felek között. A vizsgálat továbbá hozzájárul azoknak a szükséges

\footnotetext{
62 A külpolitika alakításában releváns társadalmi csoportok operacionalizálását és osztályozását Derk Bienen, Corinna Freund, Volker Rittberger végezte el. A szerzők a következő aktorok között tesznek különbséget: (1) politikai szereplők - akik politikai-adminisztratív pozíciójukat választások során szerezték meg; (2) adminisztratív szereplők - pozíciójukat kinevezés útján, a formális-legális procedúráknak megfelelően kapják; (3) vállalatok és gazdasági érdekcsoportok, szakszervezetek; (4) társadalmi és politikai érdekcsoportok (Bienen-Freund-Rittberger 1999, pp. 11-14).
} 
lépéseknek a felvázolásához, melyeket a „beágyazott bilaterializmus” létrejötte érdekében a feleknek meg kell tenniük. ${ }^{63}$

\subsection{Szociál-konstruktivizmus}

A nemzetközi kapcsolatok materialista és liberális hagyományain nyugvó elméletei mellett a '80-as évek fordulóján egy új elmélet irányzat, a szociál-konstruktivizmus jelent meg, melynek a jelesebb képviselői - Nicholas Onuf, Alexander Wendt, Peter Katzenstein - az eszmék és a kultúra normaalakító szerepét helyezték elemzésük középpontjába, és amellett érveltek, hogy a nemzetközi rendszer legfontosabb jellemzőinek tekintett anarchia, önsegély (self-help), szuverenitás nem strukturális adottságok, hanem olyan „képződmények”, melyek kialakítása és fenntartása az államok identitásával, illetve ennek változásával hozhatók összefüggésbe. Az iskola képviselői az addig uralkodó materiális struktúrák helyett a normák, identitások és eszmék szerepét hangsúlyozzák a nemzetközi rendszer és a szereplők kölcsönhatásának vizsgálatában, abból a feltételezésből kiindulva, hogy a mentális struktúrák, a társadalmi normák, valamint az elit meggyőződései befolyásolják a külpolitikai döntéseket, egyben pedig a nemzetközi rendszer struktúráját is. Mi több, a konstruktivisták azt állítják, hogy a szereplők preferenciái és a rendszer alkotóelemei társadalmi konstrukciók eredményei, melyben a normák és a különféle szabályok két fontosabb funkcióval bírnak a nemzetközi politika szereplőire nézve. Egyrészt szabályozzák a nemzetközi politika szereplőinek tevékenységeit, másrészt pedig alakítják vagy megteremtik a müködési keretfeltételeket (Harnisch 2010, p. 103). ${ }^{64}$

A szociál-konstruktivizmus elméleti és módszertani megközelítése jelentős különbségeket mutat az eddig tárgyalt elméleti iskolákhoz képest, amely az irányzat fogalmi apparátusában is tetten érhető. Mindenekelőtt a nemzetközi rendszer struktúrafogalmában jelentkeznek ellentétek: míg a neorealisták a hatalmi képességek megoszlását tekintik a struktúra egyedüli alkotóelemének, addig a konstruktivisták a társadalmi kapcsolatoknak tekintenek kiemelt figyelmet. Wendt szerint a társadalmi struktúráknak három alkotóelemük van: közös tudat, anyagi erőforrások és gyakorlatok

\footnotetext{
${ }^{63}$ A Krotz és Schild által bevezetett fogalom a francia-német államközi viszonyt jellemző mély intézményi együttmüködésére utal, amely mind a formális intézményekben, mind a különböző együttmúködési mintázatokban beazonosítható. A beágyazott bilateralizmusnak két fontos dimenzióját különböztették meg a szerzők, egyrészt az államközi kapcsolatok, másrészt pedig az Európai Unió szintjén, illetve ennek intézményeiben (Krotz-Schild 2013a, 2013b).

${ }^{64}$ A szerző Alexander Wendt-re hivatkozva a szuverenitással magyarázza a normák funkcióit. Wendt szerint a vesztfáliai államrendszer szempontjából alapvető szuverenitás-elv a kölcsönös állam-elismerést követően fejtette ki hatását, amely szabályozta a szereplők viselkedését (be nem avatkozás, egyenlőség) másrészt pedig létrehozta magát a szereplőt is (szuverén állam). Lásd bővebben: (Wendt 1999, p. 182).
} 
(Wendt 1995, p. 73). A közös tudat egy bizonyos jelenségröl elöre kialakított tudásformát közvetít, amely csak akkor nyer értelmet, ha valamilyen anyagi erőforrásra vonatkozik és csakis addig tekinthető irányadónak, amíg a szereplők az előre kialakított közös tudat mentén cselekszenek. Ebböl az államközi kapcsolatokban gyakorlatilag az következik, hogy szövetséges állammal baráti, míg ellenséges állammal konfliktusos viszonyt lehet kialakítani, melyet nagymértékben befolyásolnak és végső soron újratermelnek a történelmi tapasztalatok és a politikai elit meggyőződései.

Wendt hasonló logika mentén dekonstruálja a neorealisták nemzetközi rendszerét meghatározó anarchia fogalmát is. Az elméleti irányzat szempontjából klasszikusnak tekinthető tanulmányában az ellen érvel, hogy a neorealisták által központi fogalomnak tekintett önsegély és hatalmi politika nem vezethető le az anarchiából, mert egyik sem tekinthető az anarchia jellemzőinek (Wendt 1992, pp. 39495). „Az anarchia az, amit az államok létrehoznak” - hangsúlyozta Wendt, az egyik legtöbbet idézett konstruktivista megállapítást. A szerző álláspontja szerint nem a hatalmi képességek, vagy az államok önsegélyre alapozott stratégiái határozzák meg azt, hogy egy rendszer anarchikus-e vagy sem, hanem az állam elöre kialakított identitása és preferenciái. $^{65}$

A szociál-konstruktivizmus központi problémája a normák kérdése a nemzetközi kapcsolatokban, aminek kontextusában az irányzat nagy hangsúlyt fektet a szereplők és a struktúra változására, ugyanis a társadalmi normák változásával az állam preferenciái is változásnak vannak kitéve: alulról a társadalom részéről, fentről pedig a nemzetközi kapcsolatokat meghatározó normák, szereplők és intézmények részéről. Ebben a tekintetben fontossá válik a szociológiától kölcsönözött fogalom, a szocializáció folyamata, mert a konstruktivisták számára alapvető fontossággal bír annak megértése, hogy mivel magyarázható az állami preferenciák oly mértékü változása, amellyel egy állam megfelel a nemzetközi szervezetek által támasztott érdekeknek és követelményeknek? A kérdésre adandó egyik választ a normák intézményesülésében kell keresnünk, míg a másik része az európai integrációval, legfőképpen az európaizáció folyamatával és a csatlakozással járó feltételrendszerek teljesítésével került a szakmai érdeklődés középpontjába.

\footnotetext{
${ }^{65} \mathrm{Az}$ önsegély, hasonlóan az anarchiához társadalmilag konstruált - fejti ki a szerző -, mivel olyan interakciós folyamat eredményeként jön létre, amelyben a felek úgy cselekszenek, mintha a másik veszélyt jelentene rájuk, aminek eredményeképpen nem bíznak egymásban (ibid. p. 406). A versengő vagy önző identitás bizalmatlanságot okoz, mivel ha az egyik aktor viselkedése fenyegető, a másik is arra kényszerül, hogy az legyen - vonta le következtetését Wendt.
} 
A szakirodalomban Martha Finnemore és Kathryn Sikkink (1998) közös tanulmányukban a külső normák intézményesülését egy három szakaszból álló „életciklushoz" hasonlította ${ }^{66}$, ezek elfogadása már közép-, illetve hosszabb távon éreztetik hatásukat, mivel befolyásolják a belső jogi és társadalmi normákat, ezáltal pedig meghatározzák az állam preferenciáinak az alakulását is, végső soron pedig változásokat idéznek elő az államközi kapcsolatokban.

Az államérdek változása nem szükségszerüen a konstruktivizmus sajátossága, ugyanis a neorealizmus és a neoliberalizmus elméleti irányzatok esetében is fennáll a változás lehetősége. A különbség - mutat rá Ian Hurd - abban áll, hogy míg az előbbi a változást társadalmi tényezőknek tulajdonítja, mint pl. uralkodó eszmék és ezek kapcsolata a megélt (történelmi) eseményekhez, addig az utóbbiak a változásokat olyan eszméknek tudja be, melyek szükségleteken alapulnak, mint pl. túlélés, hatalom jólét, biztonság (Hurd 2008, pp. 302-303). Megállapítható tehát, hogy míg e két irányzat a rendszerszintű tényezőkből vezeti le az állam preferenciáinak kialakulását, addig a konstruktivizmus az állam szintjén megjelenített érdekeket tekinti irányadónak. Következésképpen a szociál-konstruktivizmus elméletének hívei ezzel szemben az immateriális struktúrákat befolyásoló érdekek, identitások és értékek megértésére törekednek, az egyén illetve az állam szintjén egyaránt (Reus-Smit 2005, p. 197).

A nemzetközi normák elterjedése, és belső jogrendbe való átültetése a '90-es évek felgyorsuló európai integrációs folyamatával új kutatási irányokat nyitott, mivelhogy új megvilágításba helyezte a nyugat-európai és a volt szocialista blokk államainak viszonyát, mi több a KKE-i államok viszonyában, így a magyar-román kapcsolatokban is változásokat eredményezett. Ebben a folyamatban négy szervezet érdemel kiemelt figyelmet - az ET, az EBESZ, a NATO, valamin az EU -, melyek eltérő stratégiák és feltételrendszerek közepette az általuk képviselt normák elfogadására késztették a térség államait. Kelley a korábbiakban idézett munkájában az európai fórumok tevékenységében két alapvető mechanizmust, a normatív nyomásgyakorláshoz

\footnotetext{
${ }^{66} \mathrm{Az}$ első szakaszban a normák keletkezéséről beszélhetünk, amelyben a normavállalkozók (norm entrepreneurs), bizonyos szervezeti bázis segítségével, igyekeznek meggyőzni az államok kritikus tömegét az adott norma elfogadásáról. A második szakasz akkor veszi kezdetét, amikor a normákat elfogadó országok száma elérte a küszöböt (kritikus tömeget). A normakövető államok a nemzetközi szervezetek segítségével más államokat is a normák elfogadására ösztönöznek, amely egy szocializációs folyamatban érhető tetten. A harmadik szakasz a normák belső elfogadására (internalizálás), a belső jogrendbe történő átültetésére vonatkozik, amely egyben azt is jelenti, hogy a belpolitika szintjén a norma egy szélesebb társadalmi támogatottsággal bír (ibid. pp. 895-905).
} 
kapcsolódó eszközöket és a tagsági feltételrendszerrel összefüggő eszközöket különböztet meg. ${ }^{67}$

A normatív nyomásgyakorlással járó eszközöket térségünk államai jórészt puha stratégiaként érzékeltek, aminek hatására - legyen bármekkora is a hivatkozott dokumentumok listája - kevés esetben fogadták el a nemzetközi normák érvényességét. Az európai fórumok sikere az esetek többségében a konkrét tagsági feltételrendszerektől és pénzügyi támogatásoktól függött, amelyre Kelley is rámutatott hivatkozott munkájában. A normák elterjedése és belső jogrendbe való beültetése tekintetében egy további tanulságot jelent annak felismerése, hogy a szervezetek által alkalmazott ellenőrző mechanizmusok nem tették lehetővé a csatlakozás utáni tényleges monitorizálást. Noha három szervezet - EBESZ, ET, EU - ellenőrzési mechanizmusa ismert, ezek gyakorlati alkalmazása több problémát felvetett a KKE-i államok esetében, mivel elég tág mozgásteret biztosított a tagállamoknak, így az adott intézmények és politikai szervezetek nehezebben érvényesíthették érdekeiket, ha a normával ellenkező magatartást észleltek a tagállam részéről.

A szociál-konstruktivizmus újabb, nem elhanyagolható szempontokra hívta fel a figyelmet az államközi kapcsolatok elemzésében, mivel az 1989-et követő események az elméleti irányzat által is hangsúlyozott tényezők, a kultúra és az identitás felértékelődését, valamint a nemzetközi normák szocializációs szerepének előtérbe kerülését eredményezték. ${ }^{68}$ A KKE-i rendszerváltást követő időszakban térségünkre nagy hatással voltak az európai fórumok, melyek eltérő stratégiákat alkalmazva a nemzetközi normák elfogadására és a belső jogrendbe való átültetésre ösztönözték a KKE-i államokat. A szervezetek által megfogalmazott normatív elvárások és konkrét csatlakozási feltételek következtében elsajátított normarendszer alapvető változásokat eredményezett a szakpolitikák alakításában és az intézményrendszer működésében, amely a szereplők viszonyrendszerének a javulását is előmozdította. Erre alapozva megfogalmazható az a következtetés, hogy az államközi kapcsolatokban bekövetkezö

\footnotetext{
67 A normatív nyomásgyakorláshoz kapcsolódó eszközök az aktorok szocializációjára irányul: nyilatkozatok, megállapítások, útmutatás, ajánlások, találkozók kezdeményezése, (helyszíni) látogatások. különböztet meg. A tagsági feltételrendszerrel összefüggő eszközök pedig kényszerítő jelleggel bírnak a tagjelölt államokra, tudniillik az adott feltételek elfogadása szorosan összefügg a csatlakozási előmenetellel: kapuör-szerepkör, teljesítmény-értékelés és monitoring, modell-szerep, pénzügyi és technikai segítségnyújtás, tanácsadás és twinning, valamint a csatlakozási tárgyalásokkal összefüggő feladatok (Grabbe 2001, idézi Kelley 2004, pp. 7-9; 19-20).

${ }^{68}$ Módszertanilag ez azt jelenti, hogy az ágens-struktúra vitában nem az ágens vagy a struktúra alakító jellegét helyezte a középpontba, hanem azt hangsúlyozta, hogy mind az ágens, mind a struktúra kölcsönösen alakítják egymást. Ebböl következik, hogy az államok identitása, preferenciái nem tekinthetők állandónak, alakíthatók, mi több a belső és külső tényezőknek betudhatóan folyamatos változásnak vannak kitéve.
} 
változásokat a többszintü együttmüködés mellett az elsajátított normák is elősegítették, ugyanis megváltozott a történelmi tapasztalatokra és a politikai elit rövidtávú, választási számításokból kialakított többnyire negatív, konfliktusos mezőben értelmezhető szomszédságképe.

Az elméleti irányzatból kiindulva - a normák elfogadásához kapcsolódóan három kérdéskört kell érintenem. Az első annak rendszerezésére tesz kísérletet, hogy a tárgyalt időszakban a felek milyen normákat és viselkedési mintákat sajátítottak el. Itt azoknak a fontosabb nemzetközi dokumentumoknak és jogszabályoknak a felsorolására törekszem, melyek elfogadása a felek viszonyának alakulásában is kimutatható. A második problémakör szorosan kapcsolódik az elsőhöz és arra próbál választ adni, hogy egy elfogadott normának, milyen mértékben lehetett a gyakorlatban érvényt szerezni. A normával meg nem egyező viselkedés, vagy a jogszabály megsértése milyen gyakorlati következményeket vont maga után a felek viszonyrendszerében? A harmadik kérdés a normával megegyező, valamint a normával meg nem egyező viselkedés belpolitikai vetületét igyekszik feltárni. Ennek egyik legfontosabb színtereit a parlamenti viták anyagai, a felszólalások és beszédek, valamint a vezető politikusok nyilatkozatai, képezik. A társadalom szintjén a választópolgárok percepciói, az időszakos közvéleménykutatások, továbbá a vezető véleményformálók, elemzők helyzetértékelései bizonyultak irányadónak.

A normák belsővé tételének folyamata - főként az integrációt követő időszakban - az európai fórumok normaalakító tevékenységének korlátait is megmutatták, amely számos tanulsággal szolgált a kisebbségi jogok érvényesítésében. A dolgozat esettanulmányaiban több példát találunk majd arra, hogy az európai fórumok stabilizációs stratégiái végső soron a nemzetiesítő államokat juttatták „,helyzetelőnyhöz” az anyaországgal szemben: míg az előzők folyamatosan halogatták a normák belsővé tételét, mi több szelektíven alkalmazták azokat, addig az utóbbiak folyamatosan védekező és magyarázkodó álláspontot voltak kénytelenek képviselni a nemzeti kisebbségek bárminemü támogatása miatt. Ebből a viszonyrendszerből kiindulva, a nemzeti kisebbségeket képviselő etnikai pártok külügyi érdekérvényesítési képessége meglehetősen korlátozott maradt, ugyanis az állami szerveket megkerülő külügyi koalícióépítés „ereje” alig mutatkozott meg a normák elsajátításának időszakában; ez többnyire információcsere folyamatára korlátozódott. 


\subsection{Az angol iskola}

A felvázolt elméleti irányzatok ugyan közelebb vihetnek az államközi kapcsolatokban megmutatkozó viszonyok megértéséhez, azonban nem alapozzák meg kellőképpen kutatásomat, ugyanis a vizsgált periódusban megítélésem szerint a felek közötti meghatározó viták nem csupán az együttmüködés jellegének és intenzitásának meghatározásából, hanem a politikai közösség öndefiníciójából kialakuló vitákból fakadtak. Nevezetesen olyan kérdések kerültek a politikai viták kereszttüzébe, mint pl. a határon túli közösségek védelme, az anyaország által nyújtandó kedvezmények és támogatások meghatározása, valamint a politikai közösség határainak újraértelmezése az állampolgárság intézményének kiterjesztésével. Ez a megközelítés indokolttá tette egy negyedik elméleti irányzat, az angol iskola bevonását elméleti fejtegetésembe, amely nem tekinti „késznek” és „változatlannak” a nemzet, a politikai közösség és állampolgárság fogalmait, mi több a belpolitikai viták és külső hatások eredményeként elfogadja ezek változásait.

Az angol iskola egyike azon elméleti irányzatoknak, amelyet megalakulása óta nem amerikai, hanem többnyire brit kutatók dominálnak. ${ }^{69}$ Figyelembe véve az irányzatnak a nemzetközi kapcsolatokra vonatkozó megállapításait és módszertani megközelítését, elmondható, hogy az angol iskola az eddig tárgyalt három irányzat között helyezkedik el. Egyrészt elfogadja a realisták által hangsúlyozott hatalom jelentőségét a nemzetközi rendszerben és ennek államközpontú megközelítését, másrészt azonban kiemelik a jog és a morális megfontolás szerepét, amely a liberalizmus elméletének egyik központi kérdésének tekinthető (Jackson-Sørensen 2013, pp. 50-51; Dunne 2013, p. 133). E két irányzathoz képest az angol iskola képviselői a nemzetközi rendszert nem az államok rendszereként, hanem az államok társadalmaként (nemzetközi társadalom) képzelik el, amelyben az államok mellett a nem-kormányzati szervezetek és az állam vezetését ellátó egyének egyaránt meghatározóak. Buzan szerint, „miként az emberek mint egyének egy társadalomban élnek, amelyet alakítanak és amely őket is alakítja, hasonló módon az államok is egy nemzetközi társadalomban léteznek, amelyet alakítanak és amely őket is alakítja" (Buzan 2014, p. 13). A nemzetközi társadalom tehát Bull klasszikusnak számító

\footnotetext{
${ }^{69}$ Az irányzat kialakulása Nagy-Britanniában a második világháború után létrejövő, főként a diplomácia és a nemzetközi kapcsolatok iránt érdeklődő oktatók rendszeres találkozóihoz, a British Committee on the Theory of International Politics megalakulásához köthető. A társaság 1959-es magalakulásától kezdődően az amerikai központú mühelyek mellett az egyik legjelentősebb fórumává vált a nemzetközi kapcsolatokat és a diplomáciatörténet érintő vitáknak, amelynek keretében olyan munkák jelentek meg mint Hedley Bull: The Anarchical Society: A Study of Order in World Politics c. könyve (Buzan 2014, pp. 6-12)
} 
meghatározásában azt feltételezi, hogy ,az államok egy csoportja tudatában bizonyos közös érdekeknek és értékeknek, alávetik magukat az együttmüködés közösen felállított szabályainak és müködtetik a közösen létrehozott intézményeket” (Bull 2002, p. 13).

A nemzetközi társadalmat (avagy az államok társadalmát) a felállított szabályok és intézményrendszerek ellenére, továbbra is a rendszer anarchikus állapota jellemezi. Ezt a szükségszerű állapotot azonban nem egy mindentől független rendező elvként értelmezi az angol iskola, hanem társadalmi konstrukcióként, amely összecseng a konstruktivizmus irányzatának megállapításával. Következésképpen a nemzetközi rendszerre, mint anarchikus társadalomra (anarchical society) tekint (Bull 2002). Az elméleti irányzat osztja továbbá a konstruktivizmus egyik központi tézisét, a normák identitásalakító hatását, valamint az ágens és a struktúra egymást kölcsönösen alakító szerepét (Bellamy 2007, p. 77).

Az angol iskola képviselöit intenzíven foglalkoztatja továbbá a rend és az igazságosság kérdése, amely jelentős vitákat eredményezett Bull klasszikusnak számító munkájának megjelenését (1977) követően. A vita a nemzetközi társadalom természetét és az államrendszerben fellelhető közös normák, szabályrendszerek és intézmények kapcsolatát érintette, aminek következtében két egymásnak nem teljesen ellentmondó álláspont, a nemzetközi társadalom plurális, valamint szolidáris változata rajzolódott ki. A plurális (pluralista) megközelítés meglehetősen államcentrikus és a nemzetközi joggal szemben a szuverenitás elvét hangsúlyozza, aminek értelmében a nemzetközi társadalomban alig találunk közös normákat és intézményeket, következésképpen nagy hangsúly helyeződik „a rendezett együttélés és verseny kereteinek megteremtésére” (Buzan 2014, p. 89). Ezzel a hagyománnyal szembehelyezkedik a szolidáris megközelítés, amely az egyénre és a társadalomra fókuszál és az igazságosság, valamint az emberi jogok fontosságát hangsúlyozza (ibid, pp. 113-14).

Buzan nem foglal állást arról, hogy a két irányzat közül melyik szolgál pontosabb magyarázattal a nemzetközi társadalomra vonatkozóan, de kiemeli, hogy a plurális és a szolidáris megközelítés „,sem fogalmilag, sem gyakorlatban nem egymást kizáró pozíciók” (ibid p. 165). Az államokat és a nemzetközi társadalmat alakító intézményeket vizsgálva arra a következtetésre jut, hogy a nemzetközi társadalom alapvetően plurális alapokon nyugszik, de a szolidáris megközelítés az utóbbi évtizedekben számos intézmény alakulását meghatározta. ${ }^{70}$

\footnotetext{
${ }^{70}$ Buzan a következő intézményeket teszi elemzés tárgyává: szuverenitás, területelvűség, hatalmi egyensúly, háború, diplomácia, nemzetközi jog, nacionalizmus, emberek közötti egyenlőség, végül pedig a piac.
} 
Az államközpontú nemzetközi rendszer változásának tényét eltérő mértékben ugyan, de a korábban tárgyalt elméleti iskolák is elfogadják. E változásokat a szakirodalomban gyakran ,poszt-vesztfáliai konstellációként” értelmezik, amely érinti a hagyományos értelemben vett állami szuverenitást (területelvűség, határok), az euroatlanti integrációval pedig a védelmi és gazdaságpolitikai kérdéseket. Az angol iskola képviselői közül Andrew Linklatert behatóan foglalkoztatja azok a változások, amelyek poszt-vesztfáliai korban a területelvüség és a szuverenitás elvére épülő államokat, a politikai közösséget, ezen belül a kisebbségeket és az állampolgárság intézményét érintik. Véleménye szerint, az utóbbi évszázadokban a modern állam sikerét az magyarázza, hogy öt behatárolható területen (erőszak, adózás, politikai identitás alakítása, jogalkotás és vitarendezés, nemzetközi jogalanyiság és a nemzetközi szervezetekben való képviselet) sikerült fenntartania monopóliumát, amelynek birtokában uralta a politikai és gazdasági élet minden területét (Linklater 2007, pp. 94 95). Európában - fejti ki a szerző - a területi állam válhatott a domináns politikai berendezkedés alapjává, mivel „elég nagynak bizonyult ahhoz, hogy a külső veszélyek ellen védelmet nyújtson, ellenben elég egybetartónak ahhoz, hogy egy központból igazgassák" (ibid. 95). Ezek az államok azonban, amelyeknek évszázadokra sikerült elnyerniük állampolgáraik lojalitását számos kihívással szembesültek az utóbbi évtizedekben. Linklater fontos fejleményként értékelte, hogy jelentősen csökkent az államok által alkalmazott erőszak, továbbá egyre inkább irrelevánssá válnak a háborúk (legalábbis Európában), amelyek jelentős szereppel bírtak az európai államépítésben. ${ }^{71}$ A béke időszakában az integráció és a globalizáció alapvető változásokhoz vezetett a gazdaságban, a jogrendszerben pedig átalakította az állam és a gazdasági szereplők viszonyát. Végül pedig, a változások a nemzeti kisebbségek helyzetét is érintették, akik egyrészt kifejezték tiltakozásukat a nacionalista-asszimilációs ideológiák ellen, másrészt pedig megfogalmazták igényüket a politikai képviseletben való részvételre. ${ }^{72}$

A nemzetállamokat érintő változások Linklater véleménye szerint kikezdik azokat a kötelékeket is, melyek „összekapcsolják a társadalom tagjait”, ellenben megteremtik annak a lehetőségét, hogy létrejöjjenek a politikai közösségek újabb formái (Linklater 2007, p. 96), amelyek a szuverenitás és területiség, valamint az állampolgárság újabb változatait hoznák létre. E fejtegetéssel Linklater tulajdonképpen

\footnotetext{
${ }^{71}$ Linklater megállapítása egybecseng Charles Tilly, a történeti szociológia egyik neves képviselőjének a megállapításával, miszerint ,a háború hozza létre az államot, az állam pedig a háborúkat.” (Tilly 1975, p. 42).

${ }^{72}$ A szerző példaként említi a Régiók Bizottságának a megalakulását, vagy a kisebbségvédelem területén az EBESZ keretében a Kisebbségi föbiztosi tisztség létrehozását, valamint a Regionális vagy kisebbségi nyelvek kartájának elfogadását (ibid. p. 93).
} 
azokat a domináns - a nemzetközi kapcsolatok elméletének neorealista irányzatához tartozó - elképzeléseket vitatja, amelyek az államot „késznek és teljesnek” tekintik (Linklater 1998, p. 27, 215; Salat 2011, p. 176). A szerző megállapítása több szempontból is megalapozottnak tekinthető. Mindenekelőtt szükséges kiemelni, hogy az államok egy részének „túlélésében” jelentős problémát okoz területük és határaik védelme egy külső (vélt vagy valós) veszéllyel szemben. További problémát jelent, hogy a létrejött politikai közösségek nem tekinthetők kellően integráltnak: egyrészt az állampolgárság intézményével kizárják az „,idegeneket”, másrészt pedig nem fektetnek kellö hangsúlyt a kulturális megosztottság kezelésének a következményeire, végül pedig az állam vezetésében eljáró illetékesek rendszerint az uralkodó kultúra fenntartásában és újratermelődésében érdekeltek.

Az angol iskola megközelítése szempontjából Magyarország és Románia is a kevésbé kész és teljesnek tekinthető államok közé sorolható. Romániában a magyar kisebbség mindenekelőtt a politikai közösség létrejöttét, illetve a többség által elfogadott narratíva intézményesülését (politikai közösség meghatározása, szimbólumhasználat, történelemszemlélet stb) vitatja (Salat 2011, p. 179), amelyet a román többség többnyire „,belső”, magyar veszélyként értelmez. De hasonló kihívásként, az állam szuverenitását, a nemzet egységét és a román politikai közösség indokoltságát érintő „külső” veszélyként tematizálja a román politikai elit az államközi kapcsolatok napirendjén megjelenő azon kérdéseket is, amelyek érintik a romániai magyarság helyzetét.

A rendszerváltást követően Magyarországon számos esetben folytak viták arról, hogy kik tekinthetők a politikai közösség tagjainak (pl. állampolgársági törvény módosítása), de a parlamenti pártok között a legnagyobb szembenállás a határon túli magyarok helyzetéről és a Magyarországhoz való viszonyukról alakult ki. Ezek a viták a magyar nemzetről folyó öndefiníciós vitákként is értelmezhetők, mi több legitimitásvitaként is, mert a parlamenti pártok egy olyan problémához kellett viszonyuljanak (határon túli magyarok), amely meghatározó kérdése volt a rendszerváltásnak.

A magyar-román államközi kapcsolatok sajátos kontextusában érdekes részletként merül fel a kérdés, hogy racionális aktornak tekintett állam (realizmus) miként jelenhet meg, mint egységes szereplő, ha az állam és a nemzet határai nem esnek egybe. Milyen hatásai lehetnek a kulturális értelemben megfogalmazott nemzetmeghatározásnak a külpolitika és az államközi kapcsolatok szintjén? A magyar külpolitikára vonatkozóan Kiss J. László találóan hívja fel a figyelmet arra, hogy a „magyar nemzet” és a „magyar érdek” megfogalmazása alapvető kérdés, egyben pedig önmeghatározása is a magyar külpolitikának (Kiss J. 2009, p. 282), ugyanis a 
kérdésekre adandó válaszoknak mind a belpolitikában, mind pedig az államközi kapcsolatokban messzemenő következményei vannak, mert befolyásolják az államközi viszonyok napirendjét és a diplomáciai kapcsolatok dinamikáját.

\section{Modellek}

\subsection{Diplomáciai tárgyalások és a kétszintü játszma}

Az egyik legismertebb játékelméleti modell megalkotása, amely az államok közötti együttmüködés dinamikáját, a külső és belső tényezők hatását vizsgálta Robert Putnam nevéhez füződik. A szerző az 1978-as bonni G7-csúcstalálkozón született egyezség hátterét vizsgálva jutott arra a következtetésre, hogy a megállapodást a nemzetközi nyomás és a belpolitikai viszonyok kedvező alakulása lette lehetővé ${ }^{73}$, aminek következtében ,minden vezető azt hihette, hogy a döntés, amit meghoztak, a nemzeti és végső soron a saját - politikai érdeküket is szolgálta" (Putnam 1988, pp. 429-30). A tárgyalások tanulságait levonva azt is mondhatnánk, hogy a döntéshozók két asztalon játszottak - innen a kétszintü játszma kifejezés: egyrészt a belpolitikában igyekeztek minél nagyobb koalíciókat kiépíteni és egyúttal a külpolitikai kérdéseket illetően konszenzusra jutni, másrészt pedig a nemzetközi szinten úgy tárgyalni, hogy azzal belpolitikai sikereket érjenek el (Putnam 1988, pp. 433-434, idézi Kiss J. 2009, pp. 68-69).

A kétszintű játszma azért válik összetetté, mert mind a külpolitika, mind a belpolitika szintjén olyan szereplők jelennek meg, amelyek nyomást gyakoroltak a tárgyaló felekre, a tárgyalások dinamikájára, és jó eséllyel befolyásolhatták azok kimenetelét is. A modell kapcsán Marton Péter elemzésében kiemelte, hogy a két szinten zajló játszma egyik fontos következménye, hogy a játékosok által az egyik asztalon megtett lépése a másik asztalon zajló játékban is lépéseket (döntéseket) eredményez, melyet a közvélemény eltérő módon, sikerként illetve kudarcként is értelmezhet, ez pedig alapvetően befolyásolja a döntéshozó újraválasztását (Marton 2013, pp. 94-95). Ennek alapján megállapíthatjuk, hogy a döntéshozóknak mind a két szinten zajló játékot figyelembe kell venniük, mi több, figyelniük kell a

\footnotetext{
$73 \mathrm{Az}$ egyezmény előtörténetéhez hozzátartozik az is, hogy a részt vevő államok között nem volt egyetértés a gazdasági válságból való kilábalás módozatait illetően. A fegyelmezett gazdaságok, mint Németország és Japán, hevesen bírálták az Amerikai Egyesült Államokat a növekvő olajimport és a dollár árfolyamának zuhanása miatt. A felek végül is egyezségre jutottak: a németek gazdaságélénkítő csomagot vezettek be, Japán elkötelezte magát a 7 százalékos gazdasági növekedés mellett, míg az Egyesült Államok energiatakarékossági programot dolgozott ki. A megegyezés hátterében azonban nemcsak a nemzetközi nyomás, hanem a belpolitikai tényezők - minisztériumok, érdek- és szakértői csoportok - is szerepet játszottak, akiknek érdekükben állt az egyezmény elfogadása azért, hogy a pozíciójukat erősítsék (ibid. pp. 427-429).
} 
tárgyalópartnerük bel- és külpolitikai pozíciójára is ahhoz, hogy a külpolitika asztalán szerzett sikereket a belpolitikában kamatoztatni tudják.

A nemzetközi szinten zajló tárgyalások és az azok nyomán megkötött szerződések ratifikációja kiváló példáját szolgáltatják az államok közötti kétszintű játszmáknak. A tárgyaló felek, figyelembe véve a belpolitikai viszonyokat és az esetleges külföldi nyomást, kialakítják a szerződéssel szembeni elvárásaikat. Putnam ennek modellezésére vezette be a nyerési halmaz (win-set) fogalmát: ez lényegében azoknak a feltételeknek, érdekeknek az összessége, amelyeket a kormány/delegáció a tárgyalások során képvisel, és el tud fogadtatni a törvényhozással (ratifikáció). A két félnek a szerződéssel szembeni elvárásait, mint ahogy a lenti ábra mutatja, az $\mathrm{A}_{\max }$ és $\mathrm{A}_{\min }$, továbbá a $\mathrm{B}_{\max }$ és $\mathrm{B}_{\min }$ nyerési halmazok adják.

2. sz. ábra: A nyerési halmazok részleges átfedése

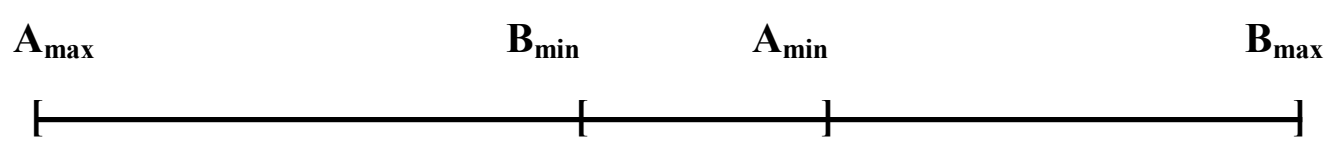

Forrás: (Putnam 1988, p. 441; Marton 2013, p. 94).

A tárgyaló felek által elérhető legnagyobb eredmények $\left(A_{\max }\right.$ és $\left.B_{\max }\right)$ nem lehetnek reális célkitüzések, mivel azokat a felek - kölcsönösen - nem fogadnák el. Ehelyett sokkal inkább egy kompromisszumos változat képzelhető el - mindkét fél abban érdekelt, hogy a minimális követeléseinél valamivel többet érjen el -, amely a nyerési halmazok részleges átfedése ( $\mathrm{A}_{\min }$ és $\mathrm{B}_{\min }$ közötti tartomány) révén valósulhat meg. A tárgyalások során tehát a felek csak akkor juthatnak megegyezésre, ha a nyerési halmazok átfedik egymást. Viszont az is megtörténhet, hogy a nyerési halmazok átfedésére nem félúton, hanem az $\mathrm{A}_{\max }$ vagy $\mathrm{B}_{\max }$ pontokhoz közelebbi tartományokban kerül sor, következésképp a nyerési halmazok eltérő kiterjedésűek lehetnek, melyet Putnam szerint olyan tényezők befolyásolnak, mint pl. az állam mérete, a belpolitikai szereplők preferenciái, az érdekcsoportok és a koalíciók elvárásai, az intézményrendszer, továbbá a felek tárgyalási stratégiái (ibid. pp. 441-443).

Összegzésként elmondhatjuk, hogy a tárgyalási készség az együttműködés nagyon fontos tényezője lehet, ha pedig a kiterjedt nyerési halmaz feltétele is adott, a felek közötti megegyezés valószínűsége - a belső és külső változók figyelembe vételével - magasnak mondható. Magyarország és Románia kapcsolatában az alapszerződés és a státustörvény vitája kiváló példáját adja az érintett felek kétszintű játszmájának, amelyben az ellenzéki pártok mellett más szereplők, így az RMDSZ, a 
nyugat-európai államok és az európai fórumok is érintettek voltak. A viták során kirajzolódó pozíciók, melyeket részletesen ismertetek az esettanulmányokban, rávilágítanak arra az összetett játszmára, melyet a résztvevő állami és nem állami szereplők a bel- és külpolitika szintjén folytattak.

\subsection{A normák belsővé tétele: a spirál-modell}

A normák intézményesülésének Finnemore és Sikkink által bemutatott és korábban tárgyalt életciklus-modellje egy olyan ideális esetet jelenített meg, amely a gyakorlatban számos problémát felvet, fóként azokban az esetekben, amikor egyes kormányzatok belpolitikai érdekekből vezérelve akadályozzák a normák átvételét, mi több, tagadják ezek létét. Ebből a feltételezésből kiindulva Risse és Sikkink egy újabb kutatás keretében az emberi jogok intézményesülését és a tagállamok stratégiáit modellezte, amely a kisebbségi jogok elfogadása szempontjából releváns lehet számunkra. A szerzők által kidolgozott modell öt szakasza segíthet megérteni a transznacionális szereplők, a kormányzat és a társadalom (ellenzék) között zajló, az emberi jogok belsővé tételének folyamatát olyan államok esetében, melyek tagadják e normák létét, vagy tudatosan késleltetik ezek bevezetését (Risse-Sikkink 1999, pp. 1-38).

A ,spirál-modell” első szakaszában az elnyomó állam képezi a vizsgálat tárgyát. Ebben a helyzetben a transznacionális szervezetek megpróbálnak elegendő információt gyüjteni az emberi jogok helyzetére vonatkozóan, hogy azt a nemzetközi közösség elé tárják, olyan hálózatot építve, mely közvetít az ellenzék és a nemzetközi közösség között. ${ }^{74}$ Risse és Sikkink e szereplők közötti dinamika megragadására vezeti be a bumeráng-hatás fogalmát, amely arra a folyamatra utal melynek során a belső ellenzék (pártok, NGO-k, mozgalmak) - kikerülve az állami szereplöket - nagyhatalmak, szomszédos államok, vagy a transznacionális szereplők támogatását kérik (ibid. p. 18).

A második szakaszban az emberi jogok megsértése megjelenik a nemzetközi politika napirendjén, a transznacionális szervezetek különböző lobbi tevékenységekbe kezdenek, és igyekeznek nyomást gyakorolni az érintett államra, amely visszautasítja a vádakat. ${ }^{75} \mathrm{~A}$ harmadik fázisban a növekvő nemzetközi nyomásnak betudhatóan az államok stratégiai lépésre szánják el magukat, „taktikai engedményeket” (tactical

\footnotetext{
74 A szerzők megjegyzik, hogy az elnyomás szintje a transznacionális szervezetek mozgásterét is befolyásolja, mert ha egy államban túl nagy elnyomás van, az egyfelől akadályozza a szervezetek müködését, másfelöl pedig a belső ellenzéknek nincsen arra lehetősége, hogy az információt továbbítsa transznacionális szervezeteknek.

${ }^{75}$ Ebben az esetben az állam más-más stratégiát követhet: (1) nem ismeri el az adott normát; (2) amellett érvel, hogy a tagállami gyakorlat megfelel a nemzetközi normáknak; (3) a belügyekbe való beavatkozásként értékeli a kritikákat; (4) nacionalista érzelmekre alapozva igyekszik ellensúlyozni a külső beavatkozást (ibid. p. 23).
} 
concessions) tesznek, amely az emberi jogok helyzetének javítására irányul. Ez az engedmény ugyan nem hoz alapvető változásokat az adott állam nemzetközi normához való viszonyában, de megteremti a belső ellenzék megerősödésének lehetőségét. Noha ebben a fázisban még nem beszélhetünk a norma elfogadásáról, azonban válaszul a külső és belső nyomásra az állam az instrumentális alkalmazkodás (instrumental adaptation) mellett dönt. A szerzőpáros kifejti, hogy az államok esetenként ratifikálnak egy nemzetközi szerződést, tárgyalnak a nemzetközi közösség képviselőivel vagy az ellenzékkel, ha stratégiai érdekük megkívánja, anélkül, hogy elfogadnák az adott normát (ibid. 12).

A modell következő szintje a „preskriptív státusz”, amely arra utal, hogy az államok elfogadják a normák létét, a politikai diskurzusukban, mind belföldön, mind pedig külföldön hivatkoznak is rá, ez azonban nem jelenti azt, hogy tiszteletben is tartják az emberi jogokat. A normák elfogadása szempontjából döntőnek bizonyul, hogy az államok túllépnek-e vagy sem instrumentális alkalmazkodás eszközein és a normák érvényességének elfogadása megjelenik-e a kormányzatnak a belpolitikai szereplőkkel, más államokkal és szervezetekkel folytatott kapcsolataiban és diskurzusaiban. ${ }^{76}$

A normák preskriptív státusza a külső és belső nyomás következtében megteremti a normák intézményesülésének és belsővé tételének lehetőségét, amely a spirál-modell utolsó szakaszát képezi. Az államokat ekkor már a szabálykövető magatartás (rule-consistent behavior) jellemzi, mivel az állami intézmények elfogadják az adott normákat és olyan törvényes kereteket alkotnak meg, melyek biztosítják a normák betartását.

Az emberi jogok elfogadása számos hasonlóságot mutat a kisebbségi jogok elfogadásával, ugyanis a rendszerváltás utáni Romániában hasonló mintázatokat és gyakorlatokat vélünk felfedezni a kisebbségi jogok intézményesülésével kapcsolatosan, amely tovább erősíti a modell magyarázóerejét és gyakorlati alkalmazhatóságát. Az empirikus részben kitérek Románia kisebbségi jogokhoz való viszonyára és az ezekkel kapcsolatos vitákra, mivel a kisebbségi jogok elfogadása és a magyar közösség jogainak biztosítása folyamatosan szerepelt az államközi kapcsolatok napirendjén. A modell további érdeme, hogy hozzásegít a normák intézményesülésében részt vevő szereplők

\footnotetext{
${ }^{76}$ Ennek értékelésére Risse és Sikkink négy indikátort vezetett be: (1) emberi jogokra vonatkozó nemzetközi szerződések, és jegyzőkönyvek ratifikációja; (2) normák belsővé tétele (alkotmány, jogszabályok); (3) intézményesített mechanizmusok, melyek az emberi jogok megsértésére vonatkozó állampolgári panaszokat kezelik; (4) a kormány diszkurzív gyakorlatában is elfogadja e normák érvényességét, a kritikákat nem kezeli belügyként, és törekszik a párbeszédre (ibid. p. 29).
} 
pozícióinak az értelmezéséhez, így ahhoz is, hogy milyen szerepet játszott az RMDSZ a kisebbségi jogok romániai intézményesülésében.

\subsection{Brubaker hárompólusú viszonyrendszere}

Kutatásom szempontjából egy harmadik modell is segíthet a szereplök közötti viszonyok értelmezésében. A Rogers Brubaker által kidolgozott analitikus keret a nacionalizmus-elméletekből kiindulva újabb megvilágításba helyezte azokat a vizsgálatokat, melyek a térség államai és a kisebbségi közösségek viszonyrendszerét állították középpontba (Brubaker 1996, 2006a).

Brubaker modelljét három releváns szereplő dinamikus kapcsolatára építi: adott egyrészt két állami szereplő, másrészt pedig egy kisebbségi közösség, amely az egyik államhoz „legális állampolgárság” révén, a másikhoz pedig „etnokulturális affinitás” alapján tartozik. E viszony legfontosabb következménye abban érhető tetten, hogy a kisebbségekre egymással két „kibékíthetetlen” folyamat hat, az állam nemzetiesítő nacionalizmusa (nemzetiesítő állam) és az anyaállam nacionalizmusa (anyaállam vagy anyaország) (Brubaker 2006, pp. 14-15). A hárompólusú kapcsolatrendszer tehát a nemzetiesítő állam, az anyaállam és a nemzeti kisebbségek közötti dinamikák eredményeként jön létre, azonban Brubaker arra hívja fel a figyelmet, hogy e szereplők „,nem szilárd entitások”, hanem relacionális fogalmak, változó és „,folyamatosan vitatott politikai mezők" (ibid. 2006, p. 65).

A három pólus első elemét a nemzeti kisebbség alkotja és olyan dinamikus (vagy egymással versengő) állapotot jelöl, amely törekszik egyrészt az állal általi elismerésre, másrészt különböző politikai és kollektív jogokat követelnek. A szerző által felvázolt keret egy lényeges pontja, hogy a kisebbségekre nem „egységes csoportként” tekint, hanem olyan versengő mezőre, mely többszereplős: szervezetek, politikai pártok és politikai vállalkozók törekednek arra, hogy a közösség legitim képviselőiként lépjenek fel. A nemzeti kisebbséget képviselő szereplők helyzetükből adódóan különböző stratégiákat követnek. Amint arra a szerző rámutat a szereplők ,alapállása” nagy változatosságot mutat, legalább három tekintetben. Elsőkén a követelések megfogalmazásában, a kisebbségi jogok kivívásában (az anyanyelvhasználat jogától a területi autonómiáig), jelentkezhetnek különbségek, másodsorban pedig abban, hogy az adott közösség részt vegyen-e vagy sem (az együttmüködés kizárása, szeparatizmus) az állam irányításában. Végül pedig a külső szereplőkhöz való viszony is jelentős viták terepét képezheti, arra nézve, hogy a nemzeti kisebbségek szempontjából mennyiben 
indokolt az anyaállam, más államok, esetleg nemzetközi vagy regionális szervezetek támogatását kérni (ibid, pp. 65-68).

A nemzetiesítő állam szintén egy dinamikus helyzetet jelöl, amelynek jellemzője, hogy az állam legitim „tulajdonosának” az államalkotó nemzetet tekinti (ibid. p. 14), mi több képviselői az államra mint „megvalósulatlan” nemzetállamra tekintenek. E felfogás eredményeként a politikai döntések, a különböző szakpolitikák és programok, valamint a diskurzusok arra irányulnak, hogy növeljék a többségi nemzet „politikai hegemóniáját”. Brubaker szerint a nemzetiesító államok nem minden esetben fogalmazzák meg nyíltan „pozíciójukat”, ami nehézséget okozhat az operacionalizálásban, egyben pedig felértékeli a percepció jelentőségét. Abban az esetben is nemzetiesítő egy állam - véli a szerző-, ha a másik két szereplő, az anyaország vagy a kisebbségi közösség képviselői az állam egészét (politikákat, szimbólumokat és egyéb gyakorlatokat) annak ,észlelik” (Brubaker 2006 pp. 68-71).

Az anyaország - hasonlóan az előzőekben tárgyalt két fogalomhoz - egy dinamikus egymással akár versengő alapállást jelöl, amelynek alapja a határon túl élő nemzetrészek iránti felelősségvállalás. Brubaker szerint egy állam akkor válik anyaországgá, amikor (1) a politikai elitek azonos nemzetiségűként kezelik vagy a nemzethez tartozóként értelmezik egy szomszédos vagy más állam állampolgárait; (2) a „közös nemzeti mivoltra” hivatkozva felelősséget vállalnak az „etnikai rokonok iránt” (ibid. p. 15). A szerző itt is hangsúlyozza, hogy az anyaállamon belül jelentős vitákhoz vezethet egyrészt a felelősségvállalás tartalmának meghatározása, amely az anyaországi szerep tagadásától a nemzeti kisebbségeket megcélzó programokon keresztül az állampolgárság megadásáig terjedhet, másrészt a kisebbségi közösségekkel kialakított kapcsolatok jellege, végül pedig a nemzetközi fórumokon való kisebbségvédelmi fellépés indokoltsága (ibid. pp. 71-72).

A szerző által kidolgozott modell újszerü jellege abban áll, hogy az entitásokat nem tekinti elve „statikusnak”, hanem a mezők (külső) dinamikus jellegére, és a mezőkön belüli versengő helyzetekre hívja fel a figyelmet (ibid. pp. 72-73). A hármas viszonyrendszerben a mezőkön belüli és mezők közötti relációk összefüggnek, „a kölcsönhatás válaszszerü és interaktív" abban az értelemben - mutat rá Brubaker - hogy a szereplők figyelemmel kísérik a másik mezőben zajló folyamatokat és jelentős vitákhoz vezethet a mezők szereplői között egy másik mezőben zajló folyamat interpretációja, amelynek az esetek döntő többségének gyakorlati (politikai) következményei is vannak. Példaként a nemzetiesítő állam intézkedése - a nemzeti kisebbség számára kedvezőtlen jogszabály gyakorlatba ültetése - hozható fel, amely a 
másik két mezőben is változásokat eredményez. Míg az anyaállam részéről a nemzeti kisebbségek támogatását, és a nemzetközi fórumokon való erőteljesebb fellépést, a nemzeti kisebbségek esetleges radikalizálódását és a nemzetiesítő állam reakcióját eredményezheti.

A „hármas konfiguráció” mint elemzési keret bevett modellnek számít azon társadalomkutatók körében, akik térségünkben a többség-kisebbség viszonyával, valamint az etnikumközi kapcsolatokkal foglalkoznak, mert egyrészt nem tekinti egységes aktornak a relacionális mező szereplőit, másrészt a korábbi elméleti irányzatoktól eltérően nagyobb magyarázóerővel bír az anyaország (Magyarország), a nemzetiesítő állam (Románia) és az RMDSZ (kisebbségi közösség képviselője) viszonyrendszerére vonatkozóan.

\subsection{A modellek bírálata}

Annak ellenére, hogy Putnam, Risse és Sikkink valamint Brubaker modellje széles körben elterjedt a szakirodalomban, a kidolgozott modelleket egyrészt aktorközpontú bírálatok érték (kik tekinthetők az egyes modellekben a releváns szereplőknek, e szereplők milyen viszonyban vannak egymással), míg mások arra hívták fel a figyelmet, hogy kidolgozottságuk ellenére nem nyújthatnak elegendő magyarázatot térségünk az államközi és a többség-kisebbség viszonyának vizsgálatában.

A kétszintü játszma modelljében Putnam a két szinten zajló tárgyalási mechanizmusokra helyezi a hangsúlyt, ezzel ellentétben pedig kevés figyelmet szentel a tárgyalásokban részt vevő szereplőkre és a szereplők közötti viszonyokra. Annak ellenére, hogy a szerző a bel- és a külpolitika szintjén meghozott döntések folyamatának vizsgálatában bírálja az államközpontú megközelítést és azt a felfogást, amely az államot egységes (és racionális) szereplőként tünteti fel (Putnam 1988, pp. 432-33), mégsem elemzi részletekbe menően azokat a szereplőket, melyek akár a belpolitika, akár a külpolitika szintjén befolyásolják a döntéshozatalt. Ebből kifolyólag az ellenzéki pártok és érdekcsoportok mellett Putnam nem számol a kisebbségi közösségek képviseletét ellátó etnikai pártokkal, illetve ezek meghatározó képviselőivel.

A modell továbbá azért tekinthető államközpontúnak, mert az elemzésben a szerző a nemzetközi szintet csupán az államközi kapcsolatokra, tehát a két állam interakciójára korlátozza és nem veszi figyelembe a belpolitika és a nemzetközi kapcsolatok szintjén zajló érdekérvényesítés transznacionális dimenzióját (Morin 2010, p. 312). E felfogás arra enged következtetni, hogy a belpolitika szintjén megjelenő szereplők, a nemzetközi intézmények és európai fórumok ugyan befolyásol(hat)ják a 
felek viszonyát, ösztönzően hatnak egyes döntések meghozatalára, azonban az államközi kapcsolatokban alakításában a két állami szereplő a meghatározó.

Az erre irányuló megközelítéseket vitatják azok a szerzők, akik a nemzetközi és regionális szervezetekben vizsgálják az érdekegyeztetés folyamatát és más szereplők, esetenként egy harmadik fél befolyását vélik meghatározónak. Patterson a háromszintü játszma bevezetését (three-level games) javasolta a modell kiegészítéseként, arra hivatkozva, hogy az EU-s szakpolitikák alakításában egyrészt a tagállami érdekek, másrészt pedig az EU egyes intézményei, főként pedig az Európai Bizottság szerepe meghatározó (Patterson 1997). A háromszintü modell az etnopolitikailag mobilizált közösségek esetében is irányadó lehet, azokban az esetekben, amikor a többség-kisebbség viszonyát a külső szereplők nagymértékben befolyásolják. ${ }^{77}$

Végül pedig a kétszintü játszmát azért érték bírálatok, mert Putnam kevés táppontot ad arra vonatkozóan, hogy az egyes szereplők milyen stratégiákat kellene kövessenek ahhoz, hogy a lehető legjobb eredményt érjék el. Amint arra Putnam rámutatott, a nyerési halmazok méretét számos tényező meghatározza, azonban ez csak részben magyarázza a kimeneti oldal eredményeit. Leonard Schoppa (1993, pp. 383-86) szerint ennél meghatározóbb szereppel bír a főtárgyalók stratégiája, amely egyrészt arra irányulhat, hogy az adott problémát a szélesebb közvélemény elé tárja, másrészt pedig az alternatívák ismertetésével befolyásolja a döntéshozatalt mindkét érintett államban.

A kétszintü játszma modelljével szemben a Risse-Sikkink által kidolgozott spirál-modell kevésbé államcentrikus, mert a hangsúlyt nem az emberi jogokat megsértő államokra helyezi, hanem a transznacionális hálózatra (emberi jogi szervezetek, államok), melyek az ellenzéki csoportokkal együttmüködve az emberi jogok intézményesülésének előmozdításában érdekeltek. Jeffrey Checkel a modellről készült könyvrecenziójában úgy látja, hogy a szerzőpáros a felülről érkező hatások hangsúlyozásával másodlagos szerepet szán az állami intézmények képviselőinek, akik nem passzív szemlélői a nyomásgyakorlásnak, hanem sajátos célkitüzéseik mentén cselekszenek (Checkel 2000, p. 1339). Ebböl következik, hogy a szerzők elöre adottnak tekintik a szocializáció eredményét, amely az államok normakövető magatartásában nyilvánul meg. Ennek kapcsán Jetschke és Liese a modell idealista jellegére mutat rá, amiért a szerzőpáros nem számolt az esetleges visszarendeződéssel, vagy annak a

\footnotetext{
77 Paul Kubicek a török-kurd kérdésben fontosnak tartotta a nemzetközi szereplök (emberjogi szervezetek) és az európai fórumok szerepét, amelyek mérsékelték ugyan a felek által képviselt álláspontokat, ellenben a belpolitikai viszonyoknak betudhatóan (emberi jogok helyzete) nem járult hozzá a háromszintű játszma által megteremtett dilemma feloldásához (Kubicek 1997, pp. 79-101).
} 
lehetőségével, hogy a demokratikusnak tekintett államokban is sérülhetnek az emberi jogok (Jetschke-Liese 2013, pp. 33-34).

Vitatható továbbá az is, ahogyan az államok a transznacionális hálózatok tevékenységének eredményeként elsajátítják az adott normát. A KKE-i államok NATO és EU-integrációja rámutatott a normatív ösztönzők korlátaira és felértékelte a tagsági feltételrendszerek, esetenként pedig a nyugati államokat, valamint a nagyhatalmi befolyás szerepét, olyan esetekben is, amikor a nemzeti érdek átértelmezése vagy a szuverenitás kérdése került napirendre. A modell további hiányossága, hogy a nyugati államok mellett nem számol az anyaállamokkal, akik érdekeltek az etnikai, nyelvi és kulturális értelemben vett nemzettársak emberi és kisebbségi jogainak biztosításában, ennek érdekében pedig támogatják a kisebbségi politikai szervezet(ek) külügyi tevékenységét, erősítve ezzel az államra nehezedő külső nyomást.

Az utóbbi két évtizedben a Brubaker által kidolgozott modellt - nagy népszerüsége ellenére - számos bírálat érte, több kutató pedig arra tett kísérletet, hogy pontosítsa, illetve kiegészítse a modellt, növelve ezáltal a hárompólusú viszony magyarázó erejét. A kritikák egy része a szereplök közötti viszonyok eltérő értelmezésére mutatnak rá, míg mások aktorközpontú megközelítésből azt róják fel a szerzőnek, hogy túlértékelte egyik, vagy másik mező szerepét, ezáltal pedig a felvázolt relációs mező kevésbé dinamikus, mint ahogyan azt Brubaker feltételezte.

Taras Kuzio tanulmányában amellett érvelt, hogy a brubakeri modellt alkalmazó szerzők pontosabb kritikai észrevételek megfogalmazása nélkül vették át és alkalmazzák a nemzetiesítő állam fogalmát. A nemzetépítés folyamatát vizsgálva a szerző kiemeli, hogy mivel Brubaker a „nemzetiesítő állam” fogalmát csupán a posztkommunista államokra korlátozva alkalmazta, nem tudott túllépni a polgári és (etno)kulturális nemzetfelfogás dichotómiáján, mi több „a posztkommunista nemzetépítéssel szemben a nyugat-európai és észak-amerikai nemzetépítést eszményíti” (Kuzio 2001, p. 144). Érvelésében Kuzio kifejtette, hogy a poszt-kommunista államokra rávetített „nemzetiesítő” szerep a liberális demokráciáknak tekinthető nyugat-európai államok politikáit is jellemzi, Charles Tilly-re hivatkozva pedig kiemeli, hogy minden európai kormány tett a lakosság homogenizációját célzó lépéseket” (Tilly 1975, p. 44, idézi Kuzio, 2001, p. 144).

Brubaker a hárompólusú viszonyrendszerben alapvetően egy folyamatos konfliktusos viszonyt ír le. Noha kifejti, hogy a nemzetiesítő állam, az anyaállam és a nemzeti kisebbség kapcsolatrendszere „nem mindenhol és nem mindig jár konfliktusokkal”, azonban a mezők kölcsönhatása és az eltérő „,nacionalizmusok” nem 
csökkentik, hanem inkább növelik a konfliktus kialakulásának a lehetöségét, amint azt Jugoszlávia példáján szemlélteti. A felvázolt viszonyrendszert többen túl statikusnak tartják, mert a szerző nem számolt a mezőkön belüli jelentősebb változásokkal, így az EU-s csatlakozást megelőző intézményi változásokkal sem (Harris, 2009), vélhetően azért, mert a versengő pozíciók már eleve meghatározzák a szereplők egymáshoz való viszonyát, amely a többséggel folytatott együttmüködés és a fegyveres konfliktus felvállalása közötti tartományában értelmezhető (Brubaker 2006, p. 64-74). Ennek kapcsán Jenne a modell korlátaira mutat rá, ugyanis a „triadikus viszony” kimenetele elméleti szempontból bizonytalan, mert nem jelzi elöre, hogy mely esetekben következhet be a szereplők radikalizációja, illetve mikor fordulhat visszájára a „radikalizációs spirál” (Jenne 2007, p. 38). A felmerülő problémákat Brubaker a „társadalmi és politikai cselekvésben rejlő esetlegességgel” magyarázza, mivel meglátása szerint - a relacionális mezőn belül nem lehet előre látni és pontosan megmagyarázni, hogy „milyen nemzetiesítő alapállás, milyen kisebbségi önértelmezés és milyen anyaország-politika válik uralkodóvá" (ibid. pp. 80-81). E folyamatokban rejlő „esetlegességek” jelentős mértékben korlátozzák a modell előrejelző funkcióját.

A nemzetiesítő államok szerepének újragondolása mellett az anyaország szerepének túlértékelése is megjelent a kritikai szakirodalomban. Michele E. Commercio az észtországi és kazahsztáni orosz kisebbség helyzetét vizsgálva arra mutat rá, hogy a nemzetiesítő politika és a gazdasági körülmények sokkal nagyobb hatással vannak a kisebbségek pozícióira, mint az orosz külpolitika, ami azon túl, hogy hallatja hangját a „közel külföldön” élő nemzettársak érdekében, kevés konkrét lépést tett az ellenük hozott intézkedések megszüntetéséért (Commercio 2010, p. 19). Mi több a kisebbségi közösségek helyzete a diszkriminatív intézkedések ellenére is konszolidálódhat - amint az észtországi oroszok példája mutatja - ha gazdasági helyzetük stabilizálódik. Ezzel szemben a kazah kisebbségpolitika, amely számos akkomodációs jellemvonást tükröz (pl. oktatás és nyelvpolitika), a romló gazdasági pozícióknak betudhatóan, nem tudta lelassítani az orosz kisebbség látványos elvándorlását (Commercio 2004, pp. 26-27).

A modell további értelmezéseiben az jelenik meg, hogy míg Brubaker túlértékelte a relacionális viszony jelentőségét, mások csupán a szereplők (mint egységes aktorok) közötti hármas viszonyrendszerre fókuszáltak. A mezők közötti relacionális viszonyt figyelembe véve Vello Pettai, a hárompólusú viszonyrendszerre építő három kötetről szóló recenziójában azt hangsúlyozza, hogy ha figyelembe vesszük a relacionális mezőben a szereplők eltérő percepcióit és alapállását, akkor a szereplőket 
úgy kellene értelmeznünk, mint (1) akik egymásról szubjektív percepcióval bírnak és (2) a pólusokon belül különböző véleménnyel rendelkeznek (Pettai 2006, p. 133). A szerző szerint egy ilyen értelmezés rendkívül összetetté tenné a modell alkalmazását és megnehezítené az egyes mezők müködésére vonatkozó hipotézisek megfogalmazását, következésképpen a szerzők többsége a modell szükítő értelmezését alkalmazza (ibid. pp. 133-134).

A nemzetiesítő állam fogalmára és a nemzetközi és regionális szervezetek szerepének mellőzésére vonatkozó kritikai észrevételekre Brubaker egy későbbi tanulmányában válaszolt, rámutatva arra, hogy a nemzetiesítő állam fogalma nem egy elmélet, hanem egy fogalmi eszköz (conceptual tool), amely nem jelezheti elöre, hogy „mennyiben lesz nemzetiesítő egy állam és milyen módon lesz nemzetiesítő” (Brubaker 2011, pp. 1807-9). A nemzetiesítő állam a szerző szerint olyan kategória, amelyet megismételve korábbi megállapítását - a következő diskurzusok, politikák és folyamatok jellemeznek: (1) az államalkotó nemzet vagy nemzetiség megkülönböztetett szerepének hangsúlyozása; (2) az államalkotó nemzet az állam tulajdonosa; (3) az államalkotó nemzet nem prosperál, kedvezőtlen helyzetben van; (4) az államalkotó nemzet kultúráját, nyelvét gazdasági és politika hegemóniáját elő kell mozdítani; (5) e lépések kompenzáló jellegének hangsúlyozása, az államalkotó nemzetet ért korábbi elnyomás és diszkrimináció ellensúlyozása céljából (Brubaker 2006, p. 89; 2011, p. 1786).

\section{A négyes viszonyrendszer, mint elemzési keret}

Brubaker modelljét a legtöbben azért illették kritikával, mert a hárompólusú viszonyrendszerre épülő modelljében nem számolt a nemzetközi szervezetekkel és kevés figyelmet fordított a térségünkben igen aktívnak mondható európai fórumok tevékenységének. A szerző munkájában a nemzetközi intézmények több helyen is megjelennek, de nem a triadikus viszonyt közvetlenül befolyásoló mezőként, hanem olyan szereplőként, amelyhez az anyaország vagy a nemzeti kisebbség panasszal fordulhat, tőlük támogatást kérhet (Brubaker 2006, pp. 64, 66), valamint nyomásgyakorló szervezetként (konkrétan említésre került az ET, az EU és az EBESZ), melyek rábírják az új államokat, hogy a kisebbségeket védő jogszabályokat foganatosítsanak (ibid. p. 109).

A térségünkkel foglalkozó szakirodalom érvényes elemzési keretnek tekinti a nemzetiesítő állam, az anyaország, a nemzeti kisebbségek és az európai fórumok viszonyrendszerének vizsgálatát, melyet számos empirikus példa és összehasonlító 
esettanulmány bizonyít. Ezzel a megközelítéssel egyet értve, úgy gondolom, hogy a bemutatott modellekhez képest a négyes viszonyrendszerre épülő analitikus keret az, amely a leginkább megragadja a szereplők közötti többszintü játszmát egy olyan időszakban, amikor a szereplők preferenciáit egyrészt a külső folyamatok, másrészt a többi szereplő „,alapállása” alakította. A szakirodalomból elsőként a modell bevezetése melletti érveket ismertetem és azokat a fontosabb munkákat emelem ki - a teljesség igénye nélkül - melyek az európai fórumok szerepét és befolyását hangsúlyozták. Másodsorban pedig a négyes viszonyrendszerrel kapcsolatos kritikai észrevételeket részletezem, míg végül a dolgozatban alkalmazott, „,kibővített” négyes viszonyrendszer fontosabb jellemzöit ismertetem.

\subsection{A modell bevezetése melletti érvek}

A szakirodalomban hivatkozott szerzők azért tartották indokoltnak a brubakeri modell kiegészítését, mert meghatározó szerepet tulajdonítottak az európai fórumoknak, egyrészt a többség-kisebbség közötti konfliktusok megelözésében, másrészt pedig olyan, a kisebbségi közösségek integrációját célzó jogszabályok elfogadásának szorgalmazásával, amellyel az államközi kapcsolatokat is befolyásolták (Zellner 1999; Galbreath 2003; 2006; Ieda 2004; Kelley 2004; Kemp 2006; Sata 2006; Harris 2007; Galbreath-McEvoy 2010; Kántor 2014).

Elsőként az EBESZ kisebbségi főbiztos tevékenységének az értékelésére vonatkozó összehasonlító kutatásban - amelyre már hivatkoztam korábban - merült fel a hármas viszonyrendszer kibővítése. A kutatásról készült módszertani bevezetőben Zellner nem fogalmazott meg lényegesebb kritikákat a modell kapcsán, de - a nyugati integrációnak betudhatóan - szükségesnek érezte a hármas viszonyrendszer kiegészítését, azon szervezetekkel (NATO és EU), melyek tagsági feltételeket támasztottak a csatlakozó államokhoz (Zellner 1999, p. 26).

Zellnerrel szemben David J. Smith már hangsúlyozta Brubaker „elméletének” hiányosságát és arra hívta fel a figyelmet, hogy bármely KKE-i állam identitáspolitikáját érintő vitában a nemzetközi szervezeteket - az euro-atlanti dimenziót - kell középpontba állítani, aminek eredményeként négyes viszonyrendszerről (quadratic nexus) beszélhetünk. (Smith 2002, p. 9). A szerző úgy látja, hogy az európaizáció - hasonlóan a Brubaker által elkülönített nacionalizmus típusokhoz „,változatosan elrendeződő és folyamatosan vitatott mező” (Brubaker 2006, p. 65), ahol különböző szereplők, államok, szervezetek, pártok és mozgalmak versengnek (Smith 2002, p. 11). Észtország példáján Smith rámutatott arra, hogy az európai normákról és a 
kisebbségi jogokról szóló vitákban - amelyeket a szereplők saját „alapállásuk” szerint értelmeztek - az európai fórumok (EBESZ, NATO, EU) hogyan váltak a relacionális mező „integráns részévé”. Smith mellett Lynn M. Tesser (2003) David J. Galbreath (2003, 2005), Judith Kelley (2004) és Anna Kyrizai (2014) is a brubakeri modell kibővítése és a négyes viszonyrendszer, mint elemzési keret indokoltsága mellett érvelt, annak betudhatóan, hogy az európai fórumok jelentősen befolyásolták a KKE-i államok kisebbségpolitikáját, mi több az integráció folyamatába az európai normák átvételére is sor került.

Az EU keleti bővítésével foglalkozó szakirodalomban is felmerült a triadikus viszony újragondolása. Csergő és Goldgeier elemzésükben azt emelték ki, hogy az integráció jelentősen befolyásolta a nacionalista törekvéseket és hangsúlyozták, hogy miközben a (többségi) nemzet újratermelődését elősegítő intézményes keretek fenntartása képezi a jelenkori nacionalizmus egyik közös pontját, változnak azok a módozatok, ahogyan a különböző szereplők megőrzik és fenntartják az állam területe feletti „fennhatóságukat” (Csergő-Goldgeier 2004, p. 22). Noha jelzik, hogy Brubaker nem számolt az európai integrációval, figyelmük az európai államok nemzetépítési és nacionalista stratégiáinak - hagyományos, állam alatti, transzszuverén és protekcionista - keretezésére irányul. A szerzőpáros arra a megállapításra jut, hogy az integráció folyamatában továbbra is meghatározó a területelvüség és a nacionalizmus. Az integráció és a nacionalizmus nem zárják ki egymást, mi több az EU keretet teremt azon „szövetséges” és „versengö” nacionalista stratégiáknak, melyek nem veszélyeztetik a demokratikus berendezkedést (ibid. p. 32).

A Csergő és Goldgeier által bevezetett transzszuverén nemzetépítési stratégiának a magyar nemzetpolitikában több kormányzati szintủ intézkedése beazonosítható, amely túlmutatott az anyaország és a nemzeti kisebbség viszonyrendszerén. Osamu Ieda (2004) a státustörvényről szóló elemzésében arra mutat rá, hogy a poszt-kommunista államokban elfogadott jogszabályok, melyek a határon túli kisebbségek integrációját célozták, komoly „intézményi kihívást” jelentettek a nemzetépítésre (nemzeti identitás újraértelmezése) és az európai integrációra (megfelelés az EU-s követelményeknek) nézve és arra a megállapításra jut, hogy térségünket a státustörvény-szindróma jellemzi (Ieda 2004, p. 4). A szerző részletesen elemzi az európai fórumok érvrendszerét és a jogszabály elfogadását követően a megfogalmazott kritikákat, ami arra enged következtetni, hogy a vitában megjelenő intézményeket (ET, EBESZ főbiztosa, EU) a relacionális mező részének tekinti (ibid. pp. 31-48). 
A hármas viszonyrendszer bővítésének szükségessége a KKE-i államok integrációja kapcsán, a tagsági feltételrendszerek meghatározásával és a csatlakozó államok kisebbségpolitikáját befolyásoló EU-s intézmények kritikai értékelésével került az érdeklődés előterébe (Johns 2003; Vermeersch 2004). Johns elemzésében arra mutat rá, hogy az EU keretén belül igencsak vitatott a kisebbségekkel kapcsolatos normák helyzete, ami egyrészt az igen eltérő tagállami jogszabályoknak, másrészt a kötelező EU-s normák hiányának tudható be. A tagállamok (Németország és Olaszország) és a tagjelölt államok (Észtország, Lettország, Magyarország) kisebbségpolitikáját vizsgálva azon a véleményen van, hogy „kettős mérce” jellemzi az EU kisebbségekkel kapcsolatos gyakorlatát, ugyanis a csatlakozás feltételrendszerével olyan elvárásokat támaszt a tagjelölt államokkal szemben, melyet számos „régi” tagállam sem teljesít (Johns 2003, pp. 690-99).

Peter Vermeersch vitatja azon sokat hangoztatott szakértői és az EU különböző intézményei által tett megállapításokat, melyek meghatározónak tartják az EU szerepét a KKE-i államok kisebbségpolitikájának változásában. Meglátása szerint ez többnyire arra vezethető vissza, hogy a kisebbségi problémák a kezdeti szimbolikus kérdésektől, normává, az emberi jogok védelmének kontextusában pedig a csatlakozási kritériumok részévé váltak, így a kisebbségvédelem összekapcsolódott a tagsági feltételrendszerrel (Vermeersch 2004, pp. 6-7). A szerző azon az állásponton van, hogy a KKE-i államok kisebbségpolitikájára ugyan hatással volt az integráció, de „ebben nem a bővítés volt az egyetlen és legfontosabb tényező”: míg egyes államok stratégiai megfontolásból, addig mások saját érdekeik mentén - az EU által biztosított mozgástéren belül - módosították a kisebbségekre vonatkozó jogszabályokat (ibid. p. 17).

Ha az európai integráció hatását a kisebbségek helyzetének alakulása szempontjából értékeljük, elmondható, hogy a változások - még abban az esetben is, ha kritikusan tekintünk ezekre - túlmutatnak a kisebbség-többség dimenzióján. A korábbiakban idézett Galbreath és McEvoy tanulmányukban a kisebbségi kérdésre fókuszálva vizsgálták az államközi kapcsolatok alakulását, és arra mutattak rá, hogy az EU intézményei számos esetben - korlátozott módon ugyan -, de pozitív irányban befolyásolták az anyaország és a nemzetiesítő állam viszonyrendszerét függetlenül az adott állam (tagállam, csatlakozó állam, vagy nem tagjelölt állam) státusától. Ennek leggyakoribb módja, amikor az EU a belpolitika szintjén segíti elő a változásokat, amelyek hatással vannak az államközi kapcsolatokra is (Galbreath-McEvoy 2010). Mindazonáltal a tanulmány legfontosabb megállapítása az, hogy kisebbségi 
kérdésekben az integráció számos esetben megmutatta korlátait és változó hatását az anyaország-nemzetiesítő állam kapcsolatára (ibid. p. 375).

\subsection{A négyes viszonyrendszert ért bírálatok}

A négyes viszonyrendszert ért legfontosabb kritikák arra vonatkoznak, hogy a triadikus viszony kibővítésével az európai fórumok is a relacionális mező részévé válnak, avagy nem, illetve mely intézmény, milyen formában alakította a többi szereplő preferenciáját és alapállását.

A fentiekben már idézett Zellner azt az álláspontot képviselte, hogy a négyes viszonyrendszerben az ET és az EBESZ is meghatározó, azonban e szervezeteket azért nem tekintették a modell integráns részének, mivel „puha kötelezettségeket” támasztottak a KKE-i államokkal szemben és a szervezeten belüli tagság sem vezetett „kölcsönös függőségi viszonyhoz” (Zellner 1999, p. 26). Az így kiegészült modellben a szereplök között négy, egymással összekapcsolódó mechanizmus különítettek el: (1) többség-kisebbség viszonyrendszere; (2) kétoldalú-nemzetközi viszony a két állam között; többoldalú-nemzetközi viszony, a két állam és az európai fórumok között; (4) transznacionális kapcsolat, a kisebbség és az anyaország kormánya között (ibid. p. 27).

Elemzésében Kemp is meghatározó szerepet tulajdonít az európai fórumoknak, ennek ellenére nem tekinti a relacionális mező külön pólusának, így nem tartja indokoltnak a négyes viszonyrendszer bevezetését. A szerző egyrészt hangsúlyozza, hogy az európai fórumok a legkülönbözőbb eszközökkel befolyásolták a csatlakozó államokat, a státustörvény vitájában pedig e szervezetek együttmüködése „összehangolt” volt: míg az EU - a bővítés folyamatában - a jogszabály módosítására ösztönözte a kormányt, az ET a Velencei Bizottság által megfogalmazta az irányelveket, addig az EBESZ föbiztosa közvetített a felek között (Kemp 2006, p. 121). Ennek ellenére az európai fórumok és a mező többi szereplője között nem jöhetett létre szerves kapcsolat, amely jelentősen befolyásolná a többi szereplő pozícióját és percepcióját. Kemp szerint az európai fórumok elsősorban keretet és mintákat biztosít azon esetekre, amikor „,a felek a belpolitika és a kétoldalú kapcsolatok szintjén kimerítették a fennálló ellentétek rendezésére vonatkozó eszközöket” (ibid. p.123).

Brubaker a hármas viszonyrendszer kibővítésére vonatkozó észrevételekre nem ad részletező választ. Azt ugyan elismeri, hogy az európai fórumok alkotta „hálózat” (EU, NATO, EBESZ, ET) eltérő mértékben ugyan, de befolyásolta a szereplőket, legfőképpen pedig a nemzetiesítő államokat (Brubaker 2011, p. 1787), azonban ezeket továbbra sem tekinti a relacionális mező részének, hanem a gazdasági függőségre épülő 
hálózatokkal együtt olyan „tényezőknek”, melyek gátat szabhatnak a nacionalista stratégiáknak.

\subsection{A dolgozatban alkalmazott négyes viszonyrendszer értelmezése}

A hármas viszonyrendszerre, valamint ennek kibővített, a négyes viszonyrendszerre vonatkozó kritikai szakirodalom és a röviden ismertetett empirikus példák alapján megállapítható, hogy az államközi kapcsolatokat és a többség-kisebbség viszonyát a négyes viszonyrendszerben indokolt újragondolni. Noha helyesnek érzem és elfogadom Zellnernek és Kempnek a két szervezet szerepére vonatkozó megállapítását, következtetéseikkel nem értek egyet. Az ET és az EBESZ tevékenységéröl készült eddigi vizsgálatok véleményem szerint azt igazolják, hogy ezek a szervezetek is - annak ellenére, hogy más eszközrendszerrel rendelkeznek - a négyes viszonyrendszer részét képezik.

Amint a főbiztos romániai tevékenységét elemző kutatás is rámutatott személyes jelenléte és aktív szerepvállalása az oktatási és nyelvi jogokkal kapcsolatosan jelentősen alakította és befolyásolta a másik két mezőben (nemzeti kisebbség és nemzetiesítő állam) zajló politikai vitákat (Horváth 2002). A külső szereplők befolyása (Velencei Bizottság, EBESZ főbiztos), amint arra a státustörvény kapcsán rámutatok, nemcsak a belpolitika, hanem az államközi kapcsolatok szintjén is meghatározónak bizonyult. A másik érv az ET és az EBESZ szerepeltetésére a kibővített modellben - amely több helyen is visszaköszön a szakirodalomban - arra vonatkozik, hogy az európai fórumok tevékenysége szorosan összefügg, ugyanis a szervezetek azzal is növelték befolyásukat, hogy állandó hivatkozási pontnak tekintették a másik szervezet által elfogadott normákat és dokumentumokat. $^{78}$

A dolgozatban azért érvelek e viszonyrendszer, mint elemzési keret bevezetése mellett, mert a szakirodalom érvényes modellnek tekinti térségünk államközi és a többség-kisebbség viszonyát feltáró folyamatok és ezek következményeinek értelmezésében. A modell alkalmazását továbbá a szakirodalmi áttekintés (I. fejezet) is indokolttá teszi, amelyben ugyan nem törekedtem aktorközpontú megközelítésre, az áttekintésből mégis kirajzolódtak a relációs mező szereplői, a mezők közötti kapcsolatok jellege (konfliktusos, avagy együttmüködésre épülő viszony), valamint a mezőkön belüli alapállások. Elfogadva Brubaker megközelítését, a négyes

\footnotetext{
${ }^{78}$ Galbreath elemzésében kiemelte, hogy a föbiztos akkor is befolyásolhatta a nyelvi jogokat érintő jogszabályok változását, amikor az EU-integrációra és az ET keretegyezményére hivatkozva, nyomás gyakorolt a lett államföre (Galbreath 2006, p. 402)
} 
viszonyrendszerre épülő kapcsolatrendszert dinamikusnak tekintem, melyben változó az egyes szereplők alapállása és folyamatosan vitatott egyik vagy másik szereplő státusa.

A négyes viszonyrendszerre épülő analitikus keretben négy releváns szereplővel számoltam, amelyek változó mértékben és eltérő módon, de befolyásolták a felek viszonyrendszerét. Ebben a relációs mezőben Romániát nemzetiesítő államnak tekintem egyrészt azért, mert a rendszerváltást követően az államot a román nép államaként határozza meg és a jogalkotásában nyíltan vagy burkolt szándékkal az állam nyelvének és kultúrájának elömozdítására törekedett. Ezzel szemben Magyarországra, mint anyaországra tekintek, mert felelősséget vállalt a határon túli magyarságért, ennek következtében pedig gyakorlati szakpolitikai lépéseket is tett, a támogatáspolitika kidolgozásától az állampolgárság megadásáig. A nemzeti kisebbség tekintetében az RMDSZ-re, mint az erdélyi magyarság képviseletét ellátó szervezetre tekintek, noha hangsúlyozom, hogy a versenypártok megjelenésével a Szövetség már nem egyetlen, de továbbra is domináns és meghatározó politikai szereplője a romániai magyar közéletnek. Az európai fórumok alkotják a mező negyedik pólusát, amelyben meghatározó az ET, az EBESZ, a NATO és az EU, valamint néhány nyugati állam (pl. Egyesült Államok, Franciaország, Németország). A vizsgált esettanulmányokban e szereplők alapállása folyamatosan változott, de a rendelkezésükre álló eszköztárral és stratégiákkal befolyásolták a négyes viszonyrendszerben zajló játszmákat.

\section{Összegzés}

A rendszerváltás utáni magyar-román államközi viszony és az erdélyi magyarság viszonyrendszerét a nemzetközi kapcsolatok uralkodó elméleteinek keretrendszerében gondoltam újra. Az elméleti irányzatok áttekintéséből megállapítható, hogy a realizmus, a liberalizmus, a szociál-konstruktivizmus és az angol iskola elméleti irányzatai egymagukban nem adnak kielégítő magyarázatot a két állam és az erdélyi magyarság kapcsolatainak értelmezéséhez, azonban a dolgozat szempontjából a négy paradigma hasznossága egymás kölcsönös kiegészítésében és a folyamatok figyelembe vételével érhető tetten.

A realizmus hatalomközpontú megközelítése azon stratégiák megragadásához és elemzéséhez segít hozzá, mellyel Magyarország és Románia az elmúlt negyedszázadban - a külpolitikai érdekérvényesítés és a diplomácia eszköztárával - hatalmuk és befolyásuk növelésére törekedett. Az átmenet kezdeti időszakában kiéleződő konfliktushangulat a realisták előrejelzéseivel ellentétes folyamatokhoz vezetett, és számos tényezőnek - beleértve a korlátozott katonai erőforrásokat - betudhatóan 
mindkét állam hatalomközpontú törekvése mérsékelt maradt, a közös biztonsági érdekek felismerése pedig a védelmi és a katonai együttműködések létrejöttét eredményezte. Mindazonáltal a két állam autonómia- és befolyásirányultságú külpolitikájában tetten érhető „rejtett realizmus” állandónak tekinthető, amely a változó regionális viszonyok közepette hatalmuk és pozícióik megerősödésére irányult.

A két állam tényleges együttmüködésének keretfeltételeit azonban az európai integrációs szervezetek által megszabott külső feltételrendszerek teremtették meg, mely egy időben a felek közötti, egyre növekvő interdependencia felismerését, végső soron pedig az együttmüködés más területekre való kiterjedését is jelentette. A liberális irányzat az államközi kapcsolatokban fellelhető együttmüködés jelenlegi korlátaira, hiányaira is rámutat, mivelhogy a két fél viszonyában ugyan történtek előremutató lépések - lásd az érvényben levő több mint ötven államközi szerződést, a közös kormányüléseket -, azonban a beágyazott liberalizmus irányába további fontos lépések megtételére volna szükség az elkövetkezendő időszakban. A további együttmüködés pedig egyre összetettebb folyamatot jelent, mert a transznacionalizáció időszakában az állam mellett újabb szereplők lépnek fel a bel- és a külpolitika szintjén az érdekérvényesítés igényével, melynek egyik legfontosabb tanulsága, hogy többszintüvé vált az érdekegyeztetés és döntéshozatal folyamata.

Az államközi kapcsolatokat jelenleg uraló, együttmüködésre épülő perspektívája aligha lenne teljes a szociál-konstruktivista iskola által hangoztatott normák, szabályok és identitások alakító hatásának vizsgálata nélkül. A nyugat európai fórumokhoz való csatlakozás mindkét állam esetében számos norma és jogszabály elfogadását, belsővé tételét feltételezte, amely megnövelte a konstruktivista elmélet magyarázóerejét.

Ezek a normák azonban számos területen, így a kisebbségi jogok terén nem váltották be a hozzá füzött reményeket, egyrészt azért mert döntő többségük nem bírt kötelező érvénnyel, másrészt puhának bizonyultak azok a monitoring eljárások, amelyek müködésüket ellenőrizték volna. Ennek ellenére a Risse és Sikkink által kidolgozott spirál modell fontos lehet a normakövető viselkedés irányába történő lépések és az ezekre adott válaszreakciók beazonosításában, másrészt pedig segít megérteni a négyes viszonyrendszerben zajló érdekérvényesítés szövevényes folyamatát. 
3. sz. ábra: Az elméletek, a folyamatok és a szereplők viszonya

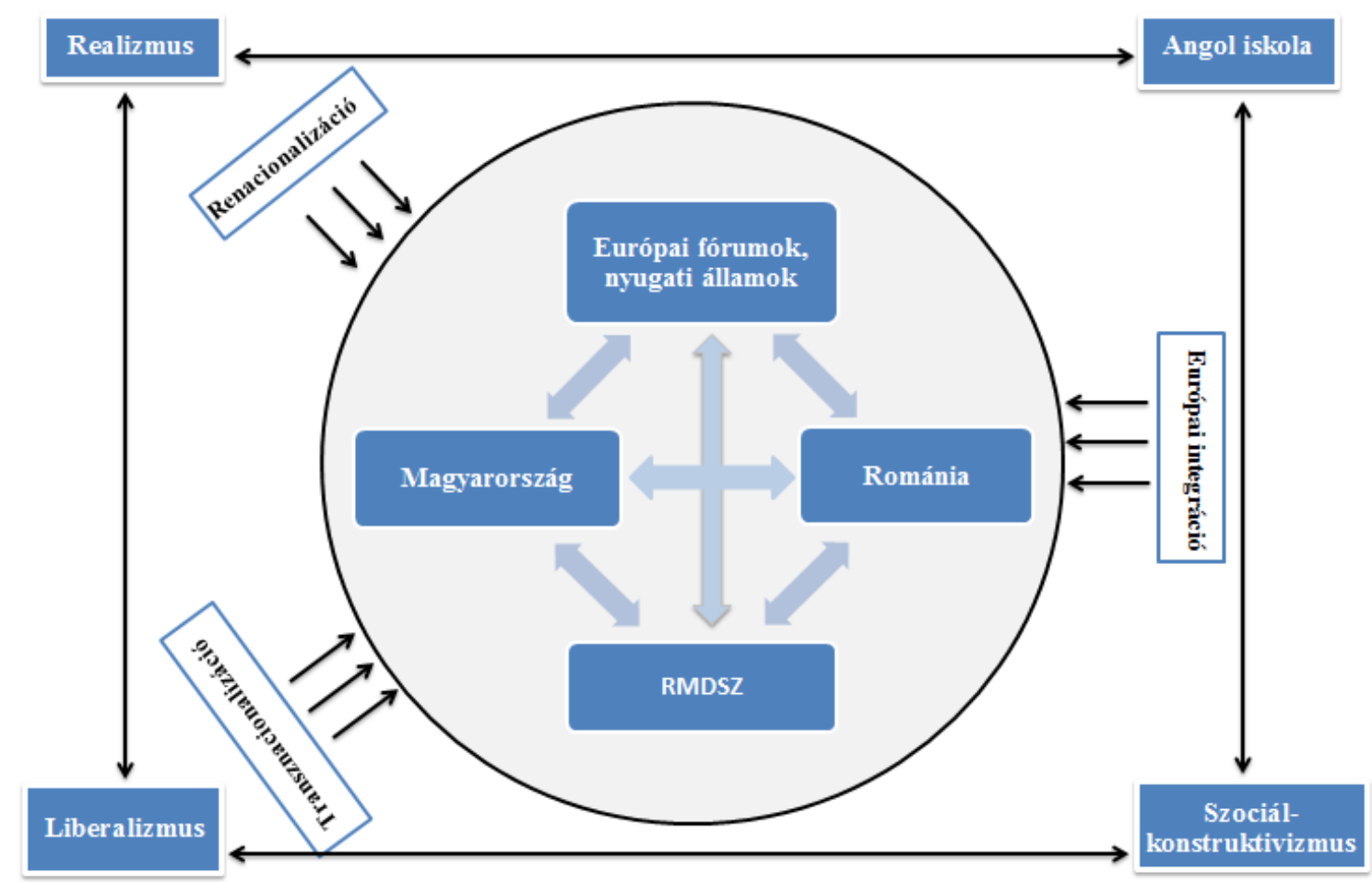

Megítélésem szerint a realizmus, a liberális institucionalizmus, valamint a konstruktivizmus több megállapítást is tesz a vizsgált szereplőkre és a felek közötti viszonyokra, azonban nem kezeli kellö hangsúllyal a szereplöket ért változásokat és azokat a politika napirendjén megjelenő vitákat, amelyek alakítják, és végső soron meghatározzák a szereplőket. Az angol iskola ebben nyújt újabb perspektívákat, mert arra hívja fel a figyelmet, hogy ezek a szereplők folyamatosan változnak és kevésbé készek, mint ahogyan a realizmus elmélete állítja. A dolgozat esettanulmányaiban tárgyalt vitákban ezekre a feltételezésekre igyekszem empirikus példákat adni.

Az elméleti fejezet utolsó részében áttekintett három modell, illetve ezek kritikai értelmezése arra világított rá, hogy a magyar-román államközi kapcsolatok, az RMDSZ, valamint az európai fórumok viszonyát a négyes viszonyrendszerben érdemes újragondolni, amelyben elfogadom egyrészt azt, hogy a modellt alkotó mezők relációs viszonyban vannak egymással, másrészt azt, hogy az egyes viták során a szereplők alapállása jelentősen változhat, végül pedig, amint arra az esettanulmányokban is rámutatok, hogy a mezőt alkotó szereplők státusát egy másik fél folyamatosan vitatja. 


\section{A KUTATÁS MÓDSZERTANA}

A dolgozatban a rendszerváltás utáni magyar-román államközi viszony alakulását, valamint az RMDSZ államközi kapcsolatok szintjén játszott szereplehetőségét vizsgáltam egy olyan időszakban, amikor a KKE-i térség fejlődését, bel- és külpolitikai opcióit korábban példanélküli módon meghatározták a nyugateurópai államok és az európai fórumok bővítési stratégiái. Mivel e folyamat diplomáciatörténeti áttekintése, valamint a külpolitikai döntéshozatal és érdekérvényesítés szempontjából történő vizsgálata túlmutatna a disszertáció keretein, három nemzet- és kisebbségpolitikai szempontból releváns döntés - az alapszerződés, a státus- vagy kedvezménytörvény, a kettős állampolgárságról szóló vita és a könnyített honosítási eljárás - kiválasztását tartottam célszerűnek. Választásom elsősorban azért esett e három döntésre, mert noha eltérő súllyal és eltérő időszakban, de megjelentek és egy hosszabb időszakon át uralták az államközi kapcsolatok napirendjét. Míg az alapszerződés tárgyalásai az integráció előtti viszonyokra világítottak rá, addig státustörvény a csatlakozási folyamatban vált meghatározó vitává. A kettős állampolgárság és a könnyített honosítási eljárás kérdése pedig már egy azonos szövetségi rendszerhez tartozó államok viszonyáról ad áttekintést, a jelentősebb vita elmaradása pedig annak tudható be, hogy mindkét állam elismerte a kettősállampolgárság intézményét és hasonló állampolgárság-politikát folytatott.

A dolgozat megírása során több kutatási módszert és eljárást alkalmazok állításaim alátámasztására és a kutatási kérdések megválaszolására. A két állam közötti, diplomáciatörténeti események felvázolásánál, az alapszerződés tárgyalásainak megkezdéséig tartó időszak elemzésénél a történeti feltáró módszert alkalmazom: a vizsgált időszak bemutatását és elemzését az eddigiekben feltárt források és dokumentumok, az erről megjelent szakirodalom, valamint saját kutatásaim és alapján végeztem el. Az összegyüjtött és rendszerezett külügyminisztériumi iratok vizsgálata az alapszerződés tárgyalásainak folyamatába, az érdekérvényesítés meghatározó pillanataiba enged betekintést nyerni. Ebből a felismerésből kiindulva a dokumentumok és sajtóanyagok alapján összeállítottam a három esetre vonatkozó tárgyalási kronológiát, amelyet a dolgozat függelékében helyeztem el. A kronológiára olyan eszközként tekintek, amely amellett, hogy gazdag tényanyagot közöl a fontosabb vitákról, tárgyalási fordulókról, a folyamat áttekintésében és a döntések elemzésnél is nélkülözhetetlen információforrást jelentett. 
A három döntés egyben olyan esettanulmányok elkészítését is lehetővé tette, melyekben jól beazonosítható és értékelhető Magyarország, Románia, az RMDSZ, az európai fórumok, valamint egyéb állami és nem állami szereplők tárgyalási pozíciói és érdekérvényesítési lehetőségei. A felek tárgyalási pozíciói és ebből adódóan érdekérvényesítési lehetőségeik meghatározták a kapcsolatok dinamikáját, egyben pedig a külpolitikai döntéshozatal folyamatát is.

Elemzésemben meghatározónak tartom az európai fórumok szerepét, mivel általuk közvetített követelményrendszerek és normatív minták befolyásolták a szereplök stratégiáit, aminek betudhatóan változtak az álláspontok, módosultak az érvrendszerek, végeredményben pedig javultak az államközi kapcsolatok. Következésképpen, az államközi kapcsolatok alakulását a kibővített négyes viszonyrendszerben értelmezem: tehát a magyar-román államközi kapcsolatok áttekintése mellett nagy figyelmet fordítok az európai fórumok szerepére és néhány nyugati államra, melyek jelentős mértékben befolyásolták Magyarország és Románia, valamint a romániai interetnikus viszonyokat. Ezen túlmenően elemzem az RMDSZ érdekérvényesítési lehetőségeit, az európai fórumok, Magyarország végül pedig a román többség tekintetében.

Számos jól dokumentált országtanulmány és összehasonlító vizsgálat készült arra vonatkozóan, hogy mely szervezetek és milyen módszerekkel befolyásolták a közép-kelet-európai államokat a vitás kérdések rendezésében, amely végső soron a taggá válás feltételrendszerének is része volt (McMahon 2007; Kelley 2004). Kutatási témám szempontjából meghatározó szerep jutott az Európa Tanácsnak, az Európai Biztonsági és Együttmüködési Szervezetnek és a Kisebbségi Főbiztosának, az Európai Unió intézményeinek, az Észak Atlanti Szerződés Szervezetének, a nyugati államok közül az Egyesült Államoknak, valamint más nyugati államoknak (Nagy-Britannia, Franciaország, Németország). Az emberjogi szervezetek közül említést érdemel az Amnesty International, a Helsinki Watch, Marshall Found, International Crisis Group, a külföldi alapítványok (Project on Ethnic Relations, Friedrich Ebert és a Konrad Adenauer Alapítvány), amelyek eltérő intenzitással és eszközrendszerrel befolyásolták a térség államainak viszonyát és a többség-kisebbség kapcsolatrendszerét. Fontos kiemelnünk továbbá a romániai nem-kormányzati szervezetek (Romániai Helsinki Bizottság, Pro Democraţia, Etnokulturális Kisebbségek Forrásközpontja) tevékenységét is, melyek különböző projektek és kezdeményezésék révén hozzájárultak a magyar-román együttélés javulásához.

A dolgozat empirikus részét az alapszerződésről, a státus- vagy kedvezménytörvényről, valamint a kettős állampolgárságról szóló vita és a könnyített 
honosítási eljárásról készített esettanulmányok alkotják. Az esettanulmányok megírásában két fő szempontot tartottam szem előtt, egyrészt a viták és döntések, komplex, összefüggő folyamat-jellegét, másrészt pedig az elemzési szintek elkülönítését.

Az esettanulmányok folyamatelemzésében a viták lefolyására és a döntések következményeinek elemzésére helyeztem a hangsúlyt. Ebből kiindulva, első lépésben áttekintettem az elözményeket és feltártam a döntéshez vezető folyamatot, ennek belpolitikai, szomszédságpolitikai és európai kontextusát. A tárgyalási pozíciók kialakítása, a szereplők érdekeinek ütköztetése (viták) az esettanulmányok második részét képezte. Az elemzés e két fázisában kiindulópontom az esetről készült tárgyalási kronológia, de felhasználtam az ide vonatkozó szakirodalmat, valamint e folyamatokban aktívan részt vevő politikusokkal készült fél-strukturált interjúkat is.

A tárgyalásokon lezajlott vitáknak egy másik színterét a parlamenti viták nyomon követése képezte. A külpolitikai döntéshozatalban játszott korlátozott szerepének betudhatóan a parlament és az ellenzéki pártok egyik államban sem lehettek alakítói a tárgyalásoknak, azonban a tárgyalások során a dokumentum tartalmának pártok általi értelmezése rendre megjelent a politika napirendjén és mindkét államban heves vitákat eredményezett a szerződés aláírását támogató és ellenző csoportok között.

A magyar Országgyülésnek a külpolitikára vonatkozó hatásköreit az alkotmány és a házszabály is részletezi ${ }^{79}$, egyben pedig behatárolja a nemzetközi szerződések tárgyalásában játszott szerepét: a házszabály 122 paragrafusának (3) bekezdése kimondja, hogy a szerződés megerősítésére vonatkozó határozati javaslatot a szerződés szövegével együtt a Kormány terjeszti elő. A javaslathoz az illetékes bizottság készít ajánlást, a szerződés szövegét tartalmazó részhez pedig nem lehet módosításokat benyújtani (4. és 5 . bekezdések). ${ }^{80}$ Ebben az esetben a törvényhozásnak két lehetősége van, vagy elfogadja, vagy pedig elutasítja a javaslatot. A szabályozás alapján látható, hogy viszonylag korlátozott az Országgyülés szerepe az egyes nemzetközi szerződések

\footnotetext{
${ }^{79}$ Az alkotmány alapján az Országgyülés: dönt a hadiállapot kinyilvánításáról és a békekötés kérdéséröl (19.§(3) g. bekezdés); fegyveres támadás esetén rendkívüli állapotot hirdet ki (19.§(3) h. bekezdés); dönt a Magyar Honvédség külföldi alkalmazásáról, békefenntartásban való részvételről $(19 . \S(3) \mathrm{j}$. bekezdés) és megköti a Magyar Köztársaság külkapcsolatai szempontjából kiemelkedő fontosságú nemzetközi szerződéseket (19.§(3) f. bekezdés). Lásd bővebben („Magyarország Alkotmánya, 1990).

A nemzetközi szerződésekkel kapcsolatos hatáskörét a törvényhozás révén gyakorolja: (1) ellenőrzi a kormánynak az országgyülési jogköröket érintő szerződéses tevékenységét és (2) megteremti a nemzetközi jog és a belső jog összhangját (Soltész 2010, pp. 240-243).

${ }^{80}$ Hasonló procedúra vonatkozik a törvényjavaslatok elfogadására is. A nemzetközi szerződésekkel kapcsolatos eljárásról szóló törvényt, amely egységes keretbe és a belső jogszabályokkal összhangba helyezte a különböző eljárásokat az Országgyülés 2005-ben fogadta el (,2005. évi L. törvény a nemzetközi szerződésekkel kapcsolatos eljárásról”).
} 
alakításában: a szerződések megszövegezésében a kormány diplomáciai tárgyalásai játszanak kulcsszerepet, a törvényhozásnak arra van lehetősége, hogy az illetékes szakbizottságokban napirendre tüzze és nyomon kövesse, illetve vitát kezdeményezzen a kérdésről (Soltész 2010, p. 243).

A román Képviselőháznak és Szenátusnak csekélyebb szerepe van az ország külpolitikájának alakításában, mint a magyar Országgyűlésnek. Ennek ellenére fontosnak bizonyultak azok az alkotmányos eszközök - kérdések és interpellációk, indítványok - melyek a kormány feletti parlamenti ellenőrzés lehetőségét biztosítják. Nemzetközi szerződések esetében a parlament két háza csak a ratifikáció folyamatába kapcsolódhat be. Az alkotmány kimondja, hogy „az elnök Románia nevében megköti a kormány által megtárgyalt nemzetközi szerződéseket és 60 napos határidőn belül ratifikálás végett a parlament elé terjeszti azokat." ${ }^{81}$ Alapvetően tehát a törvényhozás nem befolyásolhatja a szerződések tartalmi vonatkozásait, csak a végleges dokumentum elfogadásáról dönthet.

A hivatkozott alkotmányos és törvényes szabályozások alapján megállapíthatjuk, hogy a külpolitikai döntéshozatal szempontjából a nemzeti parlamentek érdemben egyik államban sem befolyásoló tényezői a külpolitikai döntéshozatalnak. Ennek ellenére az ellenzéki pártoknak a parlamenti vita lehetőséget teremt arra, hogy alakítsák a politika napirendjét, tájékoztassák a közvéleményt, valamint tematizálják a kormányzati tevékenység elleni kifogásokat (Szabó 2015a). Dolgozatomban egy további módszert képez ezeknek a parlamenti jegyzőkönyveknek a tartalomelemzése, melyet a MAXQDA számítógépes szoftver segítségével végeztem el. A program használata, egy manuálisan is kivitelezhető elemzéssel szemben elsősorban azért bizonyult hatékonyabbnak, mert az elkülönített szempontrendszerek (kategóriák) alapján segített a szövegtest rendszerezésében, amely jelentős mértékben megkönnyítette és áttekinthetővé tette a munkát.

Elemzési egységnek a parlamenti pártokat tekintettem, esetenként azonban egyegy képviselő felszólalásából is idéztem. Az elemzésnél az első szempontot a vita értelmezése képezte, ahogyan az a parlamenti vitában, a pártok felszólalásaiban értelmeződik, amelynek négy dimenzióját különítettem el: (1) a vita fő célkitűzése; (2) a döntés folyamata; (3) az elfogadott dokumentum tartalma; végül pedig (4) a döntés hatásai. A további kategóriákat több eljárás alapján alakítottam ki. A kategóriák egy részét az elemzést megelőzően különítettem el, azokból a témákból, melyek

${ }^{81}$ Románia alkotmánya: 91 . szakasz 1 . bekezdés. 
hangsúlyosan megjelentek az államközi vitában. A további kategóriákat két eljárás alapján állítottam fel. A program segítségével gyakoriság-elemzést végeztem a szövegben, és rendszereztem a leggyakrabban előforduló, a kutatás szempontjából releváns fogalmakat és szókapcsolatokat, amelyekből újabb kategóriákat alakítottam ki. Az utolsó eljárás az előbbi kiegészítésére épült, ugyanis néhány kategóriát az elemzés során alakítottam ki. A felvázolt módszer segítségével nemcsak az egyes pártok érvrendszere és stratégiái érhetők tetten, hanem a kormány és az ellenzék megosztottsága, valamint a két államban lefolytatott viták közötti tematikus különbségekről is árnyaltabb képet kaptam.

Az viták elemzése és a sajtóanyagok áttekintése a belpolitikai viszonyokra, a pártok közötti kapcsolatokra, a kormány-ellenzék viszonyára, valamint a közvéleménynek a vitára vonatkozó állapotáról ad pillanatképet. Az esettanulmányok utolsó szerkezeti egységét a döntés kimenetele és a lehetséges következmények elemzése képezte. Ennél a pontnál azt is értékeltem, hogy a viták és a meghozott döntések mennyiben és milyen mértékben járultak hozzá az államközi viszony rendezéséhez és az erdélyi magyarság helyzetének javulásához?

Az esettanulmányokban fontosnak tartottam az elemzési szintek elkülönítését, melyet Kenneth Waltz (2001) és David J. Singer (1961) munkái alapján végeztem el. ${ }^{82}$ Az elemzés első szintjét a belpolitikai körülmények jelentették, amelyhez két fontosabb mutatót rendeltem. Megkülönböztettem egyrészt a kisebbség és a kormányzat viszonyát, a közöttük fennálló kapcsolat jellegét, másrészt pedig a parlamenti pártok közötti erőviszonyokat és fontosabb vitákat. Az elemzés második szintjén a kétoldalú kapcsolatokat értékeltem: ebben kiemelt szerep jutott a felsőszintü találkozóknak és tárgyalásoknak (államföi, miniszterelnöki, külügyminiszteri), valamint a közös kormányüléseknek, miniszteri találkozóknak. A legintenzívebb munka azonban a szakértői (delegációk), valamint a szakpolitikai egyeztetések szintjén zajlottak, de ide sorolható, a nem annyira látványos, kevés médiafigyelmet élvező közös kormányközi vegyesbizottságok munkája is. A harmadik, nemzetközi szinten pedig megjelentek az európai fórumok, az Egyesült Államok, továbbá néhány nyugat-európai állam, valamint azok a nem állami szereplők (nem-kormányzati szervezetek, alapítványok) is, amelynek

\footnotetext{
${ }^{82}$ A nemzetközi kapcsolatok szakirodalmában már az 1950-es években fontos kérdésként jelent meg az elemzési szintek problémája. Elsőként Kenneth N. Waltz kísérlete ismert, aki a háború kitörésére próbált az elemzési szintek elkülönítésével magyarázatot találni. Waltz kutatásai nyomán David J. Singer, a World Politics folyóiratban megjelent tanulmányában két elemzési szintet különített el: egyrészt a nemzetközi rendszer (system), másrészt a nemzetállam szintjét (sub-system) - ez utóbbi magában foglalta az egyén szintjét is.
} 
képviselöi eltérő módszerekkel, de több ízben hatással voltak az államközi kapcsolatok alakítására és a többség-kisebbség viszonyának alakulására.

2. sz. táblázat: A vizsgálat általános kerete, elemzési szintjei és forrásai

\begin{tabular}{|c|c|c|c|}
\hline & Az elemzés szintje & A vizsgálat tárgya & Források és dokumentumok \\
\hline \multirow{6}{*}{$\begin{array}{l}\text { Magyar-román } \\
\text { államközi } \\
\text { viszony és az } \\
\text { RMDSZ }\end{array}$} & $\begin{array}{l}\text { Nemzetközi/ } \\
\text { európai szint }\end{array}$ & $\begin{array}{l}\text { Az európai fórumok } \\
\text { integrációs stratégiái } \\
\text { A nyugat-európai } \\
\text { államok stabilizációs } \\
\text { érdekeltsége }\end{array}$ & $\begin{array}{c}\text { Az európai fórumok } \\
\text { dokumentumai } \\
\text { Találkozók, tárgyalások, } \\
\text { nyilatkozatok }\end{array}$ \\
\hline & Államközi szint & $\begin{array}{c}\text { Felsőszintű találkozók } \\
\text { Kormányközi } \\
\text { együttmüködések } \\
\text { Szakértői egyeztetések }\end{array}$ & $\begin{array}{l}\text { Külügyminisztériumi iratok } \\
\text { (jegyzőkönyvek, beszámolók, } \\
\text { témavázlatok, jelentések) } \\
\text { Kétoldalú szerződések, } \\
\text { megállapodások }\end{array}$ \\
\hline & \multirow{4}{*}{$\begin{array}{l}\text { A magyarországi } \\
\text { és romániai } \\
\text { belpolitika szintje }\end{array}$} & $\begin{array}{l}\text { A román } \\
\text { kisebbségpolitikai } \\
\text { rezsim }\end{array}$ & $\begin{array}{c}\text { Kisebbségekre vonatkozó } \\
\text { jogszabályok, } \\
\text { kormányprogramok }\end{array}$ \\
\hline & & Magyar nemzetpolitika & $\begin{array}{c}\text { Külügyminisztériumi } \\
\text { dokumentumok, } \\
\text { kormányprogramok, MÁÉRT } \\
\text { zárónyilatkozatok }\end{array}$ \\
\hline & & Parlamenti viták & $\begin{array}{l}\text { Parlamenti naplók, } \\
\text { jegyzökönyvek }\end{array}$ \\
\hline & & Az RMDSZ szerepe & $\begin{array}{l}\text { Választási eredmények, } \\
\text { kormányzati/ellenzéki pozíció }\end{array}$ \\
\hline
\end{tabular}

Forrás: Saját szerkesztés

A hasonló szerkezetű esettanulmányok megteremtették annak a lehetőségét, hogy az államközi kapcsolatok szintjén megjelenő vitákat összehasonlító perspektívában is elemezzem. Annak ellenére, hogy az alapszerződés, a státustörvény és a kettős állampolgárság vitája eltérő körülmények között kerültek napirendre, a viták lefolyása, a döntési mechanizmusok és a szereplők stratégiái között számos hasonlóság kimutatható. Ebből a feltételezésből kiindulva, elsőként az egyes viták európai dimenziójára, az ezek közötti összefüggésekre mutatok rá, majd pedig viták belpolitikai és az államközi kapcsolatok szintjén megjelenő összefüggéseire. A négyes viszonyrendszert alkotó szereplők stratégiái és a képviselt álláspontok képezik az összehasonlítás harmadik dimenzióját, amelyben rámutatok azokra az „alapállásokra” is melyek alig változtak a rendszerváltást követő időszakban. Végül pedig a következményeket, az egyes viták eredményeit értelmezem, és arra mutatok rá, hogy a nemzetpolitikai döntések között szerves kapcsolat és összefüggés mutatható ki. 


\section{A MAGYAR-ROMÁN ÁLLAMKÖZI VISZONY ÉS AZ ERDÉLYI MAGYARSÁG KAPCSOLATRENDSZERE. TÖRTÉNETI ÁTTEKINTÉS}

A magyar-román alapszerződésről folyó tárgyalások mélyebb megértése és a szereplők közötti kapcsolatrendszer feltárása szükségessé teszi, annak a tágabb politikaés diplomáciatörténeti időszaknak az áttekintését, melyek elvezetnek a tárgyalások megkezdéséhez, ennek belpolitikai, valamint szomszédságpolitikai és európai kontextusához. A dolgozat szempontjából az előzmények diplomáciatörténeti áttekintése több okból is megalapozottnak tekinthető. Elsőként azért, mert a szereplők szempontjából értelmezi azokat a fontosabb eseményeket, töréspontokat és vitás kérdéseket, melyek a két fél viszonyát terhelik. Másodsorban az események felleltározása elvezet egy további szemponthoz, nevezetesen ahhoz, hogy a szereplők érvelésében, érdekérvényesítésében felfedezhetünk olyan gyakorlatokat, stratégiákat és folyamatokat, melyek ugyan túlmutatnak a megváltozott viszonyrendszereken - így a kommunista tömb felbomlásán és a rendszerváltás időszakán -, azonban gyökerei a kommunizmus történelmi örökségében keresendők. Ebből következik, hogy az államközi kapcsolatokban rendre visszaköszönnek a közelmúlt történelmi tapasztalatai, a be nem váltott ígéretek teljesítése és ebből adódóan a lezáratlan diplomáciai viták, valamint azon belpolitikai fejlemények is, melyek kihatással voltak az államközi kapcsolatok alakulására.

A fenti gondolatmenetből kiindulva az alapszerződésről folytatott tárgyalások megkezdése előtti történelmi időszakot két, távolról sem egyforma időszakra bontom. Az első időszak a '70-es évek végtől kívánja áttekinteni a felek viszonyát, és azt kívánom szemléltetni, hogy melyek voltak azok a meghatározó fejlemények és eseménysorok melyek a két állam viszonyának mélypontra jutásához vezettek. A második időszak a rendszerváltástól a magyar-román alapszerződés tárgyalásainak megkezdéséig - immár megváltozott körülmények között - elemzi a két állam változó viszonyát: a rendszerváltást követő ígéretes fejlemények hamar megváltoznak és elhidegülést, a kapcsolatok jelentős romlását eredményezték, amelynek újabb lendületét a Nyugathoz való „visszatérés” adta. 


\section{A rendszerváltás előtti időszak: az 1970-es és '80-as évek viszonyai}

Magyarország és Románia viszonyának romlásához számos tényező hozzájárult, ebből adódóan aligha tudnánk ezt egyetlen fejleményre és időpontra visszavezetni. Mindazonáltal, ha a felsőszintü találkozókat az államközi kapcsolatok egyik fontos indikátorának tekintjük, akkor megállapíthatjuk, hogy a két szomszédos állam vezetői között lezajlott három találkozó (1972, 1977 és 1988) a szocialista tömbön belül beszédes példáját szolgáltatja Magyarország és Románia viszonyának. A kommunista berendezkedésnek erre az időszakra vonatkozó szakirodalmából megállapítható, hogy Romániában a '70-es évek elejétől erősödő nacionalizmusa és centralizációs törekvései nyíltan a nemzeti kisebbségek élethelyzetének ellehetetlenítésére és a közösségi élet felszámolására irányultak. ${ }^{83} \mathrm{~A}$ rendszerben bekövetkező ,irányváltást” a szakértők többsége a diktátor hatalmának konszolidálására ${ }^{84}$, valamint az úgynevezett ,júliusi tézisekre" vezette vissza. Miután a Ceaușescu-házaspár 1971 júniusában egy ázsiai diplomáciai körutat tesz, az ott szerzett tapasztalatok mély benyomást tettek rájuk: ennek betudhatóan erősödött a párt expanzív, az élet minden területére kiterjedő vezető szerepe és a személyi kultusz. ${ }^{85}$ A tézisben megfogalmazott gondolatok ezeknek a tapasztalatoknak a gyakorlati kivitelezésére irányultak, nevezetesen a rendszer és a kommunista párt szerepének növelésére a politikai és kulturális életben, a pártpropaganda és a társadalmi mobilizáció erősítésében (Ceaușescu 1971, pp. 7-18).

A tézisek gyakorlati megnyilvánulása egy valóságos kisebb méretű „kulturális forradalmat" eredményeztek a román társadalomban, amelynek hatásai a magyar kisebbséget hangsúlyosan érintették. A szállástörvény bevezetése, a magyar nyelvü középfokú oktatás leépítésére vonatkozó kezdeményezések (román osztályok és tagozatok létrehozása), a családegyesítést támogató politika, valamint az erőltetett asszimiláció és a kihelyezés módszeréből két dolog nyilvánvaló volt: az intézkedések egyik része hátrányos, egyenesen diszkriminatív volt a romániai magyarságra nézve, másrészt azonban a nemzeti kommunizmus programjának eszközéül szolgáltak, melynek legfőbb célja az etnikailag homogén állam megvalósításában nyilvánult meg. ${ }^{86}$

\footnotetext{
${ }^{83}$ Lásd Novák Csaba Zoltán, Vincze Gábor és Földes György ide vonatkozó munkáit, amelyekre a továbbiakban hivatkozom.

${ }^{84}$ Verdery az 1965-1974 közötti időszakra teszi Ceaușescu hatalmának konszolidálását. Ez idő alatt sikerült a pártból eltávolítani ellenfeleit és marginalizálni a reformereket, technokratákat. (Verdery 1991, pp. 103; 106-108)

${ }^{85}$ A körútra június 1-24. között kerül sor. A házaspár látogatást tett Kínába, Észak-Koreába és ÉszakVietnámba és Mongóliába is.

${ }^{86}$ (Diószegi-Süle 1990, p. 70), (Tismăneanu- Dobrincu-Vasile 2007, p. 528). A romániai kommunizmus vizsgálatára létrehozott elnöki bizottság tagja volt Salat Levente egyetemi tanár, a munkacsoportban pedig a következő történészek vettek részt: Stefano Bottoni, László Márton, Lázok Klára, Nagy László
} 
A romániai fejleményekre nem volt egyértelmü magyar válaszlépés, azonban mind az MSZMP vezetőségében, mind a közvéleményben egyre erőteljesebben megfogalmazódott a határon túli magyarok problematikája. Földes György, a magyar-román kapcsolatokról szóló munkájában részletesen elemzi annak folyamatát, hogy a nemzetiségpolitikai normák miként jelentek meg a belpolitika és az államközi kapcsolatok napirendjén. Míg az 1972-es Kádár-Ceaușescu találkozón a magyar pártfőtitkár már beszélt a kisebbségek „híd szerepéről” az államközi kapcsolatokban, ez az elképzelés csak a következő, 1977-es találkozó közös közleményébe kerülhetett bele, azzal a feltétellel, hogy a nemzetiségi kérdésre a felek továbbra is belügyként tekintenek (Földes 2007, pp. 163-166; 218-220).

A két magas szintü államközi találkozó között jelentős folyamatok indultak be mind a magyar pártvezetés szintjén, mind a két nagyhatalom viszonyában. A '70-es évek első felében az MSZMP felső vezetésében vitákat kezdeményeztek a határon túli magyarok helyzetéről, amely az nemzet fogalmának fokozatos megváltozását is eredményezte. Ennek Földes két aspektusát emelte ki: a szocializmus és a kisebbségek helyzetére vonatkozóan a vitákból kirajzolódott az, hogy a szocializmus csak ott tekinthető sikeresnek, ahol „szavatolják a kollektív jogokat és a kisebbségek identitásának megőrzéséhez szükséges feltételeket," tehát a szocializmus sikere összekapcsolódott a kisebbségi jogok biztosításával, amely teljesen ellentétes képet mutatott a romániai helyzettel (ibid. p. 186). A másik szempont a kisebbségek szerepének felértékelődésére mutatott rá az államközi viszonyokban, mivel a kisebbségi jogok biztosítása - az MSZMP szerint - a jó kapcsolatok előfeltételét képezi. A kisebbségek helyzetének rendezése, amely fokozatosan a két állam közötti kapcsolatok rendezésének egyik feltételévé vált, nem talált kedvező román fogadtatásra, amit a felsőszintű találkozók eredményei is megerősítettek.

Mindeközben Románia folyamatosan hangoztatta függetlenségét, külpolitikájának pedig jelentős pillérét képezte a Nyugathoz való közeledés, főként gazdaság- és kereskedelempolitikai kérdésekben. ${ }^{87}$ A gazdasági és kereskedelmi kapcsolatok látványos bővülésének fő haszonélvezője a Ceaușescu-rezsim lett: ez a külpolitika szintjén elismertséget, nagyobb mozgásteret eredményezett, míg a

Mihály, Novák Csaba Zoltán és Olti Ágoston. A magyar kisebbséggel foglalkozó alfejezet a Magyar Kisebbség 2008-as számának vitaindítóját képezte: („A nemzeti kisebbségek helyzete: A magyarok” 2008).

${ }^{87}$ Románia 1971-ben aláírta az Általános Vámtarifa és Kereskedelmi Egyezményt, 1972-ben a Nemzetközi Valutaalap és a Világbank tagja lesz, 1973-tól kereskedelmi kedvezményben részesül az Európai Közösségtől, 1975-ben pedig az Egyesült Államoktól megkapta a legnagyobb kereskedelmi kedvezmény státusát (Verdery 1991, p. 105). 
belpolitika szintjén a házaspár hatalmának fenntartását, és a megalomániás projektek folytatását jelentette.

Mivel ebben az időszakban, amikor az államközi kapcsolatok keretében nem mutatkozott esély arra, hogy az kisebbségi problémákra hathatós megoldások szülessenek, elsőként a magyar kisebbség képviselői és értelmiségi csoportok, másrészt pedig a diaszpórában működő szervezetek és csoportosulások hívták fel a nemzetközi közvélemény figyelmét a kommunizmus elnyomó rendszerére. Elsőként a pártfunkcionáriusok emelték fel szavukat a romániai magyar kisebbség helyzetének folyamatos romlására, azzal az igénnyel, hogy a rendszerben tapasztalható hiányosságokra és problémákra vonatkozóan javaslatokat tegyenek. A levelekben, hivatalos beadványokban megnyilvánuló ellenállásnak fontos momentumait képezték Király Károlynak a vezető pártfunkcionáriusokhoz intézett levelei. ${ }^{88} \mathrm{~A}$ levelekből kiolvashatók azok a főbb problémák, melyek hátrányosan érintették a romániai magyarságot, példaként említve a nemzetiségi tanácsokkal kapcsolatos müködési zavarokat, a nemzeti kérdés megoldásában felmerülő problémákat, az anyanyelvi oktatás minőségének biztosítását, valamint a Securitate müködését körülíró „megengedhetetlen megfélemlítési eszközök” használatát. ${ }^{89}$

Király mellett Takács Lajos beadványáról érdemes említést tenni, amely számos ponton hasonlóságot mutatott a levelek tartalmával. Az RKP 1978 januárjában tartott országos konferenciáján Takács, a Magyar Nemzetiségü Dolgozók Tanácsának alelnöke készített beadványt a magyar kisebbség problémáiról. A dokumentumban Takács a nemzetiségi tanács müködésével kapcsolatos problémákat részletezte, kitért az anyanyelvi oktatás és iskolahálózat lebontására, az anyanyelvhasználat visszaszorulására, a kulturális élet beszűkülésére, melyekre vonatkozóan egy 18 pontból álló javaslatot fogalmazott meg. ${ }^{90}$

Az ellenállás ezen formái megteremtették annak a lehetőségét, hogy mind a magyarországi, mind a nemzetközi közvélemény tájékozódjon a romániai fejleményekröl. Ebben fontos szerep hárult Tóth Sándor és Tordai Zádor Jelentés Erdélyből címü tanulmányára, amely a párizsi Irodalmi Újságban jelent meg. Nem

\footnotetext{
${ }^{88}$ Király Károly Kovászna megye párttitkára volt, 1972-ben távolították el a hatalomból, de befolyása és népszerüsége továbbra is megmaradt. Ezzel magyarázható, hogy leveleinek nyilvánosságra hozatalát ekkora érdeklődés övezte.

${ }^{89}$ Király 1977 június-szeptember között levelet intézett Ilie Verdeț-hez, Fazakas Jánoshoz, valamint Vincze Jánoshoz (Király 2013, pp. 345-354). A levelek közzététele nagy nyilvánosságot kapott: tartalmát ismertetette a Szabad Európa Rádió, mi több, az Egyesült Államok Kongresszusához is eljutott.

${ }^{90}$ Részlet Takács Lajosnak, a Magyar Nemzetiségű Dolgozók Tanácsa alelnökének a magyar kisebbség problémáiról készített beadványából (Vincze 2003).
} 
sokkal később a Londonban élő Schöpflin György, a neves emberi jogi szervezet, a Minority Group Rights kiadványában egy áttekintő jelentést tett közzé az erdélyi magyarok helyzetéről (Schöpflin 1987).

A romániai magyar és magyarországi kezdeményezéseket a külföldi tiltakozások is erősítettek. Ebből a szempontból az Egyesült Államokban müködő magyar szervezetek és alapítványok szerepe kiemelkedő, különösképpen pedig a Magyar Emberi Jogok Alapítvány (Hungarian Human Rights Foundation - HHRF), amely a hetvenes évek második felétől a kisebbségben élö magyarság elleni jogsértésekre irányította az amerikai külpolitikai döntéshozók és a nemzetközi közvélemény figyelmét. A kezdetben Romániai Emberi Jogokért Bizottság nevet viselő szervezet megalakulását kettős célkitüzés motiválta: az alapítók egyrészt tudatosítani szerették volna az amerikai közvéleményben a kommunizmus elnyomó rendszerét és a romániai magyarok helyzetét, másrészt pedig rá szerették volna bírni a Kongresszust, hogy bírálja felül a Romániának megadott legnagyobb kereskedelmi kedvezményt (Herner-Kovács 2017). A HHRF megalakításától kezdődően (1976) kettős stratégiát követett: az egyik a romániai magyarsággal való szolidaritás kifejezésére irányult, amely gyakorlatilag tüntetések és tiltakozó akciók megszervezését jelentette, míg a másik, az írásos tanúvallomásokon alapuló szenátusi meghallgatások már komolyabb érdekérvényesítő munkát jelentettek. $^{91}$

Annak ellenére, hogy számos fronton zajlott a nemzetközi közvélemény tájékoztatása, nem következett be érdemi javulás a romániai magyarság helyzetében. ${ }^{92}$ A '70-es évek végére tehát a magyar pártvezetés tudatában volt annak, hogy a kivárás, a gesztusokra épített stratégia nem hoz alapvető szemléletváltást a román vezetésben és a kétoldalú kapcsolatokban megjelenő problémák - pl. az 1979-ben bevezetett üzemanyag-vásárlásra vonatkozó korlátozások - a tágabb értelemben vett nyilvánosság előtt is állandóvá váltak. ${ }^{93}$

\footnotetext{
${ }^{91}$ A Romániának megadott legnagyobb kedvezmény megadása utáni évben a HHRF már az amerikai törvényhozásban is hallatta hangját, azonban egy évtizednek kellett még eltelnie, hogy rábírja a Kongresszust a kedvezmény visszavonására (Ludányi 1990).

92 Biczó György nagykövet 1978 második felében két összefoglalót is készít, amelyben beszámolt a kisebbségekkel szembeni elnyomás erősödéséről, a tervezett betelepítésekről, valamint az oktatási és kulturális intézmények leépítéséről (Vincze 2003)

93 Hodicska Tibor -, aki másfél évtizedig volt a Magyar Nagykövetség bukaresti diplomatája -, visszaemlékezéseiben megjegyzi, hogy Budapesten folyamatosan megvolt a készség a „kapcsolatok lehetőség szerinti javítására," de ehhez konkrét előrelépésre, az emlékeztetőkben kijelölt feladatok végrehajtására lett volna szükség - vélte a diplomata (Hodicska 2014,p. 160). Ezzel szemben a román fél inkább a látszatintézkedésekben volt érdekelt, amelyeket a felsőszintü találkozókon folyamatosan napirenden tartott, de a magyar fél szempontjából érdemi előrelépések megtételére nem volt hajlandó.
} 
A kialakult helyzetben azok az apróbb lépések sem jelentettek lényegesebb elörelépést a felek közötti kapcsolatokban - a kolozsvári Főkonzulátus és a Csengersima-Pete közötti határátkelőhely megnyitása -, melyekröl az 1977-es felsőszintű találkozón történt megállapodás. A magyar-román szembenállást az erdélyi magyarok helyzetének eltérő értelmezése mellett az egyre inkább begyürüző gazdasági válság is mélyítette, ugyanis míg ez a folyamat magyar oldalon a politikai liberalizációt segítette, addig Romániában a központi vezetés elnyomását erősítette (Földes 2007, p. 276). A két állam viszonyát csak tovább rontotta a fokozódó sajtóvita, valamint az eltérő történelmi szemléletű munkák megjelenése a románok eredetéről és Erdély státusáról, amely túllépett a szaktörténészek vitáján és rendre a politikai viták kiindulópontjaként szolgált. Találóan állapítja meg e korszakról készült elemzésében Vincze Gábor, hogy „valójában a fokozatosan erősödő, kisebbségellenes román nacionalizmus offenzívájáról volt szó” (Vincze 2006, p. 262). E viták kiindulópontját Ion Lăncrănjan Cuvânt despre Transilvania (Gondolatok Erdélyröl) c. munkája jelentette, mely komoly indulatokat keltett a magyarság részéröl. ${ }^{94}$

Lăncrănjan könyvével majdnem egy időben, 1982 márciusában jelent meg az Ellenpontok szamizdat lap első száma melynek szerkesztésében és kiadásában Tóth Károly Antal, Ara-Kovács Attila és Szőcs Géza vett részt. A szerkesztők novemberi lebukásáig és az országból való kiutasításáig összesen kilenc számot jelentettek meg, melyben dokumentumokat, az erdélyi magyarság helyzetét ismertető elemzéseket és a kommunista rendszer nemzetiségpolitikáját bíráló írásokat tettek közzé (Tóth 2000). Nyugaton a szamizdat azt követően vált ismertté, hogy a szerkesztők eljuttatták a nyolcadik számban megjelent Memorandumot és az ehhez kapcsolódó programjavaslatot a Helsinki Záróokmányban foglalt elvek előmozdításán munkálkodó madridi utókonferencia résztvevőihez (ibid. pp. 16-18), augusztus elején pedig az Egyesült Államok Kongresszusa előtt Tom Lantos ismertette a dokumentumok tartalmát. Következtetésként megállapíthatjuk, hogy az Ellenpontok szerkesztői az ellenállás újabb formájával ráirányították a nemzetközi közvélemény figyelmét a romániai magyarok helyzetére, amely a későbbiekben - föként a HHRF munkatársai számára - hivatkozási alapként szolgált a kongresszusi meghallgatások alkalmával.

94 Lăncrănjan könyve ellen 36 romániai magyar értelmiségi beadvánnyal fordult a központi pártvezetéshez, de elítélő volt a magyarországi értelmiségiek véleménye is: többen, köztük Száraz György, Köteles Pál írásban cáfolták meg a könyvében szereplö állításokat. Vincze Gábor részletekbe menően elemzi a könyv megjelenésének körülményeit, az értelmiségi reakciókat, valamint a mű hatását az államközi kapcsolatok alakulásában (Vincze 2006, pp. 279-99). 
A magyar kisebbség kilátásainak romlását az újabb párthatározatok - mint pl. a két állam közötti buszjáratok megszüntetése 1983 szeptemberében - csak tovább rontották. $^{95}$ Decemberben a nemzetgyülés az államadósság csökkentéséről és visszafizetéséről rendelkezett: ennek értelmében szigorították a villany-, üzemagyag- és gázfogyasztást, valamint a lakosság alapélelmiszerekhez való hozzáférését, amely komoly ellátási problémákhoz vezetett országszerte (Novák 2016, p. 84).

A magyar külügy stratégiaváltására 1985-ig kellett várni, amit több, egymással összefüggő esemény idézett elő. A Romániához való viszony megváltozásában a külügyminisztérium tájékoztatója szolgált kiindulópontként, amely romániai magyarságról megállapította, hogy a román politika az ország területi egységét fenyegető elemként kezeli, törekszik az asszimilációra, korlátozza az anyanyelvhasználatot, mi több képviselőikre egyre nagyobb rendőri nyomás nehezedik (Földes 2007, p. 340). A határon túli magyarok helyzete ezt követően az MSZMP márciusi kongresszusán is napirenden volt, amelyhez többen, köztük Kádár János, Aczél György, Pozsgai Imre és Losonczi Pál is hozzászólt. Az irányváltásban a monori értelmiségi találkozó döntőnek bizonyult, mivel a demokratikus ellenzék és a népinemzeti mozgalom képviselői itt vitatták meg a határon túli magyarok helyzetét. ${ }^{96}$ Bárdi Nándor szerint ugyanis, a hetvenes évek elejétől a nyolcvanas évek végéig három csoportnak volt nyomásgyakorló szerepe a pártapparátusra: az első csoportot a népi írók képezték, akik a határon túli magyarok kérdését nyelvi-kulturális és demográfiai problémaként kezelték (Illyés Gyula, Csoóri Sándor); a második csoportot, a demokratikus ellenzék emberi jogi kérdésként tekintett a problémára (Beszélö, Duray Bizottság, Erdélyi Magyar Hírügynökség), míg a harmadik csoportot az MSZMP Külügyi Osztályának képviselői Szürös Mátyás, Tabajdi Csaba, Szokai Imre, akik a kulturális nemzetfelfogást tekintették irányadónak (Bárdi 2004, pp. 97-99).

Minekután mind a párt, mind az ellenzék tematizálta a határon túli magyarság problémáit, a kérdés folyamatosan napirenden volt, melyből a pártvezetés is le kellett vonja a konzekvenciákat. Noha nem volt erre elöre kidolgozott stratégia az EBEÉ ottawai értekezletén a magyar küldöttség először lépett fel az erdélyi magyarok érdekében, ismertetve kilátástalan helyzetüket. ${ }^{97}$ A magyar álláspont megváltozását

\footnotetext{
${ }^{95}$ Noha a magyar fél jelezte, hogy átveszi ezeknek a járatoknak az üzemeltetését, ezt a román pártvezetés elutasította (Földes 2007, p. 315). Az intézkedés jelentősen megnehezítette a rokoni és baráti kapcsolatok fenntartását és leszükítette az utazási lehetőségeket.

${ }^{96}$ A tanácskozáson többek között részt vett: Csoóri Sándor, Kis János, Csurka István, Tamás Gáspár Miklós, Konrád György és sokan mások.

97 Demus László a magyar kormány nevében aggodalmát fejezte ki a kisebbségek erőszakos asszimilációjára vonatkozóan (Knigth 1987, p. 224). Novemberben Magyarország a Budapesten tartott
} 
egyértelművé tette Várkonyi Péter külügyminiszter országgyűlési beszéde, majd az 1986 november végi bécsi utótalálkozón a konferencia nyitóülésén való felszólalása. ${ }^{98}$

Magyarország fokozottabb fellépése nem befolyásolta a román kommunista párt nemzetiségpolitikáját, ugyanis a '80-as évek második felétől tovább szükültek az intézményes keretek és nyilvánvalóvá váltak azok az intézkedések, melyek a magyar nyelv és kultúra nyilvánosságból történő száműzetésére vonatkoztak: a román vezetés megszüntette a TVR magyar adását és korlátozták a Bukaresti Rádió müsoridejét, határozat született a településnevek román használatáról és megérkeznek az első hírek a falurendezésről. E fejlemények újabb értelmiségi, ellenzéki mozgalmakat indítottak el. A Limes-kör létrejöttét Molnár Gusztáv kezdeményezte, és 1985-1987 között több találkozót is szerveztek Bukarestben, Brassóban és környékén. A csoportosulásnak több értelmiségi tagja volt ${ }^{99}$, akik a rendszer összeomlása utáni alternatívákat vitatták meg (Bárdi 2004, p. 83). A Limes-kör feloszlatását követően Balázs Sándor professzor egy újabb szamizdat lap, a Kiáltó Szó megjelenését kezdeményezte, amelynek 1988 során két száma jelenhetett meg.

Míg tehát Romániában egyre erőteljesebb nyomás nehezedett a kisebbségi közösségekre, addig Magyarországon a nemzetpolitikai rendszerváltás irányába tartó folyamatok indultak be, amelynek kezdete a már fentebb említett MSZMP Külügyi Osztályának képviselőinek fellépéséhez köthetők. 1988 januárjában Szürös Mátyás egy rádióbeszélgetés során fejti ki a kultúrnemzeti koncepciót, aminek értelmében a határon túli magyarok a magyar nemzet részét képezik. Néhány héttel később Szokai Imre és Tabajdi Csaba a Magyar Nemzetben közölték a „Mai politikánk és a nemzetiségi kérdés” címü írásukat, amelyben részletesen elemezték Magyarország és a határon túli magyarok viszonyának elvi alapjait. Az új nemzetstratégiának tekinthető dokumentum szakított a korábbi évtizedeken át hangoztatott állásponttal, miszerint a nemzetiségi kérdés az adott ország belügye lenne: a szerzők amellett foglaltak állást, hogy a nemzetiségi kérdés és a magyar közösség helyzete a szomszédos államok viszonyában meghatározó jelleggel kell bírjon (Szokai-Tabajdi 1988). A párt magas rangú

EBEÉ fórumon újfent hangoztatta áláspontját, és elítélte a határon túli magyarokkal kapcsolatos bánásmódot, cáfolván a Ceaușescu által sokat hangoztatott kijelentést, miszerint Romániában a nemzetiségi kérdés már megoldódott (ibid).

${ }_{98}$ A nemzetközi fórumokon hangoztatott magyar álláspontok Földes szerint úgy értelmezhetők, hogy Magyarország már lemondott arról, hogy a nemzetiségi kérdést a szocialista országok normájává tegye. Ettől kezdve arra törekedett, hogy a határon túli magyarok ügyét emberi jogi kérdésként tematizálja az európai fórumok előtt (Földes 2007, p. 366).

${ }^{99}$ A Limes-kör tagjai: Balázs Sándor, Bíró Gáspár, Cseke Péter, Cs. Gyímesi Éva, Fábián Ernő, Horváth Levente, Lőrincz Csaba, Molnár Gusztáv, Salat Levente, Szilágyi N. Sándor, Visky András, valamint Visky Ferenc. 
képviselőinek megnyilatkozása jelzésértékủ volt arra vonatkozóan, hogy az MSZMP is támogatja a nemzetpolitikai reformfolyamatokat, az aktívabb fellépést és a közvélemény tájékoztatását a határon túli magyarok helyzetével kapcsolatosan. E szemléletváltásnak betudhatóan a pártvezetés nem akadályozta meg az ellenzéki kezdeményezésre létrejött június végi tömegdemonstrációt a falurombolás ellen, amelyre válaszul Bukarest bezáratta a kolozsvári Főkonzulátust. ${ }^{100}$

A két állam közötti kapcsolatainak e feszült szakaszában került sor az új főtitkár Grósz Károly és Ceaușescu találkozójára Aradon. Azonban az aradi találkozó magyar szempontból Szűts Pál nagykövet és Hodicska Tibor ügyvivő beszámolói szerint kudarcként értékelendő, mivel a tárgyalásokon sorra lekerültek a magyar szempontból fontos kérdések (Hodicska 2014, pp. 242-251). Következtetésképpen, az államközi felsőszintü tárgyalások e fejezete aligha járulhatott hozzá a két állam viszonyának javulásához, ehelyett a diplomáciai konfliktus elhúzódását eredményezte.

A Ceaușescu-rendszer utolsó évei Románia példanélküli elszigetelését jelentette, ugyanis a diktátor és felesége hatalmának megtartása érdekében alkalmazott eszközök, az emberi jogok alapvető megsértése, valamint a kisebbségi közösségek elnyomásával kapcsolatos politikák nyugati bírálata állandóvá vált, amely nemcsak a Romániáról készült jelentésekben, ${ }^{101}$ hanem az ország külkapcsolataiban is megnyilvánultak. ${ }^{102}$ Egy évtizedes érdekérvényesítő munka után, 1987-ben a HHRF jelentős eredményt ért el az Egyesült Államokban, ugyanis kongresszusi meghallgatásai sikerre vezettek, elsőként a Képviselőházban, majd a Szenátusban szavaztak a Romániának nyújtandó legnagyobb kereskedelmi kedvezmény felfüggesztéséről (Herner-Kovács 2013). A döntés mintegy megerősítéseként 1988 júliusában a Szenátus határozatban ítélte el Romániát a nemzetközileg elismert emberi jogok megsértéséért és a falurombolásért. ${ }^{103}$

\footnotetext{
100 A demonstráció az első olyan megmozdulás volt '56-ot követően, melyet a felsőbb vezetés engedélyezett (Földes 2007, pp. 411-415). Ennek kapcsán Jeszenszky Géza a vele készült interjúban kifejtette, hogy „, a rendszer, a kommunista vezetésnek az érzékenyebb része, úgy is lehetne mondani, ezzel próbálta igazolni, hogy nem annyira népidegen és a nemzetérdektöl távol álló”.

${ }^{101}$ Amerikai jelentés az emberi jogok helyzetéről. 1989. február 13. Magyar Nemzeti Levéltár - Országos Levéltár, Külügyminisztérium TÜK-iratok (továbbiakban MOL), Románia, XIX-J-1-J, tételszám 128148, 74. doboz, 001031/2, 1-10; Az Amnesty International jelentése a romániai emberi jogi helyzetröl, 1987. július. MOL, XIX-J-1-J, tételszám 128-148, 74. doboz, 001031/2, 11-37.

102 A román külpolitika alakulása 1988-ban, 1989. május 24. MOL, XIX-J-1-J, tételszám 128-10, 74. doboz, 00490/1, 1-13.

${ }^{103}$ Az erdélyi magyarság helyzetével összefüggö fejlemények (Condemning Rumania for its human rights abuses, particularly its plan to raze agricultural villages in traditionally Hungarian areas), 1988. augusztus 10. MOL, XIX-J-1-J, tételszám 128-19, 75. doboz, 0071/1. A nemzetközi közvéleményt rangos sajtóorgánumok tájékoztatták a romániai fejleményekröl: The Washington Times: Romania set to eliminate 7000 villages by year 2000. 1988 április 6; The Economist: Fleeing to a home-to home, 1988 április 23; The Guardian: Romania accused of plot to wipe out Hungarians, 1988. április 23; New York Times: Hungary Assails Romania on Village Razings, 1988. május 29.
} 
Az európai fórumok szintjén több ajánlás és állásfoglalás foglalkozott a romániai fejleményekkel. Az ET PKGY határozatban kérte a román döntéshozókat, hogy „mondjanak le azokról a tervekről, melyek magukba foglalják a falvak lerombolását, figyelmen kívül hagyva a kisebbségi jogokat, a kulturális, etnikai és vallási identitásuk megőrzésére irányuló erőfeszítéseket” (Resolution no. 910, 1988). Az emberi és kisebbségi jogokról érkező aggasztó hírek az Európai Közösségek országait is a Romániához való viszonyuk újraértékelésére késztette. Az Európai Parlament 1988-as jelentése alapján a Bizottság nem hosszabbította meg az 1980-ban, Romániával kötött kereskedelmi egyezményt, mi több az EP arra kérte a tagállamokat, hogy tekintettel a romániai viszonyokra, függesszék fel az élelmiszerimportot (Papadimitriou-Phinnemore 2008, pp. 18-19).

Magyarország több fronton is fellépett a határon túli magyarok érdekében. Az EBEÉ bécsi találkozóján Magyarország csatlakozott ahhoz a nyolc országhoz, melyek a kisebbségvédelemre vonatkozó dokumentumok előkészítését javasolták. 1989 februárjában Horn Gyula külügyminiszter-helyettes a genfi Emberi Jogok Bizottságának ülésén elítélte a kisebbségi jogok megsértését és támogatta a Bizottság javaslatát egy különmegbízott kinevezésére a romániai emberi jogi helyzet kivizsgálására (Schöpflin-Poulton 1990, p. 23). ${ }^{104}$ Március közepén a magyar vezetés egy komoly diplomáciai lépésre szánta rá magát és a szocialista blokk államai közül elsőként csatlakozott az 1951-es genfi menekültügyi egyezményhez, amely lehetővé tette az erdélyi menekültek befogadását (Kaszás 2013). A magyar kormány döntését a közvélemény és az ellenzéki csoportok részéről érkező nyomásgyakorlás nagyban befolyásolta, azonban a legfontosabb tényezőt az erdélyi menekültek számának látványos növekedése képezte. ${ }^{105}$

Mindeközben az Országgyülés több állásfoglalásban is elítélte a romániai fejleményeket, addig a magyar diplomácia erőteljes tájékoztató kampányba kezdett: ennek egyik megnyilvánulása volt a Külügyi Intézet folyóiratának, a Külpolitikának az erdélyi magyarok helyzetét taglaló számának megjelentetése, majd angolra fordítása,

\footnotetext{
${ }^{104}$ A román képviselők, előrelátva a szavazás számukra kedvezőtlen kimenetelét, a végső szavazás előtt két nappal, meghívták a Bizottság Titkárságát egy romániai látogatásra. Amikor a határozatot támogató államok ezt írásban is kérték, a megfelelő garanciákkal, a román delegáció visszakozott, mi több nem ismerte el a szavazás végeredményét, és felhívta a Bizottság figyelmét arra, hogy nem engedélyezik a különmegbízott beutazását (Brody-Weissbrodt 1989, p. 600).

${ }^{105}$ Míg a Magyarországra menekült erdélyi magyarok száma 1988 első két hónapjában alig érte el az ezer föt, márciustól ez a szám folyamatosan emelkedett, és havonta átlagban több mint ezer fö hagyta el az országot. A Migrációs és Menekültügyi Hivatal adataira alapozva Tóth a Romániából származó, Magyarországra menekültek számát 1988-ban 13173 főre, 1989-ben 17365 före, míg 1990-ben 17416före teszi (Tóth 2011).
} 
amely eljutott a legtöbb nyugat-európai és amerikai külképviseletre. ${ }^{106}$ A nyugati közvélemény tájékoztatásában az ellenzéki pártok és más szakemberek is részt vettek. Jeszenszky Géza és Joó Rudolf az ENSZ Emberi Jogi Bizottságának sajtóértekezletén számolt be a romániai fejleményekről. Szintén Jeszenszky Géza, későbbi külügyminiszter az MDF külügyi szóvivőjeként levélben fordult az európai vezetőkhöz ${ }^{107}$, melyben a romániai kisebbségek helyzetét ismertette (Jeszenszky 2015, p. 32).

A KKE-i államok rendszerváltását megelőző utolsó magyar-román felsőszintű találkozóra a Varsói Szerződés Politikai Tanácskozó Testületének július eleji, Bukarestben megtartott ülése adott alkalmat. A Ceaușescuval tárgyaló magyar vezetés (Nyers Rezső, az MSZMP elnöke, Németh Miklós miniszterelnök és Horn Gyula külügyminiszter) konkrét feltételekhez kötötte az államközi viszony rendezését ${ }^{108}$, amelynek részeként egy miniszterelnöki találkozó, valamint egy parlamenti-tanácsi delegáció megszervezésében állapodtak meg. A decemberi belpolitikai fejleményeknek betudhatóan azonban nem kerülhetett sor e találkozókra.

1989 végére tehát olyan helyzet állt elő Romániában, amely fenntarthatatlan állapotokat idézett elő, ennek ellenére a Ceaușescu-rendszer hirtelen bukását senki sem láthatta előre, noha ehhez már számos tényező adott volt. A belpolitika szintjén mindenekelőtt a lakosságra nehezedő egyre erőteljesebb elnyomás, az emberi jogok megsértése és az ellátási gondok jelezték a rendszer végét. Külpolitika szempontjából a gorbacsovi reformok és a KKE-i államokban bekövetkezett rendszerváltások jelzésértékűnek bizonyultak, amely a temesvári eseményeket követően országos megmozdulásokat és tiltakozásokat váltott ki Romániában, megpecsételve a Ceaușescuházaspár hatalmát.

\section{A rendszerváltás és az átmenet első évei}

A kommunizmus bukása egy fontos pontként értelmezhető államközi kapcsolatokban, mert véget ért egy olyan időszak, amikor Magyarország és Románia között csak abban volt egyetértés, hogy a két állam szomszédos egymással (Horn 1991, p. 231). A

\footnotetext{
106 (Külpolitika. A magyar Külügyi Intézet elméleti és politikai folyóirata.” 1989) A folyóiratban megjelent tanulmányok a román nemzetpolitika fejleményeit, a falurendezési terveket, valamint a menekültek helyzetét elemezték.

107 A levelek konkrét hatása és eredménye nem lebecsülendő, megerősítette a magyar pártvezetés nemzetközi fórumokon hangoztatott álláspontját, ebből következően minden bizonnyal hozzájárult a Romániát elítélő magatartás kialakulásához.

108 A magyar feltételek között szerepelt a magyar kisebbség elleni diszkriminatív intézkedések megszüntetése és a falurombolási programleállítása, Magyarország elleni propaganda leállítása, a magyar sajtótermékek beengedése Romániába: Lásd bővebben: (Békés 2004, pp. 312-313).
} 
rendszerváltásban rejlő lehetőségek a két állam és a romániai magyarság viszonyának hosszú távú rendezésének a lehetőségét hordozta magában, ugyanis az a rendszer, amely legitimitását az belső és külső ellenségkeresésben, a nacionalista mozgósításban, az egységes és homogén állam megteremtésében látta, már nem létezett. Ezek a lehetőségek azonban - mind az a továbbiakban látni fogjuk -, hamar szertefoszlottak, ugyanis a rendszer bukása nem jelentett valódi törést, a múlttal való szakítást, mert az új vezetés számos politikai, hatalomtechnikai eszközt és külpolitikai gyakorlatot átvett a régi nomenklatúrától, amely alapvető módon meghatározta a rendszerváltást követő időszak politikai, gazdasági és társadalmi folyamatait, az államközi kapcsolatokat és a romániai magyarság helyzetét egyaránt.

A rendszerváltás eseményei teret engedtek a romániai magyarok önszerveződésének: a magyarság képviselői és későbbi vezetői, ugyanis a kommunista időszak alatt az erdélyi városokban működő ellenzéki csoportosulások, értelmiségi körök és mozgalmak tagjaiból kerültek ki. ${ }^{109}$ Ennek az önszerveződésnek a december 25-én megalakuló RMDSZ nyújtott intézményes keretet, amely a romániai magyarság érdekképviseletének, valamint társadalomszervezési funkciók ellátásának igényével jelent meg a romániai politikai mezőben. ${ }^{110}$ A viszonylag rövid időn belül megfogalmazott Szándéknyilatkozat - mely az Szövetség első programjának is tekinthető - néhány lényeges külpolitikai célkitűzést is megfogalmazott, amely mögött elsősorban a történelmi tapasztalat és a román többséggel folytatott bizalmatlanság állhatott. Ezt a periódust a kinyilvánított külpolitika időszakának nevezzük, mivel az RMDSZ külpolitikai céljai nyilvánosságot kaptak és kiáltványok, nyilatkozatok formájában megjelentek. ${ }^{111}$

A két állam nem hivatalos kapcsolatfelvételére a forradalmat követő napokban került sor, melyben a bukaresti Magyar Nagykövetség játszott kezdeményező szerepet. A külügyi feljegyzésekből tudjuk, hogy keresték a kapcsolatot a Nemzeti Megmentési

\footnotetext{
109 A Nemzeti Kisebbségkutató Intézet égisze alatt 2014-ben zárult le az a kutatás, amely az erdélyi magyarok rendszerváltás utáni szerepvállalását és önszerveződését elemezte Erdély 12 városában. (Bárdi-Gidó-Novák 2014, p. 11).

110 „A Romániai Magyar Demokrata Szövetség Ideiglenes Intéző Bizottságának kiáltványa. 1989. december 25. Húszéves az RMDSZ. 2009, pp. 383-384).

${ }^{111}$ Lásd bővebben: (Szabó 2015, p. 130). Az RMDSZ külkapcsolatainak építésében központi szerep jutott a Magyarországhoz füződő viszonyban. Azonban a Szándéknyilatkozat Intézményes kapcsolatokról szóló VII. fejezetében a külpolitikai célkitüzések is megjelentek: A szövetség bekapcsolódik a helsinki folyamat továbbvitelébe és képviselteti magát az e folyamatban részt vevő országokban élő kisebbségek irodalmi, müvészeti, tudományos stb. rendezvényein (4. pont); A szövetség képviselteti magát vagy megfigyelői útján van jelen nemzetközi fórumok olyan rendezvényein, amelyek napirendjén a kisebbségi kérdés valamely jelensége szerepel (5. pont); A szövetség mindent megtesz annak érdekében, hogy a Romániában élő kisebbségek aktív szerepet töltsenek be a környező országokkal való jószomszédi viszony megszilárdításában, a közép-kelet-európai népek közötti kulturális és politikai közeledésében (6. pont). „Részlet az RMDSZ Ideiglenes Intéző Bizottságának Szándéknyilatkozatából” p. 391).
} 
Front képviselöivel, aminek eredményeként december 24-én Szüts Pál nagykövet Dumitru Maziluval az NMFT tagjával folytatott beszélgetést. ${ }^{112}$ Mazilu olyan hangot ütött meg, amelyre évek óta várt a magyar Külügyminisztérium, így december végén Horn Gyula külügyminiszter Bukarestbe látogatott, ahol az új vezetés bel- és külpolitikai szándékairól szeretett volna tájékozódni: találkozott Ion Iliescuval, a Nemzeti Megmentési Front elnökével és Petre Roman miniszterelnökkel is.

A látogatás az RMDSZ szempontjából is kiemelt jelentőséggel bír, ugyanis a külügyminiszter tárgyalt Király Károllyal és Domokos Gézával. A Romániai Magyar Szónak (RMSZ) adott interjúból és a hazatérés utáni sajtótájékoztatóból kiderül, hogy a felek közeledésének lényegi feltételét az képezi, ha Magyarország tiszteletben tartja Románia területi integritását és nemzeti szuverenitását, továbbá a magyar-román viszony rendezésének feltétele a romániai magyarok jogainak biztosítása. ${ }^{113} \mathrm{~A}$ találkozón konkrét kérdésekről is született egyezség: a főkonzulátusok és a két állam fővárosában a kulturális intézetek megnyitásáról, valamint a kisebbségi oktatási hálózat bővítéséről, ennek magyar részről történő támogatásáról. ${ }^{114} \mathrm{~A}$ felsőszintü találkozón elhangzott javaslatokat - főként a román fél magatartásának betudhatóan (kivárás, halogatás) -, nem követték konkrét lépések, melyre Horn Gyula külügyminiszter a román külügyminiszternek címzett leveleiben is rámutatott. ${ }^{115}$

Belpolitikai téren jelzésértékűnek bizonyult a Nemzeti Megmentési Front (NMF) nyilatkozata a nemzeti kisebbségek jogairól, amely elítélte az előző rendszer kisebbségekkel szembeni politikáját kinyilvánította abbéli szándékát, hogy „garantálja az egyéni és kollektív nemzeti jogokat és szabadságjogokat." ${ }^{116}$ Noha a nyilatkozat nem kínált konkrét megoldást a nemzetiségi kérdésekre, több olyan ígéretet tartalmazott -

\footnotetext{
${ }^{112}$ A beszélgetés alkalmával Mazilu elismerően szólt a magyar segítségről, maga és a NMFT nevében „hálával adózott Magyarország erkölcsi, politikai és konkrét anyagi segítségéért, melyet a forradalom támogatásárt, a most kialakult helyzetért tesz." A két állam viszonyáról elmondta, hogy gyökeres változásokra kell számítani, merthogy „megszünik a mesterségesen táplált gyülölet, s felszámolják a két nép közeledésének és szoros kapcsolatának akadályait." Egyben jelezte, hogy az első lépések már megtörténtek, mivel megnyitották a magyar-román határt. Kapcsolatfelvétel a NMFT egyes tagjaival, 1989. december 25, MOL, XIX-J-1-J, tételszám 128-1, 74. doboz, 004747, 2.

${ }^{113}$ Horn Gyula magyar külügyminiszter nyilatkozata lapunk számára. Romániai Magyar Szó, 1989, Új sorozat, 8. szám, december 31, 1 és 3; „Dr. Horn Gyulának, Az MSZP elnöksége tagjának, a Magyar Köztársaság Külügyminiszterének Nyilatkozata romániai látogatása után” In: Magyar Külpolitikai Évkönyv.1989, p. 330).

${ }^{114}$ Ibid. p. 331. Az RMDSZ Ideiglenes Intéző Bizottságának január 2-i közleményéből, Domokos Géza beszámolójából azt is megtudjuk, hogy Horn Gyula üdvözölte az RMDSZ megalakulását és „támogatja az RMDSZ kiáltványában megfogalmazott alapelveket és célokat.” RMSZ, 1990. január 5., 10. szám, 2.

${ }^{115}$ Lényegében egy január végi és egy március 2-i keltezésủ levélről van szó, amelyben a magyar külügyminiszter pozitívan értékelte a találkozón elhangzott javaslatokat, azonban elégedetlenségét fejezte ki az eddigi előrelépésekkel valamint a magyarellenes fellépésekkel kapcsolatosan. („Dr. Horn Gyula külügyminiszter levele a román külügyminiszterhez.” In: Magyar Külpolitikai Évkönyv. 1990, pp. 110$11,125-126)$.

116 „A Nemzeti Megmentési Front nyilatkozata a romániai nemzeti kisebbségek jogairól (január 6.).
} 
kisebbségi jogokra vonatkozó alkotmányos garanciák, kisebbségi törvény elökészítése, anyanyelvhasználat biztosítása, valamint a nemzetiségi minisztérium létrehozása -, amelyek gyakorlati megvalósulása az erdélyi magyarok jogi helyzetének konszolidációja szempontjából jelentős előrelépést jelentett volna. Az elkövetkező fejlemények azonban az átmenet etnicizálódását eredményezték, elsőként helyi, majd országos szinten egyaránt, ugyanis az átmenetből származó strukturális problémákkal párhuzamosan a magyar közösség követelései is elötérbe kerültek, melyet a NMF nem akart vagy nem tudott kellőképpen kezelni (László-Novák 2012, p. 73). ${ }^{117}$

A magyarság látványos önszerveződése, föként az etnikailag vegyes településéken a román elit radikalizálódását váltotta ki, melyet tovább fokozott a román állam vezetőinek megnyilatkozása és a magyarellenes civil szervezetek állami támogatása (Frăția Românească, Vatra Românească). E kölcsönös mobilizáció Erdély egyik frontvárosában, Marosvásárhelyen konfliktushoz vezetett: a magyar nyelvü oktatás kérdése olyan folyamatokat indított el, amely március 19-20-én erőszakos összecsapásokhoz vezetett, melyben több személy elhalálozott, több százan megsebesültek (László-Novák 2012, pp. 83-168). Az RMDSZ Elnöksége az eseményeket követően nyilatkozatban fordult a bukaresti vezetéshez kérvén az események kivizsgálását és a vétkesek felelősségre vonását, a Vatra Românească betiltását. A többi kisebbség képviselőit arra kérték, hogy „alkossanak közös frontot demokratikus jogaink, jövőnk megvédelmezéséért."118

A márciusi események a Nemzeti Egység Ideiglenes Tanácsa Végrehajtó Bizottságának március 20-i és 21-i ülésén kerültek napirendre. ${ }^{119}$ Ennek kapcsán két fontos döntés érdemel kiemelt figyelmet: az első, miszerint döntés született egy vizsgálóbizottság létrehozásáról, az események kivizsgálása érdekében, amely másnap megkezdte feltáró munkáját. A vizsgálóbizottság jelentését 1991 januárjában vitatta meg és fogadta el a parlament, azonban a konkrét felelősök megnevezése elmaradt, a bírósági perekben pedig - tudtuk meg az RMDSZ beadványokból - csak magyar és roma nemzetiségüeket ítéltek szabadságvesztésre, a román nemzetiségü vádlottakat rendre felmentették (László-Novák 2012, pp. 179-80). A NEIT másik lépése egy kormánynyilatkozat megszövegezésére irányult, amely a korábbi magyarországi

\footnotetext{
${ }^{117}$ Az átmenet etnicizálódása főként helyi szinten, a Székelyföldön volt tetten érhető, melyet rövid időn belül a román sajtó is tematizált (rendőrlincselések, kádercsere és a térséget elhagyó román elit stb.) (László-Novák 2012, pp. 74-76).

118 „A Romániai Magyar Demokrata Szövetség Elnökségének nyilatkozata, 1990. március 20.

119 A Nemzeti Megmentési Front készülvén a közelgő választásokra hatalmának és pozíciójának megtartása érdekében 1990 februárjában párttá alakult, a történelmi pártok részvételével pedig megalakult a Nemzeti Egység Ideiglenes Tanácsa, illetve ennek megyei szervezetei.
} 
bírálatokra (Szürös Mátyás, Németh Miklós levelei, Horn Gyula nyilatkozatai) vonatkozó válaszlépés is volt egyben, külső beavatkozást hangsúlyozva, köztük a magyar fél felelősségének felemlegetését.

A marosvásárhelyi eseményekre adott román válaszlépéseket a magyar diplomácia sem hagyhatta figyelmen kívül, a diplomáciai lehetőségeket kihasználva a legerőteljesebben kívánt fellépni. A román nyilatkozatra rövid időn belül megszületett a magyar kormány nyilatkozata, melyben visszautasítja a román vádakat, és kérte a román vezetést a nemzetiségi jogok, a helsinki Záróokmányban foglaltak teljesítésére. ${ }^{120}$ Németh Miklós Petre Romanhoz címzett levelében sajnálattal állapította meg, hogy Romániában a többség-kisebbség viszonya nem a megbékélés, hanem a konfrontáció irányába fordult. ${ }^{121}$ A nyilatkozatokkal párhuzamosan a bukaresti nagykövetség találkozót kezdeményezett a felsőszintü vezetőkkel, melynek eredményeként az elkövetkező napokban Szüts Pál bukaresti nagykövet találkozott Ion Iliescuval, Petre Romannal és Sergiu Celac külügyminiszterrel. A nagyköveti beszámolókból összefoglalásképpen megállapítható, hogy a román vezetés nem volt elkötelezett az események azonnali kivizsgálásában. A találgatások, a konfliktus kialakulásáról szóló eltérő forgatókönyvek egyrészt az Iliescu vezetés hatalmának konszolidációját eredményezte, másrészt elterelte a figyelmet a gazdasági és egyéb jellegü problémákról, végül pedig megteremtették annak a lehetőségét, hogy újraszerveződjenek a hírszerző szolgálatok. ${ }^{122}$

Három hónappal a decemberi forradalmat követően a nemzetközi közvélemény figyelme újból Romániára irányult. A levéltári anyagokban nem találtam a szomszédos és a nyugat európai országok részéröl az eseményekre vonatkozó hivatalos álláspontokat, de a legfontosabb médiaorgánumok (Associated Press, Die Welt, AFP, Izvesztja, Le Figaro, Pravda, The Times, Reuter) részletesen ismertették az események kiváltó okait és lefolyását (László-Novák 2012, pp. 186-187). Javier Pérez de Cuéllar ENSZ-főtitkár felhívásában kérte a feleket, hogy „tanúsítsanak tartózkodó magatartást, s

\footnotetext{
120 „Kormánynyilatkozat a romániai magyarellenes cselekményekkel kapcsolatban” 1990. In: Magyar Külpolitikai Évkönyv 1990. pp. 339-341).

${ }^{121}$ A magyar miniszterelnök tiltakozott az RMDSZ-székház feldúlása, Sütő András súlyos bántalmazása, valamint a rendfenntartó erők tétlensége miatt, és nyomatékkal kérte, hogy „,a román hatóságok az ENSZ Alapokmányával és más, Románia által is vállalt nemzetközi kötelezettségekkel összhangban a leghatározottabban lépjenek fel az uszító szervezetekkel szemben [..], mivel a hathatós intézkedések elmaradása beláthatatlan következményekkel fenyeget, amelyekért minden felelösség a román felet terheli.” Németh Miklós üzenete Petre Romanhoz (március 20). RMSZ, 1990. március 22., 75. szám, 4.

${ }^{122}$ Bukaresti magyar nagykövet találkozója Ion Iliescu elnökkel. 1990. március 20, MOL, XIX-J-1-J, tételszám 128-13, 61. doboz, 001501/2; Bukaresti nagykövetünk látogatása Petre Roman miniszterelnöknél, 1990. március 25, MOL, Románia, XIX-J-1-J, tételszám 128-13, 61. doboz, 001501, 1 8; Bukaresti nagykövetünk látogatás S. Celac külügyminiszterrel, 1990. március 26, MOL, XIX-J-1-J, tételszám 128-13, 61. doboz, 001501/1, 1-5.
} 
törekedjenek a jószándék jegyében a megbékélésre, a további vérontás megelőzésére." ${ }^{123}$ A márciusi eseményeket azonban számtalan más fejlemény is követte - parlamenti és államfőválasztás, bányászjárás -, melyek megerősítették a nyugati és szomszédos államok, valamint a nemzetközi szervezetek feltételezéseit, miszerint az országban nem biztosítottak az alapvető emberi és szabadságjogok, valamint a kisebbségi közösségek jogainak védelme. E fejlemények gyakorlati következményeként mélypontra zuhantak a magyar-román kapcsolatok és teljességgel ellehetetlenültek a román külügynek azon próbálkozásai, mellyel Romániát az európai vérkeringésbe próbálta visszavezetni.

A marosvásárhelyi eseményeket követően az erdélyi magyarság és ennek újjászerveződő politikai képviselete új helyzet elé került, ugyanis fokozódott a közösség elleni lejárató kampány és kiéleződtek az etnikai törésvonalak a román belpolitikában. E fejlemények következményeként a Szövetség egyre inkább marginalizált helyzetben találta magát, melyből az egyetlen, járható kiutat az erdélyi magyarság problémáinak nemzetközi megjelenítése képezte, föként az európai fórumokon és nemzetközi szervezetek előtt. A Szövetség külpolitikai célkitüzéseinek kongresszus általi megerősítése ${ }^{124}$ és magyarországi támogatása új frontot nyitott az érdekérvényesítésben, amely az elkövetkező években az RMDSZ külpolitikájának intézményesülését eredményezte. Az intézményesülés azt jelentette, hogy (1) az előzetes programpontok és célkitüzések a Szövetség programjának integráns részévé váltak; (2) a külpolitikai képviselet a szövetség szervezeti struktúrájában is tükröződött: először megalakult a külkapcsolatokkal foglalkozó iroda, majd 1993-ban a Külpolitikai Tanácsadó Testület, és a szövetségi elnök által kinevezett külpolitikai tanácsos; (3) folyamatosan bővültek a Szövetség külkapcsolatai, amely egymástól jól elkülöníthető stratégiára épültek. A külügyi stratégia egyik része a külföldi látogatásokra, tájékoztató körutakra irányult, melynek alapját az egyéni kapcsolathálók és a diaszpórában müködő szervezetek meghívásai jelentették, míg a másik része az európai fórumokon való fokozatos jelenlétet, folyamatos tájékoztató munkát foglalt magába (Szabó 2015, pp. 132-33). ${ }^{125}$

\footnotetext{
${ }^{123}$ Az ENSZ-főtitkár felhívása (március 22). RMSZ, 1990. március 24, 77. szám, 6.

${ }^{124}$ A nagyváradi kongresszuson a külpolitika és a külkapcsolatok jellegére vonatkozóan nem születik kongresszusi határozat, ellenben a kongresszuson elfogadott program megerősíti a szándéknyilatkozatban foglalt elveket és további elemekkel egészíti ki: (1) kifejezi csatlakozási igényét a Magyarok Világszövetségéhez; (2) támogatja a testvértelepülések közötti együttmüködést (falvak, városok, megyék); (3) mivel a kisebbségi kérdést nem tekinti belügynek, „fenntartja magának azt a jogot, hogy tájékoztassa a nemzetközi közvéleményt, a nemzetközi intézményeket a romániai magyarság helyzetéről.” Részlet az RMDSZ I. kongresszusán elfogadott programból. Nagyvárad, 1990. április 21-22. ${ }^{125}$ A sajtóanyagok és más dokumentumokból megtudhatjuk, hogy ebben az időszakban az Egyesült Államokba járt Tőkés László, Markó Béla és Tokay György; Domokos Géza a magyar kormánnyal folytatott tárgyaláson és az EBEÉ párizsi csúcstalálkozóján vett részt, emellett pedig számos budapesti
} 
A két állam közötti diplomáciai kapcsolatokban a rendszerváltás nem jelentett töréspontot, melyet a július végi külügyi államtitkári találkozó eredményei is alátámasztanak. A találkozóról készült jelentésböl kiderült, hogy a kétoldalú kapcsolatok javulása szempontjából napirenden szereplő kérdésekre - főkonzulátusok újranyitása, nemzetiségi charta megszövegezése, nemzetiségi vegyesbizottság megalakítása, a menekültügyi kérdések rendezése - továbbra is az elutasító és a kérdés elhalasztását, újbóli felvetését kérő román álláspont volt uralkodó. ${ }^{126} \mathrm{Az}$ egyetlen lényegi változás, mely a jelentésből kiolvasható a kisebbségek helyzetének megoldására vonatkozott: a kisebbségi vegyesbizottság létrehozására vonatkozó magyar javaslatot a román fél arra hivatkozva vetette el, hogy a kisebbségi „kérdés nem kétoldalú, hanem európai dimenziójú ügy.”" ${ }^{27}$ A júliusban tárgyalt kérdések a november 15-17. közötti külügyi konzultáción is napirenden szerepeltek, azonban lényegi elörelépés nem történt, mert az egyeztetett jegyzőkönyvet a román fél nem írta alá, amely jelzésértékü arra vonatkozóan, hogy ténylegesen nem kívánt előbbre lépni az államközi kapcsolatok vitás kérdéseiben. $^{128}$ Mindazonáltal a külügyi konzultációknak volt egy másik, nem lebecsülendő fejleménye: eszerint a felek között egyetértés mutatkozott arra nézve, hogy felülvizsgálják az 1972-ben megkötött államközi szerződést. ${ }^{129}$

A zavaros belpolitikai helyzet és a Szövetség marginalizálódása, valamint a román félnek a magyar kisebbséggel szemben tanúsított álláspontja a magyar

találkozóról van tudomásunk. Az európai fórumokon az RMDSZ képviseletét a következő személyek látták el: Európa Tanács: Frunda György, póttag: Borbély Imre; Európai Biztonsági és Együttmüködési Értekezlet: Tokay György, póttag: Szabó Károly; Európa Parlament: Borbély László, póttag: Bárányi Ferenc; Fekete-tengeri Unió: Kerekes Károly, póttag: Buchwald Péter.

${ }^{126}$ 1990. július 24-26. között külügyminisztériumi találkozóra került sor Budapesten, melyen Szokai Imre államtitkár-helyettes és Romulus Neagu államtitkár vezetett. Az öt fö témakörben (politikai-jogi, gazdasági, kulturális, konzuli és állampolgári témákban a felek összesen 28 kérdést vitattak meg). Jelentés a magyar-román külügyminisztériumi tárgyalásokról, 1990. július 24-26. MOL, XIX-J-1-J, tételszám 128-13, 61D, 002743/1, 1-20.

${ }^{127}$ Ibid, 11. A jelentés is utal arra, hogy a kisebbségi kérdést a román fél olyan mederbe kívánta terelni, ahol rövid időn belül nem alakíthatók ki kötelező érvényü kisebbségjogi normák. A román külügynek e stratégiája számtalan alkalommal, így az alapszerződés tárgyalásaiban és a státustörvényről folytatott vitákban is napirendre került. Mivel a következő találkozókon a román fél újból belpolitikai kérdésként tekintett a magyar kisebbség helyzetére, megállapíthatjuk, hogy nem tekinthető következetesnek a román álláspont: ez egyrészt a politikai konjunktúra függvényében, valamint a tekintetben változott, ahonnan a lehető legkevesebb kritika volt várható.

128 Jelentés Szokai Imre helyettes államtitkár és Romulus Neagu román külügyminiszteri államtitkár november 15-17-i tárgyalásairól. MOL, XIX-J-1-J, tételszám 128-135, 61D, 003504/7, 1-11.

${ }^{129}$ A szerződés aláírására egy olyan időszakban került sor, amikor már a magyar pártvezetés számára is érzékelhetővé váltak a romániai központosítási törekvések. Ebből adódóan a magyar fél és Kádár sem szerette volna túlértékelni a szerződés aláírását és a bukaresti látogatás jelentőségét, ami alapvetően Bukarestnek kedvezett, annak ellenére, hogy főtitkári találkozó nem hozott jelentősebb eredményt (Földes 2007, p. 160-67). Mégis előrelépésként értékelhető, hogy Magyarország és Románia miniszterelnökei aláírták a Barátsági, együttmüködési és kölcsönös segítségnyújtási szerződést, amelyben a felek vállalták, hogy erősítik a két állam közötti együttmüködést, biztosítják a VSZ-tagállamok határainak sérthetetlenségét, fegyveres támadás esetén pedig katonai segítségnyújtás mellett kötelezték el magukat. 
diplomáciának sem kedvezett. Mindazonáltal Magyarország arra törekedett, hogy az erdélyi magyarság érdekérvényesítési törekvéseinek támogatásával a demokratikus intézmények kialakítását is elősegítse. Az államtitkári találkozók alkalmával tanúsított kezdeményező szerepének eredményei a kulturális és művelődési ${ }^{130}$, valamint a védelmi és katonai együttműködések terén mutatkoztak meg. ${ }^{131} \mathrm{Az}$ együttműködés ez utóbbi dimenziója kiemelt jelentőségü a két állam kapcsolatában, egyrészt mivel döntő érvként szolgált a jövőbeli konfliktus elmaradása mellett, másrészt pedig rácáfolt az államközi fegyveres konfliktus kialakulására vonatkozó előrejelzésekre.

Noha a két ország haderejének állapotáról nem rendelkezünk átfogó információkkal, az empirikus adatok a rendszerváltás időszakában a védelmi kiadások csökkenését jelezték. A Stockholmi Nemzetközi Békekutató Intézet (SIPRI) adatai alapján elmondható, hogy a jelzett időszakban jelentősen csökken Magyarország védelmi költségvetése: míg 1988-ban a védelmi költségvetés a GDP 3,6\%-át tette ki, addig 1993-ra ez az arány 1,9\%-ra csökkent. ${ }^{132}$ Románia esetében a SIPRI becslése alapján a védelemre fordított költségek a GDP több mint 4,5\%-át jelentette, amely 1991től szintén csökkenő tendenciát mutatott. A bemutatott adatok ugyan nem zárták ki egy esetleges fegyveres kialakulását a felek között, azonban a védelemre szánt költségek csökkentése, jelzésértékü arra vonatkozóan, hogy egyik állam sem fegyverkezett, következésképpen pedig minimálisra csökken a konfliktus lehetősége.

Az államközi együttműködés látványos eredményeinek elhanyagolható hatása volt az erdélyi magyarságra. A Szövetség külügyi tevékenységének szükségességét további belpolitikai fejlemények is igazolták, mivel a magyar kisebbség elleni támadásoknak egy fontos színterét a parlamenti viták és az előkészített jogszabályok képezték. Ezek közül kiemelt figyelem övezte Románia új alkotmányának az előkészítését, amely nem fejezte ki az állampolgárok - legfőképpen pedig a nemzeti kisebbségek - elvárásait, és a hatalmon levő politikai erő (Varga 2014, p. 180)

\footnotetext{
1301991 januárjában a két állam Oktatási Minisztériumának képviselői egy oktatási megállapodásról, februárban a magyar házak megnyitásáról, míg júliusban művelődési és kulturális megállapodásról egyeztek meg.

131 Májusban Somogyi Ferenc magyar és Teodor Meleșcanu román külügyi államtitkár aláírta a magyar-román nyitott égboltról szóló szerződést („Acord între Guvernul României şi Guvernul Republicii Ungaria privind stabilirea unui regim de Cer Deschis”, 1991). A dokumentum a térség államai közötti bizalom és biztonság megerősítését célozta, amely évente több próbarepülést irányzott elő a partner államban. A diplomáciai kapcsolatok intenzitásának növekedését az aláírt megállapodások mellett jelezte az is, hogy ET-i tárgyalások keretében a két ország külügyminisztere találkozott egymással, az Európai Újjáépítési és Fejlesztési Bank tanácskozásán pedig államfői megbeszélésre került sor.

132 (,SIPRI Military Expenditure Database” 1988).
} 
alkotmányaként került elfogadásra. ${ }^{133}$ Egy másik ügy, a két, többségében magyarok lakta megyében élő románok helyzetéről készült, az úgynevezett „Har-Cov jelentés”, további akadályokat gördített az etnikumközi együttmüködés elé, mivelhogy kollektív bűnösséggel vádolta az erdélyi magyar közösséget, a parlamenti vitákon felszólaló képviselők pedig számtalan alaptalan vádat fogalmaztak meg és az RMDSZ betiltását kérték. $^{134}$

A fentiekből látható, hogy ebben az időszakban sem a belpolitikai feltételek, sem az államközi kapcsolatok nem szolgálhattak megoldásokkal a kisebbségi kérdés megnyugtató rendezésére vonatkozóan. A probléma európai (nemzetközi) szintü rendezésére a sem mutatkozott sok esély, egyrészt azért, mert európai fórumok figyelmét egyre inkább lekötötték a balkáni események, másrészt pedig a rendszerváltást követően Románia viszonylag elszigetelt helyzetben volt: az európai fórumokkal való kapcsolatai esetlegesek voltak, míg az országban - néhány kivételtől eltekintve - nem voltak jelen a nemzetközi nem-kormányzati szervezetek, harmadrészt pedig állami és nem állami szereplők az emberi jogi dimenziót hangsúlyozták, ezen belül a kisebbségi kérdés kevésbé foglalkoztatta öket.

A bécsi székhelyü International Helsinki Federation az első szervezetek között jelent meg Romániában, munkájáról pedig folyamatosan tájékoztatta a nemzetközi közvéleményt (Cartner 1991). Mint más közép-kelet-európai államoknak, Romániának az Egyesült Államok is nyújtott támogatást a demokrácia-támogatási programjának keretében (USAID). Thomas Carothers szerint a támogatások három föbb beavatkozási területre terjedtek ki: választások, kormányzati intézmények és civil társadalom, Románia esetében ez a kereskedelmi megállapodások és a média támogatásával egészült ki (Carothers 1996, idézi McMahon 2007, pp. 109-110). Románia európai fórumokhoz való viszonyában számos ellentmondás lelhető fel, egyrészt azért mert érezhető volt a román közeledési szándék, másrészt azonban a külügy az ország belügyének tekintette a kisebbségi kérdést. Az EU-Románia viszony kapcsán Kelley kifejtette, hogy az ország

\footnotetext{
${ }^{133}$ Az alkotmánnyal szembeni elégedetlenségének a magyar kisebbség képviselői is hangot adtak: annak ellenére, hogy az elfogadott alkotmány 6. cikkelye elismeri a nemzeti kisebbségekhez tartozó személyek jogát identitásuk megörzéséhez, azonban a kisebbségi jogok védelmének módozatait elmulasztotta megtenni. Egy további hiányosságként értékelendő, hogy az alaptörvény nem határozta meg a többség-kisebbség intézményes viszonyát, ehelyett az egységes és oszthatatlan nemzetállam alapjának a román népet tekintette (Románia Alkotmánya, 1991).

${ }^{134}$ A jelentés alapját azt képezte, hogy ebben az időszakban a román sajtó folyamatosan tudósított arról, hogy a rendszerváltás után a Hargita és Kovászna megyei románokat folyamatosan elnyomják és diszkriminálják, aminek következtében több ezren kénytelenek voltak elhagyni a két, többségében magyarok lakta megyét. Az igazsághoz hozzátartozik az, hogy valóban elindult egy elvándorlási folyamat, ugyanis a kihelyezett pártaktivisták és egyéb káderek állásának egy része a rendszerváltás után megszünt, ezért többen hazatértek szülöhelyükre, de a román sajtó által tematizált románüldözésről nem beszélhetünk.
} 
gazdasági helyzetéből kiindulva, mindkét fél tisztában volt azzal, hogy milyen messze van egy esetleges tagság. Ebböl következhetett többek között az, hogy az EU főként gazdasági kérdésekre koncentrált, a kisebbségi kérdésre alig fordított figyelmet, Románia pedig bizonytalan volt mind a tagsággal kapcsolatos kilátások, mind pedig a kisebbségi problémák EU általi számon kérhetősége tekintetében (Kelley 2010, p. 156).

E fejlemények ellenére a román diplomácia minden eszközzel azon dolgozott, hogy a román állam bekerüljön az európai és nemzetközi vérkeringésbe: a román Külügyminisztérium fehér könyve az ország nemzetközi pozíciójának és megítélésének javítását tüzte ki célul, amelyben fö prioritásként szerepeltek a nyugat európai államokkal és szervezetekkel, valamint a szomszédos államokkal folytatott kapcsolatok bővítése. ${ }^{135}$ Az új külpolitikai stratégia gyakorlati megvalósításaként értelmezhetőek a román külügy tevékenységének aktivizálódása. ${ }^{136}$ A külkapcsolatok javításában egy további stratégiai pont a nemzeti kisebbségek helyzetére vonatkozott, tudniillik e téren Románia több bírálatot kapott. Ezeknek a kritikáknak próbált a román diplomácia elébe menni, egy újabb fehér könyv előkészítésével, amely a romániai kisebbségi rezsim bemutatására törekedett ${ }^{137}$, másrészt pedig folyamatosan napirenden tartotta egy magas szintü államközi találkozó létrejöttének szükségességét (Năstase 2006, pp. 243-46)

A külkapcsolatok bővítésére törekvő RMDSZ két fronton próbált a román törekvésekre válaszolni. Februárban az RMDSZ magyarországi támogatással levelet intézett az ET-hez, amelyben a romániai fejleményeket - a rendőrállam restaurációja, a véleményszabadság és az információáramlás és a mozgásszabadság korlátozása, az igazságszolgáltatással kapcsolatos kifogások - az etnikai diktatúra irányába tartó folyamatként értékeltek. A Szövetség elnöke és főtitkára által jegyzett levél a romániai állapotokra irányította a figyelmet és kérték az ET-képviselőket, hogy gyakoroljanak nyomást a román kormányra és kösse feltételekhez az országnak nyújtott nyugati

\footnotetext{
${ }^{135}$ A román Külügyminisztérium Fehér könyve (Carte Albă - șase luni de preocupări, acțiuni și inițiative: iunie-decembrie 1990), 1990. december 29. MOL, XIX-J-1-J, tételszám 128-2, 41D, 0045.

${ }^{136}$ Az 1990-1991 közötti külügyi iratokból megtudjuk, hogy az ENSZ BT nem állandó tagjaként és soros elnökeként (1990 augusztus) hozzájárult az iraki agresszió elítéléséhez; javultak az ET-vel való kapcsolatai, kereskedelmi együttmüködést kötött az Európai Közösséggel, valamint más nemzetközi és regionális fórumokon is hallatta hangját.

${ }^{137}$ A dokumentum statisztikai adatokra támaszkodva, vázolta a nemzeti kisebbségek jogait, a kisebbségek számszerü jelenlétét a közintézményekben, az anyanyelvi oktatás és az egyházak helyzetét, valamint a kulturális intézmények támogatásáról is közöl adatokat, kiváló eszköznek bizonyult arra vonatkozóan, hogy kisebbségi kérdésben a kormány álláspontját hangoztassa. Fehér könyv a romániai etnikai, nyelvi és vallási kisebbségek jogairól (Carte Albă cu privire la drepturile persoanelor aparținând minorităților etnice, lingvistice sau religioase din România), 1991. július 1. 1991. december 29. MOL, XIX-J-1-J, tételszám 128-2, 41D, 0045/3. Az RMDSZ képviselői és több sajtótermék munkatársa a dokumentumban fellelhető csúsztatásokra hívta fel a figyelmet, melyek nem feleltek meg a valóságnak.
} 
támogatásokat. ${ }^{138}$ A másik frontot a magyarországi politikai vezetőkkel való hivatalos kapcsolatfelvétel jelentette: a november 8-án Budapestre utazó RMDSZ-küldöttséget Antall József miniszterelnök és Szabad György házelnök is fogadta. A romániai belpolitika és az erdélyi magyarság helyzetéről folytatott tájékoztatók mellett a magyar fél egyik fontos szándéka az volt, hogy kikérje a Szövetség véleményét kisebbségi kérdésben a küszöbön álló - január végén sorra kerülő - magyar-román alapszerződésről szóló tárgyalások elő fordulóján kialakított magyar állásponttal kapcsolatban.

Az államközi kapcsolatok két évtizedének diplomáciatörténeti áttekintéséböl megállapíthatjuk, hogy noha a rendszerváltás megteremtette azokat a keretfeltételeket, melyben a felek újraértékelhették volna a másik féllel folytatott viszonyukat, erre csak néhány olyan területen kerülhetett sor, amelyben az erdélyi magyarok helyzetének rendezése nem került napirendre. A romániai belpolitikai folyamatok és a többségi nacionalizmus intézményesülése a '90-es évek elején áthidalhatatlan akadályt jelentett a magyar féllel történő jószomszédi viszony kialakítására, egyben pedig marginalizálta a legnagyobb kisebbségi közösség politikai képviseletét. A felek közötti alapkonfliktus feloldásában sajnálatos módon az európai fórumok és egyéb nemzetközi szervezetek sem jeleskedtek, szelektív jelenlétük az emberi jogok figyelemmel kísérésére, a többség-kisebbség konfliktusának megakadályozására, valamint a stabilitás fenntartására korlátozódott, aminek kontextusában a magyar kisebbség sérelmei, a román állammal szembeni elvárásai kevés relevanciával bírtak.

${ }^{138}$ Az Európa Tanácsnak szóló RMDSZ állásfoglalás, 1991. február 14. MOL, XIX-J-1-J, tételszám 12810, 50D, 00738/1, 1-3. „Felkérjük önöket, hogy csak az esetben és addig támogassák a román kormányt, amíg az hiteles garanciákat nyújt az egyéni és kisebbségi jogok minden állampolgárra kiterjedő védelmével kapcsolatban, továbbá, míg betartja a demokratikus alapelveket, melyeket a Helsinki Záróokmány és más nemzetközi emberjogi dokumentumok is tartalmaznak.” 


\section{A MAGYAR-ROMÁN ALAPSZERZŐDÉS TÁRGYALÁSAI}

\section{1. Általános európai kontextus}

Az államok közötti kétoldalú szerződések egyik leggyakoribb instrumentumai a diplomáciatörténetnek. A 20. századi Európában több példát találunk az államok közötti megbékélést, az együttmüködést, valamint a jószomszédi kapcsolatok megteremtését célzó egyezményekre. Szem előtt tartva az eltérő történelmi és politikai körülményeket, tartalmuk és célkitüzéseik alapján az államok által aláírt szerződések több típusát különböztethetjük meg. Az államközi szerződések első csoportjába azok a dokumentumok tartoznak, amelyek a második világháborút követően, a háború utáni rendezésekre vonatkoztak és rendelkeztek a diplomáciai, valamint a gazdasági kapcsolatok helyreállításáról. Két évtized elteltével, a '60-as és a '70-es években a szocialista tömb államai megújították a barátsági és kölcsönös segítségnyújtási szerződésekben foglaltakat és megerősítették a fennálló status quo-t, amellyel akarvaakaratlanul elfogadták a moszkvai vezetés által megszabott irányvonalat és szuverenitásuk korlátozását is.

A kétoldalú szerződések harmadik csoportjába sorolható azon államok által megkötött szerződéseket, amelyek új külpolitikai irány kijelölésére vonatkoznak. Példaként az NSZK és a szocialista tömb államai közötti, keleti szerződéseket (Ostverträge) említhetjük, amelyek ugyan nem tartalmaztak kivételes rendelkezéseket, de hozzájárultak az államközi kapcsolatok fejlődéséhez és a két tömb közötti enyhüléshez. ${ }^{139}$ A keleti szerződések a két német állam viszonyának a rendezését is előirányozta, aminek eredményeként 1972 decemberében az NSZK és az NDK vezetői az első alapszerződésnek (Grundvertrag vagy Grundlagenvertrag) nevezett diplomáciai egyezmény aláírása mellett döntöttek. ${ }^{140}$

A rendszerváltás időszakában az államközi szerződéseknek két mintája is megjelent az európai politika napirendjén. Először a Szovjetunió kezdeményezte a volt szocialista államokkal kötött barátsági szerződések megújítását, felbomlásáig pedig Németországgal, Ukrajnával, Fehéroroszországgal, Romániával, Litvániával és

\footnotetext{
${ }^{139}$ A Német Szövetségi Köztársaság 1970-ben a Szovjetunióval és Lengyelországgal, 1972-ben a Német Demokratikus Köztársasággal, míg 1973-ban Csehszlovákiával kötött államközi szerződést. A szerződések tartalmilag nagyfokú hasonlóságot mutattak, közös vonásként megjelent bennük az európai államok közötti baráti kapcsolatok kialakítására vonatkozó törekvés, a vitás kérdések békés eszközök útján történő megoldása, a területi követelésekröl való lemondás, valamint az európai államok területi sérthetetlenségének és szuverenitásának tiszteletben tartása.

${ }^{140}$ A dokumentumban a szerződő felek ugyan elismerték Németország megosztottságát, de nem mondtak le ennek jövőbeli újraegyesítési lehetőségéről. („Vertrag über die Grundlagen der Beziehungen”, 1972).
} 
Magyarországgal kötött államközi szerzödéseket. Az orosz érdekek mögött - véli Björn Arp -, feltehetően Oroszország korábbi befolyásának megőrzése szerepelt, mert abban reménykedett, hogy a szovjet szövetségi rendszer felbomlását követően a kétoldalú szerződések biztosítani fogják a hegemón pozícióját a térségben (Arp 2008, p. 7). Azonban a Szovjetunió felbomlása és a kelet-közép-európai államoknak az európai fórumokhoz való csatlakozási igényének kifejeződését követően nem valósulhattak meg ezen elképzelések.

Az alapszerződések megkötésének másik mintáját az újraegyesült Németország jelentette, amely nemcsak a határait legitimálta ezzel a szerződésformával, de a határain kívül élő német kisebbség helyzetét is így igyekezett rendezni (Gál 1999, pp. 3-4). A németek által „meghonosított” alapszerződés-mintát - a tipológia alapján az alapszerződések negyedik csoportját - számos KKE-i állam követte, aminek eredményeként a térség államai közötti szerződések száma meghaladta a százat ${ }^{141}$, melyek esetenként kisebbségi szempontból is figyelemreméltó rendelkezéseket tartalmaztak. $^{142}$

Noha a rendszerváltás után az alapszerződések elterjedésében a német mintakövetés fontos katalizátor szerepet töltött be, az államközi egyezmények aláírása elsősorban a béke és biztonság, valamint a stabilitás fenntartására irányultak, mivel számos vitás kérdés, megoldatlan probléma terhelte a térség államainak kapcsolatrendszerét. A problémák egy jelentős része a kisebbségi kérdés rendezetlenségéhez, a többség-kisebbség viszonyában megjelenő problémákhoz kapcsolódott, amely rövid idő alatt - a balkáni eseményeknek betudhatóan - a biztonságpolitikai napirend részévé vált. A kialakult helyzet jelentős kihívások elé állította a nyugat-európai államok és az európai fórumok képviselőit, két okból is. Egyrészt az európai fórumok a stabilitás és a béke fenntartásában voltak érdekeltek, aminek következtében elképzelhetetlennek látszott azon államok csatlakozása, amelyek belső politikai és gazdasági problémákkal küzdenek és szomszédsági kapcsolataikat pedig megoldatlan konfliktusok és problémák terhelik. Másrészt a Helsinki Záróokmány aláírása után nem született jelentősebb, a kisebbségi jogokat is érintő dokumentum. A KKE-i államokban lezajlott változások újabb lendületet adtak a kisebbségi jogi szabályozások kialakításának, amelyben két szervezet, az EBEÉ/EBESZ, valamint az

\footnotetext{
${ }^{141}$ Lásd erre vonatkozóan a Függelékben található térképet.

142 Példaként a '90-es évek elején az Antall-kormány a magyar kisebbség szempontjából kedvező alapszerződést kötött Ukrajnával, Szlovéniával és Horvátországgal (Bíró 1999, pp. 347-48).
} 
ET kardinális szerepet játszott a kisebbségi normák kiszélesítésében és elfogadtatásában, majd a különböző mechanizmusok útján történő számonkérésében.

Helsinki után a kisebbségi jogok kérdése rendre megjelent a Záróokmány által életre hívott utótalálkozókon: az EBEÉ emberi dimenzióval foglalkozó koppenhágai konferenciájának dokumentuma egy külön fejezetben foglalkozott a kisebbségi jogok kérdésével, felsorolva ezen jogosítványokat és kitért a tagállamok felelősségére is. ${ }^{143}$ Noha a dokumentum formálisan összekapcsolta a kisebbségi jogok tiszteletben tartását a béke és stabilitás kérdésével, nem vezetett be olyan ellenőrzési vagy panaszmechanizmust, amelyre a kisebbségi közösségek hivatkozhattak volna, mi több a tagállamok eltérő javaslatainak betudhatóan a szakértői találkozókra vonatkozóan sem született döntés. ${ }^{144}$

Az EBEÉ keretei között kisebbségi kérdésben igazi áttörésként értékelhető a Nemzeti Kisebbségi Főbiztos intézményének a létrehozása (Majtényi-Vizi 2003, pp. 198-203), aki a későbbiekben fontos szerepet játszott a konfliktusok megelőzésében és a felek közötti vitás kérdések tárgyalás útján történő rendezésében. A Főbiztos megjelenése és konkrét beavatkozása jelentős előrelépés volt a kisebbségvédelemben, mivel egyrészt nagyban hozzájárult ahhoz, hogy a tagállamok a kisebbségi kérdésre ne saját belügyként tekintsenek, másrészt pedig a többség-kisebbség közötti közvetítő munkája új dimenzióval egészítette ki az EBESZ, leginkább kormányközi szinten kifejtett tevékenységét.

Az EBEÉ-vel párhuzamosan az ET is törekedett arra, hogy a demokráciának, a jogállamiságnak és az emberi jogok biztosításának érvényt szerezzen a volt kommunista államokban, amelyek egyben a tagfelvételi kritériumokat is képezték. Az ET keretében elfogadott ajánlások két fontosabb dokumentum elfogadását alapozták meg, amely konkrét ellenőrzési mechanizmusokat vezetett be és referenciapontot jelentett az európai kisebbségvédelemben. Az első kiemelkedő dokumentum a Regionális vagy kisebbségi nyelvek európai chartája, amely ugyan az egyes tagállamokra bízta annak eldöntését, hogy milyen kötelezettségeket vállalnak, ellenben világosan rendelkezett a végrehajtásról és az ellenőrzési mechanizmusokról. ${ }^{145}$ A dokumentum egy kevésbé

143 ("Az EBEÉ emberi dimenzióval foglalkozó koppenhágai konferenciájának dokumentuma" (Koppenhága, 1990. június 29. In: Bíró 2002, pp. 178-198).

${ }^{144}$ Nem lebecsülendő eredménye azonban az EBEÉ állam- és kormányfőinek találkozója (Koppenhága, Moszkva), amely rendre megerősítette az emberi dimenzióval foglalkozó konferencián elfogadott dokumentumokat (Höhn 2005, pp. 176; 72-73).

145 ("Regionális vagy kisebbségi nyelvek európai chartája", 1992. október 2, In: Bíró 2002, pp. 213-231). 
hivatkozott részében az államok által aláirt két- és többoldalú megállapodásokban a kulturális és az oktatási együttmüködés elősegítését kéri az érintett államoktól. ${ }^{146}$

Az ET másik referenciadokumentuma a nemzeti kisebbségek védelméről szóló Keretegyezmény, amely számos programszerü alapelvet és rendelkezést tartalmazott, valamint a tagállamok számára (aláíró felek) kötelezettségeket is elöírt. ${ }^{147} \mathrm{~A}$ Keretegyezmény az államközi kapcsolatok javítására is konkrét javaslatot tett, ugyanis bátorította a részes, legföképp pedig a szomszédos államokat két- és többoldalú egyezmények megkötésére, annak érdekében, hogy „biztosítsák az érintett nemzeti kisebbségekhez tartozó személyek védelmét."148

A biztonság és stabilitás fenntartásának, valamint a kisebbségi problémák kezelésének összekapcsolása és kétoldalú egyezményekkel történő rendezése a kisebbségvédelmi dokumentumokon túlmutatóan az európai politika napirendjén is megjelent. Ennek kiindulópontját Édouard Balladur francia miniszterelnöknek az ET koppenhágai csúcstalálkozóján bemutatott dokumentuma képezte, amelynek kidolgozásában a tagállamok mellett az EU, az ET és az EBESZ képviselői is aktívan részt vettek, elfogadására pedig az EBESZ párizsi konferenciáján került sor. ${ }^{149}$

Az Európai Stabilitási Egyezmény végső soron nem terjedt ki az összes az összes KKE-i államra: lényegében csak arra a kilencre vonatkozott, amelyek közép és hosszabb távon számíthattak a csatlakozásra, vagyis aláírták, vagy az aláíás folyamatában volt az EU-val köttetendő társulási megállapodás. ${ }^{150}$ Az Egyezmény aláírói Európa stabilitásának kulcsát az állampolgárok akaratának demokratikus úton történő kifejeződésében, az emberi jogok és a kisebbségekhez tartozó személyek jogainak tiszteletben tartásában, a szuverén és egyenlő államok határokon átnyúló

\footnotetext{
${ }^{146}$ A felek „olyan módon alkalmazzák a létező és olyan államokkal szemben fennálló kötelezettséget tartalmazó két- és többoldalú megállapodásokat, ahol ugyanazt a nyelvet azonos vagy hasonló formában használják, vagy - ha szükséges - olyanok megkötésére törekednek, hogy azok segítsék elő az érintett államokban élö, azonos nyelvet használók közötti kapcsolatokat a kultúra, az oktatás, az információ, a szakképzés és a továbbképzés területén." (ibid. 14. cikkely). Alkalmazása a chartához hasonlóan ellenőrzési mechanizmushoz kötött: az államok által benyújtott országjelentéseket az ET Miniszteri Bizottsága ellenőrzi.

${ }^{147}$ ("Keretegyezmény a nemzeti kisebbségek védelméről", 1995. február 1. In: Bíró 2002, pp. 239-69).

${ }^{148}$ Ibid. 18. cikkely.

${ }^{149}$ A javaslat a balkáni események tanulságaként olyan biztonsági rendszer megalakítását kezdeményezte, amelynek értelmében a balkáni és kelet-európai államok között fennálló, a területi és határkérdésböl, valamint a kisebbségi problémákból eredő vitákat a felek különböző megállapodásokban és államközi szerződésekben rendeznék. A dokumentum továbbá világos napirendet jelölt ki, amelyben az EU 12 állama mellett az EBEÉ is aktív szerepet játszott volna és meghatározta potenciálisan résztvevő államok körét is. A dokumentum érdekessége - más európai egyezményekhez képest -, hogy az európai staus quo megváltozását is lehetséges forgatókönyvként kezelte, mert nem zárta ki a megállapodásokban rögzített kisebb határkiigazításokat sem (,Balladur terv” 1993).

${ }^{150}$ A szóban forgó kilenc állam a következő volt: Bulgária, Csehország, Lengyelország, Magyarország, Románia, Szlovákia valamint a balti államok: Észtország, Lettország, Litvánia (Benoît-Rohmer 1996a, p. $31)$.
} 
együttműködésében és a jószomszédi kapcsolatok fejlesztésében látták (Benoît-Rohmer 1996, pp. 81-84). Tehát az európai államok között deklaratív módon újra elismerést nyert, hogy a stabilitás és a demokrácia szempontjából az alapvető emberi jogok és a kisebbségekhez tartozó személyek jogainak biztosítása alapvető feltétel. A dokumentumban - amelynek függeléke részletes áttekintést adott az addig aláírt államközi szerződésekről és nyilatkozatokról - tételesen nem szerepelt, hogy a jószomszédi viszony kialakítása és a kisebbségi jogok rendezése feltételként jelenne meg az európai fórumokhoz való csatlakozásnál. Ehhez képest az 1995 szeptemberében megjelenő, a NATO bővítéséről szóló tanulmány jelentős szemléletbeli változást hozott és az alapszerződések megkötésétől tette függővé a jövőbeli csatlakozást. ${ }^{151}$

4. sz. ábra: Az európai biztonság és kisebbségvédelem összefüggései: az alapszerződés aláírása

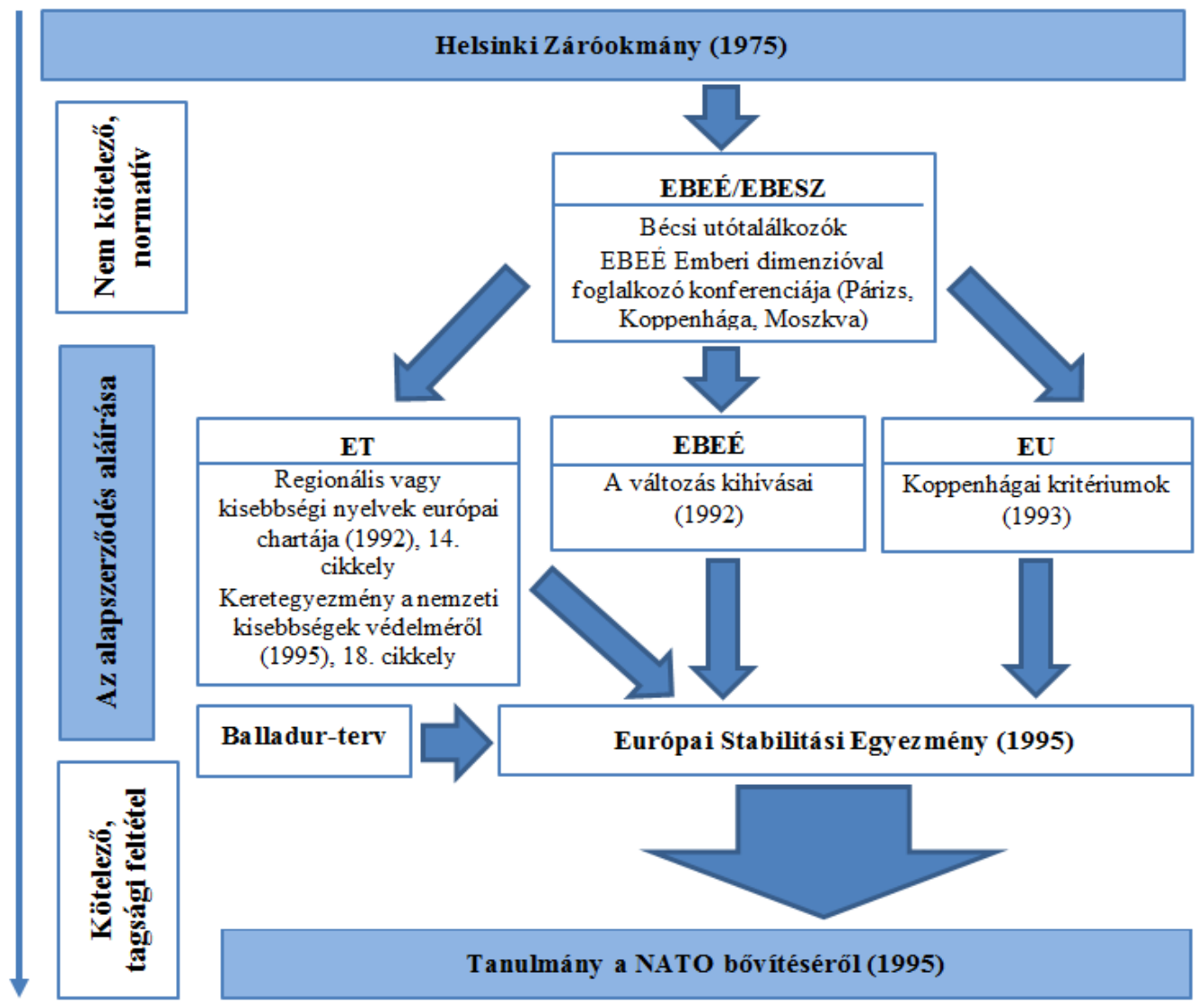

Forrás: (Arp 2008, p. 23), módosításokkal és saját kiegészítésekkel.

Az alapszerződések és a kisebbségvédelmi normák elterjedésére vonatkozó áttekintés több összefüggésre is rámutatott, nevezetesen arra, hogy a rendszerváltás

\footnotetext{
${ }^{151}$ A dokumentum egyik cikkelye explicite kimondta, hogy „azok az országok, amelyekben etnikai viták zajlanak, vagy amelyeknek területi vitáik vannak más államokkal, kötelesek ezeket a vitákat békés úton rendezni, az EBESZ alapelveivel összhangban. E viták rendezése döntő tényező lehet abban, hogy egy államot meghívnak-e a szervezetbe vagy sem" (NATO 1995).
} 
utáni alapszerződések aláírása szorosan összekapcsolódott egyrészt az európai biztonsággal és a kisebbségvédelmi normákkal, másrészt pedig az európai fórumok bővítési stratégiáival. Míg a '90-es évek első felében elfogadott, az emberi jogokra és a kisebbséghez tartozó személyek jogaira vonatkozó dokumentumok csak elvi szinten hivatkoztak az alapszerződések megkötésére, addig a NATO csatlakozási kritériumban egyenesen feltételként szerepelt az államközi egyezmények aláírása, valamint a kisebbségi problémák és a határviták rendezése.

Az európai fórumok törekvéseiből megállapítható, hogy az alapszerződésre olyan eszközként tekintettek, amely nagymértékben hozzájárul a kelet-közép-európai térség stabilizálódásához és aláírása komoly garanciaként szolgál arra nézve, hogy a határkérdés és a kisebbségi sérelmek, mint a legfontosabb konfliktust kiváltó problémák rövid időn belül rendeződjenek. Az alapszerződésről folyó tárgyalások és a dokumentum aláírása, mint azt a továbbiakban a magyar-román alapszerződés kapcsán kifejtem, részlegesen teljesítették az európai fórumok elvárásait és hozzájárultak a felek közötti kapcsolatok rendezéséhez. Az alapszerződés keretében létrejött rendezés - mint utóbb kiderült - igencsak felszínesnek bizonyult, mert a valódi megbékéléshez - a két állam elköteleződésének hiányában - elégtelennek bizonyult. A kisebbségi kérdés tekintetében a dokumentum aláírása ugyan lehetővé tette az RMDSZ kormányzati részvételét, de a kisebbségvédelem, a kisebbségi jogok tekintetében nem bizonyult elöremutatónak, és az adott helyzetet, a '90-es évek közepén érvényben levő kisebbségvédelmi garanciákat rögzítette.

\section{A magyar-román alapszerződés tárgyalásának folyamata ${ }^{152}$}

A levéltári források és a rendelkezésre álló dokumentumok alapján viszonylag jól elkülöníthetőek az alapszerződés tárgyalásának egyes periódusai, valamint a tárgyalások dinamikája is, nevezetesen az, hogy az adott időszakban milyen intenzívek voltak a két fél közötti egyeztetések, és hogyan alakultak ki, illetve milyen tényezőknek betudhatóan változtak a felek által képviselt álláspontok, melyet diplomáciai nyelven tárgyalási mandátumnak nevezünk. A magyar-román alapszerződés tárgyalásait és a szereplök pozícióit több belső és külső tényező is befolyásolta.

Elsőként a magyarországi és romániai belpolitikai erőviszonyok alakulása emelhető ki, mivel a parlamenti választások eredményei és ennek nyomán létrejövő kormánykoalíciók összetétele meghatározónak bizonyult a tárgyalások és a képviselt

\footnotetext{
${ }^{152}$ A tárgyalások folyamatát a Külügyi Szemlében megjelent tanulmányban is feldolgoztam (Szabó 2014)
} 
álláspontok szempontjából. Míg Romániában az első 1990 májusában megtartott parlamenti választáson a Nemzeti Megmentési Front kétharmados többséget szerzett, Ion Iliescu pedig a szavazatok 85\%-ával nyerte meg az államfőválasztást, a politikai pluralizmus és az elodázott reformok jelentős változásokhoz vezettek. A Frontból kiváló Iliescu pártja (Nemzeti Megmentés Demokratikus Frontja, későbbiekben Társadalmi Demokrácia Pártja) a következő, 1992. szeptember 27-i választásokon a parlamenti helyek egyharmadát szerezte meg és kisebbségi kormányzásra kényszerült, viszont élvezte a nacionalista erők támogatását (Román Nemzeti Egységpárt - PUNR, NagyRománia Párt - PRM), akik később formálisan is a kormánykoalíció részévé váltak (Bakk 1999, pp. 84-85). A koalíció létrejöttének következtében nemcsak az RMDSZ pozíciója gyengült, hanem intézményes formát öltött a többségi nacionalizmus, gyakorivá váltak a kisebbségellenes kirohanások, valamint Magyarország lejáratására irányuló törekvések. Ennek betudhatóan a hármas külpolitikai célrendszert követő Antall-, majd Boross-kormányzat jelentős akadályokba ütközött, hiszen az intézményesülő magyarságpolitikát, az RMDSZ támogatását, valamint az anyaország szerepének aktivizálódását a román fél rendre az ország belügyeibe való beavatkozásként értékelte. A romániai belpolitikai folyamatok az erdélyi magyarság és az RMDSZ pozícióját is gyengítette: a Szövetség fokozatos marginalizálódása, a magyar kisebbséget hátrányosan érintő jogszabályok elfogadása szintén kihatott a tárgyalásokra.

Végül pedig, a tárgyalásokat meghatározó külső tényezőkről kell említést tennem, valamint a kormányzati-külpolitikai opciókról: míg Magyarország, már a rendszerváltást követően kinyilvánította az európai fórumokhoz való csatlakozási szándékát, addig Romániában későbbre tehető az integrációs elköteleződés, amely a külpolitikai opciók tekintetében nagyobb mozgásteret kölcsönzött. Erre a külpolitikai határozatlanságra az európai fórumok által meghatározott bővítési feltételek nyilvánosságra hozatala és a csatlakozás menetrendjének ismertetése (társulási szerződés, tagfelvételi kérelem) tett pontot.

Figyelembe véve a levéltári anyagokat, valamint a bel- és külpolitikai tényezőket, az alapszerződés tárgyalásának három, egymással összefüggő periódusát különítettem el: (1) az elökészületek és a javaslatok ismertetése az 1991. május-1992. február közötti időszakban történt, amikor lezajlottak az első szakértői tárgyalások, ismertté váltak a felek által bemutatott szövegtervezetek, valamint az első reakciók is; (2) a konkrét tárgyalási folyamat az 1992. február-1995. augusztusa között sorra kerülő szakértő egyeztetéseket és felsőbb szintű találkozókat jelenti, amikor kevés érdemi 
elörelépésről beszélhettünk, mert a tárgyalófelek között élénk vita alakult ki a határok sérthetetlensége (5. cikkely) és a nemzeti kisebbségek jogainak garantálása (16. cikkely) körül; (3) az aláirás időszaka a NATO bővítéséről szóló tanulmány megjelenése utáni időszakot, pontosabban a tárgyalások utolsó egy évét (1995 szeptember - 1996 szeptember) foglalta magába.

\subsection{A tárgyalások elökészületei és a javaslatok ismertetése}

A magyar-román alapszerződés kérdése 1991 folyamán jelent meg a bilaterális kapcsolatok napirendjén: májusban a román, novemberben pedig a magyar tervezetet mutatták be a felek - azonban a konkrét tárgyalások csak a szakértői egyeztetések első fordulóján, 1992. január 27-30. között kezdődtek meg. ${ }^{153}$ A Külügyminisztérium 4. Területi Főosztályának feljegyzésében ${ }^{154}$, valamint a szakértői tárgyalásokról készült jelentésben ${ }^{155}$ és az utólagos feljegyzésekben a dokumentumok tartalmi különbségei mellett a felek eltérö érdekei is megjelentek.

A román tárgyalási pozíciókat leginkább a bizonyításkényszer határozta meg, ugyanis a kilencvenes évek első felében Románia viszonylag elszigetelt helyzetben volt, a tárgyalásokon tanúsított kezdeményező készségével az európai fórumok irányába is ki szerette volna mutatni együttműködési készségét, mindemellett pedig egy pozitívabb országimázs kialakítására törekedett. A kül- és belpolitika viszonylagos összefonódását jól jelezte az a tény, hogy az alapszerződések tárgyalásainak eredményeit a román vezetés a belpolitikában igyekezett kihasználni - ugyanis 1992-ben önkormányzati, parlamenti és államfőválasztásokra is sor került -, és eredményeket felmutatni a választópolgárok felé, anélkül azonban, hogy túl nagy engedményeket tettek volna a magyar félnek és az erdélyi magyar kisebbségnek. A kormány kétszintű játszmája alkalmas volt arra, hogy úgy erősítse a pozícióját a külpolitika terén, hogy közben a belpolitikában is sikereket érjen el, de mégse vállaljon nagy kötelezettségeket a kisebbségi jogok terén. Következésképp Románia abban volt érdekelt, hogy minél előbb, lehetőleg az őszi parlamenti választásokig aláírja az alapszerződést.

Romániával szemben Magyarország nem volt ilyen jellegü kényszerhelyzetben: az volt számára a legfontosabb szempont, hogy valóban normalizálódjanak a bilaterális

\footnotetext{
${ }^{153}$ A magyar delegáció tagjai: Boros Miklós, Bródi Gábor, Hodicska Tibor, Katona László, Keszthelyi Gyula, Szénási György, vezetője: Szőcs Ferenc. A román delegációt Ion Diaconu vezette, tagjai: Gheorghe Albut, Ion Donca, Avram Tura, Dumitru Tincu. Jelentés a magyar-román államközi alapszerzödésröl folytatott szakértői tárgyalások első fordulójáról, 1992. február 3. MOL, XIX-J-1-J, tételszám 128-1, 49 D, 330/1. 5.

${ }^{154}$ Mandátum a magyar-román alapszerződés tárgyalásának első fordulójához, 1992. január 23. MOL, XIX-J-1-J, tételszám 128-1, 49 D, 330. 1-4 és 1-3.

155 Jelentés a magyar-román államközi alapszerzödésröl, 1-28.
} 
kapcsolatok - aminek fontos eleme volt a demokráciára és pluralizmusra épülő politikai berendezkedés romániai kiépítésének támogatása, továbbá a kisebbségi jogi garanciák biztosítása. Cserébe Magyarország ígéretet tett arra, hogy a nyugati integrációs szervezetekben támogatja a román fél csatlakozási törekvéseit.

Ami a két fél által bemutatott szövegjavaslatokat illeti, lényeges különbségek mutatkoztak köztük mind tartalmi, mind pedig terjedelmi szempontból. A román tervezet részletesen foglalkozott a területi sérthetetlenség problémájával, viszont nem tartalmazott a kisebbségi kérdésre vonatkozó cikkelyt, megszövegezését tekintve pedig rövidebb és általánosabb volt a magyar változathoz képest. ${ }^{156}$ Ezzel szemben a magyar változat több konkrétumot tartalmazott, a területi sérthetetlenség kapcsán a Helsinki Záróokmányra hivatkozott, a kisebbségi cikkely tervezetében pedig hangsúlyozta, hogy a kérdés már nem teljességgel az adott ország belügye: a kisebbségeknek joguk van a saját kultúrájuk megőrzéséhez, továbbá oktatási, vallási és kulturális intézményrendszereket hozhatnak létre. Szintén a magyar javaslatban jelent meg, hogy a felek minden szükséges lépést megtesznek az asszimiláció, illetve az etnikai jellegü adminisztratív vagy gazdasági megkülönböztetés leküzdésére. Emellett a kisebbségi cikkely kitért az anyanyelven való oktatás biztosításának fontosságára, valamint az anyanyelv használatának szabályozására (a törvényhozásban és a közigazgatásban is). Külön cikkely foglalkozott továbbá a kulturális, tudományos és oktatási együttmüködéssel, valamint a regionális együttműködéssel, amelyről a román tervezet nem tett említést. ${ }^{157}$

A tárgyaláson a román delegációt vezető Ion Diaconu a kisebbségi cikkely megvalósítását technikai jellegű kérdésnek minősítette, s azt állította, hogy ,ezzel a cikkellyel Magyarország a nemzetiségek jogállását igyekszik kidolgozni és rögzíteni, ami Bukarest számára elfogadhatatlan". ${ }^{158}$ Ezzel szemben a határok sérthetetlenségének a kimondása elsőrendű fontosságú Románia számára, merthogy amint Diaconu kifejtette, egyrészt ettől függött az ország kapcsolatainak a jövője, másrészt a közvéleményt is igencsak foglalkoztatta. ${ }^{159} \mathrm{~A}$ határkérdés lebegtetése inkább egy

\footnotetext{
${ }^{156}$ Mandátum a magyar-román alapszerzödés szakértői tárgyalásainak első fordulójához, 1992. január 23. MOL, XIX-J-1-J, tételszám 128-1, 49 D, 330.

157 Jelentés a magyar-román államközi alapszerzödésröl. A szerződés egyeztetett szövege az 1992. január 30-i állapot alapján, 19.

${ }^{158}$ Uo, 3-4.

${ }^{159}$ Nem találtam utalást arra nézve, hogy miért tulajdonított a határkérdésnek ekkora jelentőséget a román fél, de bizonyosra vehető, hogy a magyar fél kisebbségi cikkelyével szemben nekik is fel kellett lépnie, ez pedig nem más volt, mint a területi sérthetetlenség elve. Abban az időszakban ugyanis az európai integrációs szervezetek is nagy hangsúlyt fektettek a határkérdések stabilizálására. Így a románok részéről az nem bizonyult alaptalan felvetésnek, mi több a Nyugat irányába is könnyen kommunikálható volt a
} 
tárgyalási stratégia volt, aminek képviselete a közvéleményre való hivatkozással nagyobb hitelességet kölcsönzött, ugyanis az álláspont sokkal jobban tartható, ha a tárgyalódelegáció belpolitikai nyomásra hivatkozik. A tárgyalások legvitatottabb elemévé tehát a határok sérthetetlenségére vonatkozó román, valamint a kisebbségi jogok biztosításának magyar cikkely-tervezete bizonyult: a tartalmukban csak többszöri szakértői és magas szintű diplomáciai egyeztetések után sikerült némi módosítást elérni.

Az első szakértői tárgyalásokról szóló nyilatkozatok alapján megállapítható, hogy a résztvevők pozitív fejleményként értékelték a megbeszéléseken történt elörelépéseket, mi több, Diaconu annak a véleményének adott hangot, hogy a következő szakértői tárgyalásokon akár véglegesíthető is a két fél szövegtervezete. A román sietség és elszántság mögött tetten érhető egy nagyfokú bizonyításkényszer, mivel kétség sem fért hozzá, hogy a tárgyalásokon elért eredményeket igyekeztek „hasznosítani” az európai fórumokkal folytatott egyeztetések során.

\subsection{A tényleges tárgyalási folyamat}

Az alapszerződés ügyében a konkrét tárgyalások az 1992. január végén megrendezett első szakértői megbeszélések után indultak meg, azonban a magasabb szintü nyilatkozatoktól eltekintve 1995 szeptemberéig kevés érdemi elörelépés történt, amelynek okai összefüggtek a román belpolitikai fejleményekkel. 1992 ugyanis választási év volt: februárban önkormányzati, szeptemberben pedig a parlamenti választásokkal egyszerre államfőválasztást is tartottak, melyek felszínre hozták azokat a nacionalista erőket, amelyek a leginkább igyekeztek kijátszani a magyar kártyát (magyarellenes hangulatkeltés, a Für Lajos és Entz Géza elleni támadás, külföldi propaganda-hadjárat Magyarország lejáratására) ${ }^{160}$, egyúttal pedig - a román célkitűzések ellenében - lehetetlenné tették az alapszerződés aláírását a parlamenti választások előtt. A magyar fél számára így nem volt nehéz felismerni, hogy a választásokig várnia kell, mert ezzel a kormánnyal nem célravezető megkötni az alapszerződést, ugyanis aligha várható tőle az erdélyi magyarság problémáinak rendezése és a kétoldalú kapcsolatok normalizálása. ${ }^{161}$

megalapozottsága. A másik felvetés, miszerint a kérdés a közvéleményt is foglalkoztatja, kevés valóságalappal bírt: a lakosságot abban az időszakban a növekvő infláció, a fogyasztói árak és a téli gázáremelkedések foglalkoztatták a leginkább, a határkérdést sokkal inkább a külügy tartotta napirenden. Az új román kormány programja, 1992, november 25. MOL, XIX-J-1-J, tételszám 128-2, 50 D, 2960/1, $1-3$.

160 A román tömegtájékoztatás magyarellenes megnyilvánulásai, 1992. április 23. MOL, XIX-J-1-J, tételszám 128-8, 52 D, 721/1, 1-5.

${ }^{161}$ Erre utal a Külügyminisztérium 4. Területi Főosztályának a február 24-én keltezett válasza a szakértői tárgyalások második fordulójára való román meghívásra. A Főosztály értékelte a 330/1. aktában a 
A tárgyalásoknak ebben a szakaszában kiszélesedett az alapszerződésről folyó egyeztetésekben részt vevő felek száma: egyrészt megjelentek az európai integrációs szervezetek (ET, EBESZ, NATO, EK) és a nyugati államok, továbbá az RMDSZ hivatalosan is kérte, hogy vonják be a szakértői megbeszélésekbe. Az utóbbi azonban sosem vált tényleges tárgyaló féllé, ezért szerepe - csakúgy, mint a nemzetközi szervezeteké és a nyugati államoké - tisztázásra szorul.

Az európai integrációs szervezetek és a nyugati tagállamok az alapszerződés tárgyalásának kontextusában normaalkotókként jelentek meg, a román diplomácia tevékenysége pedig arra irányult, hogy meggyőzze a Nyugatot: hazájuk elkötelezett a demokrácia, a jogállamiság és a kisebbségi jogok megvalósulása iránt, kétoldalú kapcsolataiban pedig a Magyarországgal való megállapodásra és az alapszerződés aláírására törekszik. Ez az érvrendszer nemcsak az Európa Tanáccsal, hanem az Európai Közösséggel folytatott tárgyalásokon is megjelent. A csatlakozás elérése érdekében a román fél olyan külföldi propagandaoffenzívát indított, amellyel legalább három célját kívánta megvalósítani: (1) Románia jó színben való feltüntetése; (2) a nyugati közvélemény megnyugtatása és félretájékoztatása a romániai magyar kisebbség helyzetét illetően; valamint (3) Magyarország lejáratása, tárgyalási pozíciójának gyengítése. ${ }^{162}$ Ha sikerességi kritériumként a kitüzött célokat vesszük alapul, megállapítható, hogy a külföldi propaganda felemás, de nem lebecsülendő eredményt ért el, amit az önkormányzati választásokkal szoros összefüggésben álló ET-tagság ügye szemléltet. Egyrészt tény, hogy az 1992. februári önkormányzati választások hangulata és a magyar közösséget ért jogsértések következtében Románia az ET-ben meglévő különleges meghívotti státusát nem tudta teljes jogú tagságra változtatni; másrészt

tárgyalások első fordulóját, és a következő megállapításra jutott: „Jelen helyzetben nem érdekünk, hogy a román parlamenti választások előtt a most hivatalban levő kormánnyal a tárgyalásokat folytassuk...". Román meghívás az alapszerződési tárgyalások második fordulójára, 1992. február 20. MOL, XIX-J-1-J, tételszám 128-1, 49 D, 330/4, 3. Hasonló a végkövetkeztetése a május 18-19. között sorra került államtitkári találkozónak, amelyen Meleșcanu tárgyalt magyar kollégájával, Katona Tamással, továbbá Jeszenszky Gézával is. A tárgyalásokról készült beszámoló világosan leszögezte, hogy „a román diplomácia jelenlegi célja, hogy teljesítse az európai intézményrendszerekbe való bejutás feltételeit... és hazánkkal mielőbb aláírja az alapszerződést. Álláspontunk szerint azonban a román féllel magas szintü tárgyalásokat, csak az új koalíciós kormány megalakulása után érdemes kezdeményezni, illetve folytatni." Jelentés Teodor Meleșcanu román külügyminisztériumi államtitkár budapesti tárgyalásairól, 1992. május 18-19. MOL, XIX-J-1-J, tételszám 128-13, 49 D, 1051/6, 8. A londoni székhelyü Védelmi Kutatóintézet igazgatóhelyettese az államtitkári találkozót kommentálva óvatosságra intette a magyar felet. Mint az a Hajgató Józseffel, a londoni magyar nagykövetség diplomatájával folytatott beszélgetésböl kiderült, Románia elsőrendü külpolitikai célja az EK-társulási szerződés aláírása, ennek a célnak minden mást így az alapszerződés tárgyalásait is - alárendeltek. Magyar-román alapszerződés, 1992. május 29. MOL, XIX-J-1-J, tételszám 128-123, 49 D, 330/10, 1.

${ }^{162}$ A bukaresti magyar nagykövetség is meggyőződéssel állította az egyik jelentésében, hogy a román külpolitikai stratégia része lett a magyar-román viszony terén való előnyszerzés, ennek érdekében valóságos nyilatkozatoffenzíva indult meg. Ennek fő célja a Románia-kép feljavítása is. Román-magyar kapcsolatok, 1993. január 22. MOL, XIX-J-1-J, tételszám 128-14, 34 D, 41/2, 2-3. 
viszont elérte, hogy a magyar diplomácia többször is „magyarázkodó” pozícióba kényszerüljön, azaz ezen a területen lehet némi eredményről beszélni. ${ }^{163}$

A magyar-román alapszerződés tárgyalásainak negyedik szereplője az RMDSZ. Az alapszerződés ügyében az első egyeztetések 1992. március 20-23. között zajlottak a magyar kormány és az erdélyi magyar kisebbséget képviselő szervezet között. Az egyeztetések részeként az anyaország vezetői ígéretet tettek arra, hogy az erdélyi magyarságot érintő valamennyi (magyar-román) kétoldalú megbeszélés esetén konzultálni fognak az RMDSZ vezetőségével, a szervezet pedig kidolgozza a magyarromán alapszerződés nemzetiségi cikkelyét. ${ }^{164}$ A tárgyalásokról készült beszámolóban azonban nem találtunk arra vonatkozó javaslatot, hogy a Szövetség a jövőben milyen szerepet kíván betölteni az alapszerződés tárgyalásában. Ez a későbbiekben azért válik fontos részletkérdéssé, mert az elkövetkező időszakban alapszerződésről folyó diskurzust az RMDSZ részvételének kérdése, a tárgyalásokban való megjelenésének lehetősége uralta.

A találkozó utáni héten a bukaresti nagykövetség több kérdésben is konzultált az RMDSZ vezetőségével és meghatározó politikusaival. A konzultációk után a Külügyminisztérium megbízásából a román referatúra felkérte az RMDSZ vezetőségét, hogy küldjenek levelet a magyar és román kormány képviselőinek, melyben a tárgyalásokba való bevonásukat kérik. ${ }^{165}$ Ezt követően, az Országos Elnökség április 10-i döntésének megfelelően, az RMDSZ levélben kérte a magyar és a román kormányt, hogy az erdélyi magyarság képviselőit vonják be az alapszerződés kidolgozásába. ${ }^{166}$

„,Megitélésünk szerint valahányszor a két kormány közti tárgyalások a Romániában élő magyarok helyzetét is érintik, célszerü és hasznos lenne ezeken a tárgyalásokon Szövetségünk véleményét is konzultatív minöségben meghallgatni. Kiváltképpen fontosnak tartjuk ezt az (értesüléseink szerint most készülö) magyar-román államközi

\footnotetext{
${ }^{163}$ Jó példa erre a bukaresti svájci nagykövetség egyik beosztottja és a magyar nagykövetség diplomatája közt a magyar-román viszonyról folytatott eszmecsere. A beszélgetésből kitűnik, hogy a svájci diplomata is a román félretájékoztatás áldozata lett. Az önkormányzati választások utáni időszakban több nagykövetség jelzett ilyen jellegü tendenciákat, amiből arra következtethetünk, hogy egy, a román külügy által kitervelt akcióról volt szó. A félretájékoztatás argumentumait nem részletezi a feljegyzés, de a leggyakoribb témák a magyar területi igényekhez, a kisebbségekkel való bánásmód és a kisebbségi jogok példaértékü rendezéséhez, továbbá a magyar lobbitevékenység románellenességéhez kapcsolódott. Svájci diplomata dilemmái a magyar-román történelmi disputa tárgyában, 1992. március 24. MOL, XIX-J-1-J, tételszám 128-1, 49 D, 1271, 1-2.

${ }^{164}$ Az RMDSZ küldöttség budapesti tárgyalásai, 1992. március 20-23. MOL, XIX-J-1-J, tételszám, 12813, 49 D, 1256, 1-8.

${ }^{165}$ Tájékozódás a magyar-román alapszerződés elökészitésével kapcsolatban, 1992. március 27. MOL, XIX-J-1-J, tételszám 128-123, 49 D, 330/6

${ }^{166}$ Fönöki levél - az RMDSZ Országos Elnökségének levele a magyar és a román Kormányhoz, 1992. ápr. 13. MOL, XIX-J-1-J, tételszám 128-27, 51 D, 1078/3.
} 
alapszerzödés tekintetében. Mint érintettek és érdekeltek, azt kivánjuk, hogy a ránk vonatkozó kérdésekben, rólunk, ne döntsenek nélkülünk."

E levélen kívül kevés dokumentumban azonosítható a szövetség érvrendszere. Azonban a genfi Emberi Jogi Központnak, illetve az ENSZ Kisebbségvédelmi Albizottságának írt levélben - melynek tervezetét a magyar külügy készítette el - a nemzetközi tanácskozásokon elfogadott alapelvekre hivatkozva kérték a címzettek támogatását, továbbá annak az elvárásnak adtak hangot, hogy „a kisebbségek helyzetéről maguk az érdekeltek is megnyilatkozhassanak."167 A levél tartalma arra enged következtetni - és a vizsgált dokumentumokból is az látszik -, hogy noha az RMDSZ részt akart venni a tárgyalásokon, nem volt egyértelműen meghatározott az érvelése, mellyel alá tudta volna támasztani kérését akár a román kormány, akár a nemzetközi szervezetek irányába. Ellenben az is igaz, hogy a román vezetés semmilyen - az RMDSZ szereplehetőségére vonatkozó - érvet nem lett volna hajlandó elfogadni, még abban az esetben sem, ha magyarországi románok képviseletének bevonásával érvényesülne a kölcsönösség elve.

A magyar kormány véleménye szerint az RMDSZ kérése az EBEÉ koppenhágai konferenciáján elfogadott elvek alapján is indokolt volt, mivel annak egyik pontja kitért az államok közötti együttműködés fontosságára - különös tekintettel a nemzeti kisebbségekre vonatkozó kérdésekben. De Magyarország utalt a román-német alapszerződésre is, melynek kidolgozásában a romániai német kisebbség is részt vett. Emellett a külügynek minden eszköze megvolt arra, hogy az RMDSZ tárgyaló félként való meghívását ne csak a szakértői tárgyalásokon, hanem a magas rangú találkozókon - államtitkári és külügyminiszteri szinten - is napirenden tartsa.

Magyarország támogató magatartásával szemben az RMDSZ javaslata nagy ellenállást - és ebből kifolyólag számos ellenérvet - váltott ki a román kormányban és diplomáciai testületben, annak ellenére, hogy a magyar kormány ígéretet tett arra, hogy a tárgyalásokba bevonják a magyarországi románság képviselőit is. Az RMDSZ kérésére maga a külügyminiszter, Adrian Năstase válaszolt, elutasítva a Szövetség felvetését. Szőcs Gézához intézett levelében kifejti:

„A romániai magyar nemzeti kisebbség helyzetét érintő kérdések nem képezik, és nem képezhetik kormányunk és a magyar kormány közötti megbeszélések tárgyát. Kizárólag Románia kormányának áll módjában és kötelessége is a legmagasabb nemzetközi jogi

${ }^{167}$ Az RMDSZ levele a genfi Emberi Jogi Központnak, illetve az ENSZ Kisebbségvédelmi Albizottságának. A Szövetség hasonló tartalmú levelet intézett a norvég Emberi Jogok Intézetéhez is. Szöcs-Năstase levélváltással kapcsolatos teendők, 1992. június 29.”. MOL, XIX-J-1-J, tételszám 128-27, $51 \mathrm{D}, 1078 / 4$. 
normák szintjén intézkedni a magyar kisebbséghez tartozó személyek jogainak biztositása és ezen kisebbség identitásának védelme érdekében [...]. Valóban igaz, hogy az utóbbi két évben külföldröl igen gyakran hangoztattak követeléseket és próbálták Románia kormányát a magyar nemzetiségü román állampolgárokra vonatkozó különféle intézkedések hozatalára kényszeriteni. Ez azonban nem teremt jogot, és nem jelenti azt, hogy kormányunk valaha is elfogadja az állampolgárai sorsáért viselt felelösség - függetlenül azok etnikai származásától-mással való megosztását."

Az RMDSZ tárgyaló félként való megjelenése az 1992. május 18-19. között megrendezett külügyi államtitkári találkozón is felmerült. Katona Tamás államtitkár felvetésére Teodor Meleșcanu azt mondta, hogy a Szövetség részvételére „nincs közvetlen lehetőség, és ellentétes a nemzetközi gyakorlattal, de meg kell ismerni a kisebbségek törekvéseit”. ${ }^{169}$ A román ellenállás a június elején lezajlott emlékeztető tárgyalásokon is megmutatkozott. Ion Diaconu, a román külügyminisztérium nemzetközi jogi főosztályvezetője Szőcs Ferencnek a következőt mondta ezzel kapcsolatban: „Az RMDSZ képviselőinek a két ország államközi szerződéséről folyó tárgyalásaiba való bevonása román oldalról alkotmányjogilag megoldhatatlan.” Ezt azzal indokolta, hogy a Szövetség példája nyomán a szélsőségesek is helyet követelnének a tárgyalóasztalnál. ${ }^{170} \mathrm{~A}$ román elutasítás indoklásául szolgáló másik beszédes példát Mihai Enescu, a külügyminisztérium területi igazgatója szolgáltatta. A bukaresti magyar nagykövetség ügyvivőjével, Bitay Károllyal folytatott beszélgetésen Enescu kifejtette: „Ha a tárgyalásokon az RMDSZ is részt venne, az megkérdőjelezné nemcsak a kormány, de a külügyminisztérium illetékességét is, hogy megkülönböztetés nélkül minden állampolgárt képviseljen.” Hosszabb távon pedig oda vezetne, hogy egyes nemzetközi fórumok előtt az országot nem egy hivatalos delegáció, hanem az RMDSZ képviselné. ${ }^{171}$

\footnotetext{
168 Ibid.

169 Jelentés Teodor Meleșcanu román külügyminisztériumi államtitkár budapesti tárgyalásairól, 1051/6, 4.

${ }^{170}$ Magyar-román alapszerződés tárgyalásai, 1992. június 2. MOL, XIX-J-1-J, tételszám 128-123, 49 D, $330 / 11$

${ }^{171}$ Román álláspont a magyar-román alapszerződésről, 1992. július 16. MOL, XIX-J-1-J, tételszám 128$123,49 \mathrm{D}, 330 / 12,2$.
} 
3. sz. táblázat: Érvek és ellenérvek az RMDSZ alapszerződésben való részvételéről

\begin{tabular}{|c|c|c|}
\hline Szereplő & Szerepkör & Érvek/ellenérvek \\
\hline RMDSZ & „közvetítő” & $\begin{array}{l}\text { - } \quad \text { konzultációs kérés; } \\
\text { - } \quad \text { rólunk ne döntsenek nélkülünk; } \\
\text { - hivatkozás nemzetközi dokumentumokra (ezek nevesítése nélkül). }\end{array}$ \\
\hline $\begin{array}{l}\text { Magyar } \\
\text { kormány }\end{array}$ & „,támogató” & $\begin{array}{l}\text { - a kisebbségek helyzetéről maguk az érdekeltek nyilatkozzanak } \\
\text { meg; } \\
\text { - az államok közötti együttmüködés fontossága, különös tekintettel a } \\
\text { nemzeti kisebbségekre vonatkozó kérdésekben (EBEÉ- } \\
\text { konferencia); } \\
\text { - a román-német alapszerződés kidolgozásában részt vett a német } \\
\text { kisebbség is; } \\
\text { - nem fogunk a kisebbségek feje fölött szerződni (a Horn-kormányzat } \\
\text { alatt). }\end{array}$ \\
\hline $\begin{array}{l}\text { Román } \\
\text { kormány }\end{array}$ & $\begin{array}{l}\text { „ellenző- } \\
\text { elutasító” }\end{array}$ & $\begin{array}{l}\text { - a magyar kisebbség helyzete nem képezheti a kormányközi } \\
\text { megbeszélések tárgyát; } \\
\text { - az állampolgárok képviselete a kormány illetékessége; } \\
\text { - a kisebbségi jogok védelme kizárólag a kormány hatásköre; } \\
\text { - ellentétes a nemzetközi jogi gyakorlattal; } \\
\text { - alkotmányjogilag megoldhatatlan; } \\
\text { - a szélsőségesek is helyet kérnek a tárgyalásokban. }\end{array}$ \\
\hline
\end{tabular}

Forrás: Saját szerkesztés, a külügyi iratok alapján.

A román elutasítás következtében az RMDSZ ténylegesen nem befolyásolhatta az alapszerződés munkálatait, mozgástere leszükült, a román kormánnyal folytatott konzultációi eredménytelenül zárultak. Ezzel szemben konzultatív szerepe a magyar kormány felé, valamint az erdélyi magyarság helyzetének és jogsértéseinek megjelenítésében, főként a nyugati integrációs és emberi jogi szervezetek irányába fontos tényezővé vált a tárgyalások alatt. ${ }^{172}$ A Szövetség külügyi érdekérvényesítése a nyugati integrációs szervezetekkel és államokkal való kapcsolatépítése azért volt lényeges ebben az időszakban, mert ez az intézményépítés járulékos velejárója: így tudta elfogadtatni magát a nyugati közvéleménnyel az erdélyi magyarság legitim képviselőjeként (Bíró 1996, pp. 1-4; 32-39). Másrészről az RMDSZ stratégiája arra irányult, hogy ha a kétoldalú kapcsolatokban nem válhat tényezővé, megpróbál minél nagyobb európai nyomást gyakoroltatni a román félre, hogy az rendezze a magyar kisebbség helyzetét - ebben a keretben értelmezhetőek az RMDSZ Friedrich Königgel folytatott tárgyalásai is. Ugyanakkor a magyar kormány minden eszközzel igyekezett helyzetbe hozni az RMDSZ-t: pl. segítséget nyújtott a Szövetség vezető tisztségviselőinek külföldi útjainak megszervezésében ${ }^{173}$, leveleket juttatott el az illetékes nemzetközi szervezetekhez, nyugati követségekhez és kormányokhoz, de a

\footnotetext{
${ }^{172}$ Markó Béla a vele készült interjúban kifejtette, hogy ,,szerettünk volna formálisan tárgyaló felek lenni, de nagyon jól tudtuk, hogy a nemzetközi jognak nem voltunk alanyai. De különbözö formában rendszeresen konzultált velünk a magyar fél és a román féllel is tárgyaltunk."

${ }^{173}$ Interjú Bálint-Pataki Józseffel és Jeszenszky Gézával.
} 
külügyi találkozók és nemzetközi konferenciák alkalmával is részletesen ismertette az erdélyi magyarság helyzetét. ${ }^{174}$

A román külügyminisztérium minden igyekezete ellenére a magyar kormány kitartott korábbi elképzelései mellett, miszerint csak a következő parlamenti választások után folytatja az alapszerződésről folytatott egyeztetéseket, aminek következtében a szakértői tárgyalások második fordulójára az új kormány megalakulását követően, 1993. január 26-28. között került sor, csaknem egy évvel az első forduló után. A tárgyalásokon nem történt érdemi elörelépés az alapszerződés ügyében, a felek a két vitatott cikkely szövegjavaslatait vitatták meg, valamint áttekintették a magyar-román kapcsolatok problémáit összefoglaló emlékeztetőt is. ${ }^{175} \mathrm{Az}$ RMDSZ szerepe újfent megjelent a tárgyalásokon, a konkrét részvétel tekintetében a román fél továbbra is elutasítóan válaszolt, ellenben jelezte, hogy a jövőben konzultálni fognak a Szövetség képviselőivel. Ezzel szemben a tárgyalások folytatásaként ismét magasabb szintű találkozót javasolt, amelynek elfogadását - államtitkári, helyettes államtitkári szinten a magyar fél konkrét eredmények eléréséhez kötötte. ${ }^{176}$

A szakértői tárgyalásokat követően, január 29-én, Jeszenszky Géza külügyminiszter egy értekezleten vitatta meg a részt vevő magyar diplomatákkal ${ }^{177} \mathrm{a}$ magyar-román kapcsolatok aktuális kérdéseit. ${ }^{178}$ A munkamegbeszélésen a résztvevők egyetértettek abban, hogy a kormány továbbra is erősítse viszonyát az RMDSZ-szel, folytassa a konzultációkat, mi több a további tárgyalási fordulókat kösse egyrészt az RMDSZ írásos véleményéhez, másrészt a területi cikkely magyar fél számára kedvező megfogalmazásához. ${ }^{179}$

Az alapszerződés tárgyalásainak dinamikájában fontos szerepet játszott Románia és az európai fórumok viszonyában bekövetkező változás: a nyugati elköteleződés

\footnotetext{
${ }^{174}$ A romániai magyarok helyzete (Mandátumkérés az EBEÉ helsinki utótalálkozóhoz), 1992. március 3. MOL, XIX-J-1-J, tételszám 128-27, 51 D, 1078, 1-3.

175 Jelentés a magyar-román kapcsolatok problémáit összefoglaló Emlékeztető áttekintéséröl, valamint a magyar-román alapszerzödés-tervezet szakértői tárgyalásának második fordulójáról, 1993. január 26-28. MOL, XIX-J-1-J, tételszám 128-14, 34 D, 0041/3. A magyar delegáció összetétele: Szőcs Ferenc, Szénási György, Keszthelyi Gyula, Boros Miklós; a románé: Valeriu Tudor, Ion Diaconu, Dumitru Neagu, Mihai Nicola, Gheorghe Albut, Constantin Anghel, Constantin Petcu. A tárgyaláson a nagykövetség részéről jelen volt Rudas Ernő nagykövet, továbbá Péter László, Bitay Károly, Csikós Imre, Székely Levente.

${ }^{176}$ Ibid. pp. 2-3.

${ }^{177} \mathrm{Az}$ értekezleten részt vett Kodolányi Gyula államtitkár, Zalatnay István, a HTMH elnökhelyettese, Kelemen András államtitkár, Bába Iván és Peisch Sándor helyettes államtitkár, Herman János, Kéry György és Szőcs Ferenc főosztályvezető, valamint Oberfrank Ferenc, a kabinet munkatársa.

${ }^{178}$ A találkozó napirendjén szerepelt többek között a román diplomácia propagandatevékenységének ellensúlyozása, Románia ET-tagságának támogatása a román ellenzékkel történő együttmüködés erösítése, a román fél által javasolt magasabb szintü találkozó kérdése, amellyel a román fél a tárgyalókészségét szerette volna felmutatni az európai fórumoknak.

${ }_{179}$ Megbeszélés a román külpolitika és a magyar-román kapcsolatok aktuális kérdéseiröl, 1993. január 29. MOL, XIX-J-1-J, tételszám 128-14, 34 D 0041/4, 2-3
} 
megerösödésének jelei - az ET-tagfelvétel, valamint az Európai Közösséggel folytatott kapcsolatok javulása - viszonylag rövid időn belül gyakorlati formát öntöttek. Ettől az időszaktól kezdve ugyanis már nem volt teljes bizonyítási kényszerhelyzetben a román kormány: a társult tagságra és a kisebbségi kérdések „,példaértékü” rendezésére nemcsak a külügyi találkozón, hanem a nemzetközi szervezetekkel folytatott tárgyalásokon is hivatkozhatott. A magyar külügynek és az RMDSZ-nek is egyre nehezebb lett a román külügy azon nyilatkozatainak ellensúlyozása, amelyekben az amellett érvelt, hogy Románia milyen kiválóan megoldotta a kisebbségi jogok rendezését. ${ }^{180}$

4. sz. táblázat: Románia és Magyarország csatlakozása az európai fórumokhoz

\begin{tabular}{|c|c|c|c|c|}
\hline Szervezet & \multicolumn{2}{|c|}{ Románia } & \multicolumn{2}{c|}{ Magyarország } \\
\hline & $\begin{array}{c}\text { Csatlakozási/tagfelvételi } \\
\text { kérelem }\end{array}$ & $\begin{array}{c}\text { Tagfelvétel } \\
\text { időpontja }\end{array}$ & $\begin{array}{c}\text { Csatlakozási/tagfelvételi } \\
\text { kérelem }\end{array}$ & $\begin{array}{c}\text { Tagfelvétel } \\
\text { időpontja }\end{array}$ \\
\hline ET & 1991. december 16. & 1993. október 7. & 1989. november 14-16. & 1990. november 6. \\
\hline NATO & $\begin{array}{c}\text { 2002. november 21. } \\
\text { (meghívás) }\end{array}$ & 2004. március 29. & $\begin{array}{c}\text { 1997. július 8-9. } \\
\text { (meghívás) }\end{array}$ & 1999. március 12. \\
\hline EU & 1995. június 22. & 2007. január 1. & 1994. április 1. & 2004. május 1. \\
\hline
\end{tabular}

Forrás: Saját szerkesztés.

Románia javuló nyugati megítélése Magyarországot is lépéskényszerbe hozta, amelynek eredményeként 1993 augusztusában szakértői konzultációra került sor az alapszerződés tárgyában, majd rá egy hónapra, hosszas előkészítés után a rendszerváltás után először Jeszenszky Géza külügyminiszter többnapos romániai látogatást folytatott. Az alapszerződésről folytatott harmadik tárgyalási fordulón sem közeledtek a felek által képviselt álláspontok. A tárgyalások elörehaladását az újabb szövegjavaslatok nehezítették meg: a területi sérthetetlenségre vonatkozóan a román fél az 1947-es párizsi békeszerződésre hivatkozott, míg magyar részről a kisebbségi cikkely-javaslatba bekerült az ET kisebbségi jogokra vonatkozó 1201. számú ajánlása („Európa Tanács Parlamenti Közgyülése” 1993).

A konzultáció eredménye a magyar külügyminisztériumi látogatás során is érzékelhetővé vált. Annak ellenére, hogy a román fél „történelmi látogatásnak” ítélte meg Jeszenszky romániai látogatását, néhány dokumentum aláírásától eltekintve beruházás-védelmi és a kettős adózást tiltó egyezmények - nem beszélhetünk

\footnotetext{
180 Érdemes említést tenni a június 12-i Markó-Iliescu-találkozóról, amelyen az RMDSZ vezetője a magyarság aktuális problémáit igyekezett az államelnökkel megbeszélni. Iliescu az ET-elvárásokkal összefüggésben kijelentette: „Románia a kisebbségi jogok biztosítása terén a világviszonylatban is élen jár...”. Az ET-csatlakozás kapcsán pedig elmondta: „az ET-nak legalább akkora szüksége van Romániára, mint Romániának az ET-ra”. Markó Béla látogatása Iliescunál, 1993. június 12. MOL, XIXJ-1-J, tételszám 128-27, 51 D, 1904/1, 1-2.
} 
lényegesebb elörelépésekről a kisebbségek helyzetére vonatkozóan. ${ }^{181} \mathrm{Az}$ eddig bemutatott magyar javaslatokat, a részletesebb kisebbségi cikkelyt, valamint az ezt kiegészítendő kisebbségvédelmi megállapodást a román fél rendre elutasította. De hasonlóképpen, a kisebbségi problémák megvitatására irányuló másik kezdeményezés a kisebbségi vegyesbizottság létrejötte - sem talált kedvező fogadtatásra. A román érvek rendre az alapszerződés aláírása mellett szóltak, amely az államközi kapcsolatok vitás kérdéseit rendező dokumentumként - beleértve a kisebbségi problémákat is - jelent meg a nyilvánosságban. Következésképpen a román külügyi vezetés is kivárt és a magyarországi választások eredményeitől tették függővé a tárgyalások folytatását és a dokumentum aláírását.

A magyarországi választások és a kormányváltás első éve - a román várakozásokkal ellentétben - nem hozta meg azt a változást, amely az alapszerződés rövid időn belüli megkötését eredményezte volna. Igaz ugyan, hogy az új kormányzat alapvető változásokat hozott a kétoldalú kapcsolatokban és a nemzetpolitikában ${ }^{182}$, de 1995 végéig kevés jel mutatkozott arra, hogy az integráció élvezne elsőbbséget az erdélyi magyarok helyzetének rendezése előtt. Tehát egy lassúbb átmenet érzékelhető a külpolitikai prioritások újragondolásában, mintsem egy gyors, radikális váltás.

Elődjéhez híven, Horn Gyula is szorgalmazta az RMDSZ képviselőivel folytatott találkozókat, amelyeken nemcsak az aktuálpolitikai kérdésekről, hanem az alapszerződéssel kapcsolatos tárgyalásokról is konzultáltak. Ezeken a konzultációkon és egyeztetéseken a legfontosabb szerepet Tabajdi Csaba, a Miniszterelnöki Hivatal politikai államtitkára, aki nemegyszer a közvetítői szerepet is magára vállalta. ${ }^{183} \mathrm{Az}$ egyeztetésekben és a kormány határon túli magyarsággal folytatott kapcsolataiban, így az alapszerződés tárgyalásaiban is meghatározónak bizonyult a Határon Túli Magyarok Hivatala, amelynek képviselője helyet kapott a hivatalos magyar tárgyalódelegációkban. A HTMH szerepe azonban nem merült ki a különböző tárgyalásokon való részvételben, hanem szakértői munkájával is hozzájárult a magyar és a határon túli magyar magyarok érdekeinek minél hangsúlyosabb képviseletéhez. Az intézmény keretében müködő I. Főosztály és az Elemző Főosztály számtalan tárgyalási témavázlatot készített elő a felsőszintű találkozókhoz, véleményezte a román szövegjavaslatokat, és az RMDSZszel folytatott konzultációkat követően több alkalommal javaslatot tett a kisebbségi

\footnotetext{
${ }^{181}$ Jeszenszky Géza külügyminiszter hivatalos romániai látogatásának és tárgyalásainak értékelése, 1993. szeptember 15-19. MOL, XIX-J-1-J, tételszám 128-13, 33 D, 002277/11.

182 Interjú Németh Zsolttal.

183 Feljegyzés Tabajdi Csaba és az RMDSZ küldöttségének megbeszéléseiről a magyar-román alapszerződés tárgyában, 1994. június 19. MOL, XIX-J-1-J, tételszám 128-1, 35 D, 001050/1.
} 
cikkely tartalmának átdolgozására, ezzel végső soron hozzájárult a magyar álláspont kialakításához és finomításához. ${ }^{184}$

Az RMDSZ-szel folytatott konzultációk eredményeként, a Szövetség augusztusban hozza nyilvánosságra az alapszerződésre vonatkozó állásfoglalását, melyben újra megismételte a Szövetség bevonásának fontosságát a tárgyalásokba, valamint felhívta a figyelmet arra, hogy a dokumentumnak tartalmaznia kell a Kisebbségvédelmi Megállapodást, a romániai magyarság és a magyarországi románság által megfogalmazott jogokat. A Markó Béla és Takács Csaba által jegyzett dokumentum részletezi a kisebbségvédelmi jogosítványokat és néhány, halasztás nem türő kérdés megoldását. ${ }^{185}$

Az RMDSZ által ismertetett javaslat, nem hozott alapvető változást, noha az ősz folyamán napirenden szerepelt a tárgyalások folytatása. Szeptember elején magyarországi útján Teodor Meleșcanu külügyminiszter Göncz Árpád köztársasági elnökkel, Horn Gyula miniszterelnökkel és Kovács László külügyminiszterrel is tárgyalt. A megbeszélések során a magyar fél jelezte, hogy hajlandók elfogadni a határklauzulára vonatkozó román javaslatot, de ragaszkodnak a kisebbségi jogok garantálásához. Kovács László román kollégájának kifejtette, hogy a kisebbségi jogok részletes rögzítését az alapszerződéssel szoros jogi kapcsolatban levő kisebbségvédelmi megállapodásban pontosítanák, amelynek végrehajtása és ellenőrzése a vegyesbizottság feladatát képezné. ${ }^{186}$

A kisebbségvédelmi megállapodás a külügyminisztériumi találkozót követő emlékeztetőben és a szakértői tárgyalások következő fordulójának napirendjén is szerepelt, azonban a román fél elutasított az alapszerződés kisebbségi cikkelyén kívüli bármilyen, a kisebbségekre vonatkozó megállapodást. ${ }^{187}$ Érvelésükben arra hivatkoztak,

\footnotetext{
${ }^{184}$ Interjú Bálint-Pataki Józseffel.

${ }^{185}$ Az RMDSZ által a dokumentumban a következő jogosítványokat leltározták fel: nemzeti identitás védelme, anyanyelv és szimbólumhasználat, a regionális autonómia biztosítása, magyar többségü területek különleges jogállása, etnikai arányok mesterséges megváltoztatásának tilalma, anyanyelven való oktatás szabadsága, szakoktatás támogatása, jogegyenlőség, kapcsolattartás lehetőségének biztosítása az anyaországgal). A felsorolt jogosítványok mellett olyan problémák megoldását szorgalmazták, mint egyéni és egyházi tulajdon visszaszolgáltatása, a Bolyai Egyetem visszaállítása, diplomák honosítása, anyanyelvhasználat a közintézményekben (10 százalékos küszöb bevezetése), a kolozsvári és debreceni konzulátus visszaállítása. ("Az RMDSZ állásfoglalása a magyar-román alapszerződés tárgyában" 1994. augusztus 26. In: Húszéves az RMDSZ. 2009, pp. 446-469).

${ }^{186}$ Gyorsjelentés Teodor Meleșcanu román külügyminiszter hivatalos budapesti látogatásáról, 1994. szeptember 7. MOL, XIX-J-1-J, tételszám 128-13, 46 D, 002528/6, 1-3.

187 A szakértői tárgyalásokat a két külügyminisztérium nemzetközi jogi főosztályának vezetője, Dumitru Ciaușu és Szénási György vezette. A találkozóról készült jelentés megemlíti, hogy a magyar tárgyaló delegációban helyet kapott volna a Magyarországi Románok Szövetségének az elnöke, Petrusán György is, ehhez azonban a román delegáció nem járult hozzá. Jelentés a magyar-román szakértői konzultációkról, 1994. november 16-17. MOL, XIX-J-1-J, tételszám 128-123, 45 D, 1650/5, 1.
} 
hogy egy ilyen kiegészítéssel az alapszerződés egy kisebbségi szerződés funkcióját töltené be. A kibontakozódott vitában a román delegáció vezetője, Dumitru Ceaușu hangsúlyozta, hogy a kisebbségi kérdést a kormányoknak a saját kompetenciájukban kellene megoldaniuk. Egyúttal emlékeztette a magyar felet arra, hogy annak „kívánságlistája” - a kisebbségi cikkelyben szereplő jogosítványok biztosítása - nem számíthat megértésre a román kormány részéről, de még kevésbé fogadná el azt a román parlament és a közvélemény. ${ }^{188}$ Szénási György válaszában leszögezte: „Szemben a román tévhittel, Európa nem alapszerződést vár a két országtól, hanem jószomszédi kapcsolatokat és feszültségmentes partneri viszonyt. Ennek megteremtésében jó eszköz lehet az alapszerződés." ${ }^{189}$ A kisebbségi cikkellyel kapcsolatosan pedig megjegyezte, hogy annak elhagyását a magyar fél is elfogadhatónak tartaná: ,az alapszerződésben való rögzítése fölösleges is lenne abban az esetben, ha a szerződő felek kormányai már meghozták volna azokat az intézkedéseket, melyek az illető országok nemzeti kisebbségeinek megfelelnek". ${ }^{190}$

Az alapszerződés tárgyalásaiban 1995. február-április közötti időszak rendkívül dinamikusnak ígérkezett, mivel több szakértői konzultáció is lezajlott. A négy tárgyalási fordulóra azonban nem a felek megegyezésre irányuló törekvéséből került sor, hanem sokkal inkább a nyugati nyomás volt meghatározó. A kontextus ismeretéhez hozzátartozik egy fontos fejlemény, ugyanis az EBESZ március 20-21-én tartott párizsi konferenciáján a résztvevők elfogadták az Európai Stabilitási Egyezményt, amelynek következtében mindkét állam, leginkább pedig Románia igyekezett eredményeket felmutatni, annál is inkább, mert a román kormány az EU-tagság iránti hivatalos kérelem benyújtására készült. ${ }^{191}$ Egy további tényező szintén hozzájárult a Romániára nehezedő nyomás erősödésére: az egyezmény aláirásáig megegyezés született a magyar-szlovák alapszerződés vitatott cikkelyeiről.

Az RMDSZ tudatában annak, hogy felgyorsulnak a tárgyalások, február 26-án elfogadott határozatában megerősítette, hogy (1) az alapszerződésnek integrálnia kell a

\footnotetext{
${ }^{188}$ Ibid. 4.

${ }^{189}$ Uo.

${ }^{190}$ Ibid. 5.

191 Románia 1995. június 22-én nyújtotta be hivatalos csatlakozási kérelmét. Összehasonlításképpen a román fél itt is lépéshátrányban volt, ugyanis Magyarország már 1994. április 1-jén benyújtotta a sajátját. Románia tagfelvételi kérelmét Teodor Meleșcanu külügyminiszter az EU-ügyekért felelős miniszternek, Michel Barniernek adta át. Az eseményen elhangzott, hogy „Franciaország általános politikai támogatásáról biztosította Románia felkészülését a jövőbeni tagságra, Barnier megemlítette a francia és a román nép hagyományos kapcsolatait és barátságát, és üdvözölte a román vezetés elkötelezettségét, politikai voluntarizmusát, mellyel a 2000. évet tüzték ki Románia EU-csatlakozása remélt határidejeként." Románia EU-csatlakozási kérelme, 1995. június 28. MOL, XIX-J-1-J, tételszám 128-1, $37 \mathrm{D}, 600 / 2,1-2$.
} 
két államban élő kisebbségek legitim képviselőinek véleményét; (2) a dokumentum kisebbségi megállapodást kell tartalmazzon, valamint (3) a megállapodásban foglaltak betartására vállaljanak a felek kötelezettséget. ${ }^{192}$ Ebben az időszakban lezajlott szakértői tárgyalásokon csak a határklauzuláról szóló cikkelyt sikerült véglegesíteni, a kisebbségi cikkely ügyében kevés elörelépés történt, amely annak tudható be, hogy a konzultációkat megelőzően a magyar fél által bemutatott szövegjavaslatokban helyet kapott a HTMH által kidolgozott és a külügyminisztérium illetékesei által módosított kisebbségi megállapodás. ${ }^{193} \mathrm{~A}$ bemutatott javaslat meghatározónak bizonyult a tárgyalások kimenetelére nézve, aminek következtében nem sikerült véglegesíteni magyar-román alapszerződést.

Míg a kül- és szomszédságpolitika terén a Horn-kormányzat a folytonosságot igyekezett képviselni, addig az alapszerződés tárgyalásain tanúsított, megegyezésre hajló „magatartása” a belpolitika szintjén megosztotta a parlamenti pártokat. Azzal egy időben, hogy szorgalmazta a román és a szlovák féllel a szakértői tárgyalások folytatását, mi több a magyar-szlovák alapszerződés kapcsán hajlandó volt a kompromisszumra, egy belpolitikai konfliktust is felvállalt az akkori magyar ellenzék (FIDESZ-Magyar Polgári Szövetség, Magyar Demokrata Fórum, Független Kisgazdapárt, Kereszténydemokrata Néppárt, Magyar Demokrata Néppárt) képviselőivel.

Az ellenzéki pártok részéről érkező támadások nem voltak alaptalanok, a kormány tárgyalókészségéből és a különböző nyilatkozatokból az ellenzék képviselői azt a következtetést vonták le, hogy a kormány elkötelezettebb az integráció, mint a kisebbségi jogok rendezése mellett. A kiéleződő viták, melyek a parlamenti vitákon kívül a tágabb nyilvánosságban is folytak egy alapvető változást eredményeztek, amelynek következményeként megbomlani látszott a külpolitika hármas prioritásának

\footnotetext{
192 („A Szövetségi Képviselők Tanácsának határozata a magyar-román alapszerződés kérdésében, 1995. február 26, Marosvásárhely.” In: Húszéves a RMDSZ. 2009, pp. 480-481).

193 Teljes nevén: „Egyezmény a Magyar Köztársaságban élő román nemzeti kisebbség és a Romániában élő magyar nemzeti kisebbség, valamint a hozzájuk tartozó személyek jogainak biztosításáról”. A megállapodás az alapszerződés kisebbségi cikkelyének filozófiájából indul ki, és hangsúlyozta, hogy a kisebbségi jogok érvényesítése hozzájárul a két állam közötti együttműködés erősítéséhez. A 21 cikkelyből álló dokumentum aláírását a magyar fél az alapszerződéssel egy időben képzelte el, tartalmáról pedig több ízben egyeztetett az RMDSZ felső vezetésével. Az egyezmény elfogadása és végrehajtása fontos elörelépést jelentett volna a kisebbségi közösségek életében, mivel szinte teljességgel rendezte volna a többség-kisebbség viszonyának vitás kérdéseit az identitás megőrzését, valamint azon szakterületeket, mint pl. oktatás, kultúra, vallás, gazdaság, politikai képviselet, média és sajtó. Az egyezmény megvalósítása és a végrehajtás az évente ülésező kisebbségi vegyesbizottság feladatkörébe tartozott volna, amely megvitatja a kisebbségek helyzetét, értékeli az elörelépéseket, és javaslatokat fogalmaz meg. Román-magyar alapszerződés, 1995. február 6. MOL, XIX-J-1-J, tételszám 128-1, 37 D, 00371.
} 
ingatag lábakon álló konszenzusa. ${ }^{194}$ Ebben a keretben értelmezhető a FIDESZ lépése is: a párt nemcsak nyilatkozatok szintjén fejezte ki a kormány szomszédságpolitikája iránti nemtetszését, de március 10-én ki is vonult az alapszerződést tárgyaló parlamenti albizottságból, az aláírás előtt álló magyar-szlovák alapszerződéssel szembeni tiltakozásként. A magyar-szlovák alapszerződés aláírása utáni időszakban sem normalizálódott a kormány és az ellenzék viszonya, a magyar-román alapszerződés tárgyalásainak folytatásával pedig tovább mélyült az ellentét, végső soron pedig felbomlott a külpolitikai prioritások parlamenti konszenzusa (Csigó-Kovács 2000; Győri 2000; Szabó 2015).

Az államközi kapcsolatok és a jelzett belpolitikai viszonyok változásainak időszakában 1995 nyarán lezajlott még egy szakértői tárgyalás és egy külügyminiszteri találkozó is, lényegesebb eredmények nélkül. A találkozóról készült feljegyzések alapján megállapíthatjuk, hogy a korábbi kisebbségi cikkelyre vonatkozó román álláspontok azt követően sem változtak, hogy a felek már megegyeztek az alapszerződésben foglalt területi sérthetetlenségre vonatkozó cikkelyről. A kialakult helyzet világos jelzés volt arra vonatkozóan, hogy a román fél nem mutat hajlandóságot arra, hogy érdemben bármit is elfogadjon az újabb és újabb magyar javaslatokból, amelynek kidolgozásában a HTMH kardinális szerepet vállalt. Ennek eredményeként a kisebbségi cikkelyt a felek bekezdésenként vitatták meg, de egy-két formális megfogalmazáson túl nem történtek lényegesebb változások az egyeztetett szövegben. Alapvető vita alakult ki arról, hogy a készülö kisebbségvédelmi egyezményben milyen nemzetközi dokumentumokra történjen hivatkozás. ${ }^{195}$ Példaként az ET PKGY 1201. számú ajánlására vonatkozóan a román fél azt szerette volna elérni, hogy az ajánlás rendelkezéseit ne lehessen a kollektív jogok, az etnikai elven alapuló autonómia, esetleg különleges státusz megadására vonatkozó kötelezettség elismeréseként értelmezni.

\footnotetext{
${ }^{194}$ Több interjúalany is elismerte (Jeszenszky Géza, Szent-Iványi István), hogy a rendszerváltást követően a három főbb kül- és nemzetpolitikai célkitűzésben nagy egyetértés, vagy más szóhasználattal értve konszenzus mutatkozott a parlamenti pártok között.

195 A Dumitru Ceaușu vezette tárgyalódelegáció a kisebbségekre vonatkozó nemzetközi jogi dokumentumok érvényességét, melyet a szerződés mellékletében kívántak rögzíteni, oly módon próbálták relativizálni, hogy a következő javaslattal álltak elö: a kisebbségi közösségek identitásának védelmére és fejlesztésére vonatkozó kisebbségvédelmi dokumentumokra ne jogi normaként hivatkozzanak, és ennek megfelelöen alkalmazzák, mint ahogyan a magyar javaslatban szerepelt, hanem a román „kompromisszumos javaslat alapján csupán merítsenek a dokumentumok tartalmából. Míg a román javaslat az ENSZ, az EBESZ, az ET és más releváns dokumentumokból kíván meríteni, a pontos megnevezések nélkül, addig a magyar javaslat melléklete öt dokumentumra hivatkozik és nevesíti az ENSZ Közgyülésének 135/47 számú Nyilatkozatát, az EBEÉ koppenhágai dokumentumát, az EBEÉ genfi szakértői találkozón elfogadott dokumentumát, az ET 1201. számú ajánlását, valamint az ET nemzeti kisebbségekre vonatkozó Keretegyezményét. Jelentés a magyar-román alapszerzödés tárgyában folytatott szakértői tárgyalásokról, 1995. június 19-20. MOL, XIX-J-1-J, tételszám 128-1, 37 D, $00371 / 39$.
} 
Ezeket a román javaslatokat a magyar delegációvezető, Szénási György nem tudta tárgyalási alapnak elfogadni, így a júniusi szakértői egyeztetés is számos lezáratlan kérdéssel fejeződött be.

Az alapszerződés körüli patthelyzetet az integrációs szervezetek diplomatái igyekeztek feloldani, akik emlékeztették a román felet arra, hogy az ország komoly lépéshátrányban van, nemcsak az átalakulás és az átmenet, hanem a szomszéd államokkal folytatott megegyezés tekintetében is. ${ }^{196}$ Másrészről pedig, mivel korábban a határok sérthetetlenségére vonatkozó cikkelyben a magyar fél elfogadta a kompromisszumos megoldást - a Helsinki Záróokmányra való hivatkozás mellett a területi követelésről való lemondás is szerepeljen a cikkelyben -, most a román külügy kellett volna fogadókészséget mutasson a magyar javaslatok iránt. A kialakult helyzetben a román vezetés a nyugati államok és európai fórumok irányába is lépéskényszerbe került, mert a korábban fenntartott - területi sérthetetlenségre vonatkozó - kifogások már nem bizonyultak fenntarthatónak.

A román fél, a kezdeményezés címén egy rendkívül kreatívnak tünő gesztussal kívánt a tárgyalásoknak lendületet adni: Ion Iliescu államelnök augusztus 30-án, a második bécsi döntés 55. évfordulóján tartott megemlékezésen a Magyarország és Románia közötti történelmi megbékélésre vonatkozó kezdeményezéssel állt a nyilvánosság elé, szoros párhuzamot vonva a két állam közti és a francia-német megbékélési folyamat között (Iliescu 1995). A román államfö indítványa azonban több okból is szöges ellentétben állt a nyugat-európai megbékélés szellemével. Egyrészt maga az előterjesztés időpontja (az évforduló) sem utalhatott a megbékélésre, ugyanis a bécsi döntés Románia számára Észak-Erdély elvesztését és belső migrációt eredményezett. De a beszéd a tartalmát tekintve is ellentmondást jelentett, ugyanis Iliescu a történelmi visszapillantásban többször utalt a horthysta Magyarország által elkövetett bünökre, továbbá a kilencvenes évek magyarországi viszonyaira, amelyben a vezető politikusok irányítani akarják a szomszédos államok magyar közösségét, vagy azok védelmezőiként, képviselőiként akarnak fellépni. A kisebbségi kérdés rendezésével kapcsolatban továbbra is a jól ismert álláspontját ismételte meg: az

\footnotetext{
196 A francia külügyminisztérium európai ügyekért felelős igazgatója, P. Poudale és a francia nagykövetség diplomatájának a beszélgetéséből kiderül, hogy egyre nagyobb kényszer nehezedett - az ESE-folyamat keretén belül is - a két államra. Magyar-román alapszerződés, 1995. június 16. MOL, XIX-J-1-J, tételszám 128-1, 37 D, 00371/40, 1-2. A norvég külügyminisztérium politikai főigazgatójának, Johan Lövaldnak az oslói nagykövetség diplomatájával folytatott eszmecseréjéből kiderül, hogy Románián egyre inkább úrrá lett az elszigeteltség érzése, és a csatlakozási kilátások terén az „ország túlzó elvárásai nem esnek egybe a román realitásokkal”. „Románia norvég megitélése, 1995. június 12.”. MOL, XIX-J-1-J, tételszám 128-1, 37 D, 01333/1, 1.
} 
Romániában a legmagasabb európai normák szerint biztosított, és nem képezheti tárgyát a magyar féllel folytatandó tárgyalásoknak.

Iliescu kezdeményezése csakhamar jelentős propagandaeszközzé vált - annál is inkább, mert szeptember 3-án jelent meg a már említett NATO-tanulmány -, a legfontosabb célja pedig a román diplomácia kezdeményezőként való feltüntetése és annak az állításnak a bizonygatása volt, hogy Románia mindent megtesz a két állam közötti viszonyok rendezéséért. ${ }^{197}$ A megbékélési javaslat időzítése egy másik szempontból is figyelemre méltó: előkészítette Iliescu szeptember végi amerikai látogatásának a kommunikációját, így az elnök a külvilág - föleg az Egyesült Államok felé nagyobb meggyőzőerővel tudta Romániának a kétoldalú kapcsolatok javítása iránti elköteleződését hangoztatni.

\subsection{Az alapszerződés aláírásának időszaka}

Noha 1995 szeptembere után még egy évnek kellett eltelnie a magyar-román alapszerződés aláírásáig, a többször idézett NATO-tanulmány két fontos dologra világított rá, egyrészt arra, hogy az észak-atlanti szervezet ki szeretné terjeszteni a határait, és tagjai közé újabb, KKE-i államokat fog meghívni, másrészt pedig a dokumentum explicite előírta a két fél közötti megegyezés szükségességét. Minekután egyik állam sem szeretett volna lemaradni a bővítés első hullámáról, mindkét fél nyitottnak mutatkozott a sokat nem ígérő tárgyalások folytatására, annál is inkább, mert várható volt a két államra nehezedő nyugati nyomásgyakorlás.

A két állam viszonyában és a tárgyalások kimenetelében a fő kérdés tehát az volt, hogy melyik fél hajlamosabb a kompromisszumra, amely egyben a korábbi követelésekről való lemondást és a másik fél javaslatának az elfogadását jelentené. A tárgyalásoknak ebben a szakaszában kevés jel mutatkozott a megegyezésre, ugyanis Iliescu megbékélési nyilatkozata alapján a román külügy - a magyar fél meglepetésére három dokumentumtervezetet mutatott be a soron következő szakértői tárgyalásokon. ${ }^{198}$

\footnotetext{
${ }^{197}$ Arra vonatkozóan nem állnak rendelkezésre adataink, hogy a román diplomácia tudott-e részleteket a NATO készülő tanulmányából, bár az megmagyarázná a történelmi megbékélésre tett kezdeményezés időzítését; viszont nem kizárt, hogy egyes részleteket megszerzett a román külügy, ugyanis a bővítés feltételei már 1994 őszétől napirenden szerepeltek.

198 A megbékélési nyilatkozat három dokumentum megszövegezéséhez szolgált alapul: 1. politikai szándéknyilatkozat: Iliescu elnök (szinte szó szerinti) beszédét tartalmazza; 2. kétoldalú egyezmény: az alapszerződés és az emlékeztető egyes, a román fél számára fontos területeit emeli ki, mint pl. európai integráció, együttműködés a nemzetközi szervezetekben, katonai együttmüködés stb.; 3. kisebbségi viselkedési kódex: az államok számára viselkedési mintákat határoz meg. Pozitív elemei: a nemzeti kisebbségekhez tartozó személyek jogainak szavatolása, helyi autonómia elvének és a közszolgáltatások decentralizációjának alkalmazása, míg a negatív elemek között találjuk az etnikai alapú autonóm közigazgatás kizárására, a feszültségkeltés elkerülésére és a nacionalista propaganda tilalmára vonatkozó
} 
A román fél által ismertetett közös szándéknyilatkozatra, a kétoldalú egyezményre, valamint a kisebbségi magatartási kódexre vonatkozó javaslatoknak legfőbb célkitűzése egyrészt Románia kezdeményező szerepének fenntartása lehetett, másrészt pedig az alapszerződéssel kapcsolatos tárgyalások előmozdítása, a román érdekeknek megfelelően. Ebből következően megállapíthatjuk, hogy a többéves tárgyalási folyamat után az államközi kapcsolatokban egy igencsak furcsa helyzet állt elö, mert a véglegesítés előtt álló alapszerződésről a hangsúly hirtelen e három tervezetre helyeződött át. A két állam közötti tárgyalásokban alapvető kérdésnek bizonyult, hogy mi lesz a tervezetek státusa és az mennyiben fogja befolyásolni az elért eddigi eredményeket, valamint a további menetrendet.

A rendelkezésre álló forrásokból megtudtuk, hogy a tervezetek bemutatása utáni hetekben a külügyminisztérium és a tárgyalásokban képviselt intézmények, továbbá az RMDSZ is kifejtette aggályait a dokumentumok tartalmát illetően ${ }^{199}$, Tőkés László pedig a két ország államfőjének címzett levelében alternatív megbékélésre tett javaslatot. ${ }^{200} \mathrm{~A}$ vélemények alapján két kérdésben mutatkozott konszenzus, egyrészt arra nézve, hogy a három dokumentum nem helyettesítheti az alapszerződés tárgyalásain elért eredményeket, ezeket hiba volna veszni hagyni, másrészt pedig tekintettel a magyar fél aggályaira, a tervezetek státusáról és tartalmáról folytatni kell a tárgyalásokat, ${ }^{201}$ mi több a magyar fél is készítse elő a saját tervezeteit.

Az újabb szövegváltozatok ismertetését követően a felek viszonyában nem volt érzékelhető a változás, a román kezdeményezésekre válaszul a magyar fél is napirendre tűzte a korábbi emlékeztetőkben megfogalmazott feladatokat és folytatódtak a magyar kormány és az RMDSZ közötti egyeztetések is. Az egyértelmű változás azonban a külső szereplők viszonyában nyilvánult meg, mert az integrációs szervezetek és a nyugati államok rendre szorgalmazták a felek közötti megbeszélések és tárgyalások folytatását, ami arra enged következtetni, hogy fokozatosan nőtt az alapszerződés aláírására

szabályozásokat. Román dokumentumtervezetek a magyar-román történelmi megbékélésre, 1995. szeptember 27. MOL, XIX-J-1-J, tételszám 129-1, 37 D, 02474/1.

199 Magyar-román megbékélés (román kezdeményezés), 1995. szeptember 25. MOL, XIX-J-1-J, tételszám 129-1, 37 D, 00371/43; RMDSZ álláspont a történelmi megbékélési tervezettel kapcsolatban, 1995. szeptember 27. MOL, XIX-J-1-J, tételszám 129-1, 37 D, 002474/2.

200 Az RMDSZ tiszteletbeli elnöke arra hívja fel a két államfö figyelmét, hogy a francia-német megbékélési modell helyett az olasz-osztrák (dél-tiroli) mintát tekintsék követendő modellnek, ugyanis érvel Tőkés - „magyar-román kapcsolatok tétje nem annyira az államközi kapcsolatok, mint inkább a romániai magyar nemzetközösség helyzetének a rendezése" (Tőkés 1996). A két állam viszonyának rendezésére vonatkozó eltérő elképzelések a mai napig fennmaradtak, noha Markó Béla több alkalommal egy sajátos modell kialakítását kezdeményezte (Markó 2000, pp. 238-41).

201 Ennek betudhatóan november 3-án Somogyi Ferenc közigazgatási államtitkár Budapesten tárgyalásokat folytatott Marcel Dinu külügyi államtitkárral a tervezetek céljairól. 
vonatkozó nyugati nyomás, egyrészt az európai fórumok ${ }^{202}$, másrészt a nyugati államok $^{203}$ részéről, amelyek a két állam csatlakozási esélyeit az alapszerződés aláírásával hozták összefüggésbe.

A növekvő nyugati nyomás és az eredmények nélküli tárgyalások közepette az alapszerződés kérdése a belpolitikai napirend részévé vált és mindkét államban - eltérő törésvonalak mentén - megosztotta a parlamenti pártokat. Magyarországon a kormány és az ellenzék közti, már említett vita tovább fokozódott, ez azonban érdemi módon nem tudta befolyásolni a kormány által kialakított, hivatalos álláspontot. Az ellenzék a FIDESZ memorandumát tekintette irányadónak a kormánnyal szembeni vitában: annak figyelembe vétele nélkül ugyanis elhibázott lépésnek tartotta a szerződés aláírását. ${ }^{204} \mathrm{Az}$ ellenzéki képviselők utolsó lépésként minden eszközt felhasználtak arra - pl. találkozókat szerveztek az RMDSZ-szel, Lezsák Sándor erdélyi körútra indult -, hogy minél nagyobb koalíciót alakítsanak ki az alapszerződés aláírását szorgalmazó kormánnyal szemben.

Érdekes módon, Romániában az alapszerződés kapcsán nem a kormány és ellenzéke közötti vita, hanem a mérsékelteknek és a radikálisabb vonal követőinek az ellentéte vált meghatározóvá (Ivan 2010, pp. 407-8). A Nagy-Románia Párt és a Román Nemzeti Egységpárt több képviselője élesen bírálta a külügyminisztert és az államfőt, amiért azok engedményeket tettek a magyar félnek és az RMDSZ-nek, bár érdemben nekik sem sikerült befolyásolniuk a dokumentum tartalmát.

Az 1996 tavaszán folytatódó tárgyalások tehát két dimenzióban zajlottak. Az alapszerződésről folyó tárgyalások az egy évvel korábbi állapotokhoz - az ET 1201. számú ajánlásának szerződésben való szerepeltetéséhez - tértek vissza, azzal a kiegészítéssel, hogy a felek a három dokumentum státusában is megegyeztek. A

\footnotetext{
${ }^{202}$ Ebben az időszakban Romániába látogatott Catherine Lalumiére, az Európai Parlament képviselője, az Európa Tanács volt főtitkára, Hans Peter Furrer, az Európa Tanács titkárságának politikai igazgatója, Richard Holbrooke amerikai külügyi államtitkár-helyettes, Alan Kassof, a PER elnöke, Hans Henning Horstmann, a német külügyminisztérium európai kapcsolatokkal foglalkozó igazgatója, Tom Lantos amerikai szenátor, Gebhardt von Moltke, a NATO fötitkárhelyettese, Christopher Donnelly, a NATO fötitkárának közép- és kelet-európai ügyekben illetékes tanácsadója (,MTI Hírarchívum 1988-2017’), keresőszó: alapszerződés. Magyarország és a nyugat-európai államok viszonyában Bálint-Pataki József (interjú) és Jeszenszky Géza is nyomásgyakorlásról beszél (Jeszenszky 2000), amit visszaemlékezéseiben Marcel Dinu külügyi államtitkár is megerösített (Dinu 2009, p. 192).

${ }^{203}$ Szent-Iványi az interjúban kifejtette: ,, a franciák nyiltan kimondták, hogy meg kell állapodni... ”

${ }^{204}$ A Fidesz-Magyar Polgári Párt 1995. július 13-án Horn Gyulához intézett memorandumában felsorolta azokat a feltételeket, amelyek teljesülése esetén támogatná az alapszerződés aláírását: 1. kezdjen a román kormány tárgyalásokat az RMDSZ-szel az autonómia megvalósításáról; 2. az ET 1201. sz. ajánlása legyen az alapszerződés része; 3. garantálja a román állam az anyanyelven való oktatás biztosítását, beleértve a Bolyai Egyetem visszaállítását; 4. szolgáltassa vissza a román állam az egyházi ingatlanokat; 5. az alapszerződést csak az RMDSZ egyetértésével írják alá a felek. MTI Hírarchívum 1988-2017, keresőszó: FIDESZ memorandum.
} 
március 12-i szakértői egyeztetésen a román fél bejelentette, hogy az ET ajánlásának szerepeltetését a következő három formában tudná elfogadni: (1) az ET ajánlása szerepeljen a szerződésben, de nem egyenértéküen a többi dokumentummal; (2) a két fél csatoljon egy közös értelmezést az ajánláshoz; (3) az ajánlásnak a magyar fél által fontosnak tartott részei kerüljenek bele a kisebbségi cikkelybe. ${ }^{205}$ A magyar delegáció vezetője, Szénási György a javaslatokról elmondta, hogy Románia tagfelvételével egyrészt vállalta az ET dokumentumainak végrehajtását, másrészt pedig a két állam nem köthet arról szerződést, hogy „mit nem szabad a magyar kisebbségnek”. Az ajánlásra vonatkozó közös értelmezés azért bizonyult problémásnak a magyar diplomácia szempontjából, mert a román fél fenntartásait fogalmazta meg az autonóm területi egységekkel és a különleges státusszal kapcsolatosan. A magyar álláspont az - fejtette ki Szénási -, hogy „sem szűkíteni sem bővíteni nem kívánjuk a szöveget”. 206

A tárgyalások másik dimenziója a megbékélésre vonatkozó tervezetek szövegeinek egyeztetéséről szólt, amelyben nem alakultak ki lényeges ellentétek azt követően, hogy a magyar javaslatnak megfelelően a román fél elfogadta a megbékélési csomagterv egységes jellegét és a tartalmi egyeztetéseken túl arról is sikerült dönteni, hogy a megbékélésre vonatkozó csomagterv véglegesítése után, de ezekkel egyidőben kerülne sor a Közös nyilatkozat aláírására. ${ }^{207}$

A nyár folyamán, július 4-5. között a Miniszterelnöki Hivatal és a HTMH szervezésében ültek egy asztalhoz a kormány, a parlamenti pártok és a határon túli magyar szervezetek képviselői, melyet az RMDSZ a magyar kormánnyal folytatott áprilisi egyeztetésen javasolt. A sokat ígérő csúcstalálkozó záródokumentumában a résztvevők megerősítették, hogy (1) a nemzeti érdekek képviseletéhez az aláírók minél nagyobb egyetértése szükséges; (2) összehangolt támogatásban részesítik a szomszédos országokban élő magyar közösségek autonómiatörekvéseit; (3) a nemzet jövője szempontjából meghatározó fontosságú Magyarország európai integrációja, ez azonban nem szoríthatja háttérbe a határon túli magyarok érdekeit; végül pedig (4) megvizsgálják a közös konzultáció intézményesítésének lehetőségeit (A MagyarMagyar Csúcstalálkozó Közös Nyilatkozata, 1996) Az első magyar-magyar csúcson elfogadott dokumentum tehát megerősítette a rendszerváltás utáni kormányok által képviselt külpolitikai prioritásokat, fenntartotta az egység diskurzusát, azonban a

\footnotetext{
205 Feljegyzés a magyar-román alapszerződés szakértői egyeztetésének budapesti fordulójáról, 1996. március 12. Határon Túli Magyarok Hivatala, Elemző Főosztály, ikt.szám: 028/3/1996, 2.

${ }^{206}$ Ibid. 3.

207 Jelentés a magyar-román megbékélési csomagterv és politikai nyilatkozatról tartott szakértői tárgyalásokról, 1996. március 12. Külügyminisztérium, 4. Területi Főosztály, 00644/4, 1-2.
} 
megváltozott viszonyok nem tették lehetővé a három célkitüzés egyidőben történő képviseletét és támogatását. ${ }^{208}$

A csúcstalálkozó záródokumentumára nem maradtak el a román reakciók sem, a szélsőséges pártok kemény nyilatkozatokban fogalmazták meg az autonómia elleni érveiket, ellenben a kormány mérsékelt magatartást tanúsított és a külügyminisztérium útján kért felvilágosítást követően kifejtette egyrészt, hogy „az etnikai autonómia összeegyeztethetetlen a demokráciával”, másrészt pedig - emelte ki Lazăr Comănescu a magyar kormány által elfogadott nyilatkozat következtében megtorpanni látszik az utóbbi évek közeledése. ${ }^{209}$ A kormány okkal törekedett a mérsékelt hangvételre, ugyanis ebben az időszakban Teodor Meleșcanu külügyminiszter Románia NATOcsatlakozásáról, míg Dumitru Cioflina vezérkari főnök fegyverzet-korszerüsítésről és vásárlásról tárgyalt az Egyesült Államokban. A román fél a vita kezdeményezésével vélhetően nem szerette volna a külföldön tartózkodó magas tisztségviselők tárgyalási pozícióját gyengíteni. ${ }^{210}$

Az autonómiatörekvések és a magyar-román alapszerződés szempontjából lényeges szempontnak bizonyult az Egyesült Államok véleménye. A Külügyminisztérium sajtószóvivője újságírói kérdésre miszerint tett-e az Egyesült Államok valamilyen diplomáciai lépést a magyar fél irányába a záródokumentum aláírását követően, Nicholas Burns sajtószóvivő megerősítette, hogy a két állam illetékesei tárgyaltak a kérdésről, azonban elzárkózott attól, hogy részleteket mondjon („U.S. Department of State: Daily Press Briefing” július 22). Nem sokkal később a július 29-i sajtótájékoztatón újra felmerült az a kérdés, hogy az Egyesült Államok miként viszonyul a határon túli magyarok autonómia-igényéhez. Válaszában Burns sajtószóvivő már sokkal határozottabban nyilatkozott. Kifejtette, hogy ,az Egyesült Államok teljes mértékben támogatja a közép-európai etnikai kisebbségek kulturális önazonosságuk megóvására vonatkozó erőfeszítéseit, valamint szabad és méltányos politikai részvételüket abban az országban, amelynek állampolgárai. De amint már

\footnotetext{
208 A csúcstalálkozó eredményét Németh Zsolt a következőképpen értékelte: „a magyar-magyar csúcstalálkozón megpróbáltuk, ,helyreránditani” a nemzeti elkötelezettség és az euroatlanti integrációs politika között egyetértést [...], de ez a magyar-magyar csúcs nem jelentett és nem tudott akkora kohéziót kialakítani, hogy a magyar-román alapszerzödést sikerüljön megakadályozni."

${ }^{209}$ Udvardy kronológia, keresőszó: magyar-magyar csúcstalálkozó.

${ }^{210}$ A román külügyminiszter amerikai látogatására az amerikai sajtó is felfigyelt, az Egyesült Államok Külügyminisztériumának napi sajtótájékoztatóján egy újságírói kérdésre Nicholas Burns sajtószóvivő elmondta: „Soha nem azonosítottunk olyan országcsoportokat, akik a bővítés első, második vagy harmadik körében lennének. Románia már a kezdetek óta részt vesz a Partnerség a Békéért programban, egy nagyon aktív tag és reméljük, a jövőben is fontos szerepet fog játszani. Minden bizonnyal figyelembe fogják venni a lehetséges NATO-tagságát, amikor a NATO a szervezet bővítése mellett dönt.” („U.S Department of State: Daily Press Briefing” július 17).
} 
említettük - tette hozzá -, az Egyesült Államok nem támogatja az etnikai alapú területi autonómiát. Ez egy nagyon fontos alapelve a hidegháború utáni időszaknak KözépEurópában és a volt szovjet utódállamokban” („U.S. Department of State: Daily Press Briefing” július 29). Az Egyesült Államok Külügyminisztériumának állásfoglalása amelyben elutasította a kollektív jogokra vonatkozó elvárásokat - lezárta az alapszerződés vitáját és megnyitotta az utat a felek közötti megegyezés előtt. ${ }^{211}$

A soron következő események, amelyek a magyar kormány irányváltásaként értelmezhetők, az alapszerződés megszövegezésében a szakértői szintű egyeztetések befejezését jelentették: előbb a magyar miniszterelnök nyilatkozott arról, hogy a magyar-román alapszerződés létrejöttének küszöbén állnak, majd az augusztus 13-14. között Bukarestben megrendezett államtitkári találkozó résztvevőinek megnyilvánulásából is kiderült, hogy elhárultak az alapszerződés előtt álló akadályok, így a két ország hamarosan aláírja azt. Ez gyakorlatilag azt jelentette, hogy megegyezés született az ET 1201. sz. ajánlásának a szerződésben való szerepeltetésének formájáról, és a kisebbségi cikkely néhány vitatott bekezdéséröl. A szerződés mellékletébe végül bekerült az ET ajánlására vonatkozó hivatkozás, de egy úgynevezett szükítő megjegyzést is füztek hozzá, amely lényegében korlátozta az ajánlásban a kollektív jogokra vonatkozóan megfogalmazott kitételt, és explicite kimondta, hogy az nem vonatkozik az etnikai alapú területi autonómiára. ${ }^{212}$

A román féllel való kompromisszumra törekvő álláspontján az RMDSZ és a hazai ellenzék részéről érkezett kezdeményezések ellenére sem változtatott a magyar kormány. Az RMDSZ Operatív Tanácsa augusztus 16-i állásfoglalásában megerősítette a Szövetség korábban megfogalmazott álláspontját és annak ellenére, hogy a dokumentumban számos pozitív kitételt azonosítottak, a Szövetség képviselői szűkítő jellegünek tartották az ajánláshoz füződő megjegyzést, nem tartották kielégítőnek a nyelvhasználatra vonatkozó kitételeket, valamint hiányosságként értékelték, hogy a dokumentum nem foglalkozott az egyházi és közösségi javak visszaszolgáltatásával

\footnotetext{
211 Visszaemlékezéseiben Horn Gyula miniszterelnök, saját kezdeményező szerepét hangsúlyozta a tárgyalások felelevenítésében, arra hivatkozva, hogy olyan vélemények jutottak el hozzá Bukarestből, „,melyek szerint a román fél kész változtatni addigi hajthatatlan álláspontján, s talán kompromisszumos megoldásra is hajlandó” (Horn 1999, p. 419).

${ }^{212}$ A lábjegyzet tartalma a következő: A szerződő felek egyetértenek abban, hogy az 1201-es ajánlás nem hivatkozik a kollektív jogokra, és nem kötelezi a feleket arra, hogy az említett személyek számára biztosítsák a jogot az etnikai alapú területi autonómia speciális státusára. („Szerződés a Magyar Köztársaság és Románia között a megértésről, az együttműködésről és a jószomszédságról és a vonatkozó nemzetközi dokumentumok" 1997). Kutatásaimból nem derült ki egyértelműen, hogy ki fogalmazta meg a lábjegyzetet. Marcel Dinu államtitkár visszaemlékezéseiben Dumitru Ceaușu főosztályvezetőnek tulajdonította a lábjegyzet tartalmát (Dinu 2009, p. 192), míg mások szerint a Főbiztos fogalmazhatta meg, ugyanis korábban hasonló „,szellemü” levelet írt Kovács László külügyminiszternek.
} 
végül pedig végrehajtás, a vegyesbizottságok felállítását is problematikusnak ítélték meg. ${ }^{213}$ E kifogásokból kiindulva az RMDSZ kérte a magyar és a román felet, hogy újítsák fel a konzultációkat, de ekkorra már világossá vált az RMDSZ vezetőiben is, hogy a felek lezártnak tekintik a tárgyalásokat és nem is tartanak igényt az RMDSZ közvetítő szerepére. ${ }^{214}$ Noha augusztus végén sor került egy találkozóra az RMDSZ és a magyar kormány képviselői között, de nyilvánvalóvá vált, hogy a kormány lezártnak tekinti a tárgyalásokat és aláírja az augusztus 21 -én véglegesített alapszerződést.

\section{A nemzeti parlamentekben lefolytatott viták tanulságai}

A nemzeti parlamenteknek a külpolitikai döntéshozatalban játszott korlátozott szerepének betudhatóan sem a törvényhozás, sem pedig az egyes pártok nem lehettek alakítói a tárgyalásoknak, azonban a tárgyalások során a dokumentum tartalmának pártok általi értelmezése rendre megjelent a politika napirendjén és mindkét államban heves vitákat eredményezett a szerződés aláírását támogató és ellenző csoportok között. A tárgyalások befejezését és a dokumentum véglegesítését követően a szerződés aláíását ellenző pártok mozgástere lényegesen beszükült, akiknek csupán egyetlen lehetőségük adódott a tartalmi változások kikényszerítésére, nevezetesen ha élnek a törvényhozás nyilvánossághoz kapcsolódó funkciójával és egy parlamenti vita keretében ütköztetik a kialakult álláspontokat. ${ }^{215}$

A magyar kormány és az ellenzék viszonya azt követően polarizálódott, hogy az augusztus 14-i bukaresti államtitkári találkozón a felek bejelentették a szakértői szintű tárgyalások befejezését, és az alapszerződés szövegéről szóló megegyezést. A megegyezés híre heves reakciókat váltott ki az ellenzéki pártok részéről, akik bírálták a kormányt és elfogadhatatlannak tartották a szerződés aláírását. ${ }^{216}$ Romániában az

213 („Az RMDSZ Operatív Tanácsának álláspontja a véglegesítés előtt álló magyar-román alapszerződésröl” 2009. In: Húszéves az RMDSZ. 2009, pp. 510-511).

${ }^{214}$ Az RMDSZ-ről szóló elemzésében Bakk Miklós 1996 tavaszára teszi annak az időpontját, amikortól már sem a magyar fél, sem pedig a román fél nem tartott igényt az „RMDSZ aktív partneri szerepére”. Mindenesetre a két féllel folytatott egyeztetések dinamikájában nem történt változás, a Szövetség tagjai 1996-ban Budapesten hat alkalommal, míg Bukarestben 3 alkalommal egyeztettek az alapszerződésről (Bakk 1999).

${ }^{215}$ A nemzeti parlamentben zajló viták szempontjából a törvényhozásnak a nyilvánossághoz kapcsolódó funkcióját emelhetjük ki, amely lehetőséget biztosít a parlamenti pártok számára politikai programjuk ismertetésére és ütköztetésére, továbbá aktuálpolitikai kérdésekben vitát kezdeményezni, egyben pedig a média segítségével - a szélesebb nyilvánosságot is megszólítani, befolyásolni. Ebben az értelmezésben a parlamenti viták jelentős momentumát képezhetik a politika napirendjén szereplő bel- és külpolitikai kérdéseknek. A törvényhozói hatalom külpolitikához kapcsolódó funkcióit Magyarország és Románia példáján lásd bővebben: (Szabó 2015a).

${ }^{216}$ A kérdésben Kereszténydemokrata Néppárt (KDNP) volt a legelszántabb, aki rendkívüli ülésszak összehívását javasolta. A kezdeményezéshez az ellenzéki pártok is csatlakoztak, így augusztus 27-re összegyült a szükséges aláírás (összesen 89), aminek alapján Gál Zoltán házelnök szeptember 3-ra összehívta az Országgyülés rendkívüli ülését, naprenden pedig az alapszerződés és az ellenzék által 
alapszerződésröl folytatott tárgyalások ezzel szemben a mérsékeltek és a radikálisabb oldal dimenziója mentén osztotta meg a parlamenti pártokat (Ivan 2010, 407-8). A tárgyalások során a Román Nemzeti Egységpárt és a Nagy-Románia Párt ellenezte az alapszerződést ${ }^{217}$, a tárgyalásokon történő előrelépésekre a két párt képviselői folyamatos tiltakozó akciókkal és heves nyilatkozatokkal válaszoltak, egyben pedig a kormány képviselőit is bírálták kompromisszumra törekvő magatartásukért. ${ }^{218}$ Noha a Képviselőházban nem került sor a szerződés aláírását megelőző rendkívüli vitanapra, a képviselők a ratifikációs vitán fejtették ki érveiket az alapszerződés aláírásával kapcsolatosan.

A soron következő részben az alapszerződésről tartott képviselőházi vita ${ }^{219}$ és az Országgyülésben megtartott rendkívüli ülésszak ${ }^{220}$ elemzését végzem el, összehasonlító perspektívában. Annak ellenére, hogy a két vita között számtalan különbség lehető fel, a jegyzőkönyvek alkalmasnak bizonyult arra, hogy a tartalmi kérdésekre fókuszáló elemzésben a felszólalások alapján azonosítsam a parlamenti pártok érvrendszereit és a vitában alkalmazott stratégiákat.

5. sz. táblázat: Az alapszerződésről szóló viták általános jellemzői

\begin{tabular}{|c|c|c|}
\hline & Románia & Magyarország \\
\hline A vita státusa & ratifikációs vita & rendkívüli ülés/vita \\
\hline A vita időpontja & 1996. október 3 & 1996. szeptember 3. \\
\hline A vita időtartama & $\mathrm{kb}$. 1 óra & 9 óra 26 perc \\
\hline A szövegtest mérete & 20 oldal/7000 szó & 105 oldal/44.500 szó \\
\hline Felszólalók száma & 9 & 38 \\
\hline
\end{tabular}

beterjesztett határozati javaslatok szerepeltek, melyek három pontból álltak: (1) az alapszerződést a kormány csak az Országgyülés előzetes hozzájárulásával írja alá; (2) a Kormány folytasson további tárgyalásokat az alapszerződés tartalmáról és a tárgyalásoknál vegye figyelembe a romániai magyar szervezetek véleményét; (3) a Kormány törekedjen olyan tartalmú szerződés megkötésére, amely a romániai magyarság részére biztosítja az európai normáknak és a nemzetközi szerződéseknek megfelelő autonómia és kollektív joggyakorlás lehetőségét. („Határozati javaslat, Országgyülési napló”).

${ }^{217}$ A kormányzó Társadalmi Demokrácia Pártja 1995 októberében előbb a Nagy-Románia Párttal, majd az alapszerződés aláírását megelőzően, 1996. szeptember elején a Román Nemzeti Egységpárttal is felmondta a koalíciós megállapodást.

${ }^{218}$ Petre Țurlea képviselő (UNPR) az alapszerződés aláirásának feltételeként Magyarországot kártérítés fizetésére kényszerítette volna az Észak-Erdély megszállása során meggyilkolt állampolgárokért. Gheorghe Funar, Kolozsvár polgármestere népszavazást kezdeményezését helyezte kilátásba, mert véleménye szerint a dokumentum a nemzetárulás okmánya. Corneliu Vadim Tudor, a Nagy-Románia Párt elnöke pedig az ET 1201. sz. ajánlásának kihagyását javasolta a szerződésből (Udvardy-kronológia), keresőszó: alapszerződés, 1996.

${ }^{219}$ („Camera Deputatilor: Proiectul de Lege pentru ratificarea Tratatului de înţelegere, cooperare şi bună vecinătate între România şi Republica Ungară”).

${ }^{220}$ („Országgyülési napló. 197. ülésnap a Magyar Köztársaság és Románia között kötendő Alapszerződés ügyében"). 
A módszertani részben részletesen kifejtett eljárás során az alapszerződés vitájában a következő kategóriákat különítettem el: (1) elöfordulnak mindkét vitában és dominánsak: az alapszerződés különböző értelmezései és az aláírás folyamata; Európa és az euro-atlanti integráció kérdése; a szerződő felek szerepe; (2) előfordulnak mindkét vitában, de csak az egyik fél szempontjából domináns: nemzeti kisebbség, RMDSZ, kollektív jogok és autonómia (HU); együttmüködés, történelmi megbékélés (RO); (3) csak a magyar vitában fordul elő, domináns: határon túli magyarság, Kárpát-medence, Erdély, anyaország, összetartozás, kormány-ellenzék viszony. Csak a román vitában jelent meg (4) és kevésbé domináns: a függetlenség, a területi sérthetetlenség és szuverenitás kérdése; az állam egységének problematikája, országimázs, kollektív jogok; (5) előfordulnak mindkét vitában, marginális: gazdaság; (6) csak a magyar vitában fordul elő, marginális: Trianon.

A felállított kategóriákból kirajzolódtak a viták közötti hasonlóságok és az alapvető különbségek, továbbá nyilvánvalóvá vált, hogy mi a vita tétje. Alapvető hasonlóságot képeznek a kötelező módon megjelenő témák, amelyet a vitában részt vevők nem tudnak megkerülni (az alapszerződés és ennek különböző értelmezései, a magyar és román fél viszonya). Az elemzés szempontjából azonban a különbségek érdemelnek kiemelt figyelmet, mert rávilágítanak arra, hogy a vita tematikus szempontból más-más dimenzióban folyt. Míg Magyarországon a vita nemzetpolitikai dimenzió mentén folyt (határon túli magyarság, összetartozás, kollektív jogok) és végeredményben a kormány-ellenzék szembenállásaként értelmeződött, addig Romániában a vita főként a szuverenitás, az állam egységének problematikájaként, a szomszédos államokhoz (történelmi megbékélés) és a nyugat-európai államokhoz (integráció, Románia külföldi megítélése) való viszonyban jelent meg. 
6. sz. táblázat: Alapszerződés: kategóriák a magyar és román vitában

\begin{tabular}{|l|l|c|c|}
\hline \multicolumn{2}{|c|}{ Kategóriák a magyar vitában } & Gyakoriság & \% \\
\hline \multirow{2}{*}{ Alapszerzódés } & A szerzödés értelmezése & 60 & 12,10 \\
\cline { 2 - 4 } & Tárgyalás & 33 & 6,65 \\
\cline { 2 - 4 } & Összesen & $\mathbf{9 3}$ & $\mathbf{1 8 , 7 5}$ \\
\hline Kollektív jogok, 1201. sz. ajánlás, autonómia & 44 & 8,87 \\
\hline Határon túli magyarság & 48 & 9,68 \\
\hline RMDSZ & 38 & 7,66 \\
\hline Anyaország, nemzeti összetartozás & 37 & 7,46 \\
\hline Románia, román fél & 42 & 8,47 \\
\hline Euro-atlanti integráció, csatlakozás & 31 & 6,25 \\
\hline Kormány, kormánypártok, miniszterelnök & 30 & 6,05 \\
\hline Kétoldalú kapcsolatok: megbékélés, & 19 & 3,83 \\
\hline együttmüködés & 15 & 3,02 \\
\hline Ellenzék, ellenzéki pártok & 10 & 2,02 \\
\hline Magyarország, magyar fél & 26 & 5,24 \\
\hline Külpolitika, országimázs & 14 & 2,82 \\
\hline Trianon & 9 & 1,81 \\
\hline Függetlenség, területi sérthetetlenség, szuverenitás & 3 & 0,60 \\
\hline Nemzeti érdek & 396 & 0,60 \\
\hline Gazdasági együttmüködés & $\mathbf{4 0 0}$ \\
\hline Hivatkozások & 3,85 \\
\hline Összesen & 3 & \\
\hline
\end{tabular}

\begin{tabular}{|c|c|c|c|}
\hline \multicolumn{2}{|r|}{ Kategóriák a román vitában } & Gyakoriság & $\%$ \\
\hline \multirow{4}{*}{ 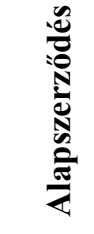 } & Értelmezés & 12 & 10,00 \\
\hline & Tárgyalás & 6 & 5,00 \\
\hline & Aláírás & 3 & 2,50 \\
\hline & Összesen & 21 & $\mathbf{1 7 , 5 0}$ \\
\hline \multicolumn{2}{|c|}{ Kollektív jogok, 1201. sz. ajánlás, autonómia } & 22 & 18,33 \\
\hline \multicolumn{2}{|c|}{$\begin{array}{l}\text { Kétoldalú kapcsolatok: megbékélés, } \\
\text { együttmüködés }\end{array}$} & 15 & 12,50 \\
\hline \multicolumn{2}{|c|}{ Euro-atlanti integráció, csatlakozás } & 11 & 9,17 \\
\hline \multicolumn{2}{|c|}{ Függetlenség, területi sérthetetlenség, szuverenitás } & 11 & 9,17 \\
\hline \multicolumn{2}{|c|}{ Magyarország, magyar fél } & 7 & 5,83 \\
\hline \multicolumn{2}{|c|}{ Magyar kisebbség, RMDSZ } & 7 & 5,83 \\
\hline \multicolumn{2}{|c|}{ Külpolitika, országimázs } & 6 & 5,00 \\
\hline \multicolumn{2}{|c|}{ Románia, román fél } & 4 & 3,33 \\
\hline \multicolumn{2}{|c|}{ Ellenzék, ellenzéki pártok } & 4 & 3,33 \\
\hline \multicolumn{2}{|c|}{ Határon túli magyarság/magyar kisebbség } & 4 & 3,33 \\
\hline \multicolumn{2}{|c|}{ Nemzeti érdek } & 3 & 2,50 \\
\hline \multicolumn{2}{|c|}{ Hivatkozások } & 5 & 4,17 \\
\hline \multicolumn{2}{|c|}{ Összesen } & 120 & 100,00 \\
\hline
\end{tabular}




\subsection{Magyarország}

A vitában a kormányoldal és az ellenzéki pártok közötti megosztottság kiválóan tükröződik az alapszerződés értelmezéséből, amelynek célkitűzését, folyamatát, tartalmát és hatásait vizsgálva, az egymásnak ellentmondó érvrendszerek is kirajzolódnak. Az alapszerződés értelmezésének fő funkciója, hogy kijelölje a vita keretét, azt, hogy ki mit mondhat el a legfontosabbnak vélt - integráció, kétoldalú kapcsolatok, kisebbségi jogok stb. - témákról.

7. sz. táblázat: Az alapszerződés értelmezései, jelentésváltozatai a magyar vitában

\begin{tabular}{|c|c|c|}
\hline & Kormányoldal & Ellenzéki pártok \\
\hline 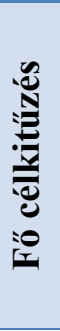 & $\begin{array}{l}\text { Az alapszerződés elösegíti integrációs } \\
\text { törekvéseinket. } \\
\text { Az alapszerződés hozzájárul a kisebbségi kérdés } \\
\text { rendezéséhez, a magyar és a román nép közötti } \\
\text { bizalom erősödéséhez. } \\
\text { Támogatja nemzeti érdekeinket. } \\
\text { Arra jó, hogy leszámoljunk illúzióinkkal. }\end{array}$ & $\begin{array}{l}\text { Az alapszerződések nem segítik elő az európai } \\
\text { integrációt. } \\
\text { Az alapszerződés rontja a kisebbségi kérdés } \\
\text { kezelésének lehetőségeit. } \\
\text { Baráti segítségnyújtás Iliescu politikai } \\
\text { kampányához. }\end{array}$ \\
\hline 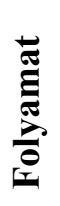 & $\begin{array}{l}\text { Az alapszerződés kompromisszum végeredménye. } \\
\text { Nem létezik olyan alapszerződés, amelyet az } \\
\text { RMDSZ, és Bukarest is támogatna. }\end{array}$ & $\begin{array}{l}\text { Az alapszerződés aláírása ténylegesen a román } \\
\text { diplomáciának a sikere. } \\
\text { Az alapszerződés a román választási kampány } \\
\text { egyik legfontosabb kérdése. }\end{array}$ \\
\hline 高 & $\begin{array}{l}\text { Az elfogadott európai normáknál szélesebb } \\
\text { jogosítványokat biztosít. Az alapszerződésben } \\
\text { semmiről sem történik lemondás, átfogó keretet ad } \\
\text { a kapcsolatok bővítéséhez. } \\
\text { Az alapszerződéstöl nem várható, hogy a két ország } \\
\text { közötti problémákat megoldja. } \\
\text { Magyar szempontból elérendő minimum és az adott } \\
\text { feltételek között az elérhető maximum. }\end{array}$ & $\begin{array}{l}\text { Az erdélyi magyarság szempontjából } \\
\text { jogfosztást eredményező szerződés. } \\
\text { Az alapszerződés deficites, nem nyújt } \\
\text { garanciákat. } \\
\text { A dokumentum tervezete arról szól, hogy az } \\
\text { erdélyi magyarságnak nincs joga az } \\
\text { eredményes és békés boldoguláshoz. }\end{array}$ \\
\hline 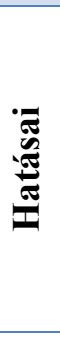 & $\begin{array}{l}\text { Az alapszerződés fontos szerepet játszik a térség } \\
\text { stabilizálásában. } \\
\text { Az alapszerződés kötelezettségei oldhatják a } \\
\text { bizalmatlanságot. } \\
\text { Változtat a kisebbségi lét mindennapjain. } \\
\text { A szerződés hiteltelenné teszi a revizionizmus } \\
\text { vádját. }\end{array}$ & $\begin{array}{l}\text { Nem stabilitást, hanem instabilitást hoz. } \\
\text { A magyar-román alapszerződés a mostani } \\
\text { koalíció hatalmon maradásának érdekeit } \\
\text { szolgálja. }\end{array}$ \\
\hline
\end{tabular}

Saját szerkesztés a parlamenti jegyzőkönyvek alapján.

A kormányt alkotó MSZP-SZDSZ koalíció a vita során az alapszerződés elfogadása és az aláírás szükségessége mellett érvel. Érvrendszerük három fontos kijelentés köré szerveződött: (1) az alapszerződés aláírása elősegíti az integrációt, (2) javít a határon túli magyarok helyzetén és hozzájárul a kisebbségi kérdés rendezéséhez, (3) hozzájárul a két ország viszonyának normalizálódásához és a térség stabilizálásához. Az ellenzéket alkotó MDF, FKgP, FIDESZ, KDNP és MDNP képviselői a kormány 
kijelentéseinek az ellentétét hangsúlyozták, vagyis (1) a dokumentum aláírása nem segíti elő az integrációt, (2) rontja a kisebbségi kérdés rendezésének lehetőségeit (jogfosztás), az RMDSZ pozícióit, ami pedig instabilitáshoz vezet, továbbá (3) az aláírás nem a magyar, hanem a román diplomácia sikereként értékelendő.

A Magyar Szocialista Párt (MSZP) az alapszerződést kompromisszumnak tartotta, amely tartalmát tekintve magyar szempontból elérendő minimum, és az adott feltételek között az elérhető maximum. Ennek alátámasztására felidézte a tárgyalások fontosabb momentumait, a román féllel folytatott szakértői tárgyalásokat, továbbá a párt programjának célkitüzéseit, amely prioritásként kezelte az integrációt, ellenben nem mondott le a határon túli magyarságról. Mivel a lemondás problémája az ellenzéki felszólalásokban uralkodó témává vált, így az MSZP stratégiája arra irányult, hogy ennek ellentmondjon: a „kiállunk”, „támogatjuk”, „fellépünk” igék nyomatékosították a párt álláspontját. Mi több a felszólalók kifejtették, hogy a kormány partnerként kezelte a határon túli szervezeteket, a dokumentumról folyamatosan konzultált az RMDSZ-el. A felszólalók azonban nem tettek említést arról - érveltek az ellenzéki pártok-, hogy a Szövetség több állásfoglalást is közzétett, amelyben kifejtették a tervezettel kapcsolatos kritikákat, ennek ellenére a kormány véglegesítette a szerződést.

Az integráció melletti érvelés domináns témája az MSZP képviselőinek: ,javítja integrációs esélyeinket”, „ha bekerülünk az integráció első körébe nagyobb eséllyel léphetünk fel", ami a dokumentumban rejlö lehetőségeket igyekszik kihangsúlyozni. Ezzel szemben kiemelte az alapszerződés elutasításának veszélyét: „nem kockáztathatjuk meg, hogy hiánya miatt, nem kerülünk be az integráció első körébe”, „feltétele az euro-atlanti csatlakozásnak”, tehát egy olyan elváráshorizontot is megjelenített, melyben a nyugat irányadó, ő az, aki megszabja a feltételeket, nem az ellenzék.

A vita során az MSZP a szerződés pozitív vonatkozásait, a szerződésben rejlő lehetőségeket emelte ki, amelynek két fontos dimenziója - a kisebbségi jogok és a kétoldalú kapcsolatok - különíthetők el. A kisebbségi jogok terén az anyanyelvhasználat és az anyanyelvű oktatás jelent meg hangsúlyosan, azonban a diskurzust a kollektív jogokról, az autonómiáról és az ET 1201. sz. ajánlásáról folyó vita uralta, arról, hogy hogyan értelmezhető a lábjegyzet tartalma, ez pedig mennyiben 
jelent lemondást az autonómiáról. Ennek tömör összefoglalóját adja felszólalásában Kovács László külügyminiszter. ${ }^{221}$

Míg az integráció kapcsán a nyugat normaalkotóként, irányadóként jelenik meg, a kisebbségi jogok kapcsán Tabajdi Csaba az európai fórumok szerepét kritikusan értékeli: „az európai normarendszer alacsonyabb, mint amit egy kétmilliós nemzeti közösség igényel”. Az MSZP az alapszerződésben a térség stabilitásának megerősödését és a kétoldalú kapcsolatok rendezésének lehetőségét is látta, aminek következtében erősödhet a két fél közötti bizalom. „Közös érdek a megbékélés” - jegyezte meg az egyik felszólaló, utalva a német-francia megbékélési modellre. ${ }^{222}$

A Szabad Demokraták Szövetsége (SZDSZ), szemben a nagyobbik kormánypárttal, a vitában pragmatikusabb álláspontot képvisel, kijelentései megalapozottabbak és számos esetben gyakorol önkritikát - amely retorikai stratégiaként is értelmezhető -, megfogalmazva a szerződéssel kapcsolatos kételyeit. A kételyek, amelyek az MSZP esetében fel sem merültek, a következő problémák köré csoportosultak: (1) hogyan rendezi a határon túli magyarság helyzetét, illetve (2) a szerződés végrehajtása román oldalon milyen problémákat vet fel; (3) a szerződés aláírásának elmaradása milyen következményeket vonna maga után? ${ }^{223}$

A párt alapszerződés-értelmezésében dominál a kompromisszum kifejezés, amely több esetben, más-más szókapcsolatban is előfordul: „vállalható”, „erős”, „kompromisszum, mint szükséges minimum”. Ebben a diskurzusban az egyidejűség problémája is megjelent: e szerint nincs olyan dokumentum, amelyet a román fél és az RMDSZ egy időben támogatna.

Egy másik értelmezésben a dokumentum aláírása nemzeti érdekként jelenik meg, ugyanis elősegíti az integrációt és a magyar érdekképviselet szélesítését. A nyugati integráció nem lemondást jelent a határon túli magyarokról - áll a felszólalásokban -, hanem sokkal inkább kötelezettségvállalást tartalmaz a határon átnyúló kapcsolatokra

\footnotetext{
221 „A lábjegyzet nem értelmezö, hanem tényrögzítö lábjegyzet. Nem normatív jellegü, nem zár ki semmit és nem biztosít semmit. Pusztán megállapítja, hogy... A lábjegyzet még az etnikai alapú területi autonómiát sem zárja ki.” Részlet Kovács László külügyminiszter (MSZP) felszólalásából, („Országgyülési napló. 197. ülésnap a Magyar Köztársaság és Románia között kötendő alapszerződés ügyében”, 1996. szeptember 3).

${ }^{222}$ A vitában az MSZP szövetségesként viszonyult a román félhez, jóhiszeműségének, a megelőlegezett bizalomnak több formája is megjelent a felszólalásokban: (1) „a szerződés betartása nekik is érdekük” Európa jobban figyel rájuk; (2) a szélsőségesek már kiszorultak a kormányból; (3) „Romániában létezik szándék a megbékélésre, a kiegyezésre és a kisebbség sorsának jobbítására.” Kocsi László (MSZP) felszólalása.

${ }^{223}$ Abban az esetben, ha nem írják alá a szerződést - fejti ki Eörsi Mátyás -, Romániában elindul egy magyarellenes kampány, aminek következtében romlik az RMDSZ helyzete és Magyarország pozíciója is.
} 
vonatkozóan és garanciákat jelent a kisebbségi jogok gyakorlatba ültetésére. Ebben a kontextusban az integráció a kisebbségvédelemmel párosul, és újra felbukkannak a nyugattal kapcsolatos elvárások. ${ }^{224} \mathrm{~A}$ vitában a nyugat, és általában véve az európai fórumok a demokrácia és az emberi jogok védelmezőiként jelentek meg, következésképpen a felszólalók amellett érveltek, hogy az integráció normatranszfert követel meg a tagjelöltektől, amely végső soron pozitívan befolyásolja a kisebbségek helyzetét is.

Az elvárások az autonómia kapcsán is terítékre kerültek. Az SZDSZ politikusai nem látnak reális esélyt arra, hogy a határon túli magyarok kivívják az autonómiát, viszont az „,európai integráció majd szükségessé teszi az autonómiák rendszerét”, ami szintén fontos érvként szolgál az integráció mellett. Az alapszerződésben foglalt garanciákat - ennek kisebbségjogi vonatkozásait - folyamatosan hangsúlyozzák a felszólalók, de a szkeptikusabbnak tűnő érvek sem maradtak el a vitában. ${ }^{225}$

A Magyar Demokrata Fórum (MDF) képviselői az alapszerződést egy szélesebb kontextusban, a kárpát-medencei magyarság szempontjából értékelték, melyet a nemzeti diskurzus $^{226}$ és a nemzet egységének képzete dominált. ${ }^{227}$ A felszólalók felidézték a Trianon utáni nemzetrészek helyzetét, a Kádár-korszakot és a rendszerváltás pillanatát, amely „a magyarság lelki egységének helyreállításaként” értelmezhető. Azonban a dokumentum elfogadásával megbomlott a parlamenti pártok konszenzusa, amely alapvető változást hozott az anyaország és a határon túli magyarság viszonyában, egyben pedig azt jelentette, hogy Magyarország cserbenhagyta a romániai magyarságot.

Ebből a kiindulásból csak negatív értelmezések kapcsolódtak a szerződéshez: (1) a tervezet arról szól, hogy az erdélyi magyarságnak nincs joga az eredményes és békés boldoguláshoz (nem beszélhetnek magyarul, nem énekelhetik a Himnuszt); (2) egy fölöslegesen váltott helyjegy az integrációs vonatra; (3) az 1972-es baráti szerződés folytatása; (4) a mostani koalíció hatalmon maradásának eszköze, továbbá (5) Iliescu elnök kampányának támogatása. A felszólalók több okból is „deficitesnek” tartották a szerződést, mert nem tartalmazza a legfontosabb követeléseket, a lábjegyzet elveti a

\footnotetext{
224 „A határon túli magyarok helyzetén nem lehet javítani az európai struktúrához való csatlakozás nélkül." Nádori László (SZDSZ) felszólalása.

${ }^{225}$ „A szerződés alapjában véve nem változtat a kisebbségi lét mindennapjain, de aláirásával a román fél elismeri, hogy a kisebbségi kérdés már nem belügy." Bauer Tamás (SZDSZ) felszólalása.

${ }^{226}$ A nemzethez kapcsolódó érvrendszert a következő kifejezések is erősítik: ,együvé tartozó egyetemes magyarság”, az „,anyaország felelőssége”, a „külön életet élő nemzetrészek”, az elszakított nemzetrészek”, „,nemzet belső összetartó ereje”, továbbá a „magyar társadalom teste”.

${ }^{227}$ Lezsák Sándor (MDF) szerint, az alapszerződés vitája arról szól, hogy ,lelkileg egyek vagyunk-e a határon túli magyarsággal?".
} 
kollektív jogok és a területi autonómia lehetőségét, végrehajtására pedig nincsenek biztosítékok.

Az MDF nem a kormány következetességét, az integráció és a megbékélés iránti elkötelezettségét, hanem ennek módját vitatja, azzal vádolva a román felelet, hogy több kétoldalú szerződés kötelezettségvállalását sem tartotta be. A szerződéssel a magyar kormány lemond a határon túli magyarokról és marginalizálja az RMDSZ-t is. E helyzetböl a kiutat Csóti György egy olyan nemzetstratégia elkészítésében látja, amely széles politikai konszenzuson nyugszik (magyar-magyar csúcs intézményesülésének szükségessége) és választ ad a nemzeti sorskérdésekre (demográfiai erózió, kollektív jogok, integráció előnyeinek kihasználása).

A Független Kisgazda Párt (FKgP) a vitában Trianontól indít, olyan alapszerződés elfogadását támogatja, amely képes a trianoni és párizsi szerződések okozta károkat helyreállítani. Az alapszerződés ellen felhozott szempontok (időpont, tartalom, hatásai) a felszólalásokban újabb érvekkel egészülnek ki: „Trianonhoz viszonyítva is visszalépést jelent”, ,jogfosztást eredményező szerződés”, „nem megoldja, hanem csak szőnyeg alá söpri a problémákat”, ,,az alapszerződéses politika zsákutcás politika”, „nincs tekintettel a magyarság érdekeire”, és nemzetellenes. A felszólalók elhibázottnak tartják a megegyezést a román féllel, két hónappal a választások előtt és elvetik a kormány által hangoztatott kényszerhelyzetet is.

Trianon visszatérö képe a felszólalóknak, az érvek nagy részében megjelennek a trianoni békeszerződésre hivatkozó kijelentések, minden probléma onnan eredeztethető: „Trianontól kezdve”, „,a trianoni békedekrétum után” „Trianonhoz viszonyítva” „annak idején Trianonban”, továbbá a „trianoni-párizsi alapon nincs őszinte megbékélés”. Az alapszerződés aláírásával óriási felelősség hárul a kormányra, ugyanis alkotmányos kötelességünk a határon túli magyarok iránti felelősségvállalás, az alapszerződés aláírásával e kötelességét azonban a kormány nem teljesíti. Ebből a helyzetböl a továbblépést a képviselők a szerződés újratárgyalásával és az európai normáknak megfelelő autonómia-megoldások biztosításában látják. Az ellenzéki pártok közül a FKgP megy a legtovább, felvázolva a határok békés megváltoztatásának lehetőségét. ${ }^{228}$

A FIDESZ-Magyar Polgári Párt alapjában véve rossz lépésnek tartotta az alapszerződés megkötését és a vitában többször hangoztatta a szerződésről kialakított

\footnotetext{
${ }^{228}$ A határváltoztatás kérdése elsőként az EBEÉ 1975-ös helsinki csúcstalálkozó záródokumentumára való hivatkozásként, majd Kávássy Sándor konkrét felszólalás-javaslatában jelenik meg, meglebegtetve annak a lehetőségét, hogy a határ menti magyar lakosság népszavazás útján döntsön az államterületi hovatartozásról.
} 
korábbi álláspontját. A FIDESZ több okból is elutasította az alapszerződés aláírását: (1) kedvezőtlen az aláírás időpontja; (2) a román diplomácia sikere és egyben Iliescu elnök kampányát segíti; (3) a kormány nem szerezte meg az erdélyi magyarság és az RMDSZ támogatását; továbbá (4) nem tartalmazza Székelyföld területi autonómiáját, következésképpen nem egyezik a magyar külpolitika érdekeivel. A magyar-szlovák alapszerződés tanulságait levonva a felszólalók amellett foglaltak állást, hogy a rosszul megkötött alapszerződések nem javítják a kétoldalú viszonyokat, hanem éppen ellenkezőleg, „növelik a feszültséget”, így nem is járulhatnak hozzá a térség stabilizálódásához és az integrációhoz.

A párt képviselőinek érvelésében folyamatosan megjelent a kormány és a határon túli magyarok megváltozott viszonyrendszere: „a kormány az RMDSZ helyett Budapestet választotta”, a kormány lemondott a határon túli magyarokról, „már nem vállal felelősséget, nem kezeskedik értük." ${ }^{229}$ A felszólalók azzal támadták a kormányt, hogy nem vette figyelembe az RMDSZ szerződéssel kapcsolatos aggályait, az 1201 -es sz. ajánlásra és az egyházi javak visszaszolgáltatására vonatkozó javaslataikat. Ebben a kontextusban a határon túli szervezetek vétójoga is felmerült. Noha a FIDESZ is elveti ennek jogi értelmezését, viszont a kormány politikai felelőssége útján felvállalhatta volna azt, hogy csak az RMDSZ támogatásával köti meg a szerződést. A felszólalók úgy látják, hogy csak olyan alapszerződést érdemes kötni, amely javítja a magyarság „békeszerződésekből előállott hátrányos helyzetét”. Ennek mentén a FIDESZ támogatta a határon túli magyarok autonómia-törekvéseit és az MDF által vázolt magyar-magyar csúcs intézményesülését. Ebből következik, hogy a párt elveti a kormány által megfogalmazott integrációs érvrendszert, amely az alapszerződés nemzeti érdekként való beállításán alapult és felszólalóik a nemzeti érdek újabb meghatározását fogalmazták meg. ${ }^{230}$

A Kereszténydemokrata Néppárt (KDNP) érvelésében a szolidaritás problémája jelent meg, ugyanis a felszólalók úgy látták, hogy a kormány nem szolidáris a határon túli magyarsággal. Ha pedig a magyar kormány nem áll ki a határon túli magyarságért vonták le a következtetést a képviselők -, akkor senki más nem fog kiállni mellettük. A

\footnotetext{
${ }^{229}$ „A mostani magyar kormány nem tekinti a határon túli magyarokat a magyarság szerves részének [...] és gyakorlatilag ezért mond le a határon túli magyarok jogairól.” Orbán Viktor (FIDESZ) felszólalása.

${ }^{230}$ Orbán Viktor felszólalásában kifejtette, hogy „a NATO és az EU bővitésben világpolitikai és stratégiai megfontolások szerepelnek, amit az alapszerződések nem befolyásolhatnak.” A FIDESZ képviselői hibaként ítélik meg az integráció és az alapszerződés nemzeti érdekként való beállítását. Rockenbauer Zoltán szerint ,nemzeti érdek az, hogy a magyarság szülöföldjén megmaradhasson magyarnak, megörizhesse nyelvét, vallását és kultúráját."
} 
lemondás következményei pedig beláthatatlanok: „Erdély nem éli túl, ha az anyaország is magára hagyja."231

A kormányzat szerződéskötésre vonatkozó, integrációs érvrendszerét is elutasították a felszólalók, akik amellett érveltek, hogy a megegyezéssel a kormány nem Európának, hanem Romániának lett a partnere. A képviselők ellenezték az alapszerződés megkötésének módját (figyelmen kívül hagyták az erdélyi magyarság véleményét), továbbá ennek tartalmát, különös tekintettel az autonómia és kollektív joggyakorlás lehetőségére. A felszólalók az autonómia intézményét a nemzeti identitás és a jövőkép-alakítás szempontjából kiemelt fontosságúnak tekintették. ${ }^{232}$

A Magyar Demokrata Néppárt (MDNP) érvrendszerét a kétoldalú és jószomszédi viszonyokra vonatkozó hivatkozások uralják: ,a Néppárt elkötelezett híve annak, hogy valamennyi szomszédunkkal baráti legyen a viszonyunk”, ,igenis akarunk megegyezést Magyarország és Románia között”, a két országnak elemi érdeke a megbékélés, ehhez pedig az alapszerződéseket jó eszköznek tekinti. Azonban a magyar-román alapszerződés számos pontban elmarad a szlovák-magyar alapszerződés szövegétől, megkötését ellenezték a romániai magyar szervezetek, nem nyújt kellő garanciákat és végső soron hiányzik a román fél jószándéka a kisebbségi problémák megoldására vonatkozóan. A képviselők szerint az utóbbi években a kormány nem változtatott a kisebbségekkel szembeni politikájával, és hiba volna azt feltételezni, hogy erre a szerződés aláírása után kerülne sor. A problémát - a MDNP értékelése alapján - tehát nem a két állam közötti kapcsolatok, hanem sokkal inkább a többség-kisebbség viszony rendezése jelenti. A felszólalók a kormány integrációs diskurzusával is szembemennek: egyetértenek abban, hogy az integráció szempontjából fontos a jószomszédi viszony kialakítása, de legalább ennyire fontos a kisebbségi jogok biztosítása is. ${ }^{233}$

\subsection{Románia}

A képviselőházi felszólalások alapján a pártok között viszonylag széles konszenzus uralkodott arról, hogy az alapszerződés hozzájárul az euro-atlanti integrációhoz és a megbékéléshez is, de tartalmával (kisebbségi jogok, a szuverenitás és függetlenség értelmezése) és az aláírás időzítésével már nem minden párt értett egyet. Az egymásnak

\footnotetext{
${ }^{231}$ Giczy György (KDNP) felszólalása.

${ }^{232}$ A felszólalók a kollektív jogokon alapuló autonómiák kialakítását vetítik előre, ezt tekintik Európa jövőjének, és nem az alapszerződésben megjelenő megoldásokat.

${ }^{233}$ A Néppárt szerint olyan szerződést érdemes megkötni, amely „egyrészt orvosolja az ott élő magyarok legsúlyosabb panaszait, másrészt jó esélyt ad a két nép közötti kapcsolatok minél szorosabbá válására" Jeszenszky Géza (MDNP).
} 
feszülő érvek alapján nem két, hanem tulajdonképpen három ellentétes álláspont körvonalazódott, ugyanis az alapszerződés elfogadását a kormányzó PDSR mellett az ellenzéki PNȚCD-PER, a PD és a PL '93-PAC is támogatta, ezzel szemben az RMDSZ ellenezte, a PUNR és a PRM pedig szélsőséges érveket is megjelenített a vitában.

8. sz. táblázat: Az alapszerződés értelmezései, jelentésváltozatai a román vitában

\begin{tabular}{|c|c|c|}
\hline & Az alapszerződést támogató pártok & Az alapszerződést ellenző pártok \\
\hline 离 & $\begin{array}{l}\text { Új alapokra helyezi a kétoldalú kapcsolatokat. } \\
\text { A stabil és fenntartható kapcsolatokra vonatkozó } \\
\text { referenciadokumentum. } \\
\text { Ratifikálása hozzájárul a térség stabilitásához, a } \\
\text { megbékéléshez és a két állam euro-atlanti } \\
\text { integrációjához. }\end{array}$ & $\begin{array}{l}\text { A ratifikálás időpontja nem megfelelö, } \\
\text { mert kampánycélokat szolgál. } \\
\text { A szerződés csak abban az esetben járul } \\
\text { hozzá a jószomszédi viszonyokhoz, ha } \\
\text { túlmutat egy politikai szándék- } \\
\text { nyilatkozaton. }\end{array}$ \\
\hline 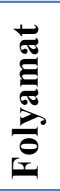 & $\begin{array}{l}\text { A szerződés előírásai demonstrálják, hogyan } \\
\text { lehet meghaladni a térségben a különbségeket. } \\
\text { A szerződés aláírása hasznos és rendkívül fontos } \\
\text { aktus. }\end{array}$ & $\begin{array}{l}\text { A Külügyminisztérium gyengének } \\
\text { bizonyult a tárgyalások során. }\end{array}$ \\
\hline 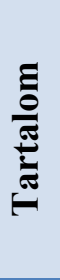 & $\begin{array}{l}\text { Egy pszichológiai küszöb meghaladását jelenti. } \\
\text { A dokumentum nagy érdeme, hogy garantálja } \\
\text { Románia nyugati határait. } \\
\text { A szerződés nem felelhet meg mindenkinek, de } \\
\text { az adott körülmények között a legjobb. }\end{array}$ & $\begin{array}{l}\text { Nem járul hozzá a magyar kisebbség } \\
\text { problémáinak kezeléséhez. } \\
\text { Alkalmazására nincs } \\
\text { mechanizmus kidolgozva. } \\
\text { Túl nagy engedményeket tesz a romániai } \\
\text { magyar kisebbségnek. }\end{array}$ \\
\hline 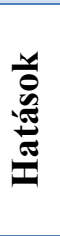 & $\begin{array}{l}\text { Pozitív hozadékai már gazdasági vonalon és az } \\
\text { integrációs szervezetekkel folytatott } \\
\text { tárgyalásokban is érzékelhetőek. } \\
\text { A szerződés végrehajtása a felek politikai } \\
\text { akaratának függvénye. }\end{array}$ & $\begin{array}{l}\text { Ha elfogadjuk az ajánlást, holnap egy } \\
\text { enklávéra ébredünk az ország közepén. }\end{array}$ \\
\hline
\end{tabular}

A Társadalmi Demokrácia Pártja (PDSR), mint kormányzó erő számára az alapszerződés aláírása stratégiai fontosságú kérdésnek bizonyult, amelynek két fő pillére volt: (1) rövidtávon az ország nyugati megítélésének javítása, hosszabb távon pedig az euro-atlanti integráció. Az országimázs szempontjából az államközi kapcsolatok a NATO taggá válás kontextusában - így Magyarországgal is - felértékelődtek. Ennek következtében az alapszerződés vitájában a PDSR fó érvei a kétoldalú kapcsolatok, a megbékélés és együttműködés és az integráció köré összpontosulnak. A PDSR értelmezésében az alapszerződés egy olyan referenciadokumentum, amely (1) a megértés és az együttmüködés szellemében új alapokra helyezi a kétoldalú kapcsolatokat; (2) egy pszichológiai küszöb meghaladását jelenti, (3) hozzájárul a stabilitáshoz és elösegíti Románia integrációs törekvéseit, mi több (4) válaszol a térség és a két ország biztonsági szükségszerüségeire is. 
A felszólalásokban az alapszerződés tehát valóságos „elixírként” jelent meg, amely megoldást kínált az ország külpolitikai kihívásaira. Ennek hangsúlyozására, továbbá egy szélesebb parlamenti és társadalmi támogatottság megszerzésére a választások előtt a PDSR-nek mindenképp szüksége volt. Így a felszólalásban gyakoriak a szerződés „nagy előnye”, „fó érdeme”, „pozitív hozadéka”, „rendelkezik azon erényekkel”, „új lehetőségeket nyit” kifejezések. E kifejezések fö funkciója legitimálni azt, hogy a Nagy-Románia Párt, a Román Nemzeti Egységpárt (határklauzula, szuverenitás, területi sérthetetlenség) és az RMDSZ (kisebbségi problémákkal foglalkozó cikkely) által felvetett kifogások nem kellően megalapozottak. Ezt az érvelési módot a kormánypárt egy integratív stratégiaként müködteti, amelyben ők és a szerződés ratifikációját támogató pártok az „,igazság” birtokosai, szerepük pedig abban nyilvánul meg, hogy az alkotmány és az európai normák szellemében egyensúlyt képeznek a szélsőségesek, akik túl soknak, és a magyar kisebbség képviselői között, akik túl kevésnek tartották a szerződés kisebbségjogi vonatkozásait.

A mintakövetés, a nyugathoz való viszonyulás az érvelés elengedhetetlen kelléke: a két fél közötti megegyezésre „az európai standardok és a nemzetközi politika elveinek figyelembevételével kerülhetett sor". 234

\section{A Kereszténydemokrata Nemzeti Parasztpárt-Román Környezetvédö Párt} (PNȚCD-PER) a két ország szempontjából az alapszerződés aláírását fontos eseménynek tartotta, amely hozzájárul az ország integrációjához. Noha nem felel meg minden parlamenti párt elvárásának, a szerződés igazolja azt, hogy „az ország egységes és nemzetállami jellege teljességgel összeegyeztethető a nemzeti kisebbségek identitását biztosító jogokkal", 235

A megbékélés melletti elköteleződés hangsúlyosan megjelent a felszólalásban, amelyre a szerződés jó kiindulópontként szolgál, ugyanis ennek aláírására a két fél szabad beleegyezésével került sor. Ahhoz azonban, hogy a hozzáfüzött reményeket betöltse, meg kell változzon a két nép között fennálló politikai légkör, amely elsősorban kölcsönös bizalomra kell épüljön. A megbékélés másik fontos eleme a jövőbetekintés, ahol újra felbukkan az európai irányultság. Azonban az európai mintakövetéssel szöges ellentétben áll az államon belüli, etnikai alapú területi autonómia gondolata, amely új határok megjelenését eredményezi, és végső soron „eltér a történelem menetétől is”.

\footnotetext{
${ }^{234}$ A mintakövetés az aláírást követő pozitív reakciók kiemelésében - Franciaország, Németország, az európai fórumok és az Egyesült Államok részéről - is tetten érhetők. Dan Marţian (PDSR), (,Stenograma ședinței Camerei Deputaţilor din 3 octombrie 1996”), továbbiakban képviselőházi vita.

${ }^{235}$ Ion Diaconescu (PNȚCD-PER). Az integratív stratégia, amely a PDSR-nél is megjelent, hasonló funkcióval bír: összeegyeztetni az egymásnak feszülő ellentéteket.
} 
A Demokrata Párt (PD) képviselője szerint a dokumentum ratifikációja felelősségteljes tett, amely nagymértékben hozzájárul a régió stabilitásához, Románia és Magyarország közötti történelmi megbékéléshez, illetve az euro-atlanti integrációhoz. A párt már a tárgyalások kezdetétől fogva támogatta a szerződés aláírását, viszont sosem támogatta a kollektív jogok és az etnikai alapú autonómia gondolatát.

Victor Boştinaru felszólalásában kifejtette, hogy a szerződéseket alá lehet írni, viszont alkalmazása a pártok politikai akaratától függ. Ennek kontextusában pedig szembemegy a kormányzó párttal, azzal vádolva őket, hogy jóhiszemüségét leszámítva nem nyújt kellő garanciákat a szerződésben foglaltak gyakorlatba ültetésére. ${ }^{236}$

A Román Nemzeti Egységpárt (PUNR) érvelését - amely a magyar kisebbség elleni szélsőséges kirohanásaival a parlamenti viták fontos szereplője volt - egy kettősség, egy kibékíthetetlennek tünő ellentét uralta, amely egyrészt abban nyilvánult meg, hogy fontosnak tartotta az alapszerződés aláírását, Románia nyugat-európai gazdasági és biztonsági szervezetekbe történő integrációját, azonban ellenzett minden olyan lépést, amely a kisebbségi jogok biztosítására irányult volna. Ennek következtében ők fogalmazták meg a szerződéssel kapcsolatos kifogások legnagyobb részét.

A párt nevében fellépő Costică Ciurtin képviselő jogi szakkifejezésekkel átszőtt felszólalásában az alapszerződésben kifogásolt részeket hasonlítja össze a parlament által ratifikált Keretegyezménnyel. ${ }^{237}$ Az összehasonlításban megfogalmazott kifogások fö funkciója a kormány támadása, amelyet a „határozottan ellenzi”, „elégedetlenek vagyunk”, „nagyon aggaszt”, kifejezésekkel is nyomatékosít, azért amiért a Keretegyezményen túlmutató, a magyar kisebbség számára pozitív rendelkezések is belekerültek a szerződés szövegébe. ${ }^{238}$ A szerződés kisebbségi jogokkal foglalkozó 15. cikkelyének több bekezdését is hevesen vitatja a felszólaló, így az anyanyelvű oktatásra, az asszimilációs politikára és az anyanyelvhasználatra vonatkozó részeket is, gyakran szélsőséges álláspontot képviselve.

A Romániai Magyar Demokrata Szövetség (RMDSZ) képviselője elismeréssel szólt arról, hogy a két állam minden erőfeszítést megtesz az euro-atlanti integráció

${ }^{236}$ „Noha kijelenti, hogy támogatja a két ország közötti szerződés ratifikációját, alávaló módon manipulálja a közvéleményt, és szándékosan pontatlanul jeleniti meg kollégáink álláspontját, akik döntő módon hozzájárultak azon megoldások körvonalazódásához, amelyröl ma szavazunk." Részlet Victor Boştinaru (PD) felszólalásából.

${ }^{237}$ Az ET Keretegyezményét a Parlament 1995. április 29-én ratifikálta. („Lege Nr. 33 din 29 aprilie 1995 pentru ratificarea Convenției-cadru pentru protecția minorităților naționale”).

${ }^{238}$ A képviselő kiemeli az ET 1201-es sz. ajánlását, amely mellékletként a szerződés integráns részévé vált, viszont kimaradt a Románia szuverenitására vonatkozó kitétel. 
érdekében, azonban az alapszerződés - amely fontos eszköznek bizonyul a kétoldalú kapcsolatok szabályozásában -, csak abban az esetben járulhat hozzá e célkitüzéshez, ha túlmutat majd egy politikai szándéknyilatkozaton. Az RMDSZ képviseletében, Vida Gyula a Szövetség alapszerződéssel kapcsolatos korábbi álláspontját foglalta össze, kiemelve a dokumentumnak a magyar közösség számára kedvező és kedvezőtlen rendelkezéseit, összességében pedig megállapítja, hogy a szerződés nem felel meg a magyar közösség elvárásainak.

A Szövetség üdvözölte az ET 1201-es számú ajánlás megjelenítését a szerződésben, azonban elfogadhatatlannak tartja a hozzá füzött szúkítő megjegyzést. ${ }^{239}$ A szerződésben szereplő pozitív kitételek mellett - anyanyelvű oktatás, kétnyelvü feliratok kérdése - számos rendelkezés található - anyanyelvhasználat a közigazgatásban és az igazságszolgáltatásban -, amelynek szabályozása nem egyértelmű, ez pedig „lehetőséget teremt az egyoldalú és szükítő értelmezésekre”. További hiányossága a dokumentumnak - fejtette ki a képviselő -, hogy hiányzik az egyházi javak visszaszolgáltatására vonatkozó kötelezettség, illetve a szerződés végrehajtására bevezetett kontrollmechanizmus sem tekinthető hatékonynak.

Az érvelésben a Szövetség programjában foglalt föbb célok is megjelennek, amely csak az autonómia különböző formáinak a megvalósításával érhetők el, ennek következtében „a szerződés első lépését képezheti azon folyamatoknak, melyek a magyar közösség életében bekövetkező valós változásokhoz vezetnek. "240

A Nagy-Románia Párt (PRM) szerint az alapszerződés aláírása hasznos és szükséges a jószomszédi viszonyok és a történelmi megbékélés szempontjából is, azonban az egységesülő Európa időszakában a román nép nem felejtheti el a történelem során a szabadságért és a társadalmi igazságosságért vívott harcokat. A múlt felidézésének fontos szerepe van az érvelésben, ugyanis ezzel Ioan Mureşan képviselő szembeállítja az ET 1201-es ajánlását, amelyet diktátumként, Románia függetlenségének és szuverenitásának megcsorbításaként értelmez. Az ebből következő jövőkép felvázolása sem marad el: „ma elfogadjuk az ajánlást, és holnap egy etnikai enklávéra ébredünk az ország közepén". ${ }^{241}$

Az dokumentum elleni második érv, az aláírás időpontjához kapcsolódik: erre ugyanis a választások után kellene sor kerüljön, mert így választási célokat szolgál -

\footnotetext{
239 „A magyar kisebbség helyzetének megoldásában a kollektív jogok különbözö formáinak gyakorlása és intézményesülése elengedhetetlen." Vida Gyula (RMDSZ) felszólalása.

${ }^{240}$ Ibid.

${ }^{241}$ Ioan Mureşan (PRM) felszólalása.
} 
hangsúlyozta a képviselő. A felszólalásban a nyugatot illetően nem képvisel következetes álláspontot a PRM: először egyfajta nyugatellenes kritika fogalmazódik meg, amiért Romániát túlságosan monitorizálják, majd az alapszerződés aláírása mellett érvelnek, amely hozzásegíti az országot az euro-atlanti integrációhoz.

A Liberális Párt '93 - Polgári Szövetség Pártja (PL '93-PAC) pozitívan vélekedett az alapszerződésről, ugyanis a dokumentum nagy előnyének tartotta azt, hogy (1) aláírására békeidőben, a két fél szabad elhatározásából került sor, (2) garantálja Románia nyugati határait, (3) hozzájárul a közép-európai térség stabilitásához, (4) aláírásával a román fél bebizonyítja a nemzetközi közösségnek, hogy képes a stabilitás megteremtésére és jószomszédi viszonyok fenntartására, (5) végül pedig fontos lépés az euro-atlanti integrációban, különösen a NATO-csatlakozásban.

A felszólaló értékelésében az alapszerződés a román diplomácia sikere, mivel a szerződés mellékletében foglalt dokumentum nem vonatkozik a kollektív jogokra és nem ismeri el az etnikai alapú területi autonómiát. A siker egy másik - geopolitikai vetülete is megjelent Vasile Popovoci felszólalásában, ugyanis az alapszerződéssel rendezzük kapcsolatainkat Magyarországgal, amely ha a térképre nézünk, ,az egyetlen járható folyosó Európába”. Az alapszerződés tehát a nemzeti érdek megjelenítésére szolgál, mivel „ratifikációja nemcsak román érdek, hanem az RMDSZ érdeke is, mivelhogy megfelelö garanciát nyújt a Szövetség alapszabályzatában foglalt célok teljesítéséhez. "242

\subsection{A pártok közötti megosztottság jellemzői és a pártok pozíciói}

Noha a két vitában a parlamenti pártok között konszenzus mutatkozott az európai integráció és a kétoldalú kapcsolatok rendezésének fontosságáról, arról már eltérő álláspontok alakultak ki, hogy e célkitüzéseket mily módon, milyen eszközökkel és feltételekkel lehet megvalósítani, egyáltalán erre az alapszerződés alkalmas eszközként szolgálhat-e? Az aktuálpolitikai helyzetnek, a pártok pozícióinak (kormánypárt vagy ellenzék), a romániai magyar kisebbség helyzetének és a külpolitikai prioritások eltérő értelmezéseinek betudhatóan a vita más-más dimenzió mentén polarizálódott, mély megosztottságot eredményezve a pártok között.

A leglátványosabb ellentét az Országgyülésben folytatott vitában rajzolódott ki. A megosztottság alapja, hogy míg az Antall-kormány kiemelten kezelte a határon túli magyarság helyzetét (egyenlő félként való megjelenítés, kisebbségi vétójog, a

${ }^{242}$ Vasile Popovoci (PL '93-PAC) felszólalása. 
nemzetpolitika a külpolitika részévé vált), addig a Horn-kormány az integrációt részesítette elönyben és annak ellenére, hogy fenntartotta az intézményes kapcsolatokat 1996 tavaszától az RMDSZ konzultatív szerepe és befolyása folyamatosan csökkent. Ennek alapján az ellenzék úgy látta, hogy 1996 augusztusára a kormány számára az integráció vált az első rendủ külpolitikai prioritássá, a határon túli magyarok kérdése pedig alárendelődött az integrációnak.

Romániában az integráció támogatásáról az összpárti konszenzus viszonylag későn jött létre ${ }^{243}$, az alapszerződés aláírásával azonban nyilvánvalóvá vált, hogy e konszenzus nem állt szilárd alapokon: a pártok eltérő módon (leghevesebben a PUNR és a PRM) ellenezték a kisebbségi jogokra vonatkozó európai normák bevezetését, valamint hangsúlyozták az ország szuverenitása és a dokumentum tartalma közötti feszültségeket („lemondás”, „,engedmény”).

Az elemzés során érzékelhetővé vált, hogy a parlamenti vitákban megjelenő pártok közötti megosztottság összetettebb, mint ahogyan az az előző kutatások megállapították. A korábbi vizsgálódásokból kiindulva (kormány - ellenzék illetve a mérsékeltek - szélsőségesek közötti megosztottság) árnyaltam a pártok helyzetét és feltártam a vitában megjelenő hasonló pozíciókat. Ennek kivitelezésére egy koordinátarendszer hatékony eszköznek bizonyult: a vízszintes tengelyen a kormányzati pozíció (kormányoldal - ellenzék), míg a függőleges tengelyen a szerződés aláírásával kapcsolatos álláspontok (támogatók - ellenzők) alapján helyeztem el a pártokat.

$\mathrm{Az}$ ábra alapján megállapítható, hogy a korábbi kutatásokhoz képest némiképp módosult az egyes pártok helyzete, ennek következtében az alapszerződés vitájában négy pozíció rajzolódott ki:

1. A kormánypárti támogatók csoportját a PDSR, az MSZP és az SZDSZ alkotja, akik a vita során a dokumentum elfogadása mellett érveltek.

2. Az ellenzéki támogatókat vagy mérsékelteket a három román párt (PL '93-PAC, PNȚCD-PER, PD) képviseli, akik ellenzéki pozícióból is támogatták az alapszerződést, viszont ellenezték a kollektív jogokat és a kisebbségi jogok bővítésének lehetőségeit.

3. Az alapszerződés aláírását ellenzők tábora a magyar ellenzéki pártokat (MDF, FIDESZ, KDNP, MDNP) és az RMDSZ-t foglalja magába, akik a mérsékeltekkel szemben azért ellenezték a szerződés aláírását, mert nem biztosította a kollektív jogokat és nem tartalmazta a romániai magyar kisebbség elvárásait.

\footnotetext{
${ }^{243}$ (A snagovi nyilatkozat. In: Valeriu 2000, pp. 67-68).
} 
4. A negyedik pozíció a szélsőséges pártoké (PUNR, PRM, FKgP), akik szélsőséges érveket is megfogalmaztak az alapszerződéssel szemben.

5. sz. ábra: A pártok pozíciói az alapszerződés vitájában

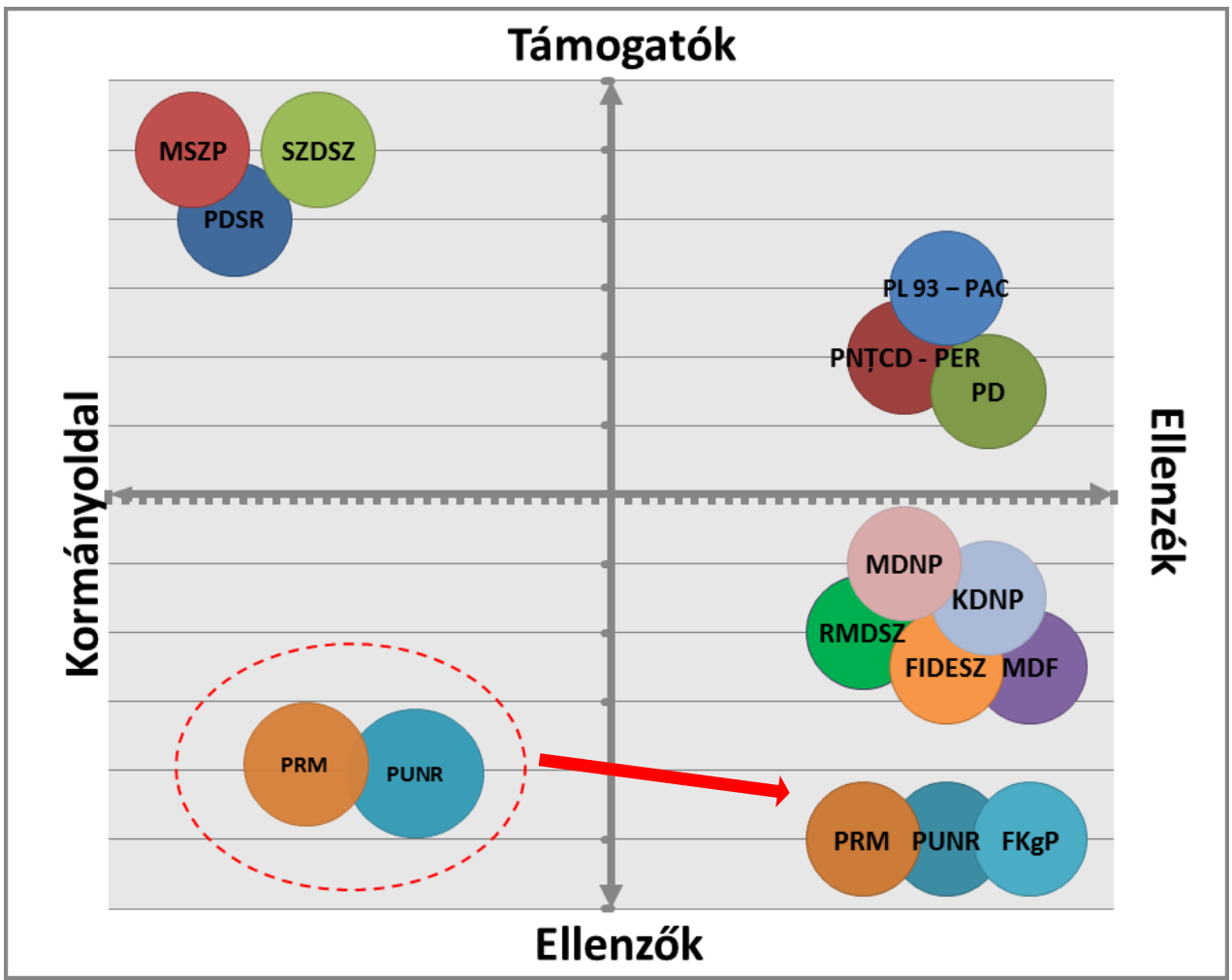

\subsection{Fö témák, érvrendszerek és stratégiák a vitában}

$\mathrm{Az}$ alapszerződés vitájában a parlamenti pártok témahasználatában (a felszólalásban uralkodó témák) és érvrendszereiben több hasonlóságot, de alapvető különbségeket is feltártunk. Az integráció támogatása és a jószomszédi kapcsolatok kialakítása eltérő hangsúllyal minden pártnál megjelent, azonban funkciója eltérő: a dokumentumot támogató pártok szerint az alapszerződés hozzájárul e célok megvalósításához, míg mások elutasítják ezt az érvet, szerintük ugyanis nem támogatja az integrációs törekvéseket, a két ország közeledését, legföképpen pedig a határon túli magyarok helyzetének rendezését.

Az integráció és a kétoldalú kapcsolatok az MSZP, SZDSZ és PDSR diskurzusát uralta, a vitában minden érvet az integrációnak és a csatlakozásnak rendeltek alá, amely nemzeti érdekké, a legfőbb külpolitikai célkitüzéssé vált. Ebböl kiindulva a kormánypártok olyan retorikai stratégiát alkalmaztak, amellyel:

1. kisebb-nagyobb sikerrel „hatástalanították” a felsorakoztatott kritikákat: a felszólalásokban olyan véleményeket és értelmezéseket fogalmaztak meg, amely 
ellentmondott a dokumentum aláírását ellenző pártok érveinek. Ezzel magyarázható az is, hogy az MSZP és SZDSZ felszólalásaiban a határon túli magyarság és a kollektív jogok kérdése hangsúlyosan jelen van.

2. arra törekedtek, hogy integrálják az egymásnak feszülő érvrendszereket (az alapszerződés erre és erre a problémára is megoldást kínál). Hasonló stratégiát követ ellenzéki oldalon a PL '93-PAC frakció, aki ellenzékiként a legmérsékeltebb hangot üti meg a vitában.

A három kormánypárt érvelési stratégiájának közös eleme a mintakövetés, amelyben a nyugat irányadó szerepe érvényesül: „a dokumentum a nemzetközi és európai normák figyelembevételével készült el”, tehát a nyugat az, aki megszabja a játékszabályokat.

Az ellenzéki pártok stratégiái az eltérő pozícióknak (támogató-ellenző) betudhatóan változatos képet mutat. Míg a támogatók alapvetően az egymásnak feszülő érveket igyekeztek integrálni, addig az alapszerződés aláírását ellenzők a kormányoldal által felsorolt érvek delegitimálására törekedtek (magyar oldalon) vagy szélsőséges értelmezéseket füztek hozzá (PRM, UNPR).

Magyar oldalon az alapszerződés vitáját a nemzetről szóló vita első állomásának is tekinthetjük, ugyanis (1) a parlamenti pártok többségénél megjelent az anyaország felelősségének kérdése, illetve a határon túli magyarok helyzetének rendezése; (2) a vitában felmerülő kérdések (Kit tekintünk a magyar nemzet részének? Alkothat-e a magyar állam a határon túli magyarsággal sorsközösséget, viselhet-e felelősséget értük? A szerződés aláírása lemondást jelent-e a határon túli magyarságról?), és a kérdésekre adott válaszokból kiderül, hogy mennyiben különbözik a kormány- és az ellenzéki pártok nemzetdefiníciója. Míg a kormánypártok államnemzeti logikában gondolkodnak, és főként az alapszerződéstől, a román féltől és végső soron a nyugati integrációtól „várták” a romániai magyarság helyzetének javulását, addig az ellenzéki pártoknál a kultúrnemzeti hagyományok érvényesülnek: a határon túli magyarok a magyar nemzet részét képezik, az anyaország támogatása számukra létfontosságú. Ennek betudhatóan az ellenzéki pártok a szerződés aláírását lemondásként, a felelősségvállalás teljes hiányaként értékelték. A vitának volt azonban egy „rejtett” funkciója, amelynek következményei a soron következő országgyülési választásokon mutatkoztak meg. Itt ténylegesen a FIDESZ-nek az alapszerződések - magyar-szlovák és magyar-román vitájában követett stratégiájáról van szó, ami arra irányult, hogy kihangsúlyozza és újrafogalmazza a párt történeti-nemzeti távlatokba mutató, nemzeti érdeket védő 
szerepét, amellyel végső soron képes maga mögé állítani és integrálni az MDF-et és a Kisgazdapártot. $^{244}$

A kormány - ellenzék vitáját az egymásnak ellentétes érvrendszerek mellett a felszólalások nyelve és retorikai elemei - metaforák, hasonlatok és történelmi személyiségekre, királyokra, fejedelmekre, költőkre történő hivatkozások, idézetek - is nagyban fokozták. ${ }^{245}$ A retorikai elemek fő funkciója a vita hangulatának fokozása mellett a rivalizálás, amelyből kiderült, hogy a pártok kit tekintek történelmi példaképnek, továbbá kinek az eszmeiségét képviselik.

A képviselöházi vitában a magyar kisebbség helyzete a kollektív jogok, az autonómia és az ET ajánlása kapcsán jelent meg, ahol a PDSR, a PL '93-PAC, a PNȚCD - PER és a PD megnyugtatóan értékelték a román diplomácia sikerét, amiért az ajánlás nem vonatkozik a kollektív jogokra. A tulajdonképpeni ellentét a szélsőségesek és az RMDSZ között alakult ki, mivel a PUNR és a PRM túl soknak, míg a Szövetség képviselői túl kevésnek és hiányosnak értékelték a szerződés kisebbségjogi vonatkozásait. A szélsőséges értelmezések retorikai stratégiaként is funkcionáltak, amely meghatározta PUNR és PRM nemzeti, nemzetállami logikát követő stratégiáját. Magyar oldalon az FKgP képviselt szélsőséges nézeteket, az állandó Trianon képpel pedig egy revizionista stratégiát követett.

Az alapszerződés tárgyalásaiban a román fél számára a határok sérthetetlenségének biztosítása alapvető volt, ugyanis a határkérdést állították szembe a kisebbségi jogok problémájával, amit a magyar fél következetesen napirenden tartott. A vitában a román felszólalók folyamatosan megjelenítették a határkérdést, amit végre garantál az alapszerződés, következésképpen létrejöhet a sokat hangoztatott történelmi megbékélés a két nép között. Ennek hangsúlyozása két szempontból vált fontossá: belpolitikai szinten elszigetelni a szélsőséges pártokat, a külpolitika szintjén pedig jelezni az európai fórumoknak, hogy az ország - az európai normák szellemében elkötelezett az államközi viszonyok rendezésében (mintakövetés).

\footnotetext{
${ }^{244}$ Köszönöm Bárdi Nándornak, hogy az alapszerződés vitájának e lényeges funkciójára felhívta a figyelmem.

${ }^{245}$ A vitában számos történelmi személyiségre, íróra, költőre hivatkoztak a felszólalók, de gyakoriak voltak a hosszabb idézetek is: II. János Pál pápa, Szent István király, Stendhal, Bethlen Gábor (MSZP); Gyulai Pál, Lord Acton, Claus Offe, Ady Endre, József Attila, Willy Brandt (SZDSZ); François Mitterrand, Németh László, Illyés Gyula (MDF); Kossuth Lajos (FKgP); Bethlenek, Bocskaiak, Báthoryak, Bolyaiak, székely falvak, korondi fazekasok, kalotaszegi hímző asszonyok, Márai Sándor (KDNP); Bibó István, Márton Áron, Reményik Sándor (MDNP).
} 
9. sz. táblázat: Uralkodó témák és stratégiák az alapszerződés vitájában

\begin{tabular}{|c|c|c|}
\hline Pártok & Uralkodó témák & Alkalmazott stratégia \\
\hline MSZP & $\begin{array}{l}\text { Integráció, határon túli magyarság, kétoldalú } \\
\text { kapcsolatok. }\end{array}$ & $\begin{array}{l}\text { Integratív stratégia } \\
\text { (az egymásnak feszülő érvek kibékítése) }\end{array}$ \\
\hline SZDSZ & $\begin{array}{l}\text { Integráció, kollektív jogok és } \\
\text { kisebbségvédelem }\end{array}$ & $\begin{array}{l}\text { Érvrendszerek szembeállítása, } \\
\text { kompromisszum }\end{array}$ \\
\hline MDF & $\begin{array}{l}\text { Anyaország felelőssége, nemzeti } \\
\text { összetartozás, Kárpát-medencei magyarság }\end{array}$ & $\begin{array}{l}\text { Retorikai, érzelmekre ható érvek (metaforák, } \\
\text { hasonlatok) }\end{array}$ \\
\hline FKgP & $\begin{array}{l}\text { Trianon, felelősségvállalás a határon túli } \\
\text { magyarokért }\end{array}$ & Revizionista \\
\hline FIDESZ & $\begin{array}{l}\text { Határon túli magyarság, az RMDSZ } \\
\text { pozíciója }\end{array}$ & $\begin{array}{l}\text { Szembeállítás, mellyel delegitimálják a } \\
\text { kormányoldal érveit }\end{array}$ \\
\hline KDNP & $\begin{array}{l}\text { Határon túli magyarság, autonómia, } \\
\text { szolidaritás }\end{array}$ & Nincs domináns stratégia \\
\hline MDNP & $\begin{array}{l}\text { Kétoldalú kapcsolatok, többség-kisebbség } \\
\text { viszonyának rendezése }\end{array}$ & $\begin{array}{l}\text { Szembeállítás, mellyel delegitimálják a } \\
\text { kormányoldal érveit }\end{array}$ \\
\hline PDSR & $\begin{array}{l}\text { Kétoldalú kapcsolatok, megbékélés, } \\
\text { integráció, országimázs }\end{array}$ & Integratív, mintakövetés \\
\hline $\begin{array}{l}\text { PNȚCD } \\
\text { - PER }\end{array}$ & $\begin{array}{l}\text { Megbékélés, integráció, területi autonómia } \\
\text { elutasítása }\end{array}$ & Integratív stratégia \\
\hline PD & Stabilitás, kollektív jogok elutasítása & Szembeállítás \\
\hline PUNR & $\begin{array}{l}\text { Integráció, szuverenitás, kisebbségi jogok } \\
\text { elutasítása }\end{array}$ & Szélsőséges értelmezések \\
\hline RMDSZ & Kollektív jogok, romániai magyar kisebbség & Etnicizáló stratégia \\
\hline PRM & $\begin{array}{l}\text { Függetlenség és szuverenitás, területi } \\
\text { autonómia elutasítása }\end{array}$ & Múltidézés, történelmi szemlélet fontossága \\
\hline $\begin{array}{l}\text { PL } 93- \\
\text { PAC }\end{array}$ & Stabilitás, jószomszédi viszonyok & Integratív stratégia \\
\hline
\end{tabular}

Forrás: Saját szerkesztés a parlamenti jegyzőkönyvek alapján

Az uralkodó érvrendszerekből a két vita közötti legjelentősebb különbség is kirajzolódott. Míg a román vitában főként a reálpolitikai érdekek - integráció, jószomszédi kapcsolatok, határok sérthetetlenségének biztosítása és a nemzet egysége jelentették a vita tárgyát, addig a magyar vitában a nemzetpolitikai tematika dominált, ebben pedig a reálpolitikai érdekek és a szimbolikus politizálás eszközei - nemzeti összetartozás, az anyaország felelőssége - ütköztek. Erre utal felszólalásában Molnár Gyula képviselő (MSZP) is, aki „az érzelmek és az ész konfliktusáról” beszél, jelezve az, hogy az aláírást támogatók egy pragmatikusabb, míg az aláírást ellenzők inkább az érzelmekre ható érveket hangoztattak.

Mivel a két állam kormánya az alapszerződést ellenző pártok érvei ellenére lezártnak tekintette a tárgyalásokat, így elhárultak az akadályok a szerződés aláírása előtt. Az RMDSZ ugyan szeptember 6-án az SZKT és a SZET együttes ülésén nyilatkozatban elfogadta a szerződés aláírását, de kijelentették, hogy a dokumentum véglegesített változata nem felel meg a Szövetség törekvéseinek (kollektív jogok elvetése, nyelvhasználatot korlátozó rendelkezés, egyházi és közösségi javak 
visszaszolgáltatása). ${ }^{246} \mathrm{Az}$ alapszerződés aláírásának helyszínéül a két állam képviselői Temesvárt választották, ahol szeptember 16-án Horn Gyula és Nicolae Văcăroiu miniszterelnökök jelenlétében a felek aláírták a dokumentumot. Figyelembe véve a közel öt évig tartó tárgyalások dinamikáját és a felek tárgyalási pozícióját, az alapszerződés létrejöttét az elméleti részben felállított négypólusú viszonyrendszerben értelmezem, melyben a fő aktorok: Magyarország, Románia, az RMDSZ, továbbá az integrációs szervezetek és a nyugati államok.

6. sz. ábra: Alapszerződés: szereplők, folyamatok, funkciók

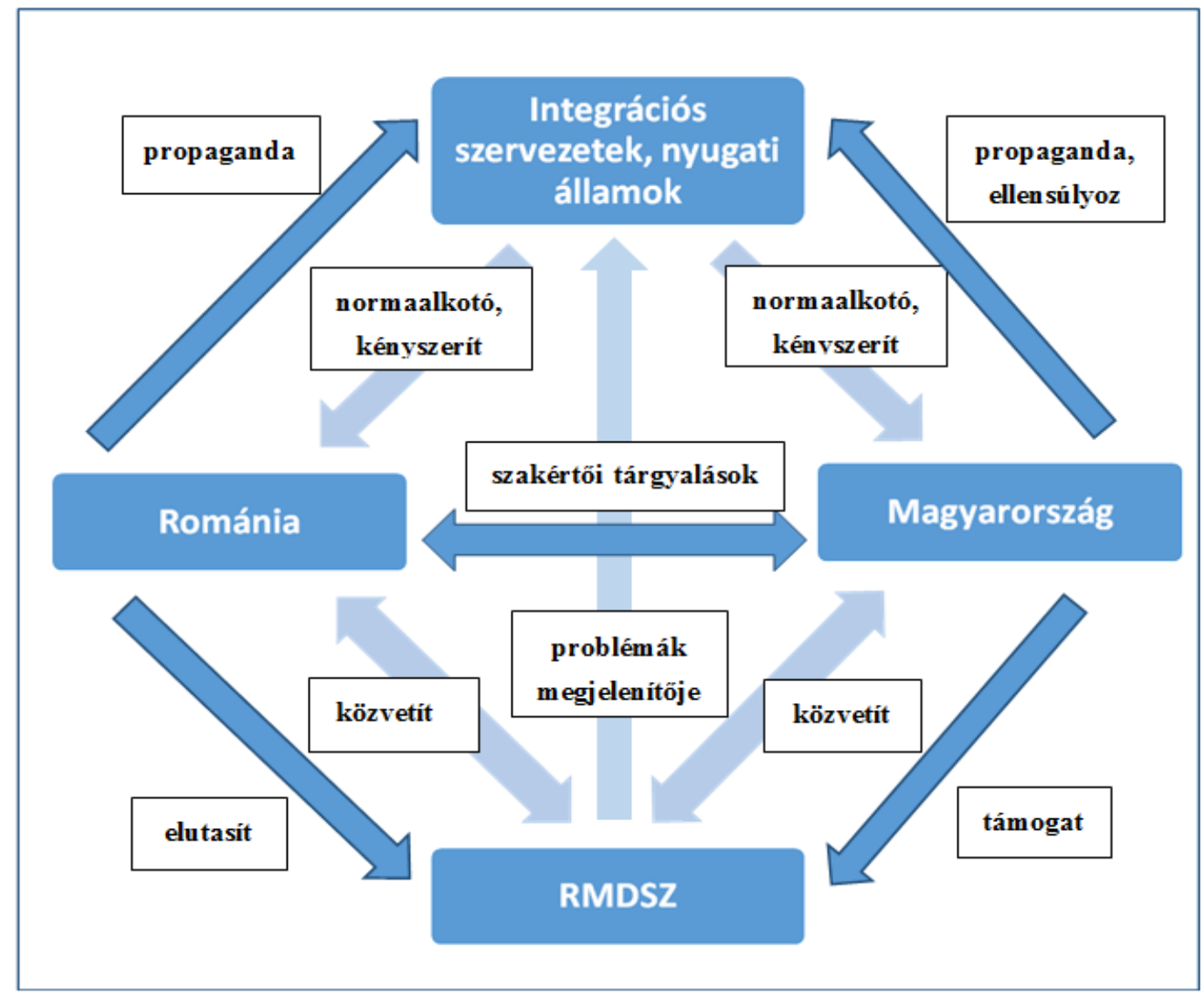

A tárgyalások folyamán magyar kormány kitüntetett szerepet szánt a határon túli magyarságnak, és a kétoldalú kapcsolatok rendezéséről azt várta, hogy a későbbikben majd érdemben tudja befolyásolni az erdélyi magyar kisebbség helyzetét és jogérvényesítését. Az erdélyi magyarság követeléseit igyekezett az egyeztetések során napirenden tartani, így teljes mértékben támogatta az RMDSZ azon kérését, hogy őket is vegyék be az alapszerződésről folytatott tárgyalásokba. Emellett támogatta a Szövetséget a külkapcsolatok építésében és abban a törekvésében is, hogy az a nyugati

${ }^{246}$ („A Szövetségi Képviselők Tanácsa és a Szövetségi Egyeztető Tanács Nyilatkozata, Marosvásárhely 1996. szeptember 6" 2009. In: Húszéves az RMDSZ. 2009, pp. 511-513). 
államok és integrációs szervezetek irányába megjelenítse a kisebbségi problémákat. ${ }^{247}$ Ezen a téren a Horn-kormányzat sem akart változást, de azzal, hogy fokozatosan az integráció kérdését tekintette elsődlegesnek a kisebbségi jogokkal szemben, a kormány és az RMDSZ, továbbá a kormány és az ellenzék között éles ellentétek alakultak ki. Mivel azonban az MSZP-SZDSZ-kormánynak megvolt a ratifikációhoz szükséges többsége, nem kényszerült arra, hogy figyelembe vegye az ellenzék követeléseit. A kormány és az ellenzék közötti vitának azonban mélyreható következményei lettek, ugyanis a rendszerváltás utáni időszakban elsőként az alapszerződésekről folyó viták vezettek oda, hogy az erdélyi magyarság státusának kérdése mélyen megosztotta a politikai elitet. A kormány-ellenzék viszonya a státustörvény körül kibontakozó vita következtében a nemzeti-integrációs dimenzió mentén tovább polarizálódott, egyúttal pedig a jobboldal megerősödését eredményezte (Csigó-Kovács 2000, pp. 252-79).

Az alapszerződést előkészítő tárgyalások során a magyar kormánynak folyamatosan meg kellett küzdenie a román propagandával, illetve ellensúlyoznia kellett azt. A külügyi iratok bizonyítják, hogy a román fél a tényeket rendszeresen saját érdekei szerinti értelmező álláspontot képviselve tájékoztatta a nyugat-európai államok követségeit, mind a magyar-román viszonyt, mind az erdélyi magyarság helyzetét illetően. Ennek következtében a magyar fél többször kényszerült védekező és magyarázkodó pozícióba az integrációs szervezetekkel szemben. A kétoldalú kapcsolatokban Magyarország, noha - a demokratizálódás és a gazdasági átmenet tekintetében is - lépéselőnyben volt Romániával szemben, nem tudta akaratát teljességgel érvényesíteni. Azonban ez nem feltétlenül a magyar diplomácia számlájára írható (bár sok esetben valóban nehezen tudta ellensúlyozni a román külügy külföldi propagandatevékenységét), hanem sokkal inkább azzal a ténnyel magyarázható, hogy a NATO biztonságpolitikai célkitüzései felülírták, illetve módosították a magyar nemzeti érdekeket: az alapszerződés aláírásával a kormány a határon túli magyarság problémáinak kezelése helyett az integrációt tette fö külpolitikai célkitűzésévé.

A román fél tárgyalási pozíciójából és érvrendszeréből az állapítható meg, hogy csak a deklaratív vagy a nyilatkozatok szintjén megmaradó jószomszédi viszonyok kialakításában volt érdekelt, a két állam közötti megbékélésben és a magyar kisebbség helyzetének rendezését illetően nem. Erre nagyon jó példával szolgál az ET-tagfelvétel utáni időszak is, amely azt mutatja, hogy Romániának nem volt tényleges célja a normatranszfer, ehelyett a külföld felé olyan látszatmegoldásokban és

\footnotetext{
${ }^{247}$ Interjú Vincze Lóránttal.
} 
kezdeményezésekben volt érdekelt, amelyek hozzájárulhattak Románia országimázsának javításához, de alapjában véve nem hoztak változást a kisebbségi jogok terén.

Annak elutasítása, hogy az RMDSZ tárgyalófélként vegyen részt a megbeszéléseken, szintén ebből a hozzáállásból ered: a román fél a kétoldalú kapcsolatokban és a belpolitikában egyaránt igyekezett gyengíteni a párt szerepét, „leszámolni vele”, viszont több találkozót és megbeszélést is tartottak az RMDSZ, illetve Ion Iliescu, Adrian Năstase, Nicolae Văcăroiu és Teodor Meleșcanu között. E tárgyalásokkal a Nyugat irányába igazolni tudta, hogy fenntartja a párbeszédet, és igyekszik megoldást találni a magyar közösség problémáira.

Mivel a román kormány tudatában volt annak, hogy a kétoldalú kapcsolatokban Magyarország leginkább a magyar kisebbség helyzetének javításáért száll síkra, az alapszerződés tárgyalásain a határok sérthetetlenségének felvetésével olyan álvitát folytatott, amellyel - föleg az uniós országok, az USA és az integrációs szervezetek szempontjából - semlegesítette a kisebbségi kérdést: ez pedig a tárgyalások többéves elhúzódását vonta maga után. Az elméleti részben ismertetett Putnam modellje alapján azt mondhatjuk, hogy a határok sérthetetlensége és a kisebbségi kérdés rendezése részben kívül esett a másik fél nyerési halmazán, a felek közötti megegyezésre csak azt követően kerülhetett sor, hogy mindkét fél engedett az előzetes elvárásaihoz képest, s a vita alapjául szolgált kérdések bekerültek a nyerési halmazok részleges átfedésének tartományába.

A külpolitika szintjén Románia a belpolitikai realitásait, a politikai és gazdasági átmenet terén elért eredményeit nagy nehézségek árán tudta a Nyugat irányába „kikozmetikázni”. Emellett folytonos bizonyításkényszerben volt, $\mathrm{s}$ agresszív propagandát folytatott. Egyrészt igyekezett biztosítani a nyugati államokat arról, hogy elkötelezett a kisebbségi jogok rendezését illetően, másrészt viszont annak érdekében, hogy lépéselőnyre tegyen szert, minden eszközzel Magyarország sarokba szorítására, az integrációs szervezetek és a nyugati államok előtti lejáratására törekedett.

Az integrációs szervezetek és a nyugati államok normaalkotókként jelentek meg a magyar-román viszonyban, fó céljuk az volt, hogy stabilizálják a volt kommunista államok rendszerváltás utáni kétoldalú kapcsolatait, ami a nyugati biztonsági és gazdasági szervezetek által támasztott csatlakozási feltételek között is szerepelt. Az integrációs szervezetek szoros kapcsolatban álltak a két állam külügyminisztériumával és diplomáciai testületével, azok közvetítésével pedig az RMDSZ-szel is. Céljuk az 
volt, hogy értékeljék az államoknak a kétoldalú kapcsolatok rendezésére tett erőfeszítéseit. Így azonnal tudomást szerezhettek és intézkedhettek, ha visszalépéseket tapasztaltak az állam jogrendjében vagy akár a bilaterális kapcsolatokban. A tárgyalások dinamikájának elemzésekor a jelentős nyugati részvétel arra is választ ad, hogy az integrációs szervezetek miként befolyásolták a kelet-közép-európai államokat - köztük Románia és Magyarország külpolitikai opcióit -, ami utólag lehetővé tette a NATO- és az EU-csatlakozást.

Az alapszerződés tárgyalásainak ideje egyben az RMDSZ külkapcsolatépítésének az időszaka is, ugyanis a Szövetség - megkerülve a román diplomáciai csatornákat - kapcsolatokat épített ki az európai fórumok képviselőivel, valamint a kisebbségi és emberjogi szervezetekkel. A kapcsolati tőke a tárgyalások folyamán vált igazán fontossá, mivel a kialakított csatornákon keresztül az RMDSZ meg tudta jeleníteni a kisebbségi problémákat, amelyeket a román fél nem volt hajlandó rendezni.

Mivel a román fél elutasította az RMDSZ részvételét az alapszerződés szövegének kidolgozásában, a Szövetségnek ebben az időszakban csekély érdekérvényesítési potenciálja volt. Hiába folytatott intenzív tárgyalásokat a magyar féllel - akiktől minden támogatást megkapott -, nem válhatott tárgyalóféllé. Következésképp az RMDSZ vezetői számára világossá vált, hogy (1) államközi szinten, a kisebbségi problémák megjelenítését illetően, szük mozgástere van; (2) képtelen felvenni a román propagandával a küzdelmet, és azt a különböző nemzetközi fórumokon ellensúlyozni: ehhez Magyarország segítsége elengedhetetlen; végül pedig (3) az erdélyi magyarság autonómia igényének nem tud nemzetközi támogatást szerezni, ugyanis éppen az Egyesült Államok az, amely a legkevésbé támogatja a keletközép-európai kisebbségek autonómiaigényét, míg az integrációs szervezetek döntően az alapvető emberi jogok biztosításában és a stabilitás fenntartásában érdekeltek, s e két feltételnek Románia eleget tud tenni.

\section{Az alapszerződés hatásvizsgálata}

Az alapszerződés hatásainak és következményeinek azonosítása módszertanilag azért bizonyult problematikusnak, mert a dokumentum aláírását követő parlamenti és államfőválasztás jelentős változásokat hozott a romániai politikai életben. Ebből adódóan nehézkesnek bizonyult elkülöníteni, hogy a bel- és külpolitika szintjén bekövetkező változások az alapszerződés aláírásának, vagy pedig a kormányváltásnak 
köszönhetők-e ${ }^{248}$ Sokkal inkább a két eseménysor összjátéka érvényesült a gyakorlatban, ugyanis az alapszerződés aláírása hozzájárult a keretfeltételek megváltozásához, mind a többség-kisebbség, mind pedig a két állam viszonyában, de a valódi változások az új kormány megalakulásának és az RMDSZ kormányzati tényezőként való elfogadásának köszönhető. ${ }^{249}$

Elöljáróban szükséges megállapítani, hogy a belpolitika szintjén az alapszerződés aláírása nem vezetett egyértelmüen a román pártrendszer etnikai alapú törésvonalának megszünéséhez, mert a kampány időszakában és a választásokon Iliescu és a volt kormánypárt a közbeszédben folyamatosan tematizálta a magyar veszélyt. ${ }^{250}$ Az egyértelmú változások a kormány megalakulását követően következtek be, amelyben az RMDSZ tisztségviselői két miniszteri és további fontos vezető pozíciókat tölthettek be. ${ }^{251}$ A Szövetség kormányzati részvételéről a november 28-án Bukarestben összehívott SZKT döntött: a kormányzati szerepvállalásra vonatkozó határozatot a jelenlevők nagy többséggel, 3 ellenszavazattal és 2 tartózkodással elfogadták. ${ }^{252}$ A kormányzati részvételt az erdélyi magyarok is pozitívan ítélték meg. Egy 1997 tavaszán végzett reprezentatív felmérésen a válaszadók 83,1\%-a helyeselte a kormánykoalíciós részvételt (Kovács-Misovicz-Bárdi 1998). A Szövetség végrehajtó hatalomban való jelenléte azonban nem jelentett megoldást arra az alapvető dilemmára, hogy kire számíthat az erdélyi magyarság jogainak kivívásában? A felmérésből kirajzolódó válaszok elgondolkodtatóak, ugyanis a megkérdezett erdélyi magyarok 52\%-a szerint csak önmagára számíthat, a válaszadók kevesebb mint egyötöde a nemzetközi

\footnotetext{
${ }^{248}$ A kormányzó PDSR a szavazatok 23\%-át szerezte meg, míg az addig ellenzékben politizáló Román Demokratikus Konvenciónak (CDR) és a Szociáldemokrata Uniónak megvolt a parlamenti többsége, az RMDSZ meghívásával, az alakuló kormánykoalíciónak csaknem 60\%-os parlamenti többsége lett.

${ }^{249}$ A dilemma Kántor Zoltán és a Bárdi Nándor által jegyzett, az RMDSZ kormányzati tevékenységét értékelő tanulmányukban is megjelent, de ők sem adnak egyértelmü választ arra, hogy a két állam viszonyának javulása az RMDSZ kormányzati részvételének, a kormány nyugatbarát politikájának vagy az alapszerződés aláirásának tulajdonítható (Kántor-Bárdi 2000, p. 166).

${ }^{250}$ Az államfőválasztás első fordulója után a PDSR több romániai napilapban közzétette Samuel P. Huntington A Civilizációk összecsapása c. munkájából a nyugati és a keleti (ortodox) civilizáció romániai határvonalait ábrázoló térképét, ahol a szerző Erdélyt a nyugati kultúrkörhöz sorolta. Az első forduló erdélyi eredményei tükrében, ahol a CDR két megye kivételével többséget szerzett, a felhívás arra világított rá, hogy az ellenzék jelöltje és támogatói „ki akarják szakítani Erdélyt Románia testéből” (Molnár 1997; Takács 1998). A PDSR ügyvezető elnöke, Adrian Năstase az RMDSZ lehetséges kormányzati részvételéről azt nyilatkozta, hogy „potenciálisan veszélyes”, mivel a magyar kormány tagjaival történő gyakori konzultációk következtében a román kabinet bizalmas jellege veszélybe kerülhet: (Udvardy-kronológia), keresőszó: Társadalmi Demokrácia Párt.

${ }^{251}$ Birtalan Álmos turisztikai, míg Tokay György nemzeti kisebbségügyi miniszter lett. Ezen kívül a Szövetség 11 államtitkári, 2 prefektusi tisztséget kapott Hargita és Kovászna megyékben, és további nyolc megyében alprefektusi kinevezéseket.

${ }^{252}$ RMDSZ Tájékoztató, IV. évfolyam, 920. szám, 1996. november 29.
} 
szervezeteket, 8,4\%-a helyi önkormányzatokat, 7,9\% a román, míg 3,8\% a magyar kormányzatot jelölte meg (ibid).

A kormányzati időszak alatt nyilvánvalóvá vált, hogy a kormányt alkotó többpárti koalíció számos működési zavarral küszködött, ennek ellenére sikerült néhány, az RMDSZ szempontjából is lényeges jogszabályi változásokat kieszközölni: a kormány sürgősségi kormányrendelettel módosította a helyi közigazgatási törvényt, valamint az oktatási törvényt, ${ }^{253}$ azonban az alkalmazás és a parlament általi elfogadtatása számos problémába ütközött. A koalíció egyik próbájának mégis az RMDSZ önálló magyar egyetemre vonatkozó javaslata bizonyult: 1998 őszén ultimátumot intézett a koalíciós partnerekhez és kilátásba helyezte a Szövetség kormányból való kilépését, amennyiben nem születik erre vonatkozó döntés (Horváth 2002, p. 47). A szeptember 30-án megjelenő kormányrendelet a magyar és német tannyelvü Petőfi-Schiller Egyetemről, mint kompromisszumos megoldás jelentős vitákhoz vezetett egyrészt a kormány és ellenzék között, másrészt felerősítette az RMDSZ-en belüli törésvonalakat, mert a kormányból való kilépés, úgy került le a napirendről, hogy közben az egyetem ügyében lényeges előrelépés nem történt. ${ }^{254}$

Az erdélyi magyarság szempontjából stratégiai kérdésnek tekinthető területeken - oktatás, egyházi vagyon rendezése - kevés érdemi eredmény született. Az oktatási törvény véglegesítése 1999-ig elhúzódott és a Kisebbségi Főbiztos beavatkozását követően szavazta meg a parlament, de jelentős vitákat generált az egyházi javak visszaszolgáltatásának kérdése is, amelyre vonatkozóan a ciklus alatt több kormányrendeletet fogadtak el (Kántor-Bárdi 2000, p. 168). A koalíciós pártok közötti ellentétek és a miniszterelnökök gyors ütemü váltakozása a reformfolyamatok megakadásához vezettek, amelynek következtében jelentősen csökkent a kormányzó pártok népszerüsége. Az RMDSZ kormányzati tevékenységéről készült elemzésükben Bárdi és Kántor - e fejlemények ellenére - úgy ítélte meg, hogy a Szövetség kormánykoalícióban való részvétele inkább kedvező változásokat hozott az erdélyi magyarság számára, azonban olyan központi kérdésekben, mint a kisebbségi társadalom és intézményrendszer építése, valamint a kulturális reprodukció biztosítása - csekély előrelépés történt (ibid. pp. 178-79).

\footnotetext{
253 22/1997-es Kormányrendelet a helyi közigazgatásról, valamint a 36/1997-es Kormányrendelet az oktatási törvény módosításáról.

${ }^{254}$ A Marosvásárhelyen ülésező SZKT megvitatta az RMDSZ koalíciós szerepvállalását. A 11 órás vitát követő szavazáson 59-37 ellenében az RMDSZ a kormányon való maradás mellett döntött.
} 
Államközi szinten megállapítható, hogy az alapszerződés aláírását követően javultak a magyar-román kapcsolatok, Adrian Severin külügyminiszter első külföldi útja Budapestre vezetett, ahol a két külügyminiszter parafálta a magyar-román alapszerződést. ${ }^{255}$ A kapcsolatok javulása mögött fontos tényezőnek bizonyultak a választások utáni belpolitikai átalakulások, a többség-kisebbség megváltozott viszonyrendszere, amely az RMDSZ kormányzati tényezőként történő elfogadásában nyilvánult meg leginkább. A kétoldalú kapcsolatokban azonban az alapszerződés aláírása és a dokumentum végrehajtásából származó mechanizmusok gyakorlatba ültetése új légkört teremtett. Az alapszerződés ugyanis előirányozta a két állam képviselőinek rendszeres (felsőszintü) találkozóit, valamint egy kormányközi vegyesbizottság létrehozását is. ${ }^{256} \mathrm{~A}$ végrehajtásról szóló tárgyalások - így a vegyesbizottság létrehozásra vonatkozó egyeztetések - kevéssel az alapszerződés parafálása után, 1997 januárjában kezdődtek meg, míg a kormányközi vegyesbizottság és ennek keretében a szakbizottságok létrehozásáról márciusban egyeztek meg a felek. A vegyesbizottság ülését végül Bukarestben október 8-án nyitották meg a két állam külügyminiszterének, Adrian Severinnek és Kovács Lászlónak a részvételével. A felállított vegyesbizottság, amelynek keretében 11 szakbizottság alakult meg a két állam között létrejövő új együttműködési mechanizmusokat kívánta újraértelmezni és új keretet adni a diplomáciai emlékeztetőkben foglalt feladatoknak, melyek az alapszerződés tárgyalásai során több esetben háttérbe szorultak. ${ }^{257}$

255 Gabriel Andreescu Adrian Severinnel készített interjúkötetéből kiderült, hogy a külügyminiszter budapesti útja mögött egyrészt reálpolitikai megfontolások álltak: Severin elmondása alapján meg szerette volna változtatni a román külpolitika alapjait, amely száz éve folyamatosan az orosz és a magyar veszélyre épített. Másrészt a reálpolitikai megfontolások mellett ott voltak a személyes kapcsolatok, saját bevallása szerint személyesen ismerte a bukaresti nagykövetet, Strasbourgból az akkori külügyminisztert, Kovács Lászlót, a Szocialista Internacionálé üléseiről Horn Gyulát, az Európa Tanács közgyüléseiről pedig a külügyi államtitkárt, Szent-Iványi Istvánt (Severin-Andreescu 2000, pp. 3-5).

${ }^{256} \mathrm{Az}$ alapszerződés hivatkozik az együttmüködés megfelelő kereteinek a megteremtésére (5. cikk, 1. bekezdés), a rendszeres eszmecserék folytatására, a miniszterelnökök és külügyminiszterek évente sorra kerülő találkozójára (3. bekezdés); valamint egyéb minisztériumok és központi szervek vezetőinek rendszeres találkozójára (4. bekezdés). A szerződés emellett tartalmazza a rendszeres konzultációk szükségességét, amelynek keretében a két állam kormányai létrehoznak egy kormányközi szakértői bizottságot a nemzeti kisebbségekkel kapcsolatos kétoldalú kérdések rendezésére (15 cikkely. 10 bekezdés).

257 Teljes nevén: Román-magyar Együttmüködési és Partnerségi Kormányközi Vegyesbizottság. A további albizottságok között említhetjük a külügyi, védelmi gazdasági, környezetvédelmi, vízügyi, a turisztikai, szociális, kulturális és oktatási, határon túli regionális együttmüködés, valamint az ifjúsági albizottságokat. („Hotărâre pentru aprobarea Protocolului dintre Guvernul României şi Guvernul Republicii Ungare privind crearea Comisiei mixte interguvernamentale de colaborare și parteneriat activ între România şi Republica Ungarã”, 1997) A határozat harmadik pontja a vegyesbizottság feladatait részletezi: (1) az alapszerződésből és más egyezményekből eredő feladatok és kötelezettségek ellenőrzése, javaslatok megfogalmazása a kapcsolatok jogi és intézményes kereteinek javítására vonatkozóan; (2) koordinálni azokat a tevékenységeket, melyet a két állam közötti partnerség fejlesztését célozzák; (3) cselekvési terveket és napirendi javaslatokat fogalmaz meg a vegyesbizottság üléseire; (4) 
Az alapszerződésben szereplő kisebbségvédelemre vonatkozó vállalások gyakorlatba ültetésére és ellenőrzésére létrejött a kisebbségi szakbizottság is, amelynek céljai között szerepelt a két államban tapasztalható kisebbségi problémák megoldása, valamint a kisebbségeket érintő együttműködések és programok kezdeményezése. ${ }^{258} \mathrm{~A}$ szakbizottságok müködési szabályzata a nemzeti kisebbségek képviselőinek a részvételét is lehetővé teszi, amennyiben a szakbizottságok társelnökei meghívásának eleget tesznek. $^{259}$ Ennek alapján az RMDSZ képviselője rendszeresen részt vett a kisebbségügyi szakbizottság munkálatain.

A két állam viszonyában bekövetkező változásokat az egyre gyakoribb felsőszintü találkozók is jelezték: 1997 májusában Göncz Árpád köztársasági elnök többnapos romániai látogatáson vett részt, amelyet Emil Constantinescu államfö 1998 januárjában viszonzott, de ebben az időszakban a külügyminiszterek is több alkalommal találkoztak. A diplomáciai kapcsolatok bővítésének tudható a konzuli hálózat bővítése is: közel egy évtizeddel bezárása után, 1997 nyarán megnyílt Kolozsváron a főkonzulátus, melyet a kölcsönösség jegyében, 1998 januárjában a szegedi főkonzulátus megnyitása követett. A kapcsolatok intenzitásának növekedését egy másik mutató is jelezte: az alapszerződést követően a két kormány több egyezményt és együttmüködési nyilatkozatot írt alá, amiket az államközi viszony javulására tett erőfeszítésekként értelmezhetünk.

Az alapszerződés további következményeinek azonosítása az európai integráció kontextusában értékelhető, mivel a két állam között megkötött szerzödés - ahogyan már korábban említettük - a NATO és EU-csatlakozás feltételeként jelent meg. A dokumentum aláírásából azonban - amint a szervezetekhez való csatlakozás feltételeiből és a bővítésre vonatkozó döntésből kiderült - nem következett egyenesen a tagjelölti státusz megszerzése. Hosszas várakozás után, 1997 nyarán vált nyilvánossá a tagjelölt államok köre. A madridi NATO csúcs három tagállamot, köztük Magyarországot hívta meg, hogy csatlakozzon a szervezethez, amelynek időpontját 1999-re jelölték ki. A csúcstalálkozón - a román külügy várakozásaival ellentétben -

figyelemmel követi a két állam közötti bizalomerősítő intézkedéseket; (5) támogatja a különböző szervek, intézmények és szervezetek, a társadalom, valamint a vállalkozói, a tudományos és kulturális szféra kapcsolatainak fejlesztését.

${ }^{258}$ Teljes nevén: Magyar Köztársaság és Románia Aktív Együttműködési és Partnerségi Kormányközi Vegyes Bizottsága Kisebbségügyi Együttműködési Szakbizottsága. Románul: Comitetului de specialitate pentru colaborarea în problemele minoritatilor nationale din cadrul Comisiei Mixte interguvernamentale de colaborare si parteneriat activ intre România si Republica Ungara.

259 („Regulamentul de funcționare a Comisiei mixte interguvernamentale de colaborare și parteneriat activ între România și Republica Ungară” 1997), 4. cikkely. 
elmaradt Románia meghívása, azonban a nyilatkozat nevesítette, mint csatlakozni kívánó államot („Madrid Declaration” 1997). A NATO tagállamok üzenetét követően az Egyesült Államok elnöke bukaresti látogatásán kifejtette, hogy az észak-atlanti szervezet továbbra is nyitott a bővítésre, mi több elismerően szólt a romániai reformokról és pozitívan nyilatkozott az etnikai konfliktusok rendezésének „román modelljéröl" (Clinton 1997). ${ }^{260}$

A NATO döntése a román politikai elit körében eloszlatta azokat az egyre valóságosabbnak tünő illúziókat, melyek a két szomszédos állam egyidejü csatlakozására vonatkoztak. ${ }^{261}$ Mircea Geoană akkori washingtoni nagykövet és későbbi külügyminiszter a döntést úgy értékelte, hogy Románia teljesíti a tagfelvételi kritériumokat, mi több néhány közép-európai állam csatlakozásával növelhetné a szervezet biztonságát, azonban a három meghívott állammal szemben a NATO nem tekintette konszolidáltnak a romániai gazdasági és politikai reformfolyamatokat (Geoană 1997, pp. 16-18).

A nyár azonban még egy további kudarcot tartogatott a román diplomácia számára. Nem sokkal a NATO bővítés bejelentése után, az amszterdami csúcstalálkozót megelőzően, július 15-én az Európai Bizottság közzétette a tíz közép-kelet európai és balti állam „uniós érettségére” vonatkozó megállapításait, amelynek alapján első körben öt tagjelölt állammal - köztük Magyarországgal - kezdte meg a csatlakozási tárgyalásokat. A bizottság véleményében kifejtette, hogy Magyarország teljesíti a politikai és gazdasági kritériumokat és az egységes piacra vonatkozó közösségi vívmányok elsajátítását már középtávon megvalósítatja, aminek alapján az EB javasolja a csatlakozási tárgyalások megindítását. ${ }^{262}$ Románia esetében az EB ugyan elismerte, hogy a politikai intézmények stabilitását, azonban, a politikai kritériumok mentén több problémát (jogállamiság, alapvető emberi és szabadságjogok), míg a piacgazdaság és a tagságból eredő követelmények tekintetében alapvető hiányosságokat állapított meg. ${ }^{263}$ Ennek következtében az EB azt javasolta, hogy Romániával azt követően induljanak

\footnotetext{
${ }^{260}$ Clinton elnök a többség-kisebbség együttmüködésre vonatkozó kijelentését újra megismételte egy stratégiailag fontos időpontban 1999 tavaszán, mielött a NATO csapatok bombázni kezdték volna Szerbiát (Andreescu 2001, pp. 5-7; Durandin-Petre 2010, p. 222).

${ }^{261}$ A volt külügyminiszter Magyarország és Románia egyidejü NATO integrációja mellett érvelt, amelyet a külügy hivatalos álláspontjaként propagált. Meleșcanu érvelésében rámutatott, hogy bármelyik állammal is létesítsen szorosabb kapcsolatot a NATO ,az nem képezhetne megfelelö alapot az államközi kapcsolatok fejlesztéséhez, sem a közép-európai térség politikai légkörére nem gyakorolna megfelelő ösztönző hatást" (Meleșcanu 1993, p. 17).

262 (,Agenda 2000: Commission Opinion on Hungary's Application for Membership of the European Union” 1997, pp. 114-17)

${ }^{263}$ (,Agenda 2000: Commission Opinion on Romania's Application for Membership of the European Union” 1997, pp. 110-114).
} 
meg a csatlakozási tárgyalások, ha az EU a koppenhágai kritériumok teljesítésében elegendő előrehaladást tapasztal. Az EB értékelő véleményének érdekessége, hogy mindkét állam esetében említést tett az alapszerződés aláírásáról, amelyben a felek rendezték kapcsolataik vitás kérdéseit, kölcsönösen elismerték a határok sérthetetlenségét, és a kisebbségek helyzetét az alapszerződés, az ET, az EBESZ és más nemzetközi szervezetek által lefektetett elvek mentén kívánják rendezni. ${ }^{264} \mathrm{Az}$ integrációs szervezetek tekintetében Magyarország kedvezőbb pozíciója Romániával szemben nem vezetett az államközi kapcsolatok romlásához, noha vitathatatlan, hogy a napi sajtóban voltak erre vonatkozó utalások. Hogy a kormányzati időszak alatt mégis javultak és nem romlottak a kapcsolatok, az egyrészt az RMDSZ kormányzati szereplésével magyarázható, amely megnövekedett politikai súlyának betudhatóan kezdeményező félként lépett fel a kormányzati munkában és több esetben közvetített a két fél között, másrészt minimalizálta külpolitikai tevékenységét, az erdélyi magyarság helyzetének külügyi megjelenítését. A másik tényező Magyarország szerepéhez köthető, amely - mint arra Bárdi és Kántor felhívták a figyelmet - támogatta Románia integrációját és nem szólalt fel Románia ellen (Kántor-Bárdi 2000, p. 166). Ezzel párhuzamosan Bukarest sem támadta Budapestet az Orbán-kormány határon túli magyarokat támogató politikája miatt. A harmadik tényező pedig Románia további csatlakozási szándékával volt magyarázható: az első körből való kimaradás tovább erősítette az integrációs elköteleződést, amely nem is annyira a megtett reformok, mint inkább a politikai diskurzus szintjén volt a leginkább beazonosítható.

\footnotetext{
264 („Agenda 2000: Commission Opinion on Hungary's Application, p. 8; 102; „Agenda 2000: Commission Opinion on Romania’s Application, pp. 17-18; 99).
} 


\section{A STÁTUSTÖRVÉNY ÉS A MAGYAR-ROMÁN ÁLLAMKÖZI VISZONY}

A szomszédos államokban élő magyarokról szóló törvény elfogadása fontos töréspontot jelentett a magyar-román államközi viszonyban, amely az alapszerződés tárgyalásai után újra a kétoldalú kapcsolatok napirendjére helyezte a magyar külpolitika rendszerváltás után megfogalmazódott egyik prioritását, amely egyrészt a határon túli magyarok helyzetének rendezésére, másrészt e közösségek és a magyar állam közötti viszonyára vonatkozott. A magyar kormányzatnak azon lépése, amellyel e viszony intézményesítése mellett döntött, heves reakciókat váltott ki Romániában és Szlovákiában, annak ellenére, hogy mindkét állam kedvezményes elbánásban részesítette a határain túl élő nemzettársakat. A román vezetés részéről érkező, elutasító álláspontok a nemzeti kisebbségek anyaország általi felelősségvállalásának korlátozott megközelítéséből eredve több ponton hasonlítottak az alapszerződés tárgyalásaiban hangoztatott érvekkel - szuverenitás és területi integritás megsértése, az európai kisebbségvédelmi standardokon való túllépés -, amely alapjában véve megkérdőjelezte a szoros partnerségre, valamint a román fél által oly sokat citált történelmi megbékélésre vonatkozó hivatkozást.

Követve a módszertani részben az esettanulmányok szerkezetére vonatkozó struktúrát elsőként azon európai szabályozásokat tekintem át röviden, melyekkel a térség államai kedvezményes elbánásban részesítik a határon túli nemzettársakat. Az elemzés hangsúlyosabb részét a magyarországi státustörvény előkészítésének és elfogadásának folyamata, valamint a magyar és a román belpolitika szintjén, a nemzeti parlamentekben lejátszódó viták képezik. Az államközi kapcsolatok szintjén a státustörvényről szóló vita azt követően alakult ki, miután a jogszabályt - a román fél szerint előzetes konzultáció nélkül - az Országgyülés nagy többséggel elfogadta. A kialakult vitában az európai fórumok is aktív szerepet játszottak, túllépve a felek közötti egyeztetések és konzultációk lehetőségein, a határon túli nemzettársak anyaországi felelősségvállalásának előremutató alapelveit fogalmazták meg. A fejezet utolsó részében a magyar-román egyetértési nyilatkozat és a törvény módosítása utáni időszak fontosabb fejleményeinek beazonosítását, a lehetséges következmények elemzését végeztem el. 


\section{A határon túli nemzettársak kedvezményes elbánására vonatkozó alkotmányos rendelkezések és politikák}

A határon túli nemzettársakért viselt anyaországi érdeklődés a nemzetközi kisebbségvédelmi rendszer első világháború utáni kialakulásával jelent meg az európai politika napirendjén, amikor a többnemzetiségü birodalmak felbomlását követően, a népek önrendelkezési elvére való hivatkozással számos közép-kelet-európai állam a területén élő jelentős kisebbségi közösséget magába foglalva teremtette meg a nemzet egységét. A Népszövetség keretei között formálódó kisebbségvédelmi mechanizmusok a nagyhatalmi megosztottság és a tagállami érdekek ütközésének következtében nem bizonyultak hatékony eszköznek a kisebbségbe került közösségek jogainak védelmét illetően: a panaszmechanizmusok kivizsgálásával és a garancia-eljárás hatékonyságával kapcsolatos problémákat a határokon túl élő jelentős kisebbséggel rendelkező államok (Eiler 2008, pp. 60-63) rendre hangsúlyozták a közgyülés előtt és az illetékes fórumokon, nem sok eredménnyel. Következésképpen az új nemzetállamokban a kisebbségeket ért diszkrimináció, az asszimilációs politikák, valamint a gazdasági és politikai életben tapasztalható marginalizáció jelentősen befolyásolta a kisebbségi közösségek társadalmi pozícióit.

A második világháborút követően megalakuló Egyesült Nemzetek Szervezete kutatásom szempontjából két fontos szemléletbeli változást hozott: egyrészt a kisebbségi jogok helyett az egyetemes emberi jogok és alapvető szabadságjogok érvényre juttatása került előtérbe, másrészt pedig implicite kimondta, az államok etnokulturális - nemzeti, vallási és kulturális - értelemben vett semlegességét a nemzetközi rendszerben. Az államok semlegességének elve olyan normatív felfogást tükrözött, amelynek gyakorlati megvalósulására kevés esély mutatkozott, ugyanis az államok a saját joghatóságuk alá tartozó területeken a dominánsnak mondható kultúra és identitás újratermelésében, valamint ennek támogatásában voltak érdekeltek. Ha tehát az államok saját területükön nem tekinthetök semlegesnek, aligha feltételezhetjük, hogy a határaikon élő közösségekkel szemben azok lennének. A második világháború utáni rendezésekben a Dél-Tirolban élő németek érdekében fellépő Ausztria az anyaország felelősségvállalásának klasszikus példáját szolgáltatta, amely nemcsak az államközi kapcsolatok rendezéséhez járult hozzá, hanem a német kisebbség hosszú távú fennmaradását lehetővé tevő autonómia létrehozását is elősegítette. ${ }^{265}$

265 A párizsi békeszerződés keretében az olaszországi német ajkú kisebbség védelméről az osztrák külügyminiszter, Karl Gruber és az olasz miniszterelnök Alcide De Gasperi 1946. szeptember 5-én írta alá a párizsi-egyezményt (teljes nevén Gruber-de Gasperi Egyezmény). Az egyezmény kimondta, hogy 
Ausztria külpolitikai fellépésének sikere kisebbségvédelmi szempontból kivételes eseményként értékelendő, ugyanis az anyaországnak viszonylag korlátozott eszközei vannak a határon túliak védelmére vonatkozóan. ${ }^{266}$ E korlátozott eszköztár ellenére számos európai állam hivatkozik az anyaország felelősségvállalásának elvére. A szakirodalom alapján - föként (Halász-Majtényi 2001; Halász-Majtényi-Vizi 2004; Halász 2006) munkáira támaszkodva - megállapítható, hogy az anyaország határain túl élő közösségek védelme és támogatása, az anyaországgal való kapcsolatuk fejlesztése európai gyakorlatnak számít, amelyre a jogszabályok szintjén egyrészt az egyes államok alkotmányaiban találunk konkrét cikkelyeket, másrészt olyan törvényeket, melyek az anyaország és a határain túl élő nemzettársak viszonyának kereteit, a támogatás, illetve a kedvezmények jellegét és a jogosultak körét határozzák meg.

A fentiekben hivatkozott szerzők munkáiból kiindulva 16 európai alkotmányban találtam az anyaország és a határain túl élő közösségek viszonyára vonatkozó cikkelyeket, konkrét utalásokat. ${ }^{267} \mathrm{Az}$ államok és határaikon túli nemzettársak viszonyára vonatkozó alkotmányos cikkelyek vizsgálatánál két lényegesebb kérdés vizsgálatát tartottam fontosnak kiemelni. Egyrészt azt, hogy az anyaország állampolgárain kívül milyen közösségekkel ápol és tart fenn kapcsolatokat, másrészt pedig a kapcsolatok tartalmi vonatkozásai érdekeltek, amelyből az anyaország és a határon kívüli közösségek viszonyára vonatkozóan vonhatunk le néhány következtetést. Az anyaország és a határon túl élő nemzettársak tekintetében (1) az olasz, görög, török és spanyol alkotmányok a külföldön dolgozó munkavállalók alkotmányos jogait hangsúlyozzák; (2) az ír, görög, horvát, szlovák és svájci alkotmányok a külföldön élő közösségeket említik; (3) a román, a magyar, az ukrán és a lenyel alkotmányok az ország határain kívül élő közösségekre hivatkoznak, míg (4) a horvát alkotmány a más államokban élő horvátokat a nemzet részének tekinti. (5) A macedón, valamint a horvát

Bolzano és Trento tartományok német lakossága teljes egyenjogúságot élvez az olasz lakossággal szemben. A dokumentum főként a kisebbségi nyelvhasználat területén irányadó, ugyanis megteremti a német és az olasz nyelv hivatali egyenlőségét, biztosítja az alap- és középfokú anyanyelvi oktatást, a kétnyelvű helységnevek használatát, az anyanyelvi nevek (vezeték- és keresztnevek) használatát, valamint a közhivatali tisztségek betöltése esetében az arányosabb foglalkoztatást. A szerződés második pontja elismerte a két régióban lakó lakosság azon jogát, amely a törvényhozó és végrehajtó hatalom gyakorlására vonatkozott, ezzel pedig megteremtette a regionális autonómia létrehozásának keretfeltételét. A jószomszédi kapcsolatok javítására vonatkozóan a dokumentum rendelkezett a déltiroliak olasz állampolgárságának visszaadásáról, a diplomák kölcsönös elismeréséről, a személyek és javak szabad mozgásáról, valamint a határforgalom kiterjesztéséről („Das Gruber-De-GasperiAbkommen", 1946).

${ }^{266}$ Kardos Gábor szerint az anyaország határon túli nemzettársak védelmében a következő eszközökkel rendelkezik: 1. nemzetközi szervezetekben és kisebbségvédelmi mechanizmusokban való részvétel; 2. lakóhely szerinti állammal való kétoldalú együttmüködés; 3. más, harmadik állammal szembeni fellépés; 4. belső jogalkotás (Kardos 2006, pp. 130-135).

${ }^{267}$ Lásd erről az Függelék 1. számú táblázatát. 
alkotmány a szomszédos államokban élő lakosságról tesz említést, míg (6) Albánia alkotmánya a határon túli albán népről beszél. (7) Németország és Macedónia - a menekültek kategóriát használta az alkotmány megszövegezésekor, végül pedig (8) Portugália alkotmányában a portugál nyelvű országok állampolgáraira történik hivatkozás.

Ami az anyaország és a határon túli közösségek viszonyának tartalmi vonatkozásait illeti az alkotmányok vizsgálata jelentős különbségekre, az anyaország eltérő szerepvállalására mutatnak rá. E szerepvállalás mértékét és összetettségét, valamint a határon túli nemzettársakra gyakorolt hatását a következő taxonómia mentén lehet rendszerezni: (1) kapcsolattartás, a kapcsolatok ápolása és fenntartása; (2) kulturális fejlődés ösztönzése, identitás megőrzésének támogatása; (3) munkavállalók védelme; (4) felelősségvállalás, jogvédelem; (5) kedvezményes elbánás, pozitív diszkrimináció; (6) intézmények létrehozása és támogatása; (7) könnyített honosítás (kettős állampolgárság). ${ }^{268}$

Az alkotmányok többsége a kapcsolattartás fenntartására, valamint a kapcsolatok ápolására hivatkozik (Írország, Albánia, Románia, Macedónia, Szlovákia, Ukrajna, Lengyelország és Svájc alkotmányai) anélkül, hogy meghatározná miben is áll e kapcsolatok javítása. Szintén több alkotmányban előfordult a más országokban élő nemzettársak kulturális fejlődésének és önazonosságának támogatása, valamint a kulturális identitás megőrzésére irányuló célkitűzések (Írország, Albánia, Románia, Macedónia, Szlovákia, Ukrajna, Lengyelország és Svájc). A kulturális kapcsolattartás alkotmányos elvén túllépve az olasz alkotmány a munkavállalók védelmét hangsúlyozza, míg a görög ennél is bővebb jogosítványokat, oktatási támogatásokat határoz meg. Két állam - Törökország és Spanyolország -, amellett, hogy fellép a külföldön munkát vállalók érdekében, támogatja hazatérésüket az anyaországba.

A határon túli közösségek jogainak védelme és az irántuk viselt felelősség Írország, Magyarország, Horvátország, Albánia, Macedónia és Szlovénia alaptörvényében jelenik meg, amely az anyaország fellépésének - az előbbi alkotmányokhoz képest jóval szélesebb - kereteit határozza meg. Az áttekintett alkotmányokban - meglepő módon - kevés helyen találtam a határon túli közösségek kedvezményes elbánására vonatkozó rendelkezéseket (Portugália és Szlovénia),

268 Brigid Fowler tanulmányában arra hívta fel a figyelmet, hogy régiónkban az anyaország felelősségvállalásában megfigyelhető egy “fokozatosság”, amely az alkotmányos felelősségvállalástól az állampolgárság megadásáig terjed (Fowler 2006, pp. 177-238). 
valamint pozitív diszkriminációként értelmezhető megállapításokat (Portugália). Noha számos európai állam alapítványi rendszere vagy más intézményes hálózata révén anyagilag is támogatja a határain túl élő nemzettársait, alkotmányos szinten a görög, a szlovák és a svájci alkotmány emeli ki e szervezetek támogatásának fontosságát.

Az alkotmányos szabályozások több KKE-i állam esetében hivatkozási pontként szolgáltak az anyaország és a határon túli közösségek kapcsolatának rendezéséhez, az addig hatályban levő jogszabályok egységes keretbe történő rendszerezéséhez, amelyek úgynevezett státus- vagy kedvezménytörvények elnevezéssel illettek. ${ }^{269}$ A térség több állama jogszabályokban és törvényerejü rendeletekben rendezte a határon túli nemzetrészek és a diaszpórában élők státusát. ${ }^{270} \mathrm{E}$ jogszabályok részletes összehasonlítását a magyar státustörvény vitája kapcsán már sokan elvégezték, ${ }^{271}$ én csupán a jogszabályok néhány tartalmi vonatkozására (a törvény hatálya, támogatások jellege) térek ki, vázolva röviden az alapvető hasonlóságokat és különbségeket.

Az áttekintett jogszabályok ${ }^{272}$ eltérő módon határozzák meg a törvény személyi hatálya alá tartozók körét: az olasz, a horvát, szlovén, a görög és a magyar törvényben az államok és területek - beleértve a szomszédos államokat - pontos megnevezése jelenik meg, míg a szlovák, a román, a bulgár, valamint az ukrán jogszabályok a határon túli, illetve külföldi elnevezéseket használják. A jogszabályok területi hatályának kérdését a Velencei Bizottság is tárgyalta jelentésében, arra a megállapításra jutva, hogy a jogszabályok által biztosított kedvezmények rendszerint az anyaországban biztosítottak, néhány kivételtől eltekintve, támogatások formájában azonban a lakóhely szerinti államban is igénybe vehető (Szlovénia, Bulgária, Magyarország, Ukrajna).

A vizsgált államokban nem mondható kivételes intézkedésnek, hogy a törvény hatálya alá tartozó személyek kérvényezhetik - a törvény feltételeinek megfelelően - a jogosultság bizonyítására szolgáló igazolványt. A törvény végrehajtását követően több állam (Szlovákia, Görögország, Magyarország, Ukrajna) bocsájtott ki - eltérő

\footnotetext{
${ }^{269}$ A két elnevezés között lényeges tartalmi különbségek vannak. Míg a státustörvénynek nevezett jogszabályok hangsúlyosan a határon túli közösségek jogállására vonatkoznak, addig a kedvezménytörvények a különböző támogatásokról és kedvezményekröl rendelkeztek. A Magyarországon elfogadott törvény körül kialakult vitában többnyire szinonimaként használták a két fogalmat, noha jóllehet a magyar jogszabály inkább kedvezménytörvény, mégis a státustörvény megnevezés terjedt el (Halász-Majtényi 2002, p. 395).

270 Ausztria (1979), Olaszország (1991, 2001-ben módosítva), Szlovénia (1996), Szlovákia (1997), Románia (1998, 2007-ben módosítva), (Görögország,1998) Oroszország (1999), Bulgária (2000), Magyarország, (2001) és Ukrajna (2004). Lásd részletesen: („Preferential Treatment of National Minorities by their Kin-State: Collection of Laws" 2001).

271 (Halász-Majtényi 2002; Halász-Majtényi-Vizi 2004; Halász 2006; Iordachi 2002; Fowler 2006; Sevel 2011),

${ }^{272}$ Lásd erről a függelékben található 2. számú összehasonlító táblázatot.
} 
megnevezéssel - igazolványokat, azonban csak a görög dokumentum szolgál személyi igazolványként.

A jogszabályok egyik legfontosabb újdonsága, hogy három állam kivételével szabályozzák a beutazást és az ott-tartózkodást: Olaszország és Ukrajna vízummentességek, más államok pedig az állandó tartózkodási engedély kiváltásában biztosítanak kedvező elbánást, Szlovákia, Görögország és Ukrajna pedig lehetővé teszi a hosszabb távú ott-tartózkodást. A tartózkodás mellett a jogszabályok számos más területen nyújtottak kedvezményeket, így az oktatás és kultúra, a munkavállalás, szociális ellátás és egészségügy, valamint utazási kedvezményeket tekintetében. Figyelembe véve a felsorolt területeket, a (1) szlovák és a magyar jogszabály tartalmazza a legszélesebb kedvezményeket, de (2) a bulgár, valamint az orosz nemzetiségüeknek nyújtott kedvezmények mértéke is jelentős. A jogszabályok következő csoportja (3) egy-egy területen nyújt jelentősebb kedvezményt, főként az oktatás és a kultúra (Ausztria, Szlovénia, Románia) vagy a munkavállalás (Görögország) területén, illetve (4) a kedvezmények mértéke elhanyagolható az olasz és az ukrán jogszabály rendelkezései szerint. Az 1-4 esetekben a kedvezményeket számos állam oktatási és kulturális, valamint gazdasági támogatásokkal, fejlesztési programokkal egészíti ki, amelynek végrehajtását az illetékes minisztériumok, valamint az erre a célra létrehozott intézmények felügyelnek.

Az áttekintett jogszabályokra vonatkozóan következtetésként megállapíthatjuk, hogy a részleteiben jelentős különbségeket is tartalmazó anyaországi szabályozások, melyek a történelmi hagyományoknak, a belpolitikai erőviszonyoknak, a gazdasági potenciálnak, valamint a határon túli közösségek lélekszámának betudhatóan számos közös vonást hordoznak, nem egyedi megoldásnak, hanem sokkal inkább európai gyakorlatnak számítanak.

\section{A szomszédos államokban élő magyarokról szóló törvény kidolgozása és elfogadása}

\subsection{Kormányváltás és a nemzetpolitika felértékelődése}

A státustörvény megjelenése a magyar belpolitika napirendjén nem előzménynélküli fejlemény, sokkal inkább egy olyan belpolitikai folyamat eredménye, amelyben meghatározó szereppel bírt a FIDESZ-Magyar Polgári Párt 1998-as választási 
győzelme és kormányzati pozícióba való kerülése ${ }^{273}$, valamint a Magyarok Világszövetségének (MVSZ) az állampolgárság kiterjesztésére tett javaslata.

A FIDESZ népszerüségének növekedéséhez és a választásokon való kiváló szerepléséhez minden bizonnyal hozzájárul az előző kormányzat rossz megítélése, a koalíció müködésében beálló zavarok, amelyek a jobboldali pártoknak kedveztek, ezen belül is a FIDESZ-nek, aki ellenzéki tevékenysége során - főként pedig a magyar-szlovák és magyar-román státustörvények vitáit követően - egységes frontot alakított ki a jobboldali, nemzeti sorskérdések iránt érzékenyebb pártok között. Mi több azáltal, hogy a FIDESZ egyre inkább elkötelezetté vált a nemzeti témák és a határon túli magyarok iránt (Waterbury 2010, p. 81), hozzájárult ahhoz, hogy megerősítse pozícióját és a jobboldal vezető politikai erejévé váljon. Waterbury nagyon éleslátó módon leírja azt a versenyt, amely a jobboldalon az ellenzéki pártok között zajlott, valamint azt a tanulási folyamatot, amelynek eredményeként a FIDESZ folyamatosan alakította és újrakeretezte a közbeszédet. A szerző szerint a FIDESZ jövőbetekintő beszédmódja felváltotta a leginkább az MDF és FKgP történelmi múlt sorscsapásait idéző diskurzusát és sikeresen tematizálta a határon túli magyarok ügyét azokkal a gazdasági és politikai kérdésekkel, amelyek megosztották a magyar közéletet (ibid. pp. 82-86).

Az 1998-as parlamenti választásokat követően a FIDESZ, az FKgP és az MDF részvételével koalíciós kormány alakult ${ }^{274}$, amely vissza kívánta állítani a magyar külpolitika hármas prioritásának egyensúlyát - az európai integrációt, a regionális stabilitásra épülő jószomszédi politikát, valamint a határon túli magyarok támogatását -, amely az előző kormányzati időszakban leginkább az első két prioritás irányába tolódott el. A külpolitikai triád hangsúlyozása és beemelése a kormányzati programba jelzésértékű volt arra vonatkozóan, hogy a kormány külpolitikájában magáévá teszi az Antall-kormány által deklarált külpolitikai célkitüzéseket. A kormány - a nemzeti beszédmódon túlmenően - kiemelt figyelmet szentelt a határon túli magyarok érdekeinek védelmére, amely a Nemzetpolitika cím alatt a kormányzati programban is megjelent. A határon túli magyarokra vonatkozó stratégiai célkitüzések az alábbi pontokban foglalhatók össze: (1) a politikai, kulturális és gazdasági kapcsolatok kiépítése és fejlesztése az EU integráció kontextusában; (2) intézményes párbeszéd és

\footnotetext{
${ }^{273}$ A választásokon való jó szereplés aligha lett volna lehetséges a Független Kisgazda Párttal kötött egyezség nélkül: a kisgazdák a parlamenti választások második fordulója előtt 82 kerületben léptették vissza jelöltjeiket a FIDESZ-MPP javára.

${ }^{274}$ Az 1998-as országgyülési képviselőválasztás végleges adatai: MSZP: 34,72\%; FIDESZ 29,27\%; FIDESZ - MDF: 12,95\%; FKgP: 12,44\% SZDSZ 6,22\%; MIÉP: 3,63\%; MDF: 0,52\%; Független: 0,26. („Központi Választási Hivatal” 1998).
} 
rendszeres találkozók a határon túli szervezetek és a magyar állam képviselői között; (3) az őket érintő jogszabályok kidolgozásában képviselőik bevonásának biztosítása; (4) a határon túli szervezetek törekvéseinek, a közösségi autonómiának a támogatása; (5) a támogatáspolitika intézményrendszerének erősítése és az anyagi támogatások növelése (Magyarország Kormánya 1998).

E stratégiai célkitűzések megvalósítására a kormány jelentős energiákat fektetett. A HTMH a Miniszterelnöki Hivataltól a Külügyminisztériumhoz, Németh Zsolt külügyi államtitkár felügyelete alá került. A határon túli magyaroknak szánt kormánytámogatások növekvő mértéke pedig lehetővé tette a programtámogatásokat, azonban a koordináció hiányában növelte az intézmények közötti párhuzamosságot (Bárdi-Misovicz 2010, pp. 204-205). ${ }^{275}$ Az egyik legfontosabb lépés azonban az anyaország és a határon túli szervezetek kapcsolatának intézményesítése bizonyult, amelynek eredményeként megalakult Magyar Állandó Értekezlet. ${ }^{276}$ A MÁÉRT létrejöttének előzményei az alapszerződések tárgyalásaira, a magyar-magyar csúcstalálkozókra nyúltak vissza, azonban megalakulása túlmutatott a korábbi kormányzatok által is rendszeresített, a határon túli szervezetekkel folytatott konzultációkon. ${ }^{277}$ A rendszeres találkozók, valamint a MÁÉRT keretében létrejövő szakbizottságok lehetőséget adtak a határon túli magyar szervezetek képviselőknek, hogy befolyásolják az őket érintő politikai-stratégiai döntések meghozatalát. Ebből adódóan a MÁÉRT-re sokan nyomásgyakorló testületként, valamint a kormányzati döntéseket legitimáló szervként tekintettek (Kántor 2002a, p. 20).

Magyarországnak a határon túli magyarok iránti fokozottabb fellépését a gazdasági fejlődés, a magyar gazdaság folyamatos bővülése is lehetővé tette. ${ }^{278} \mathrm{~A}$ gazdasági növekedés mellett a '90-es évek végén jelentősen megváltozott Magyarország geopolitikai pozíciója, amely egyrészt NATO tagságával és a balkáni eseményekben vállalt szerepével, másrészt pedig az EU-s csatlakozási tárgyalások megkezdésével állt

\footnotetext{
${ }^{275}$ A szerzők adatai szerint a határon túli magyaroknak juttatott támogatás a kormányzati időszak első évében 3,65 milliárd forintról a ciklus végére 12, 55 milliárd forintra emelkedett.

${ }^{276}$ A MÁÉRT a parlamenti, illetőleg tartományi képviselettel rendelkező határon túli magyar szervezetek, a magyarországi parlamenti pártok, a Magyar Kormány, valamint a nyugati magyarság képviselőinek konzultatív testülete, amely évente legalább egy alkalommal, Magyarország miniszterelnökének kezdeményezésére ül össze („Magyarország és a határon túli magyarság-1999 konferencia nyilatkozata”). ${ }^{277}$ Németh Zsolt a vele készült interjúban kifejtette, hogy „a MÁÉRT létrehozásakor fontos szempont volt, hogy minden politikai szubjektum vegyen részt benne: a kormány mellett a parlamenti pártok és a határon túli politikai szervezetek, mert így lehet konszenzust elérni a [...] nemzetpolitikában."

278 A kormányzati időszak alatt a Nemzetközi Valutaalap adatai alapján 3,5-4,5\%-os gazdasági növekedésről beszélhetünk, amely illeszkedik az akkori kelet-közép-európai államok teljesítményéhez, az egy före eső GDP a ciklus végére 40\%-al emelkedett, 4750 dollárról 6640 dollárra („A Nemzetközi Valutaalap idősoros adatai”).
} 
összefüggésben. ${ }^{279}$ A csatlakozási tárgyalások megkezdése új megvilágításba helyezte a magyar-magyar kapcsolatokat, ugyanis a közbeszédbe egyre inkább begyürüzött a schengeni határok problémája, ezzel összefüggésben pedig a vízumkötelezettség kérdése. Schengen megjelenése és az ehhez kapcsolódó félelmek nem voltak alaptalanok: az 1997-ben elfogadott Amszterdami Szerződés magába foglalta a korábban kidolgozott Schengeni Együttmüködést ${ }^{280}$, így várható volt, hogy a csatlakozási tárgyalások lezárása előtt - már 2002-től - életbe lép a megállapodás, Magyarország pedig az EU külső határának keleti részének védelméért lesz felelős. Az anyaország közelgő csatlakozása, valamint a határon túli magyar közösségek - köztük Románia, a volt Jugoszlávia tagállamai és Ukrajna - vízumkötelezettsége jelentős bizonytalansághoz vezetett a magyar-magyar kapcsolatokban ${ }^{281}$, ugyanis megkérdőjeleződtek a korlátlan, szabad mozgás által biztosított egyéni is intézményes kapcsolatok, amelyek a határon túli magyarok identitásának megőrzését nagymértékben elösegítették. Schengen egyben azt is jelentette, hogy a magyar közösség egy része, a szlovákiai magyarok kedvező helyzetbe kerülnek, az EU-s csatlakozással jelentős előnyökre tehetnek szert, egyfajta „,privilegizált státust” fognak élvezni (Waterbury 2010, p. 97).

Míg tehát a határon túli magyarok egy jelentős része félelemmel tekintett Magyarország közelgő csatlakozásához és a kormány eddigi kezdeményező szerepe alapján elvárta a probléma megnyugtató rendezését, addig az EU irányába a magyar fél nem tehetett olyan egyoldalú lépést, amely esetleg befolyásolná a csatlakozási tárgyalások lezárását. A kormány előtt álló dilemma a fentiekben már idézett kormányprogramból is kiolvasható: Magyarország a csatlakozással elfogadja az EU vízum- és bevándorlási politikáját és olyan ,sajátos megoldások kidolgozására és elfogadtatására törekszik, amelyek biztosítják a szomszédos országok lakosságával történő zavartalan kapcsolattartást, különös tekintettel az ott élő magyarságra"

\footnotetext{
${ }^{279}$ Magyarország geostratégiai pozíciójának megváltozását Bárdi Nándor és Lőrincz Csaba is a '90-es évek közepére teszi, ugyanis ekkor vált nyilvánvalóvá, hogy a NATO aktív szerepet vállal a balkáni rendezésekben és döntés született egy NATO-légibázis létrehozásáról a Somogy megyei Taszáron. (Bárdi 2004, 144; Lörincz 2010c, pp. 276-77).

${ }^{280}$ A schengeni megállapodás 1985-ben jött létre az Európai Közösség néhány tagállama között, azzal a céllal, hogy a belső határok megszüntetésével mélyítsék az integrációt és közös, külső határrendszert állítsanak fel. Az együttmüködés legnagyobb vívmánya a személyek szabad mozgása, amelyhez a későbbi tagállamok, valamint harmadik államok is csatlakoztak („A schengeni térség és együttmüködés” EUR-LEX).

${ }^{281}$ A schengeni egyezmény kapcsán felmerülő kérdések 1999 januárjában jelentek meg a magyar-magyar kapcsolatok napirendjén. Markó Béla szövetségi elnök január 13-i Budapesti látogatásán Orbán Viktor miniszterelnökkel és Németh Zsolt külügyi államtitkárral folytatott egyeztetésén érintették a kérdést. A szövetségi elnök beszámolója szerint a magyar fél az EU-val folytatott tárgyalásain arra törekszik, hogy megkönnyítse a határátlépést. RMDSZ Tájékoztató, VII. évfolyam, 1395. szám, 1999. január 14.
} 
(Magyarország Kormánya 1998). A kormányprogramból kiindulva a FIDESZ külpolitikai szakértője, Lőrincz Csaba javaslatot dolgozott ki a határon túli magyarok vízummentes közlekedésére vonatkozóan. ${ }^{282}$ A soron következő események - az Európai Unió Tanácsának rendelete a vízummentes és vízumköteles államokról azonban feloldották a vízumrendszer körüli dilemmákat. Ennek alapján Románia az előbbi, míg Szerbia és Ukrajna az utóbbi listára került fel: velük Magyarország a csatlakozás előtt kötött államközi megállapodást („A Tanács 539/2001/EK rendelete” 2001).

A közelgő EU-csatlakozás és a schengeni térség kapcsán felmerült aggályok megnyugtató rendezése az integrációra vonatkozó külpolitikai célkitüzés egyik sikeres fejleményeként értékelendő. Hasonló pozitív eredmények a szomszédságpolitikában is bekövetkeztek: az alapszerződések megkötése megteremtette a magyar kisebbség kormányzati tényezővé válását előbb Romániában (1996), majd pedig Szlovákiában (1998). Ezek az eredmények azonban csak részsikerként értékelendők, mivel a határon túli magyarság helyzetének konszolidálásában nem következtek be lényeges javulások és a kormányzati részvétel is csak néhány területen tette lehetővé a kisebbségi jogok bővítését. Az anyaország nemzetpolitikai aktivizálódása egyrészt e tanulságokra adott válaszként értelmezhető, másrészt azonban azzal is magyarázható, hogy az alapszerződés keretében létrehozott kisebbségi szakbizottságok - amelynek teljesítményéért a magyar fél is felelősséggel tartozik -, nem a várakozásoknak megfelelően müködtek. A müködési diszfunkciók - főként a kisebbségjogi bizottság munkájában - oda vezettek, hogy rendre elmaradtak a két kormány képviselői számára készített, a kisebbségi problémák megoldását célzó kezdeményezések, előterjesztések és ajánlások.

A törvény elökészítése melletti érveket a következő pontokban összegezhetjük: (1) sajátos jogszabályi megoldás, amely az EU-integráció kontextusában rendezi az anyaország és a határon túli magyarok kapcsolatait; (2) egyfajta válasz a kisebbségi jogok bővítésének korlátaira az államközi kapcsolatok szintjén; (3) a kormány által vállalt nemzetpolitikai célkitüzések megvalósítása és az intézményesített kapcsolatok fenntartása; végül pedig (4) belpolitikai megfontolásokból a választópolgárok mobilizációja a határon túli magyarok helyzetérőre vonatkozó vita kezdeményezése.

\footnotetext{
${ }^{282}$ A javaslat lényege abban állt, hogy a határon túli magyarok az állampolgárságuk szerinti államban bejegyeztetnek egy szervezetet, amely tagsági igazolványt állít ki. Ez az igazolvány pedig a schengeni egyezményhez való csatlakozás után érvényes vízumként müködne, amelyet elsőként a Magyar Köztársaság, majd pedig a térség államai is vízumként ismernének el (Lörincz 2010b, pp. 299-302).
} 


\subsection{A státustörvény megjelenése a politika napirendjén}

A határon túli magyarok jogi státusának rendezése a Magyarok Világszövetségének 1998 tavaszán tartott választmányi ülésén került elsőként napirendre, ahol a tanácskozást követő sajtótájékoztatón Csoóri Sándor a MVSZ elnöke a schengeni előírások ellensúlyozásaként a határon túli magyarokat megillető állampolgárság és a szavazati jog kiterjesztésére tett javaslatot. A MVSZ kezdeményezése - amely egybeesett a magyarországi parlamenti választások kampányának végével -, élénk sajtóvitát generált, amelyről a parlamenti pártok eltérő módon vélekedtek. A kormány képviselői (Horn Gyula miniszterelnök, Kovács László külügyminiszter, Tabajdi Csaba államtitkár) elutasították a kettős állampolgárság gondolatát, csakúgy, mint az RMDSZ elnöke, Markó Béla. A magyarországi kormányváltás és FIDESZ hatalomra kerülése sem hozott érdemi elörelépést a kérdésben: a nemzetpolitikai kérdéseknek nagy figyelmet fordító kormány annak betudhatóan nem foglalkozott a kettős állampolgárság problémájával, mert az egyrészt megosztaná és jelentős vitát generálna a parlamenti pártok között, másrészt pedig a kormányzó pártok között sem volt erre vonatkozóan konszenzus és egységes elképzelés, következésképp a kettős állampolgárság kérdése rövid időre lekerült a napirendröl.

A határon túli magyarok helyzete a MÁÉRT alakuló ülésén került előtérbe, ahol a résztvevők felkérték a kormányt, hogy magyarországi és határon túli magyar szakértők bevonásával hozzon létre a konferencia munkálatait segítő szakbizottságokat. A szakbizottságok megalakítására utaló kezdeményezések a határon túli politikai szervezetek aktivizálódását jelezték, valamint az EU-s csatlakozásra, a csatlakozás utáni helyzetre való előkészülést. A MÁÉRT kezdeményezését figyelembe véve a kormány rendeletben szabályozta a szakbizottságok megalakulását és müködését, amelynek alakuló üléseit 1999 őszén tartották meg. ${ }^{283}$ A kettős állampolgárság kérdése az állampolgársági és önkormányzati szakbizottság ülésén került napirendre, amelyről azonban megoszlottak a szakbizottsági tagok véleménye. ${ }^{284}$ A fordulat a MÁÉRT

\footnotetext{
${ }^{283}$ A hat szakbizottság a következő területekre terjedt ki: oktatási, kulturális, gazdasági, egészségügyi és szociális, állampolgársági és önkormányzati, valamint az európai uniós integrációs ügyekben illetékes szakértői bizottság, amelyeket megbízott államtitkárok, helyettes államtitkárok vagy miniszteri biztosok vezetnek, a szakbizottságok müködését pedig a HTMH koordinálja (interjú Bálint-Pataki Józseffel). Lásd bővebben: „A Kormány 1079/1999. (VII. 7.) sz. határozata a határon túli magyarokkal kapcsolatos feladatok végrehajtását szolgáló szakértői bizottságok létrehozásáról” 1999, pp. 4083-4084). A határozat a szakbizottságok működéséről és ügyrendjéről is rendelkezett, eszerint az ülésről jegyzőkönyv készül, a jelentést pedig a szakbizottság elnöke a kormánynak küldi meg.

${ }^{284}$ A szakbizottságok beszámolóinak rövid összegzését lásd: (Kovács 2002, pp. 240-241). A politikai vitákon túlmenően a kettős állampolgárság problematikáját tudományos igénnyel vizsgálta meg a Magyar Kisebbség - Nemzetpolitikai szemle folyóirat („A kettős állampolgárságról").
} 
második, november 11-12. közötti ülésén következett be, amelyen Németh Zsolt külügyi államtitkár a MÁÉRT és az egyes szakbizottságok legfontosabb feladatának jelölte meg a határon túli magyarok jogállásáról szóló törvény kérdéskörének a vizsgálatát. $^{285}$

A MÁÉRT résztvevői ${ }^{286}$ megvitatták a határon túli magyarok státusának kérdését és határon túli nemzetrészek közötti sokrétü kapcsolatokra hivatkozva vetették fel a jogi szabályozás szükségét, amely a Zárónyilatkozatban hangsúlyosan megjelent. ${ }^{287}$ Noha a zárónyilatkozat aláírása, ennek tartalmának elfogadását is jelentette, két magyarországi párt MSZP és SZDSZ vitatta a jogszabály szükségességét. A résztvevők a határon túli magyarok helyzetére vonatkozóan abban értettek egyet, hogy olyan nemzetrészt képviselnek, amely megkülönböztetett státust kell élvezzen. ${ }^{288}$

A MÁÉRT keretében, a státustörvény megalkotására vonatkozó elvi döntés alapján a magyar kormány elérkezettnek látta az időt a jogszabály előkészítésére: 2000 márciusában kormányhatározatot fogadott el, amiben június 30-át jelölte meg a törvényjavaslat koncepciójának elökészítésére, a végrehajtással pedig a Külügyminisztériumot és a HTMH-t bízta meg (Lőincz, 2008). Szintén március első felében a parlamenti pártok részvételével vitatták meg a határon túli magyarokra vonatkozó jelentést, amely első ízben enged betekintést a státustörvény előkészítésében részt vevő intézmények müködésébe. A vitában alapvető szemléletbeli különbségek rajzolódtak ki a határon túli magyarok támogatását illetően, a határon túli nemzetrészek magyarországi jogállását illetően, valamint a MÁÉRT szerepére vonatkozóan is

\footnotetext{
${ }^{285}$ Felszólalásában az államtitkár a kedvező külpolitikai konstellációban és a MÁÉRT legitim szerepében elérkezettnek látta annak a lehetöségét, hogy a magyarság „mozaik nemzetből” „szerződéses nemzetté” váljon („Németh Zsoltnak, a Külügyminisztérium politikai államtitkárának beszéde a MÁÉRT II. ülésén (Budapest, 1999. november 11.)” In: Magyar Külpolitikai Évkönyv. 1999, 301-306). A határon túli magyarok kedvezményes jogállására elsőként Duray Miklós tett javaslatot (interjú Németh Zsolttal).

Az államtitkár mellett Orbán Viktor miniszterelnök is a kedvező körülményekröl nyilatkozott: „Magyarország felemelkedő, jó perspektívákkal rendelkező ország, amely tud foglalkozni a határon túli magyarokkal”, így még ebben a parlamenti ciklusban reális esélyt lát a státustörvény elfogadására. Székely Kriszta: „Különleges státus a határon túli magyaroknak.”, Szabadság, 1999. november 15.

${ }^{286}$ FIDESZ (Kövér László, Simicskó István); FKgP (Bánk Attila, Horváth Béla); MDF (Dávid Ibolya, Kelemen András, Csapody Miklós); MSZP (Molnár Gyula, Tabajdi Csaba); SZDSZ (Szent-Iványi István, Törzsök Erika); MIÉP (Csurka István, Bogdán Emil). MKP (Duray Miklós); RMDSZ (Markó Béla, Tőkés László, Takács Csaba), KMKSZ (Kovács Miklós, Milován Sándor), VMSZ (Kasza József, Józsa László), VMDP (Ágoston András, Csorba Béla); HMDK (Pasza Árpád, Jakab Sándor), Muravidéki Magyar Önkormányzat (Tomka György) Pozsonyec Mária parlamenti képviselő (Szlovénia), MVSZ (Papp László)

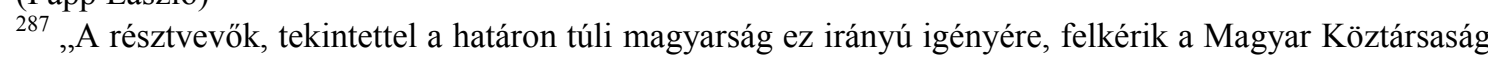
Kormányát, hogy Magyarország és a határon túli magyarság együttműködéséből fakadó előnyök érvényesülése érdekében, megerősítve a nemzeti összetartozás tudatát, Magyarország és a szomszédos országok közös integrációs törekvésével összhangban vizsgálja meg a határon túli magyarok magyarországi jogállása törvényi szabályozásának megteremtését.” („A Magyar Állandó Értekezlet második ülésének Zárónyilatkozata.” In: Kántor 2002b, pp. 166-169).

${ }^{288}$ Székely Kriszta: „Különleges státus a határon túli magyaroknak.” Szabadság, 1999. november 15.
} 
(,J/2204. számú jelentés). Noha ez utóbbi létrejöttét minden parlamenti párt üdvözölte, az MSZP - különösen pedig Tabajdi Csaba - amellett foglalt állást, hogy az üléseket a formális egyeztetések uralták, ,az üdvözölt intézményi forma nem töltődött meg kellő tartalommal, aprómunkával, konkrét gyakorlati lépéssel (ibid).

Március végén a MÁÉRT szakbizottságaiban folytatódtak a törvény előkészületei. A jogi és önkormányzati szakbizottsága ülésén részt vevő Varga Attila RMDSZ-es képviselö a Szabadság napilapban megjelent beszámolóban utalt arra, hogy még nincs elkészítve a törvény tervezete, a bizottság az alapelvekröl tárgyalt, mert alapvető problémának bizonyultak a törvény jogalanyainak meghatározása, valamint a jogosítványok megállapítása. ${ }^{289}$ A törvény tartalmáról május közepén jelentek meg az első információk, azt követően, hogy Szabó Tibor a HTMH elnöke és Németh Zsolt államtitkár a külügyi bizottság ülésén a jogszabály előkészítésének folyamatát értékelték. ${ }^{290}$ Az ülésen beszámoltak a MÁÉRT szakbizottságokban lefolyt találkozók eredményeiről. Ennek kapcsán az államtitkár megerősítette, hogy a szakbizottságokban - az ellenzéki képviselők megjegyzéseire reagálva - valóban ötletbörze folyik, amely „a politikai cselekvés legfontosabb fázisa." ${ }^{291}$ Az egyes szakbizottságokban a jogszabály speciális jellegéből adódóan a javaslatok összegyüjtése zajlik - erősítette meg a HTMH elnöke is, amely lezárult, és ezen javaslatok feldolgozását és összegzését az illetékes minisztériumok, valamint a HTMH végzi el. ${ }^{292}$ Ezt követi a koncepció elkészítése, szakbizottsági vitája, a MÁÉRT keretein belüli megvitatása végül a parlament előterjesztés követi. Az ellenzéki képviselők újból a kormány szemére vetették, hogy a nagyfokú érdeklődés ellenére nem folyt érdemi munka az egyes bizottságokban, a különböző kedvezményekről, amelyek pontosításra szorulnak, azonban már ekkor eltérő álláspontok alakultak ki (munkavállalás, egészségügyi ellátás). ${ }^{293}$

A státustörvény első koncepciója júniusban vált nyilvánossá a Külügyminisztérium Stratégiai Tervezési Főosztálya valamint a HTMH előterjesztése nyomán, azonban tényleges elkészítője Lőrincz Csaba, a FIDESZ szakértője volt. ${ }^{294}$ A

\footnotetext{
${ }^{289}$ Készülöben a státustörvény. Szabadság, 2000. március 22. 8.

290 Jegyzőkönyv az Országgyülés külügyi bizottságának 2000. május 17-én, szerdán, 9 órai kezdettel az Országház föemelet 55. számú üléstermében megtartott üléséröl.

${ }^{291}$ Ibid. Németh Zsolt felszólalása.

292 Ibid. Szabó Tibor felszólalása.

${ }^{293}$ Fenntartásainak az MSZP részéről Tabajdi Csaba egy párton belüli rendezvényen is hangot adott. A határon túli magyarok munkavállalása kapcsán megjegyezte, hogy elöször a munkaerö-piaci lehetőségeket kell felmérni, és „,csak ezt követően szabad dönteni a foglalkoztatni kívántak számáról”. MSZP-s aggályok a státustörvény koncepciójával kapcsolatban. MTI, 2000. június 23.

${ }^{294}$ Az interjúalanyok (Bálint-Pataki József, Németh Zsolt és Székely István) is kihangsúlyozták Lőrincz Csaba szerepét a jogszabály előkészítésében. Mellette még Bíró Gáspár és Jakab András nevét emelték ki.
} 
koncepció kidolgozásának okát a szerző abban látta, hogy a magyar jogszabályokban egyetlen törvény sem rendezi a szomszédos államokban élő magyarok számát, noha a határon túli magyarokat érintő jogszabályok száma Tóth Judit szerint 150-re tehető (Tóth 2000a). A koncepció a törvény célját a határon túli magyarok identitásának megőrzésében, anyagi gyarapodásában és a szülőföldön való maradásában jelölte ki. ${ }^{295}$ A dokumentum pontosítja a korábbi feltételezéseket a személyi hatályára vonatkozóan: eszerint a törvény a szomszédos államokban élő nem magyar állampolgárságú magyarokra terjedne ki. A jogosultak meghatározásában pedig a határon túli magyar közösség illetékes, amely a személy egyéni kérésére ajánlást állít ki: ennek szempontrendszerét a későbbiekben a MÁÉRT keretében határoznák meg. ${ }^{296}$ A politikai vitákból kirajzolódó legfontosabb kérdések a támogatások és kedvezmények jellegéből adódtak, amelynek pontosítása a legterjedelmesebb részét képezi a kidolgozott koncepciónak. Ennek alapján a határon túli magyarok különleges jogokat élveznének (1) kultúra és tudomány területén: díjak, ösztöndíjak, akadémiai köztestületi tagság; (2) oktatás: felsőoktatási részképzés, diák- és pedagógus igazolványok igénybevétele, továbbképzés stb; (3) három hónapot meg nem haladó munkavállalási engedély; (4) egészségügyi és szociális ellátás, családtámogatás. E kedvezményeket a jogosultak magyarországi tartózkodásuk, illetve lakhelyük szerinti országban is igénybe vehetnek. ${ }^{297}$ A tervezet további pontjai a támogatáspolitikát célozzák. ${ }^{298}$

A koncepcióról összességében elmondható hogy a rendszerváltás utáni kormányok által vallott célkitüzéseknek szellemében fogant, amelynek eszközei - még ha ebben a formában nem is kiforrottan - visszaköszönnek a dokumentumban. A javaslatban bemutatott korlátozott időtartamú munkavállalás pedig két célt is szolgált egyidőben. Egyrészt a lehetőségeknek megfelelő munkavállalást és ezáltal a szomszédos államokban élő (főként pedig az erdélyi, kárpátaljai és vajdasági) magyar közösségek gazdasági felzárkózását, másrészt pedig a magyarországi munkaerőpiacon a feketemunka csökkentését.

A koncepció a következő helyeken jelent meg: (Kántor 2002b; Lőrincz 2010, 457-65, 2008). Míg a Kántor kötetben a szerző nincs feltüntetve, addig az utóbbi két kiadásban a koncepció már Lőrincz Csaba nevével szerepelt.

${ }^{295}$ A koncepció 1. és 3. pontja.

296 7. és 8. pont.

${ }^{297}$ 9. és 10. pont. E pontokat a MÁÉRT szakbizottságaiban dolgozták ki, véglegesítését a HTMH és az illetékes minisztériumok végezték el.

298 Ebből kiindulva a törvény végrehajtásához szükséges összegeket a magyar költségvetésből különítenék el, melyet el kell választani az eddig kialakult és a továbbiakban ettől függetlenül is folyósított támogatási rendszertől. 
A Külügyminisztérium és a HTMH elöterjesztését eltérő módon fogadták a parlamenti pártok. Az MSZP elnöke, Kovács László elfogadhatónak tartotta az oktatási és kulturális területekre vonatkozó kezdeményezéseket, mert azok a határon túli magyarok szülőföldön való boldogulásának elösegítését támogatja. Ellenben hiányolta a kedvezmények forrásainak megjelölését és a munkavállalás szabályozását, mert fontosnak tartotta, hogy a munkaeröpiacon határon túli magyarok ne kerüljenek kedvezőbb elbánásba a magyar állampolgárokkal szemben. ${ }^{299}$ Az MSZP-vel szemben az MDF kiindulási pontként elfogadta a kidolgozott koncepciót, noha a párt alelnöke, Csapody Miklós szerint ,az sem címében, sem szövegében nem utal a korábban konszenzusos, a határon túli magyarok számára különleges jogállás megteremtését célzó törvényalkotói szándékra.”300

A jogszabály kiindulópontját képező koncepció körüli viták, valamint a MVSZ által, augusztus 20-án bemutatott külhoni magyar állampolgárságra vonatkozó tervezet az erdélyi történelmi egyházakat is nyilatkozatra késztette. Állásfoglalásukban kiemelték, hogy a státustörvény és az állampolgárság kérdését nem szabad szembeállítani és felajánlották részvételüket a jogalanyok kiválasztásában. ${ }^{301}$

A MÁÉRT szakbizottságokon kívül a státustörvény előkészítésében részt vevő intézmények folyamatosan konzultáltak a határon túli szervezetekkel: júliusban a HTMH és a határon túli szervezetek tanácskoztak a készülő státustörvény lebonyolításának adminisztratív feladatairól, míg októberben Markó Béla szövetségi elnök Martonyi János külügyminiszterrel, Németh Zsolt külügyi államtitkárral, valamint Szabó Tiborral, a HTMH elnökével folytatott megbeszéléséket. A különböző szinten lefolytatott tanácskozások legfőbb célja a konszenzus fenntartása és a határon túli szervezetek tájékoztatása volt. Legalábbis erre utalt Orbán Viktor miniszterelnök és Markó Béla szövetségi elnök budapesti tárgyalásain, amikor a miniszterelnök arról tájékoztatta az RMDSZ elnökét, hogy a decemberben sorra kerülő MÁÉRT ülésén napirendre tüzik a státustörvénnyel kapcsolatos kérdéseket. ${ }^{302}$ Ebben az időszakban a Szövetség párhuzamosan az államfőválasztásra való felkészüléssel - anélkül azonban,

\footnotetext{
${ }^{299}$ MSZP elnökségi ülés. MTI Hirarchívum, 2000. július 11.

${ }^{300}$ Az MDF a státustörvényről - sajtótájékoztató. MTI Hírarchívum, 2000. július 19.

301 Az egyházak képviselői a nemzeti hovatartozás kritériumként a vallási hovatartozást, valamint az egyháztagság figyelembe vételét hangsúlyozták. A romániai magyar történelmi egyházak közleménye. MTI Hirarchívum, 2000. szeptember 11.

302 Orbán Viktor és Markó Béla megbeszélése. RMDSZ Tájékoztató, VIII. évfolyam, 1829. szám, 2000. október 20 .
} 
hogy felvállalná a MVSZ javaslatát - aláírásgyüjtésbe kezd a külhoni állampolgárság érdekében. ${ }^{303}$

Az Országgyülés külügyi bizottsága november 22-i ülésén tüzte napirendre a határon túli magyarok jogállásáról készült jogszabály tervezet vitáját, amelyen, a határon túli szervezetek képviselői is részt vettek. ${ }^{304} \mathrm{~A}$ vita azonban nem a törvénytervezetről szólt, ekkora ugyanis a kormány még nem készítette elő a törvénytervezetet. ${ }^{305}$ A már ismert koncepcióhoz képest a HTMH elnöke Szabó Tibor a törvény kontextusát és hátterét ismertette, és bemutatta a Balázs Ferenc Intézet által elvégzett felmérés eredményeit, ami a jogszabály iránti nagyfokú érdeklődést mutatta ki a határon túli magyarok körében. ${ }^{306}$

Az RMDSZ álláspontját ismertető Varga Attila az erdélyi magyarság várakozásait, valamint a készülő jogszabállyal szembeni félelmeket vázolta fel. Felszólalás azért is fontos a státustörvény folyamatában, mert itt találkozunk elsőként az RMDSZ álláspontjával a tervezet előkészítése során. ${ }^{307}$ Az RMDSZ-es képviselő a jogszabály kerettörvény jellegét hangsúlyozta, melynek részletkérdéseit a végrehajtási normák szabályoznák. Ezen kívül a Szövetség kívánatosnak tartaná, hogy (1) legyen meghatározva a jogszabály személyi hatálya; (2) a munkavállalásnak legyen törvényes kerete, mert a jogi viszony elősegíti a szülőföldön maradást; (3) meghatározott feltételek mellett biztosítsa az oktatási intézményrendszerben való részvételt, és tegye lehetővé az egészségügyi ellátás bizonyos formáihoz való hozzáférést. A képviselő végül hangsúlyozta, hogy olyan jogszabályt szeretnének, amely nem lassítja Magyarország

\footnotetext{
${ }^{303}$ Az RMDSZ Operatív Tanácsa 2000 szeptemberében felkérte a helyi szervezeteket, hogy gyüjtsenek támogató aláírásokat a külhoni állampolgárság megszerzéséhez. Az aláírásgyüjtést az RMDSZ ellenzékéhez tartozó politikusok (Csapó József, Tőkés László, Katona Ádám) szorgalmazták (interjú Székely Istvánnal).

${ }^{304}$ Szabó Tibor (HTMH), Székely István és Varga Attila (RMDSZ), Duray Miklós (MKP), Breznovics László (KMKSZ), Józsa László (VMSZ), Patrubány Miklós (MVSZ).

305 Jegyzökönyv az Országgyülés külügyi bizottságának 2000. november 22-én, szerdán, 14 órakor az Országház fóemelet 55. számú termében megtartott üléséről (KUB/22/2000 KÜB/69/1998-2002).

${ }^{306}$ A jelentés szerint Kárpátalján a lakosság 86,5\%-a, Erdélyben és a Vajdaságban $80 \%$ míg a Felvidéken $64,8 \%$ igényelné a határon túli státust. Az kutatás adatai alapján a különleges státus bevezetése - áll az ismertetőben - jelentősen csökkentené az elvándorlás mértékét: a Vajdaságban 25 százalékról 8,9 százalékra, Kárpátalján 33 százalékról 15 százalékra. A HTMH elnöke azt is fontosnak tartotta kifejteni, hogy a magyarországi lakosság 60,7\%-a támogatja a státustörvény elfogadását, a vitatott munkavállalás kedvezményeket pedig többen támogatják, mint ellenzik (ibid. pp. 9-10).

307 Noha a MÁÉRT második ülése utáni időszakban, valamint a szakbizottsági üléseken ismertetett álláspontokról is több sajtóközlemény született, a nyár folyamán összehívott SZKT napirendi pontjai között is szerepelt, továbbá a szövetségi elnök is számos alkalommal nyilatkozott a sajtónak, csak részleteiben volt ismert az RMDSZ álláspontja.
} 
integrációs folyamatát, egyben pedig biztosítaná a szomszédos államokban élő magyarságnak, hogy „,valóban haza tudjon jönni, amikor Magyarországra jön.”308

A vitába bekapcsolódó Tabajdi Csaba kritikusabb hangot ütött meg. A kormány - fejtette ki - azzal, hogy belső egyeztetés és szakmai végiggondolás nélkül meghirdette a státustörvényt „csapdahelyzetbe manőverezte magát”, mert olyan javaslat támogatására kérte a szomszédos államok magyarságát, amelyet nem tud teljesíteni. A felszólaló arra hívta fel a figyelmet, hogy a koncepció jelen formájában a magyarországi jogállást, és nem a szülőföldön való boldogulást célozza, az egzisztenciateremtést, amelyet az MSZP prioritásnak tartana. ${ }^{309}$ A vita egy jelentős pontját a jogszabály végrehajtásának költségvetési vonzata képezte, több ellenzéki képviselő ugyanis a magyar költségvetésre nézve megterhelőnek ítélte a HTMH elnöke által becsült öt milliárdos keretszámot. Válaszában Szabó Tibor kifejtette, hogy törvény müködtetése és elindítására szánt keret az érintett minisztériumok becslése, azonban ezt az összeget ellensúlyozzák három hónapos munkavállalási kedvezmények után befizetett járulékok. $^{310}$

A külügyi bizottságban lezajlott vita kapcsán megállapítható, hogy a jogszabály előkészítése a különféle sajtóorgánumokban beharangozott menetrendhez és júniusi koncepcióhoz képest - a MÁÉRT szakbizottságaiban folyó egyeztetéseknek is betudhatóan - nehézkesen haladt. A jogszabálytervezet iránti élénk érdeklődés, a kiéleződő álláspontok csak növelték a várakozást, amelyet a bizottsági vita sem tudott feloldani. Ennek betudhatóan, a jogszabálytervezet hiányában a képviselők a felmerülő problémákat nem vitathatták meg érdemi módon, noha a vita tematizálta a készülő jogszabály legalapvetőbb kérdéseit. Azáltal, hogy a határon túli magyar szervezetek is részt vehettek a bizottsági vitán jelzésértékű volt számukra, hogy a MÁÉRT keretein kívül is tehetnek javaslatokat az őket érintő jogszabályok előkészítésében, még ha ennek elfogadását érdemben nem befolyásolhatják.

A MÁÉRT harmadik ülésén elfogadott zárónyilatkozat a szakbizottságokban lezajlott munka lezárásaként értelmezhető: a szakbizottságok elnökeinek és alelnökeinek, valamint a tagok munkájának a méltatása a koncepció elkészítéséért jelzés

\footnotetext{
${ }^{308}$ Ibid. Varga Attila felszólalása.

${ }^{309}$ Ibid. Tabajdi Csaba felszólalása.

${ }^{310}$ Szabó Tibor által hivatkozott szakértői anyag a következő költségvetést terhelő összegeket állapította meg: oktatási kedvezmények: 639 millió Ft; szociális és munkavállalási kedvezmények: 348 millió Ft; az egészségügyi ellátás: 320 millió forint; egészségügyi továbbképzés, illetve fejlesztési támogatás: 520 millió forint; belügyi eljárási költségek. A becslések szerint ezeket a kiadásokat százezer határon túli munkavállaló által befizetett járulékból lehetne fedezni.
} 
arra vonatkozóan, hogy a jogszabály kidolgozásának megalapozó szakasza lezárult, a tervezet megszövegezés és további egyeztetés végett átkerül a HTMH és a kormány felügyelete alá. A zárónyilatkozat - az SZDSZ fenntartásai mellett - megállapította, hogy „koncepció alapján készült törvénytervezet fö elemeiben megfelel az abban lévő elveknek és törekvéseknek, és megfelelőképpen szolgálja a szülőföldön maradás esélyeinek és lehetőségeinek" (A MÁÉRT harmadik ülésének zárónyilatkozata). Mindezek alapján a MÁÉRT felkérte a kormányt, hogy véglegesítse a törvénytervezetet figyelembe véve az EU-csatlakozás után a határon történő akadálytalan átlépést és a Magyarországon való tartózkodást. A testület egy további lényeges javaslatát képezte a státustörvény jogalanyainak meghatározása. Ennek egyik pontja kiszélesítette az ajánló szervezetek körét, és a testületben részt vevő politikai szervezetek mellett az ajánló szervezetek körébe bevonta a civil szervezeteket és egyházak is. A javaslat másik pontja pedig megfogalmazza azon kritériumokat, amelyek teljesítése esetén az ajánló szervezetek eltekinthetnek a kérelmező magyar nyelvtudásától. ${ }^{311}$

A MÁÉRT ülését követően a jogszabály megszövegezését a Külügyminisztérium és a HTMH szakértői márciusban véglegesítették. ${ }^{312}$ A 29 paragrafusból álló tervezet pontosította a törvény hatálya alá tartozók körét, az igénybe vehető támogatások és kedvezmények körét, valamint ezen kedvezmények igénybevételének eljárási rendjét és a Magyar igazolvány kibocsátásának feltételeit.

A szomszédos államokban élő magyarokról szóló törvény vitáját a külügyi bizottság április 11-én tűzte napirendre. ${ }^{313}$ A törvény előterjesztésének felelőse a Külügyminisztérium államtitkára, Németh Zsolt volt, aki pontosította a korábbi vitákban felvetődött - személyi hatályra, diszkriminatív jellegre, szomszédos államok tájékoztatására, pénzügyi vonzatokra vonatkozó - kérdéseket. ${ }^{314}$ A vitában az MSZP a korábban tanúsított álláspontjához képest konstruktív ellenzéki szereplőként lépett fel,

\footnotetext{
311 (1) az állampolgársága szerinti állam magyarként tartja nyilván; (2) szülei közül az egyik magyar nemzetiségü; (3) házastársa rendelkezik magyar igazolvánnyal; (4) valamely bejegyzett magyar szervezet nyilvántartott tagja; (5) valamely egyházi nyilvántartásban magyarként tartják számon; (6) magyar oktatási nyelvü közoktatási intézménybe járt legalább négy évet, vagy gyermeke(i) magyar oktatási nyelvü közoktatási intézménybe jár(nak).

312 („T/4070, számú törvényjavaslat a szomszédos államokban élő magyarokról” 2001) A parlamentbe benyújtott jogszabályhoz a minisztérium a jogszabály terjedelmével megegyező terjedelmü indoklást is benyújtott az egyes paragrafusok alátámasztása céljából.

313 A jogszabály parlamentbe történő benyújtását követően tíz szakbizottságban vitatták meg a jogszabálytervezetet, amelyhez összesen 144 módosító javaslatot füztek, legtöbbet a külügyi bizottságból. Ennek magyarázatát abban látom, hogy ennek a bizottságnak a keretei között már az elökészülés fázisában több vita is lezajlott, amely hozzájárult az álláspontok polarizálódásához. („Iromány módosító: T/4070 A szomszédos államokban élő magyarokról (státus tv.)” 2001).

314 Jegyzökönyv az Országgyülés külügyi bizottságának 2001. április 11-én 9 óra 30 perckor az Országház 55. számú üléstermében megtartott üléséről (KUB/7/2001. KÜB/77/1998-2002).
} 
Tabajdi Csaba, aki a korábbi szakbizottsági vitákon több alkalommal támadta a jogszabályt, a szakbizottsági vitán annak a véleményének adott hangot, hogy bizonyos pontosításokkal és a szülőföldi támogatások eszköztárának bővítésének feltételével támogatják a jogszabályt. ${ }^{315}$ Ennél kritikusabb, állásponton volt képviselőtársa Bársony András is, aki a törvény személyi hatályát, a munkavállalási kedvezményeket és az előre nem látható költségvetési terheket vitatta. ${ }^{316}$ A tervezet elutasítását egyedül az SZDSZ képviselői szorgalmazták, melyet a bizottsági szavazás végeredménye is tükrözött. ${ }^{317} \mathrm{~A}$ pártot képviselő Szent-Iványi István a határon túli magyarok becsapásaként értelmezte a tervezetet, ugyanis a Magyarországon igénybe vehető kedvezménynek betudhatóan a jogszabály valójában „szemfényvesztés”, amely elvándorlásra buzdít. Az előterjesztő államtitkár a vitás kérdésekre válaszolva eloszlatta azokat a kételyeket, amelyek arra vonatkoztak, hogy a jogszabály jelentősen megterhelné az állami költségvetést, és azt, hogy a törvénytervezetről a szomszédos államokat, valamint az európai fórumokat ne tájékoztatták volna. ${ }^{318}$

A bizottsági viták lezárását követően az Országgyülés április 19-én - jelentős médiafigyelem közepette - kezdte meg a státustörvény parlamenti vitáját. A vitára hasonlóan a külügyi bizottság ülésére - meghívást kaptak MÁÉRT tevékenységében részt vevő határon túli magyar szervezetek, az RMDSZ-t Markó Béla és Takács Csaba ügyvezető elnök képviselte. ${ }^{319}$ A vita iránti érdeklődést nemcsak a módosító javaslatok nagy száma, hanem a korábbi bizottsági vitákban kialakult ellentétek is növelték, így a határon túli magyarok szempontjából a vita jelentősége a korábbi magyar-szlovák és magyar-román alapszerződés vitáihoz hasonló. A nagyfokú érdeklődésnek betudhatóan a törvényjavaslatot az Országgyülés több ülésnapon tárgyalta, amelynek következtében a vita június második feléig elhúzódott. Végül a törvényt az Országgyülés június 19-én nagy többséggel, 306 igen, 17 nem, és 8 tartózkodás mellett szavazta meg.

\footnotetext{
${ }^{315}$ Tabajdi Csaba (MSZP) felszólalása. A jogszabállyal kapcsolatos aggályok és módosító javaslatokról bővebben lásd (Tabajdi 2006, pp. 619-627).

316 Bársony András (MSZP) felszólalása.

317 A külügyi bizottság 20 támogató és 2 ellenző szavazattal támogatta a szomszédos államokban élő magyarokra vonatkozó törvény parlamenti vitára bocsátását.

${ }^{318}$ Németh Zsolt emlékeztette a bizottság tagjait, hogy romániai látogatásán egyeztetett a státustörvényről a román külügyminiszterrel, április elején pedig a szomszédos államok és a nyugat európai államok nagykövetei is kézhez kapták a jogszabály angol nyelvü változatát.

${ }^{319}$ A szövetségi elnök a törvény célját a szülőföldön való maradás erősítésében jelölte meg, amely néhány fontos területen - oktatás, kultúra és munkavállalás - többlet-kedvezményeket biztosít a szomszédos államokban élő magyaroknak. Az RMDSZ feladatát Markó Béla abban látta, hogy „felelősséget kell vállalnia a törvény közvélemény- és a román többség felé való közvetítésében, magyarázatában." $R M D S Z$ Tájékoztató, IX. évfolyam, 1953. szám, 2001. április 19.
} 
A négy fejezetböl és 29 paragrafusból álló törvény hatálya a Magyarországgal szomszédos államokban élő magyarokra terjed ki (Ausztria kivételével), aki magyar állampolgárságát nem önkéntes lemondással veszítette el; b) nem rendelkezik állandó magyarországi tartózkodásra jogosító engedéllyel. ${ }^{320}$ Ezen kívül a törvény hatálya alá tartoznak a nem magyar nemzetiségü házastársak és kiskorú gyerekek is, akik Magyarország, illetve a szomszédos államokban lakóhelyük szerint az alábbi táblázatban foglalt támogatásokban és kedvezményekben részesülhetnek (4-18. §):

10. sz. táblázat: A 2001. évi LXII. törvény alapján nyújtott támogatások és kedvezmények

\begin{tabular}{|c|c|}
\hline Terület & Támogatások és kedvezmények jellege \\
\hline $\begin{array}{l}\text { 1. Művelődés, kultúra, } \\
\text { tudomány }\end{array}$ & $\begin{array}{l}\text { - közmüvelődési intézmények szolgáltatásainak igénybevétele; } \\
\text { kulturális javak és müemléki értékek hozzáférhetővé tétele; levéltári } \\
\text { anyagok kutatása; } \\
\text { - ingyenes könyvtárlátogatás és -használat; } \\
\text { - MTA külső köztestületi tagság. }\end{array}$ \\
\hline 2. Kitüntetések, ösztöndíjak & - címek, elismerések, díjak, oklevelek; ösztöndíjak odaítélése. \\
\hline $\begin{array}{l}\text { 3. Társadalombiztosítás, } \\
\text { egészségügy }\end{array}$ & $\begin{array}{l}\text { - egészségügyi- és nyugdíjellátásra való jogosultság, amennyiben } \\
\text { munkavállalás esetén befizette az egészségbiztosítási- és } \\
\text { nyugdíjbiztosítási járulékot; }\end{array}$ \\
\hline 4. Utazási kedvezmény & $\begin{array}{l}\text { - díjmentes utazás (6 éves kor alatt, } 65 \text { év felett); korlátozott számú, } \\
\text { 90\%-os kedvezmény a törvény hatálya alá tartozó személyeknek }\end{array}$ \\
\hline 5. Oktatás & $\begin{array}{l}\text { - szak- és egyetemi képzésben való részvétel, államilag finanszírozott } \\
\text { formában; határon túli kihelyezett képzés müködtetése; } \\
\text { - szülőföldön nyújtható oktatási-nevelési támogatás; tankönyv- és } \\
\text { taneszköz-támogatás. }\end{array}$ \\
\hline 6. Diákkedvezmények & - diákigazolvány \\
\hline 7. Pedagóguskedvezmény & - továbbképzés; szállás- és utazási költségek; pedagógusigazolvány \\
\hline 8. Munkavállalás & - évente három hónapos foglalkoztatás, amely meghosszabbítható \\
\hline $\begin{array}{l}\text { 9. Határon túli szervezetek } \\
\text { támogatása }\end{array}$ & $\begin{array}{l}\text { - közhasznú szervezetekhez benyújtott pályázatok útján a kultúra, } \\
\text { irodalom, népmüvészet, felsőoktatás, falusi turizmus, infrastruktúra- } \\
\text { fejlesztés tárgykörében. }\end{array}$ \\
\hline
\end{tabular}

Forrás: saját szerkesztés.

A jogszabályban rögzített kedvezményeket a Magyar igazolvány, valamint a Magyar hozzátartozói igazolvány felmutatásával a törvény hatálya alá tartozó személyek Magyarország területén, míg egyes támogatásokat - pályázati úton - szomszédos állam szerinti lakhelyen vehetnek igénybe (23-25. §.)

A határon túli magyar szervezetek örömmel vették tudomásul a státustörvény elfogadását: az RMDSZ képviseletében Markó Béla elmondta, hogy a jogszabály megszavazásával a „magyar kormány felvállalta a határon túli magyarok kulturális,

\footnotetext{
${ }^{320}$ („2001. évi LXII. törvény a szomszédos államokban élő magyarokról” 2001). A törvény 2002. január 1-től lépett hatályba.
} 
nyelvi identitása megőrzésének támogatását." ${ }^{\text {,21 }}$ A szövetségi elnök kiemelte, hogy a státustörvény alkalmazásában az RMDSZ a magyar igazolványt igénylő kérdések összegzésében fog támogatást nyújtani.

A Magyarországgal szomszédos államok eltérő módon ítélték meg a státustörvény elfogadását, míg Szerbia és Ukrajna nem fogalmazott meg semmilyen ellenvetést a törvénnyel szemben, addig Szlovákia és Románia - már a kidolgozás periódusában - komoly kritikával illették a tervezetet. A jogszabály elfogadása jelentős törésponthoz vezetett a magyar-szlovák és a magyar-román kapcsolatokban: a két állam vezető politikusainak elítélő nyilatkozatait több hónapos diplomáciai vita követette, amely indokolttá tette a felekkel történő folyamatos konzultációt.

\subsection{A státustörvény vitája az államközi kapcsolatokban és az európai fórumok elött}

A státustörvény kérdése a törvény koncepciójának megjelenését követöen kezdte foglalkoztatni a román politikai elitet, azonban a nyári parlamenti szünetnek betudhatóan a pártok nem tematizálták a kérdést. A készülő jogszabályt illetően a PNL diplomáciai megoldást sürgetett, míg a szélsőséges PRM egy ellentörvény elfogadását szorgalmazta, de 2000 nyarán a magyar törvényalkotói szándék nem vezetett diplomáciai nézeteltéréshez a két állam között.

A szomszédos államokra vonatkozó törvény az elökészítés fázisában, 2001 áprilisában, Mircea Geoană külügyminiszter budapesti látogatásán jelent meg az államközi kapcsolatok napirendjén. A külügyminisztériumi találkozón a státustörvény kérdése nem szerepelt kiemelt napirendi pontként: a készülő jogszabályról Martonyi János elmondta, hogy elfogadása nem áll összefüggésben azzal, hogy Románia még a vízumköteles országok között van. A külügyminiszter újra megerősítette, hogy Magyarország továbbra is támogatja Románia integrációját, a készülő jogszabályról pedig hamarosan tájékoztatják a szomszédos államokat. ${ }^{322}$ A román külügyminiszter az MSZP vezetőségével való egyeztetésen már nehezményezte, hogy a készülő törvényről a magyar kormány nem konzultált Bukaresttel, míg a külügyi bizottság tagjaival folytatott tanácskozáson arra tett javaslatot, hogy a kisebbségi szakbizottság keretében vitassák meg a jogszabályt. ${ }^{323}$

A kormány a külügyminiszteri látogatást követően elérkezettnek látta az időt, hogy a készülő jogszabálytól tájékoztassa a szomszédos államok és az EU-

\footnotetext{
${ }^{321}$ RMDSZ Tájékoztató, IX. évfolyam, 1992. szám, 2001. június 20.

${ }^{322}$ Budapesten a román külügyminiszter. MTI Hírarchívum, 2001. április 4.

${ }^{323}$ MTI Hírarchívum, 2001. április 4. Keresőszó: státustörvény, Mircea Geoană.
} 
tagállamainak nagyköveteit. A tájékoztató fontosságát a román konzultációs igény mellett több fejlemény is indokolttá tette. A belpolitika szintjén a kormányt az ellenzék részéről egyre több kritika érte a jogszabály személyi hatálya és a támogatások jellege miatt, amely - érveltek az MSZP és SZDSZ politikusai - feszültségekhez fog vezetni a szomszédos államokkal. Ezzel szemben a külügyi bizottság ülésén Németh Zsolt államtitkár az ellenzék részéről érkező vádakat azzal hárította el, hogy minden eszközzel eleget tettek a tájékoztatási kötelezettségeknek. ${ }^{324}$ A kormány által előkészített jogszabály végül az európai fórumok figyelmét is felkeltette, a csatlakozás folyamatában Magyarország részéről előrelátó lépésnek bizonyult - még ha kissé megkésve is - a tájékoztatásuk.

A szomszédos államoknak szóló tájékoztató és a jogszabály tervezetének ismeretében Adrian Năstase miniszterelnök fontos nyilatkozatot tett a szomszédos államokban élő magyarok jogairól szóló törvénytervezetet kapcsán, diszkriminatívnak nevezve a javaslatot, amiért az hátrányos megkülönböztetéshez vezet a más nemzetiségü állampolgárokkal szemben. A tervezetről negatív hangnemben nyilatkozott a román államfő valamint a külügyminiszter is ebben az időszakban, melyet a magyar fél már nem hagyhatott figyelmen kívül, így elfogadta a bukaresti nagykövet által április 20-án a külügyminisztériumnak benyújtott, konzultációra vonatkozó javaslatát.

A magyar és a román fél közötti konzultációknak két nagyobb szakasza különíthető el. Az első szakasz a törvény Országgyülés általi elfogadásáig tartott és főként tájékoztató jellegü volt, amely során a két állam nagykövetsége, Petru Cordoș bukaresti és Íjgyártó István bukaresti nagykövetek közvetítettek a két állam között, amit egy budapesti és egy bukaresti magyar-román szakértői konzultáció követett. ${ }^{325}$ A román külügy a magyar féllel történő egyeztetésektől azt remélte, hogy sikerül olyan egyezségre jutni, amelynek következtében módosulhat a jogszabály tartalma. A módosításra vonatkozó román remények azonban a törvénytervezet parlamenti vitájának lezárásával szertefoszlottak és a végső szavazás időpontjának közeledtével a román fél stratégiát váltott: elsőként a különböző sajtóorgánumokon keresztül, majd a

\footnotetext{
$324, \ldots$ a MÁÉRT őszi ülése előtt az Európai Uniónak és a szomszédos országoknak a nagykövetei számára én tartottam tájékoztatást a koncepcióról. Az elmúlt hét folyamán pedig az Európai Unió, a NATO és a szomszédos országok számára Martonyi János külügyminiszter úrral együtt tartottunk olyan tájékoztatást, amikor átadtuk a szövegtervezetnek az angol változatát és alaposan, szövegszerüen is módunk volt tájékoztatást nyújtani.” Jegyzökönyv az Országgyülés külügyi bizottságának 2001. április 11-i üléséröl. Németh Zsolt külügyi államtitkár felszólalása.

${ }^{325}$ A két egyeztetésen nem a jogszabály tartalmi vonatkozásairól, hanem főként végrehajtási kérdésekről egyeztettek a felek, a román delegáció az igazolványok kiállításához szükséges tájékoztató irodák müködését, valamint munkavállalásra vonatkozó etnikai alapú diszkrimináció lehetőségét kifogásolta. Státustörvény - magyar-román konzultációk. MTI Hírarchívum, 2001. május 24.
} 
legmagasabb szinteken a törvény elutasítását hangoztatta. Ebben az elutasító diskurzusban értelmezhető a román kormány külpolitikai tanácsadó irodájának június eleji elemzése, amely arra mutatott rá, hogy a készülő státustörvény számos ponton ellentétes a nemzetközi jog elveivel. ${ }^{326}$ A felsőszintű nyilatkozatok mellett a kormányzó PSDR vezetősége állásfoglalásban megállapította, hogy a szomszédos államokban élő magyarokra vonatkozó törvény több hátrányos megkülönböztetést hoz alkalmazása során, és túllép a nemzeti kisebbségek védelmét szolgáló európai normák keretein. ${ }^{327} \mathrm{~A}$ jogszabály végül nem felel meg az európai elvárásoknak: ezt a tényt erősíti, hogy a törvény hatálya nem terjed ki az Ausztriában élő magyarokra.

A státustörvény elfogadásának híre tovább növelte az elutasító és tiltakozó nyilatkozatok hangvételét, melyekben rejtett módon a román diplomácia kudarcérzete is meghúzódott, amiért nem tudta érdemi módon, tartalmilag befolyásolni a jogszabályt. Mircea Geoană rendkívüli sajtótájékoztató keretében ismertette a kormány álláspontját. A külügyminiszter felrótta a magyar félnek azt, hogy semmilyen formában nem konzultáltak a készülő jogszabályról, az általuk javasolt módosításokat - amelyről több alkalommal konzultáció keretében egyeztettek - pedig figyelmen kívül hagyták. Geoană a sajtótájékoztató keretében kifejtette, hogy a külügyminisztérium bekérette a magyar nagykövetet, az elfogadott jogszabállyal kapcsolatosan pedig megteszi azokat az intézkedéseket, hogy ,a területen kívüliségnek e törvényben fellelhető elemei ne érvényesülhessenek román területen." ${ }^{328}$ Ion Iliescu államfő még kategorikusabban fogalmazott a státustörvény kérdésében, annak a véleményének adva hangot, hogy a Magyar igazolványnak „semmi keresnivalója nincs Románia területén.”329 A magas rangú nyilatkozatok szintjén Adrian Năstase miniszterelnök fogalmazta meg a legélesebb kritikákat a törvény kapcsán és kilátásba helyezte - az alapszerződés

\footnotetext{
${ }^{326}$ Az iroda értelmezése szerint diszkriminációnak számít azok a kedvezmények, amelyeket egy állam etnikai származás alapján biztosít. A diszkriminációt több nemzetközi egyezmény, valamint ENSZ nyilatkozata is tiltja. A magyar kormány által kezdeményezett jogszabály és a Magyar igazolvány bevezetése túlmutat a kisebbségekhez tartozó személyek kulturális és identitásának védelmén, és a politikai viszony megteremtését jelenti, amitől tartózkodnia kellene Magyarországnak. Egy további probléma a jogszabály területen kívüli jellegére vonatkozik, így a jogszabály végrehajtása csak az érintett államok törvényeinek szigorú betartásával valósíthatók meg. Erre vonatkozó rendelkezések pedig hiányoznak a törvényböl. Az iroda végül elfogadhatatlannak tartja a szomszédos államok közösségeit képviselő szervezetek magyar állam által történő elfogadását, amelyek az adott állam törvényei szerint müködnek, így e szervezeteknek nincs szüksége más államok elismerésére. A történelem elfogadhatatlan átértékelése? "Félhivatalos" román vélemény a státustörvényröl. Szabadság, 2001. június 9, 16.

327 „Hátsó szándékai" vannak a magyar kormánynak. RTDP-állásfoglalás státustörvény ügyben. Szabadság, 2001. június 13., 8.

${ }^{328}$ Román és szlovák visszhangok a budapesti végszavazás után. RMSZ, 2001. június 21.

329 Ibid. Hasonló hangvételủ nyilatkozatok fogalmazódtak meg román oldalon is. Mikulás Dzurinda szlovák kormányfő állásfoglalásban utasította el a státustörvény elfogadását, amely szerinte nem felel meg az EU által támasztott normáknak.
} 
kivételével - a Magyarországgal kötött kétoldalú megállapodások felbontását a státustörvény elfogadása miatt. ${ }^{330}$

A román parlamenti pártok - az RMDSZ kivételével - elutasítóan nyilatkoztak a törvény elfogadásáról. Álláspontjuk leginkább a kialakult helyzet megoldásában különbözött. A PD szerint a vitát a kétoldalú kapcsolatok keretében kell rendezni, míg a PNL azt javasolta a kormánynak, hogy kérje ki az európai fórumok véleményét az elfogadott törvénnyel kapcsolatosan. ${ }^{331}$ A szélsőséges PRM ezzel szemben nem tárgyalásos úton rendezte volna a helyzetet: a jogszabály elfogadása után törvénytervezetet nyújtott be a képviselöházba, azzal a céllal, hogy megakadályozza a státustörvény Románia területén való végrehajtását. ${ }^{332}$ Az RMDSZ nevében, Markó Béla kiemelte a jogszabálynak az erdélyi magyarokra vonatkozó pozitív kitételeit, egyben pedig bírálta a román politikai elitet a státustörvény kapcsán kifejtett álláspontjukért és arra hívta fel a figyelmet, hogy Románia még mindig vízumköteles állam, ebből adódóan nem oktathat ki olyan államokat, amelyek „,már csak egy lépésre állnak az integrációtól." ${ }^{333}$ A szövetségi elnök kifejtette, hogy a státustörvény gazdaságösztönző intézkedései révén hozzájárul Románia gazdasági fejlődéséhez és az európai integrációhoz.

A státustörvény elfogadását követően a román vezetés hamar belátta, hogy a törvény állandó támadásával nem érhet el számottevő eredményeket, a diplomáciai konfliktus felvállalása pedig nem szolgálná Románia integrációs előrehaladását. A kialakult helyzetben több tárgyalásos megoldás körvonalazódott. Első körben július 12 13. között felsőszintű találkozóra került sor: Martonyi János külügyminiszter vezette

\footnotetext{
${ }^{330}$ A miniszterelnök a jogszabály alkalmazása ellen több intézkedés bevezetését is kilátásba helyezett, amely érintette volna az alapítványok alapszabályzatának felülvizsgálatát, az adó- és vámintézkedéseket, valamint a kedvezményezett személyek társadalombiztosítását. Státustörvény: román kormány. MTI Hirarchívum, 2001. június 21.

${ }^{331}$ Andrei-Ioan Chiliman (PNL) képviselő napirend előtti felszólalása a Képviselőház június 26-i ülésén.

332 A PRM által benyújtott törvénytervezet a következő a státustörvénnyel szemben a következő ellenintézkedéseket hozná: 1. azok a román állampolgárok, akik a státustörvény alapján megkapják a Magyar igazolványt, a kettős állampolgárokéhoz hasonló státust élveznek, amelynek alapján nem tölthetnek be bizonyos közhivatali, társadalmi és katonai funkciókat; 2. azok a szervezetek amelyek részesülnek a státustörvény által nyújtott kedvezményekből, külföldi jogi személyeknek minősülnek, melyeket az érvényben lévő jogszabályok alapján újra be kell jegyeztetni; 3 . Románia területén semmilyen intézmény, szervezet vagy magánszemély nem bocsáthat ki, kézbesíthet Magyar igazolványokat. Tiltott továbbá az igazolvány kiadásához szükséges ajánlások megfogalmazása. A törvénytervezet feloszlatná azokat a szervezeteket, amelyek az utóbbi cikkely ellen vétenének, a magánszemélyeket pedig a btk. alapján büntetné („Propunere legislativă nr. 359/2001).

A jogszabálytervezetet negatívan véleményezte a Törvényhozási Tanács, a Képviselőház Emberi jogok, felekezetek és kisebbségek bizottsága valamint a kormány, így nem kerülhetett a képviselőház elé megvitatásra.

${ }^{333}$ Markó Béla a státustörvény kedvezőtlen romániai fogadtatásáról. RMDSZ Tájékoztató, IX. évfolyam, 1993. szám, 2001. június 21.
} 
delegáció két napos romániai tartózkodása során tárgyalásokat folytatott a státustörvényröl, azonban Mircea Geoană külügyminiszter a román álláspont fenntartása mellett érvelt, amely nem teszi lehetővé romániai alkalmazását. A tárgyalásokon csak arról született egyezség, hogy a felek a kormányközi vegyesbizottság keretében folytatják az egyeztetéseket. ${ }^{334}$

Július végén folytatódtak a felsőszintü találkozók, ezúttal a két állam miniszterelnöke, Orbán Viktor és Adrian Năstase találkozott. A jogszabály elfogadása óta ez volt az első olyan érdemi tárgyalás, amely elörelépést jelentett a státustörvény körül kialakult magyar-román vitában. A magyar miniszterelnök több pontból álló javaslatot nyújtott át a román félnek. Míg a magyar miniszterelnök a romániai munkavállalói létszám növelésére tett javaslatot, addig a tárgyalásokon Năstase a munkavállalási korlátozások feloldását kérte. ${ }^{335}$

A másik további ésszerü megoldásnak az bizonyult, ha a felek felhívják az európai fórumok figyelmét a kialakult helyzetre, hogy közvetítsenek, és végső esetben döntsenek ök a két állam közötti vitában. E lehetőséget kihasználva, röviddel a törvény megszavazása után, június 21-én Adrian Năstase miniszterelnök a Velencei Bizottsághoz fordult, arra kérve a testületet, hogy vizsgálja meg a státustörvénynek a nemzetközi és európai normákkal való összeegyeztethetőségét („,Annual Report of Venice Commission"). Nem sokkal később Martonyi János külügyminiszter is beadvánnyal fordult a Velencei Bizottsághoz, azonban nem a jogszabály EU-konform jellegének igazolását, hanem a nemzeti kisebbségek számára biztosított kedvezményes elbánásra vonatkozó európai jogalkotás összehasonlító elemzését kérte. A felek által megfogalmazott kérdésfelvetésben világosan látszott az, hogy a román diplomáciával szemben a magyar vezetés előbbre látó volt, ugyanis az összehasonlító vizsgálat a kedvezményes elbánás európai gyakorlatának módozatait állította előtérbe, amelynek betudhatóan - a megfogalmazott kritikák ellenére - sikeresebben védhető a magyar álláspont.

Azzal, hogy a felek az európai fórumokhoz folyamodtak, világos üzenetet fogalmaztak meg: egyrészt elfogadták az európai fórumok közvetítő szerepét, melynek

334 A javaslat azért tűnt életképes megoldásnak, mert korábban, már a státustörvény napirendre kerülésekor mindkét fél felvetette, hogy a vitát a kormányközi vegyesbizottság kisebbségi szakbizottság keretei között folytassák le.

335 A román miniszterelnök azt hangsúlyozta, hogy a kvóta eltörlésével „megszünne a román munkavállalók gazdasági diszkriminációja és rendeződhetne a törvényben az erre vonatkozó kitétel is" amely elfogadható megoldásnak tűnt a román fél számára. A felek között egyetlen kérdésben mutatkozott egyetértés: a külügyminisztériumi találkozóhoz hasonlóan, a miniszterelnökök is a vegyesbizottság ülésének összehívását szorgalmazták. Státusügyben a helyzet változatlan. Szabadság, 2001. július 30., 5. 
egyik látványos következménye az lett, hogy a jogszabály vitája túllépett a belpolitikai és államközi kapcsolatok szintjén, és megjelent az európai politika napirendjén, másrészt pedig mindkét állam saját pozícióját képviselve értelmezhette nemzetközi jog és az európai normák releváns rendelkezéseit, amely az anyaország és a nemzeti kisebbségek viszonyában az európai normák kiszélesítésének lehetőségét hordozta magába. Végül pedig - a Velencei Bizottsághoz intézett kérdésekkel - mindkét fél igazolta, hogy kész a vitát tárgyalás útján rendezni, egy olyan időszakban, amikor Magyarország és Románia az európai integrációs folyamat különböző szakaszaiban voltak.

A státustörvény kapcsán kialakult vitát nemcsak a két fél szerette volna mielöbb rendezni. A Velencei Bizottság a két állam megkeresésére rövid időn belül válaszolt, amely jelzi, hogy az európai fórumok is prioritásként tekintettek a magyar-román vita megnyugtató rendezésére. A testület július elején megtartott plenáris ülésén úgy döntött, hogy az ET tagállamainak jogszabályai alapján a határon túli kisebbségeknek biztosított kedvezményes elbánás gyakorlatát tanulmányozza, amelynek fő célja megállapítani, hogy e gyakorlat mennyiben egyeztethető össze az ET normáival és a nemzetközi jog elveivel. ${ }^{336}$

A Velencei Bizottság kérésére Magyarország és Románia augusztus 21-én nyújtotta be hivatalos álláspontját. A román álláspont kiemeli, hogy az emberi jogok és a nemzeti kisebbségekhez tartozó személyek kérdésében mind a nemzetközi államközösség, mind pedig az állampolgárság szerinti állam felelősséget visel, de az elsődleges hatáskörök az állampolgárság szerinti államot illetik. Az anyaország szerepe a határon túli kisebbségek kérdésében a nemzetközi jog alapján nem elfogadott, ennek ellenére Románia is érdekelt abban, hogy a kétoldalú egyezmények keretében a legmagasabb szintü jogosítványokat biztosítsa („,The Official Position of the Romanian Government", 2001, pp. 4-6). Ez azonban nem történhet egyoldalú módon, mint a státustörvény elfogadása esetében. Egy további kifogás a jogszabállyal szemben az, hogy nemcsak a kultúra és az oktatás területén nyújt kedvezményes elbánást, hanem a munkaerő-áramlás és az utazás területén, amely a román álláspont szerint „,feszegei a jelenlegi nemzetközi jog határait” (ibid. pp. 14-15). A jelentés terjedelmes részét teszi ki a törvénnyel szembeni két legfőbb érv, a jogszabály diszkriminatív és területen kívüli

336 (,Jelentés a nemzeti kisebbségek számára az anyaállamok által biztosított kedvezményes bánásmódról.” 2001) A megfogalmazásból kivehető, hogy a Velencei Bizottság nem a magyar, illetve a román kérését elfogadva látott hozzá a munkához, mint azt a korabeli sajtó hangoztatta, hanem a két perspektívát próbálta összeegyeztetni. 
jellege. A román érvelés szerint a jogszabály diszkriminatív jellege több esetben is kimutatható $^{337}$, a területen kívüli jellegét erősíti a Magyar igazolvány megszerzésének és kibocsátásának folyamata, amellyel a státustörvény tulajdonképpen ,jogi viszonyt igyekszik kialakítani Magyarország és a határon túli közösségek között” (ibid. p. 26). Ennek alapján az állásfoglalás „megfelelő intézkedésként javasolja” az igazolvány megszüntetését, vagy az igazolvány megszerzése procedúrájának - beleértve az ajánlások kibocsátását is - Magyarországra történő áthelyezését.

A magyar álláspont kiemelte, hogy a szomszédos államokban élö magyarokra vonatkozó törvény abból a megfontolásból született, hogy a stabilitás biztosításával helyben tartsa a nemzeti kisebbségeket és fenntartsa az etnikai sokszínűséget („Paper Containing the Position of the Hungarian Government" 2001, pp. 3-4 és 6-7). A jogszabály megalkotásával a magyar állam újfent elismerte, hogy a határon túli magyarok más állam állampolgárai, a területi integritás tiszteletben tartásával nem törekszik revízióra, vagy a kettős állampolgárság megadására. ${ }^{338} \mathrm{Az}$ álláspont hangsúlyozta továbbá, hogy a magyar jogszabály nem egyedülálló a térségben és röviden vázolta a szlovén, szlovák, görög, román és néhány nyugat európai államnak a határon túli kisebbségekre vonatkozó rendelkezéseit, amelyböl azt a következtetést vonja le, hogy a nemzetközi jog keretei között a nemzeti kisebbségeknek nyújtott kedvezményes elbánás megengedett, nem diszkriminatív. A státustörvény - érvelt a magyar fél - összhangban van az ET Keretegyezményének rendelkezéseivel, mert (1) legitim célt, a nyelvi és kulturális identitás fenntartását szolgálják; (2) a jogszabály intézkedései ésszerủek és mérhetőek; (3) a jogszabály által nyújtott kedvezmények arányosak. A magyar álláspont a státustörvényre érkező bírálatokra is válaszolt. Az extraterritoriális hatályra érkező kritikákat azzal hárította el, hogy pontosította a kedvezményekhez való jutás feltételeit, valamint az ajánló szervezetek szerepét. A jogszabállyal szembeni másik vádra - a konzultációk hiányára - is reagált a magyar álláspont, egy függelékben állítva össze a szomszédos államok képviselőivel folytatott magas szintü találkozókat (ibid. pp. 27-29).

A magyar és a román álláspontban csak az állampolgárság szerinti állam (nemzetiesítő állam) szerepében mutatkozott egyetértés, ugyanis mindkét jelentés

\footnotetext{
${ }^{337}$ A jogszabályban fellelhető diszkrimináció eltérő alakzatai: (1) a magyar közösség tagjai között; (2) a Romániában élő magyar kisebbség és a Magyarországon élő román közösség között; (3) a Romániában élő nemzeti kisebbség tagjai között; (4) valamint a magyar kisebbség és a többségi román közösség tagjai között (ibid. pp. 15-17).

338 Magyarország és a határon túli kisebbségek helyzetében nem kíván védhatalmi szerepben (Schutzmacht) fellépni: az anyaország a szomszédos államban élő magyar kisebbség védelmében az illető állam után csak másodlagos szereppel bírhat (ibid. pp. 8-10).
} 
kiemelte, hogy a nemzeti kisebbségekért az állampolgárság szerinti állam felelőssége elsődleges. Ezzel szemben a két dokumentum döntő módon eltérő értelmezéseket és megállapításokat tartalmazott. Mindkét állam arra törekedett, hogy a releváns európai és nemzetközi jogi szabályozásokat a saját álláspont alátámasztására használják fel. De míg a magyar fél tágította e szabályozások értelmezését, addig a román fél a szükítő megjegyzéseket helyezte előtérbe. A térség államainak és más nyugat-európai államok gyakorlatának bemutatása is ezt a cél szolgálta: a magyar álláspont arra helyezte a hangsúlyt, hogy a szomszédos államokban élö magyarokra vonatkozó törvény nem egyedülálló, míg a román arra, hogy kevés európai államban van a státustörvényhez hasonló gyakorlat, a jogszabály pedig - ebben a formájában - túllép az európai szabályozásokon. Fontos és a téma szempontjából nem lényegtelen különbség az állásfoglalásból kirajzolódó nemzetkoncepció sem, amely a román dokumentumban explicite megjelenik. Míg a magyar nemzet-koncepció a kulturális nemzeteszmére épít - áll a jelentésben-, addig a román állásfoglalás a politikai nemzet fogalmát - az állampolgárok közösségét - állítja előtérbe. ${ }^{339}$

A román álláspont az ET PKGY napirendjén is megjelent, ugyanis a román delegáció Gheorghi Prisăcaru szenátor kezdeményezésére aláírásgyűjtésbe kezdett a magyar jogszabály felfüggesztése céljából. ${ }^{340}$ Röviddel a román beterjesztés után René van der Linden holland képviselő is indítványt nyújtott be a határon átnyúló kapcsolatok és a nemzeti kisebbségek identitásának megőrzésére vonatkozóan, melyet a teljes magyar delegáció támogatott. ${ }^{341}$ A két indítvány alapján az ET Jogi és emberjogi bizottsága szeptember végén Erik Jürgens holland képviselőt bízta meg a jelentés elkészítésével.

A felsőszintü találkozókon született egyezség eredményeként szeptember 10-én összeült a kisebbségi szakbizottság, amely szeptember-október folyamán összesen három alkalommal ülésezett. ${ }^{342}$ Magyar részről a kisebbségi szakbizottság ülésének összehívása több szempontból is kedvezőnek bizonyult. Egyrészt azért, mert a szakbizottság eddigi müködéséből arra lehetett következtetni, hogy a megfogalmazott ajánlásokat nem követik konkrét lépések, a vita „lecsengésével” pedig fennmarad a

\footnotetext{
${ }^{339}$ E különbségre a román álláspont mutat rá (ibid. pp. 2-3).

${ }^{340}$ A megfogalmazott indítvány hangsúlyozta a magyar státustörvény diszkriminatív és extraterritoriális jellegét, amely újabb feszültségekhez vezethet a térség államai között, ezért javasolta a Közgyülésnek, hogy kérje fel a magyar hatóságokat a jogszabály végrehajtásának felfüggesztésére és a konzultációk folytatására. A kezdeményező indítványát - aki a Szenátus külügy bizottságának elnöki tisztségét is betöltötte - a Közgyülés 37 tagja támogatta („Motion for a resolution presented by Mr Prisăcaru” 2001).

341 („Transfrontier co-operation in preserving the identity of national minorities” 2001).

342 A kisebbségi szakbizottság szeptember 10 és 24, valamint október 19-én ülésezett.
} 
status quo, amely a magyar félnek kedvez. Másrészt a kisebbségi szakbizottság keretei között folytatott vitában a magyar fél pozíciója előnyösebb volt, mert kisebbségi kérdésben - a státustörvény elfogadását követően - olyan helyzet állt elö, amikor akarva-akaratlanul a román fél vált a javaslattevővé: ha eredményeket akar felmutatni, akkor ő kellett kezdeményező szerepben fellépjen. A kisebbségügyi szakbizottság negyedik ülésén a felel áttekintették a romániai magyar és a magyarországi román közösség helyzetében történt fejleményeket, de az előzetes várakozásokhoz képest az egyeztetések nem vezettek előrelépésre a felek között kialakult vitában. ${ }^{343}$

Míg tehát államközi szinten sem a felsőszintü találkozók, sem a kisebbségi szakbizottság ülései nem vezettek eredményre, október-november folyamán az európai fórumok rendre ismertették a státustörvénnyel kapcsolatos álláspontjukat. Október 22én a Velencei Bizottság 48. Plenáris ülését követően tette közzé jelentését. ${ }^{344} \mathrm{~A}$ dokumentum hangsúlyozta, hogy az anyaállamoknak a határaikon kívül élő kisebbségek iránt érzett felelőssége nem új jelenség Európában, amely számos alkotmányban, jogszabályban és államközi megállapodásban fellelhető. A jelentéstevők ${ }^{345}$ kilenc államnak a határon túli kisebbségek kedvezményes elbánására vonatkozó jogszabályait hasonlították össze, amelyből megállapították, hogy az anyaállamok kisebbségeik védelme értekében egyoldalú intézkedéseket tehetnek, amennyiben tiszteletben tartják a következő elveket:

(1) az államok szuverenitása: a területen kívüli hatállyal bíró jogszabályok nem minden esetben sértik az adott állam szuverenitását ${ }^{346}$; (2) a meglévő kötelezettségek jóhiszemü teljesítése (pacta sunt servanda): a meglévő kétoldalú egyezmények kisebbségvédelmi rendelkezésének teljesítése, illetve ennek bővítése a kétoldalú tárgyalások keretében; (3)

\footnotetext{
343 A román delegációt Crisitian Diaconescu külügyi államtitkár a bizottság társelnöke, míg magyar delegációt Szabó Tibor, a HTMH elnöke vezette. Az üléseken két RMDSZ-es képviselő, Márton Árpád és Varga Attila vett részt. Annak betudhatóan, hogy a tárgyalásokon mindkét fél fenntartotta korábbi álláspontját, a végleges jegyzőkönyvben a pozitív diszkrimináció értelmezésén kívül semmilyen más utalás vagy ajánlás sem vonatkozott a státustörvényre. A felek között csak arra vonatkozóan volt egyetértés, hogy területükön elfogadják a pozitív diszkriminációt célzó intézkedéseket, amellyel a nemzeti kisebbségek és többségi lakosság közötti esélyegyenlőségét biztosítanák a kulturális és nyelvi identitás területén. A román fél azonban elutasította, hogy az etnikai alapú pozitív diszkrimináció elvét a szociális és gazdasági jogosítványokra is kiterjesszék („Protocol of the IV Meeting of the Joint Committee on National Minorities" 2001).

344 (,Jelentés a nemzeti kisebbségek számára az anyaállamok által biztosított kedvezményes bánásmódról.” 2001).

${ }^{345}$ A jelentéstevők Franz Matscher, Francois Luchaire, Giorgio Malinverni és Peter Van Dijk voltak egy alkalommal Párizsban megbeszélést folytattak a két állam képviselőivel.

346 A jelentés példaként ide sorolja a kulturális, oktatási és az identitás megtartását támogató kedvezményeket, egyéb területeken az érintett állam egyetértése explicit kell legyen. A jogalanyok nemzetiségét igazoló ajánlások vagy tanúsítványok kibocsátásában a határon túli szervezetek közjogi kompetenciákkal való felruházása problematikus, ehelyett a „természetes közremüködők a konzuli hatóságok lehetnének" (ibid. p.147).
} 
az államok közötti jószomszédi kapcsolatok elve alapján az államoknak tartózkodniuk kellene az olyan egyoldalú intézkedésektől, amelyek veszélyeztetik az államközi együttmüködést $^{347}$; (4) az alapvető emberi és szabadságjogok betartása és a diszkriminációmentesség elve. A Bizottság szerint az eltérő bánásmód az oktatás és a kultúra területén, valamint más kivételes esetekben engedhető meg, ha az kimutathatóan az anyaállammal meglévő kapcsolatok fenntartására irányul. ${ }^{348}$ A Bizottság legfontosabb megállapítása az, hogy a kisebbségek védelméért elsősorban a lakóhelyük szerinti állam tartozik felelősséggel, de elismeri az anyaországok szerepét is a kisebbségvédelemben, amely az őket összekötő nyelvi és kulturális kötelékek megőrzésére irányul. ${ }^{349}$ Emellett hangsúlyozta a meglévő államközi szerződések és megállapodások, az ide vonatkozó európai normák tiszteletben tartását, a vitarendezési eljárások igénybe vételének lehetőségét, szűk teret engedve az anyaország egyoldalú intézkedéseinek megalapozottságára.

Nem sokkal a Bizottság jelentésének nyilvánosságra kerülése után az EBESZ Kisebbségi Főbiztosa, Rolf Ekéus közleményében az államok és a nemzeti kisebbségek viszonyában a stabilitás és a status quo fenntartását hangsúlyozta és az anyaország egyoldalú intézkedéseinek negatív következményeire hívta fel a figyelmet. A dokumentumban explicite nem történik hivatkozás Magyarországra, de a státustörvény vitájának kontextusában a közlemény fö címzettje a magyar állam volt. ${ }^{350}$ A Főbiztos elismerve azt a tényt, hogy a nemzet és állam határai ritkán esnek egybe, megismételte a Velencei Bizottság véleményét, és azt hangsúlyozta, hogy a kisebbségi jogok védelme annak az államnak a kötelezettsége, amelynek területén az adott kisebbség él. Noha elfogadta, hogy egyes államok érdekeltek a határon túli kisebbségek iránt, a megítélt kedvezmények odaítélésében az államok - áll a közleményben - óvatosan kell eljárjanak, nehogy az intézkedésnek ,dizintegráló hatása legyen abban az államban, amelyben e csoportok élnek” (Ekéus 2001).

A Főbiztosnak a kedvezmények negatív hatásaira vonatkozó következtetése igencsak meglepő annak kontextusában, hogy a törvény elfogadása és hivatalba lépése után több alkalommal konzultált a két állam képviselőivel, júliusban és szeptemberben

\footnotetext{
${ }^{347}$ Jó példa erre az igazolványok bevezetése, amely kapcsán a jelentés kifejtette, hogy ez az anyaállam által biztosított kedvezmények igénybevételének megkönnyítésére és nem az anyaállam és a határon túli kisebbség közötti „,politikai kötelék létrehozására kellene irányuljon.”

348 Ibid. p. 151.

${ }^{349}$ Ibid.

350 „A történelem azt mutatja - olvasható a közleményben -, hogy ha a nemzeti összetartozás alapján államok egyoldalú lépéseket tesznek az adott állam joghatóságán kívül élő nemzeti kisebbségek védelme érdekében, akkor ez olykor feszültségekhez, sőt, erőszakos összecsapáshoz vezet” (Ekéus 2001).
} 
pedig az RMDSZ képviselőivel is. Míg a július 24-i találkozó tájékoztató jellegü volt, ahol a Szövetség képviseletében Verestóy Attila szenátor számolt be a Főbiztosnak a státustörvény elfogadását követő román reakciókról ${ }^{351}$, addig szeptember 11-én a Főbiztos Markó Béla szövetségi elnökkel folytatott tárgyalásokat. ${ }^{352}$ A Főbiztos nyilatkozata, valamint a fentebb bemutatott közlemény világosan tükrözi az EBESZ álláspontját a kérdésben, amely aligha változott egy évtized alatt: a kisebbségi jogok előremutató fejleményeként értékelendő anyaországi kedvezményes elbánás elve helyett a stabilitást és az elért vívmányokat tekinti irányadónak az európai államok számára. ${ }^{353}$

A státustörvény kérdése végül az EU-s csatlakozás kontextusában, az EB Magyarországról készült éves jelentésében is láthatóvá vált. Az EB elsősorban abban volt érdekelt - jegyezte meg Vizi Balázs - hogy politikai kérdésekben, beleértve a kisebbségvédelmet mérsékelt maradjon és elkerülje a tagjelölt államok közötti politikai konfliktusok kialakulásának lehetőségét (Vizi 2006, p. 95). Ennek megfelelően a jelentés nem részletezi a jogszabállyal kapcsolatos vitákat, de megállapítja azt, hogy (1) a törvény konzultáció nélküli elfogadása vitát váltott ki egyes szomszédos államokkal, valamint (2) egyes rendelkezései ellentétesek az európai kisebbségvédelmi normákkal amint arra a Velencei Bizottság rámutatott jelentésében (European Commission 2001, p. 91). Az EB a státustörvény kapcsán több javaslatot is megfogalmazott: elsőként arra kérte a magyar felet, hogy a csatlakozás időpontjától a törvény rendelkezéseit összhangban kell alkalmazni a csatlakozási szerződéssel és a közösségi joggal. Másodsorban az EB azt javasolta, hogy a kerettörvény végrehajtásának rendeleteit a Velencei Bizottság által megfogalmazott elvek mentén fogadják el. Végül pedig, a konfliktus rendezése érdekében arra hívta fel Magyarország figyelmét, hogy folytassa a szomszédos államokkal a jogszabályra vonatkozó konzultációkat (ibid).

Az európai fórumok álláspontját, különöse pedig a VB jelentését mindkét fél a saját győzelmeként tematizálta. A VB döntésétéről Adrian Năstase kifejtette, hogy a

\footnotetext{
351 A találkozón a szenátor hangsúlyozta, hogy a státustörvény elfogadása túlzott aggodalmakat keltett Romániában. Ebből kifolyólag - mutatott rá a Verestóy Attila - a törvény alkalmazásában továbbra is szükség van a román és magyar kormány között egyeztetésre, ennek folyamatában pedig a Szövetségnek is sajátos szerepe kell legyen. Rolf Ekéus, az EBESZ Kisebbségügyi Főbiztosának látogatása a szövetségi elnök bukaresti elnöki hivatalába. RMDSZ Tájékoztató, IX. évfolyam, 2014. szám, 2001. július 24.

Szintén aznap a kormánypárttal való találkozó után Markó Béla kifejtette, hogy „,a szövetség nem kívánja a moderátor szerepét játszani a két kormány között, de a maga eszközeivel az ellentétek elsimítására törekszik." Folytatódik a kormánypárt és az RMDSZ együttműködése (ibid).

${ }^{352}$ E találkozók célját a Főbiztos a kisebbségek jogi helyzetének és a többség-kisebbség viszonyának feltérképezésében jelölte meg. Elsőrendü feladatom - hangsúlyozta a találkozó után - megbizonyosodni arról, hogy „,a státustörvény által kiváltott vita nem vezet etnikumközi konfliktushoz.”Markó Béla az EBESZ Kisebbségügyi Főbiztosát fogadta. RMDSZ Tájékoztató, IX. évfolyam, 2035. szám, 2001. szeptember 11.

${ }^{353}$ Hasonló következtetést fogalmazott meg: (Vizi 2006, p. 95).
} 
jelentés „nagyon kedvező formában tükrözte a státustörvénnyel kapcsolatos román álláspontot, legnagyobb részt megalapozottnak találta a román fenntartásokat." ${ }^{, 354}$ Ennek értelmében a jogszabály több pontját is módosítani kell, hogy megfeleljen az európai normáknak. Hasonló véleményen voltak a vezető román napilapok, a melyek a VB döntését Románia győzelmeként értékelték. ${ }^{355}$ A román állásponthoz képest Martonyi János külügyminiszter és Németh Zsolt államtitkár a jelentést a magyar álláspont elfogadásaként értékelték, és rámutattak arra, hogy az anyaországoknak joguk van olyan törvényeket hozni, amelyekben kedvezményeket biztosítanak a határaikon túl élö nemzeti kisebbségeknek. ${ }^{356}$

A VB döntése alapján az RMDSZ szövetségi elnöke megállapította, hogy továbbra is szükség van a két fél konzultációjára, amit az RMDSZ a vita kezdetétől szorgalmazott. Markó Béla a jelentésből kiemelte, hogy a testület nem vonta kétségbe a törvény alapelveit és kimondta, hogy egy állam kedvezményeket nyújthat más országokban élő nemzettársainak. A szövetségi elnök nyilatkozata azért tekinthető fontosnak, mert újfent hangoztatta az RMDSZ részvételét a státustörvény végrehajtásában. ${ }^{357}$

Az európai fórumok által közzétett jelentések és nyilatkozatok nem vezettek a magyar-román vita megoldásához, mi több a MÁÉRT negyedik ülésének zárónyilatkozata - amely a VB döntése értelmében megállapította, hogy a jogszabály megfelel az európai normáknak és nem szorul módosításra - fenntartotta a két állam közötti nézeteltérést. ${ }^{358}$ A november 16-án Bukarestben megtartott CEFTA-ülés újabb

\footnotetext{
${ }^{354}$ Velencei Bizottság: a román kormányfő és a külügyminiszter nyilatkozata. MTI Hírarchívum, 2001. október 19., keresőszó: státustörvény.

${ }^{355}$ A napilapok a testület jelentéséböl következtetésként megállapították, hogy a státustörvény egyrészt nem érvényes Románia területén, másrészt a jogszabály végrehajtásában az ajánló szervezetek (RMDSZ, egyházak, civil szervezetek) nem vehetnek részt. Lásd az Adevărul, a Jurnalul Naţional, a Curentul, a Cronica Română, az Evenimentul Zilei, a Curierul Naţional anyagait. Román visszhang: "meglékelték" a státustörvényt. Szabadság, 2001. október 22. 8.

${ }^{356}$ A külügyminiszter a döntésről elmondta, hogy a kormány a végrehajtási rendeleteknél figyelembe fogja venni a testület javaslatait. A Velencei Bizottság jelentése: Martonyi János és Németh Zsolt nyilatkozata. MTI Hirarchívum, 2001. október 19. A Velencei Bizottság döntését Németh Zsolt a vele készült interjúban a következőképpen értékelte: „Ilyen értelemben az ajánlás nagyon nagymértékben kitágította az elkövetkezendö évekre vonatkozóan a horizontját a nemzetpolitikának, hiszen a státustörvény talán ma már nem tölt be olyan jelentös szerepet, de az a vélemény, amely megfogalmazódott a státustörvényben, hogy milyen kapcsolata lehet az anyaországnak és a külhoni magyar közösségeknek, annak normaalkotó jelentösége volt."

${ }^{357}$ Velencei Bizottság: Markó Béla nyilatkozata. MTI Hírarchívum, 2001. október 20. Az RMDSZ elnöke amellett foglalt állást, hogy az igények összegyüjtését a szövetség apparátusának kell elvégeznie, amelynek felügyeletét a Szövetség, az egyházak és a civil szervezetek képviselöiből álló testület biztosítja.

358 („A Külügyminisztérium nyilatkozata Románia Kormányának a magyar kedvezménytörvénnyel kapcsolatos 2001. október 29-i nyilatkozatával összefüggésben.” In: Magyar Külpolitikai Évkönyv. 2001, pp. 325-27).
} 
alkalmat adott a felsőszintű találkozóra, ahol a két állam miniszterelnöke a státustörvényröl folytatott tárgyalást és a felek abban egyeztek meg, hogy megújítják a szakértői tárgyalásokat.

Az kétoldalú tárgyalások a két miniszterelnök levélváltását követően indultak el, amelyben Orbán Viktor a tárgyalások folytatását a magyar-román kisebbségi szakbizottság keretében vagy pedig a két kormányfö személyes megbízottjának találkozója révén tartotta elképzelhetőnek. ${ }^{359}$ A román kormányfő az utóbbi javaslatot fogadta el, aminek eredményeként a két állam Külügyminisztériumának államtitkárai Németh Zsolt és Crisitian Diaconescu bukaresti tárgyalásain a státustörvényre vonatkozó egyetértési nyilatkozat kidolgozásban egyeztek meg. A dokumentumot a felek december 21-én véglegesítették, amit másnap, december 22-én a két állam miniszterelnöke kézjegyével is ellátott (Egyetértési Nyilatkozat, 2001). A megállapodás lezárta a két állam között kialakult vitát és a státustörvény alkalmazásában tekintettel a VB döntésére, az EBESZ Főbiztosának nyilatkozatára, valamint az alapszerződés nemzetiségi cikkelyére a következő változásokat irányozta elő: (1) a munkavállalási engedélyek román állampolgárokra való kiterjesztése; (2) Magyar igazolványt csak a magyar identitású személyek kaphatnak; (3) a Magyar igazolványok kiállítása elsősorban Magyarországon fog zajlani; (4) az ajánlószervezetek nem adhatnak ki olyan ajánlást, amely az etnikai eredetre vonatkozik; (5) az igazolvány csak személyes adatokat tartalmaz, a származásra vagy nemzeti identitásra való utalás nélkül; (6) Magyarország csak román hatóságok előzetes hozzájárulásával nyújt támogatást a romániai magyar politikai szervezeteknek; végül pedig (7) a magyar hatóságok fél éven belül kezdeményezik a törvény felülvizsgálatát és szükséges módosítását (ibid).

A két állam közötti megegyezésben - nem első alkalommal - jelentős szerepet töltött be az RMDSZ és a szövetségi elnök, Markó Béla. ${ }^{360}$ A Szövetség annak betudhatóan vállalhatta magára a közvetítő szerepet, hogy egy viszonylag intenzívnek mondható parlamenti együttmüködés keretében támogatta a szociáldemokrata kormányt. Egy esetleges vita, vagy mélyebb konfliktus felvállalása a kormány pozícióját gyengítette volna. Egy másik értelmezésben pedig maga a Szövetség, mint a

\footnotetext{
359 („A Külügyminisztérium tájékoztatója - a szóvivője útján - a kedvezménytörvénnyel kapcsolatos magyar-román tárgyalás folytatására tett magyar javaslatról, 2001. december 12." In: Magyar Külpolitikai Évkönyv. 2001, p. 363).

${ }^{360}$ Az interjúalanyok közül többen hangsúlyozták az RMDSZ és Markó szerepét, aki szorgalmazta a felek közötti együttmüködést (Markó Béla, Szent-Iványi István, Székely István), mi több Bálint-Pataki József kihangsúlyozta, hogy ,ha a Szövetség nem váll szerepet ebben az ügyben nem lett volna megegyezés”.
} 
román pártrendszer egyik legstabilabb szereplője lehet a garancia arra, hogy a jogszabály az egyezménynek megfelelően kerül alkalmazásra. ${ }^{361}$

A két állam közötti megállapodás aláírását hevesen bírálták a magyar ellenzéki pártok. Az MSZP, az SZDSZ, valamint a MIÉP a magyar munkaerőpiac védelmét hangsúlyozta és amellett foglaltak állást, hogy az államközi megállapodásnak a magyar munkavállalókra nézve komoly következményei lesznek. ${ }^{362}$ A nyilatkozat aláírásáról a román parlamenti pártok eltérő módon nyilatkoztak. Míg a PNL képviselői pozitívan fogadták a két állam közötti egyezmény létrejöttét és a megegyezést az ellenzéki munka eredményeként kommunikálta, mivel „példásan” ellenőrizték a kormány munkáját, addig a PD elnöke „,pótcselekvésnek” tekintette az egyezményt, mert nem szüntette meg a jogszabály etnikai jellegét. ${ }^{363}$

Január elején a MÁÉRT képviselői Orbán Viktor miniszterelnökkel tárgyaltak a szomszédos államokban élő magyarokról szóló törvény végrehajtásáról és nyilatkozatban foglaltak állást a magyar-román megegyezés létrejöttéért, valamint a törvény hatályba lépéséért. ${ }^{364} \mathrm{~A}$ jogszabály romániai végrehajtása január 21 -én vette kezdetét, amikor Erdély-szerte megnyíltak a tájékoztató irodák. ${ }^{365}$ Megyei és területi szinten összesen 21 iroda alakult meg (Székely 2002, p. 142), az igénylők számának megfelelő személyi állománnyal. ${ }^{366}$

\footnotetext{
361 “Az igazság, hogy a [státustörvény] ügyét mi magunk mozditottuk ki a holt pontról. [...] Sok vitánk volt, de végül meggyőztem a román miniszterelnököt, hogy fogadják el abban a formában, hogy az RMDSZ bonyolitja le ennek a státustörvénynek az alkalmazását Romániában. Tehát mi garantáljuk és a mi irodáinkban zajlik a jogszabály alkalmazása. Az RMDSZ számára ez fontos politikai eredmény volt, mert ezáltal egy nagyon komoly befolyásolási eszköz került a kezünkbe” (interjú Markó Bélával).

${ }^{362} \mathrm{Az}$ MSZP a státustörvény felülvizsgálatát kérte, amiért a kormány mindenféle ellenőrzés nélkül megnyitotta Magyarország munkaerő-piacát. Szent-Iványi István (SZDSZ) azon a véleményen volt, hogy a kormány a legrosszabb megoldást választotta, amelynek következményeként hátrányos helyzetbe kerülnek a magyarországi munkavállalók. Ennek megakadályozására az SZDSZ a státustörvény módosítását kezdeményezte. A MIÉP amellett foglalt állást, hogy tapintatosabban kezelte volna a munkavállalók kérdését, mert amíg minden magyar embernek nincs munkája, addig nem biztos, hogy a munkaerőpiac megnyitása - a legcélszerübb megoldás - összegezte Győri Béla szóvivő. Munkaerőpiacukat féltik a magyar pártok. Szabadság, 2001. december 27., 8.

${ }^{363}$ Emil Boc szerint a legjobb megoldás az lenne, ha a kezdeményezők lemondanának a törvényről. Szocialista offenzíva a megállapodás ellen. Szabadság, 2001. december 28., 8.

364 „A határon túli magyar politikai vezetők nyilatkozata a Magyarországgal szomszédos államokban élő magyarokról szóló törvény hatályba lépése alkalmából”, In: Kántor 2002, pp. 180-181.

365 A kérelmek lebonyolítására felállított irodákat több elnevezéssel illették: információs iroda, ajánlóiroda, státusiroda. A memorandum értelmében az irodák a tájékoztatásra és az igazolvány megszerzéséhez szükséges kritériumok teljesítésére vonatkozó információk továbbításában nyújtottak segítséget.

${ }^{366}$ A státusirodáknak volt egy felívelő korszaka, 370 alkalmazott volt a maximum, ami aztán lecsökkent 80 före (interjú Székely Istvánnal).
} 


\section{A nemzeti parlamentekben lefolytatott viták}

A határon túli magyarokról szóló törvény előkészítését és elfogadását - mind az már a külügyi bizottsági vitákból is kirajzolódott - eltérő módon ítélték meg a magyarországi parlamenti pártok, aminek következményeként a jogszabály célja, az egyes kedvezmények indokoltsága és a végrehajtás módozatai jelentős vitákhoz vezettek a parlamenti pártok között. A nagyfokú érdeklödésnek és az eltérö álláspontoknak betudhatóan a törvényjavaslat vitája elhúzódott: az általános vitát május elején zárták le, míg a részletes, a módosító indítványok megvitatására az Országgyűlés május végi és június első felében megtartott ülésnapjain került sor. Az eredeti törvénytervezet a részletes parlamenti vitákat követően kisebb módosításokon és kiegészítéseken esett át, de alapvető változások nem történtek. A jogszabályhoz benyújtott 144 módosító indítvány közül csak néhányat támogattak a kormányzó pártok: az indítványok egy jelentős részét a vita során visszavonták, másokat pedig leszavazták. Végül a törvényt az Országgyülés 92\%-os többséggel fogadta el.

A román parlamentben a státustörvény a jogszabály elfogadását megelőzően marginális kérdésként - egy parlamenti kérdés kapcsán - jelent meg, amely jelzi a törvényhozás korlátozott szerepét a külpolitikai döntéshozatal folyamatában. ${ }^{367}$ A jogszabály elfogadását követően az ellenzéki pártok képviselői (PNL, PD és PRM) mindkét házban - napirend előtti felszólalások, valamint pártjuk álláspontjának ismertetése keretében - kísérletet tettek arra, hogy tematizálják a kérdést, sikertelenül. A státustörvény azt követően került napirendre, miután a szélsőséges PRM 2002. február 28-án a Szenátusban egyszerű indítványt nyújtott be a kormány ellen, amiért a magyar féllel megkötött egyetértési nyilatkozat alkalmazását - parlamenti ratifikáció nélkül lehetővé tette. A Szenátus az indítvány vitáját március elején tủzte napirendre, azonban az ellenzéki támogatás nem bizonyult elegendőnek: a kormányzó PDSR az RMDSZ támogatásával 69:47 arányban, két tartózkodás mellett leszavazta az indítványt. ${ }^{368}$

\footnotetext{
${ }^{367}$ A Szenátus május 14-i ülésén Dumitru Badea (PRM) és Adrian Păunescu (PDSR) egyszerü kérdést intézett a Külügyminisztérium képviselöjéhez, amelyben a román kormány álláspontjának kifejtését kérték az elfogadás előtt álló jogszabállyal kapcsolatosan. A vitán jelen levő államtitkár, Cristian Niculescu felidézte a két fél közötti egyeztetéseket majd megismételte a miniszterelnök egy korábbi álláspontját, miszerint a két fél előzetes egyeztetése nélkül a jogszabály nem alkalmazható Románia területén.

368 („Abandonarea Transilvaniei. Erdély elárulása c. egyszerű indítvány, 2002. március 7.)
} 
Az elemzés további része egyrészt az Országgyülésben lezajlott általános vitára $^{369}$, a módosító indítványok részletes vitájára ${ }^{370}$, végül pedig a záróvitán elhangzott felszólalások elemzésére ${ }^{371}$, másrészt pedig a képviselőházi és a szenátusi felszólalások, valamint a Szenátusban lefolytatott egyszerü indítvány vitájának ${ }^{372}$ elemzésére terjed ki. Noha a Szenátusban felfolytatott vita kulcskérdése a két állam közötti megállapodás aláírása, a jegyzőkönyv elemzéséből világosan kirajzolódnak a pártok státustörvénnyel kapcsolatos álláspontjai is. A vita - hasonlóan az magyar parlamentben lefolytatott vitához - az eltérő érvrendszerek és álláspontok ütköztetésén túlmenően alkalmasnak bizonyult arra, hogy az ellenzék bírálja a kormány politikáját az államközi kapcsolatokat illetően, továbbá Románia esetében a kormány és az RMDSZ viszonyát, míg Magyarország esetében a kormány határon túli magyarokkal kapcsolatos politikáját.

11. sz. táblázat: A státustörvényről szóló viták általános jellemzői

\begin{tabular}{|c|c|c|}
\hline & Románia & Magyarország \\
\hline A vita státusa & egyszerü indítvány vitája & általános vita; részletes vita; záróvita \\
\hline A vita időpontja & 2002. március 6. & 2001. április 19. - június 19. \\
\hline A vita időtartama & 2 óra 50 perc & 13 óra \\
\hline A szövegtest mérete & 85 oldal/24152 szó & 231 oldal/93210 szó \\
\hline Felszólalók száma & 16 & 164 \\
\hline
\end{tabular}

Követve a módszertani részben megfogalmazott munkamódszert, elsőként a státustörvény értelmezésére, majd a parlamenti pártok álláspontjainak bemutatására törekszem, mindkét államban. Az elemzés második részében összehasonlító perspektívában feltárom a pártok között megosztottság főbb jellemzőit és meghatározom a pártok pozícióit, végül pedig a főbb témák és érvrendszerek elemzésére teszek kísérletet.

Az Országgyülésben, valamint a román Szenátusban zajló vitában domináns témát képez a státustörvény eltérő értelmezése (célkitüzés, folyamata, valamint hatásai). Az alapszerződés értelmezéséhez hasonlóan (1) domináns és előfordul mindkét vitában: kétoldalú kapcsolatok és a szomszédos államhoz való viszony; határon túli

\footnotetext{
369 („A szomszédos államokban élő magyarokról szóló törvényjavaslat általános vitája.” 2001. április 19; „A szomszéd államokban élő magyarokról szóló törvényjavaslat általános vitájának folytatása és lezárása" 2001).

370 („A szomszédos államokban élő magyarokról szóló törvényjavaslat részletes vitája”; „A szomszédos államokban élő magyarokról szóló törvényjavaslat részletes vitájának folytatása és lezárása”).

371 („A szomszédos államokban élő magyarokról szóló törvényjavaslat záróvitája és zárószavazása”).

372 (,Szenátusi vita jegyzőkönyve. Stenograma Şedinţei Senatului din 7 martie 2002”).
} 
magyarság/magyar kisebbség (RMDSZ szerepe); európai fórumokhoz való viszony, valamint a legfontosabb kritikák közül a törvény diszkriminatív és területen kívüli jellege; (2) csak egyik államban dominánsak: a státustörvényhez kapcsolódó különböző támogatások és juttatások, gazdasági felzárkózás és munkavállalást, határon túli közösségek megerősítése, mint nemzetpolitikai célkitüzés (HU); a román nemzeti érdek és a szuverenitás kérdése (RO); (3) kevésbé domináns téma mindkét államban: a Magyar igazolványok kibocsátása és tartalma; (4) kevésbé domináns: jóvátétel és történelmi adósság, a jogszabály jogalanyai; a jogszabály pénzügyi vonzatai; nemzetkoncepció és az alkotmányból eredő felelősségvállalás (HU); munkavállalás (RO); (5) mindkét vitában marginálisabb témát képez a külpolitikai prioritás, illetve a külpolitikai mozgástér, és a jogszabály nemzetközi jogi megalapozottsága; (6) marginális téma a jogi viszony kialakulása és kivándorlás, valamint az asszimiláció mérséklése (HU), illetve a jogszabály nyújtotta kedvezmények, a kölcsönösség elve alapján pedig a határon túli román közösségek támogatása (RO).

A két vitában a domináns és a kevésbé domináns témák összevetéséből az alapszerződés vitájához hasonló tematikai különbségek figyelhetők meg. Míg a státustörvényről szóló vitákban a felszólalók nem kerülhetik meg a jogszabály tartalmának vagy következményeinek értelmezését, sem az európai fórumokra való hivatkozást, tematikai szempontból eltérő mezőben zajlott a vita. Az Országgyülésben lefolytatott vita az alapvető nemzetpolitikai kérdések megvitatására adott lehetőséget (Milyen eszközökkel biztosítható a határon túli magyar közösségek megerősítése? A státustörvény által bevezetett kedvezmények és támogatások milyen hatást gyakorolnak a szomszédos államokban élő magyarokra?), addig a szenátusi vita a nemzeti érdek sikeres képviseletében és a román állam szuverenitásának megvédésében és a magyar törekvések „elfojtásában” értelmezhető. 
12. sz. táblázat: Kategóriák a státustörvény vitájában

\begin{tabular}{|c|c|c|c|}
\hline \multicolumn{2}{|r|}{ Kategóriák a magyar vitában } & Gyakoriság & $\%$ \\
\hline \multirow{9}{*}{ 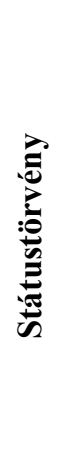 } & A jogszabály értelmezése & 120 & 12,59 \\
\hline & Kedvezmények, támogatások & 106 & 11,12 \\
\hline & Gazdasági felzárkózás, munkavállalás & 60 & 6,30 \\
\hline & Magyar igazolvány & 33 & 3,46 \\
\hline & Jogalanyok & 30 & 3,15 \\
\hline & Pénzügyi vonzatok, költségvetési terhek & 27 & 2,83 \\
\hline & Jogi kapcsolat, jogi státus & 19 & 1,99 \\
\hline & Demográfia: kivándorlás, asszimiláció & 15 & 1,57 \\
\hline & Összesen: & 410 & 43,02 \\
\hline \multicolumn{2}{|c|}{$\begin{array}{l}\text { Nemzetpolitika és a határon túli magyar közösségek } \\
\text { megerösítése }\end{array}$} & 94 & 9,86 \\
\hline \multicolumn{2}{|r|}{ Románia: tájékoztatás, többség-kisebbség viszonya } & 90 & 9,44 \\
\hline \multicolumn{2}{|c|}{ Határon túli magyarok, MÁÉRT és RMDSZ } & 83 & 8,71 \\
\hline \multicolumn{2}{|r|}{ Európai fórumok: integrációs feltételek, kritikák } & 64 & 6,72 \\
\hline \multicolumn{2}{|c|}{ Diszkrimináció és területi hatály } & 40 & 4,20 \\
\hline \multicolumn{2}{|c|}{ Alkotmányos felelősségvállalás } & 26 & 2,73 \\
\hline \multicolumn{2}{|c|}{ Jóvátétel és történelmi adósság } & 31 & 3,25 \\
\hline \multicolumn{2}{|c|}{ Nemzetkoncepció } & 28 & 2,94 \\
\hline \multicolumn{2}{|c|}{ Külpolitikai prioritás/mozgástér } & 19 & 1,99 \\
\hline \multicolumn{2}{|c|}{ Nemzetközi jog } & 11 & 1,15 \\
\hline \multicolumn{2}{|c|}{ Hivatkozások } & 57 & 5,98 \\
\hline \multicolumn{2}{|c|}{ Összesen } & 953 & 100 \\
\hline
\end{tabular}

\begin{tabular}{|l|l|c|c|}
\hline \multicolumn{2}{|c|}{ Kategóriák a román vitában } & Gyakoriság & $\%$ \\
\hline \multirow{3}{*}{} & A jogszabály értelmezése & 28 & 7,65 \\
\cline { 2 - 4 } & Magyar igazolvány & 14 & 3,83 \\
\cline { 2 - 4 } & Gazdasági felzárkózás, munkavállalás & 11 & 3,01 \\
\cline { 2 - 4 } & Kedvezmények, támogatások & 10 & 2,73 \\
\cline { 2 - 4 } & Jogi viszony, kapcsolat & 8 & 2,19 \\
\cline { 2 - 4 } & Összesen: & $\mathbf{7 1}$ & $\mathbf{1 9 , 4 0}$ \\
\hline Memorandum, egyszerú indítvány & $\mathbf{5 5}$ & $\mathbf{1 5 , 0 3}$ \\
\hline RMDSZ, magyar kisebbség & 55 & 15,03 \\
\hline Diszkrimináció és területi hatály & 46 & 12,57 \\
\hline Magyar fél, kétoldalú kapcsolatok & 38 & 10,38 \\
\hline Európai fórumok: integrációs feltétek, kritikák & 38 & 10,38 \\
\hline Szuverenitás és nemzeti érdek & 32 & 8,74 \\
\hline Határon túli román közösségek & 4 & 1,09 \\
\hline Külpolitikai prioritás & 4 & 1,09 \\
\hline Nemzetközi jog & 3 & 0,82 \\
\hline Nemzetkoncepció & 2 & 0,55 \\
\hline Hivatkozások & 18 & 4,92 \\
\hline Összesen & $\mathbf{3 6 6}$ & $\mathbf{1 0 0}$ \\
\hline
\end{tabular}




\subsection{Magyarország}

A státustörvény vitája és a jogszabály elfogadásának folyamata módosította a kormány-ellenzék szembenállását. Míg a jogszabály közigazgatási egyeztetésének folyamatában és a szakbizottsági vitákban az ellenzéki pártok közül egyedül a MIÉP támogatta a jogszabályt, addig a vita lezárásakor és a végső szavazáson, a parlamenti helyek egyharmadát magáénak tudó MSZP is támogatta a státustörvény elfogadását. A jogszabály pártok általi értelmezésében jól elkülönülnek az egymásnak ellentmondó érvek és érvrendszerek, amelyet az alábbi táblázat szemléltet.

13. sz. táblázat: A státustörvény értelmezése és jelentésváltozatai a magyar vitában

\begin{tabular}{|c|c|c|}
\hline & A törvény elfogadását támogató pártok & A törvény elfogadását elutasító pártok \\
\hline : & $\begin{array}{l}\text { A törvény a szomszédos államokban élő magyarok } \\
\text { szülöföldjén való boldogulását segíti. } \\
\text { A státustörvény kifejezi a magyarság } \\
\text { összetartozását. } \\
\text { A határon túli magyarok számára elősegíti a } \\
\text { nemzeti integrációt. }\end{array}$ & $\begin{array}{l}\text { A jogszabály nem segíti elö a határon túli } \\
\text { magyarok szülőföldön való maradását. } \\
\text { Nem az összetartozás, hanem a becsapás és a } \\
\text { szemfényvesztés törvénye. }\end{array}$ \\
\hline 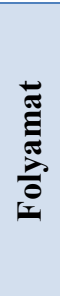 & $\begin{array}{l}\text { A jogszabály a MÁÉRT előterjesztésével, a határon } \\
\text { túli szervezetek bevonásával készült el. } \\
\text { A Külügyminisztérium folyamatosan konzultált az } \\
\text { európai fórumok és szomszédos államok } \\
\text { képviselőivel. } \\
\text { A jogszabály elfogadása megteremtette a nemzeti } \\
\text { konszenzust. }\end{array}$ & $\begin{array}{l}\text { A jogszabály kidolgozása illúziókat keltett a } \\
\text { határon túli magyarok körében. } \\
\text { Túl későn vált nyilvánvalóvá a kedvezmények } \\
\text { jellege és a kedvezményezettek köre. } \\
\text { A kormány nem tudja teljesíteni az előzetesen } \\
\text { beígért kedvezményeket. }\end{array}$ \\
\hline 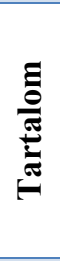 & $\begin{array}{l}\text { Több európai államban találunk hasonló } \\
\text { törvényeket és eljárásokat, amelyek hasonló } \\
\text { kedvezményeket és támogatásokat biztosítanak. } \\
\text { Szabályozza a munkavállalási feltételeket. } \\
\text { A határon túli magyarság oktatásának, nyelvi és } \\
\text { kulturális önazonosságának erősítését szolgálja. }\end{array}$ & $\begin{array}{l}\text { Az igénybe vehető kedvezmények többségét csak } \\
\text { Magyarországon lehet igénybe venni. } \\
\text { A rövid munkavállalói lehetőség nem oldja meg a } \\
\text { magyarországi munkaerő-gondokat. } \\
\text { A támogatások szétosztásának nincsenek világos } \\
\text { kritériumai. }\end{array}$ \\
\hline 茎 & $\begin{array}{l}\text { A törvény megerösíti a határon túli magyar } \\
\text { közösségeket. } \\
\text { Intézményesíti és átláthatóvá teszi a } \\
\text { magyar-magyar viszonyt. } \\
\text { Az alkotmányos felelösségvállalás tartalommal, } \\
\text { konkrét intézkedésekkel töltődik fel }\end{array}$ & $\begin{array}{l}\text { A törvénytervezet és a kedvezmények } \\
\text { elvándorlásra ösztönöznek. } \\
\text { A szomszédos államok nélkül, magyar-magyar } \\
\text { párbeszéddel nem oldható meg a határon túli } \\
\text { magyarok helyzete. } \\
\text { A jogszabály feszültséget kelt a szomszédos } \\
\text { államokkal és a többség-kisebbség viszonyában. }\end{array}$ \\
\hline
\end{tabular}

A státustörvény elfogadását támogató kormánypártok, valamint a MIÉP érvrendszere a következő kijelentések köré épült: (1) a jogszabály olyan kedvezményeket és támogatásokat nyújt, amelyek erösítik a határon túli magyar közösségek megmaradását; (2) a munkaeröpiacon nyújtott kedvezmények a magyar gazdaságra is pozitív hatással bírnak; (3) az európai gyakorlatnak megfelelő rendelkezéseket tartalmaz. Ezzel szemben az ellenzéki pártok amellett érveltek, hogy (1) a jogszabályban nyújtott kedvezmények inkább az elvándorlást segítik elö; (2) a törvényben foglalt kedvezmények túlzott tehertételeket rónak a magyar költségvetésre, 
amelyre vonatkozóan nincsenek pontos számadatok; (3) az egyeztetés hiánya, és a jogszabály elfogadása feszültséghez vezet az államközi kapcsolatokban.

A kormányzó FIDESZ a státustörvény elfogadását a magyar nemzetpolitika szempontjából mérföldkőnek tekintette és a nemzeti integráció, a határon átívelő nemzetegyesítés első lépéseként értékelte. Ennek előzményeit visszavezette a rendszerváltás időszakára, a határon túli magyarokra vonatkozó alkotmányos felelősség elvére, ami a státustörvény elfogadásával konkrét tartalmat kapott. A párt nevében felszólalók a jogszabály indokoltságát az alkotmányos felelősségen túlmenően jóvátételi kérdésként és a történelmi adósság törlesztéseként értelmezték, amelyet összekapcsoltak Magyarország növekvő gazdasági erejével és külpolitikai pozíciójának helyreállításával. Erre utal Pótápi Árpád felszólalásában: „...ma, egy évtizeddel a fél évszázados diktatúrák korszaka után, újra erősödő, gyorsan fejlödö, Európa jobbik feléhez csatlakozó állam Magyarország. „373

A magyar állam integrációs sikerétől azonban elválaszthatatlan a határon túli magyarok helyzete, amely egyik domináns témája a felszólalóknak. A képviselők úgy ítélték meg, hogy noha jelentős változások történetek a határon túli magyarok helyzetében, a többség-kisebbség viszonyában az egyéni és közösségi jogok bővítésében van bőven tennivaló. A FIDESZ nemzetpolitikája arra irányul, hogy támogassa e törekvéseket, erősítse a magyar-magyar kapcsolatokat (MÁÉRT megalakulása), a státustörvényben foglalt kedvezményekkel és támogatásokkal biztosítsa a közösségek szülőföldön való boldogulását.

Az ellenzéki pártok részéről érkező legfőbb kritikákra - a jogszabály tartalma és elfogadásának folyamata - a FIDESZ képviselői érdemben reagáltak és amellett, hogy részletezték a kedvezmények széles körét, a munkavállalási lehetőségek pozitív hozadékát hangsúlyozták, ami minkét fél számára nyerő helyzetet jelent: míg az anyaország irányába áramló illegálisan foglalkoztatott munkaerő mértéke csökken és befizetett adók jelentős bevételt képeznek, addig a munkavállalási kedvezmény mutatott rá Nagy Gábor Tamás - segíti a határon túli magyarok gazdasági megerősödését. ${ }^{374}$ A jogszabály elfogadására érkező kritikákra a FIDESZ képviselői két módon reagáltak: egyrészt arra hívták fel a figyelmet, hogy a jogszabály előkészítésébe

\footnotetext{
${ }^{373}$ Pótápi Árpád (FIDESZ) felszólalása a státustörvény általános vitájának folytatásán (2001. május 9.).

374 „Amennyiben szabályozott és átlátható keretek között oldjuk meg a határokon túli magyarok munkavállalását, az nem csupán a magyar gazdaság sikeres fejlődését, hanem az Európai Unió és a helyi, a határon túli magyar közösségek gyarapodását is jelenti.” Ibid. Nagy Gábor Tamás felszólalása (FIDESZ).
} 
bevonták a MÁÉRT képviselőit, amellyel gyakorlatilag nemzeti konszenzus alakult ki a jogszabályról. Ezt megerősítették az ,általános”, „politikai”, „társadalmi” konszenzusra vonatkozó jelzős szerkezetek. A kritikák hatástalanításának másik eszköze a szomszédos államokkal és az európai fórumokkal való egyeztetések és tájékoztatások nyomatékosítása volt. A tájékoztatók fontosságát Németh Zsolt államtitkár felszólalásaiban több alkalommal hangsúlyozta, mi több a jogszabály elfogadását a térség stabilitásának szempontjából és Magyarország integrációs esélyeinek javítása szempontjából értelmezte.

Az $M D F$ a magyar jog- és politikatörténet előzménynélküli lépéseként értékelte a státustörvény beterjesztését és vitáját. A párt képviselői feltétel nélkül támogatták a jogszabály elfogadását, azonban hangsúlyozták annak hiányosságait is: „az anyag számos kívánnivalót hagy maga után”, ,a törvényjavaslat nem hibátlan”, „,nem egy optimális, remekbe szabott törvény." A jogszabályhoz kapcsolódó kritikai megjegyzések és a benyújtott módosító indítványok egyik funkciója a konszenzusteremtés, a javaslat elfogadását ellenző képviselők meggyőzése és támogatásuk megszerzése egy olyan jogszabály elfogadásában, amely tartalmában nem tökéletes, de célkitüzésében létfontosságú. E célkitüzés pedig megteremti a kedvezmények keretének szélesítését és a jogszabály továbbfejlesztésének lehetőségét. ${ }^{375}$

Hasonlóan a nagyobbik kormánypárthoz az MDF is a nemzetpolitika keretrendszerében értelmezte a státustörvényt, melynek jelentőségét több képviselő az Antall-kormány határon túli magyarokért viselt felelősségvállalásához hasonlította. A jogszabály elfogadása pedig - vonták le következtetésüket az MDF képviselői - az alkotmányos szolidaritási kötelezettségen túlmenően konkrét intézkedéseket jelent. A vitában felszólaló képviselők előszeretettel használták a nemzeti jelőzet: „,a nemzeti összetartozásra”, „, a nemzeti hovatartozásra”, ,a nemzeti közösségre”, valamint „a nemzeti szolidaritásra" való hivatkozás gyakori szókapcsolatai a felszólalásoknak. A

\footnotetext{
375 „A törvényjavaslat sok elvárást nem teljesít. Messze nem olyan széles körben kezeli a kedvezményezetteket, mint a már emlitett európai országok többsége... [...] elsö lépésnek, kezdetnek megfelelö ez a törvényjavaslat, általános vitára feltétlenül alkalmas. A törvény gyakorlati alkalmazása számunkra kijelöli a majdani továbbfejlesztés irányait. Támogatom azt a kormányzati eröt, amely most e rendkívüli türelemmel és történelmi felelösséggel képes ezt a törvényjavaslatot jobbitani, megvalósitani, a kívánatos jövőt pedig életre segíteni." Részlet Lezsák Sándor képviselő (MDF) felszólalásából.

Csapody Miklós felszólalásában a jogszabály hiányosságai ellenére az elfogadás mellett érvelt. Ahhoz, hogy a jogszabályt „konkrétan bírálhassunk, elöször müködésbe kell léptetnünk; ahhoz, hogy a hiányosságait közös egyetértéssel és a határon túli magyarsággal egybehangzóan a későbbiekben korrigálhassuk, ezt a törvényjavaslatot müködésbe kell léptetnünk." Csapody Miklós (MDF), a státustörvény záróvitája, 217. ülésnap (2001. június 19).
} 
párt nemzetfelfogását, amely a kulturális értelemben vett nemzet-meghatározáson alapul, olyan kifejezések is erősítették, mint a „nemzettagság”, a „nemzettest” és a „történelmi haza.” Mindezen kifejezések arra szolgáltak, hogy megalapozzák a határon túli nemzetrészeknek nyújtandó kedvezményeket, legfőképpen pedig az az oktatásinevelési támogatásokat, melyet a párt képviselői a lehető legszélesebb célcsoport számára ki szerettek volna terjeszteni. Ennek érdekében a párt képviselői több módosító indítványt is benyújtottak. ${ }^{376}$

Az $F K g P$ a státustörvény elfogadását „háromnegyed évszázados kötelességként és adósságként" értelmezte, amellyel a magyar állam rendezni kívánja a határon túli három millió magyar ember helyzetét. A párt nevében felszólalók inkább a törvény címét és nem ennek tartalmát vitatták. Szengyörgyvölgyi Péter szerint a státustörvény nem szerencsés kifejezés, ehelyett találóbb lett volna, ha a jogszabálynak ,az elcsatolt területen élő magyarok", a Kárpátokon belül élő vagy a Kárpát-medencében élő magyarság helyzetéröl szóló törvény” címet adták volna. ${ }^{377}$

A vitában megjelenő megosztó témák többségéről a párt képviselöi is kifejtették véleményüket, ennek ellenére az FKgP esetében nem beszélhetünk domináns témákról. A párt érvei döntő módon arra irányultak, hogy az ellenzéki érveket ellensúlyozva részletezzék az egyes kedvezmények tartalmát és hatásait. Ebböl következik, hogy a képviselők érveik alátámasztásában „magyarázó” stratégiát alkalmaztak, a vita során pedig jogszabály rendelkezéseinek pozitív vonatkozásait emelték ki: „a kultúra támogatása rendkívül széles körü”, „külön rendelkezések szólnak a munkavállalásról és az ehhez kapcsolódó társadalmi és egészségbiztosításról”, „a kedvezmények körébe tartozik a diákigazolvány bevezetése" az utazási kedvezmény biztosítása, valamint a nyereségérdekelt gazdasági szervezetek támogatásának lehetősége.

Az ellenzéki pártok közül a MIÉP konzekvensen támogatta a státustörvény elfogadását, egyrészt azért mert „magyar érdeket szolgál”, másrészt pedig a jogszabály által bevezetett magyar igazolvány kifejezi a magyar nemzethez való tartozást és erősíti az erkölcsi és kulturális kötelékeket. Az MDF-hez hasonlóan a MIÉP is a támogatások és kedvezmények szélesebb körét támogatta, de elfogadta a jogszabály jelenlegi formáját. Amint Csurka István felszólalásában rámutat, a jogszabály „egyelőre csak ilyen szerény elönyöket tud nyújtani a határokon kívüli magyaroknak... [...] ezt a lépést

376 „,... a szülőföldön nyújtandó nevelési-oktatási támogatás, tankönyv- és taneszköz-támogatást rendkívül fontosnak érezzük, és tulajdonképpen ennek bevétele a törvény-elökészités anyagába tette lehetövé azt, hogy fenntartás nélkül támogassuk ezt az anyagot.” Ibid., részlet Kelemen András képviselő (MDF) felszólalásából.

${ }^{377}$ Szengyörgyvölgyi Péter felszólalása a státustörvény általános vitáján, 202. ülésnap (2001. április.19). 
mindenképpen meg kell tenni, még akkor is, ha a részleteiben sok kifogás emelhetö magával a törvénnyel szemben." 378

A felszólaló képviselők elvetették az MSZP és SZDSZ részéről érkező vádakat, miszerint a jogszabály gazdaságilag jelentősen megterhelné a magyar államot. A MIÉP a státustörvény alkalmazásához szükséges, a költségvetés megterhelésére vonatkozó érveket a párt elnöke arra hivatkozva delegitimálta, hogy a jogszabály elfogadása ,,az az eset, amikor nem szabad, hogy ez számítson, mert erre elő kell teremteni a pénzt." ${ }^{, 379} \mathrm{~A}$ MIÉP tehát nem tagadta, hogy a végrehajtáshoz anyagi eszközökre van szükség, de a felszólalók megítélése szerint ennél fontosabb a ,társadalmi együttmüködés, a jóindulat.” A párt képviselői amellett, hogy jelentős eredménynek tartották a törvényben megfogalmazott kedvezmények körét, a továbbfejlesztés lehetőségét a gazdasági folyamatok gyorsításában, a vállalkozások fejlesztésében és az ipar telepítésében látták, amellyel a gazdasági kötelékek erősítése is lehetővé válna. ${ }^{380}$

A státustörvény vitájában az MSZP konstruktív ellenzéki szereplöként jelent meg és a jogszabályhoz füzött kritikai észrevételeivel azt szerette volna elérni, hogy javítson a jogszabály tartalmi vonatkozásain. Az MSZP és a kormányzó pártok közötti ellentét - melyet a vita során Tabajdi Csaba több alkalommal is hangsúlyozott - abban állt, hogy míg a Fidesz a szorosabb magyar-magyar integrációban látta a határon túli magyarok helyzetének rendezését, addig a szocialisták szerint ez a szomszédos államok kormányai, az európai integráció és a közösségi autonómia kivívása nélkül nem lehetséges. Ebből a szemléletmódból kiindulva az MSZP a státustörvényt két nagyobb tematika mentén értékelte. Egyrészt vitatta azokat a kormányzati érveket, miszerint a jogszabály megoldaná a határon túli magyarok helyzetét, másrészt pedig támadta a kormányt, amiért a jogszabály elfogadásával felvállalta a konfliktust a szomszédos államokkal, amely körültekintő diplomáciai tájékoztatással és egyeztetéssel elkerülhető lett volna.

A jogszabály által nyújtott kedvezmények kérdésében az MSZP nem képviselt következetes álláspontot, amely kétirányú érveléshez vezetett. Az MSZP vezérszónoka, Tabajdi Csaba amellett foglalt állást, hogy a jogszabály rendelkezései nem segítik elő a törvény fő célkitüzéseit, mert ahhoz ,sokkal több, nem Magyarországon igénybe vehető kedvezményre, támogatásra lenne szükség”. Ezzel szemben párttársai a jogszabály

\footnotetext{
${ }^{378}$ Ibid, részlet Csurka István (MIÉP) felszólalásából.

${ }^{379}$ Ibid.

${ }^{380}$ Lásd Lentner Csaba (MIÉP) felszólalását a státustörvény részletes vitáján. 210. ülésnap, (2001. május 29).
} 
megvalósításának túlzott költségvetési terheit emelték ki, valamint arra tettek javaslatot, hogy a magyarországi szociális viszonyoknak betudhatóan a jogszabály egyes rendelkezéseinek magyar állampolgárokra való kiterjesztése is indokolt lenne. A kedvezmények kapcsán egy másik vitapontot a munkavállalás képezte: az MSZP azon az állásponton volt, hogy a jogszabályban szereplő három hónapos munkavállalás helyett hat hónapos, megújítás nélküli engedélyt kapjanak a határon túli magyarok, amely lehetővé tenné a „nem idényjellegü munkavégzést” és elősegítené a szülőföldön való maradást.

A szocialisták a szomszédos államokkal való viszonytól tették függővé a határon túli magyarok helyzetének rendezését, ebből adódóan számukra a jószomszédi viszony és a stabilitás fenntartása meghatározónak bizonyult. ${ }^{381}$ A jó viszony fenntartása érdekében a külügyminisztérium - érveltek a felszólalók - megfelelő módon kellett volna tájékoztassa a szomszédos államokat és az európai fórumokat a készülő törvény rendelkezéseiről. A párt képviselőinek értékelése szerint - figyelembe véve a jogszabályra érkező reakciókat - a tájékoztatás csak részben történt meg, a kormány „szélesebb körü konzultációt kellett volna folytasson”, amellyel elkerülhető lett volna a román és a szlovák féllel folytatott vita. ${ }^{382}$

Az MSZP, vélhetően az alapszerződés tárgyalásainak tapasztalataiból úgy kívánta rendezni a határon túli magyarok kérdését, hogy közben fenntartsa a stabilitást a szomszédos államokkal. A stabilitás fenntartásában a MÁÉRT tevékenységében részt vevő politikai szervezeteknek is nagy szerepük van - hangsúlyozták a felszólalók éppen ezért létrehozása jelentős lépést. Azonban az MSZP szerint a MÁÉRT keretében nem folyt olyan szintü egyeztetés, amiről a kormánypártok beszámoltak. A MÁÉRTben „volt egy ötletroham”, „a szakbizottságok jobb sorsra lennének érdemesek”, „háromnegyed éve nem volt összehívva” - jegyezték meg a felszólalók.

A pártok közül egyedül az MSZP vetette fel a jogszabály végrehajtásával kapcsolatos átláthatósági problémákat, mivel a jogszabály nem tartalmazott világos rendelkezéseket és garanciákat a támogatás kiosztására vonatkozóan. Az átláthatóság érdekében a szocialisták több módosító indítványt is benyújtottak, továbbá kérték a

381 „Jó lenne, ha Romániával államközi szinten konszolidálhatnánk a kapcsolatokat, és új egyezményekben rögzíthetnénk, mert így az egész törvény végrehajtásához szükséges fedezetnek legalább a felét ezen az úton biztosithatnánk. Úgy gondolom, hogy az Erdélyben élö magyarság ügyét az államközi kapcsolatok normalizálása nélkül nehezen fogjuk tudni elérni.” Vojnik Mária (MSZP) felszólalása a státustörvény általános vitájának lezárásán. 206. ülésnap, (2001. május 9).

${ }^{382}$ Ibid. Tabajdi Csaba az egyeztetésröl sarkosan fogalmazva a következőt mondta: , nem esett volna le az aranygyürü a Külügyminisztérium, a magyar diplomácia ujjáról, hogyha megadja azt a lehetöséget, hogy a szomszédokkal egyeztessen. Az egyeztetés nem egyezkedést jelent..." 
közremüködő intézmények és szervezetek tételes felsorolását, amely véleményük szerint javította volna a jogszabály végrehajtásának eredményességét. A végső szavazáson azonban e javaslatok mellett az adatvédelemre vonatkozó „,pontosításokat” is leszavazta az Országgyülés.

A parlamenti pártok közül egyedül az $S Z D S Z$ volt az, amely vehemensen ellenezte a törvény elfogadását. A párt képviselői a vitában amellett érveltek, hogy a státustörvény tervezete ellentmond saját célkitüzéseinek mivel (1) nem javítja a szülöföldön való maradás esélyeit; (2) túlzott várakozásokat keltett a határon túli magyarok között; (3) a kedvezmények és támogatások jórészt az anyaországban vehetők igénybe; (4) alkalmazása túlzott bürokráciát és nagy tehertételeket ró a költségvetésre; (5) negatívan befolyásolja az államközi kapcsolatokat és a többség-kisebbség viszonyát. E kifogások alapján Szent-Iványi István a törvénytervezetet nem a nemzeti összetartozás törvénytervezeteként, „hanem a becsapás törvénytervezeteként, a szemfényvesztés törvénytervezeteként” értékelte.

Az SZDSZ kritikai hozzáállása végigvonul a törvénytervezet vitáján, számtalan negatív értelmezést társítva a jogszabály tartalmához: a státustörvény „rossz helyen látja a problémát”, „rossz helyen keresi megoldást”, nem alkalmas arra, hogy közös dolgainkat közösen oldjuk meg”, ,alapjaiban elhibázott irányban keres megoldást”.

A vitában az SZDSZ egyrészt a határon túli magyaroknak nyújtott támogatásokat vitatta, így a magyar igazolvánnyal igénybe vehető kedvezményeket, a munkavállalási lehetőségeket, másrészt pedig a támogatások odaítélésének módját és eszközeit, amiért a törvény nem alkalmaz „differenciált megközelítést” ${ }^{383}$ A felszólalók a kormány nemzetpolitikai stratégiáját támadták a leghevesebben. Bauer Tamás képviselő szerint az SZDSZ és a kormánypártok közötti legfontosabb szemléletbeli különbség az, hogy míg a kormánypártok a határon túli magyarok helyzetének megoldását a magyar-magyar kapcsolatoktól teszik függővé, addig az SZDSZ a kisebbségi jogok kivívását és az államközi kapcsolatokat tekinti mérvadónak helyzetük

383 „Felvetödik persze az a kérdés [...], hogy nem arra van-e inkább szükség, hogy az egyes nemzeti közösségek egyes sajátos igényeinek megfelelö támogatásokat és kedvezményeket biztosítsunk. Hiszen nyilvánvaló, aki ismeri a környezö országokban élö magyarok helyzetét, hogy nem azonos körülmények között élnek a szlovéniai magyarok és a kárpátaljai magyarok, nem azonos körülmények között élnek akár a szlovákiaiak vagy a vajdaságiak. Nem azonosak a szükségleteik, nem azonosak az igényeik. Ez a törvénytervezetben sehol nem jelenik meg, nincs differenciált megközelítés, nem teszi nyilvánvalóvá, hogy mindenkin úgy kell segíteni, ahogy számára a legjobb, és nem úgy, ahogy mi elképzeljük, hogy a legjobb lenne. ”Szent-Iványi István (SZDSZ) felszólalása, a státustörvény általános vitáján. 202. ülésnap, (2001. április 19). 
rendezésében. ${ }^{384}$ Ebből a szemléletmódból kiindulva fontos a szomszédokkal folytatott „kielégítő” konzultáció, mert a kisebbségi kérdés rendezését „diplomáciai és külpolitikai eszközökkel lehet elérni." A képviselők többször hivatkoztak az előző kormányzati ciklusban megkötött alapszerződésekre, a szomszédos államokkal folytatott konzultációkra, amelyek a státustörvény esetében is irányadók lehettek volna. A kormány jelenlegi politikájával - érveltek a képviselők - ellentétet szít a szomszédos államokkal, mi több akadályozzák a határon túli magyarok többségi társadalomba való integrációját és emancipációját.

\subsection{Románia}

A román parlamentben a képviselök és szenátorok felszólalásaiból, valamint a Szenátusban lezajlott vita alapján megállapítható, hogy az RMDSZ kivételével az összes parlamenti párt ellenezte a státustörvény romániai alkalmazását abban a formában, ahogyan az Országgyülés elfogadta. A kormányzó PDSR és az ellenzéki pártok közötti ellentét azt követően polarizálódott, hogy a kormány egyetértési nyilatkozat keretében megegyezett a magyar féllel a jogszabály Románia területén való alkalmazásáról. A memorandum heves vitákhoz vezetett a felek között, a vita pedig lehetőséget adott az ellenzéknek, hogy bírálja a kormány szomszédságpolitikáját, és az RMDSZ-szel kötött együttmüködését.

14. sz. táblázat: A státustörvény és a memorandum értelmezése a román vitában

\begin{tabular}{|c|c|c|}
\hline & Kormánypártok & Ellenzéki pártok \\
\hline 选 & $\begin{array}{l}\text { A jogszabály olyan kedvezményeket nyújtott } \\
\text { volna, amelynek eredményeként a nem magyar } \\
\text { nemzetiségü román állampolgárok hátrányba } \\
\text { kerültek. }\end{array}$ & Nincs releváns érv. \\
\hline 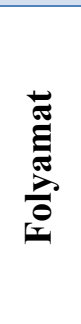 & $\begin{array}{l}\text { A törvény elfogadásáról a magyar fél nem } \\
\text { konzultált megfelelő módon a román féllel. } \\
\text { Az elfogadott jogszabály nem tükrözte a román } \\
\text { fél javaslatait } \\
\text { A kormány mindaddig ellenezte a jogszabály } \\
\text { alkalmazását, amíg nem fogadtak el közös } \\
\text { rendelkezéseket. }\end{array}$ & $\begin{array}{l}\text { A törvény elfogadásáról a magyar fél } \\
\text { nem tájékoztatta kellőképpen a román } \\
\text { felet. } \\
\text { A jogszabály körül kialakult vita } \\
\text { feszültséghez vezetett az államközi } \\
\text { kapcsolatokban. }\end{array}$ \\
\hline
\end{tabular}

384, „Ez a törvényjavaslat a probléma lényegét nem a kisebbségi jogok korlátozottságában, nem a kisebbségnek az adott ország társadalmán belüli diszkriminációjában látja, hanem a magyar államtól való elszakitottságában, és ennek megfelelöen a megoldás központi kérdésének a magyar államhoz való formális jogi kapcsolatot tekinti...” Ibid, Bauer Tamás (SZDSZ) felszólalása. 


\begin{tabular}{|c|c|c|}
\hline & $\begin{array}{l}\text { A kormány már a kezdetektől hangsúlyozta a } \\
\text { törvény diszkriminatív és területen kívüli } \\
\text { jellegét. } \\
\text { Bel- és külpolitikai megfontolásból a jogszabály } \\
\text { nem teszi lehetővé a kettős állampolgárság } \\
\text { megszerzését. }\end{array}$ & $\begin{array}{l}\text { A Velencei Bizottság jelentésében } \\
\text { megállapította, hogy a jogszabály nem } \\
\text { felel meg az európai normáknak. } \\
\text { A státustörvény diszkriminatív és } \\
\text { területen kívüli hatállyal bír. }\end{array}$ \\
\hline 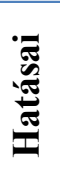 & $\begin{array}{l}\text { A memorandum aláírásával a jogszabály } \\
\text { megszűnt létezni korábbi formájában. } \\
\text { A munkavállalási kedvezmények kiterjesztése a } \\
\text { román diplomácia sikere. }\end{array}$ & $\begin{array}{l}\text { A román kormány elfogadta az } \\
\text { RMDSZ és a történelmi egyházak } \\
\text { részvételét a törvény alkalmazásában. }\end{array}$ \\
\hline
\end{tabular}

A kormányzó PDSR minden lehetséges diplomáciai eszközzel tiltakozott a státustörvény Románia területén való alkalmazása ellen, azért mert értelmezésükben (1) a támogatások túlmutattak a kulturális és oktatási kedvezmények körén; (2) a jogszabálynak területen kívüli jellege volt és diszkriminatív a nem magyar nemzetiségü román állampolgárokra nézve; (3) a magyar diplomácia nem egyeztetett megfelelő módon a román féllel, a konzultációkat követő román javaslatok pedig nem kerültek be a végleges szövegbe.

A konzultációk lezárása és a két állam közötti memorandum aláírása a kormány értelmezésében egyrészt olyan megoldás, amely megnyugtató módon rendezte a két fél között kialakult vitát, másrészt pedig diplomáciai siker, „a román fél győzelme” mert sikerült a román fél által kifogásolt rendelkezésekre elfogadható értelmezést találni: (1) megszünt a jogszabály diszkriminatív jellege; (2) Románia szuverenitását sértő rendelkezések nem kerültek alkalmazásra, (3) megnyílt a magyar munkaerőpiac a román állampolgárok előtt. A memorandum aláírása mellett további érvet a jószomszédi viszony rendezése képezte, amely ,alapvető integrációs feltétel”, Magyarország támogatása pedig segíti a román törekvéseket. Ezen eredmények tükrében a kormánypárt elvetette az ellenzéki indítványt, mi több hangsúlyozta, hogy a megállapodást ratifikáció céljából nem kell a parlament elé terjeszteni.

A vitában a nemzeti érdek és a szuverenitás védelme, valamint a román állampolgárok jogainak érvényesítése képezte a kormányzó párt állandó legitimációs érvrendszerét. A felszólaló külügyminiszter és a párt tagjai a státustörvény tartalmi kifogásainak ismertetését, valamint a memorandum aláíásának hangsúlyozását a szuverenitás és a román állampolgárok jogainak védelme szempontjából értelmezték. ${ }^{385}$ A nemzeti érdekre, mint legfontosabb elvre való hivatkozás megteremtette annak a

\footnotetext{
385 „A két fél által megkötött kormányközi megállapodás magyarázatot ad a (román) kifogásokra és tartalmazza a magyar fél által is elfogadott megoldásokat oly módon, hogy a magyar parlament által megszavazott jogszabály nem érinti a nemzeti szuverenitást és a román állampolgárok jogait." Mircea Geoana külügyminiszter (PDSR) felszólalása az egyszerü indítvány vitáján (2002. március 7).
} 
lehetőségét, hogy a kormánypárt delegitimálja az ellenzék részéről érkező támadásokat. A memorandum aláirásával - mutatott rá a külügyminiszter - „a demokrácia fegyvereivel megvédtük a román nép legitim érdekeit, a román nemzeti érdeket. „386

A vitában a kormányzó párt és az RMDSZ kapcsolata is domináns szerepet kapott, az ellenzéki pártok pedig nemcsak a két párt együttmüködését, hanem a magyar kisebbség „kivételezett” helyzetére is felhívták a figyelmet. Ezzel szemben a felszólalók a román kisebbségpolitikai rezsim alapelveinek is tekinthetö kijelentéseivel - mint pl. „az állam biztosítja a többség és kisebbség közötti esélyegyenlőséget”, „hasonló védelemben részesíti öket”, „az alkotmányban rögzített jogok és nemzetközi kötelezettségein kívül nem ismer el más jogosítványokat” - vetették el az ellenzéki vádakat.

A szélsőséges $P R M$ azzal indokolta az egyszerü indítvány benyújtását, hogy a két állam által megkötött egyetértési nyilatkozatnak komoly következményei vannak Románia nemzetbiztonságára és szuverenitására nézve. Az indítványt ismertető Corneliu Vadim Tudor szenátor amellett érvelt, hogy a kormány (1) kivonta magát a parlamenti ellenőrzés alól, mert ratifikáció nélkül alkalmazta az egyetértési nyilatkozatot; (2) elfogadta a státustörvény romániai alkalmazását, melyet az európai fórumok és a román pártok ,élesen” bíráltak; (3) európai érvekkel elbátortalanítja a románok patriotizmusát, míg terjed a magyar sovinizmus, melyet hivatalosan a magyar identitás megőrzésének ürügyén támogat; (4) az alkotmány rendelkezéseivel szemben diszkriminálja az erdélyi románokat a magyarokkal szemben; (5) az RMDSZ nagyobb előnyökre és engedményekre tett szert, mint az előző kormányzati időszakban, amikor a koalíciós kormány része volt. ${ }^{387}$

Az indítvány szövegének főbb pontjaiból látható, hogy a párt önmagában nem a memorandum aláírását vitatta, hanem a növekvő magyar veszélyre is felhívta a figyelmet, amely egyrészt Magyarország irányából, másrészt pedig az RMDSZ részéről „fenyegeti” a román nemzeti érdeket. E tekintetben a PRM álláspontjában nem következett be lényeges változás a jogszabály elfogadását követően. A párt képviselője júniusi felszólalásában a státustörvény elfogadása mögött Nagy-Magyarország visszaállítására vonatkozó törekvést vélt felfedezni ${ }^{388}$, míg az indítvány vitájában a PRM felszólalói azt hangsúlyozták, hogy Magyarország elsősorban Erdély

\footnotetext{
${ }^{386}$ Idem.

${ }^{387}$ Ibid. Corneliu Vadim Tudor (PRM) felszólalása.

${ }^{388}$ Corneliu Ciontu képviselő felszólalása, 2001. június 19-i képviselőházi ülés. A képviselő szerint a román hatóságok „furcsa és ellentétes” fellépése annak tudható be, hogy az PDSR engedett az MSZP zsarolásának, amiért az támogatta a Szocialista Internacionáléba való felvételét.
} 
„elmagyarosításában érdekelt”, a jelentős pénzügyi támogatások „a térség gazdasági gyarmatosítását célozzák”. Magyarország szerepéhez hasonlóan a szélsőségesek mélységesen elítélő és negatív módon értékelték a kormányzó párt és az RMDSZ együttműködését, amely „,népszerütlen”, „,románellenes”, megfélemlíti és diszkriminálja a választópolgárokat, és ,megrengeti a román népet”.

A kialakult helyzetből a PRM egyetlen kiutat látott: az „európai standardokra” hivatkozva kérte a parlamenti pártok támogatását, ugyanis csak az indítvány elfogadásával „őrizhető meg a román állam egységes nemzeti jellege." ${ }^{389}$ Míg tehát a kormánypárt szempontjából a nemzeti érdek a státustörvény diszkriminatív jellegének megszüntetését és a román állam szuverenitásának védelmét jelentette, addig a szélsőségesek értelmezésében a nemzeti érdek a román állam egységes nemzeti jellegének és területi integritásának megóvásaként értelmeződött, szemben a regionalizációs törekvésekkel.

Az ellenzéki pártok közül a $P D$ ugyan elítélte a jogszabály elfogadását, amiért az nem veszi figyelembe az európai normákat és azzal, hogy diszkriminatív Románia lakosságára nézve közvetlen módon befolyásolja a két állam együttmüködését és jószomszédi viszonyát ${ }^{390}$, azonban Paula Maria Ivănescu felszólalásában mégis együttmüködésre hívta a politikai szereplőket, hogy közösen találjanak kiutat a „jogszabály okozta zsákutcából”.

A vitában a demokraták álláspontja azért tekinthető figyelemre méltónak, mert érvelési stratégiája arra irányult, hogy az indítvány szövegében szorosan összekapcsolódó kérdéseket - egyrészt a kormányzati tevékenység kritikáját, másrészt pedig a PDSR-RMDSZ együttmüködését - szétválassza. A Szövetség védelmében elsőként arra hivatkozott, hogy a kisebbségi szervezet az előző kormányzati ciklusban is biztosította a politikai stabilitást, másodsorban a memorandum és a '90-es évek első felében lezajlott Hargita-Kovászna jelentés között vont párhuzamot és a kormányzati tájékoztatás fontosságát hangsúlyozta. ${ }^{391}$ Ennek ellenére a PD támogatta az indítvány elfogadását, mert Viorel Marian Pană szerint egyrészt megalapozott a szövege, másrészt úgy ítélte meg, hogy szükséges az indítványban felvetett kérdésekről vitát folytatni.

\footnotetext{
${ }^{389}$ Carol Dina (PRM) felszólalása az indítvány vitáján.

${ }^{390}$ Paula Maria Ivănescu (PD) képviselőnő napirend előtti felszólalása, 2001. június 26-i képviselőházi ülés.

${ }^{391}$ Viorel Marian Pană (PD) felszólalásában arra emlékeztetett, hogy ha a drámai helyzet ismertetésével szemben kormány képviselői megfelelöképpen tájékoztatják a vita résztvevőit - mint a memorandum vitáján -, akkor más lett volna a pártok álláspontja.
} 
A státustörvény elfogadását követően a $P N L$ úgy vélte, hogy a jogszabály erősíti az etnikai elkülönülést, amely ellentétes az egységes Európa eszméjével, ebböl kiindulva nem támogatta romániai alkalmazását. ${ }^{392}$ A párt álláspontján a két állam között megkötött egyetértési nyilatkozat sem hozott merő változásokat, amely a liberálisok szerint „,politikai kötelezettségvállalásokat” foglal magába és olyan alapvető kérdéseket érint, mint a román állampolgárok „státusza”. Ebből kiindulva a PRM indítványát Norica Nicolai képviselőnő, „parlamenti jogi aktusnak, demokratikus eljárásnak" nevezte. ${ }^{393}$

A liberálisok úgy vélekedtek, hogy a megegyezés mögött egy át nem gondolt külpolitikai lépés húzódott, ami „nem Románia érdekében történt”. E megállapítás szolgáltatja a kormány politikájával szembeni elégedetlenséget, amely egyrészt kiterjed az elodázott reformokra (gazdasági fejlődés, regionális fejlesztés, szubszidiaritás elvének gyakorlatba ültetése), másrészt pedig - parlamenti ratifikáció elmulasztásával komoly alkotmányossági problémákat érint.

Az RMDSZ annak ellenére, hogy több alkalommal tárgyalt a státustörvény kérdésében a kormányzó PDSR-vel, a jogszabály elfogadását követően nem szólalt fel a parlamentben, így elkerülte a hevesebb vitákat és a Szövetséget érintő vádakat. Az indítvány vitáján felszólaló szövetségi elnök úgy értékelte, hogy tulajdonképpen két indítvány vitájáról van szó: míg az első a kormány tevékenységét érinti, addig a másik az RMDSZ ellen irányul.

Markó Béla felszólalásában arra hívta fel a figyelmet, hogy a rendszerváltást követően napirendre került a nemzeti kérdés és az interetnikus problémák amelyre az egyik választ a konfrontáció, míg másikat az együttmüködés szolgálta. E tekintetben „,azok a bátrak - fejtette ki -, akik felvállalták a párbeszédet; azok a bátrak, akik azokban az években vállalták az együttmüködést és az interetnikus problémák megoldásának módozatait...”394 Az RMDSZ vezetője a memorandum aláírását a két állam együttmüködésének bizonyítékaként értékelte, amely pozitív hatást gyakorolt az interetnikus viszonyra. Válaszolva az ellenzéki vádakra és Magyarország megnövekedett szerepére kifejtette, hogy a státustörvény által nyújtott kedvezmények ugyan fontosak, de ,az erdélyi magyar közösség problémái itt Romániában, a parlament által elfogadott törvényekkel oldhatók meg", 395

\footnotetext{
${ }^{392}$ Andrei-Ioan Chiliman (PNL) napirend előtti felszólalása a 2001. június 26-i képviselőházi vitán.

${ }^{393}$ Norica Nicolai (PNL) felszólalása az indítvány vitáján.

${ }^{394}$ Ibid, részlet Markó Béla (RMDSZ) felszólalásából.

${ }^{395}$ Idem.
} 


\subsection{A pártok közötti megosztottság jellemzői és a pártok pozíciói}

A parlamenti pártok érvrendszerének és álláspontjának ismertetéséből megállapítható, hogy kevés olyan közös pontot és értelmezést találunk, amely mindkét vitában megjelenne. A pártok közötti konszenzus elmaradása és az ellentétek kialakulása egyrészt az eltérő ideológiai felfogásnak és meggyőződésnek tulajdonítható, ami kiválóan tükröződött a státustörvény elfogadásának folyamatában, valamint az egyetértési nyilatkozat aláírását követő időszakban is. Másrészt, a vitában képviselt álláspontok belpolitikai számításokra is visszavezethetők: a jogszabály vitatott pontjainak napirenden tartásától, valamint a kormány állandó támadásától az ellenzéki pártok népszerüségük növelését remélték.

A magyar parlamenti pártok között konszenzus mutatkozott arra nézve, hogy kiemelt figyelemben kell részesíteni és támogatni kell a határon túli magyarságot, azonban az eszközök tekintetében jelentős eltérések mutatkoztak. Az SZDSZ képviselője, Szent-Iványi István a vitában találóan fogalmazta meg a kialakult helyzetet: „Tehát a vita nem az, hogy ki akar adni és ki nem akar adni, a vita nem az, hogy ki tartja fontosnak a nemzet ügyét vagy a határon túli magyarok ügyét, hanem a vita abban van, hogy ki tudja megfelelö módon ezeket a fontos célokat szolgálni." $396 \mathrm{Az}$ ellenzéki pártok közül az MSZP és az SZDSZ folyamatosan vitatta a jogszabály célkitűzését és tartalmát, azonban a zárószavazáson az MSZP a jogszabály támogatása mellett döntött, amelyben a belpolitikai számítások is meghatározónak bizonyultak.

A román pártok - az RMDSZ kivételével - elutasították a jogszabály romániai alkalmazását, amit a szuverenitás megsértéseként és a kisebbségek védelmére vonatkozó európai standardok túllépéseként értékeltek. Mind a kormánypárt, mind az ellenzéki pártok a nemzeti érdek kontextusában értelmezték a jogszabályt, amelynek alkalmazását meg kell akadályozni. Az ellenzéki pártok álláspontján a kormányközi megállapodás sem változtatott, annak ellenére, hogy a munkavállalási kedvezmények a nem magyar nemzetiségű román állampolgárokra is kiterjedtek. Következésképpen, a vitában a pártok pozícióját két dimenzió mentén ábrázoltam: a vízszintes tengelyen a kormányoldal - ellenzék, míg a függőleges tengelyen a státustörvényt támogató és ellenző pártokat helyeztem el. A kialakult pozíciókat a következő ábra szemlélteti:

${ }^{396}$ Szent-Iványi István (SZDSZ) felszólalása a státustörvény záróvitáján. 217. ülésnap, (2001. június19). 
7. sz. ábra: A parlamenti pártok pozíciója a státustörvény vitájában

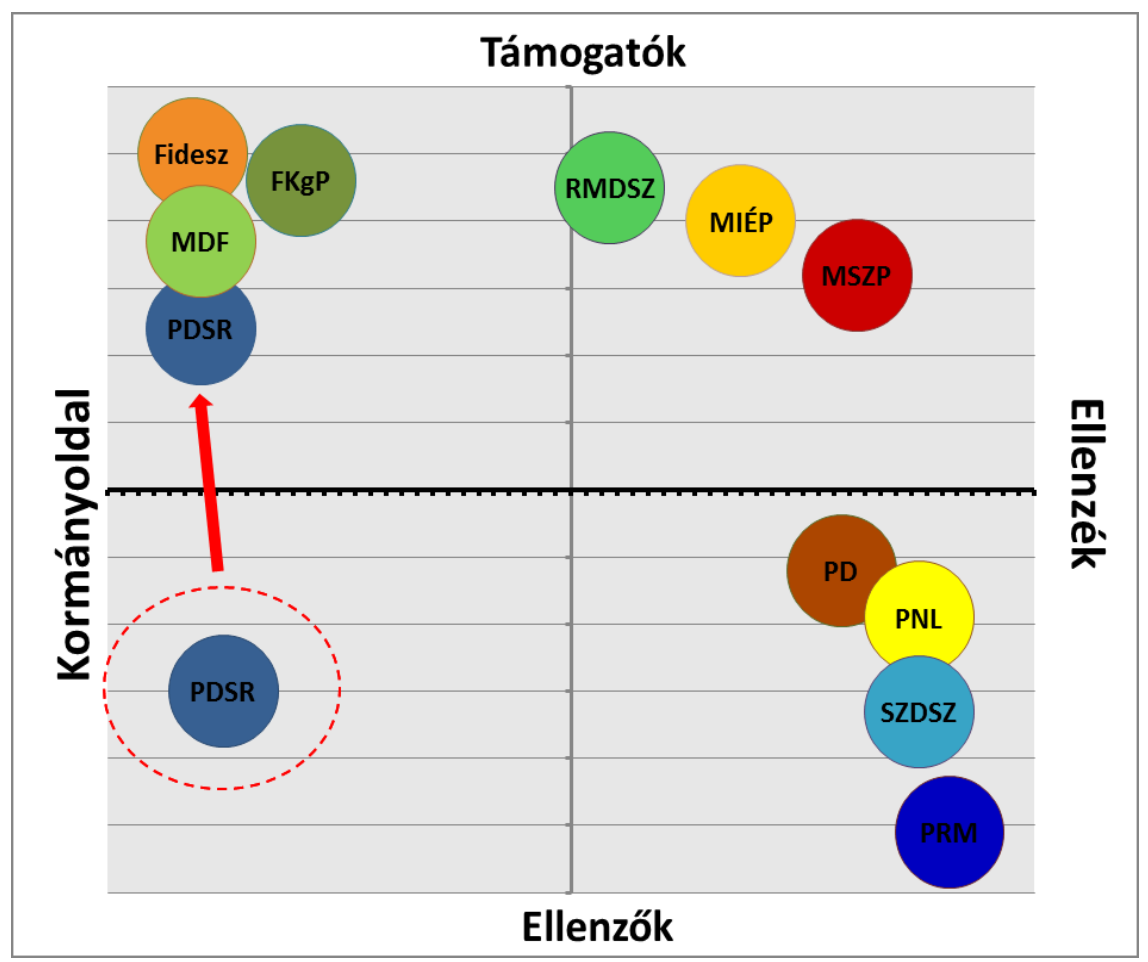

Az ábra alapján a státustörvény vitájában négy, egymástól világosan elkülönülő pozíció alakult ki:

1. a kormánypárti támogatók csoportja, amely a FIDESZ-kormányt alkotó pártokat foglalja magába. A PDSR pozíciója azért érdemel különös figyelmet, mert kezdettől fogva ellenezte a jogszabály alkalmazását. Álláspontja a memorandum aláírását követően változott meg, ezzel pedig a román ellenzéki pártok célkeresztjébe került.

2. Ellenzéki támogatók csoportját az MSZP és a MIÉP, akik annak ellenére, hogy ellenzéki pozícióból politizáltak, támogatták a jogszabály elfogadását. Az RMDSZ szerepe azért tekinthető sajátosnak ebben a csoportban, mert formálisan ugyan nem volt tagja a román kormánynak, de egy parlamenti együttmüködés keretében támogatta a PDSR-t.

3. A státustörvényt elfogadását és alkalmazását ellenző pártok a román ellenzéki pártokat (PNL, PD) és az SZDSZ-t foglalja magába, akik az ellenzéki támogatókkal szemben ellenezték a jogszabály elfogadását és alkalmazását.

4. A vitában az egyedüli szélsőséges nézeteket valló PRM alkotja a szélsőséges pártok pozícióját, aki amellett, hogy ellenezte a jogszabály alkalmazását, ellentörvény benyújtására tett javaslatot és mind Magyarország, mind az RMDSZ irányába szélsőséges nézeteket fogalmazott meg. 


\subsection{Fö témák, érvrendszerek és stratégiák a vitában}

A státustörvény és az indítvány vitájában a pártok érvrendszerében és témahasználatában számtalan hasonlóság, de alapvető különbségek is megfigyelhetők. Az erdélyi magyarság helyzete és az RMDSZ pozíciója minden parlamenti pártnál megjelent, de míg a magyar vitában a támogatás és a szülőföldön való megmaradás kérdése került elötérbe, addig a román vitában a Szövetség megnövekedett szerepe és érdekérvényesítő képessége vált a vita fő témájává.

A határon túli magyar közösségek megerösítése, a kedvezmények és a támogatások jellege, valamint a szomszédos államok tájékoztatása a kormányzó pártok domináns témáit jelentette. A felsorakoztatott érvek világosan jelezték, hogy a FIDESZ, az MDF és az FKgP számára a nemzetpolitikai célkitűzések a külpolitikai napirend részévé váltak: a kormányzó pártok egyrészt azt hangsúlyozták, hogy Magyarország lépését az európai fórumok is visszaigazolták ,az európai fórumok elismerték az anyaország felelősségvállalását", másrészt pedig kiemelték, hogy a magyar kezdeményezés nem egyedülálló a térségben, „a környező államokban is bevett gyakorlat a kisebbségek támogatása”. A magyar kormányzati lépést tehát nem egyszerüen nemzetpolitikai célkitüzésként tematizálták, amelyet Magyarország a kedvező konjunktúrának - a gazdasági fejlődésnek, külpolitikai mozgástér növekedésének - betudhatóan megtehet, hanem olyan lépésként, melyet a nyugat is támogat. A kormánypártok tehát arra törekedtek, hogy kibékítsék az egymásnak feszülö érveket és álláspontokat (FIDESZ), segítsék a konszenzus kialakításának a lehetőségét (MDF), valamint részletezzék és magyarázzák a felmerülő vitás kérdéseket (FKgP).

A kormányzó PDSR előnyösebb stratégiának látta, ha a konszenzusra irányuló törekvése helyett, a memorandum megkötésének elönyeit és az elért eredményeket domborítja ki a vitában. A Velencei Bizottság döntése nyomán elismerte ugyan a kulturális és oktatási támogatások jogosultságát, azonban a párt úgy értékelte, hogy a testület visszaigazolta a román fél aggályait, következésképpen neki adott igazat. Az egyetértési nyilatkozat aláírásával a kormány értelmezésében megszünt a jogszabály diszkriminatív jellege, ugyanis a munkavállalási kedvezmények a nem magyar nemzetiségü személyekre is kiterjedtek. A megállapodás tehát román szempontból jelentős diplomáciai siker, melyet a PDSR a nemzeti érdek hatékony képviseleteként értelmezett.

A státustörvény vitájában - az alapszerződés vitájához képest -, kevesebb szó esett a kisebbségi jogok érvényesítéséről: noha több alkalommal történt utalás arra, 
hogy a határon túli magyarok helyzete még nem „konszolidált” és számos területen vannak hiányosságok, a magyar kormányzó pártok, de az ellenzék részéről elhangzó érvek is elismeréssel szóltak a határon túli szervezetek politikai és kormányzati szerepéről, amelyek támogatása, valamint az intézményes kapcsolatok fenntartása kiemelt fontosságú nemzetpolitikai célkitüzés.

Az ellenzéki pártok (MSZP, SZDSZ, RMDSZ, PRM) helyzete, további magyarázatot kíván, annak betudhatóan, hogy kétirányú vitát folytattak: egyrészt a vita során cáfolták a kormánypárti érveket, másrészt a dokumentum aláírását ellenző pártokkal is vitát folytattak. Jó példa erre a vitában az RMDSZ és a PRM szenátorai közötti szóváltás, vagy az MSZP és az SZDSZ prominens képviselőinek, Tabajdi Csabának és Bauer Tamásnak a vitája a határon túli magyarok helyzetének rendezésére irányuló javaslatokról.

A fő témák és révrendszerek értelmezéséből a legfőbb tematikai különbségek is kirajzolódtak a vitában. Míg a magyar vita a nemzetpolitika keretrendszerben értelmeződik - beleértve az államközi viszonyokat is, melyek segíthetik a határon túli magyar közösségek helyzetének javítását -, addig a szenátusi vitában a státustörvény és a két állam megállapodása más tematikában, a szuverenitás és a nemzeti érdek védelmeként tematizálódik és a vita arról szólt, hogy a kormány fellépése a magyar nemzetpolitikai törekvésekkel és a jogszabály romániai alkalmazásával szemben mennyiben tekinthető eredményesnek.

A kormány által bemutatott eredményeket és sikereket az ellenzéki pártok az indítvány támogatásával nemzetbiztonsági kérdésnek minősítették. A PRM, PD és a PNL úgy ítélte meg, hogy a kormány nem képviselte konzekvensen a román nemzeti érdeket, a memorandum aláírásával pedig Budapest akarata érvényesült, amelynek következtében az RMDSZ pozíciója is megerösödött. Az ellenzék stratégiája tehát arra irányult, hogy az egyetértési nyilatkozat mellett a kormánypárt és a Szövetség együttmüködését is támadják, amelynek keretében magyarellenes kijelentések is elhangzottak.

A státustörvény vitája a nemzetről szóló vita újabb állomásának tekinthető, amelyre Kántor Zoltán több tanulmányában is rámutatott (Kántor 2002a). A vita során felmerülő kérdések (Ki a magyar? Ki tartozik a magyar nemzethez?), valamint a felszólalásokból kirajzolódó nemzetkoncepciók újra napirendre helyezték a nemzet meghatározásának problematikáját, melyet a státustörvény jogalanyainak minél pontosabb körülhatárolása tett szükségessé. Noha a vitában nem kaptam egyértelmü 
választ a felvetett problémákra, a különböző álláspontokból, amelyek (1) a kedvezményezettek körének lehetséges kiterjesztésére (Hogyan viszonyulunk a nyugati magyarsághoz), illetve (2) ennek korlátozása (a törvény nem terjed ki Ausztriára), végül (3) a jogalanyiság kritériumrendszerének véglegesítése vonatkozott, megszületett egy olyan - távolról sem lezárt - koncepció, amely a jogszabály alkalmazásával a szomszédos államok magyarságának szentelt kitüntetett figyelmet.

15. sz. táblázat: Uralkodó témák és alkalmazott stratégiák a státustörvény vitájában

\begin{tabular}{|c|c|c|}
\hline Pártok & Uralkodó témák & Alkalmazott stratégia \\
\hline FIDESZ & $\begin{array}{l}\text { Határon túli magyarok, MÁÉRT, } \\
\text { nemzetpolitika, kedvezmények és támogatások }\end{array}$ & $\begin{array}{l}\text { Integratív stratégia } \\
\text { (az egymásnak feszülő érvek kibékítése) }\end{array}$ \\
\hline MDF & $\begin{array}{l}\text { Nemzetpolitika és a határon túli magyar } \\
\text { közösségek megerősítése } \\
\text { Támogatások és a kedvezmények jellege }\end{array}$ & $\begin{array}{l}\text { A konszenzus megteremtésére irányuló } \\
\text { stratégia }\end{array}$ \\
\hline FKgP & Kedvezmények, támogatások, nemzetkoncepció & Magyarázó stratégia \\
\hline MSZP & $\begin{array}{l}\text { Kétoldalú kapcsolatok, határon túli magyarok, } \\
\text { MÁÉRT, a kedvezmények és támogatások } \\
\text { jellege, nemzetpolitika }\end{array}$ & $\begin{array}{l}\text { Szembeállítás, mellyel delegitimálják a } \\
\text { kormányoldal érveit }\end{array}$ \\
\hline SZDSZ & $\begin{array}{l}\text { Kedvezmények és támogatások jellege, } \\
\text { kétoldalú kapcsolatok, határon túli magyarok }\end{array}$ & $\begin{array}{l}\text { Szembeállítás, a kormány érveinek } \\
\text { cáfolata }\end{array}$ \\
\hline PDSR & $\begin{array}{l}\text { Magyar fél és a kétoldalú kapcsolatok, RMDSZ, } \\
\text { diszkrimináció és területi hatály, európai } \\
\text { fórumok, nemzeti érdek }\end{array}$ & Az elért sikerekre épülő integratív stratégia \\
\hline PRM & $\begin{array}{l}\text { PDSR-RMDSZ paktum, szuverenitás és } \\
\text { nemzeti érdek, diszkrimináció és területi hatály }\end{array}$ & $\begin{array}{l}\text { A szuverenitás és a nemzeti érdek féltése; } \\
\text { szélsőséges értelmezések }\end{array}$ \\
\hline PD & $\begin{array}{l}\text { Magyar fél, kétoldalú kapcsolatok, RMDSZ } \\
\text { helyzete, nemzeti érdek }\end{array}$ & Deetnicizáló stratégia \\
\hline PNL & Diszkrimináció és területi hatály, nemzeti érdek & Nincs domináns stratégia \\
\hline RMDSZ & $\begin{array}{l}\text { Magyar kisebbség helyzete, kedvezmények, } \\
\text { többség-kisebbség viszonya }\end{array}$ & Etnicizáló stratégia \\
\hline
\end{tabular}

A parlamenti vitákban jelentős teret kapnak a hivatkozások, amelyek alapján több típusú érvet különböztethetünk meg: (1) történelmi események, történelmi időszakok: Trianon, Kádár-korszak (magyar vita); Moldova és Havasalföld egyesülése, Nagy-Románia (román vita); (2) történelmi személyek, politikusok, írók, költők: Szabó Dezső, Bibó István, Sütő András, Illyés Gyula, József Attila (magyar vita); Ion C. Brătianu (román vita); (3) közelmúlt politikai fejleményei: mindkét vitában megjelent a kommunizmus bukása, rendszerváltás, az előző kormány sikereinek hangoztatása és a magyar-román alapszerződés; (4) nemzetközi szervezetek és európai fórumok, európai példák és gyakorlatok: az EU, a Velencei Bizottság, minkét vitában megjelent; európai 
autonómiaformák, ET 1201. sz. ajánlása (magyar vita); (5) kutatóintézetek: Balázs Ferenc Intézet felmérése (magyar vita). ${ }^{397}$

8. sz. ábra: A státustörvény és az egyetértési nyilatkozat: szereplők, folyamatok, funkciók

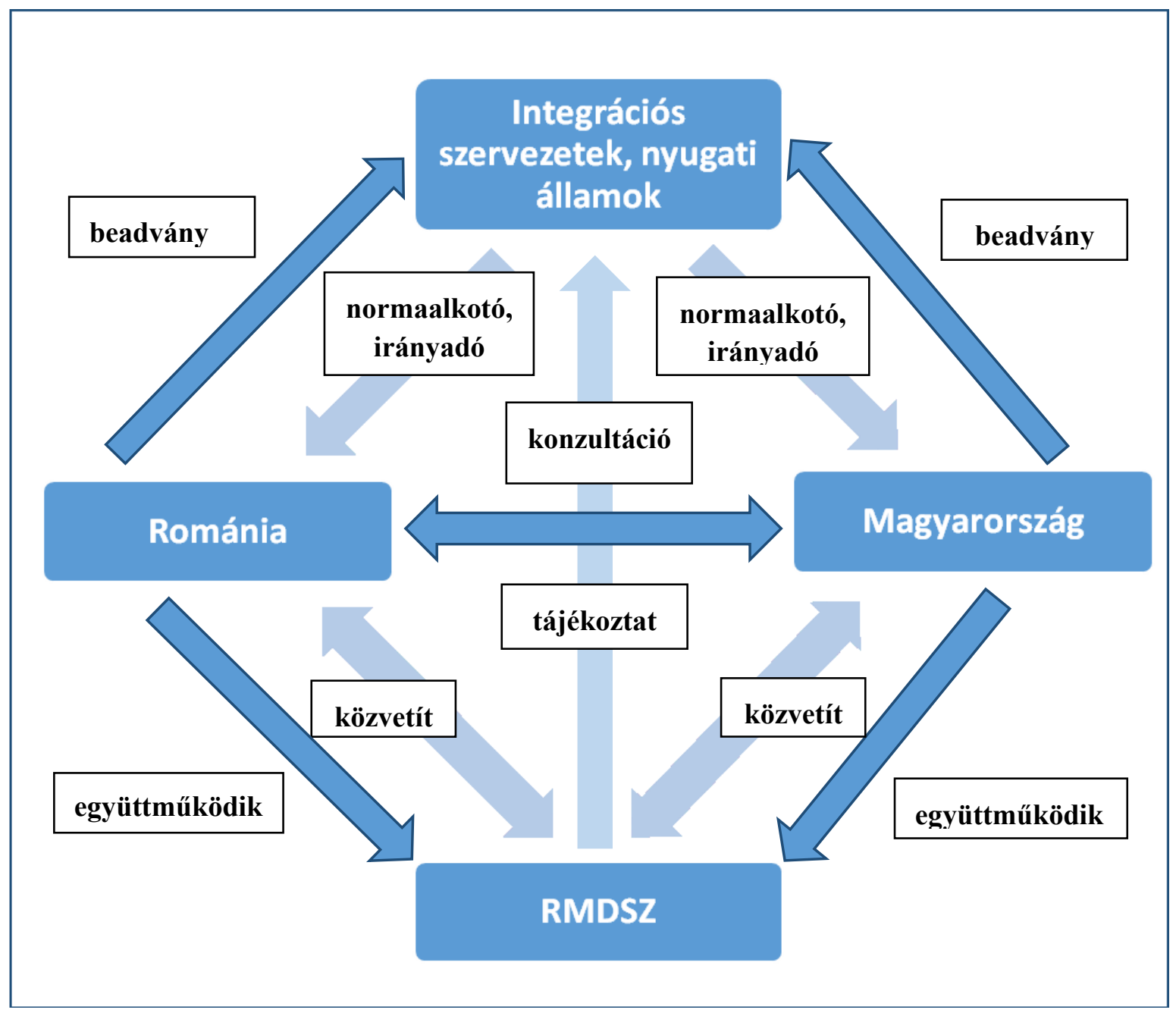

Magyarország és a határon túli magyar közösségek viszonyában a magyar-magyar kapcsolatok intézményesítése és a határon túli politikai szervezetek bevonása a státustörvény előkészítésén dolgozó szakbizottságok munkájába jelentős, példanélküli fejleményként értékelhető. A MÁÉRT megalakításával a kormány egyrészt az érdekérvényesítés új terepét hozta létre, ahol csökkent az ellenzéki pártok szerepe, másrészt olyan konszenzust kívánt kialakítani a határon túli magyarok ügyében, amely elősegíti a nemzeti integrációt. A jogszabály elfogadásának folyamatában ezért a kormány kiemelten nyilatkozott a határon túli szervezetek szerepéröl és a MÁÉRT-ben

\footnotetext{
397 A Balázs Ferenc Intézet által készített felmérés rámutat annak a veszélyére, hogy az aktuálpolitikai kérdéseket tematizáló kutatások hogyan rendelődnek alá a pártérdekeknek, és a vitában felszólaló képviselők a felmérés megállapításait miként használják fel saját érvrendszerük alátámasztására.
} 
folyó munkáról, amelyet a külügyi vitákon számos esetben megkérdőjeleztek az ellenzéki pártok. A folyamatos ellenzéki támadások, azonban csak részben tükröződtek a jogszabály záró szavazásán, amelyen az MSZP képviselői is megszavazták a törvénytervezetet.

A jogszabály elfogadása jelentős feszültségekhez vezetett a magyar-román és magyar-szlovák relációban: a két szomszédos állam azzal vádolta a magyar felet, hogy nem tájékoztatták őket megfelelő módon, a jogszabály elfogadásával pedig ,kész tények elé” állította öket a magyar vezetés. Noha mind a bizottsági viták, mind a parlamenti viták keretében felmerült a tájékoztatás, a probléma jellegéből adódóan a legkörültekintőbb és legrészletesebb tájékoztató sem előzhette volna meg a felek között kialakult vitát. ${ }^{398}$ A kormány döntése mögött nagy szerepet játszhatott az alapszerződés tárgyalásainak tapasztalatai, amely során többéves tárgyalásokat követően lehetett eredményeket felmutatni. A státustörvény esetében egy hasonlóan hosszú egyeztetési folyamatot a kormány nyilvánvalóan el szeretett volna kerülni. Ennek ellenére a kialakuló vitában a magyar fél nyitott volt a konzultációkra, mert pozíciója előnyösebbnek bizonyult, ugyanis a jogszabály alkalmazásával - végrehajtási rendeletek elfogadásával - volt hová „visszalépnie”. Ezt bizonyítja a román féllel megkötött egyetértési nyilatkozat is. A dokumentum olyan kompromisszumos megoldásnak bizonyult, amely nem eredményezett lényeges módosulásokat a jogszabály végrehajtásában, következésképpen elfogadható volt a magyar fél számára.

A román diplomáciát valóságos sokként érte a magyar fél fellépése és kisebbségi kérdésben kezdeményező pozícióba való kerülése. E pozícióhoz viszonyulva hangsúlyozva a jogszabály elutasítását és a román állam szuverenitását védelmezését -, úgy próbált fellépni, hogy a kialakult államközi vita semmilyen formában ne befolyásolja Románia integrációját. A nyílt vita felvállalása helyett a Velencei Bizottság megkeresése kiváló kezdeményezésnek bizonyult, a testülettől pedig azt várta, hogy foglaljon állást az anyaország felelősségének kérdésében, amely közvetve az európai kisebbségvédelem időszerü kérdéseit is érintette. ${ }^{399}$ Ha a Putnam által kidolgozott modellt a státustörvény vitájára alkalmazzuk, akkor elmondható, hogy a vitatott témák

\footnotetext{
${ }^{398}$ Bárdi Nándor szerint a státustörvény körül kialakult konfliktust „lehetett volna másként kezelni, de nem lehetett megspórólni”. A történész úgy vélte, hogy a kormányzat ott hibázott, hogy nem tájékoztatta megfelelőképpen az adott állam közvéleményét (Bárdi 2004, p. 180).

399 A Velencei Bizottsághoz benyújtott román álláspont megjelentetését és népszerüsítését a román külügy kiemelt prioritással kezelte. Maga a külügyminiszter és néhány munkatársa szerkesztésében szakmai kiadványt jelentetett meg, azzal a céllal, hogy a nemzetközi jog és a Velencei Bizottság ajánlására alapozva elítélje a státustörvényt (Năstase és mtsai. 2002).
} 
részben kívül esnek a két állam nyerési halmazán, egyetértésre pedig azt követően kerülhet sor, ha a román állam nem gördített akadályokat a jogszabály romániai alkalmazása elé, másfelől a magyar fél a román javaslatoknak megfelelően kiterjeszti a kedvezmények bizonyos körét a nem magyar származású román állampolgárokra.

A kormányzó párt mozgásterét a belpolitikai erőviszonyok nagyban meghatározták. Az ellenzéki pártok részéről érkező kritikák egy része a kormányprogram megvalósítása terén elért hiányosságokra mutattak rá, másfelől pedig a magyar kisebbségnek tett engedmények és az RMDSZ-szel kötött parlamenti megállapodás került a figyelem középpontjába. E megállapodás a kormányzó PDSR-t arra késztette, hogy az államközi vita ellenére fenntartsa az együttmüködést: ez szükségessé tette a szövetséggel folytatott rendszeres egyeztetéseket és konzultációkat.

A státustörvény elfogadása és a magyar-román vita kialakulása az európai fórumok napirendjére helyezte a határon túli nemzettársakért viselt anyaországi felelősség kérdését. Az alapszerződés vitájához hasonlóan az európai fórumok normaalkotókként jelentek meg, szerepük pedig a keretek - az anyaországi felelősség meghatározásában bizonyult irányadónak. A Bizottság jelentése az érvényben levő európai gyakorlatokról, a követendő mintákról adott áttekintést, egyben pedig iránymutatásként szolgált a felek közötti vitás kérdések feloldásában. Az európai fórumok - különösképpen a Főbiztos - a stabilitás fenntartásában voltak érdekeltek, ezért a hangsúly a konzultációk folytatására helyeződött, egyrészt a két állam képviselői között, másrészt az európai fórumok és a két érintett állam bevonásával, esetenként pedig a Főbiztos és az RMDSZ között.

A Szövetség a MÁÉRT, valamint a külügyi bizottság ülésein több alkalommal kifejezte a törvénnyel szembeni elvárásait: elsőként azt szerette volna elérni, hogy legyen törvényes kerete a magyarországi munkavállalásnak, másodsorban az erdélyi magyarok részesüljenek oktatási kedvezményekből és kapjanak hozzáférést az egészségügyi ellátáshoz. A kialakult vitájában az RMDSZ szerepe, mind magyar oldalról, mind pedig a román belpolitikai helyzetnek betudhatóan felértékelődött. Ezt a pozíciót kihasználva folyamatosan közvetített a felek között és sikerült meggyőznie a kormányzó pártot a jogszabály elfogadásáról. A kormányzó párttal kötött együttmüködés következtében jelentős jogszabályi változások, a magyar kisebbség szempontjából is fontos döntések elfogadása jellemezte ezt az időszakot, amelyben a Szövetség felhagyott a sérelmi politizálással és az európai fórumokat megcélzó panaszokkal. Ehelyett a Szövetség külkapcsolatai visszafogottabbá váltak és az európai 
fórumok tájékoztatása alkalmával a reformfolyamatokban való részvétel és a konkrét célkitüzések hangsúlyozása, valamint a magyar közösséget is érintő szakpolitikai keretek hiányossága kapott kiemelt figyelmet.

\section{A státustörvény módosítása és hatásvizsgálata}

A magyar-román memorandum aláírása - mint az a korábban ismertetett ellenzéki pártok reakcióiból látható volt - nem tett pontot s státustörvény körül kialakult vitás kérdések rendezésére, mi több az eltérö értelmezések - melynek terepét a külügyi bizottság jelentette -, tovább mélyítették a pártok közötti megosztottságot. Az MSZP és az SZDSZ képviselői már a bizottság január 11-i ülésén számos ponton vitatták a két állam kormányfője által aláírt megállapodást. ${ }^{400}$ Míg az MSZP úgy értékelte, hogy a miniszterelnöki megállapodás felülbírált egy Országgyülés által elfogadott törvényt és elmarasztalta a kormányt, amiért a munkavállalói kedvezményeket a nem magyar nemzetiségű román állampolgárokra is kiterjesztették ${ }^{401}$, addig az SZDSZ képviselője „presztízsmegállapodásként” értékelte az együttműködési nyilatkozatot, amely alapjában módosította a jogszabály célkitűzését. ${ }^{402} \mathrm{Az}$ egyetértési nyilatkozattal szembeni kifogások az SZDSZ-t a törvény módosítására, az MSZP-t pedig egy határozati javaslat benyújtására késztette, azonban a bizottság következő ülésén mindkét indítvány tárgysorozatba-vételét elvetette. ${ }^{403}$ Ez azt jelentette, hogy parlamenti eszközökkel az ellenzéknek már nem volt lehetősége a jogszabály módosítására, azonban a közelgő kampányidőszak lehetőséget adott a kérdés újbóli felvetésére.

Az országgyülési választások kampányában az MSZP nem zárta ki a törvény bizonyos részeinek átgondolását. A módosítás lehetőségét és az egyetértési nyilatkozat újratárgyalását elsőként az MSZP elnöke, Kovács László vetette fel. A konzultációk folytatásának ötletét, valamint a memorandum újratárgyalását, az RMDSZ vezetése szükségtelen lépésnek tartotta. ${ }^{404}$ A magyar felvetést Adrian Năstase miniszterelnök is

\footnotetext{
400 Jegyzőkönyv az Országgyülés külügyi bizottságának a 2002. január 11-én (pénteken) 10 órai kezdettel az Országház föemelet 55. számú üléstermében megtartott üléséröl, KUB/1/2002. KÜB/100/1998-2002.

401 Tabajdi Csaba (MSZP) felszólalása.

402 „,Van két olyan kérdés, ahol egyértelmüen román vonatkozásban nem érvényesül a törvény eredeti célkitüzése. Nem érvényesül a hozzátartozói igazolványok kiadása vonatkozásában, hiszen erröl lemondott a megállapodás, és nem érvényesül az a törvényes feltétel sem, hogy a magyar igazolvány kiadásának feltétele az ajánló testületek által adott ajánlás. Igaz, hogy van egy dokumentációs jelzés, de román vonatkozásban ezt hatályon kivül helyezték. Ez haladéktalanul szükségessé teszi a törvény módositását." Szent-Iványi István felszólalása.

403 Jegyzökönyv az Országgyülés külügyi bizottságának 2002. január 30-án, szerdán 9 órakor az Országház föemelet 55. számú üléstermében megtartott üléséröl, KÜB/2/2002. KÜB/101/1998-2002.

404 Az RMDSZ szatmári kongresszusán - a magyar kormány módosítási szándékát figyelembe véve határozatot hozott a jogszabály módosításáról és amellett állt ki, hogy a törvény „új formájában is őrizze
} 
elutasította, aki szerint román oldalon nem vetődött fel a módosítás szükségessége és az államközi kapcsolatok jelenlegi szakaszában „,nem lenne hasznos az élénk vitát okozó kérdés újbóli megnyitása." 405

A választások után az MSZP és SZDSZ által alkotott kormány azonban nem tett le a státustörvény módosításáról: az erre irányuló törekvése megjelent a kormányprogramban, ${ }^{406}$ majd június végén a Külügyminisztérium tájékoztatta az ET PKGY elnökét és fôtitkárát a státustörvény módosításáról. Május és június folyamán a határon túli magyarok képviselőivel tartott egyeztetéssorozatot követően a magyar kormány július 17-re hívta össze a MÁÉRT ülését. Az ülésen felszólaló Kovács László külügyminiszter a szomszédos államok reakcióira, valamint az európai fórumok részéről érkező álláspontokra hivatkozva kezdeményezte a jogszabály módosításáról szóló eszmecserét, amely egyszerre több elvi követelménynek kell megfeleljen. ${ }^{407} \mathrm{~A}$ résztvevők tudomásul vették a jogszabály módosításának tényét, ugyanakkor fontosnak tartották, hogy a módosításra irányuló javaslatokat a MÁÉRT keretében vitassák meg. ${ }^{408} \mathrm{Az}$ a jogszabály módosítására vonatkozó érdemi egyeztetések a MÁÉRT következő, november 17-i ülésén került sor. A résztvevőkből megalakult ad hoc bizottság kidolgozta azokat az elveket, melyek figyelembe vételével támogatják a kormánynak a jogszabály módosítására irányuló kezdeményezését. A bizottság által kidolgozott elvek érintették az oktatás-nevelési támogatásokat, a munkavállalás valamint a törvény jogalanyaira vonatkozó rendelkezéseket. ${ }^{409}$

meg lényegét.”(„A Romániai Magyar Demokrata Szövetség VIII. Kongresszusán elfogadott dokumentumok. 1. számú Határozat a kedvezménytörvény módosításával kapcsolatban, 2003. február 2." In: Húszéves az RMDSZ. 2009, p. 559)

405 Románia ragaszkodik a státustörvény módosítását ígérő Orbán-Năstase egyezményhez. Szabadság, 2002. május 8., 1. és 8.

406 („A Medgyessy Péter miniszterelnök által beterjesztett és az Országgyülés által elfogadott Kormányprogram külpolitikai része, 2002. május 25.” In: Magyar Külpolitikai Évkönyv. 2002). A kormányprogram a kedvezménytörvényt „eredeti céljainak” megtartásával módosítaná, amely összhangban lenne a határon túli magyarság érdekeivel, az európai normákkal és a szomszédos államok elvárásaival.

407 A módosítás (1) legyen összhangban a jogszabály eredeti céljaival; legyen elfogadható (2) Magyarország és a határon túli magyarok, (3) az európai fórumok és (4) a szomszédos államok számára.

(„Kovács László külügyminiszter beszéde a MÁÉRT ötödik ülésén” 2002, pp. 291-292).

408 („A Magyar Állandó Értekezlet V. ülésének zárónyilatkozata” In: Kántor 2002, p. 294).

409 A bizottság három területen javasolt módosításokat: (1) oktatás-nevelési támogatások: a támogatások kiterjesztése egy gyermekre; a támogatás címzettje lehessen oktatási intézmény valamint pedagógusszervezet; (2) munkavállalás terén támogatták, hogy a törvény hatálya alá tartozó személyek munkavállalására a „, külföldiek magyarországi foglalkoztatásának engedélyezésére vonatkozó általános szabályokat kell alkalmazni”; (3) a támogatások igénybevétele a Magyar igazolvány, valamint a Magyar hozzátartozói igazolvány ad lehetőséget. E dokumentumok kiadásának rendjét és a határon túli szervezetek szerepét a kormány végrehajtási utasítások szintjén, a MÁÉRT részvevőivel egyeztetve rendezi.,„A Magyar Állandó Értekezlet VI. ülésének Zárónyilatkozata, 2002. november 17.)”, In: Magyar Külpolitikai Évkönyv. 2002, pp. 376-380. 
A határon túli szervezetek tájékoztatása és a jogszabály módosításába való bevonásuk mellett a magyar kormány államközi szinten is tárgyalásokat kezdeményezett a román féllel: nyár folyamán, július 6-án egy miniszterelnöki találkozóra, míg szeptember 4-5 között külügyminiszteri találkozóra került sor, amelyek napirendjén szerepelt ugyan a státustörvény módosítása, a tárgyalások mégis a magyar-román stratégiai partnerségre vonatkozó nyilatkozat előkészítése szempontjából bizonyultak kiemelkedőnek, amit november 29-én írt alá a két állam miniszterelnöke. ${ }^{410}$ Magyarország és Románia kormányainak újabb célkitüzése, amely arra irányult, hogy a kisebbségi szakbizottság hatáskörébe utalja a jogszabály módosításának az elökészítését, nem hozott eredményt. ${ }^{411}$ Következésképpen a módosításnál egyrészt a kormány elképzelése, másrészt a MÁÉRT ülésén elfogadott elvek, valamint az európai fórumok újabb javaslatai érvényesültek.

December 5-én Günter Verheugen, az EU bővítési biztosa levelet küldött Medgyessy Péter miniszterelnöknek, amelyben a státustörvénnyel kapcsolatos kifogásainak adott hangot. A biztos arra hívta fel a figyelmet, hogy a magyar nemzetre való utalást „kulturális jellegü hivatkozásra” kellene cserélni, ugyanis a jogszabályban oly módon értelmeződik, „mintha azzal Magyarország különleges politikai kötődés létrehozására törekedne, ami ütközik a szomszédos államok joghatóságának és szuverenitásának elvével.” További kritikaként jelent meg a jogszabály területen kívüli és diszkriminatív hatásai. Végezetül, a biztos újból felhívta a magyar fél figyelmét, hogy a csatlakozáskor a módosított jogszabály összeegyeztethető kell legyen a közösségi joggal („Günter Verheugen’s Letter).

A korábbiakban már említett Jürgens-jelentést a Közgyülés 2003 júniusában fogadta el („Resolution 1335”). A jelentés kidolgozásának időbeli elhúzódása annak tudható be, hogy az ET PKGY jogi és emberjogi bizottsága kétszer, először 2002. június 24-én, másodszor pedig szeptember 2-án kérte a jelentés átdolgozását és kiegészítését, amelyet több szempontból a magyar ET-delegációt vezetője, Tabajdi Csaba is élesen kritizált. Figyelembe véve a kritikákat és a javaslatokat a jelentéstevő december 4-6 között látogatást tett Pozsonyban és Bukarestben, tárgyalt a két kormány képviselőjével és Markó Béla szövetségi elnökkel is. E találkozók alapján a jelentést 2003 májusában véglegesítette, amiben tükröződnek a jogszabállyal szembeni kifogások

\footnotetext{
${ }^{410}$ („Nyilatkozat a magyar-román stratégiai partnerségi kapcsolatokról és együttmüködésről. Európáért a XXI. században” In: Magyar Külpolitikai Évkönyv. 2002, pp. 393-396).

411 A kisebbségi vegyesbizottság 2002. szeptember 13-14 között Gyulán, valamint 2003. június 12-én Sepsiszentgyörgyön megtartott ötödik ülésének jegyzökönyve értelmében a felek tárgyaltak a jogszabály módosításáról, ellenben konkrét módosítási javaslatokról nem egyeztek meg.
} 
egyrészt az európai fórumok, másrészt a szomszédos államok részéről. Jürgens a nemzet fogalmának európai értelmezését vizsgálva arra a következtetésre jutott, hogy a jogszabályban szereplő nemzetkoncepció „bizonyos körülmények alatt az államhatárok el nem ismeréseként értelmezhető" (ibid). További módosítást igényel a Hozzátartozói igazolvány, a gazdasági és szociális kedvezmények, és a magyar szervezetek szerepe a jogszabály alkalmazásában, melyek kétoldalú egyezményekkel is rendezhetők. E javaslatok figyelembe vételével a jelentés felkérte a magyar kormány képviselőit, hogy az európai fórumok ajánlásai értelmében folytassa a szomszédos államokkal való tárgyalásokat és módosítsa a jogszabályt. ${ }^{412}$

A parlamenti pártok és a határon túli szervezetek a MÁÉRT május 24-i ülésén vitatták meg a jogszabály módosításának tervezetét és abban értettek egyet, hogy (1) meg kell őrizni a törvény eredeti céljait; (2) a jogszabály Magyarország EU-taggá válása után is maradjon érvényben; (3) semmilyen formában ne sérüljön a Magyar igazolvány jelentősége. ${ }^{413}$ Az Országgyülés június 16-án kezdte meg A szomszédos államokban élő magyarokról szóló 2001. évi LXII. törvény módosításának tárgyalását, és a részletes vitát másnap zárta le. A módosításról szóló vitában kirajzolódtak a pártok közötti ellentétek: míg a kormánykoalíció a módosítás és a jogszabályról szóló többéves vita lezárása mellett érvelt, addig az ellenzéki képviselők több szempontból nemzetfogalom, támogatási rendszer, igazolvány kérdése - „visszalépésként” tekintettek a módosított tervezetre ${ }^{414}$, amely tükröződött a zárószavazás eredményében. $^{415}$

A módosítás az európai fórumok és a szomszédos államok által kifogásolt rendelkezéseket kívánta rendezni. A jogszabály alapját érintő elvi módosítást képez a preambulumban szereplő, az egységes magyar nemzetre való hivatkozás, amely kikerült a szövegből. ${ }^{416}$ A gyakorlati módosítások között említendő, hogy a (1) Magyar igazolvány vagy Magyar hozzátartozói igazolvány iránti kérelmeket a diplomáciai és konzuli képviseletekhez lehet benyújtani, (2) az ajánlószervezetek pedig formálisan

\footnotetext{
412 A Jürgens-jelentés 13. pontja.

413 „A Magyar Állandó Értekezlet VII. ülésének Zárónyilatkozata (2003. május 24.)”. A FIDESZ, valamint a határon túli szervezetek közül KMKSZ és a VDMP nem írta alá a zárónyilatkozatot.

414 A szomszédos államokban élő magyarokról szóló 2001. évi LXII. törvény módosításáról szóló törvényjavaslat általános és részletes vitája június 16-17. között zajlott le (79. és 80. ülésnapok).

${ }^{415}$ Az Országgyülés a státustörvény módosítását a 195:173 arányban fogadta el.

416 A módosított jogszabályba a következő értelmezés került: „a magyar nemzeti azonosságtudata megerősítésének, valamint a magyar kulturális örökséghez való kötődésének, mint a magyar nemzethez való tartozása kifejezésre juttatásának érdekében” megnevezés került („2003. évi LVII. törvény a szomszédos államokban élő magyarokról szóló 2001. évi LXII. törvény módosításáról”, 1§. idézi Kántor 2010, p. 494).
} 
megszünnek, ugyanis szerepük csak a tájékoztatásra korlátozódott. A módosítások a kedvezmények és a támogatottak körét is érintették. Míg a határon túli magyarokat érintő munkavállalási kedvezmények megszüntek, addig a támogatásban részesülők köre a MÁÉRT javaslatok alapján bővült: ennek következtében lehetővé vált az oktatási-nevelési támogatás egy gyerek utáni igénylése, míg oktatási támogatásban részesülhettek az oktatási és nevelési intézmény mellett működő szülői, illetve pedagógus szövetségek. ${ }^{417}$

A státustörvény módosítását pozitívan értékelte a román külügyminisztérium és magas szintü tárgyalásokat kezdeményezett a jogszabály romániai alkalmazásáról, amelynek keretében július elsején a két állam miniszterelnöke egy kétoldalú megállapodás előkészítésében egyezett meg. Röviddel a miniszterelnöki találkozó után, július 18-án Kovács László és Mircea Geoană társelnökletével ülésezett a magyar-román kormányközi vegyesbizottság, amelynek keretében a felek megegyeztek a státustörvény romániai alkalmazásáról. ${ }^{418}$

A státustörvény végrehajtásáról szóló megállapodást a két állam miniszterelnöke szeptember 23-án írta alá. A megállapodás értelmében (1) a nem magyar nemzetiségü román állampolgárok nem részesülhetnek kedvezményekben; (2) az igazolvány kiadásával kapcsolatos eljárás Magyarország területén zajlik; (3) megszünt az ajánlószervezetek szerepe; (4) a magyar nyelven tanuló diákok és pedagógusok Magyarország területén igénybe vehetik az oktatási kedvezményeket; (5) az oktatási kedvezmények szétosztásában pedig az Iskola Alapítvány az illetékes. ${ }^{419}$

A státustörvény alkalmazásáról szóló második magyar-román megállapodás lezárta a jogszabály elfogadását követő több éves vitát a felek között, amelynek következtében zökkenőmentesen folytatódhatott az igazolványok iránti kérelmek leadása, illetve kibocsátása. A jogszabály életbe lépésétől 2007. január 31-ig a Magyarországgal szomszédos államokban 879805 kérelmet regisztráltak, amelynek

\footnotetext{
${ }^{417}$ Ibid. 14.§.

${ }^{418}$ Az ülést követő sajtótájékoztatón mindkét fél jelentős eseménynek nevezte a megállapodást, a magyar külügyminiszter pedig kiemelte, hogy ,a megállapodás egyetlen pontja sem korlátozza a kedvezménytörvény eredeti céljainak érvényesülését, hatékony alkalmazását, tehát azt, hogy segítséget nyújtson a határon túli, így a romániai magyaroknak is a szülőföldön való boldoguláshoz és magyarságuk, azaz nyelvük és kultúrájuk megőrzéséhez.” Kedvezménytörvény - a magyar és a román külügyminiszter nyilatkozata. MTI, 2003. július 18. (keresőszó: kedvezménytörvény).

419 „Megállapodás a Magyar Köztársaság Kormánya és Románia Kormánya között (Bukarest, 2003. szeptember 23,” In: Magyar Külpolitikai Évkönyv, pp. 318-320).
} 
több mint felét, 514246 kérelmet $(58,45 \%)$ Romániában nyújtották be. ${ }^{420}$ A kérelmek időbeli alakulásából, amelyröl részletes áttekintést az alábbi táblázat nyújt, jól látható, hogy a Magyar igazolványok iránti kérelmek kétharmadát a törvény életbe léptetésének első évében nyújtották be. Az ezt követő években folyamatosan csökkent az érdeklődés az igazolványok iránt, amely egyrészt azzal magyarázható, hogy az oktatási-nevelési támogatás folyósításához már nem volt feltétel az igazolvány megléte, másrészt pedig „elfogytak” a potenciális érdeklődők.

16. sz. táblázat: Regisztrált kérelmek száma éves bontásban (2002-2007)

\begin{tabular}{|c|c|c|c|c|c|c|}
\hline & $\mathbf{2 0 0 2}$ & $\mathbf{2 0 0 3}$ & $\mathbf{2 0 0 4}$ & $\mathbf{2 0 0 5}$ & $\mathbf{2 0 0 6}$ & $\mathbf{2 0 0 7}$ \\
\hline Kérelmek száma & 340154 & 92718 & 74754 & 6427 & 143 & 50 \\
\hline \% & 66,15 & 18,05 & 14,55 & 1,27 & 0,02 & 0,01 \\
\hline
\end{tabular}

Forrás: saját számítások (Császár 2009, p. 104) alapján.

A dokumentum kiváltása mögötti indokok - a kérelmezők bevallása szerint többfélék. A kolozsvári Etnikumközi Viszonyok Kutatóközpontjának 2003-as vizsgálatából megállapítható, hogy mind az érzelmi, mind pedig a materiális ösztönzők szerepet játszottak a Magyar igazolványok igénylésénél. A kérelmek 60\%-a mögött érzelmi indokokat találunk, míg a fennmaradó 40\% esetében a támogatások és a kedvezmények mögötti anyagi ösztönzők és előnyök érvényesültek. ${ }^{421}$

17. sz. táblázat: A Magyar igazolvány kiváltása

\begin{tabular}{|l|c|}
\hline \multicolumn{1}{|c|}{ A kiváltás mögötti indokok } & A válaszadók aránya (\%) \\
\hline Minden magyarnak kell legyen igazolványa & 23,2 \\
\hline Az igazolványban azt írja: ,magyar vagyok” & 13,7 \\
\hline A magyar nemzethez tartozás bizonyítéka & 19,3 \\
\hline Másképp érzem magam, amikor Magyarországra utazom & 4,3 \\
\hline Valamire hasznos lehet & 19,3 \\
\hline Kedvezmények, támogatások & 11,9 \\
\hline Segít a munkavállalásban & 6,3 \\
\hline Személyes környezet hatására & 2,1 \\
\hline
\end{tabular}

Forrás: Az erdélyi magyarok röntgenképe 2003 október (CCRIT), Szabadság, 2003. december 4.

Ami a támogatásokat és kedvezményeket illeti, a válaszadók több mint fele az oktatási-nevelési támogatást tartja a legfontosabbnak (56,8\%), míg valamivel több, mint

\footnotetext{
${ }^{420}$ Császár Melinda doktori dolgozatában a Belügyminisztérium valamint az RMDSZ státustörvénnyel foglalkozó Központi Tájékoztató Iroda adatait felhasználva elemezte a kérelmezők szocio-demográfiai adatait (Császár 2009, p. 104).

${ }^{421}$ („Az erdélyi magyarok röntgenképe 2003 október”) A kutatás részletes adatait, amelyre hivatkoztam a Szabadság napilap 2003. december 4-i száma ismertette.
} 
egyharmaduk az utazási kedvezményeket emelte ki. A megkérdezettek 4,4\%-a a diákigazolványt, 1,5\%-a pedig a pedagógusigazolványt és szintén 1,5\%-a az ingyenes múzeum-, illetve könyvtárlátogatást jelölte meg a legjelentősebb kedvezményként

A státustörvény elfogadásáról és végrehajtásáról kialakult államközi vita a többség-kisebbség viszonyának alakulását is befolyásolta, amely tükröződött az országos reprezentatív mintán végzett közvéleménykutatásokban is. Ebből kiemelkedik az Etnokulturális Kisebbségek Forrásközpontja által kezdeményezett és lefolytatott, az Etnikumközi kapcsolatok barométere c. kutatási projekt, amely három egymást követő évben, 2000 és 2002 között vizsgálta az etnikumközi kapcsolatok alakulását. A 2001ben elvégzett vizsgálat, amelynek adatfelvételére október 16-30. között került sor, a többség-kisebbség viszonyának romlását mutatta ki. Annak ellenére, hogy a kormányzó Szociáldemokrata Párt és a Szövetség között példátlan együttmüködés alakult ki, a státustörvény mellett, több olyan kérdés is a napirendre került - csángóoktatás, a két többségében magyarlakta megyére vonatkozó titkosszolgálati jelentés -, amely mind a románok, mind pedig a magyarok megítélése szerint negatívan hatott az etnikumközi viszonyra. Az Orbán-Năstase egyezmény megkötése, a Szövetség együttmüködésének megújítása a kormánypárttal, valamint a kétoldalú tárgyalások folytatásának következtében Romániában a vita fokozatosan lekerült a napirendröl, amely a magyarok és a románok közötti viszony javulását eredményezte.

\section{9. sz. ábra: A magyar-román viszony megítélése 2000-2002 között}

Kérdés: Véleménye szerint, jelenleg a románok és a magyarok közötti viszony jobb vagy rosszabb az elmúlt évhez képest?

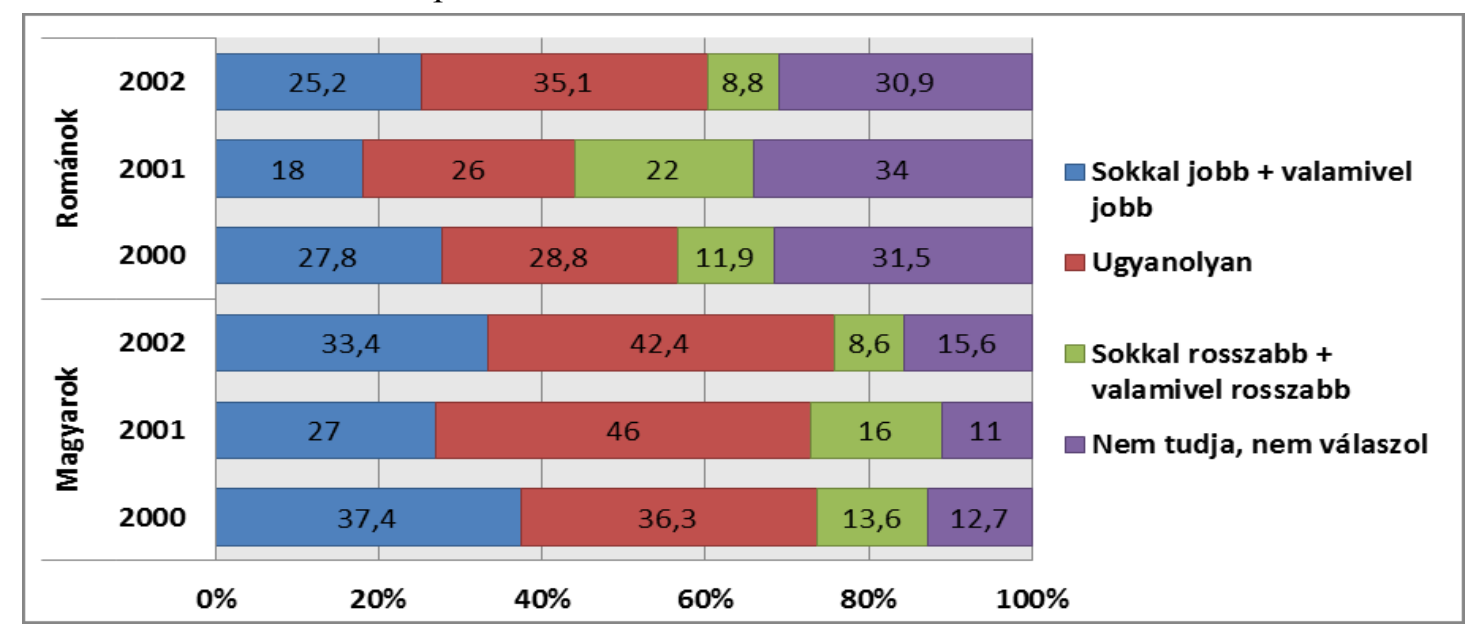

Forrás: („Etnikumközi kapcsolatok barométere”), 2000-2002 közötti adatsorok. 
Államközi szinten a státustörvény vitája alkalmat adott arra, hogy a nemzet meghatározásából eredő eltérő álláspontokat, beleértve a nemzeti kisebbségek helyzetének megoldását, a felek az európai normák figyelembe vételével rendezzék. Az európai normák hangsúlyozása a román fél diskurzusában kulcsfontosságúnak bizonyult. „Függetlenül a viták hangnemétől, sem a román kormány, sem a magyar, nem a kétoldalú kapcsolatokat terhelö problémaként, hanem az európai standardokkal összefüggésben álló problémaként kezelte, amelyben kikérték az európai fórumok véleményét" idézte fel Bogdan Aurescu, a külügyminisztérium államtitkára a két állam viszonyának alakulásáról, aki annak a meggyőződésének adott hangot, hogy a vita nem befolyásolta a kétoldalú kapcsolatokat (Chiriac 2005, p. 86).

A jogszabály elfogadását követő reakciók és az államközi szinten lefolyt viták alapján, nem osztom a kétoldalú tárgyalásokat is irányító diplomata véleményét. Mindazonáltal a státustörvény körül kialakult vita megteremtette annak a lehetőségét, hogy mind Magyarország, mind Románia meghaladva a kölcsönös történelmi sérelmeket pragmatikusabb kapcsolatokat alakítsanak ki, és tegyék rendszeresebbé a különböző szakpolitikai egyeztetéseket, amelyek megalapozzák az együttműködés kereteit. A kisebbségi vegyesbizottság, majd a kormányközi vegyesbizottság összehívása világos jelzés volt erre vonatkozóan, amelyet felsőszintű találkozók egész sora követett: 2004 márciusában és áprilisában Mircea Geoană tett hivatalos látogatást Magyarországra, míg júliusban miniszterelnöki találkozóra került sor.

$\mathrm{Az}$ intenzívebb kapcsolatoknak az eddigi mintázatoktól eltérően már nem a román álláspontot igazoló funkciója volt. Április 25-én hosszú viták és tárgyalások után felavatták Aradon a helyreállított Szabadság-szobrot, júliusban pedig a két állam miniszterelnökének részvételével határátkelőhelyet adtak át. A többéves vita lezárása tehát olyan helyzetet teremtett, amelyben a felek új alapokra helyezhették kapcsolataikat. Ennek egyértelmü jelei a 2005-2008 között lezajlott négy egymást követő kormányülés munkáiban mutatkoztak meg leginkább, ami az államközi kapcsolatok leglátványosabb és legeredményesebb időszakának tekinthető.

Kétség sem fér hozzá, hogy a két állam viszonyának rendeződésében az RMDSZ-nek jelentős érdemei vannak. Azáltal, hogy a kormánypárttal kötött együttmüködés alapján részt vállalt az erdélyi magyar közösség szempontjából is lényeges reformfolyamatok elindításában, jelentős vitákat indított el a Szövetség különböző döntéshozatali fórumain - ami a Reform-tömörülés kiválását - egyben pedig 
a pártszerü müködés irányába terelte a szervezetet. ${ }^{422}$ Mindennek ellenére a Szövetség nem talált kiutat abból a sajátos helyzetből, amely egyrészt a jogszabály elfogadásával Budapest, másrészt a kormányzó párttal kötött együttmüködés következtében Bukarest jelentőségét növelte. A két központ jelentőségét Markó Béla RMDSZ elnök is elismerte: az SZKT ülésén elhangzott beszédében kiemelve a román pártokkal folytatott pragmatikus viszony, valamint a mindenkori magyar kormány és ennek ellenzékével való együttműködés szükségességét, Kós Károly Kiáltó szó című kiáltványából merítve, amellett érvelt, hogy az erdélyi magyarság önállóságra van ítélve. ${ }^{423}$ A Szövetség önállóságát a státustörvény elfogadását követő időszakban azonban mindkét centrum korlátozta, egyben pedig kijelölte azokat az érdekérvényesítési lehetőségeket, amelynek keretében a Szövetség megvalósíthatja célkitűzéseit.

422 A 2003-as szatmári kongresszus alapszabályzata ugyan hangsúlyozza az önkormányzati elv érvényesülését, azonban az elnök és az Ügyvezető Elnökség szélesebb hatáskörei, a parlamenti csoport funkciójának felértékelődése, valamint a platformok szerepének csökkenése a pártszerü működés irányába tett lépésként értékelhetők.

423 Önállóságra ítélve. Markó Béla szövetségi elnök Marosvásárhelyen, az SZKT ülésén elhangzott politikai beszámolója. RMDSZ Tájékoztató, X. évfolyam, 2211. szám, 2002. május 27. 


\section{A KETTŐS ÁLLAMPOLGÁRSÁG KÉRDÉSE A MAGYAR-ROMÁN KAPCSOLATOKBAN}

A magyar állampolgárság kiterjesztése a Magyarországgal szomszédos államokban élő magyar kisebbség számára - a státustörvényt követően - újra a közbeszéd tárgyává és a politikai napirend meghatározó elemévé tette az anyaország határon túli magyarokkal kapcsolatos politikáját. A kettős állampolgárság bevezetésének kérdése - hasonlóan az alapszerződésről és a státustörvényről folyó vitákhoz - 2004 második felében mélyen megosztotta a magyarországi parlamenti pártokat és döntő módon belpolitikai vitaként, tehát pártpolitikai küzdelemként volt értelmezhető (Bárdi 2004, p. 52; Waterbury 2010, pp. 123-27), amiben az ellenzéki pártok által hangsúlyozott alkotmányos felelősségvállalásból következő érvek a kormányzó pártok által tematizált gazdasági, a jóléti nacionalizmust erősítő érvrendszerekkel ütköztek.

Érdekes módon a magyar-román kapcsolatokban a kettős állampolgárság kérdése, így a 2010-ben bevezetett könnyített honosítási eljárás és a szavazati jog biztosítása nem vezetett jelentős vitákhoz a felek között, annak betudhatóan, hogy a két állam hasonló állampolgárság-politikát folytat: Románia már a '90-es évek elejétől kezdve egyszerüsítette a román állampolgárság megszerzésének folyamatát a lakóhely megváltoztatása nélkül a moldovai állampolgároknak, aminek következtében több százezerre tehető a moldáv-román kettős állampolgárok száma. Ennek ellenére az egyszerüsített honosítási eljárás nem bizonyult problémamentesnek: míg Románia a Moldovai Köztársasággal és közvetlenül az EU-val került konfliktusba, addig Magyarország lépésével szemben Szlovákia fogalmazott meg éles kritikákat (Bauböck 2010).

A soron következő fejezetben elsőként az állampolgárság kiterjesztésének és a könnyített honosítási eljárás intézményének európai gyakorlatát és az ezzel szorosan összefüggő szavazati jog kérdését tekintem át, ezt követően pedig Magyarország és Románia állampolgárság-politikáját elemzem, kiemelve azokat a fontosabb momentumokat és jogszabályi változásokat, melyek lehetővé tették az állampolgárság egyszerüsített honosítási eljárás során történő - kiterjesztését. Az állampolgárság megadásának kérdése több alkalommal megjelent a parlamenti viták napirendjén: a parlamenti pártok állampolgársággal kapcsolatos pozícióit külön alfejezetben elemzem és arra mutatok rá, hogy e lényeges nemzetpolitikai lépést a pártok milyen érvekkel és stratégiákkal próbálták saját politikai érdekeik és célkitüzéseik elérésére felhasználni. 
Az állampolgárságról folytatott parlamenti viták, az államközi kapcsolatokban is meghatározó vitákat eredményeztek elsöként a moldáv-román, másodsorban pedig a magyar-szlovák relációkban, amellyel összefüggésben - immár EU-s vonatkozásban újra előtérbe került az anyaország felelősségének és a nemzetiesítő államok szuverenitásának kérdése. A fejezet végén a kettős állampolgárság várható hatásainak felleltározására teszek kísérletet és azokra következményekre fókuszálok, aminek a jelei a magyar-magyar kapcsolatokban érzékelhetővé váltak.

\section{Kettős állampolgárság és szavazati jog - európai kitekintés}

Az állampolgárság intézménye az államok és polgáraik között fennálló viszony közjogi leképeződéseként értelmezhető. A modern értelemben vett állampolgárságra nagy hatást gyakorolt a francia forradalom eszmeisége, a népszuverenitás és a polgári jogegyenlőség (Halász 2009, p. 11), valamint a polgári, politikai és szociális jogok (ún. generációs jogok) 18-20. századi kiszélesedése (Marshall 1950), ami hozzájárult a központi államhatalom által fokozatosan elismert alapvető állampolgári jogok és kötelezettségek kiszélesedéséhez.

Az állampolgárság meghatározásakor Kivisto és Faist a fogalom két jellemzőjét emelte ki: míg az állampolgárság egyik értelmezése arra vonatkozik, hogy ki és milyen feltételekkel válhat a politikai közösség tagjává, addig a második értelmezés szerint az állampolgárság számos kölcsönös joggal és kötelességgel jár, melyek „helyenként és korszakonként változnak, mások egyetemesek" (Kivisto-Faist 2008, pp. 1-2). Az állampolgárság által biztosított jogok közül leggyakrabban a politikai folyamatokba és közügyekbe való beleszólás lehetőségét (aktív, illetve passzív választójog) emeli ki a szakirodalom, míg a kötelezettségek között az állam törvényeinek betartása, a sorkatonai szolgálat és az adófizetés említhető meg.

A '80-as és '90-es évek meghatározó társadalmi, gazdasági és politikai változásai (globalizáció, transznacionalizáció, európaizáció), valamint a globális migráció jelenségének következtében egyrészt megnövekedett az állampolgárság iránti szakmai érdeklődés (Culic 2009, p. 6), amely hozzájárult az állampolgárság újabb formáinak és jelentésváltozatainak azonosításához ${ }^{424}$, másrészt pedig korábban nem tapasztalt módon befolyásolta és liberalizálta az állampolgárság intézményét. E

${ }^{424}$ Kivisto és Faist szerzőpáros az állampolgársággal kapcsolatos diskurzusokat elemezve az állampolgárság 19 jelentésváltozatát összesítette. Meglátásuk szerint, az állampolgársággal kapcsolatos vizsgálódásoknak egyik mutatóját képezik a fogalomhoz kapcsolódó ,jelzős szerkezetek terjedése”, mint pl. globális, egyetemes, kozmopolita, posztnacionális stb. állampolgárság (Kivisto-Faist 2008, p. 2). 
folyamatok legfontosabb következményének tekinthető a kettős állampolgárság növekvő mértékü elfogadása és elterjedése nemcsak az európai, hanem a világ más államaiban is. A kettős, illetve többes állampolgárság elfogadása azért értékelhető jelentős fejleményként, mert „néhány évtizeddel ezelőtt az állampolgárságot és a politikai lojalitást elválaszthatatlannak tartották az adott politikai közösségtől" (Faist-Gerdes-Rieple 2006, p. 913).

E pozitívnak tekinthető trend mögött egy több mint egy évszázados fejlödési folyamat áll annak betudhatóan, hogy az államok „,nemkívánatosnak tekintették a kettős kötődést" és azért nem támogatták a kettős állampolgárság intézményét, mert problematikusnak vélték az adózási és hadkötelezettségek teljesítését, valamint a másik államhoz való kötődést (Kovács 2011, p. 193). A 19. század második felétől elsőként az Egyesült Államok kötött az állampolgárság szabályozására vonatkozó szerződéseket (Bancroft-szerződések), ami a kettős állampolgárság lehetőségének kialakulására, illetve korlátozására vezethető vissza. ${ }^{425}$ A Népszövetség keretében az állampolgári jogok összeütközéséről szóló Hágai Egyezmény is a kettős állampolgárság elutasításának szellemében fogant, mert megerősítette az Állandó Nemzetközi Bíróság véleményét és az állampolgárság kérdését belső joghatóságba való tartozó kompetenciaként határozta meg. ${ }^{426}$

A kettős állampolgárság visszaszorítását célzó népszövetségi logika az ET által 1963-ban elfogadott egyezményben is tükröződött, mivel kimondta az állampolgárság elvesztésének a lehetőségét azon személyek esetében, akik saját akaratukból, honosítás útján szerzik meg egy másik állam állampolgárságát („Convention on the Reduction” 1963, 1. cikk). Az egyezményt ratifikáló nyugat-európai államok alacsony száma jelzésértékű volt arra vonatkozóan, hogy a tagállamok többsége - az egyre nagyobb méreteket öltő bevándorlásnak köszönhetően - hajlanak a kettős állampolgárság elfogadására. A nyugat-európai államok kettős állampolgársággal kapcsolatos toleranciája tehát a lakónépesség és az állampolgárok közötti kongruencia

\footnotetext{
${ }^{425}$ George Bancroft amerikai diplomata kezdeményezésére az Egyesült Államok 26 államközi szerződést kötött az európai államokkal az állampolgárság szabályozására vonatkozóan, megakadályozva ezzel a kettős állampolgárság elterjedését. Az egyezmények alapján öt évet meghaladó tartózkodás után lehetővé vált az amerikai állampolgárság megszerezése, visszatelepedés esetén pedig az eredeti állampolgárság visszaszerzése, és az amerikai állampolgárság automatikus elvesztése.

426 „Minden állam maga határozza meg jogszabályai útján, hogy kik az állampolgárai. E jogszabályokat más államoknak el kell ismerniük annyiban, amennyiben azok összhangban állnak a nemzetközi egyezményekkel, a nemzetközi szokásokkal, valamint az állampolgárságra vonatkozólag általánosan elismert jogelvekkel.” Hágai Egyezmény, 1. cikkely. A szerződő felek egyrészt elismerték, hogy „,minden személynek joga van egy állam állampolgárságára, azonban csak egy államéra” másrészt pedig vállalták, hogy erőfeszítéseket tesznek abba az irányba, amellyel „megszüntetik a hontalanságra és a kettős állampolgárságra vonatkozó esetek kialakulását („Hágai Egyezmény”1930).
} 
fenntartásának (normatív) követelményével is magyarázható (Faist-Gerdes-Rieple 2006, p. 914).

A kettős állampolgárság elfogadásának kérdésében az 1997-ben elfogadott Állampolgárságról szóló Európai Egyezmény jelentős szemléletváltást eredményezett, ugyanis államok saját döntésére bízza a kettős állampolgársággal kapcsolatos kérdések rendezését. ${ }^{427} \mathrm{Az}$ egyezmény az állampolgárság fogalmát valamely személy és egy állam közötti jogi kötelékeként határozta meg, tekintet nélkül a személy etnikai származására. Tehát az állampolgárság megszerzésében nem tekinti relevánsnak az etnikai jelleget, mi több kijelenti, hogy az állampolgárságra vonatkozó szabályozások nem tartalmazhatnak diszkriminatív intézkedéseket. ${ }^{428}$ További fontos rendelkezése az egyezménynek, hogy elfogadja a kettős, vagy többes állampolgárság megszerzésének a születéssel, a házasságkötéssel, valamint a korábbi megtartásával - tehát honosítással, amikor nincs lehetőség az erről való lemondásra - történő létrejöttét (14-16. cikkelyek).

A kettős állampolgárság kérdése végül az EBESZ Kisebbségi Főbiztosának ajánlásaiban is megjelent. A Főbiztos által 2008-ban közzétett Bozeni/Bolzanói Ajánlások a nemzeti kisebbségekröl az államközi kapcsolatokban c. dokumentum 11. pontja értelmében az államok a külföldön élő egyének számára az állampolgárság megadásakor „figyelembe vehetik a preferált nyelvtudást, valamint kulturális, történelmi vagy családi kötődéseket, tiszteletben tartva a baráti és jószomszédi kapcsolatokat, valamint a szuverenitás elvét (Szarka és mtsai. 2009). A jelentés kifejti továbbá, hogy az államoknak „tartózkodniuk kell az állampolgárság tömeges megadásától még akkor is, ha a lakóhely szerinti állam megengedi a kettős állampolgárságot. Az ajánláshoz füzött értelmező jegyzet - figyelembe véve a fenti elveket - továbbra is az állam szuverén döntéseként értelmezi az állampolgárság megadásának feltételeit, azonban a nyelvi, családi és történelmi kötődések hangsúlyozásával - ami kedvezményezett eljárást jelent az állampolgárság odaítélésében - az etnikai jelleg már releváns az állampolgárság megszerzésében.

A Ljubljanai útmutató a sokszínü társadalmak integrálásához c. dokumentum megerősíti a Bolzanói ajánlásban foglaltakat, némileg pedig kiegészítve, több ponton

\footnotetext{
${ }^{427}[\ldots]$,tudomásul véve az államoknak a többes állampolgárság kérdésére vonatkozó eltérő felfogását, és felismerve, hogy minden állam szabadon döntheti el, hogy belső jogában milyen következményeket füz ahhoz a tényhez, hogy egy állampolgára egy másik állampolgárságot is megszerez vagy azzal rendelkezik” Az egyezmény preambuluma (,2002. évi III. törvény az állampolgárságról szóló Európai Egyezmény kihirdetéséröl").

${ }^{428}$ Mint azt a későbbiekben látni fogjuk, e normatív feltételnek nem felelnek meg az európai államok állampolgárság-politikái, ugyanis az állampolgárság megszerzésében az etnikai kötődés kedvezményezett eljárást von maga után.
} 
keresztül foglalkozik az állampolgársággal. A 32. pont a befogadó állampolgársági politikát a társadalmi integráció szempontjából tekinti lényegesnek, míg a következő pont megismétli a Bolzanói ajánlásban már ismertetett elvet miszerint az állampolgárság odaítélése az állam szuverenitását érintő kizárólagos hatáskör („Ljubljanai útmutató” 2012, pp. 43-44). Noha elismeri az állampolgárság kedvezményes odaítélésének kulturális, történelmi vagy családi kötelékek esetében - módját, az állampolgárságpolitika korlátait is hangsúlyozza. ${ }^{429} \mathrm{Az}$ útmutató az állampolgárság megadását az anyaország felelősségvállalásaként értelmezi, azonban kifejti, hogy elsősorban a lakóhely szerinti állam felelőssége a kisebbségek védelme. Végül pedig a dokumentum elöremutató javaslatokat fogalmaz meg a többes állampolgárságra vonatkozóan, ami - a Főbiztos értelmezése szerint - nem akadályozza, hanem sokkal inkább támogatja az állampolgárok integrációját a társadalomba.

Az idézett nemzetközi dokumentumok és ajánlások alapján az állampolgárság kapcsán két típusú változás érhető tetten: míg az első trend a kettős állampolgárság tiltásától, illetve ennek korlátozásától a fokozatos elfogadáshoz, mi több támogatáshoz kapcsolódik, addig a másik változás az állampolgárság odaítélésében következett be azáltal, hogy felértékelődött az etnikai kötődés, mint releváns tényező az állampolgárság odaítélésében.

A kettős állampolgárság elterjedése elsőként az állampolgárság megszerzésének eltérő módozatával és az állampolgárok egyre növekvő migrációjával áll összefüggésben. Az utóbbi évtizedekben ugyanis, a migrációs folyamatok az állampolgárság megszerzésének eltérő - a származáson (ius sanguinis) és a születési helyen alapuló - gyakorlatának betudhatóan a kettős állampolgárok számának folyamatos növekedését eredményezték. ${ }^{430} \mathrm{~A}$ kettős állampolgárság intézményének elfogadását az egyes államok honosítási politikája is elősegítette, amely az esetek többségében nem írja elő a korábbi állampolgárságról történő lemondást. Az általam vizsgált EU-s tagállamok, valamint a térség államai közül, a 38 esetből 22 európai állam támogatja a kettős állampolgárság intézményét oly módon, hogy a honosítás útján

\footnotetext{
${ }^{429}$ Az útmutató az állami hatáskör korlátozásaként értelmezi, hogy (1) az állampolgárság odaítélésének alapját képezi az állam, valamint az érintett egyén közötti tényleges kapcsolat (genuine link); (2) az állampolgárság korlátozásával az államok nem sérthetik meg egymás szuverenitását és a jószomszédi kapcsolatokat; (3) az állampolgárság odaítélése, megvonása nem eredményezhet hátrányos megkülönböztetést; (4) az állam területén tartózkodó személyeket állampolgárságra való tekintet nélkül megilletik az emberi jogok.

430 Példaként megjegyzendő, hogy kettős állampolgár lesz az a gyerek, akinek szülei olyan államból származnak, amelyben az állampolgárság megszerzése származáshoz kötött, ellenben jogszerüen olyan államban van állandó lakhelyük, amely az állampolgárság odaítélésénél a területi elvet követi.
} 
történő új állampolgárság megszerzésével nem jár együtt automatikusan a másik elvesztése. Ezzel ellentétben, 10 államban - köztük Ausztria, Bulgária, a Balti-államok - az új állampolgárság megszerzésének feltételéül szabja a korábbi állampolgárságról történő lemondást. ${ }^{431}$

Az előző állampolgárságról történő lemondás nem képezi a honosítás legfontosabb feltételét. Az állampolgárság megadásának emellett más feltételei is vannak, amelyet a Global Citizenship Observatory (2017) adatbázisa alapján néhány európai példával is szemléltetek: ${ }^{432}$

1. állandó lakhely: az állampolgárság megadását az államok kivétel nélkül lakóhelyhez kötik, azonban az erre vonatkozó szabályozások eltérőek, ugyanis egyes államok több éves ott-tartózkodáshoz köthetik az állandó lakhellyel járó státus megadását, míg más államok esetében a folyamatos - tehát megszakítás nélküli - tartózkodás lehet feltétel. Ebből következik, hogy az állampolgárság megszerzése 3-10 évig is eltarthat, esetenként pedig, ha beleszámítjuk az állandó lakhellyel járó státus megadása előtti időszakot, akkor meghaladhatja a 10 évet (pl. Macedónia). Az állandó lakhelyre vonatkozó adatok alapján elmondható, hogy viszonylag rövid időszak szükséges az állampolgárság megszerzéséhez Lengyelországban, Bosznia és Hercegovinában, valamint Szerbiában (3 év), az esetek közel felében (16 állam) öt év, míg a fennmaradó 19 állam esetében 6-10 év.

2. A nyelvismeret egy további fontos feltételét képezi az állampolgárság megszerzésének. Négy állam kivételével, ahol nem találtam a nyelvtudásra vonatkozó feltételeket (Ciprus, Írország, Olaszország, Szerbia), a legtöbb állam valamilyen szinten elvárja az állam nyelvének ismeretét: néhány esetben elegendő az alap- vagy középfokú nyelvismeret, az esetek többségében követelmény a folyékony nyelvtudás.

3. Az adott állam jogrendjének, társadalmának és kultúrájának ismerete - általánosabb megfogalmazásban az állampolgári ismeretek - a honosítás feltételét képezik. A vizsgált államokban az állampolgári ismeretek az alábbi területekre terjednek ki: (1) az alkotmányos berendezkedés és az alkotmány rendelkezéseinek ismerete (Bosznia és Hercegovina, Magyarország, Észtország, Lettország, Litvánia, Moldova); (2) a

\footnotetext{
${ }^{431}$ Lettországban a kérelmezők nem kell lemondjanak korábbi állampolgárságukról abban az esetben, ha az EU, az EFTA, valamint a NATO-tagállamok állampolgárai, valamint ausztráliai, brazíliai és új-zélandi állampolgársággal rendelkeznek. A moldáv szabályozás elöírja, hogy arról az állampolgárságról kell lemondani, amellyel Moldova Köztársaság nem kötött kétoldalú megállapodást. A spanyol állampolgársági törvény is több kivételt említ, eszerint a spanyol állampolgárság felvételével összeegyeztethető a latin-amerikai államok, az andorrai, Fülöp-szigetek-i, Új-Guinea-i valamint a portugál állampolgárság.

${ }^{432}$ Lásd erröl a Függelékben található 3. számú táblázatot.
} 
demokratikus rend és az állam történelme (Ausztria); (3) kultúra, történelem, alkotmány és himnusz; (4) nyelv és kultúra (Szlovákia); (5) az állampolgársággal járó jogok és kötelezettségek ismerete (Franciaország); (6) történelem és kultúra (Görögország); (7) a társadalom és jogrendszer ismerete (Németország); valamint a társadalom alapos ismerete (Hollandia, Egyesült Királyság). Az állampolgári ismeretek felmérésére konkrét tesztet 12 államban alkalmaznak. ${ }^{433}$

4. A megfelelő anyagi háttér egy további feltételét jelenti a honosításnak. A kérelmező azt kell igazolja, hogy törvényes jövedelemmel, anyagi háttérrel rendelkezik és nem terheli meg az adott állam szociális ellátórendszerét.

5. A kérelmezőnek a honosítási eljárás során bizonyítania kell, hogy büntetlen előéletü, valamint jelenleg, vagy az utóbbi években nem folyt ellene bírósági eljárás és nem is ítélték el bírósági eljárás során. ${ }^{434}$

6. Az állam iránti húség és lojalitás kifejezése a honosítás további feltételét képezi: 13 állam esetében a kérelmezők szóbeli, írott vagy mindkét formában kifejezik az ország iránti hűségüket és leteszik az állampolgársági esküt, a vizsgált államok egyharmada pedig átvilágítja a kérelmezőket, hogy nemzetbiztonsági szempontból nem jelentenek-e kockázatot

7. A felsorolt feltételeken kívül, az egyes államok további rendelkezéseket és feltételeket szabhatnak az állampolgárság megszerzésére vonatkozóan. E feltételek egyik része a kérelmező erkölcsi feddhetetlenségére vonatkozik. A vizsgált állampolgársági törvényekben ,jó jellemként”, ,jó erkölcsként” jelent meg, de Romániában pl. a jó magaviseletet, Spanyolországban pedig a tiszteletreméltó életet követelnek meg. A feltételek egy másik része a társadalmi integrációra vonatkozik, noha a fogalom és az ehhez kapcsolódó elvárásokat nem határozták meg kellőképpen. Végül a feltételek az adófizetési kötelezettséget is érintik, eszerint a kérelmezőnek nem lehet adóhátraléka, vagy adótartozása az állam felé.

Az állampolgárság megszerzésére vonatkozó feltételek egy kettősségre mutatnak rá: a vizsgált államok állampolgárság-politikája egyrészt befogadó, mert világos egyidőben teljesítendő követelményekhez köti az állampolgárság megszerzését, másrészt azonban kirekesztő azokkal a bevándorlókkal szemben, akik nem teljesítik a törvényben megfogalmazott feltételeket. A honosítási folyamat önmagában azonban

\footnotetext{
433 Ausztria, Csehország, Dánia, Egyesült Királyság, Észtország, Hollandia, Magyarország, Moldova, Németország, Románia, Spanyolország, Szlovákia

${ }^{434}$ A vizsgált államok egyharmadában az illetékes szervek azt is megvizsgálják, hogy a kérelmező nem jelent-e nemzetbiztonsági kockázatot. Ha ez bizonyítást nyer, elutasítják az illető honosítási kérelmét.
} 
túlmutat a feltételeken, ugyanis normatív értelmezésében megfogalmazódnak a jó állampolgárokra vonatkozó modellek és minták (Dumbrava 2014b, p. 42). Noha az 1-6. pontokban felsoroltak szükségesek, de nem képezik elégséges feltételét annak, hogy valaki ,jó állampolgárrá" váljon. Véleményem szerint e feltételekből éppen az a nehezen mérhető követelmény hiányzik - a megfelelő társadalmi integráció komponense - melyet maguk a jogszabályok sem határoznak meg pontosan. ${ }^{435} \mathrm{~A}$ megfelelő integráció hiányában az „új állampolgárok” jelentős társadalmi feszültségeket okozhatnak, és erősíthetik azokat a negatív percepciókat, melyek a bevándorlók integrációjával kapcsolatosan folyamatosan a nyugat-európai államok napirendjén szerepelnek (pl. multikulturalizmus kudarca).

Míg tehát a kettős állampolgárság kérdése a nyugat-európai államok esetében többnyire a bevándorlók integrációjából és az állampolgárság elvének felülvizsgálatából eredeztethető, addig térségünkben - mutat rá Culic - az állampolgárság-politikák az nemzetépítés középpontjában álltak (Culic 2009, pp. 6-7), oly módon, hogy (1) a tituláris nemzet államaként jelölték meg az államot (pl. Románia), aminek egy igen fontos következménye lett, hogy aszimmetrikus viszony alakult ki az állampolgársággal rendelkező többség és kisebbség között; (2) kizárták a politikai közösségből a jelentős számú közösségeket, akadályozva őket az állampolgárság megszerzésében vagy a politikai részvételben (lásd Balti-államok); (3) különböző érvekre hivatkozva a határon túli nemzettársakat és a diaszpórában élő közösségeket is bevonták a nemzetépítési projektekbe és könnyített honosítási eljárás révén, áttelepülés nélkül megadták nekik az állampolgárságot, esetenként pedig biztosították a szavazati jogot is. A térség államainak erre irányuló politikája az anyaország felelősségének legfontosabb lépéseként értékelhető. ${ }^{436}$

Hasonlóan a 6. fejezetben vizsgált státus- vagy kedvezménytörvényekhez, a kettős állampolgárság intézménye is szolgálhatja (1) az anyaország és a határon túli közösségek közötti kapcsolatok „újraéledését”, tehát kulturális és identitásépítő hatása megkérdőjelezhetetlen, hasonlóan (2) azokhoz az utilitarista-pragmatikus érvekhez,

\footnotetext{
${ }^{435}$ Az ENSZ Szociális Fejlesztési Kutatóintézetének (UNRISD) egyik jelentése a társadalmi integráció három értelmezését különítette el. Eszerint a társadalmi integráció jelensége (1) olyan irányzat, amely egyenlő jogokat és lehetőségeket biztosít minden ember számára, ami az életlehetőségek javulását feltételezi. A fogalom (2) második értelmezése negatív jelentéssel bír, ugyanis a társadalmi integráció egyes csoportok szempontjából - nem kívánt „egységesülést” eredményez. A társadalmi integráció végül (3) azt a módszert jelenti, aminek segítségével leírhatóvá válnak a társadalomban kialakult emberi kapcsolatok mintázatai (de Alcántara-Ghai 1994, p. 1).

${ }^{436}$ Lásd erről a VI. fejezetben megfogalmazott, a határon túli közösségek iránti anyaországi felelösségvállalás taxonómiáját.
} 
melyek az állampolgárság megszerzését anyagi és gazdasági haszonszerzéssel (kedvezőbb munkavállalási lehetőségekkel), vagy éppenséggel a jobb minőségü szolgáltatások meglétével indokolják. Szintén az anyaország felelősségéből következik az a diskurzus, amely (3) az állampolgárság odaítélésében történelmi jóvátételt, igazságtételt vél felfedezni, amely konkrétan megjelenik a lengyel, a cseh, a lett, a litván, a bulgár valamint a román állampolgársági törvényben (Bauböck-Perchinig-Sievers 2009, pp. 31-39). ${ }^{437}$ Dumbrava egyik dolgozatában amellett érvel, hogy a külhoni állampolgárság megadása melletti indokok közül (az állampolgárság visszaállítása, a demokratikus folytonosság biztosítása, nemzeti szolidaritás) az első, az állampolgárság visszaállítása nyújtja a legmeggyőzőbb magyarázatot, azon személyek esetében, akiket a múltban - valamilyen okból kifolyólag - megfosztottak állampolgárságuktól (Dumbrava 2014a).

Térségünkben a határon túli közösségeknek nyújtandó állampolgárság mellett további érvek fogalmazhatók meg, melyek (4) kisebbségvédelmi lépésként is felfoghatók, ugyanis Oroszország és Szerbia abból a megfontolásból adott a határain túl élő közösségeknek állampolgárságot, mert azt feltételezték, hogy az újonnan alakult államokban hontalanok lesznek, vagy az állampolgárság megszerzésénél olyan feltételeket támasztanak, amiket nem tudnak teljesíteni (Pogonyi 2017a, p. 31). Az állampolgárság kiterjesztésében (5) a geopolitikai megfontolások szintén nagy szerepet játszanak, amely számos esetben államközi viták és konfliktusok forrásaként értelmezhetők (lásd Oroszország fellépését az ún. „közel külföldön”). Térségünket jellemző (6) népességfogyás ellensúlyozása vagy a homogenizációs törekvések érvényesítése szempontjából is értékelhető a honosítási eljárás (Waterbury 2014; Dumbrava 2018), aminek következtében biztosítható a pozitív vándorlási mérleg. Végül pedig szükséges kihangsúlyozni (7) az állampolgárság megadása és a szavazati jog kiterjesztése mögött húzódó belpolitikai érdekeket, melyek egyrészt a határon túli közösségek mobilizációjára irányulnak és a pártpolitikai küzdelmekbe való bevonásukat, valamint a választásokon való részvételüket eredményezi (Pogonyi 2017a, pp. 36-39; Waterbury 2014, pp. 44-46).

Az állampolgárság kiterjesztése melletti különböző megfontolások és érvrendszerek magyarázattal szolgálnak arra, hogy milyen tényezőknek betudhatóan értékelődött fel az etnikai kötődés az állampolgárság megszerzésében, aminek fontos

\footnotetext{
437 Noha a magyar állampolgársági törvény nem tartalmaz erre vonatkozó hivatkozást, ellenben a történelmi jóvátételre való hivatkozás a státustörvény-vitáját követően a kettős állampolgárságról szóló vitákban is meghatározó érvnek bizonyult.
} 
következménye, hogy az európai államok döntő többsége jelentős mértékben leegyszerüsítette a honosítási eljárást és lehetővé tette az állampolgárság könnyített úton történő megszerzését azon szomszédos államokban vagy a diaszpórában élő közösségek számára, akiket a közös nyelv, a kultúra, a rokoni kapcsolatok a származási államhoz kötnek. A már hivatkozott Globalcit adatbázisából Pogonyi alapján (2017a, pp. 54-62) a könnyített honosítási eljárásnak azon a dimenzióit választottam ki, amelyek szorosabb kapcsolatot vagy etnikai kötődést feltételeznek: (1) más állam polgára: szomszédos állam, volt gyarmat, az EU vagy az EGT állampolgára; (2) származás, tehát állampolgár felmenőkkel rendelkezik: szülei, nagyszülei, házastársa az illető állam polgárai voltak; (3) szocializáció: olyan kiskorú vagy felnőtt személyek, akik az alap-, közép- vagy felsőfokú képzést abban az államban végezték; végül pedig (4) kulturális kötődés, amely során az illető személy nemcsak származását, hanem identitását és az államhoz, a társadalomhoz való kötődését is igazolni tudja az állampolgársági kérelem benyújtásakor.

A vizsgált EU-28 tagállam és a térség államainak állampolgársági törvényeit figyelembe véve 35 állam esetében 71 olyan rendelkezést azonosítottam, amely megfelel a fentebb ismertetett négy dimenzió valamelyikének. ${ }^{438}$ Ezzel szemben csupán három állam esetében (Észtország, Luxembourg, Egyesült Királyság) nem találtam olyan cikkelyt, amely az etnikai kötődést figyelembe véve könnyítené meg a honosítási eljárást.

Az első dimenzió, amely az állampolgárság megszerzését más állam polgárának teszi lehetővé, 14 esetben bizonyult relevánsnak: egyszerüsített honosítási eljárást során számos állam lehetővé teszi az állampolgárságát megszerezését, amennyiben a kérelmező egy EU-s tagállam állampolgára (pl. Görögország, Románia), esetenként pedig az Európai Gazdasági térség (Ausztria, Csehország), vagy egy NATO (Lettország) tagállam állampolgára. Külön csoportot képeznek a honosításnál azon államok, melyek a szomszédos államok, vagy a szükebb régió államainak (Fehéroroszország, Finnország és Svédország), vagy a volt gyarmatbirodalom (Spanyolország) államainak polgárai számára teszi lehetővé az állampolgárság megszerzését.

Az állampolgárság könnyített úton történő megszerzésének leggyakoribb esetét (23 állam) képezi az, amikor a kérelmezőnek valamely felmenője, szülők, nagyszülők állampolgársággal rendelkezett, de az emigráció során vagy elvesztették, vagy le kellett

\footnotetext{
${ }^{438}$ Lásd erről a Függelékben található 4. számú összefoglaló táblázatot.
} 
mondaniuk róla. Az államok többsége - ha bizonyítható, hogy a kérelmező egy volt állampolgár leszármazottja -, kedvezményes eljárás során megadja az állampolgárságot. Feltételként néhány éves ott-tartózkodást jelölnek meg, amely a rendes honosítási eljáráshoz képest jóval rövidebb időszakot jelent (Montenegróban tíz év helyett öt év, Albániában öt év helyett három, míg Dániában kilenc év helyett három év).

A könnyített honosítási eljárás egy további esetét a szocializáció jelenti és olyan kérelmezők számára teszi lehetővé az állampolgárság megszerzését, akik nem feltétlenül születtek az adott államban, de kiskorukban egy meghatározott időszakot ott éltek, vagy abban az államban szocializálódtak (összesen 15 állam). A szocializáció közegének a jogszabályok az oktatási intézményekben való részvételt jelölik ki, öt állam állampolgársági törvényében szerepel az alap-, illetve a középfokú oktatásban való részvétel, Görögország és Szlovénia esetében a felsőfokú képzés befejezése.

A kulturális hovatartozás képezi a könnyített honosítási eljárás utolsó feltételét, amelynek etnikai tartalma nyilvánvaló (Pogonyi 2017a, p. 60). A vizsgált államok jogszabályaiban 19 esetben volt azonosítható a kulturális hovatartozás bizonyos eleme. Leggyakrabban a határon túli, vagy a diaszpórában élő személyek származás útján tudják igazolni az államhoz való kulturális kötődésüket. Dániában a dán kultúrával való azonosulás jelenik meg feltételként, míg Franciaországban és Oroszországban az állam hivatalos nyelvének anyanyelvi szintü ismerete képezi az állampolgárság megszerzésének követelményét. Szlovákiában a kérelmező úgy igazolhatja szlovák etnikumát, hogy a külföldi szlovákokról rendelkező törvény alapján rendelkezik szlovák státussal és legalább három éve az országban tartózkodik.

A külhoni állampolgárság elfogadásával és a kettős állampolgárok számának növekedésével a '90-es évektől folyamatosan emelkedett azon államok száma, melyek megadták a szavazati jogot a szomszédos államokban vagy a külföldön állandó lakhellyel rendelkező állampolgáraik számára. Az empirikus adatok szerint a külhoni állampolgárok a 2000-es évek elején 63 államban vehettek részt a választásokon (Nohlen-Grotz 2000, p. 1116), a 2007-ben kiadott IDEA kézikönyv a külhoni szavazásról 115 államot és területet nevez meg (Ellis és mtsai. 2007, pp. 11-13), míg egy újabb összeállítás szerint a világ 183 államából 129 teszi lehetővé a külhoniak választásokon való részvételét (Collyer 2014, p. 64).

Bauböck az érdekeltség-alapú állampolgárságról szóló tanulmányában megállapította, hogy a szavazati jog bevezetése nem köthető egy adott régióhoz sem politikai vagy választási rendszerhez: a külhoniak szavazási lehetőségét (1) sok esetben 
háborúk után vezették be; vagy (2) a demokratikus rendszer megszilárdulásának időszakában, végül pedig (3) az okok a kibocsátó államok attitüd-változásának is betudható (Bauböck 2014, pp. 15-17). Az a felismerés, hogy a (4) külhoniak a külföldröl hazaküldött pénzösszegekkel és a gazdasági kapcsolatok ösztönzésével erőforrásként jelennek meg, fontos érvként jelenik meg a szavazati jog kiterjesztéséről szóló vitákban, mi több a szakirodalomban arra is találunk hivatkozásokat, amikor a pénzküldeményeket a politikai jogok és a politikai befolyás növelésére használják fel (Pogonyi 2014, p. 127).

A külhoni állampolgárok szavazati jogának megadása olyan normatív problémákat érint, mint a demokratikus részvétel vagy a legitimitás kérdése (Bauböck 2014), ugyanis míg a leadott szavazatok a politikai részvétel egyik mutatójaként értékelhetők, addig a választások transzparenciája és egy más államban való állandó lakhely további problémákat vet föl. Ennek következményeire több szerző, köztük Pogonyi és munkatársai is rámutattak, akik szerint a külhoni szavazók „nagymértékben befolyásolhatják a választások eredményeit, anélkül, hogy a politikai következményeket viselnék a leadott szavazatokért” (Pogonyi-Kovács-Körtvélyesi 2010, p. 4). ${ }^{439}$

Ha az európai államok körében vizsgáljuk a külhoni szavazás intézményét, megállapíthatjuk, hogy a vizsgált EU-28 tagállam és a térség államai közül Görögország, Írország és Málta, valamint az EU-tagjelölt Albánia és Montenegró nem teszi lehetővé, a lakóhellyel nem rendelkező kettős állampolgárok részvételét a választásokon. További korlátozásokat találunk Cipruson, ahol csak a köztisztviselők és ezek házastársai, Dániában a köztisztviselők, postai alkalmazottak, egyetemisták és diákok, valamint Svédországban, ahol csak azok szavazhatnak, akiknek korábban állandó lakhelyük volt az államban.

Ezzel szemben a vizsgált államok nagy részében a külhoniak szavazhatnak az államfőválasztáson, a parlamenti vagy EP-választásokon, valamint részt vehetnek az országos referendumokon. ${ }^{440}$ A külhoni állampolgárok a legtöbb államban a parlamenti választásokon vehetnek részt, mi több néhány állam - köztük Franciaország, Horvátország, Olaszország, Macedónia, Portugália és Románia - külföldi körzetek létrehozásával speciális helyeket biztosít a diaszpóra képviselőinek. A EU keleti bővítése lehetővé tette az újonnan csatlakozó 13 tagállam számára, hogy képviselőket küldjenek az EP-be. Azonban a régi és az új tagállamok nem mindegyike teszi lehetővé

\footnotetext{
${ }^{439}$ A szerzők rámutattak arra, hogy a 2000-es években lezajlott horvát parlamenti választások, valamint a 2009-es román államfőválasztás eredményei a külhoni szavazatok felértékelődését mutatta.

${ }^{440}$ Lásd erről a Függelék 5. számú összeállítását.
} 
a külhoni szavazást, Csehországban az első generációs külhoni állampolgárok csak az állam területén szavazhatnak, de Belgium, Bulgária, Dánia, Görögország és Olaszország is lehetővé teszi az EP-választásokon való részvételt, ha az illető állampolgár valamely másik tagállam területén él. Ezzel szemben a magyar és a szlovák külhoni állampolgárok nem szavazhatnak az ötévente sorra kerülő választásokon.

\section{A magyar és a román állampolgársággal kapcsolatos viták}

\subsection{A magyar és a román állampolgárság-politika a '90-es években}

Magyarország és Románia az 1989-et megelőző kommunista időszakban - a szocialista államok közötti együttmüködésre hivatkozva - nem támogatta a kettős állampolgárságot, amely az 1971-es román állampolgársági törvényben is tükröződött. ${ }^{441}$ A két állam továbbá egy államközi egyezményben is akadályozta a kettős állampolgárság megszerzésének lehetőségét: a magyar és román állampolgársággal is rendelkező személynek nyilatkoznia kellett arról, hogy - az egyezmény hatálybalépése után - melyik állampolgárságát kívánja megtartani („Egyezmény a kettős állampolgárság eseteinek megoldásáról” 1979).

A KKE-i államok rendszerváltása jelentősen befolyásolta a két állam állampolgárság-politikáját. A változások egyrészt érintették a korábbi szocialista időszak alatt hozott megszorító intézkedések megszüntetését. Magyarország 1990. februárjában felmondta az 1979-es egyezményt, míg Románia a 137/1990 számú törvényerejü rendelettel előkészítette a korábbi állampolgársági törvény módosítását. ${ }^{442}$

Az új román jogszabály (1991. évi 21. törvény) rendelkezett az állampolgárság megszerzésének és elvesztésének módozatairól: (1) születés; (2) örökbefogadás; (3) visszatelepedés vagy repatriálás; (4) kérelemre történő megszerzés. ${ }^{443}$ E lehetőségeken túlmenően a törvény az állampolgárság megszerzését azon személyek számára is lehetővé tette, akik 1989. december 22-e előtt különféle okokból elvesztették. A felsorolt esetek egyikében sem köti az állampolgárság megszerzését, a korábbiról

\footnotetext{
${ }^{441}$ A jogszabály 3. cikkelye kimondta, hogy az a román állampolgár, aki egy külföldi állam törvénye szerint annak állampolgára, a román rendelkezésekkel szemben a külföldi jogszabálynak nincs semmi hatálya („Az 1971/24-es törvény a román állampolgárságról"). Ezen túlmenően a román állampolgárság megszerzését, a korábbi állampolgárságról történő lemondás feltételeként szabta (10. cikkely).

${ }^{442}$ A jogszabály lehetővé tette az állampolgárság visszaszerzését, azon személyek számára akik 1989 decembere elött elveszítették, továbbá hatályon kívül helyezte a jogszabály kettős állampolgárságot tiltó rendelkezését is A kettős állampolgárságot érintő rendelkezéseknek azonban néhány korlátozó eleme hatályos maradt: az első szabad választásokon nem lehettek a kormány tagjai a kettős állampolgársággal rendelkező személyek („137/1990 számú törvényerejű rendelet”).

${ }^{443}$ A honosítás feltételei: az állam és a román nép iránti hüség, 18 év feletti életkor, legalább öt éves tartózkodás, jó magaviselet, rendezett anyagi helyzet, román nyelv ismerete.
} 
történő lemondáshoz, mi több az állampolgárság elvesztésének esetei között sem sorolja fel a kettős állampolgárságot olyan tényezőként, amely a román állampolgárság elvesztését eredményezné („Törvény a román állampolgárságról, 1991”). Ebből következik a törvény egyik legfontosabb újítása, az, hogy elismerte a kettős állampolgárság intézményét. A kettős állampolgárság támogatásaként értelmezhető a jogszabály azon rendelkezése is, amely kérelmezés útján lehetővé teszi az állampolgárság visszaszerzését „még akkor is, ha más állampolgársággal rendelkeznek és nem helyezik át lakhelyüket Romániába” (37. cikkely). E jogszabályi változások mögött Iordachi két típusú szándékot azonosított. A törvénynek azon rendelkezése, amely lehetővé tette az állampolgárság visszaszerzését azon román állampolgárok számára, akik korábban elvesztették azt, a demokratikus szándékokról tanúskodnak. Ezzel szemben nacionalista indíték húzódott meg azon törvényhozói akarat mögött érvelt a szerző -, mivel az állampolgárság kiterjesztését főként a bukovinai és Moldova Köztársaságban élő románokra akarta kiterjeszteni, azzal a célkitüzéssel, hogy „,egyetlen politikai közösségbe egyesítse az összes románt” (Iordachi 2000, pp. 52-53). Costica Dumbrava az állampolgárság kiterjesztését „rejtett nacionalizmusként” értelmezi annak betudhatóan, hogy a román vezetés nem támogatta a „,nemzet etnokulturális alapon történő értelmezését” (Dumbrava 2013).

A román-állampolgárság politikában bekövetkező változások jelentős vitákhoz vezettek a szomszédos Moldova Köztársasággal, annak ellenére, hogy a függetlenség kikiáltása után Románia - a vízum- és útlevélmentes beutazás bevezetésével jelentősen megkönnyítette a határátlépést, valamint oktatási programokat és ösztöndíjakat hozott létre a moldovai diákoknak (Iordachi 2002, p. 95). A kettős állampolgárság megszerzését támogató román jogszabállyal szemben a szintén 1991ben módosított moldovai állampolgársági törvény leszűkíti a kettős állampolgárság megszerzésének lehetőségét. ${ }^{444}$ Noha a törvény következő bekezdése két módon - a köztársaság érdekében és kivételes esetekben - is lehetővé tette a kettős állampolgárságot, megszerzését azonban államföi döntéshez kötötte, megakadályozva ezzel a kettős állampolgárság intézményének elterjedését.

Ennek ellenére a kilencvenes években jelentősen megnőtt a moldáv-román kettős állampolgárok száma, amelyre vonatkozóan két egymástól jelentősen eltérő adatsor áll rendelkezésre. A román külügyminisztérium hivatalos adatai szerint 1991.

\footnotetext{
${ }^{444}$ Az 1991. évi 596. törvény hatodik cikkelye kimondja, hogy „A Moldovai Köztársaság állampolgára nem lehet más állam állampolgára, kivételt képeznek azon államközi szerződések által biztosított esetek, amelyekben Moldova is részes” („Lege Nr. 596 din 1991”).
} 
január és 2002 júniusa között 108 ezer állampolgársági kérelmet hagytak jóvá (Panainte-Nedelciuc-Voicu 2014, p. 12), míg ennél sokkal optimistább moldáv becslés alapján 300 ezret (Iordachi 2002, p. 96). Ha ehhez hozzávesszük a Dnyeszteren túli területek lakosságát, akik a Szovjetunió felbomlása után orosz állampolgárságot szereztek, akkor indokoltnak tekinthetők azok a moldáv félelmek, melyek a román, illetve az orosz befolyás veszélyeire hívták fel a figyelmet a '90-es években. A román állampolgárság-politika befogadó jellege tehát nem segítette sem a román-román integrációt, sem pedig a román-moldáv kapcsolatok mélyülését (Iordachi 2004, pp. 249-50; Culic 2013, p. 107), sokkal inkább egy mobilitási pályát nyitott meg a kettős állampolgároknak Románia és a KKE-i térség irányába.

Romániával ellenben Magyarországon nem alakult ki politikai konszenzus a határon túli magyaroknak nyújtandó állampolgárságról. A rendszerváltó pártok közül egyedül az SZDSZ programjában szerepelt a kettős állampolgárság bevezetése (Pogonyi 2017, p. 83). A kisebbségi kérdésre vonatkozó részben kifejtették, hogy „,minden magát magyarnak valló személy - és az ő jogán családja - legyen jogosult a magyar állampolgárságra" (Szabad Demokraták Szövetsége 1989, p. 59, idézi Pogonyi 2017, p. 83). A módosított alkotmányban megjelenő felelősségi klauzula, valamint az Antallkormány külpolitikájában a határon túli magyaroknak szánt kitüntetett szerep nem irányult az állampolgárság kiterjesztésére. Ennek ellenére az 1993. évi LV. törvény a magyar állampolgárság keletkezésének, megszerzésének és megszünésének szabályairól néhány elemében tükröződik a kulturális nemzetfelfogás. A jogszabály alapján magyar állampolgárságot (1) születéssel; (2) honosítással és (3) visszahonosítással lehet megszerezni, amelyet a jogalkotó eltérő feltételek teljesítéséhez kötötte („1993. évi LV. törvény a magyar állampolgárságról”). 
18. sz. táblázat: A magyar állampolgárság odaítélésének feltételei (1993. évi LV. törvény)

\begin{tabular}{|c|c|c|c|c|c|}
\hline \multirow{2}{*}{ 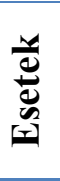 } & \multirow[b]{2}{*}{ Születés } & \multirow[b]{2}{*}{ Honosítás } & \multicolumn{2}{|c|}{ Kedvezményes honosítás } & \multirow[b]{2}{*}{ Visszahonosítás } \\
\hline & & & $\begin{array}{l}\text { Házastársi viszony, } \\
\text { menekültstátus }\end{array}$ & $\begin{array}{c}\text { Magyar } \\
\text { nemzetiségü, nem } \\
\text { magyar állampolgár }\end{array}$ & \\
\hline \multirow[b]{3}{*}{ 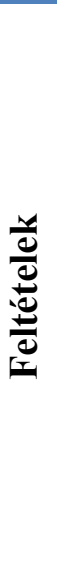 } & \multirow{3}{*}{$\begin{array}{l}\text { - magyar állampolgár } \\
\text { gyermeke; } \\
\text { Magyarországon } \\
\text { született hontalan } \\
\text { gyermeke; } \\
\text { - Magyarországon } \\
\text { talált gyermek. }\end{array}$} & \multicolumn{4}{|c|}{$\begin{array}{l}\text { Büntetlen előélet, megélhetése és lakhatása biztosított, honosítása nem sért } \\
\text { államérdeket. }\end{array}$} \\
\hline & & \multicolumn{3}{|c|}{ Alkotmányos alapismeretek vizsga magyar nyelven. } & \multirow[b]{2}{*}{$\begin{array}{l}\text { - állandó lakhely } \\
\text { - Egyéni } \\
\text { kérelemre } \\
\text { visszahonosítható } \\
\text { az a személy, } \\
\text { akinek megszünt } \\
\text { az } \\
\text { állampolgársága. }\end{array}$} \\
\hline & & $\begin{array}{l}-8 \text { éves } \\
\text { állandó } \\
\text { tartózkodás }\end{array}$ & $\begin{array}{l}\text { - } 8 \text { éves állandó tartózkodás; } \\
\text { Ha } \\
\text { - legalább } 3 \text { éve érvényes } \\
\text { házasságban él; } \\
\text { - kiskorú gyermeke magyar } \\
\text { állampolgár; } \\
\text { - magyar állampolgár } \\
\text { fogadta örökbe; } \\
\text { - menekültstátusa van. }\end{array}$ & $\begin{array}{l}\text { - } 1 \text { éves állandó } \\
\text { tartózkodás; } \\
\text { - magát magyar } \\
\text { nemzetiségűnek } \\
\text { vallja; } \\
\text { - felmenője magyar } \\
\text { állampolgár volt. }\end{array}$ & \\
\hline
\end{tabular}

Forrás: Az 1993. évi LV. törvény, valamint (Tóth 2014, p. 78) alapján, saját módosításokkal.

A 18. számú táblázat alapján megállapítható, hogy a honosítás mindhárom módozatánál feltételként szerepelt a bejelentett lakcím vagy az állandó tartózkodás, amely 1-től 8 évig terjedhet. E feltétel vonatkozott a magyar nemzetiségű személyekre, amely további kritériumokkal (büntetlen előélet, stabil anyagi háttér, állampolgársági vizsga) egészül ki.

Áttekintve a román és a magyar szabályozást megállapítható, hogy mindkét jogszabály támogatja a kettős állampolgárság intézményét, mi több az Országgyülésben a képviselők között abban is egyetértés volt, hogy ennek szabályozására nem szükséges államközi szerződéseket kötni (Tóth 2004, pp. 39-40). Az állampolgárság-politikák közötti legnagyobb különbség a kedvezményes honosítás feltételeiben mutatkozott meg: míg a román politikai pártok között a rendszerváltást követően kialakult és fenn is maradt a parlamenti konszenzus az állampolgárság kiterjesztéséről, addig a magyar parlament hasonló kedvezményes elbánásban nem részesítette a határon túli magyarokat. A kedvezményes honosításra és a visszahonosításra vonatkozó magyar kritériumok - ami alapján a határon túli magyarok magyar állampolgárságot szerezhettek volna - a román jogszabályhoz képest sokkal szigorúbbnak bizonyultak. A román állampolgársági törvényhez képest, amely áttelepülés nélkül lehetővé tette az állampolgárság megszerzését, a magyar jogszabály állandó lakhelyhez kötötte a kedvezményes honosítást és a visszahonosítást, továbbá a magyar nemzetiségüek számára is elöírta az állampolgársági teszt elvégzését. 


\subsection{A kettős állampolgárságról szóló magyarországi népszavazás}

A rendszerváltás időszakában a kettős állampolgárság megadására vonatkozó SZDSZ-es javaslatot követően a '90-es években az állampolgárság kiterjesztése sem a választási programokban - kampányidőszakban -, sem pedig a kormányprogramokban nem jelent meg vélhetően azért, mert egyrészt maguk a parlamenti pártok sem tartották megvalósítható lépésnek, másrészt pedig az alapszerződések aláírása után újabb vitákat eredményezett volna az államközi kapcsolatokban, melyet az MSZP-SZDSZ koalíció az integráció kontextusában - minden lehetséges eszközzel igyekezett elkerülni.

Ezzel magyarázható, hogy a kettős állampolgárság nem pártkezdeményezésre jelent meg a politika napirendjén, hanem egymástól elkülönülő politikai-civil kezdeményezésként. Az állampolgárság kiterjesztésének gondolata a '90-es évek második felében került be a köztudatba, miután a Magyarok Világszövetsége programjába foglalta az állampolgárság alanyi jogon történő kiterjesztését (Patrubány 2005, p. 40). Ezt követően Erdélyben Katona Ádám, az RMDSZ Erdélyi Magyar Kezdeményezés platform vezetője több alkalommal is javasolta a Szövetség vezetőségének, hogy fejezzék ki a kettős állampolgárság iránti igényüket. A javaslatot nem támogatta a Szövetség akkori vezetősége, sőt az októberben Romániába látogató Kovács László külügyminiszter egy interjúban kifejtette, hogy nem tartja reális elképzelésnek, „mi több, a magyar kormány nem is foglalkozik ezzel a kérdéssel”. ${ }^{445} \mathrm{Az}$ MVSZ 1998-ban sorra kerülő választmányi ülésén fogalmazta meg az állampolgárságra vonatkozó javaslatát, amely - Csoóri Sándor szerint - reális megoldást jelenthetne a határon túli magyarok akadálytalan magyarországi beutazására azt követően, hogy Magyarország csatlakozik a schengeni térséghez. A kormány képviselői, akárcsak a HTMH, közleményben utasították el a MVSZ kettős állampolgárságra vonatkozó javaslatát, azzal indokolva álláspontjukat, hogy alkalmatlan eszköz a határon túli magyarok helyzetének javítására.

Az ellenzéki pártokkal ellentétben (az MDF, az FKgP, a KDNP és a MIÉP) a FIDESZ sem támogatta a javaslatot: noha a '98-as választási programjukban jelentős nemzetpolitikai célkitüzéseket fogalmaztak meg, a kettős állampolgárság bevezetése nem szerepelt e programpontok között. ${ }^{446}$ Figyelembe véve a választási programban,

\footnotetext{
${ }^{445}$ RMDSZ Tájékoztató, V. évfolyam, 1130. szám, 1997. október 10.

${ }^{446}$ A felelősség a magyar nemzetért c. fejezetben kifejtették, hogy Magyarországnak a határon túli magyarokért viselt felelőssége abból ered, hogy az állam és a nemzet határai nem esnek egybe. Ezért fontos (1) a határon túli politikai szervezetek bevonása az őket érintő kormányzati döntésekbe; (2) az intézményesített párbeszéd létrehozása a magyar állam és a határon túli szervezetek között. A FIDESZ
} 
majd a későbbiekben a kormányprogramban megfogalmazott nemzetpolitikai célkitüzéseket a FIDESZ vezette kormánykoalíció fenntartván korábbi álláspontját, elutasította az állampolgárság kiterjesztését: 1999 januárjában Orbán Viktor a Markó Bélával folytatott tárgyalásokon jelezte, hogy a kettős állampolgárság továbbra sem szerepel napirenden, míg márciusban Martonyi János külügyminiszter a Szabadság napilapnak adott interjúban „politikai és jogi képtelenségnek” nevezve kifejtette, hogy nem tartja célravezetően a magyar állampolgárság megadását a kárpát-medencei magyarságnak.

Az állampolgárság kiterjesztése az RMDSZ politikusait is megosztotta: az MVSZ javaslatát, több a Szövetség „radikálisabbnak” tekintett politikusa támogatta, míg Markó Béla szövetségi elnök és Takács Csaba ügyvezető elnök ellenezte bevezetését. A sajtónyilatkozatokból kirajzolódó álláspontok világossá tették, hogy a kormány nem látta elérkezettnek az időt az állampolgársági törvény módosítására, helyette a MÁÉRT keretében a határon túli magyarok státusát szabályozó törvény kidolgozását kezdeményezte, mint „köztes megoldást” (Kovács 2002, pp. 238-49).

A kormányzati elutasítást követően a MVSZ kezdeményező szerepe nem torpant meg: a státustörvény kidolgozásának folyamatában egy újabb javaslattal állt a közvélemény elé ${ }^{447}$, azonban az állampolgárság kérdése lekerült a napirendről, annak betudhatóan, hogy egyre intenzívebbé vált a státustörvényről folyó vita, elsőként a parlamenti pártok között, majd pedig a szomszédos államokkal.

Az MVSZ vezetősége 2003. tavaszán újabb vitát kezdeményezett az állampolgárság kiterjesztéséről, és azt követően, hogy az MSZP-SZDSZ kormánykoalíció módosította a státustörvényt, a szervezet elnöksége országos népszavazás kezdeményezése mellett döntött, melyet augusztus 18-án jelentettek be (Patrubány 2005, p. 41). A kezdeményezés első lépéseként az Országos Választási Bizottság megvizsgálta a felteendő kérdést, majd egy sikertelen kísérletet követően az

támogatja továbbá a kollektív jogok elismerését, és az autonómia-törekvéseket, és a gazdasági kapcsolatok fejlődését („A Fidesz-Magyar Polgári Párt választási programja” 1998).

${ }^{447}$ Patrubány Miklós MVSZ elnök 2000 augusztusában átadta az ország legfőbb közjogi méltóságainak a külhoni állampolgárság törvénytervezetét, novemberben pedig a külügyi bizottságban is ismertette javaslatát. A brit és a holland többszintü állampolgársági modell alapján készült tervezet kiegészítené a státustörvényben foglalt kedvezményeket, és érdemi választ adna a schengeni dilemmára, ugyanis a javaslat értelmében a kérelmezők magyar útlevelet és külhoni magyar személyi igazolványt kapnának. A törvénytervezet előkészítői Borbély Imre, Zétényi Zsolt, Gehér József és Váradi Vilmos voltak. Jegyzőkönyv az Országgyülés külügyi bizottságának 2000. november 22-én, szerdán, 14 órakor az Országház föemelet 55. számú termében megtartott üléséröl.

Borbély Imre szerint a külhoni magyar állampolgár az útlevél és a személyi igazolvány mellett jogosult lenne munkavállalásra, felsőoktatásban való részvételre, valamint választható lenne bizonyos köztisztségekbe, de nem rendelkezne aktív választójoggal (Borbély 1999). 
Alkotmánybíróság 2004 márciusában hagyta jóvá népszavazást. ${ }^{448}$ Ezt követően indult meg az aláírásgyüjtés, amelynek során sikerült a törvényben elöírt számot meghaladó aláírást összegyüjteni. ${ }^{449}$

A parlamenti pártok és a határon túli magyar szervezetek eltérő módon viszonyultak az MVSZ kezdeményezéséhez, amely Magyarország és a határon túli magyarok közötti közjogi viszony létrejöttének szükségességét hangsúlyozta. E meghatározó nemzetpolitikai kérdésről azonban nem mutatkozott konszenzus abban az időszakban, így várható volt, hogy a népszavazási kampány a magyar-szlovák és a magyar-román alapszerződések, valamint a státustörvény után újra polarizálja a pártok viszonyát, és a két blokk vezetőjének szembenállását. ${ }^{450}$

A parlamenti pártok az Országgyülés szeptember 13-i ülésén egyhangúlag támogatták az országos ügydöntő népszavazás kiírását a kedvezményes honosítás kérdésében, azonban az állampolgárság kiterjesztésében - amint az a parlamenti felszólalásokból és a későbbi nyilatkozatokból is érzékelhetővé vált -, megoszlott a pártok véleménye: míg a kormánypártok ellenezték a kettős állampolgárság megadását ${ }^{451}$, addig az ellenzéki pártok támogatták a jogszabály módosítását.

A kettős állampolgárságról folyó kampányban az MSZP a határon túli magyarok megmaradása és szülőföldön való boldogulásuk támogatását hangsúlyozta, amellyel szembeállította egyrészt a költségtételeket, amely az állampolgárság megadásából származnának ${ }^{452}$, másrészt pedig a migrációs folyamatoknak a határon túli magyar

\footnotetext{
448 A népszavazáson megfogalmazott kérdés: "Akarja-e, hogy az Országgyülés törvényt alkosson arról, hogy kedvezményes honosítással - kérelmére - magyar állampolgárságot kapjon az a magát magyar nemzetiségünek valló, nem Magyarországon lakó, nem magyar állampolgár, aki magyar nemzetiségét a 2001. évi LXII. törvény 19. §-a szerinti „Magyar igazolvánnyal” vagy a megalkotandó törvényben meghatározott egyéb módon igazolja?"

449 A választási törvény szerint az országos népszavazás kiúrásához 200 ezer aláírás összegyüjtése szükséges. Az MVSZ 2004. júliusáig 320 ezer aláírást gyüjtött össze, amelyből az Országos Választási Bizottság legalább 274.332 és legfeljebb 278.799 aláíást talált érvényesnek („Az Országos Választási Bizottság 108/2004. (VIII. 12.) határozata").

${ }^{450}$ Az Orbán-Gyurcsány között levő ellentét egyrészt belpolitikai tényezőkkel, másrészt a magyar politika vezéresedésének folyamatával magyarázható, amely Körösényi szerint nem csupán „,a politikai vezetők szerepének megerősödését jelentette”, hanem olyan „vízióval rendelkező karizmatikus vezetők megjelenését", akik képesek pártjukat mobilizálni és dominálni (Körösényi 2015, p. 406).

${ }^{451}$ Az állampolgársággal kapcsolatos kormányzati pozíció kialakításában döntően belpolitikai számítások voltak meghatározók. Az SZDSZ-en belül komoly viták folytak arról, hogy a párt miként viszonyuljon a kezdeményezéshez (interjú Szent-Iványi Istvánnal). Kormányzati szinten, a miniszterelnök részvételével két tanácskozás is lezajlott, amelyen a HTMH képviselője is részt vett (interjú Bálint-Pataki Józseffel), ezen kívül pedig Markó Béla, az RMDSZ elnöke is több alkalommal tárgyalt Gyurcsány Ferenccel, arra kérve a miniszterelnököt, hogy ne forduljanak szembe a népszavazással.

${ }^{452}$ Gyurcsány Ferenc miniszterelnök számos alkalommal hangsúlyozta annak a veszélyét, hogy a közel 800 ezer magyar igazolvánnyal rendelkező határon túli magyarnak az állampolgárság megadása személyenként évente 168 ezer forint többletköltséget jelentene a magyar államnak.
} 
közösségekre gyakorolt negatív hatásait. ${ }^{453} \mathrm{Az}$ MSZP álláspontja szerint az állampolgárság kiterjesztése tovább növelné Magyarország „,vonzerejét” és újabb tételekkel terhelné a magyar költségvetést. Hasonlóan az MSZP-hez, az SZDSZ sem támogatta a kettős állampolgárság kiterjesztését, abból a megfontolásból, hogy az nem segítené a határon túli magyarok problémáinak megoldását. Másrészt az SZDSZ értelmezése szerint az állampolgárság kiterjesztése ,igazságtalan” és „hátrányos megkülönböztetést jelent”, mert a határon túli magyarok adófizetés nélkül részesülnének olyan szolgáltatásokban, amelyért az magyarországi magyaroknak fizetniük kell („Az SZDSZ a népszavazási kérdésekről” 2004).

Az MDF a népszavazási kampány során támogatta az állampolgárság kiterjesztését és az MVSZ aláírásgyűjtési akciójával párhuzamosan saját indítványt terjesztett be, azonban a tervezet tárgysorozatba vételét elutasította a törvényhozás. Javaslatuk szerint a határon túli magyarok a könnyített honosítási eljárás során szerezhetnének állampolgárságot és mentesülnének az állandó magyarországi lakhely és a stabil anyagi helyzet (megélhetés) követelményei alól. ${ }^{454}$ A parlamenti pártok közül a FIDESZ „pálfordulása” a legszembetűnőbb a kettős állampolgárság kérdésében, ugyanis - amint arra már fentebb utaltam - nem támogatta az MVSZ javaslatát, mi több a státustörvény vitájában a VB-nek megküldött magyar álláspontban határozottan elutasította a határon túli magyarok kettős állampolgárságát. ${ }^{455}$

Politikai stratégiájának részeként a FIDESZ a 2004-es EP-választások kampányában folyamatosan a nacionalista és konfrontatív beszédmódját visszafogva, szakpolitikai kritikákat fogalmazott meg a kormányzó MSZP-SZDSZ koalícióval szemben, ily módon helyreállítva a párt arculatát (Waterbury 2010, p. 124). Az állampolgárság nyílt ellenzése magában hordozta annak a veszélyét, hogy elveszíti a határon túli magyar támogatók legitimitását, a kormánypárthoz hasonló álláspont pedig

\footnotetext{
${ }^{453}$ A MÁÉRT nyolcadik ülésén Gyurcsány Ferenc hangsúlyozta Magyarország elszívó hatását, aminek következtében másfél évtized alatt több mint 200 ezer kárpát-medencei magyar telepedett le az anyaországban („Gyurcsány Ferenc Miniszterelnök beszéde a MÁÉRT VIII. ülésén)” In: Magyar Külpolitikai Évkönyv, 2004, p. 401).

${ }^{454}$ Herényi Károly (MDF), felszólalása.

${ }^{455}$ (2.2.) A jogszabály, hasonlóan a magyar jogrendszerhez, [...] nem ismeri el a kettős állampolgárság fogalmát. (2.3.) A státustörvény elismeri, hogy a külhoni magyarok az adott állam polgárai és világosan elutasítja azt az elképzelést, miszerint a magyarként való önmeghatározás alapja a kettős állampolgárság lenne. [...] Anyaországi szerepéből kiindulva, Magyarország mindig elismerte, hogy semmiféle állampolgárság-szerü viszonyban nincs a határon túli magyarokkal. (2.4.) Következésképpen a törvény arra törekszik, hogy egyszer és mindenkorra választ adjon azokra a híresztelésekre, melyek szerint irredenta követeléseink lennének, $[\ldots]$ vagy kettős állampolgárságot biztosítanánk a magyar származású személyeknek („Paper Containing the Position of the Hungarian Government” 2001), saját fordítás.
} 
támogatóinak mobilizációját nehezítette volna. Figyelembe véve e tényezőket a FIDESZ a népszavazási kezdeményezés mellett döntött és a kampányban az „igenre” buzdította a magyar választókat. Elsőként, a státustörvény módosítását követően Orbán Viktor beszélt a kettős állampolgárság támogatásáról 2004 tavaszán, hangsúlyozva, hogy „a megoldást a jövőre nézve nem a státustörvény, hanem a kettős állampolgárság képezi”. ${ }^{456}$ Nem meglepő tehát, hogy a FIDESZ a népszavazás vitáján a szomszédos államokban és a diaszpórában élő magyarok igényeinek eleget téve, valamint a magyar társadalom jelentős részének támogatottságára hivatkozva támogatta az állampolgárság kiterjesztését és négypárti egyeztetést javasolt a jogszabály módosítása céljából. ${ }^{457}$

Az ellenzéki pártokon kívül a köztársasági elnök is támogatta az állampolgársági törvény módosítását, aminek érdekében konzultációt folytatott a határon túli politikai szervezetek képviselőivel, akik „történelmi igazságtételnek” tekintették a kezdeményezést, és a MÁÉRT ülésén amellett érvelt hogy „megadásának nincs jogi akadálya" és nem kell nagyobb kitelepedési hullámmal sem számolni ${ }^{458}$, amely a kormánypártok egyik fö érvrendszerének bizonyult. ${ }^{459}$

A magyar belpolitika állapotát és a pártok közötti megosztottságot világosan jelezte a MÁÉRT nyolcadik ülése ahol a résztvevők nem fogadtak el közös nyilatkozatot, ehelyett az ellenzéki pártok és a határon túli politikai szervezetek közös felhívással fordultak a magyar választópolgárokhoz, arra kérve őket, hogy a december 5-re kitüzött ügydöntő népszavazáson minél nagyobb számban vegyenek részt és szavazzanak igennel a kettős állampolgárságra („Nyilatkozat a kettős állampolgárságról” 2004). A MÁÉRT tagszervezeteinek konszenzusa mögött - mutatott rá Bárdi Nándor - voltak hangsúlykülönbségek ami az állampolgárság támogatását és az ezzel felmerülő problémákat (Bugár Béla és Markó Béla), illetve ennek követelését (Duray Miklós és Kasza József) illeti (Bárdi 2004, p. 60). A határon túli politikai szervezetek közös nyilatkozatát követően az RMDSZ közleményben foglalt állást a kettős állampolgárság mellett és felkérték a kormánypártokat és „,ne folytassanak az anyaországi választókat és a határon túli magyarokat egymással szembeállító kampányt” („Közlemény a kettős állampolgárságról” 2004).

\footnotetext{
${ }^{456}$ Orbán Viktorral készült interjú a Kossuth Rádió Vasárnapi Újság c. műsora (2004. május 28).

${ }^{457}$ Pokorni Zoltán (FIDESZ) felszólalása a népszavazás vitáján.

458 („Mádl Ferenc köztársasági elnök beszéde a MÁÉRT VIII. tanácskozásán” 2004).

459 Az RMDSZ megbízásából a kolozsvári Etnikumközi Viszonyok Erdélyi Kutatóközpontja által 2003 októberében - tehát jóval népszavazási kampányt megelőzően - készített felmérés alapján az erdélyi magyarok pozitívan vélekedtek az állampolgárság kiterjesztéséről, 82 százalékuk igényelné is, 13,6 százaléka pedig az állampolgárságra olyan dokumentumként tekint, amely lehetőséget teremt a Magyarországra történő áttelepedéshez (Horváth 2003, p. 52).
} 
A szomszédos államokat Románia kivételével nem foglalkoztatta az állampolgárságról szóló belpolitikai viták (Kántor-Majtényi 2005). A parlamenti és államfőválasztási kampány időszakában elhangzó román álláspontok többnyire a választópolgárok mobilizációját szolgálták. A szociáldemokraták államfőjelöltje, Adrian Năstase miniszterelnök Gyulafehérváron kemény fellépést helyezett kilátásba a kettős állampolgárság ellen, amellyel nyilván a szélsőséges szavazatok megszerzésére törekedett (Culic 2005, p. 131). A miniszterelnök nemkívánatosnak nevezte a FIDESZ és más magyarországi pártok politikai játszmáit Románia területén, egyrészt hangsúlyozva azt, hogy a két állam között érvényben van a kettős állampolgárság elkerülésére vonatkozó államközi szerződés, másrészt pedig Románia újból a Velencei Bizottsághoz fordul, amely már „kifejezte ellenvetését a kettős állampolgárság etnikai alapú megszerzésére vonatkozóan” (Curierul Naţional 2004). Az állampolgárság kérdésében azonban magyar-román vita elmaradt: hamar kiderült ugyanis, hogy a miniszterelnök által hivatkozott kétoldalú megállapodás már a rendszerváltás óta hatályon kívül van, míg az államfőválasztás második fordulójának eredményei a várakozásokkal szemben nem a szociáldemokraták, hanem a liberálisok és demokraták győzelmét eredményezték, amellyel a kérdés csakhamar lekerült a politika napirendjéröl.

Ezzel ellentétben a magyar parlamenti pártok között egyre hevesebb viták zajlottak, a rendkívül intenzív kampányban az erőteljes kormányzati hangulatkeltést nem sikerült a magyar ellenzéknek, valamint a kezdeményező MVSZ-nek ellensúlyoznia és az érzelmi érveken felülkerekedő jóléti sovinizmus - a ,mennyibe kerül ez a magyar adófizetőknek” típusú érvek), egyrészt növelte az állampolgárság elleni szavazók táborát, másrészt választók demobilizációját eredményezte. ${ }^{460}$

A december 5-én sorra kerülő referendumon, amelyen a választópolgárok a Munkáspárt által a korházprivatizáció ügyében is kifejthették véleményüket, a nyolc millió választópolgár kevéssel több mint egyharmada, 37,49\%-a járult az urnákhoz. Az alacsony részvétel következtében a népszavazás nem volt érvényes, ehhez a

\footnotetext{
${ }^{460}$ Annak ellenére, hogy a 2004 novemberben elvégzett közvéleménykutatások 40 százalék feletti részvételt jeleztek a biztos szavazók körében - a Capital Research felmérése alapján a megkérdezettek 47 százaléka, míg a Medián mérése alapján kevesebb, a választópolgárok 42 százaléka jelezte részvételét, a tényleges részvétel ennél alacsonyabbnak bizonyult. A Medián összeállításából kiderült, hogy a rendszerváltás utáni népszavazási kezdeményezéseken viszonylag nagy különbség alakult ki az elöre jelzett (biztosra mondta részvételét) és a tényleges részvételi adatok szerint. Ennek alapján a négyigenes népszavazáson a biztos szavazók 66 százaléka jelezte részvételét, míg a valódi részvétel 58 százalék volt, de a legnagyobb különbség az EU-hoz történő csatlakozáskor alakult ki: akkor a választópolgárok 71 százaléka jelezte részvételét, míg a tényleges részvétel 46 százalékos volt („Felmérés a népszavazásról.” 2007).
} 
választójogosultak legalább egynegyede kellett volna azonos választ adjon. A végleges eredmények alapján az érvényesen szavazó választópolgárok 51,57\%-a szavazott igennel (1 521271 fö, az összes választópolgár 18,9\%-a), míg 48,43\%-a nemmel (1 428 578 fö, az összes választópolgár 17,75\%-a). ${ }^{461}$

A kampány időszaka alatt készült felmérésekből viszonylag keveset tudunk az állampolgárok motivációiról. Kovács M. Mária szerint a jóléti protekcionizmus magyarázattal szolgálhat egyrészt azért, mert Szlovákiát leszámítva a határon túli magyarok életszínvonala alacsonyabb az anyaországénál, másrészt pedig a kampányban az MSZP is folyamatosan a reformmal járó költségeket emelte ki (Kovács M. 2006, pp. 436-37). Ehhez kapcsolódnak a migrációval kapcsolatos érvek, amelynek nem pozitív vetületei, a magyar népességfogyást valamelyest ellensúlyozni képes hatásait, hanem az ellenzék által hangsúlyozott veszélyei és tehertételei - mint „félelmetes és beláthatatlan következményeket hozó mumus” (Bárdi 2004, p. 52) - váltak hangsúlyossá.

A népszavazás eredményei jelentős töréspontot eredményeztek a magyar-magyar kapcsolatokban. A határon túli magyarok erőteljes kiábrándulásként, „árulásként”, „lemondásként” több székelyföldi településen pedig gyászként élték meg a népszavazás eredményét (Jakab-Peti 2005, pp. 118-21). Székelyföldön több személy a Magyar igazolvány visszaadása mellett döntött (Culic 2006, p. 175), néhány önkormányzat december 5-ét követően pedig a magyarországi testvértelepülési kapcsolatának újraértékelésére tett javaslatot. A határon túli politikai szervezetek közös nyilatkozatban foglaltak állást az állampolgárság mellett, arra kérvén a magyarországi parlamenti pártokat, hogy módosítsák az állampolgársági törvényt. ${ }^{462}$ Erre irányuló javaslatukat nem sokkal később Szabadkán is megismételték, a Határon Túli Magyar Szervezetek Fórumának alakuló ülésén.

A nemzeti integráció és a népszavazás eredményeinek ellensúlyozásaként 2005 januárjában Gyurcsány Ferenc miniszterelnök öt pontból álló javaslatot jutatott el a MÁÉRT képviselőihez, amelyben javaslatot tett a (1) a Szülőföld-alap bővítésére; (2) az akadálytalan határátlépés érdekében nemzeti vízum bevezetésére; (3) a honosítási folyamat felgyorsítására; (4) az autonómia-törekvések támogatására; (5) a határon túli

\footnotetext{
461 („Országos népszavazás: A 2004. december 5-i népszavazás végleges eredménye”,)

462 „Az aláírók meggyőződésüknek adtak hangot, hogy az egyébként üdvözlendő Szülőföld-program vagy bármilyen anyagi támogatás nem helyettesítheti sem azt az erkölcsi jóvátételt, amelyet a határon túli magyarok számára a kettős állampolgárság lehetősége jelent. Ebből kiindulva felkérték a magyar kormányt és a parlamenti pártokat, hogy a nemzetközi joggal összhangban alkossák meg azt a törvénymódosítást, amely lehetővé teszi a határon túli magyarok számára, hogy szülőföldjük elhagyása nélkül rendelkezhessenek magyar állampolgársággal” („A határon túli magyar szervezetek közös nyilatkozata a kettős állampolgárságról” 2004).
} 
magyar közjogi státusának létrehozására („Gyurcsány Ferenc levele a MÁÉRT tagjaihoz” 2005). E programpontokból 2005 folyamán több is megvalósult. A Gyurcsány-kormány egyik első intézkedése között szerepelt a Szülőföld Alapról szóló törvény elfogadása, amely 1 milliárd forintos tőkével pályázati úton kívánt hozzájárulni a határon túli magánszemélyek szülőföldön való boldogulásához. ${ }^{463}$ Szintén fontos lépésként értékelhető, az állampolgársági törvény módosítása, amely hozzávetőleg felére csökkentette az állampolgársági kérelem elbírálásának időtartamát, azonban továbbra is magyarországi lakhelyhez kötötte az állampolgárság megszerzését. A jogszabály legfontosabb rendelkezése mégis abban állt, hogy eltörölte „,a legalább egy éves állandó lakhelyre" vonatkozó feltételt, így kedvezményes úton már a letelepedést követően lehetővé vált az állampolgársági kérelem benyújtása („2005. évi XLVI. törvény az állampolgárság módosításáról” 2005). Szintén ebben a törvényben bevezetik a nemzeti vízumot, amely három hónapot meghaladó magyarországi beutazás és otttartózkodás, valamint a rokonlátogatást hivatott megkönnyíteni, amely azonban továbbra sem oldotta meg a munkavállalási tartózkodásra valamint egyéb jövedelemszerzési tevékenységre vonatkozó kedvezményes elbírálást.

\subsection{A román állampolgársági törvény módosítása és a román-moldáv viták}

A rendszerváltást követő időszakban a román parlamenti pártok állampolgárságra vonatkozó konszenzusa töretlen maradt, mi több a belpolitikában egyetlen párt vagy politikus sem kérdőjelezte meg, hogy a moldovai és ukrajnai románok könnyített honosítással román állampolgárságot szerezzenek. Ebből adódóan a román állampolgárság megszerzésének könnyítése és az ebből eredő viták a 2000-es években nem a belpolitika szintjén, hanem az államközi kapcsolatokban mutatkoztak meg, legfőképpen Moldova Köztársasággal, kisebb mértékben pedig Ukrajnával, akik nem ismerték el a kettős állampolgárság intézményét. ${ }^{464}$

A fentiekben már bemutatott '91-es román állampolgársági törvény tartalmát tekintve egyike a legváltozékonyabb jogszabálynak, melyet a több alkalommal módosítottak (Panainte-Nedelciuc-Voicu 2014, p. 4). A jogszabályi változások egyrészt érintették azon személyek körét, akik kedvezményes honosítási eljárás során román állampolgárságot szerezhettek, kiterjesztve azon személyek leszármazottaira -

\footnotetext{
${ }^{463}$ A törvény kedvezményezettjei között nem-kormányzati szervezetek, oktatási intézmények, határon túli önkormányzatok, valamint vállalkozások is szerepeltek (,2005. évi II. törvény a Szülőföld Alapról”).

${ }^{464}$ A 2002-ben módosított moldovai állampolgársági törvény lehetővé teszi a moldáv mellett egy másik állam állampolgárságának a megszerzését is.
} 
elsőként a másodfokú, majd harmadfokú leszármazottakra is -, akik 1989 előtt különféle okokból elvesztették az állampolgárságukat (Iordachi és mtsai. 2012, 13647). Az állampolgárság ilyen irányú kiterjesztése egyrészt lemondás az állami vagy etatista megközelítésről - melyet világosan tükrözött a '91-es törvény szellemisége - és a vérségi vagy származási elv irányába tartó átmenetként értékelhető (Iordachi 2013, p. 2; Panainte-Nedelciuc-Voicu 2014, p. 4). Az állampolgársági törvény vizsgálata során, Iordachira hivatkozva Culic is hasonló következtetésre jut, azzal egészítve ki álláspontját, hogy a jogszabályi változások „felzárkóztatást” jelentenek a román állampolgárság megszerzésének - születéssel járó - alapvető módjához (Culic 2013, p. 119). Az állampolgársági törvény módosításai jelentős mértékben egyszerüsítették a honosítás feltételeit és procedúráját, végül pedig a kérelmek elbírálását végző intézmények feladat- és hatásköreit is bővítették: az állampolgársággal kapcsolatos ügyintézésre a Belügyminisztérium külön hatóságot hozott létre, annak érdekében, hogy a folyamatosan növekvő kérelmeket belátható időn belül elbírálja.

19. sz. táblázat: A román állampolgársági törvény fontosabb módosításai

\begin{tabular}{|c|c|}
\hline Jogszabály & Fontosabb rendelkezések \\
\hline 1999 évi. 192. számú törvény & $\begin{array}{l}\text { - egyszerüsíti a honosítási eljárást (6 éves állandó lakhely, az állam } \\
\text { nyelvének és törvényeinek ismerete); }\end{array}$ \\
\hline 2001/167-es sürgősségi kormányrendelet & $\begin{array}{l}\text { - hat hónapos időszakra felfüggeszti a repatriálást, mint az } \\
\text { állampolgárság megszerzésének módját, azon személyek esetében } \\
\text { akik különböző okokból elvesztették román állampolgárságukat; }\end{array}$ \\
\hline 2004/43-as sürgösségi kormányrendelet & $\begin{array}{l}\text { - könnyített (vissza)honosítási eljárás bevezetése (román nyelv és } \\
\text { kultúra ismerete), ami lehetővé teszi a kérelem benyújtását négy } \\
\text { éves ott-tartózkodás után; } \\
\text { - négy éves időtartamra megtiltja az országból történő kiutazást; }\end{array}$ \\
\hline 2008/147-es sürgősségi kormányrendelet & $\begin{array}{l}\text { - lehetővé teszi az állampolgárság megszerzését visszahonosítás } \\
\text { útján, másodfokú leszármazottak számára; }\end{array}$ \\
\hline 2009/36-os sürgősségi kormányrendelet & $\begin{array}{l}\text { - kiterjeszti az állampolgárság megszerzését a harmadfokú } \\
\text { leszármazottak számára; } \\
\text { - öt hónapra csökkenti a honosítási kérelmek elbírálási határidejét, } \\
\text { és megszünteti a korábbi négy éves állandó tartózkodást, azon } \\
\text { kérelmezők esetében, akik jogszerüen az országban tartózkodnak; }\end{array}$ \\
\hline $\begin{array}{l}\text { 2010. évi 112. sz. törvény; 2010/5-ös } \\
\text { számú kormányrendelet }\end{array}$ & $\begin{array}{l}\text { - az Állampolgári Hatóság (Autoritatea Naţională pentru Cetăţenie) } \\
\text { felállítása, feladat- és hatáskörének kijelölése; }\end{array}$ \\
\hline $\begin{array}{l}\text { 2013. évi } 2 \text {. sz. törvény egyes } \\
\text { intézkedésekrőll a bírói hatóságok } \\
\text { tehermentesítése érdekében, valamint a } \\
\text { Polgári perrendtartási törvény-könyvről } \\
\text { szóló } 134 / 2010 \text {. sz. törvény } \\
\text { végrehajtásának elökészítéséröl }\end{array}$ & $\begin{array}{l}\text { - szabályozza azokat a módozatokat, amelyek alapján a bíróságon } \\
\text { fellebbezni lehet az állampolgárság megszerzését és a } \\
\text { visszahonosítást elutasító döntés ellen; }\end{array}$ \\
\hline $\begin{array}{l}\text { Az állampolgársági törvény 2013-as } \\
\text { módosítása }\end{array}$ & $\begin{array}{l}\text { A honosítási eljárás feltételeinek teljesítéséröl kérelem alapján a } \\
\text { hivatal köteles } 60 \text { napon belül tájékoztatni a kérelmezőt. Az } \\
\text { Állampolgársági Bizottság döntéséröl a hivatal elnöke három } \\
\text { napon belül rendeletet bocsájt ki, további három napon belül pedig } \\
\text { a kérelmezővel tudatni kell a rendelet tartalmát. }\end{array}$ \\
\hline
\end{tabular}

Forrás: (Panainte-Nedelciuc-Voicu 2014, p. 5; Culic 2013, pp. 117-21). 
Az állampolgársági törvény folyamatos módosítása rámutatott arra, hogy a román állampolgárság kiterjesztésének nem volt világos koncepciója, a jogszabályt érintő változások sokkal inkább a jogalkotó - a parlament és a kormány - azon szándékát tükrözik, amellyel az alkalmazásából eredő müködési zavarokat igyekeztek rendezni, ami leginkább a nagyszámú igénylő miatt alakult ki. A 2000-es évek elejétől ugyanis fokozatosan nőtt a román állampolgárságot igénylők száma annak betudhatóan, hogy Moldova Köztársaság módosította állampolgársági törvényét elismerve a kettős állampolgárságot, továbbá a román állampolgárok 2001-től kezdődően vízummentesen utazhattak a schengeni térségben (Iordachi 2009, p. 194), ami egyben az útlevélellenőrzés bevezetését eredményezte a moldáv-román határon. A 2001-2004 közötti módosítások a növekvő kérelmek körül kialakult helyzetet kívánták rendezni, elsőként az állampolgárság visszaállításának felfüggesztésével, majd a honosítási eljárás folyamatos egyszerüsítésével, amely jelentős vitákhoz vezetett a szomszédos Moldova Köztársasággal, amelynek okai a moldovai belpolitikában keresendők. A 2001-es választásokat ugyanis a Kommunista Párt nyerte meg, az új államfö, Vlagyimir Voronin által követett „moldovanizmus” hatására jelentősen romlott a két állam viszonya. ${ }^{465}$

Románia EU-s csatlakozásának időszaka újabb lehetőséget teremtett a két állam kapcsolatának rendezésére: 2006 elején bizalomerôsítő külügyminisztériumi találkozóra került sor, amelyen a felek a vízummentességre vonatkozó egyezmény kidolgozásáról döntöttek, és a román fél - Mihai-Răzvan Ungureanu román külügyminiszter személyében - az állampolgársági kérelmek felgyorsítására tett javaslatot. Az államközi egyezményt még az év őszén aláírta a két állam, amelynek értelmében Románia 2007től kezdődően sürgősségi eljárással és ingyenesen nyújtott vízumot a moldovai állampolgároknak (,Acord din 20.10.2006 între Guvernul Republicii Moldova şi Guvernul României”), és a folyamat felgyorsítása érdekében két konzulátus megnyitását helyezték kilátásba, ami 2007 januárjában megtartott államfői találkozó napirendjén is szerepelt. A felek között a vita azt követően alakult ki, hogy a Romániában a kormány bejelentette az állampolgári törvény módosítását, arra hivatkozva, hogy fel kell gyorsítani a több százezerre tehető kérelmek elbírálásának folyamatát.

A román állampolgárság odaítélésének felgyorsítását elítélte a moldáv fél, elsőként a külügyminiszter, majd pedig az államfő is negatívan nyilatkozott a román lépésről, a moldáv belügyekbe való beavatkozásként és nemzetbiztonsági kockázatként

\footnotetext{
${ }^{465}$ A moldovanizmus kulturális-nyelvi hagyományainak erősítéseként történelmi és nyelvészeti munkák jelentek meg, köztük egy moldáv-román szótár is (Ivan 2012, p. 5).
} 
értékelve a román törekvéseket. Miután 2007 szeptemberében a román államfö a Legfelsőbb Védelmi Tanács ülésén kérte a kormány képviselöit, hogy egyszerüsítsék az állampolgári kérelmek elbírálását, tekintettel a moldovai állampolgárokkal szembeni „morális és politikai kötelezettségekre” („Declaraţie de presă a preşedintelui Traian Băsescu” 2007), válaszul a moldáv hatóságok bevonták a Román Televízió (TVR) sugárzási engedélyét, valamint módosították az állampolgársági törvényt, amelynek értelmében a kettős vagy többes állampolgárok nem tölthettek be közhivatali tisztséget („Lege Nr. 273 din 07.12. 2007”). A moldáv félelmek nem bizonyultak alaptalanoknak, ugyanis az EU több tisztségviselöje is aggodalmát fejezte ki amiatt, hogy a moldovai állampolgárok tömegesen szereznek román állampolgárságot (Deutsche Welle 2009). A román útlevél tehát „,arany jegyként” jelent meg a közbeszédben, aminek segítségével a „hátsó ajtón” lehetővé vált az uniós államokba való szabad beutazás.

A 2009-es moldáv parlamenti választás újabb vitához vezetett a két állam között azt követően, hogy az ellenzék választási csalással vádolta meg a győztes Kommunista Pártot. A szavazatok újraszámlálásának követelését zavargások és erőszakos összecsapások követték, aminek halálos áldozata is volt („,Moldova. Country Reports on Human Rights Practices” 2010). A moldáv államfő meggyőződéssel állította, hogy Románia áll az események mögött és nemkívánatos személynek nyilvánították a román nagykövetet, illetve vízumkényszert vezettek be a román állampolgárokkal szemben (Evenimentul Zilei 2009). Válaszul Traian Băsescu a parlament két házához intézett beszédében elítélte a moldáv vádakat és hangsúlyozta, hogy Románia támogatja a külföldön élő románokat és felelősséget visel állampolgáraiért, ennek érdekében újra felhívta a kormány figyelmét az állampolgári törvény módosítására, oly módon, hogy az állampolgárságukat valamilyen okból elvesztett személyek harmadfokú leszármazottai is állampolgárságot szerezhessenek („Mesajul preşedintelui României, Traian Băsescu” 2009). A két állam viszonya a Kommunista Párt ellenzékbe vonulásával lényegesen javult: 2010 óta pedig több magas szintü találkozóra került sor, mi több a kormányközi vegyesbizottságok is megkezdték munkájukat (Ivan 2012, p. 7).

A két állam közötti kapcsolatokból látható, hogy a román állampolgárság kiterjesztése alapvető vitapont, mert a moldovai hatóságok állandó veszélyként tekintettek a kettős állampolgárokra, ami részben megalapozott volt: a merészebb becslések szerint a lakosság 35-40\%-a lehetett kettős vagy többes állampolgár. Ehhez hasonló számadatokat közöltek a vezető nyugati hírportálok és médiaorgánumok, akik 
egymillió före tették a román-moldáv kettős állampolgárok számát. ${ }^{466}$ A fentiekben már idézett külügyminisztériumi forrás szerint a 2002-ig 108 ezer, míg 2000-2008 között kevéssel több mint tízezer fó szerzett egyszerüsített honosítás útján román állampolgárságot, akiknek kétharmada moldovai (Iordachi 2009, p. 119). A Soros Alapítvány támogatásával készült kutatás szerint 2009-től jelentősen megugrott a román állampolgárságot igénylők száma, mivel az állampolgárságot a második és harmadik generációs leszármazottakra is kiterjesztették. Ennek értelmében 2011-ben már több mint százezer kérelmet regisztráltak, és 69 ezret hagytak jóvá. Összességében tehát 1991-2012 decemberéig 323 ezerre tehető a kettős állampolgárok száma (PanainteNedelciuc-Voicu 2014, pp. 12-13). Nyilvános adatigénylési kérelmemre az Állampolgári Hatóság 2002 január-2018 márciusa közötti időszakra a következő adatokkal szolgált: Moldova Köztársaságból 637.495 állampolgársági kérelmet regisztráltak az illetékes szervek, ami alapján 521 ezer személy kapott állampolgárságot. Ha ehhez hozzáadjuk a '90-es évek adatait, akkor 1991-2018 márciusával bezárólag hozzávetőlegesen 630 ezer román-moldáv kettő állampolgárral számolhatunk.

Az államfó által hivatkozott erkölcsi és politikai kötelezettség mellett az állampolgárság kiterjesztése együtt járt a választójog megszerzésével. A 2004. évi 373. sz. törvény a parlament két házának megválasztásáról lehetővé tette, hogy a külföldön tartózkodó román állampolgárok a diplomáciai képviseleteken kialakított szavazóhelységekben - érvényes okmányok birtokában - leadhassák szavazatukat („Lege nr. 373 din 24 septembrie 2004”), míg a 2008-ban módosított, többségi és arányos elemeket is tartalmazó „egyéni választókörzetes rendszer” (Székely 2009, p. 7) külföldi választókörzeteteket (négy képviselői, két szenátori) hozott létre. A pártok és főként az államfő az állampolgárság kiterjesztésével felismerték a szavazatszerzés újabb terepeit, egyrészt a moldovai kettős állampolgárok, másrészt az Olaszországban, Spanyolországban elő vendégmunkások körében (Szele-Tófalvi 2011, pp. 66-67).

A külföldön élő románok és a román-moldáv állampolgárok szavazati joga az utóbbi években több alkalommal is a politikai viták kereszttüzébe került. A 2009-es államfőválasztás első fordulójának eredményei világosan tükrözték a román-moldáv kettős állampolgárok és a külföldön élő románok preferenciáit. A Központi Választási

\footnotetext{
${ }^{466}$ Noha a hivatalos adatok jóval kevesebb kettős állampolgárról tanúskodnak, az eltúlzó számadatokhoz nagymértékben hozzájárult a román államfö, Traian Băsescu nyilvánosan többször elhangzott és a nyugat-európai média- és sajtóorgánumokban is leközölt nyilatkozata, miszerint 800 ezerre tehető a hivatalos szerveknél regisztrált moldovai kérelmek száma (Bidder 2010). Băsescu, aki a román állampolgárság kiterjesztésének legfontosabb „hajtómotorja” 500 és 900 ezerre tette a moldáv-román állampolgárok számát.
} 
Iroda (Biroul Electoral Central) adatai alapján a külföldi szavazókörzetekben közel 95 ezer szavazatot adtak le, aminek több mint felét, 56\%-ot a hivatalban lévő államfö kapta. Băsescu népszerüségét a többi jelölttel szemben világosan jelezte az a tény is, hogy a Moldovai Köztársaságban a szavazatok 91\%-át szerezte meg (Központi Választási Iroda 2009a). Támogatottsága a második fordulóban tovább növekedett, ekkor már a voksok 95\%-át szerezte meg. ${ }^{467}$

A 2012 júliusában a kormányzó Szociálliberális Unió (USL) az államfö felfüggesztését kezdeményezte, aminek következtében július 29-én referendumot tartottak Traian Băsescu államfő leváltásáról. Az referendumot megelőzően a kormány és az a ellenzék, valamint az államfö között két kérdésben alakult ki vita: egyrészt a szavazóbázis meghatározásánál kiket tekintenek szavazóknak, másrészt pedig hogyan állapítják meg a referendum érvényességét (Iordachi 2013, p. 15), aminek meghatározáskor - a jogszabályok alapján - a választói névjegyzékben szereplő állampolgárok számát veszik alapul. A nagyszámú Băsescu-ellenes szavazat ${ }^{468}$ azonban nem bizonyult elegendőnek az államfő leváltásához, és a referendum érvényességének kérdése jelentős belpolitikai vitát generált a parlamenti pártok, a kormány és az államfő között. $^{469}$ A vitát - melyet élénk nyugati érdeklődés követett - végül az Alkotmánybíróság zárta le, megismételve a referendum érvénytelenségéről szóló döntést, aminek értelmében a felfüggesztett államfő újra elfoglalhatta hivatalát.

A legutóbbi, 2014-es államfóválasztás már nem hozott olyan szoros eredményt, mint a 2009-es, ellenben a külföldi választókörzetekben leadott szavazatok jelentősen növelték Johannis előnyét. ${ }^{470}$ A külföldi szavazók mobilizációja - melyet a választókörzetek kijelölése körüli viták váltottak ki - jelentősen megnövelte a

\footnotetext{
${ }^{467}$ A második forduló szoros eredményt hozott, ugyanis a szociáldemokraták jelöltje, Mircea Geoana korábbi külügyminiszter alig több mint 70 ezer szavazattal kapott kevesebbet, mint Băsescu, akinek győzelmét több elemző a külföldi szavazatoknak tulajdonította, amit a hivatalos adatok is alátámasztottak. A második fordulóban jelentősen megnőtt a külföldi körzetekben a részvétel, ugyanis másfélszer annyian voksoltak mint az első fordulóban: a 147 ezer érvényes szavazatnak Băsescu 79\%-át, míg Geoana 21\%-át szerezte meg (Központi Választási Iroda 2009b). A Moldovai Köztársaságban a hivatalban levő államfő tovább növelte népszerüségét és a második fordulóban voksok $95 \%$-át sikerült megszereznie.

${ }^{468}$ A referendumon részt vevő 8.459053 fö döntő többsége $87.52 \%$-a, vagyis 7.403 .836 fö az államfő menesztése mellett szavazott, míg 11,15\%-a, 943 ezer fö a hivatalban levő államföt támogatta.

${ }^{469}$ A referendumon a névjegyzékben szereplő állampolgároknak 46,24\%-a vett részt (Központi Választási Iroda 2012), kevesebb, mint az érvényes jogszabályok alapján a névjegyzékben szereplő választópolgárok fele plusz egy. A kormánypártok nem fogadták el a referendum érvénytelenségéről szóló döntést, érvényesnek tekintve a döntést abból kiindulva, hogy az utóbbi években jelentősen csökkent az ország lakossága, aminek következtében a választói névjegyzékben is kevesebb szavazópolgár kellene szerepeljen, mi több megkérdőjelezték a külföldön tartózkodó állampolgárok szavazati jogát is (Iordachi 2013, p. 15).

${ }^{470}$ PNL-PDL jelöltje, Klaus Johannis a második fordulóban több mint egymillió szavazattal szerzett többet a szociáldemokraták jelöltjénél, Victor Pontánál
} 
részvételt, aminek betudhatóan háromszor annyian szavaztak, mint a 2009-es államfőválasztás második fordulójában, a jobboldali jelölt pedig a külföldi körzetekben leadott szavazatok 89,73\%-át (338.873 fó) szerezte meg. ${ }^{471}$

\section{A kedvezményes honosítás és az állampolgárság kiterjesztése a parlamenti vitákban}

Az előző két fejezetben arra mutattam rá, hogy az állampolgárság kiterjesztése eltérő intenzitással ugyan, de megjelent mindkét állam politikai napirendjén: míg Magyarországon a kettős állampolgárság kérdése mélyen megosztotta a parlamenti pártokat, a népszavazás eredményeként pedig a magyar társadalmat is, addig Romániában egyetlen politikai alakulat sem kérdőjelezte meg, hogy a volt román állampolgárok leszármazottai könnyített honosítási eljárással állampolgárságot szerezzenek. Ennek ellenére a parlamenti vitákban számos alkalommal megjelent az állampolgárság kérdése, de nem a 2004-es kettős állampolgárságról szóló magyarországi viták kontextusában, hanem a román állampolgársági törvény 2009-ben történő módosításakor, amelynek során a kormány által elfogadott sürgősségi kormányrendeletet mindkét ház, elsőként a Szenátus ${ }^{472}$, majd a Képviselőház ${ }^{473}$ is megvitatta. A vita tárgyát azonban nem az állampolgárság kiterjesztése és a könnyített honosítási eljárás képezte - ugyanis erről konszenzus volt a pártok között -, hanem az, hogy a pártok miként tudják túllicitálni politikai ellenfeleiket. Tehát a javaslatok az állampolgársági törvény módosítását célozták, amely lehetővé tenné az állampolgárság megadásának legkedvezőbb formáját, azzal a nem titkolt célkitüzéssel, hogy megnyerjék a moldovai állampolgárok, mint potenciális jövőbeli szavazók bizalmát. Ezzel magyarázható a jogszabály módosításának folyamata és az erről folytatott vita, amelyben a PD-L és a PSD újabb javaslatokat tett az állampolgársági kérelmek gyorsabb elbírálására. ${ }^{474}$

471 A korábbi államfőválasztáshoz hasonlóan Moldova Köztársaságban a végeredmény magas jobboldali
$(78,58 \%)$ támogatottságot eredményezett (Központi Választási Iroda 2014).
472 (,,Szenátusi vita jegyzőkönyve. Dezbaterea şi adoptarea Proiectului de lege privind aprobarea
Ordonanţei de urgenţă a Guvernului nr. 36/2009 pentru modificarea şi completarea Legii cetăţeniei
române nr. $21 / 1991$ (L121/2009)”).
473 („,Képviselőházi vita jegyzőkönyve. Dezbaterea Proiectului de Lege privind aprobarea Ordonanţei de
urgenţă a Guvernului nr.36/2009 pentru modificarea şi completarea Legii cetăţeniei române nr.21/1991”).
474 A kormány által elfogadott sürgősségi rendelet bizottsági vitáján a képviselök pl. azt is támogatták,
hogy az állampolgári esküt a prefektúrákon, az illetékes prefektus jelenlétében is lehessen letenni. Ezen
túlmenően PD-L szenátorai törvényjavaslatot nyújtottak be a '91-es törvény módosítása érdekében,
Mircea Lubanovici (PD-L) képviselő a napirend előtti felszólalásában pedig a román állampolgárság
kiterjesztéséről beszélt a diaszpórában élő románok számára. Az állampolgárság kérdésében a
szociáldemokrata képviselő Tudor Panţîru (PSD) tevékenysége kiemelkedő, aki amellett, hogy támogatta 
Az Országgyülésben a MVSZ kezdeményezését követően jóval intenzívebb vita folyt a kettős állampolgárságról, amely 2004 szeptemberétől - 2005 júniusáig uralta a politika napirendjét, különösen pedig a népszavazási kampány időszakában. E háromnegyed éves időszak alatt a kettős állampolgárság számos alkalommal, különböző kontextusokban szerepelt a napirenden. Noha a vita már a parlamenti ülésszak végén tematizálódik, az Országgyűlés szeptember 13-án vitatta meg a MVSZ kezdeményezését ${ }^{475}$, melyet a november $17-\mathrm{i}$ parlamenti vitanap követett. ${ }^{476}$ Ezzel párhuzamosan a kormányzó MSZP-SZDSZ koalíció további jogszabályokat kezdeményezetett a népszavazást megelőzően: december elsején az Országgyülés megkezdte a határon túli magyarok nemzetpolgárságáról szóló határozati javaslat ${ }^{477}$ és a Szülőföld Alapról szóló törvénytervezet együttes vitáját, a sikertelen népszavazást követően pedig, elfogadta, majd 2005 márciusában vitát kezdeményezett a Szülőföld Alapról szóló törvény módosításáról ${ }^{478}$, májusban az 1993-as állampolgársági törvény módosításáról. ${ }^{479}$

20. sz. táblázat: A honosítási eljárásról/ kettős állampolgárságról szóló viták jellemzői

\begin{tabular}{|c|l|l|}
\hline & \multicolumn{1}{|c|}{ Románia } & \multicolumn{1}{c|}{ Magyarország } \\
\hline $\begin{array}{c}\text { A viták } \\
\text { státusa és } \\
\text { időpontjai }\end{array}$ & $\begin{array}{l}\text { Az állampolgársági törvény } \\
\text { módosítására irányuló } \\
\text { törvénytervezet vitája. } \\
\text { Szenátus: 2014. június 6. } \\
\text { Képviselőház: 2014. október } \\
26 .\end{array}$ & $\begin{array}{l}\text { A népszavazás kezdeményezésének vitája: 2004. szeptember 13. } \\
\text { Vitanap az Országgyülésben: november 17. } \\
\text { Határozati javaslat vitája: december 1. } \\
\text { Vita a Szülőföld Alapról: december 1 - február 14. } \\
\text { A Szülőföld Alapról szóló törvény módosítása: 2005. március } 21 . \\
\text { Állampolgársági törvény módosítása: 2005. május 3-június 6. }\end{array}$ \\
\hline $\begin{array}{c}\text { A szövegtest } \\
\text { mérete }\end{array}$ & 23 oldal/7300 szó & \multicolumn{1}{c|}{285 oldal/130.000 szó } \\
\hline $\begin{array}{c}\text { Felszólalók } \\
\text { száma }\end{array}$ & 20 & 219 \\
\hline
\end{tabular}

Az elemzés a két állam nemzeti parlamentjében lefolytatott, az állampolgárság kérdésének szempontjából releváns viták összehasonlító vizsgálatára terjed ki. Elsőként

a pártja által benyújtott törvényjavaslatot az állampolgársági törvény módosítására, több mint tíz alkalommal intézett kérdést a Belügyminisztériumhoz és az Igazságügyi Minisztériumhoz.

475 („Vita a Magyarok Világszövetsége által kezdeményezett országos népszavazásról” 2004).

476 („Új magyar nemzetpolitika belföldön és külföldön” 2004).

477 („A határon túli magyarok nemzetpolgárságáról és a szülőföld-programcsomag létrehozásáról szóló országgyülési határozati javaslat" 2004).

478 („A Szülőföld Alapról szóló 2005. évi II. törvény módosításáról szóló törvényjavaslat általános vitája” 2005).

${ }^{479}$ („A magyar állampolgárságról szóló 1993. évi LV. törvény módosításáról és a külföldiek beutazásáról és tartózkodásáról szóló 2001. évi XXXIX. törvény módosításáról szóló törvényjavaslat általános vitája" 2005; „A magyar állampolgárságról szóló 1993. évi LV. törvény módosításáról és a külföldiek beutazásáról és tartózkodásáról szóló 2001. évi XXXIX. törvény módosításáról szóló törvényjavaslat részletes vitája” 2005; „A magyar állampolgárságról szóló 1993. évi LV. törvény módosításáról és a külföldiek beutazásáról és tartózkodásáról szóló 2001. évi XXXIX. törvény módosításáról szóló törvényjavaslat zárószavazása” 2005). 
az állampolgárság kiterjesztése kapcsán megfogalmazott értelmezéseket rendszerezem, majd a parlamenti pártok álláspontját, végül pedig a fóbb témákat és a vita során képviselt érvrendszereket mutatom be.

Az Országgyülésben, valamint a Képviselőházban és a Szenátusban lezajlott viták tartalomelemzése rámutat egyrészt a vitákban fellelhető domináns és kevésbé domináns témákra, valamint a tematikai különbségekre. Mindkét vitában (1) meghatározó a könnyített honosítási eljárással kapcsolatos értelmezések (fő célkitüzése, tartalma, stb), az állampolgárság megszerzésének módja és folyamata, illetve az állampolgársági törvény módosítására vonatkozó javaslatok. Ebbe a csoportba sorolható az MVSZ által kezdeményezett népszavazás a kettős állampolgárság kiterjesztéséről, mi több (2) dominánsnak tekinthető a vitákban megjelenő nemzetpolitikai célkitüzésre való hivatkozások, illetve a magyar kormány által tematizált különféle programok. Noha a román vitában is megjelentek nemzetpolitikai kérdések, ezek közel sem annyira hangsúlyos témák, ebből adódóan a román felszólalók - szemben a magyar vitában, ahol a képviselök folyamatosan hivatkoznak a határon túli magyarokra és az anyaország által folyósított támogatásokra - csak érintőlegesen utalnak az alkotmányból eredő felelősségre és a nemzetpolitikai elvekre.

A viták közötti további tematikai különbséget a felsorakoztatott (3) érvek és ellenérvek jelentik. A magyar vitában gyakoriak a szakpolitikai érvek, míg a román vitában ez teljességgel hiányzik, csupán néhány alkalommal hivatkoznak történelmi vagy morális érvekre. (4) Kevésbé domináns témák a két vitában az európai fórumok szerepe, és az integráció jelentősége, valamint a szomszédos államok és nyugat-európai államok állampolgárság-politikája. A kérdés belpolitikai jellegét világosan jelzi az a tény is, hogy az állampolgárság csakis belpolitikai kérdésként tematizálódott, ugyanis (5) mindkét vitában marginális kérdésként jelent meg a külpolitikai mozgástér problematikája, valamint a szuverenitás is, amely arra enged következtetni, hogy az állampolgársággal felmerülő kérdéseket az képviselők az állam sajátos joghatóságába tartozó döntésként értelmezik. 
21. sz. táblázat: Kategóriák a kettős állampolgárság vitájában

\begin{tabular}{|c|c|c|c|}
\hline \multicolumn{2}{|r|}{ Kategóriák a magyar vitában } & Gyakoriság & $\%$ \\
\hline \multirow{6}{*}{ 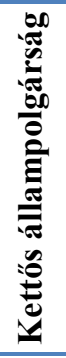 } & A könnyített honosítási eljárás értelmezése & 105 & 8,18 \\
\hline & Az állampolgársági törvény módosítása & 97 & 7,55 \\
\hline & $\begin{array}{l}\text { Az állampolgárság megszerzésének módja és feltételei, } \\
\text { javaslatok }\end{array}$ & 85 & 6,62 \\
\hline & MVSZ népszavazási kezdeményezése & 183 & 14,25 \\
\hline & Útlevél és nemzeti vízum & 45 & 3,50 \\
\hline & Összesen & 515 & 40,01 \\
\hline \multirow{7}{*}{ 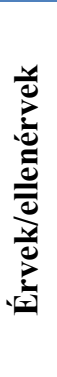 } & Demográfiai folyamatok, migráció & 55 & 4,28 \\
\hline & Gazdasági és költségvetési érvek & 51 & 3,97 \\
\hline & Szociális ellátórendszer, társadalombiztosítás, nyugdíj & 40 & 3,12 \\
\hline & Munkavállalás & 23 & 1,79 \\
\hline & Egészségügy, kórház-privatizáció & 14 & 1,09 \\
\hline & Történelmi és morális érvek, a jóvátétel problémája & 13 & 1,01 \\
\hline & Összesen & 205 & 15,97 \\
\hline \multicolumn{2}{|c|}{ Nemzetpolitikai elvek, célkitüzések, programok } & 200 & 15,58 \\
\hline \multicolumn{2}{|c|}{ Határon túli magyarok, MÁÉRT, RMDSZ } & 115 & 8,96 \\
\hline \multicolumn{2}{|c|}{ Támogatáspolitika } & 60 & 4,67 \\
\hline \multicolumn{2}{|c|}{ Európai integráció, európai fórumok } & 43 & 3,35 \\
\hline \multicolumn{2}{|r|}{ Románia és más államok állampolgárság-politikája } & 39 & 3,04 \\
\hline \multicolumn{2}{|c|}{ Nemzet egysége, nemzetkoncepciók } & 35 & 2,73 \\
\hline \multicolumn{2}{|c|}{ Szomszédos államok, állampolgárok } & 16 & 1,25 \\
\hline \multicolumn{2}{|c|}{ Történelmi, nyelvi, kulturális kötődés } & 12 & 0,93 \\
\hline \multicolumn{2}{|c|}{ Nyugat-európai államok, állampolgárok } & 10 & 0,78 \\
\hline \multicolumn{2}{|r|}{ Külpolitikai prioritások, külpolitikai mozgástér } & 5 & 0,39 \\
\hline \multicolumn{2}{|c|}{ Nemzeti érdek } & 5 & 0,39 \\
\hline \multicolumn{2}{|c|}{ Hivatkozások } & 33 & 2,57 \\
\hline \multicolumn{2}{|c|}{ Összesen } & 1284 & 100,00 \\
\hline
\end{tabular}

\begin{tabular}{|r|l|c|c|}
\hline \multicolumn{2}{|c|}{ Kategóriák a román vitában } & Gyakoriság & $\%$ \\
\hline & A könnyített honosítás értelmezése & 15 & 14,15 \\
\cline { 2 - 4 } & A jogszabály módosítása & 33 & 31,13 \\
\cline { 2 - 4 } & Állampolgárság megszerzésének módja és & 18 & 16,98 \\
\cline { 2 - 4 } & feltételei & $\mathbf{6 6}$ & $\mathbf{6 2 , 2 6}$ \\
\hline Történelmi és morális érvek, a jóvátétel problémája & 10 & 9,43 \\
\hline Határon túli románok & 7 & 6,60 \\
\hline Nemzetpolitikai elvek, célkitüzések, programok & 6 & 5,66 \\
\hline Szomszédos államok állampolgárság-politikája & 3 & 2,83 \\
\hline Európai integráció, európai fórumok & 3 & 2,83 \\
\hline Külpolitikai prioritások & 2 & 1,89 \\
\hline Jogi státus, kapcsolat & 2 & 1,89 \\
\hline RMDSZ & 2 & 1,89 \\
\hline Gazdasági és költségvetési érvek, munkavállalás & 1 & 0,94 \\
\hline Szuverenitás és nemzeti érdek & 1 & 0,94 \\
\hline Hivatkozások & 3 & 2,83 \\
\hline Összesen & $\mathbf{1 0 6}$ & $\mathbf{1 0 0 , 0 0}$ \\
\hline
\end{tabular}




\subsection{Magyarország}

A kettős állampolgárságról szóló vitákat a kormány és az ellenzék megosztottsága jellemezte, amely a pártok között mély, kibékíthetetlennek tünő törésvonalakat eredményezett a vizsgált időszakban. A kormánypártok abból kiindulva, hogy (1) az állampolgárság megadása nem járul hozzá az erdélyi magyarok helyzetének rendezéséhez; (2) megterheli a magyar költségvetést és (3) kontraproduktív az autonómia-mozgalmak szempontjából, ellenezték az állampolgárság kiterjesztését és a népszavazási kampányban a nemmel való szavazásra biztattak. Ezzel ellenétben az ellenzéki pártok és a független képviselők a kettős állampolgárság megadása mellett érveltek, (1) látszat-intézkedésnek tekintették a kormány nemzetpolitikai javaslatait; (2) elítélték a kormány negatív üzeneteit tartalmazó kampányát, és az állampolgárság (3) pozitív következményeit emelték ki a vitában (szülöföldön való maradás, gazdasági előnyök, a határon túli magyarok identitásának erősítése).

28. sz. táblázat: A kettős állampolgárság értelmezése a magyar vitában

\begin{tabular}{|c|c|c|}
\hline & Kormányoldal & Ellenzéki pártok \\
\hline 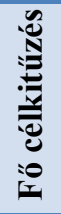 & $\begin{array}{l}\text { A kettős állampolgárságot egyetlen kormány sem } \\
\text { tekintette alkalmas eszköznek a határon túli magyarok } \\
\text { rendezésére. } \\
\text { Az állampolgárság kiterjesztésére - a határon túli } \\
\text { magyarok érdekében - nemet kell mondani. }\end{array}$ & $\begin{array}{l}\text { Lehetővé kell tenni a határon túli magyaroknak, hogy } \\
\text { lakóhelyük megváltoztatása nélkül szerezzenek } \\
\text { állampolgárságot. }\end{array}$ \\
\hline 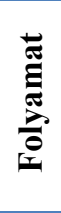 & $\begin{array}{l}\text { Az előző kormánynak megvolt a lehetősége az } \\
\text { állampolgárság beterjesztésére, mégsem élt vele. } \\
\text { Nem ismertek az állampolgárság megadásának } \\
\text { társadalmi-nemzetpolitikai következményei. }\end{array}$ & $\begin{array}{l}\text { A kormány és Gyurcsány Ferenc által kezdeményezett } \\
\text { negatív kampány megosztja a magyar társadalmat. } \\
\text { A parlamenti pártok hozzanak létre egy négypárti } \\
\text { bizottságot, mely előkészíti az állampolgársági törvény } \\
\text { módosítását. }\end{array}$ \\
\hline$\underset{\frac{1}{\pi}}{\frac{\Xi}{\pi}}$ & $\begin{array}{l}\text { A magyar állampolgársággal számtalan juttatás alanyi } \\
\text { jogon jár, amely megterheli a költségvetést. } \\
\text { Lehetetlen és meggondolatlan lépés az állampolgárság } \\
\text { és az autonómia egyidejü támogatása. } \\
\text { A szavazati jog megadásával olyan állampolgárok } \\
\text { szólnak bele a politikai döntésekbe, akik nem élnek } \\
\text { Magyarország területén. }\end{array}$ & $\begin{array}{l}\text { Az állampolgársági törvény módosítása helyett } \\
\text { benyújtott nemzetpolitikai programok félmegoldásnak } \\
\text { és pótcselekvésnek bizonyulnak. } \\
\text { A kormány az áttelepülő határon túli magyarokkal és a } \\
\text { költségvetést megterhelő kiadásokkal riogatja a } \\
\text { közvéleményt. }\end{array}$ \\
\hline 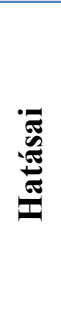 & $\begin{array}{l}\text { A kettős állampolgárság növeli a határon túli magyarok } \\
\text { anyaországba és a nyugat-európai államokba történő } \\
\text { áttelepedését. } \\
\text { Nem a kettős állampolgárság megadása, hanem az } \\
\text { autonómia-megoldások javítják a kisebbségek } \\
\text { helyzetét. A kettős állampolgárság megadása a } \\
\text { kisebbségi jogok kivívása szempontjából lehetetlen } \\
\text { helyzetet teremt a határon túli magyarok számára. }\end{array}$ & $\begin{array}{l}\text { Az állampolgárság megadása nem növelné, hanem } \\
\text { mérsékelné a Magyarországra történő bevándorlást. } \\
\text { Az állampolgárság kiterjesztésének pozitív hatásai } \\
\text { lesznek a gazdaságra és a társadalombiztosításra. } \\
\text { A kettős állampolgárság intézménye erősíti a határon } \\
\text { túli magyar közösségeket. }\end{array}$ \\
\hline
\end{tabular}

A kormányzó pártok közül az MSZP következetes álláspontot képviselt a vitában és elutasította a kettős állampolgárság megadását. Noha nem vitatta az MVSZ népszavazási kezdeményezésének jogszerüségét, a képviselők rendszerint „szerencsétlen, helytelen és rosszul időzített” kísérletről beszéltek, Gyurcsány Ferenc 
miniszterelnök egyenesen a „populista politika megnyilvánulásaként” tekintett a népszavazásra.

Az MSZP nem vitatta továbbá a pártok között kialakult nemzetpolitikai konszenzust sem, amelynek alapja a határon túli magyarok autonómia-küzdelmének támogatása és a szülőföldön való boldogulás elősegítése, de erre a párt szerint az állampolgárság kiterjesztése nem a megfelelő eszköz. Ezért a kampány utolsó napjaiban új nemzetpolitikai javaslatot terjesztett a parlament elé, ami (1) megfelel az integrációt követő időszak követelményeinek; (2) elősegíti a szülőföldön való boldogulást és a békés nemzetegyesítést és (3) összhangban van a kormányzás célkitüzéseivel is. A nemzetegyesítés és a felelős kormányzat mint célkitűzések, az új nemzetpolitikai szemléletet is tükrözik, egyben jelzés arra vonatkozóan, hogy a vita nem a határon túli magyarokról szólt, hanem alapvetőn belpolitikai kérdésként tematizálódott. Ezt látszik alátámasztani a miniszterelnök által ismertetett „új nemzetpolitikai program”, amelynek a nemzetegyesítés a sarokpontja. Ez a program nem korlátozódhat csak Magyarország és a határon túli magyarok viszonyára, hanem ki kell terjedjen a gazdasági és társadalmi határok lebontására. ${ }^{480} \mathrm{~A}$ vitában az MSZP nemzetegyesítési koncepciója kibővül és a képviselők szociális és társadalomegyesítésként értelmezték az összmagyar integrációt.

Az új program benyújtása mögötti szándék egyértelmü: kilépni az ellenzéki pártok által uralt nemzetpolitikai diskurzusból, és konkrét adatokon alapuló érvekkel elutasítani az állampolgárság megadását. A felszólaló képviselők szerint az állampolgárság megadásakor elsősorban a demográfiai folyamatokkal kell számolni, mert növekedne az áttelepülők száma. A határon túli magyarok által megszerzett magyar állampolgárság a magyarországi népességfogyás pótlását legalizálná, „minden harmadik fiatal elhagyná szülőföldjét”, „,ömeges exodust”, „második Trianont” „újkori népvándorlást” eredményezne - hívták fel a beláthatatlan következményekre a figyelmet a képviselők. Az állampolgárság elutasítását az MSZP gazdasági érvekkel, a magyar költségvetésre háruló terhekkel támasztotta alá, valamint azzal, hogy az új állampolgárok jelentősen megterhelik a szociális, társadalombiztosítási és egészségügyi rendszert. Az MSZP diskurzusában szintén fontos érvként jelet meg a munkavállalás problémája. A felszólalók amellett foglaltak állást, hogy a magyar munkaerőpiac nem tudná felszívni a határon túlról beáramló munkaerőt, „engedély nélkül lesznek

\footnotetext{
480 „A magyar kormány nemzetpolitikája tehát arról szól, hogy bontsuk le azokat a határokat, amely magyart magyartól elválaszt. Ezek a határok nemcsak az országhatárok, ezek szociális, jövedelmi, tudásbeli, egészségbeli határok” Részlet Gyurcsány Ferenc miniszterelnök felszólalásából az „Új magyar nemzetpolitika belföldön és külföldön" címü politikai vitanapon elhangzott beszédéböl (2004. november $17)$.
} 
foglalkoztathatók", Csizmár Gábor foglalkoztatási és munkaügyi miniszter egyenesen a munkaerőpiacon kialakuló feszültségek lehetőségét emelte ki felszólalásában. ${ }^{481}$ A párt szerint jelenleg Magyarország gazdasági ereje és versenyképessége nem teszi lehetővé a határon túli magyarok ilyen mértékü támogatását. ${ }^{482}$

Az állampolgárság megadása helyett az MSZP nemzetpolitikai programokban (Szülőföld Alap, nemzetpolgárság és útlevél) gondolkodott, melyek elősegítik a szülöföldön való maradást, a nemzeti önazonosság megőrzését és lehetővé teszik a szabad határátlépést. A vitában gyakori eleme a felszólalásoknak a határon túli származás hangsúlyozása, amellyel a szocialista képviselők egyrészt legitimálták a vitában felsorakoztatott érvrendszerüket, másrészt úgy jelentek meg, mint akik „valóban” ismerik a határon túli magyarok helyzetét. ${ }^{483}$ A párt által kezdeményezett programok azonban tovább növelték a kormány és az ellenzék megosztottságát, így sikertelen kísérletként értékelhető a miniszterelnöknek a pártok közötti együttmüködésére, összefogásra és párbeszédre vonatkozó felhívása.

Az SZDSZ felelőtlenségnek tartotta a népszavazás megtartását, a kampány során pedig a nemmel történő szavazás mellett foglalt állást, azért mert a párt álláspontja szerint (1) az állampolgárság kiterjesztése felgyorsítja a szülőföld elhagyását; (2) az állampolgárság alanyi jogon történő megadása ellentétes a nemzetközi gyakorlattal; (3) a döntés következményei nem voltak világosan végiggondolva, következésképpen ,nem kényszerithetök a magyar állampolgárok arra, hogy egy kérdésben, aminek nem ismerik a következményeit, felelös döntést hozzanak. "484 A felszólaló képviselők annak a véleményüknek adtak hangot, hogy a kettős állampolgárság helyett, a magyar kormány a határon túli magyarok problémáinak megoldását kell támogassa, illetve segítenie kell a szomszédos államokat az integrációban. Az integrációs diskurzus azért lényeges az SZDSZ szempontjából, mert a felszólalók továbbra is az európai fórumoktól várták a kisebbségi jogok rendezését. E tekintetben Magyarország mozgástere - az integrációt követően - „megnövekedett”, „óriásit tágult”, „képesek vagyunk döntéseket

\footnotetext{
481 „Új magyar nemzetpolitika belföldön és külföldön” címủ politikai vitanap.

482 „,Támogatást csak olyan ország nyújthat, amelynek gazdasága nem roppan össze. Összetartozunk, egy töröl származunk. De ha a fatörzs, az anyaország megroppan, azt a határon túlra nyúló ágai is megsínylik.” Lendvai Ildikó (MSZP) felszólalása Gyurcsány Ferenc „Új európai alkotmány, új felelősség”" beszéde kapcsán (2004. november 2). A kettős állampolgárság vitájában az MSZP a 800 ezer Magyar Igazolvánnyal rendelkező határon túli magyart potenciális áttelepülőként kezelte. Ebből adódóan nem tekinthetők reálisnak azok a becslések, amelyek több milliárd forintos költségvetési terhekröl beszélnek.

${ }^{483}$ Határon túli származására hivatkozott többek között: Korzós Lajos, Újhelyi István, Vitányi István, Balogh József, Szabó Zoltán, Szücs Erika.

${ }^{484}$ Kuncze Gábor (SZDSZ) felszólalása Gyurcsány Ferenc „Közös felelősségünkröl” c. beszéde kapcsán (2004. november 15).
} 
befolyásolni”, ami lehetőséget teremt az EU-s keretek közötti érdekérvényesítésre. A párt elnöke szerint az állampolgárság helyett arról kellene vitázni, hogy „,mit jelent az EU-csatlakozásunk a határon túliaknak, hogyan tudunk ebböl az ö számukra is profitálni, hogyan tudjuk ennek minél több elönyét a számukra megszerezni. "485

A határon túli magyarok helyzetének rendezése - az európai dimenzión túlmenően - összefonódik a többségi nemzettel, következésképpen Magyarország úgy tud segíteni, ha közben „a többségi nemzet tagjainak” is segít, valamint „együtt kezeli őket az ottani barátaikkal, rokonaikkal”. Ezt a rendezést „nem viszi előre”, „nem szolgálja" az állampolgárság megadása, mert nehezíti az eddig elért eredményeket (kisebbségi jogok kivívása, egyházi ingatlanok visszaadása). A parlamenti vitában elsőként az SZDSZ-nél jelent meg a kettős állampolgárság intézménye és az autonómiakövetelések, mint egymást kizáró törekvések. Eörsi Mátyás szerint a FIDESZ képviselői „lehetetlen dolgot” követelnek. Fodor Gábor is hasonlóan vélekedett, a vitában két alkalommal is felhívta a figyelmet arra, hogy az állampolgárság megadása csökkenti az autonómia kivívásának lehetőségét és a „kisebbségi jogvédelmi törekvéseiket”, mert egyrészt „lehetetlen helyzetet teremt” az ott élő közösségek számára, másrészt pedig a többség nagyobb valószínűséggel utasítja el a kettős állampolgársággal rendelkező magyarok törekvéseit. ${ }^{486}$ A párt képviselői szerint „ösztönözni”, „,bátorítani” „segíteni” kell a határon túli magyarokat, hogy szülőföldjükön tudjanak boldogulni, ezért a felszólaló képviselők egyöntetűen támogatták a Szülőföld Alap létrejöttét, majd az állampolgári törvény módosítását, és a nemzeti vízum bevezetését, de azt is hangsúlyozták, hogy aki Magyarországon akar élni, annak lehetővé kell tenni, „,meg kell könnyíteni" a letelepedését.

A nagyobbik ellenzéki párt, a FIDESZ a kettős állampolgárságot a nemzeti összefogásra és a határokat átívelő nemzeti újraegyesítésre hivatkozva támogatta, amely összeegyeztethető a szülőföldön való maradás és az autonómiaküzdelmek támogatásával. E nemzetpolitikai szempontból fontos döntések előkészítésében és kidolgozásában a FIDESZ elengedhetetlennek tartotta a határon túli szervezetek

\footnotetext{
485 Uo.

486 „,Ugyanis, ha a kettös állampolgárságot alanyi jogon meg fogják kapni a határon túli magyarok, onnantól kezdve minden autonómiatörekvésükre, minden kisebbségi jogvédelmi törekvésükre azt fogja válaszolni a többség: „Kérem szépen, milyen állam polgárai önök? Egy más állam polgárai? Tessék akkor elmenni a szomszédba, és ott kérni ezeket a jogokat, ott kérni az autonómiát, ott kérni a segitséget! Lehetetlen helyzetbe fognak kerülni ezek a közösségek [...] és ezzel jobb tisztában lenni, mint hogy megint magunkat becsapjuk mindenféle illúziókkal." Fodor Gábor a Népszavazásról c. napirend előtti felszólalása (2004. november 23). A népszavazás utáni felszólalásában a képviselő az állampolgárság megszerzését a politikai jogok korlátozásaként értelmezte: „Lehetetlen helyzetbe kerültek volna például egy képviselö-választáson, például az ottani politikai közéletben való részvételnél, amikor megkérdezik tôlük, hogy melyik állam polgárai." Fodor Gábor napirend elötti felszólalása (2004. december 7).
} 
részvételét és a konszenzus fenntartását. Az állampolgárság kérdésében szorgalmazott négypárti egyeztetés és a határon túli szervezetek bevonása a döntés-előkészítés folyamatába a felszólalók konszenzuskereső magatartásáról tanúskodik, azonban a merev és elutasító kormányzati pozícióknak betudhatóan a FIDESZ érvrendszere arra irányul, hogy szembehelyezkedjen és elutasítsa vagy cáfolja a kormányzó pártok érvrendszereit. Míg tehát a kormánypártok nemet mondanak a nemzeti összefogásra és a népszavazásra, addig a FIDESZ támogatja a nemzet újraegyesítését, osztja a határon túli szervezetek álláspontját, „,meghallgatjuk őket, mielőtt rájuk vonatkozó döntést hozunk”.

A kormányzó pártokkal szemben a FIDESZ a határon túli közösségekre nem tehertételként tekint (az állampolgárság mint tehertétel), hanem a gazdasági és kulturális téren értelmezhető lehetőségként. ${ }^{487}$ E szemléletbeli különbségnek a felszólalásokban gyakorlati következményei is vannak, amely a kormánypártokéval teljesen ellentétes érvrendszerekben nyilvánulnak meg. Következésképpen az (1) az állampolgárság megadása nem növeli, hanem „mérsékli” az áttelepedési szándékot, nem eredményez „tömeges elvándorlást”; (2) a Magyarországon munkát vállaló határon túli magyarok nem terhelik, hanem erősítik a társadalombiztosítást; valamint (3) hivatkozva a szomszédos államok állampolgárság-politikájára elterjedt a kedvezményes honosítás gyakorlata - kivételt képez Ukrajna -, amely nem jelent veszélyforrást.

A kormányzó pártok és a FIDESZ közötti polarizálódó vita következtében a FIDESZ nem támogatta a kormány nemzetpolitikai programjait, noha egyes elemeit vitára érdemesnek tartotta. A párt szerint a kormány javaslatával „kompenzálni próbálja” a kettős állampolgárság elleni kampányt, az „új nemzetpolitika megtévesztés”, „a nemzetpolitikai vitanap figyelemelterelés”. A felszólalók szerint a Szülőföld Alapra vonatkozó törvényjavaslattal a kormány „csak a lelkiismeret-furdalásukat akarja tompítani”, mert állampolgárságot nem lehet kifizetni „ilyen-olyan-amolyan nagyságrendü", a támogatáspolitikát jelentősen érintő és befolyásoló javaslatokkal. ${ }^{488} \mathrm{~A}$ FIDESZ diskurzusában domináns témát képeztek a támogatáspolitikával összefüggő kérdések, a kormány által bemutatott nemzetpolitikai programokon túlmenően a felszólalók a határon túli támogatásokat kezelő alapítványok helyzetét ismertetve és az alapvető gazdasági problémákat részletezve - fenntartás, finanszírozás - arra mutattak

\footnotetext{
487 „,...hanem ahelyett, hogy erőforrásként, lehetőségként, a magyar gazdaság erejét növelő, kiterjeszteni segítö tényezöként venné számításba a határon túli magyar nemzetrészeket, ehelyett elidegeníti tölünk." Kövér László (FIDESZ) felszólalása az „Új magyar nemzetpolitika belföldön és külföldön” c. vita napján. 488 „,...ez a törvényjavaslat olyan, mintha Jézus harminc ezüstpénzért elárulná a tanitványait”. Részlet Láyer József (FIDESZ) felszólalásából A határon túli magyarok nemzetpolgárságáról és a szülőföldprogramcsomag létrehozásáról szóló országgyülési határozati javaslat, valamint a Szülőföld Alapról szóló törvényjavaslat együttes általános vitáján (2004. december 1).
} 
rá, hogy nem igazi reformokról, csupán átcsoportosításokról van szó. ${ }^{489}$ A szakpolitikai programok - vélték a képviselők - nem váltják ki az állampolgárságot, aminek következményeit a kormánypártoknak viselniük kell: „Önöket a történelem el fogja ítélni." ${ }^{490}$

A parlamenti vitákban az $M D F$ „,nemzeti szándékából” kiindulva elkötelezett volt a határon túli magyarokat megillető állampolgárság kiterjesztésében. Az ellenzéki pártokkal ellentétben, a vitában az MVSZ népszavazási kezdeményezésében problémákat és kockázatokat látott, „iszonyú sok veszélyt is rejt magába”, „,nem jó a kérdés", amely egy esetleges érvénytelen népszavazás következtében beláthatatlan következményekkel bírna. ${ }^{491}$ Ehelyett az MDF diskurzusában saját törvényjavaslatuk képez domináns témát, a viták során ennek pozitív vonatkozásait folyamatosan hangsúlyozták a felszólalók: (1) a jogszabály-módosítás a szülőhely elhagyása nélkül teszi lehetővé az állampolgárság megszerzését; (2) nem várja el a megélhetési feltételek igazolását; (3) nem jelent költségvetési terhet a magyar államra; (4) az állampolgársággal alanyi jogon nem jár a választójog. E javaslatokról több alkalommal kívánt vitát kezdeményezni az MDF - beleértve a négypárti egyeztetéseket -, de sikertelenül.

Az állampolgárság támogatása mellett felszólaló képviselők érvrendszere számos hasonlóságot mutat a nagyobbik ellenzéki párt által vázolt érvekkel. A felszólalók elsősorban hangsúlyozták, hogy az állampolgárság megadása csökkenti az áttelepedési szándékot, továbbá, hogy a határon túli magyarok igénye ,alapvetően nem anyagi természetü”, mint ahogyan a kormánypártok állítják és noha költségtételt jelent, nem terheli meg jelentős mértékben a magyar költségvetést. Az MDF meggyőződéssel vallotta, hogy e lényeges nemzetpolitikai döntésben nem lehet anyagiak alapján dönteni: „Forintositható-e minden kérdés? És ha igen, akkor szabad-e ebben a kérdésben forintok alapján dönteni? Én azt mondom, hogy az igaz nemzeti érzésü igaz magyar ezt a kérdést másképp itéli meg, nem anyagiak alapján. "492 A képviselők végül rámutattak

\footnotetext{
489 A képviselők részletezték az oktatási-nevelési támogatások kifizetése körül kialakult helyzetet, valamint az Apáczai Közalapítvány, a Segítő Jobb Alapítvány, a Mocsáry Alapítvány, az Illyés Alapítvány valamint az Új Kézfogás Közalapítvány múködtetése során észlelt problémákat, valamint a Sapientia EMTE, a Selye János Egyetem, és a Rákóczi Ferenc Főiskola müködtetésére nyújtott támogatások csökkenéséről.

${ }^{490}$ Uo. Tóth István (FIDESZ) felszólalása.

491 „Nehezen tudok nagyobb tragédiát elképzelni annál, mint ha egy ilyen fontos nemzetstratégiai kérdésben egy elutasitó vagy érvénytelen döntés születne. Azt hiszem, hogy ez a környezö magyarság számára, a környezö országokban élö, a határokon túl élö nemzetrészek, magyar testvéreink számára egy lelki Trianonnal érne fel." Herényi Károly (MDF) napirend előtti felszólalása (2004. november 9).

${ }^{492}$ Herényi Károly (MDF) felszólalása „Új magyar nemzetpolitika belföldön és külföldön” vitanapján (2004. november 17).
} 
arra is, hogy a honosítási eljárásban alkalmazott kedvezmények bevett európai gyakorlatnak számítanak, „a környező országok már megoldották” következésképpen „magyarságból, nemzettudatból nem vagyunk különbek”.

Az MDF szerint nincs szükség új nemzetpolitikára, ugyanis az Antall József által kitűzött szomszédságpolitikai és határon túli magyarokra vonatkozó feladatok még aktuálisak, ezért a felszólaló képviselők - noha rokonszenveznek a kormányzati javaslatokkal -, „kidolgozatlannak” ítélték meg és számtalan javaslatot fogalmaztak meg, amely a könnyített honosítási eljárástól a nemzeti vízum bevezetésén keresztül gazdasági befektetések szorgalmazásáig terjedt.

A képviselők gyakorta hivatkoznak a saját, az ellenzék, a kormány, az Országgyülés valamint a „nemzeti” felelősségére a kettős állampolgársággal kapcsolatos döntésben. Ebből következik, hogy a vitában a párt az Országgyülés „lelkiismereteként” jelenik meg, ugyanis a számításba vehető javaslatok mellett a következményekkel is számol, anélkül, hogy külső szereplőkre hárítaná a felelősséget. $^{493}$

A parlamenti pártok között a független képviselök frakciója ${ }^{494}$ már a MVSZ által kezdeményezett aláírásgyüjtés időszaka alatt tematizálta az állampolgárság kiterjesztését, amely ,,alapvetően erősítheti a magyar nemzeti összetartozást, lendítő erőt adhat az ország, a nemzet felemelkedéséhez az Európai Unión belül is." ${ }^{495}$ A felszólaló képviselők - támogatván a népszavazási kezdeményezést ${ }^{496}$ - amellett érveltek, hogy a magyar állam egyoldalú nyilatkozattétellel, alanyi jogon kellene lehetővé tegye az állampolgárság megszerzését, amely megszüntetné a trianoni ,jogfosztottságot”.

A független képviselők ,alamizsnaként” tekintenek a Szülőföld Alapra, és túl kevésnek tartották a kormány által benyújtott nemzetpolitikai programot, mert „nem jelent gyógyírt” a határon túli magyarok sebeire, nem csillapítja a népszavazást okozó fájdalmat. A frakció által vallott nemzetpolitika pillérei egyrészt kiterjedtek a népességfogyás megállítására és szórványápoló tevékenységre, másrészt pedig az autonómia és a szülőföldön való maradás támogatása.

\footnotetext{
493 „Ennek keretében elvárjuk, hogy az Országgyülés március 15-ig közösen alkossa meg a határon túliak jogviszonyát szabályozó törvényt. Ha erre nem képes a Magyar Országgyülés, akkor javasoljuk, hogy oszlassa fel önmagát, és adja át helyét olyan erőknek, akik képesek ezt a feladatot felelösen, a nemzeti elkötelezettségnek megfelelöen el is látni.” Dávid Ibolya (MDF) felszólalása (2004. december 6).

${ }^{494}$ A frakciót 12 képviselő alkotta, jórészt volt MDF-es politikusok.

${ }^{495}$ Körömi Attila (független) napirend utáni felszólalása (2004. május 17).

496 „Én szomorúnak érzem, hogy Magyarországon népszavazás kell ahhoz - az állampolgárság megadásához -, amit másutt körülöttünk a kormányok maguktól is megléptek." Kelemen Attila (független) felszólalása A Szülöföld Alapról szóló törvényjavaslat együttes általános vitáján (2004. december 1).
} 


\subsection{Románia}

Amint már a fentiekben utaltam rá, a honosítási eljárás könnyítésében a parlamenti pártok között konszenzus mutatkozott. E konszenzus azt követően is fennmaradt, miután a 2008-as parlamenti választásokat követő nagykoalíciós (PSD-PC és PD-L) kormány 2009 október első felében felbomlott. Következésképpen mély ellentétek nem alakulhattak ki a parlamenti pártok között: a vita ellenben lehetőséget biztosított a pártok számára az állampolgársági törvényt módosító elképzelések és javaslatok, valamint a versengő koncepciók bemutatására.

A PSD két alkalommal is javaslatot tett az állampolgársági törvény módosítására. Elsőként a külügyi bizottság munkálatain, amikor Titus Corlăţean bizottsági elnök kezdeményezésére a 2009/36-os számú sürgősségi rendelethez füztek módosító javaslatokat, másrészt Tudor Panţîru tett az állampolgárságra vonatkozó politikai nyilatkozatot, felvázolva a szükséges módosítási lehetőségeket. A képviselő hangsúlyozta, hogy noha a rendszerváltást követő időszakban több alkalommal módosították az állampolgársági törvényt, nem létezik a határon túli románokra vonatkozó stratégia, aminek „lényeges alkotórésze” az állampolgárság megadása. A párt nevében felszólalók elsősorban morális érvekre és „morális kötelezettségekre” hivatkozva javasolták az eljárás egyszerűsítését, olyan érvek is elhangoztak miszerint az állampolgárság megadása segíti Moldova Köztársaság demokratizálódását és modernizálódását, valamint európai integrációját.

A Szenátusban, mint első megkeresett házban a kormányrendelethez füzött javaslatokon kívül ${ }^{497}$, Tudor Panţîru képviselő újabb javaslatokat terjesztett be, melyek a folyamat felgyorsítása érdekében több, az eljárásra vonatkozó módosítást tartalmaztak. Ennek értelmében szorgalmazta az Állampolgári Bizottság tagjainak növelését, javasolta a konzulátusokra maximálisan benyújtható évi 30 ezer kérelemre vonatkozó határ eltörlését, az állampolgárságra vonatkozó miniszteri rendelet azonnali kiadását, a személyi adatok védelmére hivatkozva pedig az állampolgári döntésről szóló hivatalos értesítést (Hivatalos Közlöny helyett), fel kellene váltsa a postai értesítés. ${ }^{498}$

Az állampolgárság kiterjesztésében a parlamenti pártok közül a $P D-L$ ment a legtovább, ugyanis az állampolgárság kiterjesztését a diaszpórában élő román identitásukat megtartó személyekre is ki szerette volna terjeszteni, akik „különleges

\footnotetext{
497 A javaslat értelmében (1) az állampolgárságot harmadik generációs leszármazottak esetén elismerés útján is meg lehet szerezni; (2) az állampolgári kérelmek iktatása a Prefektusi Hivatalokban is lehetővé válik; (3) bővítik az Állampolgári Hatóság tagjainak létszámát. („A Szenátus külügyi bizottságának jelentése." 2009)

498 Tudor Panţîru (PSD-PC) képviselő politikai nyilatkozata a Képviselőház 2009. október 6-i ülésén.
} 
módon ragaszkodnak az anyaországhoz" és a hagyományos román értékek „vitathatatlan” őrzői. ${ }^{499}$ Hivatkozva a Demokrata Liberális Párt kormányprogramjára, Mircea Lubanovici az állampolgárság megadását erkölcsi jóvátételként értelmezte.

A párt által támogatott javaslatok számos eljárásbeli és az állampolgári kérelmek adminisztrációjára vonatkozó módosítást tartalmaztak. A jogszabály módosítása tegye lehetővé, (1) a kérelmek román diplomáciai és konzuli szolgálatokon történő benyújtását, melyet az illető intézmény öt napon belül továbbít az Állampolgári Hatóságnak; (2) a kérelmező büntetlen előéletét igazoló, saját felelősségre benyújtott nyilatkozattételt; (3) az állampolgársági kérésre adott hat hónapon belüli választ, az erre vonatkozó döntésről pedig postai úton értesíteni a kérvényezőt. A javaslatok a PD-L elképzelése szerint erősítenék az anyaország és a diaszpórában élő közösség viszonyát, jóvátételként szolgálna a kommunizmus hibáiért, végeredményben pedig „ösztönzést és motivációt jelent Románia politikai, gazdasági és társadalmi életében való részvételre." ${ }^{, 500}$

A PNL és a Kisebbségi frakció is támogatta a jogszabály módosítását, főként történelmi-jóvátételi érvekre hivatkozva. Míg a liberális képviselő - Gheorghe Gabor a módosítás pozitívumaként az eljárás felgyorsítását emelte $\mathrm{ki}^{501}$, addig a kisebbségi frakció képviseletében - Aurel Vainer - igazságtételként, a „román demokráciában bekövetkező fontos haladásként” értelmezte a módosításokat. ${ }^{502}$

A kormány sürgősségi rendeletéhez a parlamenti pártok közül egyedül az RMDSZ viszonyult kritikusan. Felszólalásában Cseke Attila emlékeztette a szenátorokat arra, hogy néhány évvel korábban a magyar Országgyülés is hasonló vitákat folytatott az állampolgárság kérdésében: akkor a kormány és a román politikai osztály többsége is ,vehemens, elutasító álláspontot fogalmazott meg” az eljárással kapcsolatosan. ${ }^{503}$ Az RMDSZ képviseletében a szenátor annak a véleményének adott hangot, hogy a moldovai állampolgárok helyzetén nem az állampolgárság megadásával, hanem egyrészt az életszínvonal emelésével, másrészt pedig a Moldovai Köztársaság integrációjának támogatásával lehet segíteni. Ezen túlmenően nem tartotta megalapozottnak azokat a módosítási javaslatokat, melyek mellőzték az állampolgársági eljárásból a személyes interjúkat, valamint az elismerés fogalmának a bevezetését, mint

\footnotetext{
${ }^{499}$ Uo, Mircea Lubanovici (PD-L) politikai nyilatkozata.

${ }^{500}$ Uö.

${ }^{501}$ Gheorghe Gabor (PNL) felszólalása, képviselőházi vita (2009. október 26).

${ }^{502}$ Uo, Aurel Vainer (kisebbségi frakció) felszólalása.

${ }^{503}$ Cseke Attila (RMDSZ) felszólalása a Szenátus 2009. június 9-i vitáján.
} 
az állampolgárság megszerzésének újabb módozatát. ${ }^{504}$ A törvényt döntő házként végül a Képviselőház szavazta meg, kisebb, nem a Szövetség által kifogásol rendelkezések módosításával. Ennek ellenére Márton Árpád képviselő az EU-s tagállamok számára követendő példának nevezte a jogszabályt és támogatta elfogadását. ${ }^{505}$

\subsection{A parlamenti pártok pozíciói}

Figyelembe véve a parlamenti pártok által megfogalmazott álláspontokat és a vitában megjelenő képviselők felszólalásait, megállapítható, hogy a könnyített honosítási eljárás bevezetése csak a magyar parlamenti pártok között eredményezett mély megosztottságot, a román viták tétje inkább az volt, hogy ki tudja a legliberálisabb módosító indítványokat benyújtani. Következésképpen - noha az egyes javaslatok megvalósíthatóságáról eltérő vélemények fogalmazódtak meg - a pártok egyetértettek az állampolgársági törvény módosításában, és az eljárás egyszerüsítésében. Szemben a magyar vitával, a román felszólalók nem kérdőjelezték meg a határon túli románok állampolgársághoz való jogát, az állampolgárság bevezetése ellen sem fogalmazódtak meg gazdasági, szociális és a társadalombiztosítást érintő kérdések, melyek domináns témái voltak a magyar vitának.

Az Országgyülésben lefolytatott vita, hasonlóan az alapszerződésről és a státustörvényről folyó vitához nemzetpolitikai dimenzióban zajlott, ahol a kormánypárt a kettős állampolgárság támogatása helyett nemzetpolitikai programok sorozatával kívánta alakítani a korábban jobboldali pártok által dominált diskurzust. A határon túli magyarok támogatásának elsődleges módja ennek következtében újra a politikai napirend legfontosabb kérdésévé vált, a vita pedig két szemléletmód, a kormánypártok által támogatott közösségi programokra épülő szakpolitikák és az ellenzék szempontjából elsőbbséget élvező egyéni jogkiterjesztés megvalósítása mentén polarizálódott. ${ }^{506}$ Azonban a vita tétje - annak ellenére, hogy a határon túli magyarok

\footnotetext{
${ }^{504}$ A Szövetség által felvázolt kritikákat nem vették figyelembe a képviselők: 8 igen és 84 nem arányban leszavazták azt a kezdeményezést, hogy a törvénytervezetet visszaküldjék a külügyi bizottságba. A jogszabályjavaslatot a szükséges módosításokkal nagy többséggel, 85 igen és 7 nem szavazattal fogadta el a Szenátus.

${ }^{505} \mathrm{Az}$ állampolgársági törvény módosítását a Képviselőház döntő házként 209 igen, 1 nem és 2 tartózkodó szavazattal fogadta el.

${ }^{506}$ Erre utal Gyurcsány Ferenc miniszterelnök az „Új magyar nemzetpolitika belföldön és külföldön” vitanapon elhangzott beszédében: „A nagy különbség egyébként, úgy látom, hogy a parlament két fele között elsösorban abban van, hogy a parlamenti patkó baloldalán elhelyezkedők közösségi programokban gondolkodnak. Azt mondják, hogy az ott élö nemzeti közösséget erösitsük meg abban, hogy ott legyen munkahely; legyen értelme vállalkozni; legyen értelme tanulni; legyen támogatás a tanuláshoz, a kultúra elsajátitásához [...]. A patkó jobboldala, a konzervatív oldal, úgy látom, hogy inkább az egyének jogkiterjesztését támogatja [...], amely azzal a veszéllyel jár, hogy húzza, közelíti öket ahhoz a Magyarországhoz, ahol a jogok jelentös részének igénybevétele megtörténhet."
} 
helyzete állandó elemét képezi a felszólalásoknak és hivatkozásoknak -, belpolitikai jellegü, amit Eörsi Mátyás felszólalásában is hangsúlyoz: „szegény, határon túli magyarok azt gondolják, hogy ez a vita róluk szól, akár a mai vita, akár a népszavazás vitája. Sajnos, tévednek. Ez a vita [...] a magyar politikáról szól."

A 2005 tavaszán módosított állampolgársági törvény vitájában közeledtek a pártok közötti ellentétek, amelyet a szavazás végeredménye is tükrözött, azonban nemzetpolitikai kérdésekben a kormány és az ellenzék közötti vitát nem szüntette meg. ${ }^{508}$ A pártok pozícióit a viták alapján a következő kétdimenziós ábrán (kormány és ellenzéki pozíció; a kettős állampolgársághoz való viszony) szemléltetem.

10. sz. ábra: A parlamenti pártok pozíciói a kettős állampolgárság vitájában

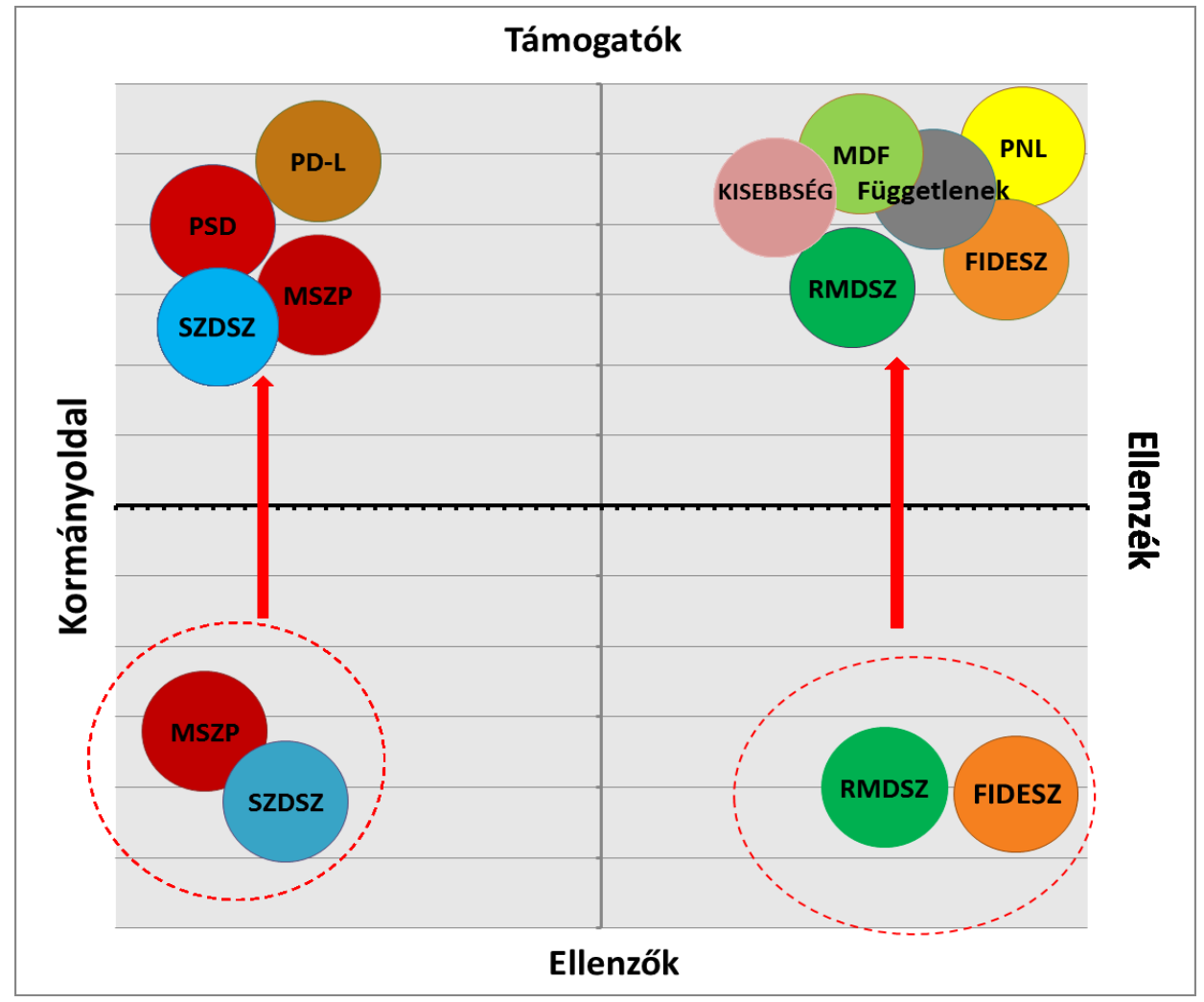

A nemzeti parlamentekben lefolytatott viták alapján négy, egymástól jól elkülöníthető pozíció alakult ki:

1. A kormányzó támogatók csoportját a román kormánypártok alkotják (PD-L és PSD), melyek egymást túllicitálva igyekeztek a jogszabályra vonatkozóan minél kedvezőbb módosítási javaslatokat tenni.

\footnotetext{
${ }^{507}$ Eörsi Mátyás (SZDSZ) felszólalása A Szülőföld Alapról szóló törvényjavaslat vitáján.

${ }^{508}$ A jogszabály módosítását 340 képviselő szavazta meg, 48-an nem szavaztak, legtöbben (27 képviselő) a FIDESZ frakcióból.
} 
2. Kormánypárti ellenzők csoportja a magyar kormánypártokat (MSZP és SZDSZ) foglalja magába, melyek nem támogatták a kettős állampolgárság megadását. Pozíciójuk a viták következtében mégis módosul, így 2005 tavaszán kezdeményezték és támogatták is az állampolgársági törvény módosítását.

3. Ellenzéki támogatók csoportját alkotják a magyar és a román ellenzéki pártok (FIDESZ, MDF, Függetlenek, PNL), melyek támogatták a kedvezményes honosítás bevezetését.

4. Sajátos a Szövetség pozíciója a vitában: míg a Szenátusban az RMDSZ nem támogatta az állampolgársági törvény módosítását, addig a képviselőházi vitában már elismerően szólt a módosított jogszabályról.

\subsection{Fö témák, érvrendszerek és stratégiák a vitában}

A vitában hangoztatott érvek és a pártok pozícióinak ismertetése alapján megállapíthatjuk, hogy a lefolytatott vitákban nem azonosíthatók nagy tematikai különbségek: a kettős állampolgárság és a honosítással kapcsolatos értelmezések, módosításai javaslatok valamint a felsorakoztatott érvek/ellenérvek mindkét vitában hangsúlyos szerepet kapnak, ami a vita nemzetpolitikai jellegét erősítik. A kevésbé hangsúlyozott témák - szomszédos államok állampolgárság-politikája, európai fórumok szerepe, külpolitikai mozgástér - arra mutatnak rá, hogy az állampolgárság kérdése mindkét vitában belpolitikai kérdésként jelent meg. Az a tény, hogy a képviselők kevés alkalommal hivatkoznak az uniós elvárásokra, az európai fórumok szerepére jelzi egyrészt azt, hogy az állampolgárság kérdésében az európai fórumok szerepe a korábban lefolytatott nemzetpolitikai kérdéseket érintő vitákhoz képest kevesebb relevanciával bír, másrészt pedig az állampolgárság kiterjesztését mindkét állam saját szuverén döntéseként értelmezte.

A magyar és a román vitákban az állampolgárságra jogosultak meghatározásában mutatható ki érdemi különbség. A magyar vitában a felszólalók a határon túli magyaroknak szóló állampolgárság mellett érveltek, tehát a magyar államhoz való etnikai és kulturális kötődés elve érvényesült, másképpen fogalmazva a kulturális nemzetfelfogás szempontjából vitatták az állampolgárság kiterjesztését. Ezzel szemben román oldalon az etnicitás nem bizonyult releváns változónak: a képviselők és a szenátorok a volt román állampolgárokról, illetve ezek leszármazottairól beszéltek, és noha történt utalás a külhoni románokra, a könnyített honosítási eljárás mögött nem az etnikai érvek, hanem a történelmi jóvátétel dominált. E különbséget a külügyi bizottság elnöke, Titus Corlățean is kifejtette, hangsúlyozva a magyar és a román állampolgárság- 
politika közötti különbségeket. Az állampolgárság kiterjesztése - mutatott rá - „,nem etnikai kérdés tisztelt kollégák - és itt egy nagyon világos választ szeretnék adni - mi mindazokat megcéloztuk, akik román állampolgársággal rendelkeztek, legyenek azok román, magyar, német, zsidó vagy más etnikumúak. Ez a nagy különbség a román, valamint a Budapest által javasolt jogszabály között és nagyon világosnak és következetesnek kell lennünk ebben az érvelésben. "509

A magyar parlamenti pártok továbbra is egyetértettek a határon túli magyarok helyzetének javításában, azonban az eszközök tekintetében, nevezetesen abban, hogy az állampolgárság kiterjesztése ehhez mennyiben járul hozzá, arról megoszlottak a vélemények. A kormányzó pártok gazdasági, demográfiai és szociális érvekre hivatkozva utasították el az állampolgárság megadását és a vitában azt az álláspontot képviselték, hogy az anyaországnak ez a lépése nem segítené a határon túli közösségeket, mi több gyengítené az eddig elért eredményeket, és akadályozná a többségi társadalomba való integrációt és az autonómia-küzdelmeket. Alternatívaként új nemzetpolitikai programot dolgoztak ki, amellyel egyrészt ellensúlyozni kívánták a kettős állampolgárság kapcsán képviselt pozíciókat, másrészt pedig a pártverseny logikáját követve, úgy kerülhettek domináns pozícióba, ha kezdeményezőként jelennek meg a jobboldali pártok által uralt nemzetpolitikai kérdésekben, és a miniszterelnök legyőzi az ellenék vezető szereplőjét, Orbán Viktort. ${ }^{510}$

Az ellenzéki pártok stratégiája arra irányult, hogy megcáfolják az állampolgárság kiterjesztése ellen felhozott érveket, megkérdőjelezzék a kormány elkötelezettségét a határon túli magyarok iránt és rámutassanak arra, hogy a kormány által beterjesztett programok nem jelentenek reális megoldásokat, csupán „kényszermegoldások”. A FIDESZ és az MDF politikusai ezeket az érveket a támogatáspolitikában fellelhető müködési zavarokkal indokolták, amik állandó hivatkozási pontnak bizonyultak a vita során.

\footnotetext{
${ }^{509}$ Titus Corlățean (PSD) felszólalása a Szenátus 2009. június 9-i ülésén.

$510 \mathrm{Az}$ állampolgárság kiterjesztése mögötti álláspontok kialakulásában Markó Béla is belpolitikai tényezőket (választási megfontolást) tartja meghatározónak (interjú).
} 
22. sz. táblázat: Uralkodó témák és alkalmazott stratégiák a státustörvény vitájában

\begin{tabular}{|c|c|c|}
\hline Pártok & Uralkodó témák & Alkalmazott stratégia \\
\hline MSZP & $\begin{array}{l}\text { Nemzetpolitikai célkitüzések és } \\
\text { programok, az állampolgárság } \\
\text { kiterjesztését ellenző érvek. }\end{array}$ & $\begin{array}{l}\text { Konszenzuskeresés, integratív stratégia (az } \\
\text { egymásnak feszülő érvek) }\end{array}$ \\
\hline SZDSZ & $\begin{array}{l}\text { Nemzetpolitikai programok, európai } \\
\text { fórumok, határon túli magyarok } \\
\text { pozíciója }\end{array}$ & Integrációs diskurzus \\
\hline FIDESZ & $\begin{array}{l}\text { Népszavazási kezdeményezés, az } \\
\text { állampolgársághoz kapcsolódó érvek, } \\
\text { határon túli magyarok, támogatáspolitika }\end{array}$ & $\begin{array}{l}\text { Delegitimáció (a kormányzati érvek } \\
\text { cáfolata) }\end{array}$ \\
\hline MDF & $\begin{array}{l}\text { Népszavazási kezdeményezés, saját } \\
\text { jogszabályjavaslat, nemzetpolitikai } \\
\text { programok }\end{array}$ & $\begin{array}{l}\text { Felelősség diskurzus (az érintett szereplők } \\
\text { felelősségének hangsúlyozása) }\end{array}$ \\
\hline Függetlenek & $\begin{array}{l}\text { Népszavazási kezdeményezés, } \\
\text { nemzetpolitikai programok }\end{array}$ & $\begin{array}{l}\text { A felszólalások alapján nem azonosítható be } \\
\text { egy domináns stratégia. }\end{array}$ \\
\hline PD-L & $\begin{array}{l}\text { A jogszabály módosítása, történelmi } \\
\text { jóvátétel, határon túli románok. }\end{array}$ & $\begin{array}{l}\text { Túllicitálás (felülemelkedni a másik } \\
\text { kormánypárton) }\end{array}$ \\
\hline PSD & $\begin{array}{l}\text { Az állampolgárság megszerzése - a } \\
\text { feltételek könnyítése. }\end{array}$ & $\begin{array}{l}\text { Túllicitálás (felülemelkedni a másik } \\
\text { kormánypárton) }\end{array}$ \\
\hline PNL & Történelmi jóvátétel. & $\begin{array}{l}\text { A felszólalások alapján nem azonosítható } \\
\text { domináns stratégia }\end{array}$ \\
\hline RMDSZ & $\begin{array}{l}\text { A jogszabály módosítása során felmerülő } \\
\text { dilemmák, európai minták és } \\
\text { állampolgárság-politikák. }\end{array}$ & $\begin{array}{l}\text { Konstruktív ellenzéki szerep, deetnicizáló } \\
\text { stratégia }\end{array}$ \\
\hline Kisebbségi & Történelmi jóvátétel. & $\begin{array}{l}\text { A felszólalások alapján nem azonosítható be } \\
\text { egy domináns stratégia. }\end{array}$ \\
\hline
\end{tabular}

A vitában felszólaló képviselők gyakran hivatkoztak a történelmi múlt eseményeire és jeles személyiségekre érvrendszerük alátámasztása céljából, ami egyben erősíti a felszólalás súlyát, legitimitását. Míg a román vitában csak kivételes helyzetekben találunk hivatkozásokat, addig a magyar vitákban a felszólalások gyakori eleme. A lezajlott vitákban megkülönböztethetőek (1) történeti és a közelmúlt politikai eseményeire hivatkozó érvek (alapszerződések, kedvezménytörvény). Ezek közül Trianont többször említik a képviselők, míg a kormánypárti képviselők szerint a trianoni örökségre a nemzetpolitikai programok jelentik a megoldást, addig az ellenzék szerint a magyar nemzet egyesítésére csakis az állampolgárság jelenthet megoldást. További hivatkozásokat találunk (2) történelmi személyiségekre és a szomszédos államok politikusaira, (3) költőkre, közéleti személyiségekre, (4) határon túli településekre, valamint az Európában fellelhető autonómia-formákra. 


\section{Az állampolgársági törvény módosításának következményei és a magyar-magyar kapcsolatok ,újraértelmeződése”}

A kettős állampolgárságról szóló vitában az MSZP-SZDSZ kormány által meghirdetett nemzetpolitikai átalakulásnak a koalíció 2006-os választási győzelme új lendületet adott: az újonnan létrehozott Szülőföld Alap vált a támogatáspolitika fő intézményévé, azonban 2006 júliusától a kormány megszüntette a HTMH-t és a Teleki László Intézetet, az elemzői és tanácsadói feladatok ellátására pedig létrehozta a Magyar Külügyi Intézetet (Kántor 2014, pp. 230-31). Ebben a kormányzati időszakban nem került sor az állampolgársági törvény módosítására, noha az ellenzéki pártok erre kísérletet tettek. $^{511}$ Nem meglepő tehát, hogy a 2010-es választásokat követően a FIDESZ-KDNP képviselői az Országgyülés első ülésén kezdeményezték a jogszabály módosítását, melyet a ház nagy többséggel május 26 -án szavazott meg. ${ }^{512}$ A módosítás lehetővé tette a határon túli magyarok és a diaszpórában élők számára, hogy lakóhelyük megváltoztatása nélkül magyar állampolgárságot szerezzenek. $^{513} \mathrm{~A}$ könnyített honosítási eljárás bevezetése jelentősen mobilizálta a határon túli magyarokat, az egyre növekvő igényeket a kormány a kérelmek gyorsított elbírálásának folyamatával kívánta ellensúlyozni, aminek eredményeképpen 2018 tavaszáig több mint egymillió személy szerzett magyar állampolgárságot. ${ }^{514}$

23. sz. táblázat: Honosítási kérelmek és az „új magyar állampolgárok” számának alakulása 2011-2018 között

\begin{tabular}{|c|c|c|c|c|c|c|c|c|c|c|c|}
\hline & 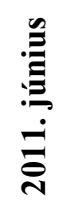 & 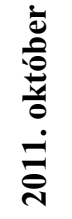 & 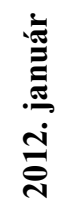 & 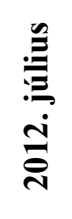 & 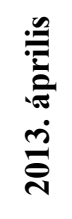 & 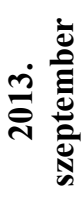 & 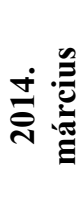 & 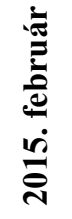 & 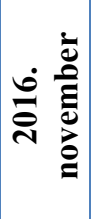 & 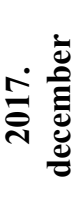 & $\stackrel{\infty}{\infty}$ \\
\hline $\begin{array}{l}\text { Benyújjtott kérelmek } \\
\text { száma (ezer) }\end{array}$ & 100 & 150 & 200 & 300 & 420 & 500 & 610 & 710 & n.a. & n.a. & n.a. \\
\hline $\begin{array}{c}\text { Állampolgárok száma } \\
\text { (ezer) }\end{array}$ & n.a & 55 & 100 & 200 & 341 & 430 & 560 & 670 & 920 & 1000 & 1010 \\
\hline
\end{tabular}

Forrás: http://www.allampolgarsag.gov.hu, valamint Semjén Zsolt miniszterelnök-helyettes sajtónyilatkozatai.

\footnotetext{
511 („,T/10896 A magyar állampolgárságról szóló törvény módosításáról” 2009).

512 A jogszabály módosítását 344 képviselő támogatta, nemmel szavazott Gyurcsány Ferenc, Molnár Csaba, Szanyi Tibor (mindhárman MSZP), és tartózkodott Baracskai József, Oláh Lajos, Vitányi Iván (MSZP), valamint Dorosz Dávid és Szabó Tímea (mindketten LMP).

513 A jogszabály kimondja, hogy kérelemre „kedvezményesen honosítható az a nem magyar állampolgár, akinek felmenője magyar állampolgár volt, vagy valószínüsíti magyarországi származását, és magyar nyelvtudását igazolja (,2010. évi XLIV. törvény a magyar állampolgárságról” 2010).

514 A romániai magyar kettős állampolgárokra vonatkozó adatsorok hiányosak: csupán a 2013-ban közzétett adatok közöltek részletes kimutatást. Eszerint 2013 áprilisáig a román állampolgárok 282 ezer kérelmet (az összes leadott kérelem 67\%-a), míg az év szeptemberéig 331 ezer kérelmet (az összes leadott kérelem 66\%-a) adtak le.
} 
Az állampolgársági törvény módosítása kezdetét jelentette annak a szakpolitikai átalakulásnak, melyet a kormány nemzetpolitikai stratégiája összegezett (,Magyar nemzetpolitika" 2011). A dokumentum alapvető céljaként fogalmazza meg a külhoni magyarok szülőföldjükön történő megerősítését számbeli, szellemi, gazdasági és jogi értelemben vett gyarapodását, ami hozzájárul az intézményrendszer kiépítéséhez, a többszintü integráció és az öngondoskodás kialakulásához. A kormány emellett új alkotmányt fogadott el, amiben újra megfogalmazást nyert Magyarország felelősségvállalása a határon túli magyarokért, a választási törvény 2012-es módosításával pedig a külhoni magyarok is szavazhattak a 2014-es országgyülési választásokon.

A jogszabályi környezet megváltoztatásán túlmenően Kántor a „nemzetpolitikai fordulat" további szintjeit különbözteti meg: (1) a magyar-magyar kapcsolatok: a kormányváltással folytatta munkáját a 2004-ben megalakított KMKF, több éves szünet után a miniszterelnök 2010 novemberében összehívta a MÁÉRT ülését, a diaszpórában müködő szervezetek közös fórumaként pedig létrejött a Magyar Diaszpóra Tanács; (2) a közigazgatás szintjén a Közigazgatási és Igazságügyi Minisztériumon belül létrejött a Nemzetpolitikáért Felelős Államtitkárság és a Bethlen Gábor Alapkezelő Zrt.; míg 2012-től a kormány (3) tematikus programokat hirdetett meg (Kántor 2015). Ezeknek az intézkedéseknek az eredményeit foglalja össze egy nemrégiben megjelent kormányzati kiadvány (,Nemzetpolitikai eredmények 2010-2018”).

Az állampolgárság kiterjesztése ellen egyedül a szlovák fél tett ellenintézkedéseket (Vass 2013). A román vezető politikusok és a politikai pártok részéről nem érkeztek elutasító reakciók, ami több tényezőnek tudható be. Elsőként elmondható, hogy a két állam állampolgárság politikája számos hasonlóságot mutat, mi több Semjén Zsolt miniszterelnök-helyettes több alkalommal is hivatkozott arra, hogy a magyar jogszabály kidolgozásánál a román mintát követték. A vita elmaradása az RMDSZ kormányzati szerepével is magyarázható, amire a szövetségi elnök is felhívta a figyelmet. ${ }^{515}$ Mindezeken túlmenően a magyar diplomácia is előbbre látó volt, mint a státustörvény időszakában: a június végén sorra kerülő „,bizalomerősítő” külügyminiszteri találkozón a magyar külügyminiszter arról biztosította román kollégáját, hogy betartva a nemzetközi jogi szabályozásokat az állampolgárság odaítélése nem tömegesen, hanem egyéni kérelmek alapján történik („Külügyminiszteri

\footnotetext{
${ }^{515}$ Markó Béla a Szövetség erős kormányzati pozíciójának tulajdonítja azt, hogy „,a törvény alkalmazása zökkenőmentesen indult el" (interjú).
} 
találkozó” 2010). Az állampolgársági törvény módosítása ellen egyedül a Szenátus külügyi bizottsága lépett fel, és határozatot fogadott el a jogszabály módosítása, valamint a trianoni békeszerződés évfordulójává nyilvánított emléknap (Nemzeti Összetartozás Napja) ellen. A Szenátus lépését nem követte más intézkedés, így a román fél „hallgatólagosan” tudomásul vette a honosítási eljárás bevezetését.

A szomszédos államok reakcióit leszámítva az állampolgársági törvény módosítását nem érték bírálatok a nyugati államok részéről. Az állampolgárság kérdése - az új alaptörvény elfogadásával - került a Velencei Bizottság figyelmébe (Pogonyi 2017a, pp. 92-93). A jelentés az állampolgárság kiterjesztése és a határon túli magyarok vonatkozásában hangsúlyozta, hogy ,a alkotmányozó fordítson megfelelő figyelmet a jószomszédi viszony elvére, valamint kerülje az extraterritoriális elemek és megfogalmazások alkalmazását, amelyek a szomszédos államok körében neheztelést válthatnak ki” (Velencei Bizottság 2011, 39. bekezdés, idézi Pogonyi 2017a, p. 93) Az alkotmányban szereplő nemzetfelfogás - véli a testület -, amely a határon túli magyarokat is a magyar nemzet részének tekinti és az anyaországi felelősségének hangsúlyozása „rossz hatással lehet az államközi kapcsolatokra és etnikai feszültségeket okozhat.” A Bizottság a jelentés további részében a státustörvény során hangsúlyozott érveket sorolja fel, amely arra enged következtetni, hogy az anyaország szerepéről a testületnek továbbra is változatlan az álláspontja. ${ }^{516}$

A szakirodalomban számtalan empirikus példát találunk az anyaország felelősségének növekedése, valamint az adott kisebbség radikalizálódása közötti összefüggésekre (Jenne 2007; Saideman-Ayres 2008), ami negatívan befolyásolja az államközi kapcsolatok alakulását. Az, hogy mégsem alakult ki vita Magyarország és a szomszédos államok között, azzal magyarázható - véli Pogonyi -, hogy nem éledt újra a területi revizionizmus gondolata (Pogonyi 2017b, p. 10). Az anyaország - érvel Pogonyi - támogatja a magyar kisebbség autonómia-küzdelmét, de „racionális érdekei megkívánják”, hogy együttmüködjön a szomszédos államokkal (ibid. p. 11).

Míg tehát a román politikai elit nem fogalmazott meg lényeges kritikákat a román közvélemény álláspontja nem ennyire egyértelmű a magyar állampolgárság

\footnotetext{
${ }^{516}$ A VB megismételve a státustörvény kapcsán megfogalmazott javaslatait kifejtette, hogy az anyaország szerepet játszhat a nemzeti kisebbségek védelmében és erősítheti a nyelvi és kulturális kötetlékeket, azonban , a kisebbségek védelméért elsősorban a lakóhely szerinti állam tartozik felelősséggel” (Velencei Bizottság 2011, 42. bekezdés). A jelentés továbbá megerősítette a kétoldalú kapcsolatok és az államközi egyezmények szerepét a kisebbségvédelemben és arra hívta fel a figyelmet, hogy az anyaország egyoldalú fellépése akkor tekinthető legitimnek, ha tiszteletben tartja az államok területi szuverenitásának, a pacta sunt servanda, az államok baráti kapcsolatainak és az alapvető emberi és szabadságjogok elvét.
} 
kapcsán. Az IRES közvélemény-kutató intézet 2011 és 2013 márciusában végzett reprezentatív felmérést az interetnikus viszonyok alakulásáról (IRES 2011, 2013). A kutatás eredményeiböl kiderült, hogy a válaszadók többsége pozitívan ítélte meg a magyar-román államközi kapcsolatok és az interetnikus viszonyok alakulását, azonban a romániai magyarok kettős állampolgárságáról már eltérően vélekednek: míg 2011-ben a megkérdezettek hozzávetőlegesen fele-fele arányban támogatták, illetve ellenezték, 2013-ra javult a kettős állampolgárság elfogadása. ${ }^{517}$ Ezzel ellentétben válaszadók több mint kétharmada elutasítja a megyei önkormányzatok elnökeinek állampolgári igényét, azzal indokolva válaszukat, hogy a magyar állampolgárság birtokában biztosan, illetve valószínűleg megváltozna a román államhoz füződő magatartása.

24. sz. táblázat: A román közvélemény viszonya a román állampolgársághoz

\begin{tabular}{|c|c|c|c|}
\hline \multirow{2}{*}{ A felmérésben szereplő kérdés } & \multirow{2}{*}{ Válasz/álláspont } & \multicolumn{2}{|c|}{ Év } \\
\hline & & 2011 & 2013 \\
\hline \multirow{3}{*}{$\begin{array}{l}\text { Mit gondol, milyen a viszony Románia és } \\
\text { Magyarország között? }\end{array}$} & Jó + nagyon jó & $55 \%$ & $57 \%$ \\
\hline & Rossz + nagyon rossz & $35 \%$ & $39 \%$ \\
\hline & Nem tudja, nem válaszolt & $9 \%$ & $3 \%$ \\
\hline \multirow{3}{*}{$\begin{array}{l}\text { Hogy látja, milyen volt az utóbbi években a románok } \\
\text { és a magyarok viszonya? }\end{array}$} & Jó + nagyon jó & $63 \%$ & $64 \%$ \\
\hline & Rossz + nagyon rossz & $33 \%$ & $34 \%$ \\
\hline & Nem tudja, nem válaszolt & $3 \%$ & $2 \%$ \\
\hline \multirow{3}{*}{$\begin{array}{l}\text { Milyen véleménnyel vannak a romániai magyarok } \\
\text { kettős állampolgárságáról? }\end{array}$} & Jó + nagyon jó & $47 \%$ & $52 \%$ \\
\hline & Rossz + nagyon rossz & $50 \%$ & $41 \%$ \\
\hline & Nem tudja, nem válaszolt & $3 \%$ & $6 \%$ \\
\hline \multirow{3}{*}{$\begin{array}{l}\text { Egyetért Ön egyes erdélyi megyék önkormányzati } \\
\text { vezetőinek lépésével, hogy magyar állampolgárságot } \\
\text { kérjenek? }\end{array}$} & Egyet értek & $25 \%$ & $25 \%$ \\
\hline & Nem értek egyet & $72 \%$ & $70 \%$ \\
\hline & Nem tudja, nem válaszolt & $3 \%$ & $5 \%$ \\
\hline \multirow{5}{*}{$\begin{array}{l}\text { Úgy véli, hogy miután megszerzik a magyar } \\
\text { állampolgárságot, megváltozik a Romániához füződő } \\
\text { magatartása? }\end{array}$} & Biztosan igen & $36 \%$ & $32 \%$ \\
\hline & Valószínüleg igen & $25 \%$ & $24 \%$ \\
\hline & Valószínüleg nem & $16 \%$ & $16 \%$ \\
\hline & Biztosan nem & $19 \%$ & $23 \%$ \\
\hline & Nem tudja, nem válaszolt & $4 \%$ & $4 \%$ \\
\hline
\end{tabular}

Forrás: (IRES 2011, 2013).

Hasonlóan a parlamenti pártok álláspontjához, a román közvéleményben is konszenzus uralkodik a határon túli románokkal kapcsolatos politikákról, az erre

517 A kolozsvári Nemzeti Kisebbségkutató Intézet felmérése alapján a kettős állampolgárság bevezetésével többen értenek egyet, mint az IRES által bemutatott adatok. Eszerint a 2012-ben végzett kutatásban a válaszadók 53,9\%-a értett egyet és csupán 30,2\%-a ellenezte az állampolgárság bevezetését. 2014-re a támogatók száma valamelyest növekedett $(54,9 \%)$, valamint nőtt az ellenzők aránya $(35,1 \%)$ is (Kiss 2015, pp. 31-32). 
vonatkozó közvéleménykutatások a különböző intézkedések ${ }^{518}$ magas, $70 \%$ feletti támogatottságát mutatták ki (Kiss-Barna 2013, p. 63). Ezzel szemben a határon túli magyarokra vonatkozó intézkedések támogatottsága alacsonyabb, mi több a szerzőpáros arra a következtetésre jut, hogy a kérdés a népszavazás óta ,azonos szerkezetben osztja meg” a magyar közvéleményt (ibid).

A könnyített honosítási eljárással kapcsolatosan az RMDSZ vezetői eltérő véleményeket fogalmaztak meg. Néhány politikus az elsők között igényelte az állampolgárságot (Borboly Csaba, Tamás Sándor), azonban Markó Béla szövetségi elnök - fenntartva korábbi álláspontját - jelezte, hogy nem fog élni a lehetőséggel (Népszava 2011), mi több, a szavazati jog kiterjesztése ellen érvelt (Markó 2011). Elutasító álláspontja a FIDESZ és az RMDSZ közötti viszonyra is visszavezethető, amit tovább romlott a 2010-es kormányváltást követően, annak betudhatóan, hogy a támogatási források elosztásánál a Szövetség marginális pozícióban találta magát. A magyar kormány elsőként megszüntette a státus-irodákat, az oktatási-nevelési támogatások kiosztásával pedig a Románia Magyar Pedagógusok Szövetségét bízta meg (Kiss 2013, pp. 64-65). Második döntésével pedig - a honosítási eljárással kapcsolatos ügyintézést segítő demokrácia-központok finanszírozásával - nyíltan támogatta az EMNT intézményesülését, majd a 2012-es választások alkalmával az MPP-t és az EMNP-t (Pogonyi 2017a, pp. 107-9). Az RMDSZ ellenzékének támogatása azonban nem vezetett sikerre, ugyanis az EMNP és az MPP választási eredményei alulmúlták a várakozásokat, ami a FIDESZ-t is stratégiaváltásra, az RMDSZ-szel folytatott viszony újraértékelésére késztette. ${ }^{519}$ A kapcsolatok normalizálódásában az az új szövetségi elnök, Kelemen Hunor játszott nagy szerepet.

A FIDESZ-RMDSZ viszonyának közeledését az is indokolta, hogy az erdélyi magyarság egyértelműen támogatja a kettős állampolgárságot. Ez látszik egyrészt leadott, nagyszámú kérelmekből, másrészt a szociológiai felmérések is erre engednek következtetni. A 2012-2014 között, a Nemzeti Kisebbségkutató Intézet munkatársai által végzett kutatásokból kiderül, hogy az erdélyi magyarok döntő többsége támogatja a magyar állampolgárság-politikát. Míg a 2012-es adatok alapján a válaszadók 9\%-a nem értett egyet a magyar állam nemzetpolitikai lépésével, addig ez az arány 3\%-alá csökkent, míg a támogatók aránya 85,6\%-ről 94,6\%-ra emelkedett (Kiss 2015, pp. 2223). E nagyfokú támogatottság mellett az RMDSZ is pragmatikus álláspontra

\footnotetext{
518 A felmérés keretében tízfajta intézkedésre kérdeztek rá, melyeket négy nagyobb dimenzióba csoportosítottak: (1) nemzeti közösség kiterjesztése; (2) hagyományos identitáspolitika; (3) szociális komponens; (4) bevándorlás-politika.

${ }^{519}$ Interjú Markó Bélával és Székely Istvánnal.
} 
helyezkedett: az EMNP, az egyházak és más civil szervezetek mellett támogatta az erdélyi magyarok regisztrációját, aminek eredményeként Erdélyböl közel 100 ezer ember regisztrált a 2014-es országgyülési választásokra, a határon túlról érkező 128.429 szavazat pedig egy plusz mandátumhoz juttatta a FIDESZ-KDNP pártszövetséget (Herner-Kovács-Illyés-Rákóczi 2014, pp. 10-11). A választások után tovább javult a kormánypártok és a Szövetség viszonya és 2015 őszétől - az Eurotrans Alapítványon keresztül - bekapcsolódott a honosítási eljárásba.

A román többség és a magyar kisebbség magyar állampolgársághoz való viszonya, illetve az ebből adódó következmények csak a tudományos diskurzus szintjén jelentek meg. Salat Levente, aki a többség-kisebbség viszonyát a kommunitárius politikaelmélet szempontjából elemezte, a kedvezményes honosítás bevezetése kapcsán arra a megállapításra jutott, hogy a döntés „kikezdi az önálló erdélyi magyar politikai közösség létrejöttének maradék esélyeit”, mert gyengíti egyrészt az autonómia különböző alakzatainak a megvalósulási esélyeit (beleértve a nem terület alapú hatalommegosztás intézményesítését) és a román államhoz füződő viszonyát (integrációját), másrészt pedig elősegíti az erdélyi magyarság belső töredezettségét (Salat 2011, pp. 186-90). A magyar állampolgársági törvény módosításának a Magyar Kisebbség c. folyóirat egy teljes számot szentelt és egy ankétban való részvételre kérte fel azon kárpát-medencei szakértőket és szakpolitikusokat, akik „karakteres véleménnyel rendelkezhetnek" a kettős állampolgárságról. ${ }^{520}$

A döntés jelentőségét több válaszadó (Antal Árpád-Tamás Sándor, Borbély Zsolt Attila, Egry Gábor, Salat Levente) is kiemelte, azonban a lehetséges következményekről már megoszlottak a vélemények. Pozitív változásként értékelték a hozzászólók, hogy a könnyített honosítási eljárás „,erősítheti az összetartozás szubjektív érzését” (Pogonyi 2013, p. 219), növeli a magyar államhoz való érzelmi kötődést (Antal Árpád-Tamás Sándor, Borbély Zsolt Attila), valamint „hálózatszerűen” összeköti a határon túli magyar közösségeket, erősíti az identitást és akadályozhatja a „szétfejlödést” (Wetzel 2013, pp. 269-70). A magyar identitás erősödéseként értelmezhető az a ,zsenge pozitív folyamat”, aminek következtében az eltérő motivációknak betudhatóan egyre többen kezdtek el magyarul tanulni és „fedezik fel elveszettnek hitt magyar gyökereiket" (Egry 2013, p. 218).

\footnotetext{
520 A kezdeményezőket az a cél vezérelte, hogy vitát kezdeményezzenek a nemzetpolitikai és magyarságpolitikai szempontból egyaránt fontos döntés politikai és társadalmi következményeiről (Toró 2013, p. 154). Az ankétra 12 válasz érkezett a következő személyektől: Antal Árpád, Bauer Tamás, Borbély Zsolt Attila, Dénes Iván Zoltán, Egry Gábor, Gajdos István, Korhecz Tamás, Pogonyi Szabolcs, Salat Levente, Tamás Sándor, Tóth Judit, Tóth Mihály, Varga Zs. András, Wetzel Tamás, Zubánics László.
} 
Ahhoz azonban, hogy az állampolgárság és a magyar államhoz való kötődés megerősítse a határon túli közösségeket, közpolitikák és konkrét intézkedések (Erdő és Földalap”, a magyar tőke székelyföldi jelenléte) szükségesek (Antal-Tamás 2013, pp. 159-60). Az állampolgárság kiterjesztésével szembeni érv, hogy a nyugat-európai munkaerőpiac megnyílásával hozzájárul az elvándorlás felgyorsulásához (Korhecz Tamás, Pogonyi Szabolcs), oly módon, hogy nem Magyarország válik az első számú célországgá.

A válaszadók többségénél megjelent a kettős állampolgárság és az autonómiaküzdelmek viszonya, amely az interjúk szempontjából azért bír fontossággal, mert olyan tekintélyes gondolkodók - mint pl. Bauböck - is a két törekvés egymás kölcsönösen kizáró volta mellett érvel (2007, p. 2441). Míg az Antal Árpád-Tamás Sándor szerzőpáros nyitva hagyja a kérdésre adandó választ, addig Borbély Zsolt Attila és Wetzel Tamás amellett érvel, hogy az állampolgárság nem csökkenti az autonómia kivívásának lehetőségét. Velük szemben Korhecz Tamás téves felvetésnek tulajdonítja az állampolgárságot mint a „magyarok önazonosságát megőrző, valós egyenrangúságát és gyarapodását elősegítő intézményi” elképzeléseket (Korhecz 2013, pp. 214-15), Bauer Tamás szerint az egyedüli megoldást nem az állampolgárság, hanem az autonómia jelentheti, míg Tóth Judit álláspontja szerint a két folyamat kizárja egymást. Salat nem tartja kizártnak, hogy az autonómia érdekében „az identitásukban megerősödött" határon túli magyarok fellépése határozottabb lesz, azonban a várható eredmények, ,az állam jogrendjének átalakítása” tekintetében - amely lehetővé tenné az autonómia valamely formájának létrejöttét -, elengedhetetlen a román fél meggyőzése, aminek - a kettős állampolgárok nagy számának betudhatóan - egyre kisebb az esélye (Salat 2013, pp. 234-35).

Az állampolgárság és az ezzel összefüggő szavazati jog kiterjesztéséről is eltérő vélemények fogalmazódtak meg. Míg Borbély az állampolgárság legfontosabb dimenziójának vélte a szavazati jog megadását, addig az Antal-Tamás arra világított rá, hogy „képviselői tét hiányában” alacsony határon túli részvétel várható. Bauer szerint így is problematikus azon határon túli magyarok részvétele a választásokon, akik nem élnek életvitelszerüen Magyarországon. Ennek egyik kihatása lehet az anyaországi és a határon túli magyarok közötti feszültség növekedése, továbbá a magyar belpolitika exportjának további „káros következményei”, mint például a klientúra-építés, határon túli magyar szervezetek megosztása és az érdekképviselet gyengülése (Pogonyi 2013, pp. 222-23), továbbá az anyaországi erőforrások felértékelődésének eredményeképpen a „vazalluselitek” kialakulása (Egry 2013, p. 201). 
11. sz. ábra: A nemzetpolitikára fordított források 2009-2017 között (milliárd Ft) ${ }^{521}$

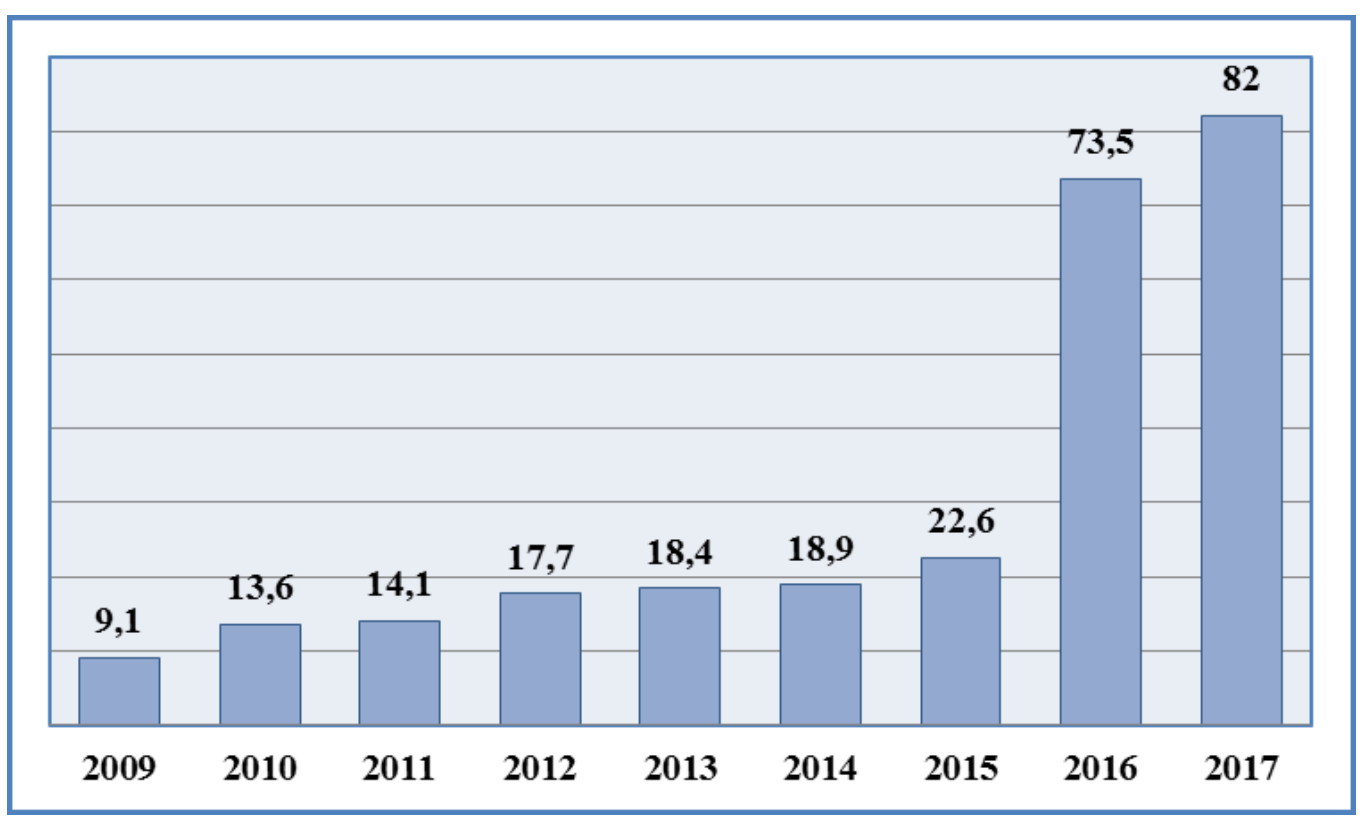

Forrás: Nemzetpolitikai eredmények 2010-2018, p. 15.

A többség-kisebbség viszonyában a közösségi integráció kérdése újabb problémaként vetődött fel, melyet tovább nehezít az állampolgárság megszerzése (Salat Levente, Bauer Tamás), mi több - mutat rá Bauer - ha egy egész nemzeti kisebbség válik állampolgárrá, akkor az „állampolgári lojalitás válik kérdésessé” (Bauer 2013, p. 70). Ezzel szemben Borbély nem lát a két folyamat között ellentmondást: az említett szerzőkkel szemben a megmaradás kulcsát nem az integrációban látja, hanem a „minél nagyobb fokú szegregációban és elkülönülésben” (Borbély 2013, p. 178).

Végül az új nemzetpolitikai irányzat - véli Salat - felszámolja a rendszerváltást követő kormányok által „kvázi önálló politikai közösségeknek” tekintett határon túli magyar kisebbségeket és ,átállította az intézményesített diaszpóra pályájára” (Salat 2013, p. 231). A támogatási rendszer átalakítása - melyben a gazdasági befektetések másodlagos jelleggel bírnak -, a román államtól részben „átvett” finanszírozási szerepek, valamint a magyar tőke jelenléte az erdélyi médiatérben ebbe az irányba ható folyamatként értékelhető.

Az állampolgárság kiterjesztése nem újította meg a romániai magyarság helyzetéről folyó államközi vitákat, ellenben az az ellentétek az erdélyi magyar politikai szervezetek szintjén újultak meg, annak következtében, hogy a magyar nemzetpolitika vezérszólamának tekinthető összmagyar integráció versenyhelyzetet teremtett e pártok

\footnotetext{
521 A Nemzetpolitikai Államtitkárság, a Bethlen Gábor Alap és a Szabolcs-Szatmár-Bereg megye és Kárpátalja Együttmüködésének és Összehangolt Fejlesztési Feladatainak Kormányzati Koordinációjáért Felelős Kormánybizottság.
} 
között. E versenyhelyzet egyelöre nem eredményezett lényeges változásokat sem a mobilizáció, sem pedig a közösségi célkitüzések megvalósítását célzó programok és szakpolitikák tekintetében, ami létfontosságú az erdélyi magyarság megmaradása és szülőföldön való boldogulása szempontjából. Az bizonyosan elmondható, hogy állampolgárság kiterjesztése és az új nemzetpolitikai irányzat olyan beavatkozást jelent a határon túli magyar közösségek életébe, ami a szakértők és politikusok véleményét figyelembe véve - a döntéshozók eredeti elképzelése és minden jószándéka ellenére néhány pozitívnak tekinthető változás mellett számos kockázatot és visszafordíthatatlan folyamat felgyorsulását eredményezheti. 


\section{A kisebbségben levő közösségek védelmétől az állampolgárok egyéni jogvédelméig. Az esettanulmányok összehasonlítása}

A magyar-román alapszerződésről, a státustörvényről és a kettős állampolgárságról szóló viták a rendszerváltást követően alapvető módon meghatározták Magyarország és Románia viszonyának alakulását, a magyar-magyar kapcsolatok fejlődését és az európai fórumok irányába képviselt álláspontokat. A három vitáról készült, hasonló szerkezetü esettanulmány lehetővé tette az összehasonlítást, annak ellenére, hogy a viták eltérő időszakban és más-más kontextusban kerültek az államközi kapcsolatok napirendjére.

Míg az alapszerződésről folyó tárgyalások az integráció előtti viszonyokról adtak áttekintést, addig a státustörvényről szóló vita, a csatlakozási folyamatban vált meghatározóvá, végül az állampolgárság kapcsán felmerülő vita nem az egyazon szövetségi rendszerhez (NATO, EU) tartozó államok között, hanem a szomszédos államokkal alakult ki. Elsőként a viták európai dimenziójára helyezem a hangsúlyt és arra mutatok rá, hogy a vizsgált döntések - melyek az adott időszakban európai gyakorlatnak számítottak - milyen összefüggésben jelentek meg az államközi kapcsolatokban. A viták meghatározó mozzanatai, vagyis a folyamatok egy újabb dimenziót képeznek, amelyben a belpolitikai viszonyok, a kormányzat és a határon túli magyarok kapcsolata nem függetleníthető a külpolitikai környezettől. Az összehasonlítás harmadik dimenzióját a négyes viszonyrendszer szereplőinek stratégiái és érdekérvényesítési lehetőségeik azonosítása képezte. Külön figyelmet érdemel a döntéshozatal folyamata és az intézményrendszerben bekövetkező változások, valamint a parlamenti pártok által képviselt álláspontok alakulása. A döntések eredményeinek összevetése képezi az összehasonlítás utolsó aspektusát és arra mutatok rá, hogy a magyar kormány kezdeményezései túlmutattak a romániai magyarság helyzetének rendezésén: a magyar-magyar kapcsolatok alakulásában a belpolitikai (pártpolitikai) számításokon túlmenően a külpolitikai stratégiának is meghatározó szerepe volt.

Mindenekelőtt szükséges hangsúlyozni, hogy az államközi kapcsolatok alakulását meghatározó viták nem tekinthetők elkülönült, az adott időszakban csak a két állam vonatkozásában megjelenő kérdéseknek. Az alapszerződés, a státustörvény és könnyített honosítási eljárás esetében is egy európai trendröl beszélhetünk, amelyben a két állam nem kezdeményező, hanem sokkal inkább mintakövető magatartást tanúsított, azáltal, hogy az európai gyakorlatnak megfelelő lépéseket tett - eltekintve a bel- és 
külpolitikai motivációktól - a határon túli kisebbségek érdekében. ${ }^{522}$ A térség államai között aláírt közel száz alapszerződés, tíz státustörvény, valamint a legtöbb európai állam által bevezetett honosítási eljárás Magyarország és Románia számára olyan mintaként szolgált, amiket a felek nem kérdőjeleztek meg, mi több az európai példák a hivatkozások állandó elemévé váltak mind a diplomáciai tárgyalások, mind pedig a parlamenti viták alkalmával. A mintakövetés gyakorlatából és az érvrendszerek szerkezetéből a belpolitikai tényezők felértékelődése egyre hangsúlyosabban kirajzolódott. Míg az integráció előtti időszakban a külpolitikai környezet szerepe volt a meghatározóbb, a csatlakozás időszakában pedig a kettős diskurzus, a külpolitikai kötöttségek és a belpolitikai stratégiák jelentek meg, addig az integrációt követően - az állampolgárság esetében - már a belpolitikai számítások bizonyultak döntő tényezőnek.

A három döntés eltérő „időzónában” jelent meg az államközi és az európai politika napirendjén. A KKE-i államok rendszerváltását követően az alapszerződések aláírásának időszakában a kisebbségvédelem összekapcsolódott a nyugati államok által hangsúlyozott béke és stabilitás fenntartásával, valamint a bővítési stratégiákkal. Annak ellenére, hogy Magyarország és Románia felkészültsége lényegesen különbözött, csatlakozási igényük kifejezésével teljesíteniük kellett az európai fórumok feltételrendszerét: ebből adódott, hogy a NATO-csatlakozást megelőző időszakban a kisebbségvédelem és a határkérdés fontosságát eltérő módon értékelő felfogások az alapszerződésről folyó tárgyalások központi kérdéseivé váltak. A vitába beavatkozó nyugati szereplök, különösen az Egyesült Államok fellépése a stabilitás primátusát érvényesítette a kisebbségi jogok védelmével szemben, ami a feleket megállapodásra késztette. A státustörvény vitájában, noha élénk nyugati érdeklődés kísérte végig a tárgyalásokat a meghatározó beavatkozás elmaradt. A fő kérdés tulajdonképpen az volt, hogy a két állam az EU-bővítésének kontextusában, tárgyalásos úton képes-e - az európai fórumok által megfogalmazott iránymutatások és a belpolitikai tényezők figyelembe vételével - rendezni a kialakult vitát. A kormányok kétszintű játszmája a státustörvény folyamatában is beazonosítható: belpolitikai szinten minél nagyobb koalíciót építeni, míg az államközi kapcsolatok és az európai fórumok viszonylatában úgy tárgyalni, hogy a képviselt álláspontok alapvetően ne érintsék az integrációs esélyeket, a megegyezés pedig ne jelenthesse az eredeti álláspontok feladását. A

\footnotetext{
522 Igaz ugyan, hogy Románia a rendszerváltást követően az elsők között egyszerüsítette az állampolgárság megszerzését a lakóhely megváltoztatása nélkül a volt román állampolgárok számára (Horvátországgal egy időben, 1991-ben), azonban a kérelmek feldolgozása a 2000-es évek során gyorsult fel, a jogszabály többszöri módosítását követően. Ekkor már több szomszédos állam is hasonló állampolgárság-politikát folytatott (pl. Bulgária, Szerbia).
} 
harmadik „időzónában”, a csatlakozást követő időszakban már nem érzékelhetőek a nyugati ösztönzők, az európai fórumok kevés relevanciával bírtak, annak betudhatóan, hogy az állampolgárság kérdése döntő módon belpolitikai témaként tematizálódott és alapvetően nem befolyásolta a magyar-román kapcsolatok alakulását, mert az állampolgárság kiterjesztése és a könnyített honosítási eljárás bevezetése - a térség államainak felfogásában - nem tartozik a hagyományos kisebbségvédelmi instrumentumok közé. Ennek ellenére a vita nem maradt el a szomszédos államokkal: az állampolgárság által létrejött közjogi viszonyt Magyarország tekintetében a szlovák fél, míg Románia tekintetében a moldáv fél bírálta.

Az eltérő „,időzónákban” zajló viták rámutattak azokra az alapvető változásokra, melyek érintették a négyes viszonyrendszer szereplőinek - Magyarország, Románia, RMDSZ, valamint európai fórumok és nyugati államok - stratégiáit, az érdekérvényesítési lehetőségeket és a képviselt álláspontokat. A legfontosabb változások között említhető (1) az adott államok integrációs helyzete (a csatlakozásban való előrehaladás); (2) az európai fórumokkal való együttműködés jellege; (3) a Szövetség pozíciója; valamint (4) a magyar kormány és a határon túli magyarok viszonya.

A magyar-román alapszerződés tárgyalásainak kezdetén még nem voltak világosak a NATO és EU-csatlakozási kritériumok, noha látható volt, hogy a béke és stabilitás fenntartása, mint alapelv - a balkáni eseményeknek betudhatóan - szerepelni fog a csatlakozási feltételek között. Magyarország, Romániával szemben lényegesen előnyösebb pozícióban volt, mind a gazdasági szerkezetátalakítás és a demokratizálódás, mind pedig az európai fórumokkal való viszony tekintetében, a külpolitikai prioritásokból kiindulva pedig az Antall-kormány olyan rendelkezéseket kívánt beépíteni az alapszerződésbe, amelynek eredményeként javul a romániai magyarság helyzete és az autonómia kivívásának lehetősége, végső soron pedig a két állam viszonya is. Ennek érdekében folyamatosan konzultált az RMDSZ-szel és tájékoztatta az európai fórumokat a tárgyalásokról, valamint kísérletet tett a román fél meggyőzésére, kevés eredménnyel.

A határkérdés „lebegtetését” a kisebbségi jogosítványokkal szemben olyan stratégiaként értelmeztem az alapszerződés tárgyalásaiban, amelyek ugyan aszimmetrikus viszonyban voltak, mégis fenntartották a felek tárgyalási készségét. A két állam megegyezését azonban nem a kisebbségi jogok elfogadása, hanem a NATO csatlakozási kritériumok megjelenése és az Egyesült Államok kollektív jogokra vonatkozó állásfoglalása befolyásolta, ami elörevetítette a szerződés aláírását is. A 
nagyhatalmi fellépés tehát közvetett beavatkozásként értékelhető egyrészt az államközi kapcsolatok szintjén, másrészt pedig a kisebbségi érdekérvényesítés szintjén, mert nyilvánvalóvá vált, hogy az RMDSZ vezetősége nem tud nemzetközi támogatást szerezni az erdélyi magyarság autonómia-küzdelméhez, ami alapvető stratégiaváltásra késztette a szervezetet és a külügyi érdekérvényesítő munkával szemben a kormányzati részvétel felértékelődését eredményezte. ${ }^{523}$

Noha a magyar-román alapszerződés aláírását számos bírálat érte, a benne rejlő lehetőségek kiaknázásának elmulasztása mindkét felet terheli. Beszédes példaként az alapszerződés által létrehozott vegyesbizottságok emelhetők ki, melyek - a román érdekeknek megfelelően - nem hoztak jelentős eredményeket. E tapasztalatokat is figyelembe véve, a hatalomra kerülő magyar jobboldali koalíció a határon túli magyarokkal folytatott intézményes viszony kialakítását és magyarországi jogállásuk kodifikációját tűzte ki célul. Magyarország pozíciójának felértékelődését és a határon túli magyarokról szóló törvény elfogadását a szomszédos államok közül Románia és Szlovákia kemény bírálatokkal illette, és a kialakult vitában az alapszerződés tárgyalásaiban is használt érvrendszereket hangsúlyozta, annak ellenére, hogy korábban ők is hasonló jogszabályokat fogadtak el. A magyar jogszabály összetettebb jellege az európai fórumok figyelmét is felkeltette, és annak ellenére, hogy a Velencei Bizottság és a Főbiztos is elismerte az anyaország felelősségének tényét, továbbra a szuverenitás, az érvényben levő megállapodások elsőbbségét, és jószomszédi kapcsolatok fenntartását, végső soron pedig a lakóhely szerinti állam felelősségét hangsúlyozták a kisebbségvédelemben.

Már a státustörvény vitájában felmerült a kettős állampolgárság kérdése, napirendre mégis csak az MVSZ többszöri kezdeményezését követően került. Az állampolgárság, amely jelentős nemzetpolitikai lépésként értékelhető, mégsem vezetett jelentősebb vitákhoz a szomszédos államokkal, elsősorban azért, mert hagyományos értelemben véve nem minősült kisebbségvédelmi eszköznek, ezzel szemben európai gyakorlatnak számított, mi több Szlovákia kivételével a szomszédos államok is elfogadták a kettős állampolgárság intézményét. A magyar-román vita elmaradása annak is betudható, hogy az alapszerződéshez és a státustörvényhez képest az

\footnotetext{
${ }^{523}$ A szövetségi elnök több interjúban és kongresszusi beszámolóban is érinti a külpolitikai képviselet és a kormányzati részvétel körüli dilemmákat. Az V. kongresszusi beszámolójában így fogalmaz: [...] „, valóban lemondtunk valamiröl: a tiltakozás, a nemzetközi fórumokhoz való hagyományos felfolyamodás, söt, a hazai panasztétel bizonyos eszközeiröl is. Lemondtunk nemcsak egy retorikáról, hanem egy ellenzéki magatartásról is, és joggal tehető fel újból és újból a kérdés: mi van a mérleg másik tányérján, mit kaptunk cserében?" (Markó 2000, p. 320).
} 
állampolgárság kiterjesztésével a magyar kormány lépése nem a kisebbségi közösségek védelmét célozta, hanem a magyar állam és a romániai magyarság közötti közjogi viszony kialakítását kezdeményezte, amit azért nem vitatott a román fél, mert összeegyeztethetőnek tartotta saját nemzetpolitikai célkitűzéseivel.

Ha a döntések vizsgálatakor a román pozíciók és stratégiák azonosítására törekszünk, akkor elmondható, hogy a '90-es években Magyarországhoz képest Románia állandó lépéshátrányban volt mind a gazdasági átmenet, mint pedig a demokratizálódás tekintetében, ebből következően rosszabb integrációs kilátásokkal rendelkezett. Elsősorban ezzel magyarázható, hogy Románia folyamatosa a róla kialakult kép javításán fáradozott. Államközi szinten a felsőszintű találkozók létrejöttét és a közös nyilatkozatok elfogadását részesítette előnyben - ehhez az alapszerződésről folyó tárgyalások alkalmas eszköznek bizonyultak -, azonban a kapcsolatok tényleges rendezését nem szorgalmazta. A magyar fél irányába megfogalmazott vádak, az európai fórumok félretájékoztatása és a Szövetség tárgyalási részvételének elutasítása már rövid távon eredményesnek bizonyult, ugyanis a magyar külügy rendre „magyarázó pozícióban" találta magát az európai fórumok előtt.

A belpolitika szintjén a román vezetés kevés hajlandóságot mutatott a kisebbségi kérdés rendezésére. A normák intézményesülésének spirál-modelljét alkalmazva elmondható, hogy az Iliescu-rezsim először tagadta a kisebbségi jogok létjogosultságát, a magyarországi kezdeményezéseket a belügyekbe való beavatkozásként értékelte, és a diplomáciai csatornákon a határok sérthetetlenségének elsőbbségét hangsúlyozta. Néhány taktikai engedmény és látszatintézkedés bevezetését - melyet a diplomáciai csatornákon a nyugat-európai államok irányába sikeresen propagált - visszalépések követték (oktatási törvény módosítása, szélsőséges pártok kooptálása). Ebben az időszakban alig került sor normatranszferre, mi több a román fél folyamatosan megkérdőjelezte az alapvető emberi és kisebbségi jogok létjogosultságát és minden eszközzel az RMDSZ és az erdélyi magyarság marginalizálására törekedett. A román vezetés viszonylag későn, a szerződés aláírásának időszakában mutatott arra hajlandóságot, hogy sajátos értelmezésben, diszkurzív szinten - preskriptív státusz elismerje a nemzetközi normákat (ET PKGY 1201. sz. ajánlás).

Az 1996-os kormányváltás lényeges változásokat eredményezett, mert megteremtette annak a lehetőségét, hogy elinduljon az európai fórumok által szorgalmazott normák beépülése, ami lehetővé tette a csatlakozási folyamatok megkezdését. A státustörvényről folyó vitában Románia úgy próbálta védeni nemzeti érdekét, hogy a Magyarországgal kialakult vita ne befolyásolja az integrációs folyamat 
során elért eredményeket. A tárgyalási készség fenntartása, és a Velencei Bizottság megkeresése - amely a román diplomácia kiváló „érzékéről” tanúskodott -, arra irányult, hogy a nemzetközi jog elveire hivatkozva elejét vegye az anyaország által tanúsított felelősség felértékelődésének. A hagyományos román érvekre hivatkozva szuverenitás, belügyekbe való beavatkozás, területen kívüli hatály - a vita arra is rámutatott, hogy kisebbségi kérdésekben a román fél konkrét ösztönzők hiányában nem hajlandó engedményeket tenni, annak ellenére, hogy kedvezményekben részesíti a határon túli román nemzettársakat. A román diplomácia sikere abban is tetten érhető, hogy a magyar féllel olyan megállapodást sikerült kötni, ami az akkori munkaerö-piaci lehetőségek között jelentős eredménynek mondható.

Románia szempontjából a könnyített honosítási eljárás nem bizonyult problematikusnak. Noha a kérdés marginálisan a 2004-es népszavazás alkalmával megjelent az államközi kapcsolatokban, a magyar fél lépését nem támadta Románia, részben azért mert hasonló állampolgárság-politikát folytat és úgy tünt, hogy a magyar állam és a romániai magyar kisebbség között létrejött egyéni közjogi viszony egyezik a román nemzetpolitikai célkitüzésekkel, amely egyrészt az állam birtokosaként a román népet határozza meg, hosszabb távon pedig a homogenizációt tartja irányadó célkitűzésnek.

Az államközi kapcsolatokban az RMDSZ érdekérvényesítési lehetősége mindvégig korlátozott volt, mert nem léphetett fel tárgyaló félként a kialakult vitákban. Ennek ellenére fontos közvetítő szerepet játszott a két állam viszonyában, mi több folyamatosan megjelenítette a romániai magyar kisebbség igényeit mind a román, mind pedig a magyar kormány irányába. Mivel a '90-es évek első felében a román kormány számos alkalommal a magyar kisebbségre nézve hátrányos jogszabályokat alkotott, a Szövetség - a magyar diplomácia segítségével - a kisebbségi problémákat az európai fórumok és nyugati államok irányába is megjelenítette. Ez a stratégia megfelel a spirál modellben bemutatott bumeráng-hatásnak, ami a külkapcsolatok építése szempontjából (állami és nem állami szereplőkkel egyaránt) részben sikeresnek tekinthető, mert ráirányult a figyelem a romániai emberi és kisebbségi jogok helyzetére. A külpolitikai érdekérvényesítésben azonban a Szövetség nem tudott áttörést elérni, külügyi tevékenységével pedig nem tudta a nemzetközi politika napirendjére helyezni az erdélyi magyarság rendezésének kérdését. ${ }^{524}$ Ennek következtében az alapszerződés aláírása és

524 A kolozsvári Kisebbségkutató Intézet kutatási programjának keretében készült interjúban (2012) Markó Béla a következőképpen vélekedett a külpolitikai képviselet kérdéséről, mint a kormányzati integráció egyik jelentős hátrányáról: [...] „,nem lehet külföldön, például Brüsszelben vagy másutt sérelmi 
a kormányzati részvétel jelentős stratégiaváltásra késztette a Szövetséget és a konkrét érdekérvényesítő munkát felhagyva a puha külpolitikai képviseletre helyezte a hangsúlyt. Ez gyakorlatilag azt jelentette, hogy a Szövetség felhagyott az európai fórumokat megcélzó érdekérvényesítő munkával és a sérelmi - panaszokon alapuló politizálással és külügyi kapcsolatrendszerét a nyugati közvélemény tájékoztatására használja (Szabó 2015, p. 146).

A státustörvény vitája nem hozott lényegesebb változást az érdekérvényesítésben, azonban a Szövetség elönyösebb pozícióban találta magát, mert ellenzékből támogatta a kormány tevékenységét, míg magyar oldalon a MÁÉRT létrehozásával intézményesültek a magyar-magyar kapcsolatok és az alapszerződés során folytatott egyeztetéseket felváltották a rendszeres találkozók, a szakbizottságokban pedig érdemi javaslatok megvitatására is lehetőség nyílt. A megnövekedett mozgástér azonban nem vezetett a Szövetség korábbi pozíciójának megváltozásához, a státustörvény vitájában továbbra is közvetítő szerepet játszott és szorgalmazta a kormányközi egyezség létrejöttét. Ekkorra az RMDSZ szempontjából leértékelődtek a külkapcsolatok és a belpolitikai alkuk váltak meghatározóvá, amitől a Szövetség érdekeinek érvényesítését remélte. Azonban a Szövetség stratégiaváltásának volt egy lényeges, elöre nem látott következménye, ugyanis a kormányzati részvétellel, illetve a kormánykoalíció támogatásával legitimálta a román kisebbségpolitikai rezsimet.

A KKE-i államok rendszerváltását követően a nyugati államok és az európai fórumok a térség stabilizálásának igényével léptek fel, és normaalkotó tényezőként jelentek meg az államközi kapcsolatokban. Stratégiájukban megjelentek a normatív ösztönzők, majd a csatlakozási kritériumok megjelenésével a konkrét feltételek. Magyarország és Románia viszonyában, főként az alapszerződés tárgyalásainak időszakában a nyugati tényezők erős befolyása és nyomásgyakorlása mutatható ki, aminek döntő megnyilvánulási formája az Egyesült Államok autonómiára és kollektív jogokra vonatkozó álláspontja. Az európai fórumok elsősorban a stabilitás és a konfliktusok békés rendezésében, továbbá az alapvető emberi jogok tiszteletben

politikát folytatni, ha ott van az ember az illetö ország kormányában. Tehát lecsökkentek a külsó befolyásolási eszközeink. [...] Egyáltalán nehéz azt mondanunk, hogy Romániában diszkrimináció van, amikor a magyar képviselet ott van a kormányban. Ezt bemértük, akkor is tudtuk, de nekem az volt a konklúzióm ezzel kapcsolatosan, hogy 1996-ig vajmi keveset értünk el strasbourgi, washingtoni ilyenolyan beleszólással, ahhoz képest, hogy a kormányzás eszközeivel mennyit értünk el. Tehát ezzel, hogy kormányra mentünk igen ott volt az is, hogy tulajdonképpen nekünk senki sem bizonyitotta be, hogy az a bizonyos külső, külföldi sérelmi politika az komoly eredményekhez vezethet." Köszönettel tartozom Székely István Gergőnek, hogy az interjú anyagát rendelkezésemre bocsájtotta. 
tartásában voltak érdekeltek, az alapszerződésben pedig olyan eszközt láttak, amely rendezheti a két állam viszonyát, egyben pedig biztosítja a régió stabilitását. Hogy ezen túlmenően miként érvényesülnek a kisebbségi jogok, vagy milyen formában valósul meg a kisebbségek integrációja, másodlagos tényezőnek bizonyult. A két állam közötti tárgyalások szorgalmazása arra irányult, hogy létrejöjjenek az együttmüködés csatornái, ami különösen a státustörvény vitájában bírt nagy fontossággal. Az európai fórumok szempontjából ekkor már nem az volt a kulcskérdés, hogy melyik állammal kezdhetik meg a csatlakozási tárgyalásokat, hanem, hogy az integrációs folyamatban a két állam figyelembe véve a Velencei Bizottság és az EBESZ javaslatait - miként rendezi a kialakult vitát. Az európai fórumok tehát továbbra is normaalkotó szereplőként léptek fel és az anyaország felelősségének kérdésében, majd pedig a könnyített honosítási eljárás kapcsán is a területi integritás és sérthetetlenség, a szomszédos államokkal kötött szerződések valamint a diszkriminációmentesség elveinek tiszteletben tartását kérték az érintett felektől. A normaalkotók szerepe, azonban lényegesen csökkent olyan ügyekben, mint az állampolgárság, annak betudhatóan, hogy a felek között nem alakult ki államközi vita.

Amint az elemzésben rámutattam, az államközi viták egy másik dimenzióban, a parlamenti pártok szintjén is zajlottak, azonban a törvényhozó hatalomnak a külpolitikai döntéshozatalban korlátozott szerepének betudhatóan lényegesen nem befolyásolták a kormány által képviselt álláspontokat. A parlamenti viták elemzéséből egy lényeges különbség rajzolódott ki: míg Romániában a nemzetpolitikai célkitüzésekről széles konszenzus uralkodott a parlamenti pártok között - ezt esetenként a szélsőséges pártok vagy az RMDSZ kérdőjelezte meg -, addig Magyarországon, a határon túli magyarok helyzetének rendezése a politikai viták kereszttüzében állt. Ennek a különbségnek számos gyakorlati következménye tetten érhető. Elsőként az, hogy noha a politikai viták lényegesen hozzájárulhatnak a politikai akaratképzéshez, azonban az Országgyülésben a határon túli magyarokról szóló viták rendre megosztották a parlamenti pártokat és a közvéleményt, ami nehezítette a döntéshozatalt és az elfogadható megoldás megszületését. A kialakult viták pedig az európai fórumok figyelmét is felkeltették és a két állam viszonylatában a magyarországi belpolitikai eseményekre irányította a figyelmet, amely vegyes megítélés alá esett. Ezzel szemben Romániában a nemzetpolitikai célkitüzések széles konszenzusnak örvendtek és az államközi kapcsolatok szintjén megjelenő vitákat (alapszerződés, státustörvény) a szuverenitás, valamint a nemzeti érdek keretében értelmezték, az állampolgársági törvény módosításakor pedig a parlamenti pártok egymást túllicitálva érveltek az eljárás 
felgyorsításában. Az magyar parlamentben lefolytatott intenzív vitákhoz képest, a Képviselöházban és a Szenátusban lefolytatott viták visszafogottabb hangvételüek, a felszólalók pedig, ha vannak is köztük kisebb jellegü ellentétek, a nemzeti érdeket szem előtt tartva a konszenzusra és az egység felmutatására törekedtek.

A lezajlott viták vizsgálata számos tanulsággal szolgált a döntéshozatal mechanizmusainak feltárására vonatkozóan mind a belpolitika, mind pedig az államközi kapcsolatok szintjén. Az alapszerződés vitája a diplomáciai tárgyalások klasszikus esetét jelenítették meg, ahol a külügyminisztériumok, az illetékes főosztályok előkészítő munkájával elöterjesztették a szövegváltozatokat (politikai szint), a javaslatokat pedig a tárgyaló delegációk (több intézmény képviseletével) szakértői tárgyalások során megvitattak (szakértői szint). E tárgyalások dinamikáját több tényező is alakította, elsősorban a két állam tárgyalási stratégiája és mandátuma, a belpolitikai tényezők (kormányváltás), végső soron pedig a külső tényezők (európai fórumok, Egyesült Államok), akiknek meghatározó szerep jutott a felek közötti megegyezésben. Ezzel szemben az RMDSZ, noha számtalan kísérletet tett, nem válhatott tárgyaló féllé, érdemben tehát nem befolyásolta a dokumentum tartalmát, azonban a felek között fontos konzultációs feladatokat látott el.

Az alapszerződés aláírása új együttmüködési formáknak tette le az alapját, azonban a megalakult vegyesbizottságokban rejlő lehetőségeket a felek nem használták ki és csak azt követően aktivizálódott a kisebbségi vegyesbizottság tevékenysége - a két állam közötti vitarendezés egyik potenciális színtereként - miután az Országgyűlés elfogadta a határon túli magyarokról szóló törvényt. A jogszabály elfogadását melynek előkészítésében a HTMH és határon túli szervezetek, beleértve az RMDSZ tisztségviselői is rész vettek - jelentős viták követték kormányzati szinten, amit megnyugtató módon a kormányközi megállapodás rendezett. A vegyesbizottság szerepe azt követően értékelődött fel, miután az új magyar kormány a státustörvény módosítását helyezte kilátásba. Ekkor a két kormány között már nem a miniszterelnökök megbízottjai közvetítettek, hanem a külügyminiszterek társelnökletével zajló vegyesbizottság ülésének keretében egyeztettek a felek, amely mindkét állam részéről jelezte a probléma kiemelt helyzetét. A státustörvény újabb példáját szolgáltatta annak, hogy az államközi kapcsolatokban és a vitarendezésben az RMDSZ nem válhatott tárgyaló féllé, de román belpolitikai viszonyok közepette felértékelődött a pozíciója, aminek eredményeként meghatározó szerepet töltött be a felek közötti megegyezésben.

A két döntéshez képest a kettős állampolgárság eltérő összefüggésben ugyan, de alapvetően belpolitikai kérdésként tematizálódott mindkét államban. Lényegesebb 
különbségeket egyrészt a kezdeményezők körében, másrészt a jogalkotási eljárásban találhatunk. Míg Magyarországon nem politikai kezdeményezés állt az állampolgári törvény módosításának hátterében, addig Romániában a parlamenti pártok és az államfő képezte a honosítási eljárás könnyítésének „hajtómotorját”, akinek egyéni kezdeményezései napirenden tartották a kérdést. Ami az eljárást illeti, a referendumot követően nem módosult jelentős mértékben a magyar a jogszabály: a parlamenti pártok megosztottságának eredményeként a konszenzus a 2010-es parlamenti választásokat követően jött létre. Ezzel szemben Romániában az állampolgári törvény módosításában széles egyetértés mutatkozott, aminek eredményeként a módosításról szóló sürgősségi kormányrendeletet mindkét ház megvitatta és nagy többséggel elfogadta.

Az intenzív vitákat kiváltó alapszerződés és státustörvény hatásvizsgálatakor a pozitív következményeket, a két állam és a magyar kisebbség kapcsolatában bekövetkező, előremutató fejleményeket emeltem ki. Míg az alapszerződés aláírására főként integrációs szükségszerüségből került sor, olyan fejleményeket eredményezett, melyek túlmutattak a szerződés aláírásán. Noha a felek közötti megegyezés mindkét állam integrációs előrehaladását segítette, a magyar félnek már rövidtávon, a román félnek csak középtávon kedvezett. A státustörvény vitája és következményei egy tipikus, mindkét fél számára előnyös pozíciót jelenített meg, ugyanis egyrészt elismerést nyert az anyaországnak a határon túli magyarok nyelvi és kulturális támogatásának legitimitása, másrészt román oldalról az egyenlő bánásmód hangsúlyozása megnyitotta a magyar munkaerőpiacot a román állampolgárok előtt. Kormányközi szinten mégis nem a nemzetpolitikai vitákat lezáró megállapodások jelentették a legnagyobb sikereket, hanem a 2005-2008 között négy alkalommal sorra kerülő kormányülések, amik elősegítették a stratégiai jellegü közös projekteket és a határ menti együttmüködéseket.

Az alapszerződés aláírása és a státustörvény elfogadása a romániai magyar kisebbség szempontjából is pozitív fejleménynek tekinthetők, a döntések következményei - annak ellenére, hogy az előzetes elvárásokhoz képest az alapszerződés kevesebb rendelkezést tartalmazott - jelentős folyamatokat indítottak el. A Szövetség kormányzati részvétele, majd a kormányzó párttal folytatott együttmüködés eredményeként alapvető jogszabályi változások következtek be, a növekvő magyarországi támogatások pedig - a koordináció és az egyeztetések hiányának ellenére - segítették az oktatási és kulturális intézményrendszer bővítését. A rendszerváltást követő két évtized fejleményei azonban rámutattak arra, hogy az elért pozíciók nem eléggé stabilak, az adott helyzetet megkérdőjelező bármilyen változás, amely a Szövetség helyzetét - kormányzati pozícióból ellenzéki szerepbe kerülés -, 
vagy a magyar kormánnyal folytatott viszony jellegét érinti, a következmények tekintetében nem beláthatóak.

A 2010-et követő időszak és a könnyített honosítási eljárás következményeiről még korai lenne végleges következtetéseket levonni, de az bizonyos, hogy a magyar állam és a határon túli magyarok között létrejött közjogi viszony a hagyományos nemzetpolitikai megközelítést - amelyben a közösségként való elképzelés, a közösségi érdekvédelem vagy kisebbségvédelem volt a meghatározó -, az egyéni, az állampolgári jogvédelem irányába tereli. ${ }^{525}$ Noha a tényleges következmények beazonosításakor nem hagyhatjuk figyelmen kívül az anyaországgal való kapcsolatok egyre intenzívebbé válását, a magyar identitás és nemzeti öntudat megerösítését, az látható, hogy az állampolgárság megadásának másik oldalán tornyosuló következmények - minden jószándék ellenére - számos veszélyt hordoznak magukban, amely jelentős hatással lehet az erdélyi magyarság migrációs potenciáljára, a gazdasági és társadalmi pozíciókra, végső soron pedig a Szövetségnek a romániai politikai rendszerben elfoglalt helyére és érdekérvényesítő potenciáljára.

525 Salat e változást a következőképpen látja: „A folyamat lényege következésképpen úgy is megfogalmazható, hogy a nemzetpolitika jelenlegi főiránya az elszakadt nemzetrészeket az önálló politikai közösségként való elfogadtatás érdekében folytatott küzdelem pályájáról átállította az intézményesített diaszpóra pályájára" (Salat 2013, p. 231) 


\section{KÖVETKEZTETÉSEK}

Doktori dolgozatomban az 1989-es rendszerváltást követő magyar-román államközi viszony és az RMDSZ kapcsolatrendszerét vizsgáltam három fontosabb, az erdélyi magyarság szempontjából releváns döntés - a magyar-román alapszerződés, a státustörvény és a könnyített honosítási eljárás bevezetése - perspektívájából. A két állam, valamint az erdélyi magyarság képviseletét ellátó szervezet kapcsolatának elemzése során kiléptem a Brubaker-i értelmezési keretből és az európai fórumok, valamint más nyugati államok befolyásának megragadására a négyes viszonyrendszert alkalmaztam, ami némiképpen a szakirodalmi áttekintésben is tükröződött. Magyarország és Románia, az RMDSZ valamint az európai fórumok és a nyugati államok viszonyára vonatkozó szakirodalom tanulmányozása során az alapvető kérdésfelvetések elemzésére, a kutatások módszertanára és a levont következtetések értelmezésére helyeztem a hangsúlyt és arra mutattam rá, hogy a rendszerváltás időszakát jellemző „fokozott” konfliktushangulat számos belső és külső tényező hatására a szereplők viselkedésének megváltozását, a különböző szinten megvalósuló együttmüködési formák kialakulását eredményezte.

Az állami és nem állami szereplők kapcsolatainak alakulását, a bel- és külpolitika szintjén alkalmazott stratégiák feltárását, az eltérő érdekek és pozíciók beazonosítását, valamint a viták és a döntések folyamatának követését a nemzetközi kapcsolatok elméletének perspektívájából értelmeztem és az foglalkoztatott, hogy az elméleti irányzatok mennyiben alkalmazhatók az államközi kapcsolatok vizsgálatára nézve és milyen értelmezési lehetőséggel, illetve magyarázattal szolgálnak a két állam viszonyára vonatkozóan. A vizsgálat erőteljes történeti jegyeket visel, mivel nagyszámú, az elemzési időszakra vonatkozó levéltári anyag, kormányzati és más jellegü dokumentum valamint állásfoglalás feltárását és elemzését végeztem el. Ennek ellenére dolgozatom nem tekinthető a magyar-román államközi kapcsolatok történetét összefoglaló munkának. Ehelyett arra törekedtem, hogy a rendelkezésemre álló szakirodalom és az azonosított dokumentumok alapján feltárjam a nemzetpolitikai szempontból meghatározó viták bel- és külpolitikai körülményeit, a szereplők pozícióit és érdekérvényesítési lehetőségeit. Ebben a törekvésemben nagy segítségemre volt az egyes döntésekről készült tárgyalási kronológiák, amelyben végigkövethető a vizsgált folyamat egésze: az államközi találkozók és tárgyalások eredményei, a Szövetség pozíciója, valamint az európai fórumok által képviselt álláspontok. A három döntés 
nemcsak a külpolitika, hanem a belpolitika szintjén - a nemzeti parlamentekben - is komoly vitákat eredményezett a pártok között. A parlamenti viták jegyzőkönyveinek elemzése során rámutattam arra, hogy az alapszerződés, a státustörvény és a kettős állampolgárság kérdése a két államban más-más dimenzió mentén osztotta meg a parlamenti pártokat, azonban a vita lényegében nem befolyásolta a kormány álláspontját és a külpolitikai döntéshozatal folyamatát.

A soron következőkben elsőként felelevenítem a disszertáció elején megfogalmazott kutatási kérdéseket, majd megfogalmazom az ezekre adandó válaszokat és összefoglalom a legfontosabb következtetéseket. A nemzetközi kapcsolatok általam is vizsgált (meta)elméletek bö szakirodalma arra ösztönzött, hogy megvizsgáljam a négy nagy paradigma alkalmazhatóságát az államközi viszonyok elemzésében és az érdekelt, hogy $\left(\mathrm{K}_{1}\right)$ az elméleti irányzatok mennyiben alkalmasak a magyar-román államközi viszony 1989 utáni alakulásának értelmezésére. Másodsorban $\left(\mathrm{K}_{2}\right)$ az államközi kapcsolatok alakítását befolyásoló szereplők és intézmények, a müködtetők világa érdekelt: egyrészt azon intézmények köre, akik az államközi kapcsolatokat müködtetik, másrészt pedig a mechanizmusok, vagyis a külpolitikai döntéshozatal folyamata. A disszertáció harmadik kérdésfelvetése $\left(K_{3}\right)$ az RMDSZ pozíciójára és szereplehetőségére vonatkozott és a döntések során azt vizsgáltam, hogy az államközi kapcsolatok szintjén a Szövetség milyen érdekérvényesítési lehetőségekkel rendelkezett a külpolitika szintjén, milyen stratégiákat követett a magyar, a román és az európai fórumokkal folytatott viszonyban? Végül pedig a román fél által sokat citált történelmi megbékélés és a két nép közötti közeledés kérdése foglalkoztatott és a döntések hatásvizsgálata annak a kérdésnek a megfogalmazását tette indokolttá, hogy $\left(\mathrm{K}_{4}\right)$ milyen lehetőségei vannak a megbékélésének, amikor az erdélyi magyarság képviseletét ellátó szervezetet rendre mellőzik az őket érintő államközi szerződések és együttmüködések kialakítása során?

\section{A NK elméletei, mint értelmezési keret az államközi kapcsolatok vizsgálatában}

A magyar-román államközi viszony és az RMDSZ kapcsolatrendszerét a nemzetközi kapcsolatok négy meghatározó irányzatának (realizmus, liberális institucionalizmus, konstruktivizmus, angol iskola) perspektívájából értelmeztem és arra mutattam rá, hogy egymagában egyik elméleti irányzat sem szolgált kimerítő magyarázattal az 1989 utáni fejlemények elemzésére. Az elméletek magyarázó ereje az egyes paradigmák ötvöződése és egymás kölcsönös kiegészítése nyomán növekedett. Az így módon kialakított több súlypontú értelmezési keretben - a vizsgált időszaktól 
vagy vitától függően - kimutatható az egyik elméleti irányzat domináns pozíciója (meggyőzőbb magyarázata) a másikkal szemben.

A szakirodalom a realizmus egyik legalapvetőbb jellemzőjeként az államok hatalomközpontúságát emelte ki, amelyek következtében az állami szereplők olyan stratégiákat követnek, ami hozzájárul a rendszeren belüli hatalmuk növekedéséhez, vagy legalább a szomszédos államokkal szembeni relatív hatalmuk fenntartásához. Nem meglepő tehát, hogy a kommunista tömbben a két állam szembenállását, a rendszerváltás folyamatát, mint a rendszerben bekövetkező instabilitást, Magyarország felelősségvállalásának hangsúlyozását, valamint a romániai magyar kisebbség helyzetét olyan tényezőként értelmezték a térséggel foglalkozó kutatók, amely jelentős konfliktuspotenciált jelenthetett a magyar-román államközi viszony tekintetében. A konfliktus kialakulásának a lehetősége azonban számos tényező egyidejü és egymást erősítő hatására csökkent (együttműködés a védelem, a gazdaság és kultúra területén, integrációs célkitűzések stb.) és az államközi kapcsolatokban a hangsúly a különböző szintű együttmüködésre helyeződött át. Az együttmüködésnek és a stabilitásnak az alapját az alapszerződés tárgyalásának és aláírásának időszaka teremtette meg, amitől a felek relatív hatalmuk növelését remélték. Noha a kialakult vitában föként a román fél hivatkozott a függetlenségére és az állami szuverenitás fenntartására, a vitában megjelenő európai fórumok és nyugati államok, melyek a nyomásgyakorlás különböző eszközeivel is éltek növekedett a liberális institucionalizmus, a normák deklaratív elfogadásával pedig a konstruktivizmus magyarázóereje.

A konfliktus elmaradásával a realista elmélet magyarázó ereje ugyan csökkent, de beazonosítható egyrészt diszkurzív szinten az államközi és parlamenti vitákban elhangzott érvrendszerekben, másrészt pedig Magyarország és Románia külpolitikai érdekérvényesítésében is fellelhető egy lappangó realista stratégia, amely a regionális viszonyok közepette az állam relatív hatalmának fenntartására, pozíciójuk erősítésére szolgált.

A magyar-román alapszerződés aláírását követően javultak a kapcsolatok, azonban az együttmüködés intézményes kereteit igencsak próbára tette a státustörvényről szóló vita. A diplomáciai tárgyalások tétjét és a megegyezés szükségszerüségét nagyban meghatározta egyrészt a felek integrációs elköteleződése és a nyugati mintakövetés, másrészt pedig az európai fórumok aktív részvétele és szerepük felértékelődése a kialakult vitában. A jogszabály kapcsán létrejött megállapodásban kifejeződött az európai normák elfogadására és intézményesítésére vonatkozó hajlam, 
amely a viselkedési mintázatok lassú, igencsak korlátolt változását - lásd a kisebbségi jogok romániai gyakorlatba ültetését - vetítette előre.

A státustörvény vitájában a felek közötti együttmüködésre való hajlamát a liberális institucionalizmus elméletét igazolja, amit jelentős mértékben kiegészít - a magyar nemzetről szóló öndefiníciós vita eredményeként (kit tekinthetünk a magyar nemzet részének) - a konstruktivizmus és az angol iskola által nyújtott értelmezések. A kettős állampolgárság vitájában megjelenő főbb témák, melyek alapvető gazdasági társadalmi és szociális problémákat, de leginkább a magyar nemzet önmeghatározásának identitásbeli kérdéseit érintették, rámutattak arra, hogy a belpolitikai tényezők és a globális problémák következtében a távolról sem lezárt nemzetfogalom milyen változásoknak van kitéve. Ezeknek a folyamatoknak az értelmezéséhez nyújtott fontos táppontokat az angol iskola hangsúlyozván a korábban egységesnek tekintett állami szereplők „kevésbé kész” jellegét. A nemzetpolitikai szempontból releváns viták ennek alapján arra engednek következtetni, hogy a státustörvény és a kettős állampolgárság a maga nemében fontos korszakot zárt le a nemzetpolitikában, azonban a nemzetépítésben újabb fejleményekkel kell számolnunk.

A 2010 utáni időszakban ugyan csökkent az európai fórumok szerepe, de mindkét államban a politikai napirend részét képezi az európai normák követésének és intézményesítésének kérdése, amelyre elérő válaszok születtek. Románia arra törekedett, hogy - a teljesség igénye nélkül - beépítse jogrendjébe az európai normákat és a meglévő struktúrákban (NATO, EU) növelje befolyását, érdekérvényesítő képességét. Magyarország kül- és nemzetpolitikájában bekövetkező változások is befolyásának növekedését célozták, mind a határon túli magyarokkal, mind a szomszédos államokkal szemben, azonban más eszközökkel. Romániával ellentétben, az Orbán Viktor vezette magyar kormány befolyásának növekedését az autonómiairányultságú külpolitikában látja, amely egyrészt az európai fórumokkal szembeni (nyílt) konfliktusok felvállalását és az uralkodó irányzatok megkérdőjelezését jelenti, másrészt újabb gazdasági és kereskedelmi kapcsolatok kialakítását szorgalmazza.

\section{A magyar-román kapcsolatok müködtetöi}

Az államközi szinten lezajlott viták vizsgálatából kirajzolódott azon szereplők és intézmények köre, akik meghatározó szereppel bírnak a külpolitikai döntéshozatalban és fenntartják a diplomáciai kapcsolatokat. A „müködtetők világának” meghatározó szereplői mindkét államban a miniszterelnök és a külügyminiszter, illetve a különböző 
minisztériumok, a román politikai rendszernek betudhatóan pedig az államfő, aki számos alkalommal befolyásolta a viták alakulását. A külpolitika alakításában a végrehajtás mellett a döntés-elökészítésben részt vevő intézmények is jelentős szerepet játszottak (MÁÉRT, a külügyminisztériumokban müködő főosztályok, HTMH). E két utóbbi intézmény számos szakértőt foglalkoztatott, akik részt vettek a jogszabályok és stratégiák előkészítésében. Míg a Nemzetközi Jogi Főosztály vezetője az alapszerződés tárgyalásait vezette, a HTMH képviselője is állandó tagja volt a delegációnak. A hivatal a státustörvény kidolgozásában is meghatározó szerepet játszott és megszüntetéséig folyamatos koordinációs tevékenységet töltött be a kormány és a határon túli magyar szervezetek között.

A vizsgált esettanulmányokban rámutattam arra, hogy a határon túli magyarok szempontjából meghozott döntéseknek a nemzeti parlamentekben lefolytatott intenzív viták fontos terepét képezték, de a napirend alakításán és a közvélemény befolyásolásán kívül a kormány álláspontjával szemben az ellenzék nem érvényesíthette akaratát, következésképpen a lefolytatott viták nem befolyásolták a külpolitikai döntéshozatalt. Az államközi kapcsolatok müködtetésében meghatározó intézmények szerepének és hatáskörének vizsgálata - legfőképpen pedig a parlamenti pártok eltérö, sok esetben egymásnak ellentmondó álláspontja - rámutatott arra, hogy az államot aligha lehet egységes szereplőként megjeleníteni. Az intézmények és a pártok közötti ellentétekből, valamint a döntéshozók többszintü játszmákban való részvételéből az érdekegyeztetés szövevényes útja rajzolódott ki, és rávilágított arra, hogy a nemzeti érdek mögött ritkán oly mértékü a konszenzus, mint amilyet a szakértők és elemzők feltételeznek. A döntéshozatalban megjelenő szereplők és a döntéshozatal folyamatának vizsgálata megerősítette a liberális institucionalizmus által megkérdőjelezett elképzelést, az állam fekete dobozként való megjelenítését. Az esettanulmányokban arra világítottam rá, hogy noha a döntéshozatal folyamatát számos ,misztérium” övezi, a szereplők viszonya és az alapvető mechanizmusok jórészt tetten érhetőek.

Az etnikai pártok külpolitikai érdekérvényesitésének korlátai, az államközi kapcsolatokban játszott szereplehetősége

A magyar-román államközi viszony vizsgálatában kiemelt szerepet tulajdonítottam az RMDSZ bel- és külpolitikai érdekérvényesítési lehetőségének, amelyet nagymértékben meghatározott a román belpolitikai és a szélesebb értelemben vett európai környezet.

A román demokrácia konszolidációjának időszakában a Szövetség számára egyedüli stratégiakén a külügyi érdekérvényesítés lehetősége merült fel, aminek 
eredményeként az RMDSZ képviselői - megkerülve a román állami szerveket - számos alkalommal tájékoztatták az európai fórumokat az erdélyi magyarság helyzetéröl, felhívva a figyelmet a román kisebbségpolitika visszásságaira. A külügyi érdekérvényesítés korlátai viszonylag hamar, már az alapszerződés tárgyalásai során megmutatkoztak, egyrészt abban, hogy a Szövetség tárgyaló félként nem vehetett részt a szakértői munkálatokban, másrészt pedig a személyes kapcsolathálóra és a magyar diplomácia hathatós segítségére és támogatására épülő külügyi koalícióépítés nem érhetett el átütő - az erdélyi magyarság problémájának megjelenítését és rendezését a nemzetközi politikában - külpolitikai sikereket.

Az alapszerződés aláírása és a román belpolitikában bekövetkező változások megnyitották a Szövetség számára a kormányzati részvétel lehetőségét, amely jelentős stratégiaváltásra késztette a Szövetséget és a belpolitikai, a román féllel megkötött alkuk felértékelődését eredményezte. Ez a stratégiaváltás nem a Szövetség tudatos döntésének tulajdonítható. A döntés mögött egyrészt a román partnerek által támasztott és kevésbé hangsúlyozott követelményrendszer fogalmazódott meg, miszerint a kormányzati részvétel egyik alapfeltétele a külpolitikai érdekérvényesítésről történő lemondás, ami gyakorlatilag azt jelentette, hogy a Szövetség az erdélyi magyarság problémáit nem tematizálja az európai fórumok előtt. A stratégiaváltás másrészt a külpolitikai környezet alakulásának a következménye, ugyanis a térségben jelen levő európai fórumok a többség-kisebbség viszonyának rendezését és a konfliktus elkerülését az együttmüködésben, a sajátos akkomodációs stratégiák kialakításában látták, amely egyrészt biztosította a stabilitást, másrészt pedig az RMDSZ kormányzati pozícióba való kerülésével, a többséggel folytatott együttmüködés újabb dimenzióit nyitotta meg.

Az európai fórumok konfliktuskezelő stratégiája azonban nem volt tekintettel az erdélyi magyarság sajátos igényeire, azokra az elképzelésekre, melyek az autonómia különböző alakzatainak kialakítására vonatkoztak, következésképpen a kisebbségi jogkövetelésekkel szemben rendre a stabilitás primátusának elve érvényesült. A nyugat által szorgalmazott stratégiák és szakpolitikai javaslatok tehát nem számoltak azokkal a hosszabb távon kialakuló, a magyar kisebbségre nézve hátrányos következményekkel, amely egyrészt a többségi nemzet domináns pozíciójából, másrészt az RMDSZ korlátozott érdekérvényesítéséből adódtak.

A dolgozat fontos következtetése, hogy a rendszerváltást követő időszakban a Szövetség folyamatosan szorgalmazta az együttmüködést román és a magyar kormány képviselőivel, közvetítő munkájával pedig - melyet nyilvánosan csak néhány esetben méltattak a felek - hozzájárult az államközi kapcsolatok fejlesztéséhez és az 
interetnikus viszony javításához. A Szövetség azokban az esetekben tudta döntő mértékben meghatározni és alakítani az államközi kapcsolatokat, amikor a belpolitikai koalícióépítés eredményeként felértékelődött a szerepe és ezt a pozíciót mindkét fél elfogadta, illetve legitimnek tartotta. Ennek a pozíciónak nyilvánvaló korlátai voltak, amely nem jelenthetett egyenrangú, a tárgyalásokban is résztvevő felet, azonban lehetőséget biztosított a Szövetség politikusainak arra, hogy ismertessék álláspontjukat, fogalmazzák meg javaslataikat mindkét fél irányába és a kritikus pillanatokban közvetítsenek a felek között.

\section{Európai fórumok és a normák világa}

A disszertációban hangsúlyosan kitértem az európai fórumok szerepére és amellett érveltem, hogy meghatározó szereppel bírtak az államközi kapcsolatok és az RMDSZ viszonyrendszerének alakulásában. Erre elsőként a szakirodalmi áttekintésben mutattam rá, ahol a négyes viszonyrendszerben elemeztem a szereplők viszonyát, az egyes esettanulmányokban pedig hangsúlyoztam az európai fórumok stratégiáit és az európai normák és gyakorlatok elfogadtatására vonatkozó kísérleteket. A vizsgálat esettanulmányok során - főként az alapszerződés és a státustörvény vitájában megerősítést nyert a szakirodalomban található felismerés, miszerint a tagjelölt államok leginkább akkor tanúsítottak normakövető magatartást, amikor érzékelték az európai fórumok jelenlétét és nyomásgyakorlását, másrészt a normatív ösztönzők mellett a tagfelvétellel járó feltételrendszerek is világosak voltak. Ha az európai fórumok nem voltak aktívak az adott államokban (pl. Románia 1990-1993 között) és nem tették nyilvánvalóvá a tagsági feltételeket a normatív ösztönzők (nyilatkozatok, ajánlások, találkozók) nem érték el a várt hatásokat. Románia a '90-es évek első felében szemléletes példáját szolgáltatta annak, hogy a kormányzat belpolitikai stratégiákból vezérelve miként próbálta akadályozni az európai normák beépülését a román jogrendbe.

Azzal, hogy az európai fórumok és a nyugati államok a biztonság és a konfliktuskezelés elsőbbségét érvényesítették a kisebbségek helyzetének megnyugtató rendezése helyett, jelentősen behatárolták azokat a demokratikus kereteket, amelyben a kisebbségi közösségek érdekeiket hosszabb távon érvényesíthetik. A többség-kisebbség békés, konfliktusmentes együttélését, esetenként a kisebbségek döntéshozatalban való részvételét támogató stratégiák a nemzetállamon belül a tituláris nemzet reprodukcióját, végső soron pedig dominanciáját vetíti előre, aminek megváltoztatására a kisebbségi közösségeknek aligha lesz lehetőségük 


\section{A megbékélés hiányzó láncszemei}

Az RMDSZ stratégiaváltásában minden bizonnyal az a kevésbé hangoztatott felismerés is hozzájárult, hogy nem tudta elfogadtatni részvételét az államközi tárgyalásokon. Noha a magyar fél több alkalommal támogatta a Szövetség bevonását az alapszerződés munkálataiba, a román fél többszöri elutasítása következtében nem jelenhetett meg tárgyaló félként, amely meghatározónak bizonyult a Szövetség érdekérvényesítésére nézve. A román elutasítás - amely a státustörvény vitájában is újból megismétlődött alapjában megkérdőjelezi a román fél által hangsúlyozott, a két állam közötti történelmi megbékélés létrejöttét. Megítélésem szerint, amikor a román fél a megbékélésre hivatkozik, akkor csakis a jelenség felszínes változatát fogadja el, amely kimerül a hagyományosnak mondható diplomáciai kapcsolatokban és a gazdasági, kulturális és tudományos együttműködésekben.

Ahhoz azonban, hogy a történelmi megbékélésről, mint realitásról beszélhessünk, jelentős lépések megtételére volna szükség az elkövetkezendő időszakban. A legfontosabb kérdés e tekintetben - amit az RMDSZ vezetői is számos alkalommal hangsúlyoztak - az erdélyi magyarság részvételének formális biztosítása az őket érintő államközi együttmüködések megkötésekor. Azt gondolom ugyanis, hogy hosszútávon az erre irányuló lépések nagymértékben elősegíthetik a két állam kapcsolatának mélyülését, a felek közötti bizalom kialakulásának szilárdabb alapokra helyezését. A megbékélés esélyeit jelentősen növelné, ha a folyamatot kulturális megbékélés is kísérné (Iordachi 2001), és a megbékélés kiterjedne az értelmiség szorosabb és intenzívebb együttmüködésére, valamint az ifjúsági csereprogramokat müködtető intézményi struktúra létrehozására (Salat 2004).

\section{Alternativák és kilátások}

A magyar-román államközi viszony és az erdélyi magyarság kapcsolatrendszerének jövőbeli alakulása elviekben többesélyes kimenetelü, az alternatívák felvázolásánál - az elmúlt negyedszázad fejleményei alapján - három tényezőt szükséges figyelembe venni. $\mathrm{Az}$ államközi kapcsolatok alakulásában meghatározónak bizonyult a nyugati mintakövetés és az európai fórumokhoz - különösen a NATO-hoz és az EU-hoz füződő viszony, és a két állam tekintetében a tagállami pozíciók erősítésére tett eltérő kísérletek. A másik tényező a magyar nemzetpolitika fejleményeivel, illetve ennek következményeivel hozható összefüggésbe. Az esettanulmányok összehasonlításának egyik fontos megállapítását a magyar nemzetpolitikában bekövetkező változás képezte, 
miszerint az anyaország a hagyományos felelősség elve és a kisebbségvédelmi mechanizmusok alapján a határon túli közösségek védelme helyett (alapszerződés, státustörvény) az egyének jogainak védelmét - a magyar állampolgárság kiterjesztésével közjogi viszony kialakítását - helyezte előtérbe, melyet a témával foglalkozó szakértők jelentős fejleményként értékeltek.

Figyelembe véve az európai fórumok befolyását és a magyar nemzetpolitika hatását, az államközi kapcsolatok jelenlegi helyzetéből több alternatíva is kirajzolódik. Elsőként számolni lehet a (1) a jelenlegi helyzet fennmaradásával, vagyis a status quo fenntartásával, abból kiindulva, hogy az utóbbi években a hagyományos diplomáciai érintkezések helyett lényeges, mélyreható változások nem történtek a két állam viszonyában és olyan kérdésekben sem alakult ki vita a felek között - a magyar állampolgárság tömeges felvételét nem követték ellenintézkedések - ami jelentős konfliktuspotenciált hordozna magába. Ebben a helyzetben a szereplők saját pozícióik megőrzésére koncentrálnak, így aligha képzelhető el lényegesebb változás államközi szinten és az erdélyi magyarság helyzetében.

(2) Ezzel ellentétben ha az EU-n belül tovább erősödnek a nemzetállami reflexek, mind azt a gazdasági válság és újabban a migrációs válság esetében is láthattuk, akkor kevés esélye van az államközi kapcsolatok mélyülésének, továbbá az arra irányuló kezdeményezéseknek, melyek a történelmi megbékélés irányába tett lépések esélyeit növelnék. Ez az alternatíva Romániában hosszabb távon a nemzetállami felfogást erősíti, amely semmilyen tekintetben nem kedvez az erdélyi magyarság közép- és hosszú távú fennmaradásának és a magyar kisebbség fokozatos marginalizálódását, a meglévő pozíciók feladását, végső soron pedig a magyar intézményrendszer lassú erodálását eredményezi.

Végül az utolsó alternatíva (3) a két állam kapcsolatainak mélyülését feltételezi, abban az esetben, ha az EU-t érintő kihívásokra a döntéshozók szorosabb integrációval válaszolnak. Ennek következményeként elképzelhető, hogy az államközi kapcsolatokban napirendre kerülnek olyan kérdések, melyeket a felek - a benne rejlő tehertételeknek betudhatóan - rendre megkerültek. A kapcsolatok növekvő intenzitása, valamint a magyar kisebbség képviselőinek a tárgyalásokba történő bevonása megteremti azokat a keretfeltételeket, amely egyrészt közelebb visz a történelmi megbékélés létrejöttéhez, másrészt megnyithatná a többség és a kisebbség közötti alkalmi alkuk intézményesítésének útjait, és jó eséllyel készítené elő a magyar kisebbség számára nagy fontossággal bíró - a román állam intézményi reformját is megcélzó - kezdeményezéseket. 


\title{
FÜGGELÉK
}

\section{Kronológiák}

\section{A magyar-román alapszerződés tárgyalásainak kronológiája ${ }^{526}$}

\begin{abstract}
1991
Május 11-én Teodor Meleșcanu külügyi államtitkár Bukarestben átadja Somogyi Ferenc külügyi államtitkárnak az magyar-román alapszerződés (Szerződés a Magyar Köztársaság és Románia között a megértésről, az együttmüködésről és a jószomszédságról, továbbiakban alapszerződés) román tervezetét.
\end{abstract}

November 15-én a magyar külügy is előterjesztette dokumentum-tervezetét, melyet a budapesti román nagykövetnek adtak át.

\section{2}

Január 27-29. között kerül sor a Budapesten a szakértői tárgyalások első fordulójára. A magyar delegáció vezetője Szőcs Ferenc, a Külügyminisztérium IV. Területi Főosztályának vezetője, míg a román delegációt Ion Diaconu, a román külügy Nemzetközi jogi főosztályának igazgatója vezette. A tárgyalások konstruktív légkörben zajlottak, a legnagyobb nézeteltérések a kisebbségi jogok, a határok sérthetetlensége, a gazdasági és kereskedelmi együttmüködéseket érintő kérdésekben jelentkeztek.

Január 31. A román delegáció pozitívan értékelte a szakértői tárgyalások első fordulóját. Albut referens szerint látszik, hogy mindkét fél szeretne eredményeket elérni. Ion Diaconu főosztályvezető a szövegtervezetekröl megjegyezte, hogy „kölcsönös jószándékkal mindkét esetben megtalálható a mindkét felet kielégítő megfogalmazás."

Jeszenszky Géza magyar és Adrian Năstase román külügyminiszter febr. 6-án Madridban találkozott, ahol a készülő alapszerződésröl is egyeztettek. A felek megegyeztek abban, hogy a kétoldalú kapcsolatok fejlesztésének alapja a közvélemény pontos tájékoztatása.

Március 20-23. között a Külügyminisztérium meghívására az RMDSZ delegációja Budapestre utazik. A tárgyalások során a magyar fél ígéretet tett arra, hogy minden az erdélyi magyarságot érintő kétoldalú tárgyalás kapcsán konzultálni fog az RMDSZ vezetőségével, az RMDSZ pedig kidolgozza a magyar-román alapszerződés nemzetiségi cikkelyét.

Április 13. Az RMDSZ Országos elnökségének április 10-i döntése alapján a Szövetség levelet intéz a magyar és a román Kormányhoz, hogy az erdélyi magyarság képviselőit is vonják be az alapszerződés tárgyalásaiba.

Május 18-19. Teodor Meleșcanu külügyi államtitkár tárgyalásokat folytatott Katona Tamás államtitkárral és Jeszenszky Géza külügyminiszterrel Budapesten. Meleșcanu az alapszerződésről megjegyezte, hogy amennyiben a magyar fél nyitottabb lesz a határok sérthetetlensége cikkely kapcsán, úgy a román fél is kész engedményeket tenni a kisebbségi cikkelyben szereplő követeléseknek, ugyanakkor sürgette a szakértői tárgyalások folytatását.

\footnotetext{
${ }^{526}$ A kronológia elkészítésekor a budapesti Külügyminisztérium titkos ügykezelésű iratait vettem alapul. A külügyminisztériumi iratok alapján készült összeállítást a következő kronológiákkal egészítettem ki, melyet zárójelben tüntettem fel: Udvardy Frigyes: A romániai magyar kisebbség történeti kronológiája [http://udvardy.adatbank.transindex.ro/], az MTI hírarchívuma [http://archiv1988tol.mti.hu/Pages/HirSearch.aspx?Pmd=1] illetve Kuszálik Péter: Az RMDSZ tizenöt éve a sajtó tükrében c. kronológiája [http://rmdszkronologia.adatbank.transindex.ro/].
} 
Június 29. Az RMDSZ javaslatára - miszerint az alapszerződés kisebbségi kérdésekkel kapcsolatos tárgyalásokba öket is vonják be - maga a külügyminiszter, Adrian Năstase válaszolt, elutasítva Szövetség kérését, mi több azt is hangsúlyozta, hogy a magyar kisebbség helyzete nem képezheti a kétoldalú megbeszélések tárgyát.

Június végén az RMDSZ levelet intéz a genfi Emberi Jogi Központnak, illetve az ENSZ Kisebbségvédelmi Albizottságának a romániai magyar kisebbség helyzetéről, és a román kormány döntéséről, miszerint képviselőik nem vehetnek részt az alapszerződés tárgyalásain.

Október 2. A bukaresti magyar Kultúrház megnyitója alkalmával Bába Iván helyettes külügyi államtitkár tárgyalt Teodor Meleșcanu külügyminiszterrel. Az alapszerződés kapcsán a felek megegyeztek abban, hogy két vitás cikkelyről külön konzultáción egyeztetnek és október végén újabb szakértöi tárgyalásra kerülhet sor.

December 2. Teodor Meleșcanu a párizsi Külügyi Intézetben tartott előadást a magyar-román kapcsolatokról és az erdélyi magyarság helyzetéről. Az alapszerződésről kifejtette, reális esély van arra, hogy mint a határok sérthetetlensége, mind a kisebbségi jogokkal kapcsolatos cikkely szerepeljen a végső dokumentumban.

December 29. Traian Chebeleu román külügyminisztériumi államtitkár a Curierul National lapban elmondta, hogy a két ország kapcsolatait terhelő problémák lélektani jellegúek. Románia azért ragaszkodik a határok sérthetetlenségéről szóló cikkelyhez, mert elejét szeretné venni mindenféle félreértésnek és belemagyarázásnak.

\section{3}

Január 26-án Teodor Meleșcanu külügyminiszter szakértői tárgyalások előtt fogadta az RMDSZ küldöttségét. Lényegi egyezség nem született - mondta Markó Béla szövetségi elnök - de a gesztust pozitívan értékelték.

Január 26-28 között Bukarestben került sor a magyar-román kapcsolatok problémáit áttekintő Emlékeztető és az alapszerződéssel kapcsolatos szakértői tárgyalások második fordulójára, ahol a felek újabb szövegjavaslatokat adtak át egymásnak a két vitatott cikkelyre vonatkozólag.

Január 29-én Jeszenszky Géza külügyminiszter vezetésével, Kodolányi Gyula államtitkár, Zalatnai István, a HTMH elnökhelyettese, Kelemen András államtitkár, Bába Iván és Peisch Sándor helyettes államtitkárok, Hermann János, Kéry György és Szőcs Ferenc főosztályvezetők, valamint Oberfrank Ferenc a kabinet munkatársa részvételével áttekintették a magyar-román kapcsolatok aktuális kérdéseit. A találkozón döntés született arról, hogy a Külügyminisztérium alakítson ki intézményes kapcsolatot az RMDSZ-el, és az alapszerződés, továbbá a kisebbségi megállapodás ügyében folyamatosan konzultáljanak.

Február 26-án a HTMH meghívására az RMDSZ küldöttsége tárgyalásokat folytatott Budapesten. A magyar fél ígéretet tett arra, hogy nem avatkozik be az RMDSZ politikájába és minden legitim törekvésében támogatja. A felek megegyeztek továbbá abban, hogy törekednek az intézményesített kapcsolatok kialakítására.

Március 20-án Gyulán, (Liviu Rebreanu mellszobrának felavatása alkalmából) Jeszenszky Géza és Teodor Meleșcanu külügyminiszterek nem-hivatalos keretek között áttekintették a kétoldalú kapcsolatok függőben lévő kérdéseit. A magyar felvetésekre (kolozsvári főkonzulátus, az aradi Szabadságszobor helyreállítása, határátkelöhelyek) érdemi román válasz nem volt. Meleșcanu az alapszerződés megkötésének fontosságát hangsúlyozta, és ennek hatáskörébe utalta a kisebbségi jogok kérdését is.

Június 5-én nem hivatalos keretek között Budapesten megrendezett NATO szemináriumon tárgyalt Jeszenszky Géza és Teodor Meleșcanu. Mindkét fél elkötelezett az alapszerződés aláírására, és Budapest támogatja Románia ET-csatlakozását, ha a kisebbségek helyzete rendeződik. 
Augusztus 31. Budapesten folytatódott a szakértői tárgyalások harmadik fordulója. A felek újabb szövegjavaslatokról egyeztettek, konkrét eredmények nélkül. Nem sikerült előre lépni a kolozsvári főkonzulátus megnyitása és az aradi Szabadság-szobor ügyében sem.

Szeptember 15-19. között került sor Jeszenszky Géza első, bukaresti külügyminiszteri látogatására. Bukarestben találkozott Ion Iliescu államfővel, Nicolae Văcăroiu miniszterelnökkel és Teodor Meleșcanu külügyminiszterrel. A román fél által „történelminek” nevezett találkozó során Jeszenszky az alapszerződésről elmondta, hogy elfogadására csak akkor van lehetőség, ha azt a magyar közvélemény és az erdélyi magyarság elfogadja.

\section{4}

Március 3. Marcel Dinu külügyminiszteri államtitkár találkozót kezdeményezett Rudas Ernő bukaresti nagykövettel, a KEK-be való belépés támogatása kapcsán. Az államtitkár további tárgyalásokat javasolt az alapszerződés tárgyában, mi több emlékeztette a nagykövetet, hogy az átadott román javaslatra a magyar fél még nem válaszolt.

Április 13. Nem tapasztalható elörelépés az alapszerződés tárgyalásait illetően, így a felek a sajtón keresztül üzennek egymásnak, számon kérve azt, hogy az átadott szövegjavaslatokra nem érkezett válasz. Mircea Geoană külügyi szóvivő felvetéseire Herman János külügyi szóvivő, helyettes államtitkár válaszolt.

Június 29-én Tabajdi Csaba a Miniszterelnöki Hivatal politikai államtitkára kezdeményezésére RMDSZ küldöttség utazott Budapestre. A találkozón részt vett Markó Béla elnök, Takács Csaba ügyvezető elnök, Frunda György szenátor, Varga Attila képviselő, Bakk Miklós szakértő, illetve Szőcs Ferenc főosztályvezető. A tárgyalásokon érintették az RMDSZ viszonyát az alapszerződéshez, a dokumentum szerkezeti elemeit, tartalmi vonatkozásait, továbbá ennek garanciális elemeit. Az RMDSZ vezetői szerint szükséges az alapszerződés aláírása, de nem mindenáron, éppen ezért nem is tartották indokolnak a folyamat felgyorsítását.

Július 7-én Varsóban találkoztak a kelet-európai államok külügyminiszterei az amerikai külügyminiszterrel, ahol a regionális együttmüködésekről és amerikai beruházási lehetőségekről egyeztettek. Meleșcanu az alapszerződés megkötését fontos célnak nevezte, ezzel ugyanis rögzítené a két ország, hogy nincsenek területi követelései egymással szemben, mi több a kisebbségi jogok is biztosítva vannak.

Július 16. Triesztben, a Közép-európai Kezdeményezés csúcsértekezletének keretében Horn Gyula miniszterelnök tárgyalásokat folytatott Nicolae Văcăroiu miniszterelnökkel. A találkozón részt vett a két ország külügyminisztere is. Az alapszerződés kapcsán a felek egyetértettek abban, hogy ezt mihamarabb alá kell írni, a dokumentumnak viszont biztosítania kell a kisebbségi jogokat.

Július 20-án a Parlamentben fogadta Horn Gyula miniszterelnök, Kovács László miniszterelnök és Tabajdi Csaba államtitkár Markó Bélát, az RMDSZ elnökét. A felek ragaszkodtak ahhoz, hogy az alapszerződésben konkrét garanciák szerepeljenek a kisebbségi kérdés rendezését illetően.

Július 29-én Markó Béla szövetségi elnök, Takács Csaba ügyvezető elnök, Frunda György szenátor, Varga Attila képviselő és Bakk Miklós, a Politikai Főosztály referense Budapestre utazott Tabajdi Csaba államtitkár meghívására. A megbeszélésen a felek egyetértettek abban, hogy az alapszerződésnek garanciákat kell tartalmaznia a romániai magyarság helyzetének rendezésével kapcsolatban, és a kisebbségi cikkelyekbe bele kell foglalni az RMDSZprogramban szereplö alapelveket, a különbözö autonómiaformákat.

Augusztus 8-án az RMDSZ szakértői bizottsága (Bakk Miklós, Varga Attila, Béres András) tárgyalásokat folytatott a HTMH képviselőivel az alapszerződés tárgyában. A konzultáció a július 29-i találkozó folytatása ahol a magyar féllel történő tárgyalás eredményeként az 
Ügyvezető Elnökség négy munkacsoport elemezni (költségvetési támogatás, ösztöndíjrendszer, önkormányzati együttműködés, gazdasági együttmüködés) megalakítását kezdeményezi.

Augusztus 16-án Teodor Meleșcanu fogadta Markó Bélát, akivel a romániai magyarságot érintő problémákról beszélgettek. Abban egyeztek meg, hogy hamarosan konzultatív tanácskozást tartanak az alapszerződés kisebbségi cikkelyéről.

Augusztus 22. Romániából Magyarországra utazott Max van der Stoel, az EBEÉ Kisebbségi Főbiztosa. A román és a magyar féllel folytatott tárgyalásokon az alapszerződés mielőbbi megkötését szorgalmazza.

Augusztus 24-én találkozóra került sor az RMDSZ (Takács Csaba ügyvezető elnök, Bodó Barna politikai alelnök) és a HTMH képviselői közötti egyeztetésre. A találkozón továbbá részt vett Tabajdi Csaba államtitkár is.

Augusztus 29-én negyedik alkalommal találkoznak a magyar Kormány és az RMDSZ között. A találkozón a kormány részéről Tabajdi Csaba államtitkár és a HTMH főosztályvezetője BálintPataki József, míg az RMDSZ részéről Tőkés László tiszteletbeli elnök, Takács Csaba ügyvezető elnök és Bodó Barna politikai elnök. A találkozón az RMDSZ által elkészített állásfoglalását mutatta be, mely az alapszerződés előkészítéséhez nyújt kisebbségvédelmi szempontokat.

Szeptember 2-án Teodor Meleșcanu külügyminiszter az RMDSZ küldöttségével tárgyalt, ahol a Szövetség bemutatja állásfoglalását az alapszerződéssel kapcsolatban.

Szeptember 5. Teodor Meleșcanu külügyminiszter Budapesten tárgyal Göncz Árpád köztársasági elnökkel, Horn Gyula miniszterelnökkel és Kovács László külügyminiszterrel. A tárgyalások során a magyar fél jelezte, hajlandók elfogadni a határklauzula román javaslatát, de ragaszkodnak a kisebbségi jogok garantálásához, így az alapszerződést egy kisebbségvédelmi megállapodás egészítené ki.

Szeptember 29. Douglas Hogg brit államminiszter Bukarestbe látogatott. Hogg az alapszerződés mielőbbi kidolgozására ösztönözte a román felet, rámutatva arra, hogy a román fél nemzetiségi kérdésekben engedményeket kell tegyen.

Október 6-i keltezéssel Hargita és Kovászna megye tanácselnökei (Sántha Pál Vilmos és Orbán Árpád) levelet intéz Horn Gyula miniszterelnökhöz, és az RMDSZ elnökéhez, melyben kérik, hogy az alapszerződésről folytatott tárgyalásokba és a konzultációs folyamatokban kapjon helyet a két megye két-három küldöttje, mint a székelység szószólói.

Október 13-án az Országgyülés elnökének, Gál Zoltánnak a meghívására Budapestre utaztak az RMDSZ képviselői és szenátorai, ahol találkoztak Tabajdi Csaba államtitkárral, a HTMH vezetőivel. A megbeszélésen napirenden szerepelt az alapszerződés, a diplomák honosítása, az egyházi vagyon visszaszerzésének kérdése is.

November 2-án Szőcs Ferenc föosztályvezető bekérette Románia budapesti nagykövetét Ioan Doncát és tájékoztatta az aznap, Bukarestben átadott magyar jegyzék tartalmáról, és az alapszerződés tárgyalásainak újraindításáról.

November 4. Az EU-misszióvezetője szerint vontatottan haladnak az alapszerződés tárgyalásai, ennek kétoldalú keretben való tartása nem szolgálja a tényleges rendezést. Az erdélyi magyarság követeléseiről kifejtette, hogy erre igen nehéz lesz nyugati szövetségeseket keresni, erre a román demokrácia kiteljesedése és a helyi autonómia erősödése hozhat megoldást.

November 16-17. között újabb szakértői tárgyalásokra került sor. A román delegációt Dumitru Ceauşu míg a magyart Szénási György vezette. A tárgyalások középpontjában a két vitás cikkely állt. A román fél szerint a magyar kisebbségi cikkely túlsúlyos, olyan másodlagos kérdéseket is szabályoz (kétnyelvü feliratok), melyeknek nincs helye államközi szerződésekben. Érvelésében Ceaușu arra utalt, hogy az EU egy olyan alapszerződést vár, melyben a kisebbségi jogok minimumát biztosítjuk. A magyar fél megerősítette, hogy az alapszerződést nem célnak, 
hanem eszköznek tekinti és az EU sem egy alapszerződést vár a két államtól, hanem a létező problémák megoldását.

November vége elkészült a magyar Kormány Kisebbségvédelmi Megállapodása (Egyezmény a Magyar Köztársaságban élő román nemzeti kisebbség és a Romániában élő magyar nemzeti kisebbség, valamint a hozzájuk tartozó személyek jogainak biztosításáról), melynek kidolgozásában a HTMH és az RMDSZ is részt vett.

December 5-6. között Budapesten kerül sor az EBEÉ államföinek csúcstalálkozójára. A találkozón Ion Iliescu államfő Horn Gyulával tárgyalt és megegyeztek abban, hogy folytatódnak az alapszerződés tárgyalásai.

\section{5}

Markó Béla RMDSZ elnök január 19-én találkozót kezdeményezett Teodor Meleșcanuval, melyen részt vett Takács Csaba ügyvezető elnök is. Az RMDSZ vezetői ismertették álláspontjukat az alapszerződéssel kapcsolatos szakértői tárgyalásokról.

Január 23-án Viorel Hrebenciuc kormányfőtitkár Budapesten tárgyalásokat folytatott Tabajdi Csabával a kétoldalú kapcsolatokról. A kormányfötitkárral való találkozót Göncz Árpád köztársasági elnök és Horn Gyula miniszterelnök lemondta, így tiltakozva azon fenyegetések ellen, melyek az RMDSZ betiltását helyezték kilátásba.

Február 1-én Strasbourgban Teodor Meleșcanu és Kovács László külügyminiszterek aláírták az európai kisebbségvédelmi keretegyezményt. A felek megállapodtak abban, hogy felgyorsítják az alapszerződés tárgyalásait.

Február 7-8. között Budapesten folytatódtak a szakértői tárgyalások. A magyar delegációt Szénási György föosztályvezető, a románt pedig Dumitru Ceaușu vezette. A tárgyalásokon a felek a két vitatott cikkelyt tekintették át, a magyar küldöttség itt mutatja be az alapszerződést kiegészítő kisebbségvédelmi megállapodást.

Február 21-22 között újabb szakértői tárgyalásokra kerül sor Bukarestben. A felek véglegesítik a határok sérthetetlenségére vonatkozó területi cikkelyt, azonban a román fél ellenzi a kisebbségvédelmi megállapodás megkötésének gondolatát.

Február 25. Az RMDSZ Szövetségi Képviselők Tanácsa (SZKT) határozatot adott ki, amelyben amellett foglalnak állást, hogy az alapszerződésben integrálni kell mindkét államban élő kisebbségek képviselőinek véleményét. Az alapszerződés részletes kisebbségvédelmi megállapodást is kell tartalmazzon, amely garantálja az autonómia jogát.

Március 1-én az RMDSZ küldöttség (Markó Béla, Tőkés László, Takács Csaba, Dézsi Zoltán és Frunda György) Budapesten tárgyalt Tabajdi Csaba államtitkárral az alapszerződésről.

Március 3-án a Magyarok Világszövetségének székházában tárgyaltak a határon túli magyar szervezetek és pártok. A résztvevők hangsúlyozták, hogy a magyar Kormány nem hagyhatja figyelmen kívül a kisebbségi közösségek véleményét, egyúttal ellenezték az alapszerződés március végi aláírását is.

Március 6-7. A budapesti szakértői tárgyalásokon a felek a kisebbségi cikkely kivételével egyeztetik az alapszerződés szövegét, az ET 1201 sz. ajánlás kapcsán, az előző tárgyalási fordulókhoz hasonlóan kevés egyetértés mutatkozott.

Március 7-én Marcel Dinu államtitkár meghívására Bukarestbe látogatott Somogyi Ferenc közigazgatási államtitkár. Somogyi Ferenc kifejtette, hogy a magyar fél a nemzetközi standardoknak megfelelően kívánja megfogalmazni az alapszerződés kisebbségi cikkelyét. A román fél válaszában rámutatott arra, hogy csak olyan megfogalmazást tudnak elfogadni, „amihez a kormányzat a szükséges belső feltételeket meg tudja teremteni.” Az álltitkár a találkozóról az RMDSZ-t is tájékoztatta. A Szövetség vezetői kifejtették, hogy az alapszerződést csak az ET 1201 sz. ajánlás szerepeltetésével tudják elfogadni. 
Március 8-án Teodor Meleșcanu külügyminiszter a parlamentben tájékoztatta a két ház külügyi bizottságát az alapszerződés tárgyalásairól. A találkozón az RMDSZ részéről Markó Béla elnök, Borbély Imre, Pécsi Ferenc és Szilágyi Zsolt képviselők vettek részt. A szövetségi elnök beszámolója szerint a találkozónak nem is annyira tájékoztató jellege volt, mint inkább az, hogy a külügyminiszter összpárti támogatást szerezzen az ET 1201 sz. ajánlás elutasításához.

Március 14-15. között Bukarestben folytatódnak a szakértői tárgyalások. A magyar delegációt Somogyi Ferenc államtitkár vezeti, de a küldöttségnek tagja Lábody László, a HTMH elnöke is.

Március 16-án Budapesten, Teodor Meleșcanu külügyminiszter találkozott Kovács László külügyminiszterrel. Mindkét fél pozitívan értékelte a szakértői tárgyalásokon tapasztalható elörelépéseket, azonban a fennálló véleménykülönbségekre hivatkozva megállapították, hogy a szövegtervezet véglegesítése és aláirása az Európai Stabilitási Egyezmény zárókonferenciájáig nem lehetséges.

Március 20-21. között Párizsban az EBESZ konferenciáján elfogadják a Balladur-terven alapuló Európai Stabilitási Egyezményt. Ebben az időszakban több szakértői tárgyalási fordulóra is sor kerül, ugyanis Románia eredményeket szeretett volna felmutatni az Európai Unióhoz való hivatalos tagfelvételi kérelem benyújtása előtt. A konferencia elötti napon Horn Gyula Miniszterelnök és Vladimír Mečiar szlovák kormányfö aláírta a magyar-szlovák alapszerződést.

Március 27-én Budapesten, Horn Gyula fogadta az RMDSZ elnökét, Markó Bélát. Horn tájékoztatta az RMDSZ elnökét arról, hogy folytatódnak az alapszerződéssel kapcsolatos szakértői tárgyalások, de a magyar kormány ragaszkodni fog ahhoz, hogy a szerződésben szerepeljenek az európai kisebbségvédelmi normák.

Április 10-én Luxemburgban tartották meg az EU és a társult kelet-közép-európai államok külügyminisztereinek találkozóját. Az értekezleten tárgyalt Kovács László magyar és Teodor Meleșcanu román külügyminiszter is, akik a szakértői tárgyalások folytatásában állapodtak meg. Április 12-én Kolozsváron, az MSZP küldöttsége konzultált az RMDSZ vezetőségével. Csintalan Sándor, a küldöttség vezetője kijelentette, hogy az ET 1201 sz. ajánlásától nincs visszalépés.

Április 20-án Teodor Meleșcanu fogadta az SZDSZ delegáció vezetőjét, Eörsi Mátyást, akivel kisebbségi problémákról és az alapszerződés aktuális tárgyalásairól egyeztettek. A külügyminiszter igyekezett meggyőzni az SZDSZ-es politikust, hogy a kisebbségi törvény elkészítése és elfogadása, nagyon sok, az alapszerződésben tárgyalt kisebbségi kérdést megoldana.

Április 25-26. között szakértői tárgyalásokra kerül sor Budapesten. A megbeszélések vontatott ütemben haladtak, a román fél továbbra is hevesen ellenezte az ET 1201-es ajánlás szerepeltetését a tervezetben, utalva arra, hogy ezt sem a román törvényhozás, sem a közvélemény nem fogadná el.

Május 23-án az MDF elnöke, Lezsák Sándor erdélyi körútján Tökés László püspökkel, az RMDSZ tiszteletbeli elnökével és Markó Béla szövetségi elnökkel. Az MDF elnöke fontosnak tartotta, hogy az RMDSZ feje fölött ne hozzon a magyar kormány döntéseket, és az alapszerződés aláírásának legyen előfeltétele az anyanyelvü oktatás megoldása illetve az egyházi javak visszajuttatása.

Június 6-án az alapszerződésről folytatott miniszteri értekezlet megállapítja, hogy folytatni kell a tárgyalásokat a román féllel, azonban tartalmilag a szerződés nem lehet gyengébb, mint a magyar-szlovák alapszerződés, és el kell érni, hogy az anyanyelvhasználatra, a vegyesbizottságra vonatkozó magyar javaslat, továbbá az ET 1201 sz. ajánlása bekerüljön a tervezetbe. 
Június 8-án Markó Béla az RMDSZ elnöke megbeszélést folytatott Ion Iliescu államfővel. A találkozón részt vett Traian Chebeleu nagykövet, elnöki szóvivő is. A több mint két órás beszélgetésen több fontos kérdést is érintettek, így a tanügyi törvénytervezetet, mely a Szövetség álláspontja szerint visszalépést jelent az eddigi helyzethez képest. Elfogadása esetén - jelezte Markó Béla - lehetetlenné válik a magyar-román közeledés és az alapszerződés ügyének elősegítése.

Június 16. Franciaország ösztönzi a magyar felet az alapszerződés aláírására. Ez a párizsi Magyar Nagykövetség egyik diplomatájának Paul Poudadeval, a francia Külügyminisztérium európai ügyekért felelős igazgatójával való beszélgetésből derült ki.

Június 19-20. között a szakértői tárgyalások újabb fordulójára került sor Bukarestben. A tárgyalásokon a kisebbségi cikkely bekezdéseit vitatták meg. A román fél jelezte, számukra elfogadhatatlan a kisebbségi Vegyesbizottság felállítása, helyette az ellenőrzési mechanizmust kormány-tisztiviselői szintü konzultációkra utalnák át, míg az ET 1201 sz. ajánlása nem kerülne említésre a szerződésben: ezt egy külügyminisztériumi levélváltásban kapna helyet az EBESZ és az ET egyéb releváns dokumentumaival, szükítő értelmezéssel. A szükítő értelmezés azt jelentené: mindenfajta etnikai alapú autonómia, a kollektív jogok és az állampolgárok csoportjainak speciális státusza is kizárt.

Június 20. A szakértői tárgyalások végén Marcel Dinu külügyi államtitkár fogadta Szénási Györgyöt, a magyar delegáció vezetőjét. Szénási elmondta, hogy az 1201-es ajánlás jogi normaként való elfogadtatása minimális igény. Az államtitkár válaszában utalt arra, hogy továbbra is elkötelezettek az alapszerződés megkötése mellett, de az etnikai elvű autonómiát a román társadalom nem fogadná el.

Június 27-én Cannes-ban tartották az EU csúcstalálkozóját, melyre a társult országok vezetőit is meghívták. A találkozón Ion Iliescu és Horn Gyula az alapszerződésről elmondta, hogy ezt igyekeznek a július végi külügyminiszteri találkozó után véglegesíteni.

Július 5. Amerikai kezdeményezésre, háromtagú ET delegáció érkezik Bukarestbe azzal a céllal, hogy szövegszerü javaslatokat tegyen az 1201 sz. ajánlás szerepeltetéséről az alapszerződésben.

Július 13. A FIDESZ-Magyar Polgári Párt memorandumot intézett Horn Gyula miniszterelnökhöz, amelyben konkrét feltételekhez kötik az alapszerződés támogatását.

Július 19-20. között Teodor Meleșcanu meghívására Bukarestbe látogatott Kovács László külügyminiszter. A találkozón a kétoldalú kapcsolatok eddigi eredményeit és a további aktuális feladatokat beszélték meg. Az 1201 -es ajánlásra vonatkozó magyar felvetésre, miszerint a felek az ET PKGY értelmezését tekintsék irányadónak, nem érkezett érdemi román válasz. Másnap Kovács László az RMDSZ vezetőségével egyeztetett, kifejtette, hogy a két fél között kisebbségi kérdésekben továbbra is elvi különbségek vannak.

Ion Iliescu elnök augusztus 30-án, a II. bécsi döntés 55. évfordulóján szervezett ünnepségen Magyarország és Románia közötti történelmi megbékélésre vonatkozó kezdeményezést intézett a nyilvánossághoz.

Szeptember 3-án jelent meg a NATO tanulmány, amely a taggá válás feltételeként jeleníti meg az államok közötti területi és etnikai viták békés rendezését, az EBESZ alapelveivel összhangban.

Szeptember 22-én Teodor Meleșcanu külügyminiszter fogadta Szőcs Ferenc bukaresti magyar nagykövetet és átnyújtotta a magyar-román megbékélésre vonatkozó három okmánytervezetet (Politikai szándéknyilatkozat, Kétoldalú egyezmény, Kisebbségi viselkedési kódex).

Október 7-én Varsóban tartották a Közép-európai Kezdeményezés konferenciáját. Nicolae Văcăroiu köszönetét fejezte ki Horn Gyulának, amiért támogatta Románia taggá válását. Az alapszerződésről folytatott tárgyalásokról megállapították, hogy azok holt pontra jutottak, de a közeljövőben tárgyalásokat indítanak a román megbékélési dokumentumokkal kapcsolatosan. 
November 3-án Budapesten, Somogyi Ferenc államtitkár tárgyalásokat folytatott Marcel Dinu külügyi államtitkárral Ion Iliescu elnök történelmi megbékélést szorgalmazó nyilatkozatáról és a nyilatkozatból ihletődött három dokumentum céljáról és szerepéről.

December 16-án Madridban az EU csúcstalálkozóján Horn Gyula megbeszélést folytatott Ion Iliescu államfővel. A felek abban egyeztek meg, hogy márciusig véglegesítik az alapszerződést és a megbékélési nyilatkozat keretében átadott három dokumentumot.

\section{6}

Február 13-án újraindultak a tárgyalások az alapszerződés tárgyában. Somogyi Ferenc államtitkár Bukarestben találkozott Marcel Dinu államtitkárral, Teodor Meleșcanu külügyminiszterrel és Ion Iliescu államfővel. A találkozók utáni sajtótájékoztatón Somogyi Ferenc bejelenti, hogy a német-francia mintára alapítványt hoznak létre a két ország fiataljai közötti kapcsolatok megerősítése és fejlesztése érdekében.

Február 29-én Bukarestben folytatódnak a szakértői tárgyalások. A találkozón a felek az alapszerződés vitás pontjai mellett első alkalommal tekintették át a megbékélési nyilatkozaton alapuló három dokumentumot (Politikai szándéknyilatkozat, Kétoldalú egyezmény, Kisebbségi viselkedési kódex).

Március 4-én a Teodor Meleșcanu külügyminiszter találkozót kezdeményezett az RMDSZ vezetőségével. A találkozón az alapszerződésről és a megbékélési dokumentumokról egyeztettek. Markó Béla a találkozó után elmondta, hogy az RMDSZ álláspontja változatlan, az alapszerződésnek tartalmaznia kell a romániai magyarság helyzetének rendezéséhez szükséges elveket és megoldásokat, beleérte az ET 1201-es ajánlását is.

Március 12-13. között újabb szakértői tárgyalásokra került sor Budapesten. Szénási György és Dumitru Ceauşu vezetésével a felek az alapszerződés és a megbékélési dokumentumokat tekintették át, azonban konkrét elörelépésről nem beszélhetünk.

Április 11-én Horn Gyula miniszterelnök Budapesten fogadta Markó Bélát és Takács Csabát. Az RMDSZ vezetői az aktuális romániai politikai helyzetről számoltak be és megerősítették álláspontjukat az alapszerződéssel kapcsolatosan. A Szövetség elnöke egy olyan találkozót javasolt, ahol a magyarországi pártok, a határon túli szervezetek képviselői a magyarság helyzetéről és jövőképéről egyeztetnének.

Május 24-én Salzburgban, az Európai Mủvéseti Fórumon találkozott Kovács László magyar és Teodor Meleșcanu román külügyminiszter. Kovács László román kollégájának elmondta, hogy Magyarország továbbra is ragaszkodik az 1201 sz. ajánlás szerepeltetéséhez. A felek abban állapodtak meg, hogy júniusban folytatódnak a szakértői egyeztetések.

Július 4-5. között a Miniszterelnöki Hivatal és a HTMH szervezésében sor kerül a kormány, a parlamenti pártok és a határon túli magyar szervezetek találkozójára. A sokat ígéró csúcstalálkozó záródokumentuma leszögezi, hogy az anyaország és a nemzet jövője szempontjából meghatározó fontosságú a mielőbbi euroatlanti integráció és összehangolt támogatásban részesítik a szomszédos országokban élő magyar közösségek autonómiatörekvéseit.

Augusztus 11. Horn Gyula miniszterelnök az MTV müsorában arról nyilatkozott, hogy a megegyezés küszöbén állunk a magyar-román alapszerződés megkötésében, ugyanis a magyar fél elfogadta a román külügy az ET 1201 sz. ajánlásának értelmezését.

Augusztus 13-14-én államtitkári konzultációt tartottak Bukarestben. A tárgyalásokat követő sajtótájékoztatón Somogyi Ferenc és Marcel Dinu delegációvezetők bejelentették, hogy megegyezés született az ET 1201 sz. ajánlásáról, így elhárultak az akadályok az alapszerződés véglegesítése előtt. 
Augusztus 15. A magyar ellenzéki pártok nyilatkozatokban bírálták a kormányt a magyar-román alapszerződés elfogadott változatáért.

Augusztus 16-án ülésezett az RMDSZ Operatív Tanácsa (Csávossy György, Dézsi Zoltán, Kötő József, Markó Béla, Szabó Károly, Takács Csaba, Tőkés László, Vida Gyula), amely megfogalmazta fenntartásait az alapszerződéssel kapcsolatosan. Noha a szerződés sok pozitív elemet tartalmaz, az autonómiára és a kollektív jogokra való utalást kiiktatták. Nem szerepel kitétel továbbá az egyházi ingatlanok visszaszolgáltatásáról és a végrehajtás garanciáinak szabályozásáról sem. Ennek tisztázására az RMDSZ konzultációt javasol a magyar és a román féllel.

Augusztus 19-én találkoznak a szlovákiai magyar pártok és az RMDSZ vezetői. A tárgyaláson arra a megállapításra jutottak, hogy az alapszerződés tárgyalásai nem tekinthetők lezártnak, ugyanis ez szemben áll a magyar kormány kötelezettségvállalásával, amelyet aláírt a júliusi magyar-magyar csúcson.

Augusztus 21-én Szénási György külügyi főosztályvezető és Marcel Dinu külügyi államtitkár irányításával Budapesten véglegesítik a magyar-román alapszerződés szövegét. Kovács László külügyminiszter sajtótájékoztatón jelentette be, hogy szeptemberben írják alá az alapszerződést, melynek tartalmával az SZDSZ is egyetért. A külügyminiszter elmondta azt is, hogy az alapszerződés tárgyában nem lesz újabb magyar-magyar csúcs. A FIDESZ, az MDF, az FKGP, a KDNP a külügyi bizottság rendkívüli ülésének összehívását javasolja.

Augusztus 26-án Budapesten, az RMDSZ küldöttségét (Markó Béla, Tőkés László, Takács Csaba) fogadta Horn Gyula miniszterelnök, Tabajdi Csaba és Somogyi Ferenc államtitkárok. A beszélgetésen nem közeledtek a felek álláspontjai, az RMDSZ kifejtette ellenvetéseit a szerződéssel kapcsolatban. A magyar fél elmondta, hogy részükről lezárultak az alapszerződés tárgyalásai és a román féllel nem szándékoznak újabb egyeztetéseket kezdeményezni.

Augusztus 27. A KDNP kezdeményezésére összegyült a szükséges aláírás az Országgyülés rendkívüli ülésszakának megnyitásához. A kezdeményezők azt szerették volna elérni, hogy a kormány az alapszerződést csak az Országgyülés előzetes hozzájárulása alapján írja alá.

Augusztus 27. A Romániai Magyar Történelmi Egyházak Elöljáróinak Állandó Értekezlete állásfoglalásban ellenezte az alapszerződésnek az aláirását. Véleményük szerint az egyházi javak maradéktalan visszaszolgáltatása jogos követelése a történelmi egyházaknak, erről azonban az alapszerződés nem tartalmaz konkrét intézkedéseket.

Augusztus 29. Ion Iliescu államfő a Cotrocen-i palotába hívta össze a parlamenti pártok vezetőjét. A nacionalista pártok élesen bírálták az RMDSZ-t és az alapszerződést, mely szerintük túl nagy engedményeket tesz a magyar kisebbségnek. A PDSR és a CDR támogatja az alapszerződés aláirását.

Augusztus 30-án ülésezett az Országgyülés külügyi bizottsága, amelyen részt vett Dézsi Zoltán az SZKT elnöke és Tokay György képviselő. Kovács László ismertette a kormány álláspontját, miszerint az alapszerződést meg fogják kötni, jelenleg az aláíás helyszínéről folynak az egyeztetések.

Szeptember 3-án az Országgyülés maratoni vita keretében vitatta meg az ellenzék indítványát. A rendkívüli ülésszakon elvetették azt a javaslatot, hogy Markó Béla felszólalhasson, ennek következtében Tőkés Lászlóval csak meghívottként vehettek részt a vitán.

Szeptember 4-én, Pápán Markó Béla, az RMDSZ elnöke megnyitotta a magyar-magyar csúcsot, amelyen azonban csak az ellenzéki pártok képviselöi vettek részt. A találkozón ismertették Tökés László Illúziók nélkül c. állásfoglalását és elítélték a magyar kormány engedékenységét.

Sorin Ducaru külügyi szóvivő sajtótájékoztató keretében jelentett be, hogy az alapszerződést szeptember 16-án, Temesváron fogják aláíni. 
Szeptember 16-án Temesváron, Ion Iliescu államfö, Teodor Meleșcanu külügyminiszter, Kovács László Külügyminiszter, Tabajdi Csaba és Somogyi Ferenc államtitkárok jelenlétében Horn Gyula és Nicolae Văcăroiu miniszterelnökök aláírták a magyar-román alapszerződést. Az RMDSZ-t Dézsi Zoltán, az SZKT elnöke képviselte. Magyarországon az ellenzék több városban is tüntetést szervezett, az alapszerződés ratifikációja ellen, az Országgyülésben, napirend előtti felszólalásban az ellenzék közös nyilatkozatban ítélte el az alapszerződést.

Szintén szeptember 16-án az Országházban az ellenzéki frakciók vezetői közös nyilatkozatban ítélték el az alapszerződés aláírását, azzal érvelve, hogy a kormány a határon túli magyarság fenntartásai ellenére írta alá az alapszerződést.

Az alapszerződésről történő megegyezést és ennek aláírását üdvözölte Bill Clinton az Egyesült Államok elnök, Jacques Chirac francia államfö, John Major brit kormányfö, Javier Solana, a NATO főtitkára, Peter Leuprecht, az Európa Tanács helyettes footitkára, a német, a portugál továbbá más európai államok külügyminisztériumai. Több vezető újság méltatta a szerződés aláírását, így a International Herald Tribune, The New York Times, a Frankfurter Allgemeine Zeitung és a Handelsblatt.

Szeptember 26-án a Képviselőház, majd október 3-án a Szenátus is ratifikálta a magyar-román alapszerződést. Ezt követően október 10-én Ion Iliescu államfő is aláírta a dokumentumot.

December 10-én az Országgyülés ratifikálta a magyar-román alapszerződést. A név szerinti szavazáson az alapszerződés mellett 249 képviselő szavazott igennel, 53-an ellene, míg 12 képviselö, köztük Eörsi Mátyás is tartózkodott.

December 27-én Budapestre érkezett Adrian Severin román külügyminiszter. Tárgyalásokat folytatott Göncz Árpád köztársasági elnökkel, Horn Gyula miniszterelnökkel, Gál László házelnökkel és Kovács László külügyminiszterrel, akivel kicserélték az alapszerződés ratifikációs okmányait. 


\section{9}

November 11-én megkezdődött Budapesten a MÁÉRT második ülése, amelyen a legnagyobb vitákat kiváltó kérdésnek a határon túli magyarok jogállása bizonyult, amit az MSZP és az SZDSZ támadott leginkább, noha elfogadták, hogy a határon túli magyarok megkülönböztetett státust kell élvezzenek. A résztvevők Magyarország és a határon túli magyarság együttmüködésére hivatkozva felkérték a kormány képviselőit, hogy vizsgálják meg a határon túli magyarok magyarországi jogállásának lehetséges törvényi szabályozását.

\section{0}

Január 14-én kolozsvári előadásán Szabó Tibor a HTMH elnöke kifejtette, hogy a magyar kormány augusztus végéig kidolgozza azt a törvénycsomagot, „amelynek célja, megnyugtató megoldást keresni a határon túli magyarok identitásának megőrzésére, szülőföldjükön maradásukra."

Február 28. Németh Zsolt külügyi államtitkár a külügyi bizottság ülésén a határon túli magyarság politikai és gazdasági helyzetének javulásáról tájékoztatta a képviselőket. Felszólalásában részleteket közölt a státustörvény-tervezetéröl, amely részben kerettörvényjellegü, részben konkrét intézkedéseket tartalmaz, elfogadását követően pedig jogi viszony létesül Magyarország és a határon túli magyarok között.

Március 21. Az Országgyülés különbizottsága által előkészített, a határon túli magyarokra vonatkozó politikai feladatok végrehajtásáról szóló jelentést vitatta meg a parlament. Az előterjesztő, a KÜM politikai államtitkára Németh Zsolt elmondta, hogy az utóbbi évtizedben erősödött a magyar kisebbség beolvadása és elvándorlása, de reálisan javultak identitásuk megőrzésének feltételei. Ehhez hozzájárul a készülő státustörvény, amely kedvező fogadtatásra számíthat az euroatlanti közösségben.

Március 22. A MÁÉRT jogi és önkormányzati szakbizottságának budapesti ülésének résztvevői a státustörvény megalapozó elvekről tárgyaltak. Az RMDSZ képviseletében Varga Attila vett részt az ülésen, aki az RMDSZ álláspontját közvetítve kijelentette, hogy a törvény azokra a határon túli területeken élő magyarokra kell kiterjedjen, amelyek egykor Magyarországhoz tartoztak.

Május 5. Szabó Tibor, a HTMH elnöke kolozsvári előadásán a státustörvényröl elmondta, hogy az előkészítés fázisában van, a szakbizottságokban már megfogalmazódtak azok a javaslatok, melyek a törvény fontosabb elemeit tartalmazzák: ezek kiterjednek a munkavállalásra, a szociális és egészségügyi szolgáltatásokra, az oktatásra, valamint utazási, diák- és pedagóguskedvezményekre.

Május 17-én a külügyi bizottságban Németh Zsolt ismertette a magyarországi pártok és a határon túli szakértől által kidolgozott javaslatcsomagot. $\mathrm{Az}$ alapvető kérdésekben határátlépés, ingyenes egészségügyi ellátás és a korlátlan munkavállalási lehetőség konszenzus volt az előkészítők között. A határon túli szervezetek javasolták, hogy a tervezetbe kerüljön bele a vállalkozások támogatása, a hitelfelvételi lehetőségek szélesítése, valamint a magyar állampolgárokéval azonos mértékủ illetékrendszer bevezetése.

\footnotetext{
${ }^{527}$ A kronológia elkészítésekor a Udvardy Frigyes: A romániai magyar kisebbség történeti kronológiáját (http://udvardy.adatbank.transindex.ro/), az MTI hírarchívumát (http://archiv1988tol.mti.hu/Pages/HirSearch.aspx?Pmd=1), az RMDSZ Tájékoztatót, illetve Kuszálik Péter: Az RMDSZ tizenöt éve a sajtó tükrében c. kronológiáját (http://rmdszkronologia.adatbank.transindex.ro/) használtam fel.
} 
Május 23-25. Az SZDSZ erdélyi körútján vett részt Magyar Bálint pártelnök, Szent-Iványi István, a Parlament külügyi bizottságának elnöke, Rajk László országgyülési képviselö, AraKovács Attila, a Szabaddemokrata Hirlap főszerkesztője és Udvarvölgyi Zsolt, az alakulat külügyi referense. Az RMDSZ képviselöivel folytatott egyeztetéseken elmondták, hogy a MÁÉRT szakbizottságaiban nem zajlott le olyan munka, amelyről a kormány beszámol és a javaslatcsomag még teljesen kidolgozatlan.

Július 10-én a HTMH és a határon túli szervezetek vezetői a státustörvényről folytattak egyeztetést, amelyen az RMDSZ-t Takács Csaba ügyvezető elnök képviselte. A tanácskozáson a jelenlevők elfogadták azt a javaslatot, miszerint a törvény adminisztrációs feladatainak lebonyolításáért a határon túli legitim szervezetek lesznek a felelösök. Az ügyvezető elnök szerint a törvény olyan keretet kell biztosítson, amelyben a kedvezmények az EU-s csatlakozás után sem sérülhetnek.

Július 19. Az MDF szerint a kormány által előkészített státustörvény koncepció megfelelő alap a további egyeztetésekhez - mondta Csapody Miklós. Az alelnök szerint a javaslat vitatott pontja, hogy ki a magyar és hogy ezt a kérdést milyen szervezet hivatott eldönteni. Csapody szerint elfogadható az arra vonatkozó javaslat miszerint a határon túli magyar közösség legyen illetékes a nemzetiségi hovatartozás megállapításában, de a végső döntés jogát Magyarországnak kell fenntartani.

Július 22. A státustörvény magyarországi megítélésére vonatkozó, a magyar kormány kezdeményezésére készült közvéleménykutatás eredményeit ismertették a román lapok. A beszámoló kiemelte, hogy a magyar állampolgárok közel 75\%-a nem ért egyet a határon túli magyaroknak nyújtandó munkavállalási engedéllyel, a megkérdezettek alig 15\%-a ért egyet azzal, hogy a határon túli magyaroknak kettős állampolgárságot adjanak. A válaszadók többsége nem tartja szükségesnek, hogy törvényben szabályozzák a határon túli magyarok jogállását, a megkérdezettek 18\%-a szerint a jogszabályt nem a magyar kormány, hanem a határon túli magyar szervezetek kellett volna kezdeményezzék.

Augusztus elején jelennek meg a közbeszédben az első román reakciók a státustörvényt illetően. A kormány képviseletében Vasile Dâncu, valamint a PNL képviselői diplomáciai megoldásokat részesítenék előnyben. A PNL nem tartja előremutatónak egy ellentörvény elfogadását - a státustörvény romániai alkalmazását tiltó jogszabályt -, mert a „törvényhozási háborút” indítana el a két állam parlamentje között.

Augusztus 19. Az MVSZ ismertette a külhoni állampolgárságról szóló törvénytervezetét, amelynek koncepciója nem ütközne a kormány és a HTMH által kidolgozott státustörvénnyel, de számos ponton kiegészítené azt. A külhoni állampolgárság kedvezményezettjei magyar útlevelet kapnak és szabadon utazhatnak a schengeni térségben. Hasonlóan a státustörvényhez, a külhoni állampolgárság is számos kedvezményt biztosítana a munkavállalás, orvosi ellátás, valamint az oktatás területén.

Az augusztus 20-i ünnepség keretében Orbán Viktor fogadta a határon túli magyarok képviselőt. A megbeszélésen részt vett Németh Zsolt külügyi államtitkár, valamint Szabó Tibor a HTMH elnöke is. A kormányfö felkérte a jelenlevőket, hogy fogalmazzák meg álláspontjukat a MVSZ külhoni állampolgársággal kapcsolatos javaslatáról.

Szeptember 14. A romániai magyar történelmi egyházak vezetőinek állandó értekezlete állásfoglalásában köszönetét fejezte ki a magyar kormánynak, hogy különleges jogállást és ezzel járó kedvezményeket kíván biztosítani a határon túli magyaroknak. A MVSZ által bemutatott kettős állampolgárságról szóló törvényt figyelemre méltó kezdeményezésnek tartják és javasolják ennek megvitatását a következő MÁÉRT ülésén. Szintén az állásfoglalásban a magyar egyházak felajánlották részvételüket a státustörvény jogalanyainak a meghatározásában. 
November 24. A HTMH sajtótájékoztató keretében ismertette a budapesti Balázs Ferenc Intézet által, a státustörvény kapcsán végzett kutatását, amely igencsak rácáfolt a státustörvény korábbi, kedvezőtlen anyaországi fogadtatására utaló megállapításokkal. Az Intézet által végzett közvéleménykutatás kimutatta, hogy az anyaországi megkérdezettek 60,7 \%-a támogatja a státustörvény megalkotását, a válaszadók mintegy 30\%-a elutasítja azt és közel 10\%-a nem tud dönteni.

December 14-én tartották Budapesten a MÁÉRT harmadik ülését, amelyen részt vett Németh Zsolt, a KÜM politikai államtitkára és Szabó Tibor, a HTMH elnöke. Németh Zsolt ismertette a kormány határátlépés problémáira vonatkozó javaslatait, amelyet a résztvevők kedvezően fogadtak. A tervezet további elemét képezné, hogy a magyar igazolvány kiadásához szükséges ajánlás megtételére az érdekvédelmi szervezetek, az egyházak és a civil szervezetek részvételével bizottságok alakulnak, akik döntenek a státustörvény kedvezményezettjeiröl.

December vége. Első ízben fogalmazzák meg fenntartásaikat az európai fórumok képviselői. Michael Lake budapesti EU-nagykövet megerősítette, hogy a külügy korábban bemutatta a törvény koncepcióját az Európai Bizottság bel- és igazságügyi biztosának, António Vitorinónak, amely nem nevezhető konzultációnak.

\section{1}

Január 18-án a MÁÉRT résztvevői Budapesten konzultáltak a státustörvényről, ahol az RMDSZ képviseletében Markó Béla szövetségi, Takács Csaba ügyvezető és Tőkés László tiszteletbeli elnök volt jelen. A jogszabálytervezetről szóló konzultáció azért vált szükségessé, mert a MÁÉRT legutóbbi ülésén számos, főként technikai jellegü és a végrehajtásra vonatkozó javaslatot kapott a kormány, melynek jó részét a közigazgatási egyeztetés megkezdése elött beépítette javaslatba.

Január 22. Mádl Ferenc köztársasági elnök kezdeményezésére a parlamenti pártok egyeztettek a státustörvényről, amelyen kiderült, hogy a szomszédos államokban élő magyaroknak biztosított státustörvényről nincs konszenzus a pártok között. Az ellenzéki pártok közül a törvénytervezettel szembeni legtöbb kifogást az SZDSZ fogalmazta meg. Szent-Iványi István kifejtette, hogy a javaslat jelenlegi formájában több fontos kérdésre nem ad választ, mint pl. kiket érintene, mit biztosítana, milyen áron, és azt meg ki állná?

Február 20-23. között Németh Zsolt külügyi politikai államtitkár látogatást tett Romániában, ahol találkozott Mircea Geoană külügyminiszterrel, az RMDSZ vezetöségével és a történelmi egyházak képviselőivel. Az államtitkár a MÁÉRT intézményesítése után a készülő státustörvényt tekintette a legfontosabb politikai lépésnek, aminek elfogadása mind a kormánynak, mind pedig a határon túli politikai szervezeteknek prioritás.

Március 21. A magyar kormány előző napi ülésén jóváhagyta a szomszédos államokban élő magyarokról szóló törvényjavaslatot, amelyet az Országgyülés a tavaszi ülésszak alatt elfogadhat, és január elsejétől léphet életbe, tájékoztatta a sajtó képviselöit Németh Zsolt államtitkár. A kormány 800 ezerre becsüli azon személyek számát, akik ki fogják váltani a magyar igazolványt. Szabó Tibor, a HTMH elnöke eredményes lépésként értékelte a kormány döntését.

Április 4-én Mircea Geoană külügyminiszter hivatalos látogatást folytatott Budapesten, ahol találkozott Martonyi János külügyminiszterrel. A felek áttekintették a gazdasági kapcsolatok fejlesztésére vonatkozó javaslatokat. A román külügyminiszter Kovács László MSZP-elnökkel való tanácskozásán sajnálatosnak nevezte, hogy a magyar kormány hivatalos úton még nem konzultált a román féllel a készülő státustörvényröl.

Április 6-án Martoni János külügyminiszter tájékoztatta az EU és a NATO tagországok, valamint a szomszédos államok nagyköveteit a státustörvény tervezetéről, amelyen részt vett 
Németh Zsolt politikai államtitkár, Gottfried Péter, a magyar Integrációs Államtitkárság vezetöje és Szabó Tibor, a HTMH elnöke. A külügyminiszter hangsúlyozta, hogy a készülő tervezet összhangban áll Magyarország külpolitikai prioritásaival és bízik abban, hogy „a törvényt a parlament a lehető legszélesebb támogatással fogadja el, és az a jövő év elején hatályba léphet."

Április 11. Ion Iliescu államfő szerint Magyarországnak körültekintő módon kellene eljárnia a határon túli magyarokra vonatkozó státustörvényt illetően, és konzultálnia kellene a szomszédos államokkal, amint arra Mircea Geoană budapesti látogatásán is felhívta a magyar fél figyelmét.

Április 19. Az Országgyülés megkezdte a szomszédos államokban élő magyarokról szóló törvény vitáját, melyet Martonyi János külügyminiszter ismertetett. A vitában kirajzolódó álláspontok alapján a kormánypárt mellett az MSZP és a MIÉP is támogatta a javaslatot, egyedül az SZDSZ jelezte, hogy ellenzi a tervezet elfogadását.

Április 23. Adrian Năstase, Románia miniszterelnöke diszkriminatívnak nevezte a határon túli magyarok jogairól szóló törvénytervezetet, mert a javaslat „hátrányos megkülönböztetést jelent a más nemzetiségủ állampolgárokkal szemben." A helyzet tisztázásához - vélte a kormányfő - a tervezetet az EU-nak és az ET-nek is láttamoznia kell.

Petru Cordoș, Románia budapesti nagykövete nyilatkozatban megerösítette, hogy Románia konzultálni kíván a magyar féllel a státustörvény kapcsán. Erre vonatkozóan néhány nappal korábban, április 20-án átadta a Külügyminisztériumnak a magyar-román konzultációs javaslatra vonatkozó szóbeli jegyzéket.

Május eleje. Mircea Geoană sajtótájékoztatón jelentette be, hogy a magyar féllel május 9-én kezdődnek el a tárgyalások a státustörvény tervezetéről. A KÜM elsőként a nagykövettel közölte a javaslattal kapcsolatos észrevételeiket és kifogásaikat, amelyet a két fél közötti konzultációk és egyeztetések fognak követni.

Május 14. Adrian Năstase miniszterelnök nyilatkozatban foglalt állást a státustörvény ellen, miszerint a román hatóságokkal való konzultálás és megfelelő kétoldalú megállapodás nélkül nem alkalmazható Románia területén a törvény. A kormányfő kijelentette, hogy a román állami intézmények révén megakadályozzák a törvény romániai alkalmazását.

Május 15. A magyar külügyminisztérium kész folytatni a már megkezdett konzultációt Romániával a szomszédos államokban élő magyarokról szóló törvényjavaslatról, és várja a román fél érdemi felvetéseit, amelyekre válaszolni fog - közölte az MTI-vel Horváth Gábor külügyi szóvivő. A román kormányfő nyilatkozatára válaszolva a szóvivő kifejtette, hogy a törvénytervezetről már elkezdődött a felek között egy egyeztetési folyamat.

Május 16. A státustörvényről szóló konzultációkról Íjgyártó István, Magyarország bukaresti nagykövete elmondta, hogy az újabb fordulóra Budapesten kerül sor. A román fél kérdéseire felvilágosításokkal szolgált, fenntartásokat azonban nem fogalmaztak meg. A státustörvény vitájában a román államfö is megszólalt, arra kérvén a politikai pártok képviselöit, hogy a jogszabálytervezetet „,ne használják ürügyként szélsőségesen nacionalista álláspontok megfogalmazására, a többség és a kisebbség közötti feszültség növelésére.”

Május 23-24. között az Országgyülés több, összesen kilenc bizottsága tárgyalta a státustörvényhez benyújtott módosító indítványokat, amelynek többségét a bizottságok elutasították. Az indítványok többnyire a törvény alkalmazására, és végrehajtására vonatkoztak. A kormánypárt annak ellenére fenntartja a törvény körül kialakult konszenzust, hogy az SZDSZ nem támogatta a javaslatot és az MSZP is több módosító javaslatot is benyújtott a dokumentumhoz.

Május 24-én magyar-román konzultációt tartottak a státustörvény tárgyában. A tárgyalásokon kiderült, hogy a román fél elvi kérdésekre és néhány gyakorlati problémára szeretni választ kapni, mint pl. milyen alapon állítják fel és miként müködnek majd Románia területén a 
státusirodák, valamint a jogszabálytervezet munkavállalásra vonatkozó része az etnikai megkülönböztetés veszélyét hordozza.

Május 30-án az Országgyülésben folytatódott a státustörvény vitája. A vitán megfogalmazott álláspontokból kiderült, hogy nem változott alapvetően a pártok törvénytervezetről alkotott véleménye: a magyar kormánypártok, valamint az MSZP és a MIÉP módosításokkal támogatják, míg az SZDSZ elutasítja az előterjesztést.

Május 31. Mádl Ferenc köztársasági elnök beiktatása után első ízben fogadta a határon túli magyar szervezetek képviselőit, akikkel a szomszédos országokban élő magyarokról szóló törvényjavaslatról konzultált. Az államfö arra kérte az érdekvédelmi szervezetek vezetöit, hogy „segítsenek oldani országaik többségi nemzeteinek politikai tényezőiben és az egyszerü állampolgárokban a törvény iránti ellenérzéseket".

Június 9. A román külügyminisztérium külpolitikai tanácsadó irodájának értékelés szerint a készülő státustörvény számos ponton ellentétben áll a nemzetközi jog szabályaival. Az iroda értelmezése szerint a törvény által nyújtott etnikai származás alapján biztosított kedvezmény diszkriminációnak számít. Elfogadhatatlannak tartja továbbá tervezet, területen kívüli jellegét, a történelmi értékítéletet tartalmazó megfogalmazást, valamint a szomszédos államok közösségeit képviselő szervezetek elismerését.

A készülő magyar státustörvény a szlovák vezetés szerint számos ponton ütközik a nemzetközi jog alapelveivel. A szlovák vezetés véleménye azt követően körvonalazódott, hogy június 7-én Jaroslav Chlebo külügyi államtitkár tárgyalt Boros Miklós pozsonyi magyar nagykövettel, és emlékeztető jegyzékben átadta neki a szlovák álláspontot.

Június 13. A kormányzó PDSR országos vezetősé állásfoglalásában aggasztónak találta, hogy a státustörvényt ,jóvátételi aktusként” tematizálja a magyar kormánypárt. A PDSR szerint a jogszabálytervezet kettős mércét alkalmaz, és nem felel meg az európai elvárásoknak, amit az is mutat, hogy nem mindegyik Magyarországgal határos államban élő magyar közösségre terjed ki. Az állásfoglalásban a kormánypárt valamennyi felelős európai erőhöz, különösképpen a magyar parlamenti pártokhoz fordult azzal a felhívással, hogy a térségben kialakult jó megértés és bizalom megőrzésének tudatában cselekedjenek, mivel a térség stabilitása és biztonsága alapvetően függ attól, hogy milyen módon kezelik a nemzeti kisebbségek problémáját.

Június 15. Az RMDSZ meghívására az MSZP küldöttsége kétnapos bukaresti látogatásra érkezett. A pártok képviselői az elfogadott státustörvényről konzultáltak. Az MSZP frakcióvezetője Nagy Sándor kifejtette, hogy pártjuk támogatta a törvény alapgondolatát, néhány részletkérdéssel azonban nem értettek egyet. A frakcióvezető szerint túlzó a román miniszterelnök státustörvényről kialakított álláspontja, mivel a romániai magyaroknak nyújtott kedvezmények nem érintik negatívan az ország román lakosságát.

Dobos Ferenc, a Balázs Ferenc Intézet munkatársa a HTMH székhelyén mutatta be a határon túli magyarok körében végzett kutatást a státustörvény várható hatásairól. A vizsgálat szerint az erdélyiek a kedvezmények közül a nemzeti vízumot tartják a legfontosabbnak, melyet az egészségügyi ellátás követ. Az előző évhez képest, hozzávetőleg 10\%-al igényelnének többen magyar igazolványt $(93,2 \%)$ és a jövőben a kormánytól elvárnák a kettős állampolgárság megadását.

Június 19-én a magyar Országgyülés több mint 90\%-os többséggel elfogadta a szomszédos államokban élő magyarokról szóló törvényt. A pártok közül egyedül az SZDSZ nem támogatta a törvény megszavazását. A szavazás végső eredménye: 306 igen (92,4 százalék), 17 nem (5,1 százalék), 8 tartózkodott (2,5 százalék). A szavazás végeredményét a képviselők és a jelen lévő határon túli magyar szervezetek képviselöi tapssal üdvözölték.

Június 21. A státustörvény elfogadása után a román külügyminisztérium bekérette a bukaresti magyar nagykövetet és tiltakozó jegyzéket nyújtottak át neki, ugyanakkor utasították a 
budapesti román nagykövetet, hogy tájékoztassa a magyar külügyet Bukarest álláspontjáról. Mircea Geoană külügyminiszter elmondta, hogy a magyar fél semmilyen formában nem konzultált a törvény előkészítése elött, a román szakértők elutaztak Budapestre, akiket a külügyminiszter fogadott, a végleges jogszabály azonban nem tartalmazza a román fél észrevételeit. Geoană a kormány nevében kijelentette: a román fél úgy fog eljárni, hogy "a területen kívüliségnek e törvényben fellelhető elemei ne érvényesülhessenek román területen".

Az RMDSZ üdvözli a státustörvény elfogadását, Markó Béla szerint „a jogszabály egységes keretbe foglalja mindazokat a szándékokat, amelyek kifejezik azt, hogy Magyarország segíteni kíván a határain kívül élő magyar közösségeknek és magyar nemzetiségü személyeknek”. A szövetségi elnök szerint a román külügy mesterségesen felnagyította és túldramatizálta a státustörvény kérdését, mellyel rontja külföldi megítélését és az euro-atlanti felzárkózás lehetőségeit, de a vita az államközi kapcsolatok fejlődésének is árt.

Adrian Năstase miniszterelnök a státustörvény elfogadását követően hangsúlyozta, hogy Románia az 1996-ban megkötött alapszerződésen kívül kész felbontani az összes, Magyarországgal kötött kétoldali szerződést, mivel a két állam között is érvényesek a diszkriminációt tiltó rendelkezések. A kormányfő a Magyarországról Romániába folyósított munkanélküli segélyek és nyugdíjak, valamint a személyi jövedelemadó rendszerének átvilágítását helyezte kilátásba.

Június 26. Annak ellenére, hogy az EB még nem fejezte be a magyar státustörvény vizsgálatát, Günter Verheugen bővítési biztos véleménye szerint a jogszabály összhangban van a társulási szerződésben foglaltakkal. A biztos kifejtette, hogy az EB felhívja a magyar kormány figyelmét arra, hogy továbbra is folytasson konzultációkat a szomszédos államokkal a törvény gyakorlatba ültetése érdekében.

Június 28. A státustörvény körül kialakult vita következtében a két kormány képviselöi arról állapodtak meg, hogy Budapesten összehívják a magyar-román kormányközi vegyesbizottságot. A miniszterelnökkel való találkozót követően Markó Béla elmondta, hogy az RMDSZ nem tudja helyettesíteni a két kormány között szükséges konzultációt, ugyanakkor a Szövetség szeretné, ha a kormány tagjai folytatnák a konzultációkat.

Strasbourgban az ET PKGY ülésén a román delegáció aláírásgyüjtést kezdeményezett a státustörvény elleni indítványhoz, mivel az diszkriminatív rendelkezéseket tartalmaz és feszültséget teremt a térségben. Az indítványban a kezdeményezők arra kérik az ET vezetőségét, hogy szólítsa fel Magyarországot a törvény végrehajtásának felfüggesztésére.

Július 6. A román kormány javaslatának támogatását kérte Adrian Năstase kormányfö Günther Verheugentől, az EU bővítési biztosától arra vonatkozóan, hogy mindaddig ne léptessék érvénybe a státustörvényt, amíg Magyarország nem zárja le a csatlakozási tárgyalásokat az EUval. A kormányfő levelében kifejtette, hogy a román fél által javasolt kompromisszumos megoldás összhangban van a koppenhágai csúcsértekezleten hozott döntésekkel, ennek értelmében Magyarországnak az európai normákhoz kell igazítania törvényhozását.

A Velencei Bizottság munkabizottságot hozott létre annak kapcsán, hogy Magyarország és Románia kormányai is megkereséssel fordultak a testülethez. A VB összeurópai kitekintésben vizsgálja meg a kisebbségek identitásának védelmét és ápolását célzó európai jogi szabályozást és gyakorlatot.

Július 12. Bukarestbe érkezett a Martonyi János magyar külügyminiszter vezette delegáció (Szabó Tibor HTMH elnök, Lőrincz Csaba helyettes államtitkár). A román kormányfővel és az RMDSZ elnökével a státustörvény alkalmazásáról egyeztettek. A kormánypárttal folytatott tárgyalásokon a román fél azt hangsúlyozta, hogy Románia számára csak a státustörvény felfüggesztése lehet elfogadható megoldás. 
Július 13-án Snagovban a státustörvényröl tárgyalt a két állam külügyminisztere, azonban az álláspontok nem közeledtek. A felek abban állapodtak meg, hogy a tárgyalások folytatódnak a kormányközi vegyesbizottság keretében. A román álláspontot megerősítve a külügyminiszter kifejtette, hogy a törvény számos eleme differenciáltan kezeli a román állampolgárokat, területen kívüli hatálya miatt elfogadhatatlan, és a jogszabály számos gazdasági és szociális aspektusa túllép a nemzeti kisebbségek védelmével foglalkozó európai normák keretein.

Július 23-24. Romániába látogatott Rolf Ekéusz, az EBESZ Kisebbségügyi Főbiztosa. A külügyminiszterrel folytatott tárgyaláson a Főbiztos kijelentette, hogy a státustörvényre európai választ kell adni. Másnap a Főbiztos az RMDSZ vezetőségével tárgyalt. A kolozsvári találkozón a felek megállapították, hogy a státustörvény „,nem igazolja sem a félelmeket, amelyeket a különféle, Magyarországon kívüli kormányok politikusaiban keltett, sem azt a hatalmas illúziót, amelyet a kezdeményezők vélnek felfedezni ebben a kedvezménytörvényben."

Július 26. Romano Prodi az EB elnöke a román miniszterelnökhöz írt levelében hangsúlyozta, hogy az EB folytatja a státustörvény elfogadása utáni helyzet vizsgálatát. Az EB-enöke kifejtette, hogy a jogszabály kerettörvény, így a végrehajtás kidolgozása előtt nem alkalmazható, a Bizottság pedig azt várja el a magyar kormánytól, hogy „a végrehajtási utasítások kidolgozása során a diszkriminációt tiltó elvet tartsák tiszteletben.”

Július 28. Marosvásárhelyen került sor a magyar-román kormányfői találkozóra, amelyen a két állam képviselöi a státustörvény alkalmazásáról és a kétoldalú kapcsolatok fejlesztéséről tárgyaltak. Orbán Viktor egy több pontból álló javaslatot mutatott be a román kormányfönek egy magyar mintára előkészített román státustörvényre, magyarországi román munkavállalói létszám megemelésére, autópálya építésre, valamint közös beruházási alap létrehozására vonatkozóan. A tárgyalásokon Năstase a munkavállalási kvóta eltörlését javasolta, amellyel megszünne a román munkavállalók gazdasági diszkriminációja.

Szeptember 6-7. között Szabó Tibor a HTMH elnöke, valamint Öry Csaba, a Miniszterelnöki Hivatal államtitkára a státustörvényről folytatott tárgyalásokat a román parlament munkaügyi bizottságával, a társadalombiztosítási föigazgatósággal és a Munkaügyi Minisztérium vezetőivel. A tárgyalásokat értékelve a HTMH elnöke kifejtette, hogy a román félnek nem szakmai, hanem politikai problémái vannak a jogszabállyal.

Szeptember 10. Budapesten megkezdődött a magyar-román vegyesbizottság kisebbségi szakbizottságának ülése. Az ülésen megvitatták a státustörvény kapcsán átadott magyar javaslatokat, melyek a munkavállalással, az egészségügyi kérdésekkel és az utazási kedvezményekkel kapcsolatosak. Cristian Diaconescu külügyi államtitkár szerint a román fél első alkalommal kapott részletesebb válaszokat a törvény kapcsán megfogalmazott aggodalmakra.

Szeptember 11. Markó Béla szövetségi elnök fogadta Rolf Ekéuszt, az EBESZ Kisebbségi Főbiztosát, aki a romániai kisebbségek jogi helyzetének alakulásáról kívánt tájékozódni. AZ RMDSZ elnökének elmondta, hogy elsőrendü feladata megbizonyosodni arról, hogy a státustörvény által kiváltott vita nem vezet etnikumközi konfliktushoz. Markó Béla a közigazgatási törvény alkalmazásáról, valamint az elkobzott egyházi ingatlanok visszaszolgáltatását szabályozó törvény problémáiról tájékoztatta a Föbiztost.

Október 16. Ülésezett az RMDSZ Operatív Tanácsa, melyen a státustörvény végrehajtását, az ajánlószervezetek létrehozásának kérdését vitatták meg. A szövetségi elnök szerint Romániában az RMDSZ rendelkezik azzal a tapasztalattal és apparátussal, amely a törvény alkalmazásának előkészítéséhez szükséges. Tökés László tiszteletbeli elnök szerint viszont az RMDSZ, az egyházak és a civil szféra együttmüködése szükséges a végrehajtáshoz.

Október 22. A VB közzétette jelentését, amelyben megalapozottnak tartotta, hogy egyes államok egyoldalúan elönyökhöz igyekeznek juttatni a határaikon túl élő nemzettársakat. 
Mindazonáltal számos módosítást javasolt (területen kívüliség elve, igazolást kibocsátó hatóság, kedvezmények jellege), amelynek alapján folytatni kell a két állam közötti konzultációkat.

Az október 25-26. között ülésező MÁÉRT zárónyilatkozatában megelégedéssel vette tudomásul a VB döntését, megerősítette a státustörvény egyik alapelvét, miszerint pozitív megítélés alá esik, ha valamely ország anyaországként kedvezményeket és támogatást nyújt határon túli nemzeti kisebbségei számára és megállapították, hogy a VB döntése nyomán a törvény nem szorul módosításra. A nyilatkozatban a résztvevők továbbra is szükségesnek tartják a többségi nemzet kormányaival folytatott konzultációt a törvény végrehajtása érdekében.

Október 26. Az EBESZ Kisebbségügyi Főbiztosa feszültségek és konfliktusok forrásaként értékelte azon államok politikáját, akik egyoldalú lépéseket tesznek a határon túli nemzeti kisebbségek védelme érdekében. A Főbiztos emlékeztet, hogy az államok joghatósága nem terjed ki a határon túli nemzetrészekre, de figyelembe véve a diszkrimináció tilalmának elvét kedvezményeket biztosíthat ezen személyeknek.

Október 29. A román kormány nyilatkozatban állt ki a státustörvény módosítása mellett, végrehajtását pedig mindaddig fel kell függeszteni, amíg meg nem szerzik a szomszédos államok beleegyezését. A komán kormány a VB döntését tartja irányadónak, a MÁÉRT ülésének zárónyilatkozata pedig ennek elutasításaként értelmezhető. A román fél továbbra is elfogadhatatlannak tartja a törvényben szereplö, etnikai alapon nyújtott gazdasági és szociális jogosítványokat.

November 14. Az EB Magyarországról készített éves országjelentésében megállapította, hogy a státustörvény jelenleg nincs összhangban az EU alapszerződésében szereplö diszkriminációmentesség elvével, ezért Magyarországnak, legkésőbb az EU-csatlakozásáig hozzá kell igazítania a törvényt a jelenleg érvényes uniós joganyaghoz.

November 16-án a CEFTA-ülés keretében Bukarestben egyeztetett a két állam kormányföje. Adrian Năstase miniszterelnök egy dokumentumot adott át a magyar kormányfőnek, amely a státustörvénnyel kapcsolatos román álláspontot tartalmazta. A miniszterelnök hangsúlyozta, hogy jogosnak tartják az identitás megőrzését szolgáló törődést kulturális, vallási és nyelvi téren, de a két fél álláspontja eltér a nemzeti kisebbségeknek nyújtott gazdasági és szociális jogosultságok ügyében.

December 17-én államtitkári találkozóra került sor Bukarestben, ahol Németh Zsolt folytatott tárgyalásokat Cristian Diaconescu államtitkárral. A találkozón a két állam képviselöje abban állapodott meg, hogy a státustörvényre vonatkozó egyetértési nyilatkozatot dolgoznak ki, amelyben a felek részletesen meghatározzák a státustörvény közös értelmezéseit.

December 21. Folytatódott a két állam közötti államtitkári megbeszélés a két állam között kidolgozásra kerülő egyetértési nyilatkozatról. A felek úgy értékelték, hogy a tárgyalásokat követően közeledtek az álláspontok a konzulátusok és az ajánlószervezetek jogköreiről és az igazolványok kiadásának feltételeivel. A külügyi szóvivő bejelentette, hogy a nyilatkozatot a két állam miniszterelnöke Budapesten írja alá.

December 22. Budapesten Adrian Năstase román és Orbán Viktor magyar miniszterelnök aláírta a státustörvényre vonatkozó egyetértési nyilatkozatot. A dokumentum tisztázta a külképviseletek, konzulátusok szerepét a Magyar igazolványokkal kapcsolatban és rögzítette az ajánlószervezetek kompetenciáit. Az egyenlő bánásmód elve alapján a státustörvény hatálya a munkavállalási jog területén kiterjedt a román anyanyelvü állampolgárokra.

December vége. Az MSZP a státustörvény felülvizsgálatát kezdeményezi, álláspontja szerint ugyanis a két állam között megkötött egyetértési nyilatkozat ellentétes a nemzeti érdekekkel, és a hatályban lévő jogszabályokkal. A szocialistákkal összhangban a magyar szakszervezetek is aggodalmukat fejezték ki a magyar munkaerópiacnak a veszélyeztetettségéről a román anyanyelvü állampolgárok elött. 


\section{2}

Január 9. A státustörvény végrehajtásának aktuális kérdéseiröl tárgyalt Orbán Viktor miniszterelnök a határon túli magyar szervezetek képviselőivel. A tanácskozással párhuzamosan a HTMH szervezésében az információs irodák vezetőinek találkozására került sor, ahol az RMDSZ-t Székely István és Nagy Zsolt képviselte.

Január 21-én országszerte megnyílnak a státustörvény romániai végrehajtásában segítséget nyújtó információs irodák.

Március 7-én a Szenátus 69 nem 47 igen és 2 tartózkodással elutasította a Nagy-Románia Párt által benyújtott Erdély elárulása c. egyszerü indítványt, amelyet a PNL és a PD képviselöi is támogattak. A vitában Mircea Geoană külügyminiszter kifejtette, hogy a memorandum révén Románia konkrét előnyökre tett szert a magyarországi munkaerőpiacon.

Június 14. Nyilvánosságra került az ET megbízásából készült jelentés a magyar státustörvényről. Az Eric Jürgens holland képviselő által előkészített dokumentum a VB és az EBESZ javaslatokon túlmutató, negatív kritikákat fogalmazott meg a magyar jogszabállyal kapcsolatosan. A jelentés felidézte a szomszédos államok bírálatát, miszerint az megsérti a területi szuverenitást, és az alapvető szabadságjogokat.

Június 26. A magyar külügyminisztérium Bársony András államtitkár útján magyar kormány státustörvényre vonatkozó módosítási szándékairól tájékoztatta az ET PKGY elnökét és főtitkárát. Markó Béla szövetségi elnök a magyar kormány tervezetére reagálva megismételte az RMSZ álláspontját, miszerint a kedvezménytörvényt nem szükséges módosítani. Markó szerint egy három pólusú egyeztetésre lenne szükség, egyrészt a két kormány között, másrészt pedig az RMDSZ és a magyar, valamint a román kormány képviselői között.

Július 8. Kétnapos romániai látogatásán Medgyessy Péter magyar miniszterelnök tárgyalt az RMDSZ vezetőségével a határon túli magyaroknak szánt támogatások felhasználásáról, a Sapientia Egyetemről és a MÁÉRT összehívásának fontosságáról. Az RMDSZ-szel folytatott egyeztetéseket követően miniszterelnöki találkozóra került sor, ahol a felek megegyeztek abban, hogy a státustörvénnyel kapcsolatos problémákat a kormányközi vegyesbizottság kisebbségi albizottság hatáskörébe utalják.

Július 10-én Markó Béla szövetségi elnök Bukarestben fogadta az EBESZ Kisebbségi Főbiztosát Rolf Ekéuszt. A megbeszélésen a Szövetség képviselői az RMDSZ és a kormánypárt közötti megállapodás végrehajtásáról, valamint a magyar státustörvényröl tájékoztatták a Főbiztost.

Július 30-án a kisebbségi albizottság bukaresti ülésén a két állam képviselöi abban egyeztek meg, hogy ösz folyamán tartják meg a vegyesbizottság kisebbségi albizottságának teljes ülését. Az ülésen a magyar társelnök, Szabó Vilmos államtitkár megerősítette, hogy a magyar félnek szándékában áll a törvény módosítása. Az államtitkár átadta román kollégájának, Cristian Diaconescunak Medgyessy Péter levelét a román emlékeztetőre vonatkozó válasszal, és a két állam együttmüködésére vonatkozó válaszjegyzéket is.

Szeptember 4. Bukaresti látogatásán Kovács László külügyminiszter tárgyalásokat folytatott kollégájával az államközi kapcsolatok alakulásáról, akit Adrian Năstase kormányfö és Ion Iliescu államfö is fogadott, majd pedig egyeztetett az RMDSZ vezetöivel is. A külügyminiszter látogatásának legfőbb célja a stratégiai partnerségre vonatkozó megállapodás előkészítése volt. A felek abban is megegyeztek, hogy a kisebbségi albizottság ülésére szeptember 9-én, Gyulán kerül sor.

Október 2-án Mádl Ferenc köztársasági elnök hivatalos látogatásra Romániába érkezett, ahol Ion Iliescu államfővel folytatott tárgyalásokat a gazdasági kapcsolatok fejlesztéséröl, az euroatlanti integrációról és a nemzeti kisebbségek helyzetéről. A találkozón a román államfő 
hangsúlyozta, hogy az államközi kapcsolatok jelenlegi fejlődése lehetővé teszi a közelmúlt kényes kérdéseinek nyílt és pragmatikus megvitatását is. A román államfö emlékeztette magyar kollégáját arra, hogy Bukarest számtalan javaslatot tett a státustörvény módosítására. Válaszában a magyar államfö kiemelte, hogy a jogszabály által nyújtott kedvezmények nem diszkriminációt, hanem jogtöbbletet jelentettek.

Október 30. Nyilvánosságra került a státustörvény módosításával megbízott tárcaközi munkacsoport javaslata jogszabály módosítására vonatkozóan, ami figyelembe vette Bukarest és Pozsony valamint az európai fórumok által jelzett kifogásokat. A tervezet szerint a szülők helyett a kiskorú gyerekek kapnának támogatást, valamint kiterjesztenék az oktatási-nevelési támogatásban részesíthetők körét.

November 17-én, a MÁÉRT ülésén a magyarországi és a határon túli magyar szervezetek a státustörvény módosításáról, valamint a magyar uniós csatlakozás következményeiről tanácskoztak. Medgyessy Péter miniszterelnök 2003 tavaszára rendkívüli MÁÉRT összehívását helyezte kilátásba, a FIDESZ képviseletében Németh Zsolt pedig a határon túli magyarok támogatására és a státustörvény végrehajtására fordított összeg elkülönítésére tett javaslatot.

\section{3}

Március eleje. Az ET raportőre, a magyar státustörvényről készült jelentés kidolgozója Erik Jürgens elfogadta a magyar észrevételek többségét, amelyek Tabajdi Csaba szerint már tükröződnek a Párizsban véglegesített jelentésben, ugyanis érdemi kérdésekben a jelentés már nem marasztalja el Magyarországot. A jelentés végső változatában már nem jelent meg a jogszabály diszkriminatív jellege, valamint a területenkívüliségre vonatkozó kitétel sem.

Április 17. Bálint-Pataki József, a HTMH elnöke és Szabó Vilmos, a Miniszterelnöki Hivatal határon túli magyarokért felelős politikai államtitkára kezdeményezésére Budapesten került sor a státustörvény módosított szövegtervezetének szakértői egyeztetésére. Az RMDSZ képviseletében Nagy Zsolt ügyvezető elnök vett részt az egyeztetésen, aki az egygyermekes családok oktatási-nevelési támogatásának folyósítását, valamint az utazási kedvezmények körének bővítését javasolta.

Május 21-én ülésezett az RMDSZ Operatív Tanácsa, amely a státustörvény módosítása kapcsán álláspontjában kifejtette, hogy a tervezet megfelel a VB jelentésében foglalt alapelveknek. A módosított jogszabály következtében nem szükül a kedvezmények eddigi köre, és az egy gyermek esetén is folyósítható a támogatás.

Május 24-én zárult a Budapesten a MÁÉRT hetedik ülése. A státustörvény módosítását is tartalmazó zárónyilatkozat elfogadásával alapvető ellentét alakült ki a résztvevők között, amelynek következtében három párt, illetve szervezet képviselője, Németh Zsolt (Fidesz), Kovács Miklós (KMKSZ) és Ágoston András (VMDSZ) nem írta alá a dokumentumot.

Június 16-án a magyarországi parlamenti pártok a státustörvény módosításáról vitáztak. Kovács László külügyminiszter szerint a módosítás megfelel az európai normáknak, mi több a javaslatot a határon túli magyarság 98\%-át képviselő szervezetek is elfogadták. A Fidesz vezérszónoka szerint sajnálatos, hogy a jogszabályból kimarad az egységes magyar nemzetre vonatkozó utalás, emellett károsnak és önveszélyesnek ítélte meg a módosított jogszabályt.

Június 26. Az ET PTKGY Emberi jogi és jogi bizottsága határozattervezetében felkérte a magyar kormányt és az Országgyülést, hogy a nemzetközi szervezetek által megfogalmazott javaslatokat figyelembe véve módosítsa a státustörvényt. A határozattervezet ugyanakkor felszólított minden érintett kormányt az eddigi tárgyalások folytatására. A VB jelentésére hivatkozva a dokumentum megállapítja, hogy a kisebbségek védelmében az államok kétoldalú alapon kell eljárjanak, figyelembe véve az államok területi szuverenitását, a jószomszédságot, a jóhiszemüséget és az emberi jogok tiszteletben tartását. 
Az Országgyülésben a státustörvény módosításáról szavaztak. Az új jogszabály szerint megszüntetik az ajánlószervezetek tevékenységét, a magyar igazolvány iránti kérelmeket pedig kizárólag a magyar diplomáciai és konzuli képviseletekhez lehet benyújtani.

Szeptember 24. Magyarország és Románia miniszterelnökei aláírták a státustörvény végrehajtásáról szóló kormányközi megállapodást, amely lezárta a felek közötti vitát. A dokumentum értelmében megszünt az erdélyi ajánlószervezetek szerepe és az igazolvány kiadására csak Magyarország területén kerülhet sor. 
December 6. A Párizsban tartózkodó Pozsgay Imre államminiszter a nemzetiségi törvény módosításáról nyilatkozott. A tervezet három fontosabb újítást vezetett be, egyrészt lehetővé teszi az erdélyi menekülteknek a magyar állampolgárság megszerzését, valamint „automatikusan” megadja a magyar állampolgárságot a más államokból hazatérő magyaroknak, végül pedig a magyar diaszpóra számára bevezeti a kettős állampolgárság intézményét.

\section{0}

Február 9. A Magyarországon tartózkodó több ezer - többségében magyar - romániai menekült rendezetlen helyzetét szem előtt tartva a magyar külügyminisztérium Havasi Béla miniszterhelyettes útján felmondta a kettős állampolgárság eseteinek megoldásáról és megelőzéséről szóló, 1979. július 13-án aláírt magyar-román államközi megállapodást.

\section{1}

Február 21. A román Szenátus az állampolgársági törvény módosításáról szavazott. A módosítást, annak ellenére, hogy elismeri a kettős állampolgárságot nem támogatta az RMDSZ frakció, azért mert az egyik cikkely az állampolgárság visszavonásról is rendelkezett, abban az esetben, ha az illető személy cselekedetével megsérti a román állam érdekeit.

\section{2}

Május 4. A CDR törvényjavaslatot nyújtott be, amely lehetővé tenné Moldova Köztársaság lakosainak, hogy román állampolgárságot szerezzenek. Corneliu Coposu nyilatkozatában kifejtette, hogy a törvény hatályát ki lehetne terjeszteni az Ukrajnában élő román nemzetiségü személyekre is.

\section{7}

Augusztus 11. Az RMDSZ Erdélyi Magyar Kezdeményezés platformja, élén Katona Ádámmal arra hívta fel a Szövetség vezetőinek figyelmét, hogy a közelgő kongresszuson vállalja fel az erdélyi magyarok kettős állampolgárságának képviseletét.

Október 8. Adrian Severin meghívására Bukarestbe érkezett Kovács László külügyminiszter a magyar-román kormányközi vegyesbizottság megnyitása alkalmából. Az államfövel folytatott találkozót követő sajtótájékoztatón a külügyminiszter pozitívan értékelte az RMDSZ kormányzati részvételét, de kifejtette, hogy „,nem tartja reálisnak a romániai magyarok kettős állampolgárságára vonatkozó elképzelést”, mi több a magyar kormány nem foglalkozik ezzel a kérdéssel.

Október 21. Horn Gyula romániai látogatásán a román kormány és az RMDSZ képviselőivel folytatott tárgyalásokat követően kifejtette, hogy a kettős állampolgárság kérdése nem időszerü.

\footnotetext{
${ }^{528}$ A kronológia elkészítésekor a Udvardy Frigyes: A romániai magyar kisebbség történeti kronológiáját (http://udvardy.adatbank.transindex.ro/), az MTI Hirarchívumát (http://archiv1988tol.mti.hu/Pages/HirSearch.aspx?Pmd=1), valamint az RMDSZ Tájékoztatót használtam fel.
} 
Április 5. A MVSZ választmányi ülésén Csoóri Sándor elnök a schengeni határok ellensúlyozására a magyar állampolgárság kiterjesztésének kérdését vetette fel, amelyről a szervezet vitát készül kezdeményezni Magyarországon és a határon túli magyarok körében.

Április 6-án közleményt adott ki a HTMH, amelyben a magyar állampolgárság kiterjesztésére vonatkozó javaslatról kifejtette, „hogy a jogi akadályok és a politikai következmények miatt alkalmatlan eszköz a magyar kisebbségek jogi védelmére és helyzetük javítására." A Miniszterelnöki Hivatal politikai államtitkára, Tabajdi Csaba szerint is el kell utasítani a kettős állampolgárság kérdését, mert nem szolgálnák a KKE-i stabilitást, ellenben Magyarország csatlakozása során meg kell oldja, hogy a schengeni határ ne okozzon törést a magyar-magyar kapcsolatokban.

A magyarországi parlamenti pártok eltérően nyilatkoztak a MVSZ-javaslatáról. Míg az MDF, az FKgP, a KDNP és a MIÉP támogatta a kettős állampolgárság bevezetését, addig az MSZP és az SZDSZ ellenezte azt. Az RMDSZ elnöke szerint egy kétmilliós közösség számára a kettős állampolgárság gondolata nem jelent megoldást.

Szeptember 12. Az Erdélyi Magyar Civil Társadalomért Polgári Tömörülés Alsócsernátonban megrendezett fórumán határozatot fogadott el a kettős állampolgárságról, amelyben felkérték a magyar kormányt, hogy teremtse meg azokat a törvényes kereteket, amelyek ,a magyar állampolgárság nemzeti hovatartozás alapján való elnyeréséhez" szükségesek.

\section{9}

Január 13-án Budapesten Orbán Viktor miniszterelnök fogadta Markó Bálát, az RMDSZ elnökét. A találkozón a felek hangsúlyozták, hogy a kettős állampolgárság kérdése továbbra sincs napirenden, ellenben Magyarország abban érdekelt, hogy az EU-csatlakozás után a határátlépés és az anyaországgal folytatott kapcsolattartás gördülékeny maradjon.

Február 27. Az RMDSZ kongresszusát előkészítő SZKT-n vita alakült ki Markó Béla és Tőkés László tiszteletbeli elnök között a kettős állampolgárság kérdéséről. Tőkés László szerint a Szövetségnek meg kellene fogalmaznia az erre vonatkozó igényét. A szövetségi elnök emlékeztetett, hogy a kettős állampolgárság nem szerepel a magyar kormány napirendjén.

Március 22. A Szabadság napilapnak adott interjúban Martonyi János külügyminiszter problematikusnak nevezte annak a törvényhozási aktusnak az elfogadását, amely magyar állampolgárnak nyilvánítana minden magát magyarnak tekintő, Kárpát-medencében élő magyart.

Szeptember 30. A Magyar Kisebbség tematikus számában (1999/2-3) foglalkozik a kettős állampolgárság kérdésével, amelyhez vitaindítót Tamás Sándor írt.

Október 18-án az EBESZ bécsi konferenciáján Patrubány Miklós MVSZ-alelnök ismertette a külhoni állampolgárság intézményére vonatkozó elképzelését.

\section{0}

Január 14-én a magyar-magyar kapcsolatokról tartott előadást Kolozsváron Szabó Tibor, a HTMH elnöke. A MVSZ által szorgalmazott, kettős állampolgárságra vonatkozó javaslatát nem tartja szerencsésnek, ehelyett a kormány státustörvényt dolgoz ki a határon túli magyarok identitásának megőrzésére és megmaradásuk elősegítésére érdekében.

Március 15-től kezdődően nyolc romániai magyar idegenrendészeti hivatalánál kérhetik a moldovai állampolgárok a román állampolgárságuk visszaállítását, abban az esetben is, ha nem Romániában van az állandó lakhelyük.

Március 24. Kétoldalú, román-moldáv külügyminiszteri találkozóra került sor Bukarestben azt követően, hogy diplomáciai vita alakult ki a két állam között a román állampolgárság 
kiterjesztéséről. A moldovai állampolgárok - annak ellenére, hogy Moldova nem ismeri el a kettős állampolgárságot - Romániában is kérvényezhetik a román állampolgárságuk visszaállítását.

Augusztus 18-án a MVSZ elnöke bemutatta a külhoni állampolgárságról szóló törvénytervezetét, amely kiegészítené a készülő státustörvényt. A javaslat értelmében a kedvezményezettek magyar útlevelet kapnának.

Szeptember 26. Bukarestben ülésezett a Szövetség Operatív Tanácsa, amely közleményben felkérte a helyi szervezeteket, hogy - ahol erre igény mutatkozik-, gyüjtsenek támogató aláírásokat a külhoni állampolgárság intézményének létrehozásához.

\section{2}

November 1. A Moldovai Köztársaság parlamentje arról döntött, hogy elismeri a kettős állampolgárság intézményét. A döntést Mircea Geoană román külügyminiszter ,a helyes irányba tett lépésként" értékelte, egyben arra hívta fel a két állam vezetőinek figyelmét, hogy Románia integrációjával meg kell találni azt a megoldást, amely hozzájárul a Prut folyó két oldalán élő románok közötti kapcsolatok fenntartásához.

\section{3}

A Képviselőház április 8-i és a Szenátus május 22-i ülésén megvitatta és elfogadta az állampolgársági törvény módosítását, amelynek társkezdeményezője Tamás Sándor RMDSZ-es képviselő volt. A módosítás alapján, a volt román állampolgárok, akik valamilyen okból kifolyólag elveszítették állampolgárságukat, lakóhelyük szerinti állam külképviseletén kérvényezhetik az állampolgárság visszaszerzését.

Augusztus 4. A határon túli politikai szervezetek örömmel fogadták Kovács László külügyminiszter bejelentését, miszerint a kormány kész szakértői szintű tárgyalásokat folytatni a kettős állampolgárság kiterjesztéséről a szomszédos államok kormányaival és az EU-val.

Augusztus 14. Az EMNT Kezdeményező Testülete csatlakozott a Vajdasági Magyar Demokrata Párt kezdeményezéséhez, kettős állampolgárságot igényelve a magyar kormánytól. A Szövetség képviseletében Markó Béla kifejtette, hogy ő is tárgyalna a kettős állampolgárság kérdéséről, „de ebben az ügyben a döntés alapvetően a magyar kormányon múlik.”

Augusztus 18-án a MVSZ népszavazás kezdeményezését jelentette be a kettős állampolgárság ügyében. A tájékoztató szerint a kezdeményezéshez csatlakozott a Jobbik Magyarországért Mozgalom, valamint más civil szervezetek is.

Augusztus 30. Markó Béla szövetségi elnök szakértői bizottság létrehozását jelentette be, amelynek az lesz a feladata, hogy elemezze a kettős állampolgárság körül kialakul helyzetet.

Szeptember 11. A Krónikának adott interjúban Bársony András, a külügyminisztérium politikai államtitkára szerint Magyarország EU-csatlakozása után tủzhetné napirendre az állampolgársági rendszer megváltoztatását. Az államtitkár elmondta, hogy a minisztérium szakértői elemzik a kettős állampolgárság gyakorlatát az EU-tagállamaiban.

Szeptember 30. Az Országos Választási Bizottság hitelesítette az MVSZ népszavazási kezdeményezését, amelyen a következő kérdést fogalmazták meg: „Akarja-e, hogy az Országgyülés törvényt alkosson arról, hogy kedvezményes honosítással magyar állampolgárságot kapjon az a nem Magyarországon lakó, nem magyar állampolgár, aki magyar nemzetiségét a magyarigazolvánnyal vagy a megalkotandó törvényben meghatározott egyéb módon igazolja."

December 3. Mádl Ferenc köztársasági elnök által felkért szakértői testület arra a megállapításra jutott, hogy az állampolgárság megszerzésének leegyszerüsítése nem ütközik sem a magyar 
alkotmány, sem a nemzetközi jog rendelkezéseivel. A köztársasági elnök nyilatkozatát pozitívan fogadták a határon túli szervezetek. Az RMDSZ a MVSZ javaslatát követően 80 ezer aláírást gyüjtött a kettős állampolgárság támogatására.

December 4. A magyarországi parlamenti pártok egyetértettek a köztársasági elnök állásfoglalásával, derült ki a Dávid Ibolya által kezdeményezett többpárti megbeszélést követően. Az MDF elnökének tájékoztatása szerint a parlamenti pártok szakértői csoportot hoznak létre, és felkérték a kormányt, hogy január 30-ig küldje meg a négy pártnak a kettős állampolgárság kérdésében készített háttértanulmányokat.

December 9. Az RMDSZ képviseletében Takács Csaba, a HTMH elnökének jelenlétében ismertette a Szövetség hatástanulmányát, ami szerint a fiatal, 19-24 év közötti korosztály 10-14\%-a „a kitelepedést megkönnyítő eszköznek tekintené a kettős állampolgárság megadását."

\section{4}

Május 28. Orbán Viktor, a FIDESZ elnöke a Kossuth Rádió Vasárnapi Újság c. müsorában arról beszélt, hogy „a megoldás a jövőre nézve már nem a státustörvény, hanem a kettős állampolgárság".

Június vége. Patrubány Miklós, a MVSZ elnöke bejelentette, hogy összegyült a referendum kírásához szükséges 200 ezer támogató aláirás, amelyet a kettős állampolgárság ügyében kezdeményeztek.

Szeptember 13. Az Országgyülés az MVSZ sikeres aláírásgyüjtése után ügydöntő népszavazást rendelt el a kettős állampolgárság kérdésében. A parlamenti pártok közül a FIDESZ és az MDF a választóktól a határon túli magyarok igényének támogatását kérte, míg az SZDSZ ellenezte a javaslatot.

Október 5. A FIDESZ a kettős állampolgárság ügyét „pártok felett álló, nemzeti kérdésnek tekinti”, ennek következtében a referendumon a kettős állampolgárság támogatására hívta fel a figyelmet.

November 10. Gyurcsány Ferenc miniszterelnök szerint a kettős állampolgársággal rendelkező határon túli magyarok Magyarországra történő áttelepülése súlyos terheket róna a magyar munkaerőpiacra és a szociális ellátórendszerre.

A Medián közvéleménykutatásából kiderül, hogy a magyarországi választópolgárok közül másfélszer annyian vannak a kettôs állampolgárságot támogatók, mint ahányan ellenzik azt. A referendumon való részvétel a legoptimistább becslés szerint 45 százalék körülire várható.

November 11. A kormány a referendumon a kettős állampolgárság elutasítását támogatja, mert az elkészült háttértanulmányok szerint a határon túli magyaroknak nyújtott állampolgárság jelentősen megterhelné a magyar költségvetést.

November 12. Budapesten tartották a MÁÉRT nyolcadik ülését, amelynek fő témája a kettős állampolgárság volt. A feszült légkörben lefolyt tanácskozást követően a résztvevők a kormánypártok kivételével nyilatkozatot fogadtak el a kettős állampolgárság támogatásáról és felkérték a magyarországi választópolgárokat a népszavazáson való részvételre.

November 13-án sajtótájékoztató keretében Patrubány Miklós ismertette a MVSZ által készített hatástanulmányt, ami alapján a határon túli magyarok esetleges áttelepülése nem kiadásokat, „hanem többletbevételt jelentene a magyar költségvetésnek.” Patrubány egyben kifogásolta, hogy a MÁÉRT ülésére nem hívták meg a referendumot kezdeményező MVSZ képviselőjét.

November 13. Az MSZP elnöke, Hiller István a „nemzetpolgárság” jogi intézményének megalkotását, és a határon túli magyarok szabad beutazását lehetővé vető jogszabály előkészítését kérte a kormánytól. 
November 16-án folytatódott az MDF által kezdeményezett négypárti egyeztetés a kettős állampolgárságról. A FIDESZ a nemzeti összetartozás törvényének javaslatával megoldhatónak látja, hogy a magyar állam a határon túli magyarok bevándorlása nélkül biztosítsa a magyar állampolgárságot.

November 18. Gyurcsány Ferenc miniszterelnök a TV2 reggeli müsorában arról beszélt, hogy a kettős állampolgárságról szóló népszavazás „nem egyesíti, hanem szétszakítja a nemzetet”. A miniszterelnök szerint a kettős állampolgárság vitája arról szól, hogy miként lehet utazási kedvezményeket adni anélkül, hogy olyanokat ígérjünk, amiket nem tudunk teljesíteni.

November 18. Az RMDSZ közleményben arra kérte a magyar állampolgárokat, hogy a népszavazáson szavazzanak igennel a kettős állampolgársággal kapcsolatos kérdésre, egyben pedig felszólították a magyarországi kormánypártokat, hogy „ne folytassanak az anyaországi választókat és a határon túli magyarokat egymással szembeállító kampányt".

December eleje. Egyre feszültebb a vita a kormány- és az ellenzéki pártok között a kettős állampolgárság kérdésében. Az egymásnak ellentmondó érvek a kettős állampolgárság megadását követő, Magyarországra áttelepülő személyek számáról, valamint a társadalombiztosítási és nyugdíjrendszert ért kihívásokról szólt.

December 1-én az Országgyülés megvitatta a Szülőföld Alapról szóló javaslatot. A tervezet szerint a kormány egymilliárdos kezdőtőke mellett egy húszmilliárdos hitelprogrammal, valamint a Magyarországra történő beutazáshoz szükséges úti okmánnyal biztosítaná a határon túli magyarok szülőföldön maradását. Az ülésen felszólaló határon túli politikai szervezetek képviselői a kettős állampolgárság megadását kérték.

Adrian Năstase miniszterelnök kampánytémának nevezte a kettős állampolgárság kérdéséről kialakult vitát, amelynek szerinte nincs nemzetközi jogi és politikai alapja. A miniszterelnök arra hívta fel a figyelmet, hogy ha a romániai magyarok nem egyéni, hanem kollektív formában jutnak magyar állampolgársághoz, akkor kész az európai fórumokhoz fordulni.

December 2. Mircea Geoană a magyar külügyminiszterhez intézett levelében, hivatkozva a két állam között 1979-ben megkötött egyezményre, kifejtette, hogy az erdélyi magyarok akkor kaphatják meg a magyar állampolgárságot, ha lemondanak román állampolgárságukról.

A határon túli magyar politikai szervezetek és a kettős állampolgárság bevezetését támogató magyarországi pártok nyilatkozatot adtak ki, amelyben felkérték a magyarországi választópolgárokat, hogy mondjanak igent a kettős állampolgárságra, amely a nemzet újraegyesítésének eszközét képezi és arra hívták fel a politikai pártok figyelmét, hogy a kampány hátralevő részében „tartózkodjanak a túlzó kijelentésektől, a demagógiától és minden olyan megnyilvánulástól, amely hangulatot próbál szítani a határon túli magyarsággal szemben."

Az EP néppárti politikusai elítélték Adrian Năstase miniszterelnöknek a kettős állampolgárság intézményére vonatkozó rosszindulatú kijelentéseit. Ewa Klamt néppárti képviselő szerint az EU „,nem érintett abban, hogy tagországai kinek adják meg az állampolgárságot akár egy másik tagországban, akár azon kívül. Ez a tagállamok kizárólagos illetékessége."

December 3. Renate Weber jogász és emberjogi szakértő szerint az alapszerződés aláírásával megszünt minden olyan egyezmény, amelyet annak idején a Varsói Szerződés tagországai egymással kötöttek. Jelenleg nincsen olyan európai norma, amely tiltaná a kettős állampolgárság intézményét, mi több a módosított román alkotmány is elismeri ennek létét. Corneliu Liviu Popescu nemzetközi jogász is alaptalannak nevezte a miniszterelnök fenntartásait. Az MTI-nek adott nyilatkozatban kifejtette, hogy Năstase ugyan kifogásolhatja az állampolgárság megadását, azonban „önmagának mond ellent, hiszen a moldovai személyeknek megadott román állampolgárság is gyakorlatilag tömeges méretekben valósul meg." 
December 6. Az Országos Választási Iroda előzetes jelentése alapján eredménytelen volt a kettős állampolgárságról és a korházak privatizációjáról szóló népszavazás. A 37,5 \%-os részvétel mellett a kettős állampolgárságot támogató szavazatok száma 1516303 (51,55 százalék), míg a nemeké 1424909 (48,45 százalék) volt. A referendum eredményét Markó Béla szövetségi elnök a nemzetpolitikai konszenzusra való törekvés kudarcaként értékelte.

A sikertelen népszavazást követően polarizálódtak az ellentétek a parlamenti pártok között. A FIDESZ frakcióvezetője, Áder János a kormányt és az MSZP-t tette felelőssé a referendum eredménytelenségéért. Herényi Károly, az MDF frakcióvezetője nemzeti tragédiaként értékelte az eredményeket.

December 6. Mádl Ferenc köztársasági elnök Gyurcsány Ferenc miniszterelnök, Szili Katalin házelnök és Petrétei József igazságügyi miniszterrel folytatott tárgyalásokat és felkérte a parlamenti pártokat, hogy ,a kölcsönös kompromisszum igényével kezdjenek egyeztetést, és dolgozzanak ki olyan törvényjavaslatot, amely hozzájárulhat a nemzet egységéhez".

December 7. Az Országgyülés a népszavazás eredményét vitatta meg. Gyurcsány Ferenc miniszterelnök szerint az elbukott népszavazás jelzés arra vonatkozóan, hogy az állampolgárok nem kérnek a FIDESZ politikájából. Dávid Ibolya felszólalásában azt javasolta, hogy amennyiben a parlament március 15-ig nem tudja elfogadni a határon túli magyarok jogviszonyát szavatoló törvényt, úgy oszlassa fel magát.

December 18. A romániai parlamenti választások után Marosvásárhelyen ülésező SZKT és SZET állásfoglalásában megdöbbenéssel vette tudomásul, hogy a parlamenti pártok a határon túli magyarok kérdését pártpolitikai küzdelmek céljára használták fel. Az igen szavazatok többsége jelzés arra vonatkozóan - áll a dokumentumban -, hogy „Magyarország népe valójában nem utasította vissza a kettős állampolgárság eszményét," amelyről a közeljövőben ki lehet alakítani egy megfelelő megoldást.

December 20. A MÁÉRT tagszervezetei közös nyilatkozatban foglaltak állást a népszavazás eredményéről és arra kérték a magyarországi parlamenti pártokat, hogy módosítsák az állampolgársági törvényt, amely „lehetővé teszi a határon túli magyarok számára, hogy szülőföldjük elhagyása nélkül rendelkezhessenek magyar állampolgársággal.”

\section{5}

Január eleje. Gyurcsány Ferenc miniszterelnök a népszavazást követően több pontból álló javaslatcsomag kidolgozását jelentette be, amely egy öt évig érvényes nemzeti vízumot, a határon túli magyar fogalmának közjogi tartalommal való megtöltését, a honosítási eljárás felgyorsítását, az autonómiatörekvések támogatását és a Szülőföld-program elindítását tartalmazta.

Január 6-7. között Szabadkán tanácskoztak a határon túli magyar politikai szervezetek vezetői, akik elítélték azokat a magyarországi pártok képviselőit, akik félrevezették a választópolgárokat és a nemmel való szavazás mellett kampányoltak. A résztvevők ismételten felszólították az Országgyülést, hogy alkosson olyan törvényt, amely lehetővé teszi a magyar állampolgárság megszerzését.

Január 9. A Szabadkán megalakult Határon Túli Magyar Szervezetek Fóruma (HTMSZF) felkérte az államföt, hogy kezdeményezze az Országgyưlésben a határon túli magyarok számára a magyar állampolgárság kedvezményes megszerzését szabályozó törvény elfogadását.

Március 1. Avarkeszi Dezső letelepítési, bevándorlási és honosítási kormánybiztos önálló módosító indítványt nyújtott be az állampolgársági törvény módosítására vonatkozóan. A javaslat jelentősen lerövidítené az állampolgárság megszerzését, ugyanis már a letelepedési engedély kiváltása után lehetne kérelmezni az állampolgárságot, amit a belügyminisztérium 12 hónapon belül terjeszthet fel a köztársasági elnöknek. 
Május 4. A könnyített honosítási eljárás kérdését vitatta meg az Országgyülés. Avarkeszi Dezső kormánybiztos szerint a javaslat értelmében a jelenlegi 42 hónapról 19-20 hónapra csökken az állampolgárság megszerzésének folyamata, valamint az állampolgári vizsga díja is kisebb lesz. A FIDESZ képviseletében Szentgyörgyvölgyi Péter pótcselekvésnek nevezte az előterjesztést.

Június 7. A magyar Országgyülés egyhangúan elfogadta a magyar állampolgárságról és a külföldiek beutazásáról szóló törvényt.

Szeptember 5. Gyurcsány Ferenc miniszterelnök a határon túli magyar politikai szervezetek vezetőivel tanácskozott, akik kifejtették, hogy a határon túli magyarok továbbra is igénylik a kettős állampolgárságot.

Szeptember 20. A kormány a magyar személyi igazolvány bevezetésével kapcsolatosan tájékoztatta a határon túli magyar szervezeteket, amelyre minden határon túli, magyar állampolgársággal nem rendelkező magyar jogosult lenne. Azok a határon túli magyarok esetében, akik a közeljövőben nem lesznek EU-s állampolgárok a kormány nemzeti vízum bevezetését fontolgatja.

\section{6}

Október 16. Jelentősen megugrott a román állampolgárságot igénylő moldovai állampolgárok száma - tájékoztatott Mihai-Răzvan Ungureanu külügyminiszter. A román állampolgárság iránti igény megnövekedése azért tekinthető meglepőnek, mert a rendszerváltást követő 15 évben 130 ezer moldovai állampolgár szerzett román állampolgárságot, 2006 során pedig 400 ezer kérést iktattak az illetékes szerveknél.

\section{7}

Január 16. Traian Băsescu román és Vladimir Voronin moldáv államfö Kisinyovban két ideiglenes román konzulátus megnyitásáról folytatott tárgyalásokat, amely a két vezető reményei szerint felgyorsítja a vízumkibocsátás folyamatát. A román államfó ígéretet tett arra, hogy folytatják a román állampolgárságra vonatkozó kérelmek feldolgozását, aminek száma jelenleg meghaladja a félmilliót.

Március 9. A román állampolgársági törvény módosítási szándékát - amellyel Bukarest jelentősen megkönnyítené a román állampolgárság megszerzését -, a moldovai kormány nemzetbiztonságának és stabilitásának veszélyeztetéseként értékelte. Andrei Stratan külügyminiszter szerint, a moldáv kormány már nem támogatja a tervezett két konzulátus megnyitását.

Március 13. A moldáv külügyminiszter után az államfó és a kormányfö is bírálta Romániát az állampolgársági törvény esetleges módosításáért. A moldáv vezetők szerint a tömegesen nyújtott állampolgársággal Románia beleavatkozik az állam ügyeibe és veszélyezteti a Moldovai Köztársaság nemzetbiztonságát is.

Március 23. Újabb népszavazás kezdeményezését helyezte kilátásba az MVSZ a külhoni magyarok magyar állampolgárságának visszaállítására. A kezdeményezésről Markó Béla kifejtette, hogy az erdélyi magyarság továbbra is támogatja a kettős állampolgárság intézményét, ám ehhez a magyarországi pártok konszenzusa szükséges.

Szeptember 15-16. A KMKF budapesti ülésén elfogadta a Szili Katalin által előterjesztett nemzetpolitikai stratégiát, ami alapján olyan intézményrendszert hoznak létre, amely kiszámíthatóvá teszi az anyaországi támogatási rendszert. Németh Zsolt külügyi bizottsági elnök szerint a legfontosabb megoldás a kettős állampolgárság megadása lenne.

Szeptember 25. A Legfelső Védelmi Tanács ülésén Traian Băsescu román államfő felkérte a kormány képviselöit, hogy egyszerüsítsék a moldovaiak által benyújtott állampolgársági 
kérelmek procedúráját. Az államfő kifejtette, hogy „Románia erkölcsileg és politikailag is adósa Moldova Köztársaságnak”, amit a gyorsított eljárással odaítélt román állampolgársággal lehetne „törleszteni”.

Október eleje. A moldovai vezetés elítélte Traian Băsescu államfönek a kettős állampolgárság megszerzésére irányuló javaslatát. Kisinyov bevonta a TVR sugárzási engedélyét. Az EU is aggodalmát fogalmazta meg a moldvaiaknak nyújtott állampolgárságról.

\section{9}

Március 2. A KMKSZ közgyülésén Orbán Viktor, a FIDESZ elnöke a KKE-i államok gyakorlatára hivatkozva a kettős állampolgárság megadásáról beszélt.

Április 14. A román államfó a parlament együttes ülésén az állampolgársági törvény módosítását kérte, arra hivatkozva, hogy azon moldovai állampolgárok, akik akaratuk ellenére veszítették el, könnyített eljárással szerezhessék vissza román állampolgárságukat.

Április 16. Románia sürgősségi kormányrendelettel kívánja módosítani az állampolgársági törvényt - nyilatkozta Emil Boc kormányfö, aki kifejtette, hogy könnyítést azok az elsö-, másod- és harmadfokú leszármazottak igényelhetnek, akiknek felmenői román állampolgárok voltak. Nem szükséges továbbá bizonyítani a román nyelvtudást sem.

Április 29. Crisitian Diaconescu az EU külügyminiszteri találkozóján kifejtette, hogy az állampolgársági törvény módosítása nem jelenti azt, hogy a moldovai állampolgárok, tömegesen kettős állampolgárok lesznek. A külügyminiszterek szorgalmazták azt, hogy a két állam folytassa a párbeszédet a vita rendezése érdekében.

Május 8. Az ukrán külügyminisztérium aggodalmát fejezte ki a román állampolgársági törvény módosítása miatt, amelyről Kijev tájékoztatta az EU-t is. A román külügyminisztérium azonban hangsúlyozta, hogy a kedvezményes elbánás nem érinti az Ukrajnában élő román kisebbséget.

Június 9. Az RMDSZ szenátusi frakciója nem szavazta meg az állampolgársági törvény módosítására vonatkozó sürgősségi kormányrendeletet. Cseke Attila szenátor szerint a módosítás, amely a harmadfokú leszármazottaknak is lehetővé teszi a román állampolgárság megszerzését, kiszámíthatatlan folyamatokat indíthat el.

Október 12. A FIDESZ-KDNP politikusai - Semjén Zsolt (KDNP), Simicskó István (KDNP) és Németh Zsolt (Fidesz) - a parlamentben törvénymódosítást nyújtottak be a kettős állampolgárság ügyében. A javaslat szerint egyéni kérelemre kedvezményes eljárásban honosítható az a személy, aki magyar állampolgár felmenőkkel rendelkezik és igazolja magyar nyelvtudását.

November 16. Román-moldáv miniszterelnöki találkozó volt Bukarestben, ahol Emil Boc kormányfő Vlad Filat kormányfőt fogadta. A tárgyalásokon a felek áttekintették az államközi kapcsolatok vitás kérdéseit és megegyeztek a nagykövetek mielőbbi kinevezéséröl. Emil Boc kifejtette, hogy 2010-től egy kormányügynökség foglalkozik a moldovai állampolgárok által benyújtott állampolgársági kérelmek elbírálásával.

\section{0}

Május 5. Martonyi János leendő külügyminiszter az InfoRádióban arról beszélt, hogy a hivatalba lépő új kormány első intézkedései között szerepel majd az állampolgársági törvény módosítása. Martonyi kifejtette, hogy az állampolgárság megszerzése nem jár a szavazati jog kiterjesztésével.

Május 19. A román lapok a magyar állampolgárság kiterjesztésével foglalkoznak. A Gândul napilap szerint a PSD nem ellenzi a kettő állampolgárság megadását. Az Adevărul kifejtette, 
hogy a magyar kormány a román modellre hivatkozik, amikor az állampolgárság megadásáról nyilatkozik.

Május 26. Az Országgyülés nagy többséggel megszavazta az állampolgársági törvény módosítását, aminek értelmében a határon túli magyarok könnyített honosítási eljárás során magyar állampolgárságot szerezhetnek. Az Országgyülés 344 igen, 3 nem szavazat (Gyurcsány Ferenc, Molnár Gyula és Szanyi Tibor) és 5 tartózkodás mellett döntött így.

Június 18. Semjén Zsolt miniszterelnök-helyettes bukaresti látogatása során kifejtette, hogy a magyar állampolgárság megszerzését lehetővé tevőtörvény román mintára készült.

Június 29. Külügyminiszteri találkozóra került sor Bukarestben. Martonyi János román kollégájával folytatott tárgyalásokon elmondta, hogy Magyarország nem tömegesen, hanem egyéni elbírálás során ad állampolgárságot a határon túli magyaroknak, betartva a nemzetközi szabályokat. Bukaresti látogatása során a külügyminiszter találkozott Emil Boc miniszterelnökkel, és Markó Béla miniszterelnök-helyettessel.

November 5. Budapesten került sor a MÁÉRT kilencedik ülésére, amelyen a résztvevők üdvözölték az új magyar kormány nemzetpolitikai törekvéseit és a könnyített honosítás bevezetését, amely „a nemzeti összetartozás erősítését szolgálja.” A kulturális értelemben összetartozó nemzetet az állampolgárság - áll a zárónyilatkozatban - közjogi egységgé formálja.

November 24. Az egyszerüsített honosítási eljárás elősegítése és a kettős állampolgársággal kapcsolatos tájékoztatás érdekében a magyar kormány együttmüködési megállapodást kötött az EMNT-vel. A megállapodás keretében Erdély-szerte Demokrácia Központokat hoznak létre. Az elképzelések szerint 20 iroda müködtetését indítják el, hozzávetőleg 60 alkalmazottal.

November 25. Az Új Magyar Szónak adott interjúban Markó Béla RMDSZ elnök szerint a magyar kormánynak ,azokat az erdélyi szervezeteket kell támogatnia morálisan és politikailag, amelyeket az erdélyi magyarság is támogat."

\section{1}

Január 3-ától kezdődően lehetővé vált a honosítási kérelmek leadása. Az első kérelmet Bukarestben, Rétvári Bence államtitkár jelenlétében adták le. A kérelmeket a magyarországi anyakönyvi hivatalokban, a megyeszékhelyeken, a külképviseleteken, valamint a Bevándorlási és Állampolgársági Hivatalnál lehet leadni.

Február 2. Az MTI-nek adott nyilatkozatában Toró T. Tibor kifejtette, hogy a magyar kormány együttmüködése által létrehozott demokrácia-központok „nem a pártalapítás támogatásának szándékából" jöttek létre. Az ügyvezető azon RMDSZ-es vádakra kívánt reagálni, ami szerint a kormány az új intézményi hálózat finanszírozásával anyagilag is támogatná az EMNT-t.

Március 30. Az IRES közvélemény-kutató intézet felmérése szerint a román állampolgárokat megosztja az erdélyi magyarok kettős állampolgársága. Az országos mintán, 1177 személy megkérdezésével lezajlott felmérés szerint a válaszadók fele nem nézi jó szemmel az erdélyi magyarok kettős állampolgárságát, a könnyített honosítási eljárásról a megkérdezettek 9 százaléka nagyon jó, míg 38 százaléka volt jó véleménnyel. A megkérdezettek több mint kétharmada elutasítja a romániai magyar önkormányzati vezetők magyar állampolgárság iránti igényét.

November 25-én zajlott le a MÁÉRT tízedik ülése. A zárónyilatkozatban a résztvevők elítélték Szlovákiának a kettős állampolgársággal kapcsolatos, saját állampolgárait érintő magatartását és felkérték a magyar kormány képviselőit, hogy lépjen fel a nemzetközi fórumokon a hasonló jogsértések megakadályozása érdekében.

December 23. Nagy többséggel, 256 igen, 36 nem szavazattal az Országgyülés elfogadta a választójogi törvény módosítását, aminek értelmében a magyarországi lakóhellyel nem 
rendelkező magyar állampolgárok szavazati jogot kapnak és pártlistákra szavazhatnak a következő országgyülési választásokon.

\section{3}

Április 3. A Soros Alapítvány jelentése szerint 1991-2012 között a román hatóságokhoz közel 450 ezer állampolgársági kérelem érkezett a Moldovai Köztársaságból, az illetékes szervek pedig 323049 állampolgársági kérelmet dolgoztak fel, amiknek döntő többségét pozitívan bírálták el. Az alapítvány becslése szerint, a kiskorú gyerekeket is beszámítva a jelzett időpontban 400 ezer moldovai kapott román állampolgárságot.

\section{4}

Május 14. Semjén Zsolt miniszterelnök-helyettes a Kossuth téren elhangzott beszédében egymillió új magyar állampolgár honosítását tüzte ki célul a kormányzati ciklus végéig.

\section{5}

Február 18. Együttmüködési megállapodást írt alá az RMDSZ által alapított Eurotrans Alapítvány, a Miniszterelnökség, valamint a Külgazdasági és Külügyminisztérium képviselőivel Budapesten a könnyített honosítási eljárással járó ügyintézés érdekében.

Szeptember eleje. Megkezdték müködésüket az Eurotrans Alapítvány által koordinált területi irodák, melyek a könnyített honosítási eljárással kapcsolatos dokumentáció összeállításában segítenek. 


\section{2. Érvényben levő magyar-román államközi megállapodások és nemzetközi szerződések (1990-2017) $)^{529}$}

Állategészségügyi egyezmény a Magyar Köztársaság Kormány és Románia Kormánya között Aláírás helye, ideje: Budapest, 1992. október 20

Hatálybalépés: 1994. június 4.

Megállapodás a Magyar Köztársaság és Románia között a kettős adóztatás elkerülése és az adóztatás kijátszásának megakadályozására a jövedelem- és vagyonadók területén

Aláírás helye, ideje: Bukarest, 1993. szeptember 16.

Hatálybalépés: 1995. december 14.

Megállapodás a Magyar Köztársaság és Románia között a beruházások kölcsönös védelméről és elősegítéséröl

Aláírás helye, ideje: Bukarest, 1993. szeptember 16.

Hatálybalépés: 1996. május 6.

Légiközlekedési megállapodás a Magyar Köztársaság Kormánya és Románia Kormánya között Aláírás helye, ideje: Bukarest, 1995. szeptember 12.

Hatálybalépés: 1997. július 15.

Megállapodás a Magyar Köztársaság Kormánya és Románia Kormánya között az EBESZ 1994.évi Bécsi Dokumentumát kiegészítő bizalom- és biztonságerősítő intézkedésekről és katonai kapcsolatok fejlesztéséröl.

Aláírás helye, ideje: Arad, 1996. szeptember 6.

Hatálybalépés: 1997. szeptember 25.

Szerződés a Magyar Köztársaság és Románia között a megértésről, az együttmüködésről és a jószomszédságról

Aláírás helye, ideje: Temesvár, 1996. szeptember 16.

Hatálybalépés: 1996. december 27.

Egyezmény a Magyar Köztársaság Kormánya és Románia Kormánya között a minősített katonai információk kölcsönös védelméröl

Aláírás helye, ideje: Debrecen, 1997. február 17.

Hatálybalépés: 2003. november 18.

Jegyzőkönyv a Magyar Köztársaság és Románia Kormánya között a Magyar Köztársaság és Románia közötti együttmüködési és aktív partnerségi kormányközi Vegyes Bizottság létrehozásáról és müködés szabályzat

Aláírás helye, ideje: Budapest, 1997. március 12.

Hatálybalépés: 1997. május 29.

Egyezmény a Magyar Köztársaság Kormány és Románia Kormánya között az államhatáron keresztül megvalósuló vasúti határforgalom lebonyolításáról

Aláírás helye, ideje: Budapest, 1997. március 12.

Hatálybalépés: 1998. március 17.

529 Az összeállítás a Külgazdasági és Külügyminisztériumhoz benyújtott, nyilvános adatigénylési kérelmemre adott válasz, valamint a két állam külügyminisztériumának szerződéstára alapján készült el. 
Egyezmény a Magyar Köztársaság Kormánya és Románia Kormánya között a környezetvédelem terén való együttmüködésről

Aláírás helye, ideje: Bukarest, 1997. május 26.

Hatálybalépés: 2000. december 14.

Megállapodás a Magyar Köztársaság Kormánya és a Román Kormány között a nukleáris balesetek esetén adandó gyors értesítésről

Aláirás helye, ideje: Bukarest, 1997. május 26.

Hatálybalépés: 1998. október 1.

Egyezmény a Magyar Köztársaság Kormánya és Románia Kormánya között a Magyarországon, illetve Romániában akkreditált oktatási intézmények által kiadott diplomák, oklevelek, tanulmányi bizonyítványok és tudományos fokozatok kölcsönös elismeréséről

Aláírás helye, ideje: Bukarest, 1997. június 6.

Hatálybalépés: 1999. január 18.

Megállapodás a Magyar Köztársaság Kormánya és Románia Kormánya közötti együttmúködésről a katonai szállítások területén

Aláirás helye, ideje: Félix-fürdő, 1997. október 20.

Hatálybalépés: 2000. május 23.

Megállapodás a Magyar Köztársaság Kormánya és Románia Kormánya közötti közös békefenntartó zászlóalj létrehozásáról

Aláirás helye, ideje: Budapest, 1998. március 20.

Hatálybalépés: 1999. július 13.

Tudományos és Technológiai Együttmüködési megállapodás a Magyar Köztársaság Kormánya és Románai Kormánya között

Alárás helye, ideje: Budapest, 1999. november 26.

Hatálybalépés: 2000. augusztus 16.

Egyezmény a Magyar Köztársaság Kormánya és a Románia kormánya között a szezonális munkavállalók foglalkoztatásáról

Aláírás helye, ideje: Budapest, 2000. május 9.

Hatálybalépés: 2002. január 1.

Egyezmény a Magyar Köztársaság Kormánya és Románia kormánya között a gyakornokok cseréjéröl

Aláirás helye, ideje: Budapest, 2000. május 9

Hatálybalépés: 2002. január 1.

Egyezmény a Magyar Köztársaság Kormánya és Románia Kormánya között állampolgáraik és más személyek visszafogadásáról

Aláirás helye, ideje: Bukarest, 2001. december 10.

Hatálybalépés: 2002. november 30.

Egyetértési Nyilatkozat a Magyar Köztársaság Kormánya és Románia Kormánya között A szomszédos államokban élő magyarokról szóló törvényről és a kétoldalú együttmúködés egyéb kérdéseiről

Aláirás helye, ideje: Budapest, 2001. december 22.

Hatálybalépés: 2002. január 1.

Nyilatkozat a Magyar-Román Stratégiai Partnerségi Kapcsolatokról és Együttmüködésről Európáért a XXI. században 
Aláírás helye, ideje: Budapest, 2002. november 29.

Hatálybalépés: 2002. november 29.

Megállapodás a Magyar Köztársaság Kormánya és Románia Kormánya között a minősített katonai információk kölcsönös védelme tárgyában Debrecenben, 1997. február 17-én aláírt Egyezmény I. Cikkének módosításáról

Aláírás helye, ideje: Arad, 2002. október 17.

Hatálybalépés: 2004. január 26.

Megállapodás a Magyar Köztársaság Kormánya és Románia Kormánya között a katonai együttmüködésröl

Aláírás helye, ideje: Budapest, 2003. április 7.

Hatálybalépés: 2004. január 30.

Megállapodás a Magyar Köztársaság Kormánya és Románia Kormánya között a vízumkötelezettség kölcsönös megszüntetéséröl

Aláírás helye, ideje: Budapest, 2003. április 9.

Hatálybalépés: 2003. október 23.

Egyezmény a Magyar Köztársaság Kormánya és Románia Kormánya között a katasztrófák esetén történő együttmüködésről és kölcsönös segítségnyújtásról

Aláírás helye, ideje: Budapest, 2003. április 9.

Hatálybalépés: 2004. június 23.

Egyezmény a Magyar Köztársaság Kormánya és Románia Kormánya között a határvizek védelme és fenntartható hasznosítása céljából folytatandó együttmüködésröl

Aláírás helye, ideje: Budapest, 2003. szeptember 15.

Hatálybalépés: 2004. június 23.

Megállapodás a Magyar Köztársaság Kormánya és Románia Kormánya között

Aláírás helye, ideje: Bukarest, 2003. szeptember 23.

Hatálybalépés: 2003. december 17.

Egyezmény a Magyar Köztársaság és Románia Között a közúti és vasúti határforgalom ellenőrzéséről

Aláírás helye, ideje: Bukarest, 2004. április 27.

Hatálybalépés: 2005. szeptember 13.

Egyezmény a Magyar Köztársaság és Románia Között a közúti és vasúti határforgalom ellenőrzéséről. Az Ảrtánd-Bors határátkelő hely megnyitása és üzemeltetése

Aláírás helye, ideje: Bukarest, 2004. április 27.

Hatálybalépés: 2005. szeptember 13.

Megállapodás a Magyar Köztársaság Kormánya és Románia Kormánya között a gazdasági együttmüködésről

Aláirás helye, ideje: Budapest, 2005. április 26.

Hatálybalépés: 2005. november 28.

Egyezmény a Magyar Köztársaság és Románia között a szociális biztonságról

Aláirás helye, ideje: Bukarest, 2005. október 20.

Hatálybalépés: 2006. november 1. 
Egyezmény a Magyar Köztársaság Kormánya és Románia Kormánya között a Magyar Köztársaság Bukaresti Kulturális Központja és a Budapesti Román Kulturális Intézet müködéséről

Aláírás helye, ideje: Bukarest, 2005. október 20.

Hatálybalépés: 2006. július 29.

Megállapodás a Magyar Köztársaság Kormánya és Románia Kormánya Között a Magyar-Romána Gozsdu Közalapítvány létrehozásáról

Aláírás helye, ideje: Bukarest, 2005. október 20.

Hatálybalépés: 2006. december 29.

Szerződés a Magyar Köztársaság és Románia között a magyar-román államhatár rendjéről, az együttmüködésről és a kölcsönös segítségnyújtásról

Aláírás helye, ideje: Bukarest, 2005. október 20.

Hatálybalépés: 2007. január 6.

Igazgatási Megállapodás a Magyar Köztársaság és Románia között a szociális biztonságról szóló Egyezmény végrehajtására

Aláírás helye, ideje: Bukarest, 2006. október 19.

Hatálybalépés: 2007. május 10.

Megállapodás a Magyar Köztársaság Kormánya és Románia Kormánya között a Magyar Köztársaság és Románia között a közúti és vasúti határforgalom ellenőrzéséről szóló, Bukarestben, 2004. április hónap 27. napján aláírt Egyezmény végrehajtásáról

Aláírás helye, ideje: Bukarest, 2006. december 21.

Hatálybalépés: 2007. december 15.

A Magyar Köztársaság Kormánya és Románia Kormánya között a Tanács 2003. február 18-án kelt, 343/2003/EK rendeletének alkalmazása érdekében történő együttmüködésről (közigazgatási)

Aláírás helye, ideje: Nagyszeben, 2007. november 14.

Hatálybalépés: 2008. szeptember 3.

Megállapodás a Magyar Köztársaság Kormánya és Románia Kormánya között a légtérrendészeti feladatokban történö együttmüködésröl

Aláírás helye, ideje: Nagyszeben, 2007. november 14

Hatálybalépés: 2008. október 30.

A Magyar Köztársaság Kormánya és Románia Kormánya közötti, a romániai magyar hadisírok és a magyarországi román hadisírok helyzetéröl szóló megállapodás

Aláírás helye, ideje: Bukarest, 2008. március 6

Hatálybalépés: 2009. március 6.

A Magyar Népköztársaság és a Román Szocialista Köztársaság között Bukarestben, 1973. november 28-án aláirt konzuli egyezmény módosításáról szóló megállapodás

Aláírás helye, ideje: Bukarest, 2008. szeptember 25.

Hatálybalépés: 2010. március 5.

Megállapodás a Magyar Köztársaság Kormánya és Románia Kormánya között a határokat átlépő bünözés megelőzése és leküzdése érdekében folytatott együttmüködésröl

Aláírás helye, ideje: Szeged, 2008. október 21.

Hatálybalépés: 2010. január 17. 
Jegyzökönyv a Magyar Köztársaság Kormánya és Románia Kormánya között Kiszombor-Nagycsanád (Cenad) határátkelőhelyen közös kapcsolattartási szolgálati hely létrehozásáról

Aláirás helye, ideje: Bukarest, 2009. december 28.

Hatálybalépés: 2010. február 25.

A Magyar Köztársaság Kormánya és Románia Kormánya között a magyar-román államhatárt keresztező földgázszállító vezetékekkel, valamint a villamos távvezetékekkel kapcsolatos együttmüködésről szóló megállapodás

Aláírás helye, ideje: Budapest, 2010. május 12.

Hatálybalépés: 2010. október 16.

A Magyar Köztársaság Kormánya és Románia Kormánya között a Szolnok-Nagykereki (HU) és Santăul Mare (Nagyszántó) - Cluj-Napoca (Kolozsvár) (RO) közötti autópálya-kapcsolat létesítéséről szóló Megállapodás

Aláírás helye, ideje: Budapest, 2011. július 5.

Hatálybalépés: 2012. szeptember 27.

A Magyar Köztársaság Kormánya és Románia Kormánya között a Szeged-Makó-Csanádpalota (H) és Nădlac-Arad (RO) közötti autópálya-kapcsolat létesítéséről szóló Megállapodás

Aláírás helye, ideje: Budapest, 2011. július 5.

Hatálybalépés: 2012. szeptember 27.

Magyarország Kormánya, valamint Románia Kormánya között a magyar-román államhatáron átvezető közúti kapcsolatokról szóló Megállapodás

Aláírás helye, ideje: Bukarest, 2014. július 24.

Hatálybalépés: 2014. december 19. 


\section{Alapszerződések Európában (térkép)}

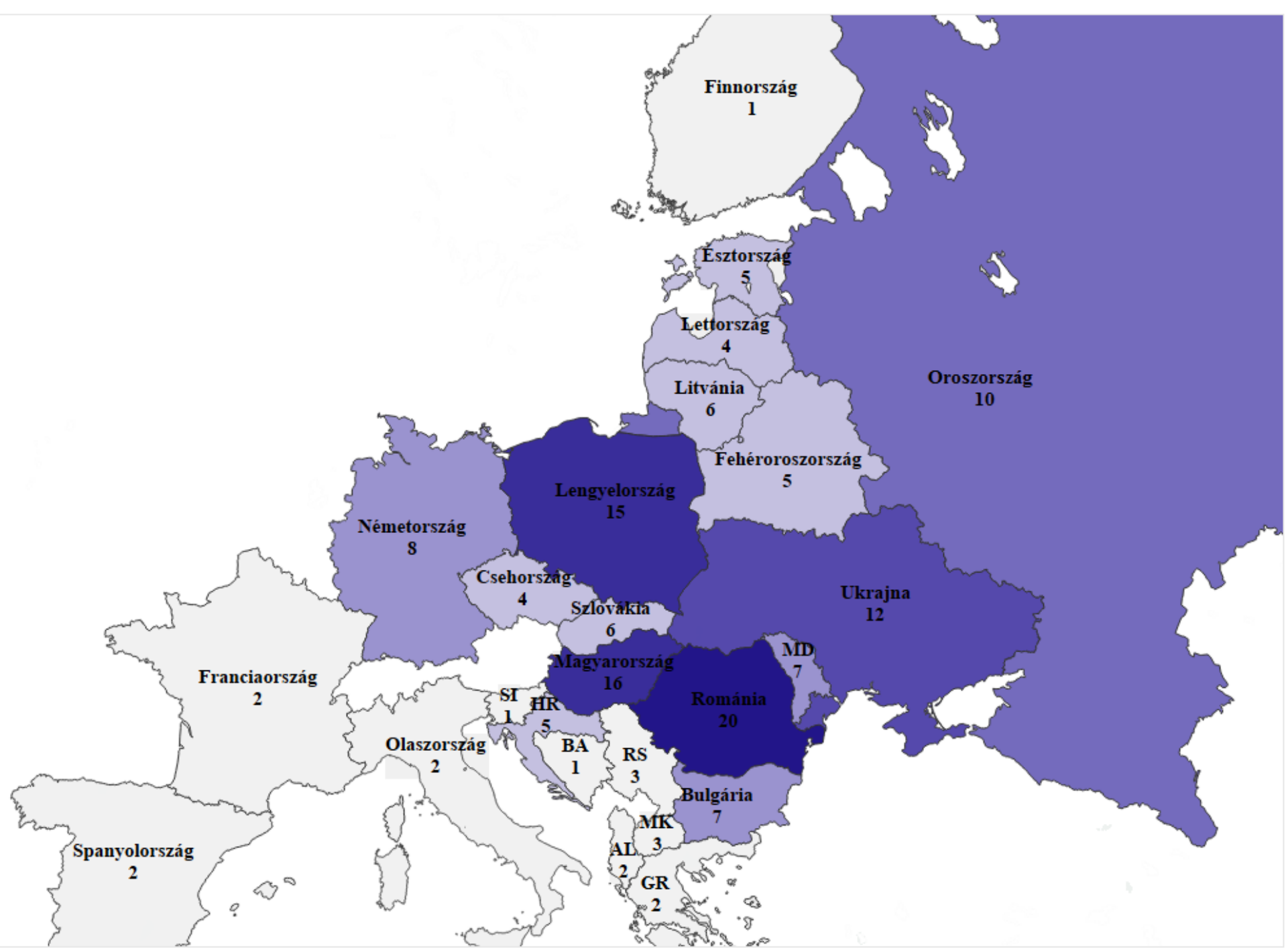

*SI-Szlovénia: 1; HR-Horvátország: 5; BA-Bosznia-Hercegovina: 1; RS-Szerbia: 3; MK-Macedónia: 3; AL-Albánia: 2; GR- Görögország: 2; MD Moldova Köztársaság: 7. Forrás: Saját szerkesztés (Lantschner-Medda-Windischer 2001, pp. 534-561; Gál 1999; Arp 2008) alapján. 


\section{4. Összefoglaló táblázatok}

1. sz. táblázat: A határon túli közösségek helyzetére és az anyaország szerepére vonatkozó cikkelyek az európai alkotmányokban

\begin{tabular}{|c|c|}
\hline $\begin{array}{l}\text { Államok (az alkotmány } \\
\text { elfogadása) }\end{array}$ & Releváns cikkelyek \\
\hline $\begin{array}{l}\text { Olaszország, } 1947 \\
\text { (több alkalommal } \\
\text { módosítva) }\end{array}$ & $\begin{array}{l}\text { 35. cikkely: A Köztársaság elismeri a törvény által megállapított kötelezettségeknek } \\
\text { megfelelöen az elvándorlás szabadságát és védi külföldön az olasz munkaerőt. }\end{array}$ \\
\hline $\begin{array}{c}\text { Írország: } 1973 \\
\text { (1998-ban módosítva) }\end{array}$ & $\begin{array}{l}\text { 2. cikkely: [...] Az ír nemzet különösen elkötelezett külföldön élö az ír származású } \\
\text { személyek iránt, akikkel osztozik az ír nemzet kulturális identitásában és örökségében. }\end{array}$ \\
\hline Görögország, 1975 & $\begin{array}{l}\text { 108. cikkely: (1) Az állam gondoskodik a külföldön élö görögökröl és az } \\
\text { anyaországgal való kapcsolattartás fenntartásáról. Támogatja tovább a külföldön } \\
\text { dolgozó görögök oktatását és szakmai elöre menetelét. } \\
\text { A } 2001 \text {-es alkotmánymódosítást követően a cikkely egy újabb bekezdéssel egészült } \\
\text { ki: (2) A Határon túli Görögök Tanácsának szervezeti, müködési és illetékességi } \\
\text { feladatait törvény szabályozza. A Tanács feladata a külföldön élö görög közösség } \\
\text { képviselete. }\end{array}$ \\
\hline $\begin{array}{l}\text { Portugália, 1976, } \\
\text { (2001-ben módosítva) }\end{array}$ & $\begin{array}{l}\text { 15. cikkely: (3) A portugál nyelvű országok állampolgárai és a Portugáliában állandó } \\
\text { lakhellyel rendelkező személyeknek a törvény és a kölcsönösség értelmében elismerik } \\
\text { azon jogait, melyek más külföldieket nem illetnek meg. Ez alól kivételt képez az } \\
\text { államfö, a Képviselöház elnöke, a miniszterelnök, a Legfelsőbb Bíróság, a fegyveres } \\
\text { erők fôparancsnokának pozíciója, valamint a diplomáciai szolgálat. }\end{array}$ \\
\hline Törökország, 1982 & $\begin{array}{l}\text { 62. cikkely: Az állam megteszi a szükséges intézkedéseket annak érdekében, hogy } \\
\text { biztosítsa a külföldön dolgozó török állampolgárok családjainak, a gyermekek } \\
\text { oktatásának és társadalombiztosításának egységét, védi a hazájukhoz füződő } \\
\text { kapcsolataikat és segíti őket a hazatérésben. }\end{array}$ \\
\hline $\begin{array}{l}\text { Spanyolország, 1978, } \\
\text { (1992-ben módosítva) }\end{array}$ & $\begin{array}{l}\text { 42. cikkely: Az állam különös figyelemmel kíséri a külföldön tartózkodó spanyol } \\
\text { munkavállalók gazdasági és szociális jogainak védelmét és olyan szakpolitikát folytat, } \\
\text { amellyel a hazatérésüket támogatja. }\end{array}$ \\
\hline $\begin{array}{l}\text { Magyarország, } 1949 \\
\text { (1990-ben módosítva) }\end{array}$ & $\begin{array}{l}\text { 6. cikkely: (3) A Magyar Köztársaság felelősséget érez a határain kívül élő magyarok } \\
\text { sorsáért, és előmozdítja a Magyarországgal való kapcsolatuk ápolását. }\end{array}$ \\
\hline $\begin{array}{l}\text { Horvátország, } 1990 \\
\text { (több alkalommal } \\
\text { módosítva) }\end{array}$ & $\begin{array}{l}\text { 10. cikkely: A Horvát Köztársaság védi azon állampolgárainak jogait és érdekeit, akik } \\
\text { külföldön élnek vagy tartózkodnak, és támogatja hazájukhoz füződő kapcsolataikat. A } \\
\text { más államokban élő horvát nemzet részei iránt a Horvát Köztársaság különös } \\
\text { gondossággal jár és védelemben részesíti őket. }\end{array}$ \\
\hline Albánia, 1991 & $\begin{array}{l}\text { 8. cikkely: (1) Az Albán Köztársaság védi az állam határain kívül élö albán nép } \\
\text { jogait. (3) Az Albán Köztársaság segítséget nyújt a határokon kívül élő és dolgozó } \\
\text { albánoknak a nemzeti kulturális örökséggel való kapcsolat fenntartásához és } \\
\text { fejlesztéséhez. }\end{array}$ \\
\hline Macedónia, 1991 & $\begin{array}{l}\text { 49. cikkely: A Köztársaság gondoskodik a szomszédos államokban élő macedón } \\
\text { lakosság, valamint a hazájából elüzött személyek státusáról és jogairól, segíti } \\
\text { kulturális fejlődésüket és támogatja a velük való kapcsolatot. }\end{array}$ \\
\hline Szlovénia, 1991 & $\begin{array}{l}\text { 5. cikkely: Az állam joghatósága alá tartozó területén védi az alapvető emberi- és } \\
\text { szabadságjogokat. Védi és garantálja az öshonos olasz és magyar közösség jogait. } \\
\text { Gondoskodik az őshonos szlovén nemzeti kisebbségekröl a szomszédos országokban, } \\
\text { a kivándorolt szlovénekröl és a vendégmunkásokról, valamint serkenti kapcsolataikat } \\
\text { hazájukkal. } \\
\text { A szlovén állampolgársággal nem rendelkező szlovének Szlovéniában külön jogokat } \\
\text { és kedvezményeket élvezhetnek Ezen jogok és kedvezmények fajtáit és terjedelmét } \\
\text { törvény határozza meg. }\end{array}$ \\
\hline $\begin{array}{c}\text { Románia, } 1991 \\
\text { (2003-ban módosítva) }\end{array}$ & $\begin{array}{l}\text { 7. szakasz: Az állam támogatja az ország határain kívüli románokkal való } \\
\text { kapcsolattartást, és cselekszik az etnikai, kulturális, nyelvi és vallási identitásuk } \\
\text { megörzéséért, fejlesztéséért és kifejezéséért, tiszteletben tartva annak az államnak a } \\
\text { törvényeit, amelynek az állampolgárai. }\end{array}$ \\
\hline
\end{tabular}




\begin{tabular}{|c|l|}
\hline $\begin{array}{c}\text { Államok (az alkotmány } \\
\text { elfogadása) }\end{array}$ & \multicolumn{1}{c|}{ Releváns cikkelyek } \\
\hline Szlovákia, 1992 & $\begin{array}{l}\text { 7.a cikkely tartalma a 2001-es alkotmánymódosítás következtében: } \\
\text { A Szlovák Köztársaság támogatja a külföldön élö szlovákok nemzeti öntudatát és } \\
\text { kulturális önazonosságát, támogatja az e célból létrehozott intézményeiket, és } \\
\text { kapcsolattartásukat az anyaországgal. }\end{array}$ \\
\hline Ukrajna, 1996 & $\begin{array}{l}\text { 12. cikkely: Ukrajna gondoskodik az állam határain kívül élö ukránok nemzeti, } \\
\text { kulturális és nyelvi szükségleteinek a kielégítéséről. }\end{array}$ \\
\hline Lengyelország, 1997 & $\begin{array}{l}\text { 6. cikkely: (2) A Lengyel Köztársaság segítséget nyújt a határokon kívül élö } \\
\text { lengyeleknek a nemzeti kulturális örökséggel való kapcsolat fenntartásához. }\end{array}$ \\
\hline Svájc, 1999 & $\begin{array}{l}\text { 40. cikkely: (1) A Svájci Államszövetség elösegíti a külföldön élö svájci férfiak és } \\
\text { nök, valamint ezek kapcsolatát hazájukhoz. (2) Az állam támogatja azokat a a } \\
\text { szervezeteket, melyek e célokat követik. Az állam megállapítja a külföldön élő } \\
\text { svájciak jogaira és kötelezettségeire vonatkozó szabályokat, különös tekintettel a } \\
\text { politikai jogok gyakorlására, a kötelezö sorkatonai szolgálat letöltésére, valamint a } \\
\text { társadalombiztosítási kötelezettségek teljesítésére vonatkozóan. }\end{array}$ \\
\hline
\end{tabular}

Forrás: („Verfassungen der Welt. Gegenwärtige und historische nationale und internationale Verfassungstexte”) utolsó elérés 2018. január 14-én. Saját fordítás, melynek szövegét - amennyiben létezett - összevetettem a korábbi magyar fordításokkal. 
2. sz. táblázat: Státus- vagy kedvezménytörvények Európában

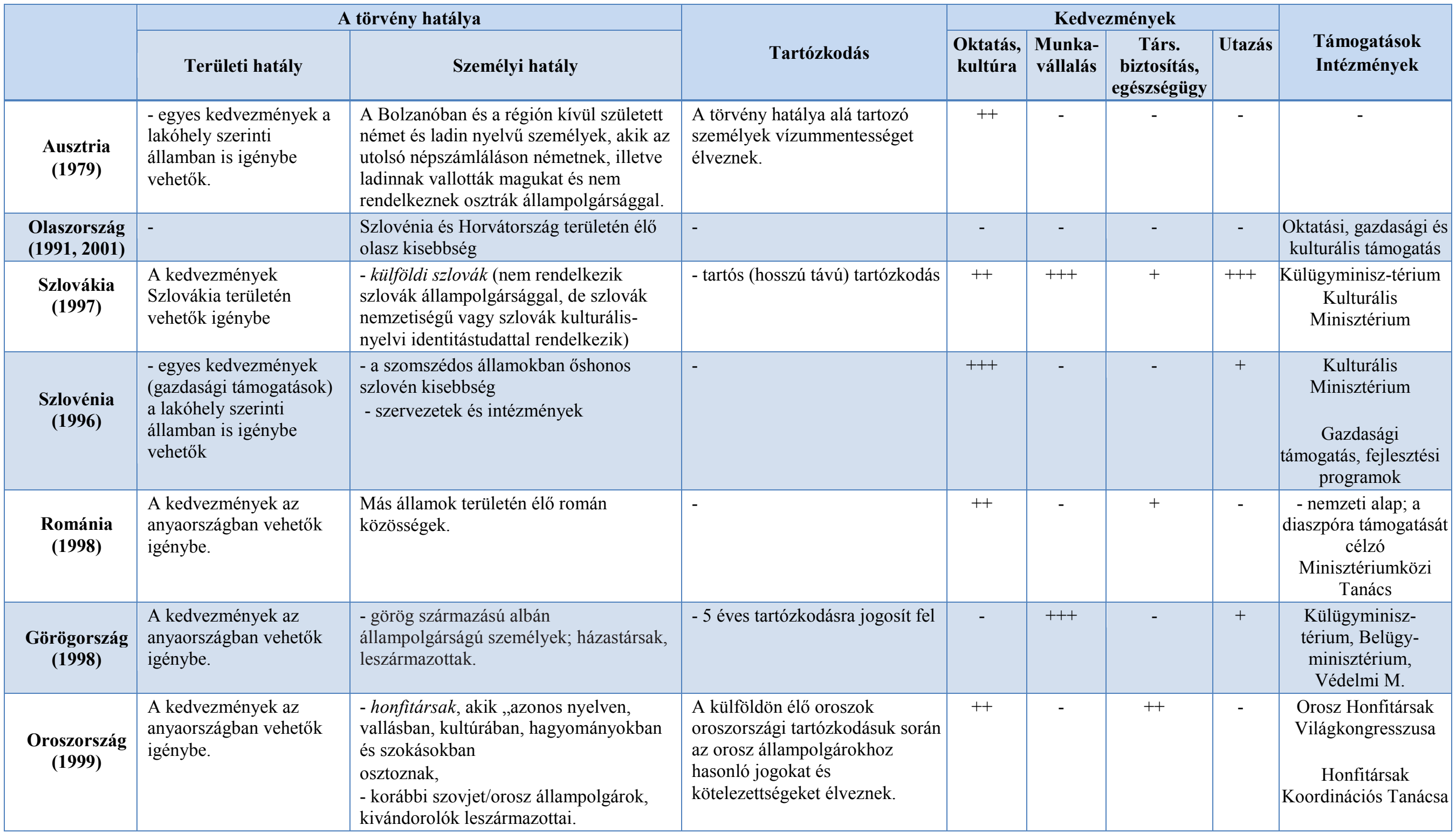




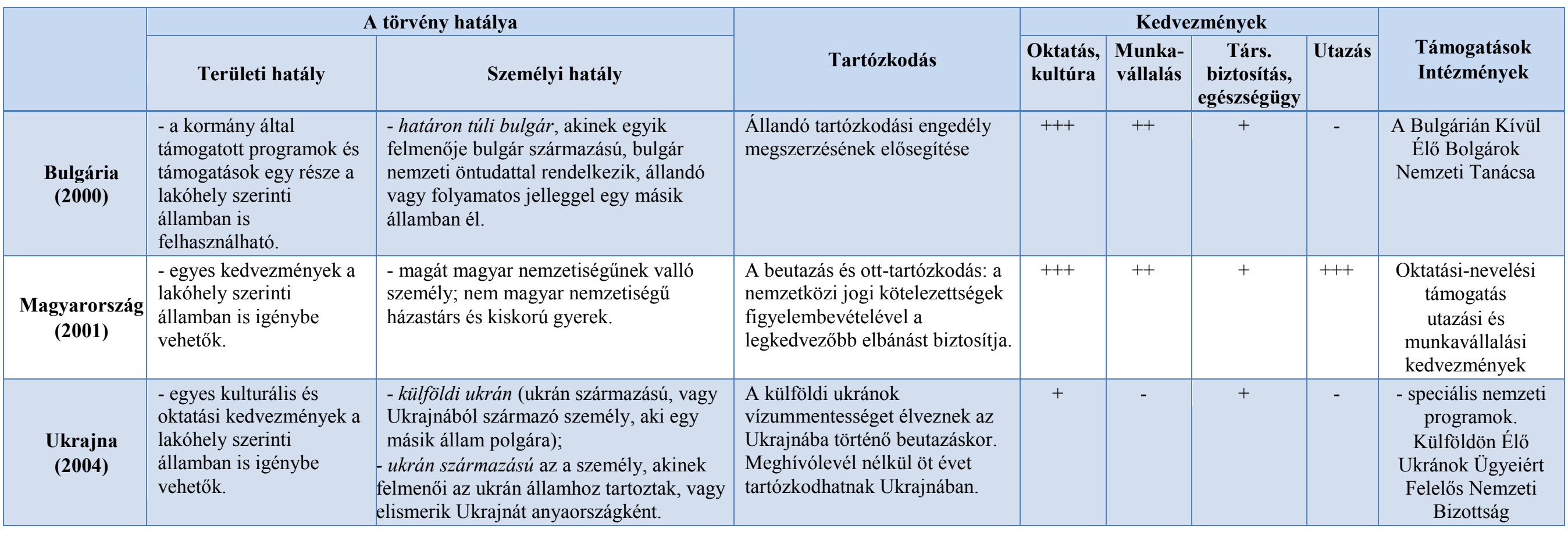

Forrás: Saját szerkesztés a Velencei Bizottság dokumentumgyüjteménye alapján („Preferential Treatment of National Minorities by their Kin-State: Collection of Laws" 2001), saját kiegészítésekkel.

+ Alapvető kedvezmények, minimális támogatás

+++ A támogatások széles köre, jelentős kedvezmények 
3. sz. táblázat: Az állampolgárság megszerzése: a honosítás feltételei az EU-28 és a térség államaiban

\begin{tabular}{|c|c|c|c|c|c|c|c|c|c|}
\hline $\begin{array}{l}\text { Államok / } \\
\text { Feltételek }\end{array}$ & & 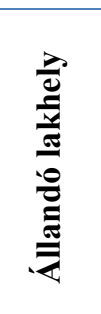 & 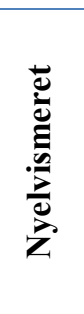 & 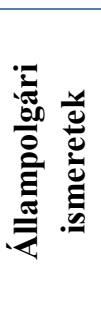 & 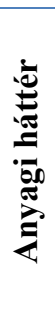 & 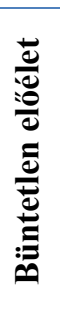 & 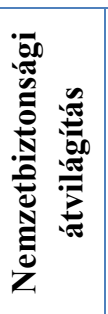 & 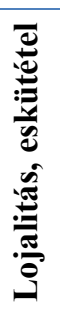 & Egyéb \\
\hline Albánia & - & 5 év & + & - & + & + & + & - & - \\
\hline Ausztria & Igen & 5 év & +++ & +++ & + & + & + & - & - \\
\hline Belgium & - & 5 év & +++ & - & - & + & - & - & $\begin{array}{l}\text { Megfelelő társadalmi } \\
\text { integráció. }\end{array}$ \\
\hline $\begin{array}{c}\text { Bosznia és } \\
\text { Hercegovina }\end{array}$ & Igen & 3 év & ++ & + & + & + & + & & - \\
\hline Bulgária & Igen & 5 év & +++ & - & + & + & - & - & - \\
\hline Ciprus & - & 5 év & - & - & - & - & - & + & Jó jellem. \\
\hline Csehország & - & 5 év & +++ & +++ & + & + & + & - & $\begin{array}{l}\text { Megfelelő társadalmi } \\
\text { integráció, nincs köztartozása }\end{array}$ \\
\hline Dánia & - & 9 év & +++ & +++ & + & + & - & + & Nincs adó/köztartozása. \\
\hline Egyesült Királyság & - & 5 év & ++ & +++ & - & - & - & + & Jó jellem. \\
\hline Észtország & Igen & 5 év & +++ & +++ & + & - & - & + & - \\
\hline Fehéroroszország & - & 7 év & +++ & - & + & + & - & - & - \\
\hline Finnország & - & 5 év & ++ & - & + & + & - & - & - \\
\hline Franciaország & - & 5 év & ++ & + & - & + & - & - & Jó jellem. \\
\hline Görögország & - & 7 év & ++ & + & + & + & - & - & Jó erkölcs. \\
\hline Hollandia & Igen & 5 év & +++ & +++ & - & + & - & + & - \\
\hline Horvátország & - & 8 év & +++ & + & - & - & - & - & - \\
\hline Írország & - & 5 év & - & - & - & - & - & + & Jó jellem. \\
\hline Koszovó & - & 5 év & + & + & + & - & - & & $\begin{array}{l}\text { Megfelelő társadalmi } \\
\text { integráció. }\end{array}$ \\
\hline Lengyelország & - & 3 év & +++ & - & + & - & + & & - \\
\hline Lettország & Igen & 5 év & +++ & + & + & - & - & + & - \\
\hline Litvánia & Igen & 10 év & +++ & + & + & + & + & & - \\
\hline Luxemburg & - & 7 év & ++ & + & - & + & - & - & - \\
\hline Macedónia & - & 8 év & +++ & - & + & + & + & + & - \\
\hline Magyarország & - & 8 év & +++ & +++ & + & + & + & & - \\
\hline Málta & - & 7 év & +++ & - & - & - & - & - & Jó jellem. \\
\hline Moldova & - & 10 év & + & +++ & + & - & - & - & \\
\hline Montenegró & Igen & 10 év & +++ & - & + & + & + & & $\begin{array}{l}\text { Nincs köztartozása, } \\
\text { adóhátraléka. }\end{array}$ \\
\hline Németország & - & 8 év & +++ & +++ & + & + & - & + & - \\
\hline Olaszország & - & 10 év & - & - & + & + & - & - & - \\
\hline Oroszország & - & 5 év & +++ & - & + & + & + & & A törvények betartása \\
\hline Portugália & - & 6 év & ++ & - & - & + & - & - & $\begin{array}{l}\text { Szoros kapcsolatot ápol a } \\
\text { nemzeti közösséggel. }\end{array}$ \\
\hline
\end{tabular}




\begin{tabular}{|c|c|c|c|c|c|c|c|c|c|}
\hline $\begin{array}{l}\text { Államok / } \\
\text { Feltételek }\end{array}$ & 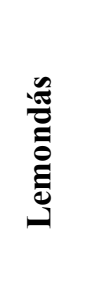 & 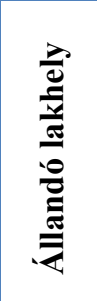 & 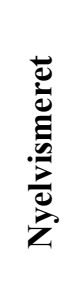 & 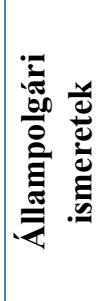 & 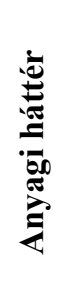 & 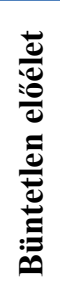 & 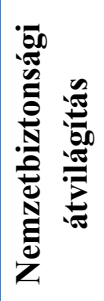 & 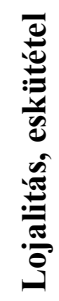 & Egyéb \\
\hline Románia & - & 8 év & +++ & +++ & + & - & + & + & Jó magatartás. \\
\hline Spanyolország & Igen & 10 év & +++ & +++ & - & - & + & + & Tiszteletreméltó élet. \\
\hline Svédország & - & 5 év & $+?$ & - & + & - & - & - & - \\
\hline Szerbia & - & 3 év & - & - & - & - & - & + & - \\
\hline Szlovákia & - & 8 év & ++ & +++ & - & + & - & - & Jó jellem. \\
\hline Szlovénia & - & 5 év & +++ & - & + & + & + & + & - \\
\hline Ukrajna & Igen & 5 év & +++ & - & + & + & - & - & - \\
\hline
\end{tabular}

Nyelvtudás: + alapfok; ++ középfok; felsőfok, +++ folyékony nyelvtudás

Állampolgársági ismeretek: +++ formális, írásbeli teszt

Forrás: Global Citizenship Observatory (GLOBALCIT), 2017. http://globalcit.eu/acquisitioncitizenship/, letöltés ideje: 2018. április 25. 
4. sz. táblázat: Az állampolgárság megszerzése: a kedvezményes honosítás feltételei az EU-28 és a térség államaiban

\begin{tabular}{|c|c|c|c|c|}
\hline $\begin{array}{l}\text { Államok / } \\
\text { Feltételek }\end{array}$ & Más állam polgára & Származás (állampolgár felmenők) & Szocializáció & Kulturális kötödés \\
\hline Albánia & - & $\begin{array}{l}\text { Közvetlen, vagy második generációs } \\
\text { leszármazottak esetében legalább } 3 \text { évet } \\
\text { meghaladó állandó lakhellyel kell rendelkezzen. }\end{array}$ & - & $\begin{array}{l}\text { Születi albán származásúak; albán } \\
\text { származású és (1) egy EU-tagállam, vagy } \\
\text { az USA állampolgára; (2) más állam } \\
\text { polgára/ hontalan, de egyik szülő albán } \\
\text { állampolgár; (3) más állam polgára/ } \\
\text { hontalan, de Albániában született. }\end{array}$ \\
\hline Ausztria & $\begin{array}{l}\text { Az EGT tagállamának állampolgára; } \\
\text { - állandó tartózkodás: } 6 \text { év. }\end{array}$ & Egy elhunyt állampolgár gyermeke. & - & - \\
\hline Belgium & - & Elhunyt állampolgár gyermeke. & - & - \\
\hline $\begin{array}{c}\text { Bosznia és } \\
\text { Hercegovina }\end{array}$ & - & Elhunyt állampolgár gyermeke. & - & $\begin{array}{l}\text { Emigráns, második vagy harmadik } \\
\text { generációs emigráns leszármazottja. }\end{array}$ \\
\hline Bulgária & - & Elhunyt állampolgár gyermeke. & - & $\begin{array}{l}\text { A kérelmező származás révén válik } \\
\text { állampolgárrá. }\end{array}$ \\
\hline Ciprus & $\begin{array}{l}\text { Nagy-Britannia vagy a Brit } \\
\text { Nemzetközösség állampolgára, ciprusi } \\
\text { leszármazott, és legalább egy évet ott } \\
\text { élt. }\end{array}$ & $\begin{array}{l}\text { Elhunyt állampolgár gyermeke, aki } 1960 . \\
\text { augusztus 16. elött született. Ha állandó } \\
\text { lakhelye külföldön van, állampolgárként kell } \\
\text { nyilvántartani, olyan esetben is, ha állampolgár } \\
\text { házastársa, özvegye. }\end{array}$ & - & - \\
\hline Csehország & $\begin{array}{l}\text { - EU, Svájc vagy az EGT állampolgára } \\
\text { - állandó tartózkodás: } 3 \text { év. }\end{array}$ & $\begin{array}{l}\text { Csehszlovák állampolgár közvetlen } \\
\text { leszármazottja, de nem lett sem cseh, sem } \\
\text { szlovák állampolgár. }\end{array}$ & $\begin{array}{l}10 \text { éves kora óta Csehországban élő, } \\
\text { állandó lakóhellyel rendelkező személy. }\end{array}$ & - \\
\hline Dánia & $\begin{array}{l}\text { Egy északi állam polgára, } 23 \text { év alatti } \\
\text { és összesen } 10 \text { évet élt Dániában. }\end{array}$ & $\begin{array}{l}\text { Dán állampolgár gyermeke, } 20 \text {. életévének } \\
\text { betöltése elött Dániában tartózkodott, legalább } \\
2 \text { éve tartózkodik az országban és betöltötte } 18 \text {. } \\
\text { életévét. }\end{array}$ & $\begin{array}{l}\text { A személy } 15 \text { éves korát megelőzően } \\
\text { Dániában tartózkodott, dán iskolába } \\
\text { járt/szakmai képzésben részesült. }\end{array}$ & $\begin{array}{l}\text { Dél-schleswigi származású, dániai } \\
\text { lakhely (min. } 2 \text { év), dán alapfokú } \\
\text { oktatásban részesült és azonosul a dán } \\
\text { kultúrával. }\end{array}$ \\
\hline $\begin{array}{l}\text { Fehéroroszor- } \\
\text { szág }\end{array}$ & $\begin{array}{l}\text { A SZU-ban vagy Fehéroroszországban } \\
\text { született/ állandó lakhellyel } \\
\text { rendelkezett 1991. november 12-ét } \\
\text { megelőzően. } \\
\text { Orosz, kazah, kirgiz, ukrán vagy volt } \\
\text { szovjet állampolgár és rokonainak } \\
\text { állandó lakhelye van az országban. }\end{array}$ & - & - & $\begin{array}{l}\text { Fehérorosz identitással rendelkező } \\
\text { személy, vagy fehérorosz nagyszülők } \\
\text { leszármazottja. }\end{array}$ \\
\hline Finnország & $\begin{array}{l}\text { Valamely északi állam állampolgára, } \\
\text { akinek legalább két évig állandó }\end{array}$ & - & $\begin{array}{l}23 \text { év alatti felnőtt, akinek az állandó } \\
\text { lakhelye az utóbbi } 10 \text { évben Finnország }\end{array}$ & - \\
\hline
\end{tabular}




\begin{tabular}{|c|c|c|c|c|}
\hline $\begin{array}{l}\text { Államok / } \\
\text { Feltételek }\end{array}$ & Más állam polgára & Származás (állampolgár felmenők) & Szocializáció & Kulturális kötödés \\
\hline & lakhelye volt Finnországban. & & volt. & \\
\hline Franciaország & - & - & $\begin{array}{l}\text { Olyan személy, aki (1) az utóbbi öt } \\
\text { évben Franciaországban nevelkedett; (2) } \\
\text { akit három évig intézetben neveltek; (3) } \\
\text { öt évig francia iskolába járt. }\end{array}$ & $\begin{array}{l}\text { Aki elismeri a francia nyelv hivatalos } \\
\text { státusát, anyanyelven beszél franciául, } \\
\text { vagy az alapfokú francia oktatásban } \\
\text { részesült. }\end{array}$ \\
\hline Görögország & $\begin{array}{l}\text { Valamely EU-s tagállam állampolgára } \\
\text { és három éve telepedett le } \\
\text { Görögországban. }\end{array}$ & $\begin{array}{l}\text { Felmenői bizonyíthatóan görög állampolgárok } \\
\text { voltak. }\end{array}$ & $\begin{array}{l}\text { Olyan kiskorú személy, akinek állandó } \\
\text { lakhelye van, vagy 6-9 évet görög } \\
\text { oktatási intézménybe járt. Olyan felnőtt, } \\
\text { akinek állandó lakhelye van az országban } \\
\text { és ott végezte felsőfokú tanulmányait. }\end{array}$ & Görög származású személy. \\
\hline Hollandia & - & - & $\begin{array}{l}\text { Legalább } 4 \text { éve van állandó lakhelye } \\
\text { Hollandiában }\end{array}$ & - \\
\hline Horvátország & - & - & - & $\begin{array}{l}\text { Külföldön élő horvát személy. Emigráns, } \\
\text { vagy emigráns felmenőkkel rendelkezik. }\end{array}$ \\
\hline Írország & - & - & - & $\begin{array}{l}\text { Ír származású személy, vagy ír } \\
\text { egyesületi tagsággal rendelkezik. }\end{array}$ \\
\hline Koszovó & - & $\begin{array}{l}\text { A koszovói diaszpóra tagja, elsőgenerációs } \\
\text { leszármazott és fenntartotta családi kapcsolatait. }\end{array}$ & - & - \\
\hline Lengyelország & - & - & - & $\begin{array}{l}\text { Lengyel diaszpóra tagjaként más állam } \\
\text { állampolgára (Örményország, Azerbaj- } \\
\text { dzsán, Georgia, Kirgizisztán, Tadzsikisz- } \\
\text { tán, Türkmenisztán, Üzbegisztán, vagy } \\
\text { az Orosz Föderáció ázsiai része). }\end{array}$ \\
\hline Lettország & $\begin{array}{l}\text { Az EU, az EFTA, a NATO tagállamai, } \\
\text { valamint Ausztrália, Új-Zéland, vagy } \\
\text { olyan államok állampolgára, amellyel } \\
\text { Lettország kettős állampolgárságra } \\
\text { vonatkozó megállapodást kötött. }\end{array}$ & - & - & - \\
\hline Litvánia & - & $\begin{array}{l}\text { Egyik szülő állampolgár volt, de elhalálozott a } \\
\text { gyermek születése előtt. }\end{array}$ & - & $\begin{array}{l}\text { Litván származású személy, akinek } \\
\text { sosem volt litván állampolgársága. }\end{array}$ \\
\hline Macedónia & - & $\begin{array}{l}\text { A személy egy macedón állampolgár első } \\
\text { generációs leszármazottja. }\end{array}$ & - & - \\
\hline Magyarország & - & Magyar állampolgár felmenőkkel rendelkezik. & $\begin{array}{l}\text { Kiskorúként Magyarországon volt az } \\
\text { állandó lakhelye. }\end{array}$ & $\begin{array}{l}\text { Olyan személy, akinek magyar } \\
\text { származása bizonyítható. }\end{array}$ \\
\hline Málta & - & $\begin{array}{l}\text { Olyan személy, aki Máltán született, máltai } \\
\text { állampolgártól, de elveszítette }\end{array}$ & - & - \\
\hline
\end{tabular}




\begin{tabular}{|c|c|c|c|c|}
\hline $\begin{array}{l}\text { Államok / } \\
\text { Feltételek }\end{array}$ & Más állam polgára & Származás (állampolgár felmenők) & Szocializáció & Kulturális kötödés \\
\hline & & $\begin{array}{l}\text { állampolgárságát. Állampolgárságot } \\
\text { házasságkötést követő öt év után lehet } \\
\text { kérelmezni. }\end{array}$ & & \\
\hline $\begin{array}{l}\text { Államok / } \\
\text { Feltételek }\end{array}$ & Más állam polgára & Származás (állampolgár felmenők) & Szocializáció & Kulturális kötödés \\
\hline Moldova & - & - & $\begin{array}{l}\text { A } 18 \text { éves koruk elött Moldovában } \\
\text { letelepedett személyek kérelmezhetik az } \\
\text { állampolgárságot. }\end{array}$ & - \\
\hline Montenegró & - & $\begin{array}{l}\text { Montenegrói állampolgár leszármazottja ( } 3 \text {. } \\
\text { generáció) és két éve állandó lakhelye van az } \\
\text { országban. Állampolgársági kérelmet } 3 \text { éves } \\
\text { házasság és } 5 \text { évet meghaladó ott-tartózkodás } \\
\text { után lehet benyújtani. }\end{array}$ & $\begin{array}{l}\text { A személy } 18 \text { éves kora előtt } 10 \text { évet } \\
\text { megszakítás nélkül Montenegróban élt. }\end{array}$ & - \\
\hline Németország & $\begin{array}{l}\text { Az EU tagállamok és Svájc } \\
\text { állampolgárai, akiknek } 8 \text { éve van } \\
\text { lakhelyük Németországban. }\end{array}$ & $\begin{array}{l}\text { Olyan külföldön élő személy, aki német } \\
\text { állampolgár felmenőkkel rendelkezik. }\end{array}$ & $\begin{array}{l}\text { Kelet-Európából származó német } \\
\text { etnikumú emigráns, akit diszkrimináció } \\
\text { ért származása miatt és németországi } \\
\text { belépésekor különleges bizonyítványt } \\
\text { szerzett. }\end{array}$ & $\begin{array}{l}\text { A személy nem kelet-európai állam } \\
\text { polgára, de ahol hivatalos vagy beszélt } \\
\text { nyelv a német és négy éve telepedett le, } \\
\text { vagy külföldön élö, német származású } \\
\text { felmenőkkel rendelkezik. }\end{array}$ \\
\hline Olaszország & $\begin{array}{l}\text { EU-tagállam állampolgára és négy éve } \\
\text { letelepedett az országban. }\end{array}$ & $\begin{array}{l}\text { Olasz állampolgár gyermeke vagy unokája és } \\
\text { három éve telepedett le az országban. } \\
\text { Teljesítette az olasz sorkatonai szolgálatot, } \\
\text { vagy } 18 \text { év alatti és két éve ott van állandó } \\
\text { lakhelye. }\end{array}$ & - & - \\
\hline Oroszország & $\begin{array}{l}\text { A volt SZU tagköztársaságának } \\
\text { állampolgárságával rendelkezik. } \\
3 \text { évig szolgált az orosz hadseregben, } \\
\text { és } 2002 \text {. július } 1 \text {. elött elvégezte a } \\
\text { középfokú oktatást. }\end{array}$ & - & - & $\begin{array}{l}\text { Olyan személy, akinek Oroszországban } \\
\text { van állandó lakhelye és részt vett abban } \\
\text { az állami programban, amely a külföldön } \\
\text { élö oroszok hazatelepítését célozta. } \\
\text { Orosz anyanyelvủ személy, aki } \\
\text { Oroszország vagy a SZU területén élt. }\end{array}$ \\
\hline Portugália & - & $\begin{array}{l}\text { Külföldön született, portugál felmenökkel } \\
\text { rendelkezö személy (2. generáció), aki } \\
\text { elvesztette állampolgárságát. Nem szükséges az } \\
\text { állandó, portugál lakhely. }\end{array}$ & $\begin{array}{l}\text { Portugáliában született kiskorú, aki ott } \\
\text { végezte alapfokú iskoláit. }\end{array}$ & $\begin{array}{l}\text { Portugál felmenökkel rendelkezik vagy a } \\
\text { portugál diaszpóra tagja. A szefárd } \\
\text { zsidók is kérvényezhetik honosításukat, } \\
\text { amennyiben bizonyítást nyer a spanyol } \\
\text { kultúrához való kapcsolatuk. }\end{array}$ \\
\hline Románia & $\begin{array}{l}\text { EU-tagállamok polgárai, akik } \\
\text { Romániában születtek, vagy ott }\end{array}$ & $\begin{array}{l}\text { Román állampolgár felmenőkkel rendelkezik } \\
\text { (2. generáció), vagy olyan } 3 \text {. generációs }\end{array}$ & - & - \\
\hline
\end{tabular}




\begin{tabular}{|c|c|c|c|c|}
\hline $\begin{array}{l}\text { Államok / } \\
\text { Feltételek }\end{array}$ & Más állam polgára & Származás (állampolgár felmenők) & Szocializáció & Kulturális kötödés \\
\hline & $\begin{array}{l}\text { telepedtek le (4 év). Nem szükséges } \\
\text { állandó lakhely. }\end{array}$ & $\begin{array}{l}\text { felmenőkkel rendelkezik, akik elvesztették } \\
\text { állampolgárságukat. }\end{array}$ & & \\
\hline Spanyolország & $\begin{array}{l}\text { Latin-amerikai államok, Andorra, } \\
\text { Fülöp-szigetek, Egyenlítői-Guinea és } \\
\text { Portugália állampolgárai, akik a } \\
\text { honosítási kérés benyújtását } \\
\text { megelőzően két évet éltek } \\
\text { Spanyolországban. }\end{array}$ & $\begin{array}{l}\text { Spanyolországban, spanyol állampolgártól } \\
\text { született kiskorú. Állampolgár özvegye, } \\
\text { gyermeke vagy unokája, aki külföldön született } \\
\text { és egy éve Spanyolországban él. }\end{array}$ & - & $\begin{array}{l}\text { A szefárd zsidók két évig tartó } \\
\text { spanyolországi tartózkodás után } \\
\text { kérvényezhetik honosításukat. }\end{array}$ \\
\hline Svédország & $\begin{array}{l}\text { Dánia, Finnország, Izland és Norvégia } \\
\text { állampolgárai, akik Svédországban } \\
\text { telepedtek le ( } 2 \text { év). Nem szükséges } \\
\text { állandó lakhely. }\end{array}$ & - & $\begin{array}{l}\text { Olyan kiskorú személy, aki három éve } \\
\text { telepedett le Svédországban. }\end{array}$ & - \\
\hline Szerbia & - & $\begin{array}{l}\text { A kérvényező szülei szerb állampolgárok } \\
\text { voltak. }\end{array}$ & - & $\begin{array}{l}\text { Cselekvőképes személy, aki } \\
\text { hüségnyilatkozatot tesz, egy szerbiai } \\
\text { nemzetiség tagja és Szerbiában van az } \\
\text { állandó lakhelye, vagy a volt Jugoszlávia } \\
\text { területén született és annak } \\
\text { állampolgárságával rendelkezik. }\end{array}$ \\
\hline Szlovákia & - & - & $\begin{array}{l}\text { Kiskorúként legalább három évet élt } \\
\text { Szlovákia területén. }\end{array}$ & $\begin{array}{l}\text { A szlovák etnikumú, vagy külföldi } \\
\text { szlovák státussal rendelkező személy, aki } \\
\text { legalább három évet kell az országban } \\
\text { tartózkodjon. }\end{array}$ \\
\hline Szlovénia & - & $\begin{array}{l}\text { Szlovén állampolgár közvetlen leszármazottja } \\
\text { (4. generációig) és a kérvény benyújtása előtt } \\
\text { legalább egy évet Szlovéniában tartózkodott. }\end{array}$ & $\begin{array}{l}\text { Az a személy, aki Szlovéniában végezte } \\
\text { felsőfokú tanulmányait, } 7 \text { éve } \\
\text { folyamatosan ott tartózkodik. }\end{array}$ & - \\
\hline Ukrajna & - & $\begin{array}{l}\text { Állampolgár házastársa, akivel legalább két } \\
\text { évet éltek együtt elhalálozott. }\end{array}$ & $\begin{array}{l}\text { Ukrajnában élő kiskorú, akinek egyik } \\
\text { vagy mindkét törvényes gyámja } \\
\text { törvényesen ott él és kezdeményezte a } \\
\text { gyermek honosítását. }\end{array}$ & $\begin{array}{l}\text { A személy szülei, nagyszülei, } \\
\text { (fél)testvérei, gyerekei vagy unokái } \\
\text { 1991. augusztus 24-ét megelőzően ukrán } \\
\text { lakhellyel rendelkeztek, vagy ott } \\
\text { születtek. Az ilyen személyek abban az } \\
\text { esetben regisztrálhatók állampolgárként, } \\
\text { ha lemondanak külföldi } \\
\text { állampolgárságukról. }\end{array}$ \\
\hline
\end{tabular}

Forrás: Global Citizenship Observatory (GLOBALCIT), 2017, http://globalcit.eu/acquisition-citizenship/, letöltés ideje: 2018. április 25. 
5. sz. táblázat: A külhoni állampolgárok választójoga az EU-28 és a térség államaiban

\begin{tabular}{|c|c|c|c|c|}
\hline $\begin{array}{c}\text { Államok/ } \\
\text { A választás típusa }\end{array}$ & $\begin{array}{l}\text { Államfö- } \\
\text { választás }\end{array}$ & $\begin{array}{l}\text { Parlamenti } \\
\text { választás }\end{array}$ & $\begin{array}{l}\text { Népszavazás/ } \\
\text { Referendum }\end{array}$ & EP-választás \\
\hline Albánia & KV & Nem & Nem & - \\
\hline Ausztria & Igen & Igen & Igen & Igen \\
\hline Belgium & NV & Igen & Nincs & $\begin{array}{l}\text { Nem, kivételt képeznek azon állampolgárok, akik más } \\
\text { EU-s tagállamban élnek. }\end{array}$ \\
\hline $\begin{array}{l}\text { Bosznia és } \\
\text { Hercegovina }\end{array}$ & Igen & Igen & Igen & - \\
\hline Bulgária & Igen & Igen & Igen & $\begin{array}{l}\text { Nem, de kivételt képeznek azon állampolgárok, } \\
\text { akiknek a választást megelőzően bulgár, vagy az EU- } \\
\text { tagállamában állandó lakhellyel rendelkeznek. }\end{array}$ \\
\hline Ciprus & Nem* & Nem* & Nem* & Nem* \\
\hline Csehország & Igen & Igen & Igen & $\begin{array}{c}\text { Az első generációs külhoni állampolgárok az állam } \\
\text { területén szavazhatnak. }\end{array}$ \\
\hline Dánia & NV & $\mathrm{Nem}^{* *}$ & Nem** & $\begin{array}{l}\text { Nem, de kivételt képeznek azon állampolgárok, akik } \\
\text { más EU-s tagállamban állandó lakhellyel } \\
\text { rendelkeznek. }\end{array}$ \\
\hline Nagy-Britannia & NV & Igen & Igen & Igen \\
\hline Észtország & $\mathrm{KV}$ & Igen & Igen & Igen \\
\hline Fehéroroszország & Igen & Igen & Igen & - \\
\hline Finnország & Igen & Igen & Igen & Igen \\
\hline Franciaország & Igen & Igen & Igen & Igen \\
\hline Görögország & $\mathrm{KV}$ & \multicolumn{2}{|c|}{ Csak az állam területén. } & $\begin{array}{l}\text { Nem, de kivételt képeznek azon állampolgárok, akik } \\
\text { más EU-s tagállamban állandó lakhellyel } \\
\text { rendelkeznek. }\end{array}$ \\
\hline Hollandia & $\mathrm{NV}$ & Igen & Igen & Igen \\
\hline Horvátország & Igen & Igen & Igen & Igen \\
\hline Írország & Nem & Nem & $\mathrm{Nem}$ & Nem \\
\hline Koszovó & Igen & Igen & $\mathrm{Nem}$ & - \\
\hline Lengyelország & Igen & Igen & Igen & Igen \\
\hline Lettország & KV & Igen & Igen & Igen \\
\hline Litvánia & Igen & Igen & Igen & Igen \\
\hline Luxemburg & $\mathrm{NV}$ & Igen & Igen & Igen \\
\hline Macedónia & Igen & Igen & $\mathrm{Nem}$ & - \\
\hline Magyarország & $\mathrm{KV}$ & Igen & Igen & Nem \\
\hline Málta & KV & Nem & $\mathrm{Nem}$ & Nem \\
\hline Moldova & Igen & Igen & Igen & - \\
\hline Montenegró & $\mathrm{Nem}$ & $\mathrm{Nem}$ & $\mathrm{Nem}$ & - \\
\hline Németország & $\mathrm{KV}$ & Igen & $\mathrm{NV}$ & Igen \\
\hline Olaszország & $\mathrm{KV}$ & Igen & Igen & $\begin{array}{l}\text { Nem, de kivételt képeznek a szavazati joggal } \\
\text { rendelkezö, más EU-tagállamban élő állampolgárok. }\end{array}$ \\
\hline Oroszország & Igen & Igen & Igen & - \\
\hline Portugália & Igen & Igen & $\mathrm{Nem}$ & Igen \\
\hline Románia & Igen & Igen & Igen & Igen \\
\hline Spanyolország & $\mathrm{NV}$ & Igen & Igen & Igen \\
\hline
\end{tabular}




\begin{tabular}{|c|c|c|c|c|}
\hline $\begin{array}{c}\text { Államok/ } \\
\text { A választás típusa }\end{array}$ & $\begin{array}{c}\text { Államfö- } \\
\text { választás }\end{array}$ & $\begin{array}{c}\text { Parlamenti } \\
\text { választás }\end{array}$ & $\begin{array}{c}\text { Népszavazás/ } \\
\text { Referendum }\end{array}$ & EP-választás \\
\hline Szerbia & Igen & Igen & Nem & - \\
\hline Szlovákia & Nem & Igen & Nem & Nem \\
\hline Szlovénia & Igen & Igen & Igen & Igen \\
\hline Ukrajna & Igen & Igen & Igen & - \\
\hline
\end{tabular}

KV - közvetlen választás; $\mathrm{NV}$ - nincs választás

* Csak köztisztviselők és ezek házastársa.

** Köztisztviselők és postai alkalmazottak, egyetemisták és diákok.

Forrás: A Global Citizenship Observatory (GLOBALCIT) adatbázisa és (Lappin 2016) alapján, saját kiegészítésekkel. 


\section{KÖNYVÉSZET}

\section{Levéltári források}

Magyar Nemzeti Levéltár - Országos Levéltár, Külügyminisztérium TÜK-iratok. Románia, XIX-J-1-j, 1989-1995.

\section{Interjúk}

Bálint-Pataki József, a HTMH munkatársa, 2002-2005 között pedig a Hivatal vezetője (Budapest, 2019. május 1).

Jeszenszky Géza, egyetemi oktató és politikus, 1990-1994 között Magyarország külügyminisztere (Budapest, 2019. április 29).

Markó Béla, az RMDSZ volt szövetségi elnöke (Marosvásárhely, 2019. február 25).

Németh Zsolt, országgyülési képviselő (FIDESZ), a külügyi bizottság elnöke (Budapest, 2019. április 29).

Székely István, az RMDSZ ügyvezető alelnöke (Kolozsvár, 2019. február 13).

Szent-Iványi István, SZDSZ-es politikus, 1994-1997 között külügyi államtitkár (Budapest, 2019. április 30).

Vincze Lóránt, a FUEN elnöke (Kolozsvár, 2019. február 27).

\section{Memoárok, naplók, beszédek}

Dinu, Marcel (2009): 42 ani de diplomație. Ambasador sub patru președinți. Bucureşti: Fundația Europeană Titulescu - C. H. Beck.

Hodicska Tibor (2014): Négyszemközt Ceaușescuval. Budapest - Csíkszereda: PONT Kiadó, Pallas-Akadémia Kiadó.

Horn Gyula (1991): Cölöpök. Budapest: Móra Ferenc Könyvkiadó.

(1999): Azok a kilencvenes évek. Budapest: Kossuth Kiadó.

Király Károly (2013): Nyilt kártyákkal I. Pécs: Sétatér Alapítvány.

Markó Béla (2000): A feledékeny Európa: beszédek, elöadások, interjúk (1990-1999). Marosvásárhely: Mentor Kiadó.

Năstase, Adrian (2006): România după Malta. 875 de zile la Externe (vol.1 - vol.10). 2. Kötet, Bucureşti: Fundația Europeană Titulescu.

\section{Dokumentumok, jogszabályok, nyilatkozatok}

„137/1990 számú törvényerejü rendelet. Decret-lege nr. 137 din 11 mai 1990 privind unele dispoziţii referitoare la cetăţenia română. Publicat în Monitorul Oficial nr. 75 din 21 mai". http://legislatie.just.ro/Public/DetaliiDocument/948, letöltés ideje: 2018. május 7.

„1993. évi LV. törvény a Magyar Állampolgárságról”. 1993. Országgyülés. https://mkogy.jogtar.hu/jogszabaly?docid=99300055.TV, letöltés ideje: 2018. május 8. 
„2001. évi LXII. törvény a szomszédos államokban élő magyarokról”. 2001. Magyar Közlöny.

http://www.magyarkozlony.hu/dokumentumok/68f117ae4b7f3160046ce3d9a74f ca32195c456d/megtekintes, letöltés ideje: 2018. február 1.

„2002. évi III. törvény az Európa Tanács keretében, 1997. november 6-án kelt, az állampolgárságról szóló Európai Egyezmény kihirdetéséről”. 2002. https://net.jogtar.hu/jogszabaly?docid=A0200003.TV, letöltés ideje: 2018. április 27.

„2003. évi LVII. törvény a szomszédos államokban élő magyarokról szóló 2001. évi LXII. törvény módosításáról". https://mkogy.jogtar.hu/?page=show\&docid=a0300057.TV, letöltés ideje: 2018 . március 7.

„2005. évi II. törvény a Szülőföld Alapról”. https://mkogy.jogtar.hu/jogszabaly?docid=a0500002.TV, letöltés ideje: 2018. május 19.

„2005. évi L. törvény a nemzetközi szerződésekkel kapcsolatos eljárásról”. https://net.jogtar.hu/jr/gen/hjegy_doc.cgi?docid=a0500050.tv, letöltés ideje: 2017. november 6 .

„2005. évi XLVI. törvény a magyar állampolgárságról szóló 1993. évi LV. törvény és a külföldiek beutazásáról és tartózkodásáról szóló 2001. évi XXXIX. törvény módosításáról”. $2005 . \quad 2005 . \quad$ június. https://mkogy.jogtar.hu/jogszabaly?docid=a0500046.TV, letöltés ideje: 2018. május 19.

„2010. évi XLIV. törvény a magyar állampolgárságról szóló 1993. évi LV. törvény módosításáról." $2010 . \quad$ Magyar Közlöny. https://mkogy.jogtar.hu/jogszabaly?docid=a1000044.TV, letöltés ideje: 2018. június 9.

„A Fidesz-Magyar Polgári Párt választási programja”. 1998. https://gondola.hu/cikkek/6328-1998 A Fidesz -

_Magyar_Polgari_Part_valasztasi_programja.html, letöltés ideje: 2018. május 9.

„A határon túli magyar szervezetek közös nyilatkozata a kettős állampolgárságról”. 2004. december 20. http://www.alkotmanyossagimuhely.hu/2004_dec_kozos_nyilatk.htm, letöltés ideje: 2018. május 12.

„A határon túli magyarok nemzetpolgárságáról és a Szülőföld-programcsomag létrehozásáról szóló országgyülési határozati javaslat vitája". Országgyülés, 2004. december

https://www.parlament.hu/internet/plsql/ogy naplo.naplo_fadat_aktus?p_ckl=37

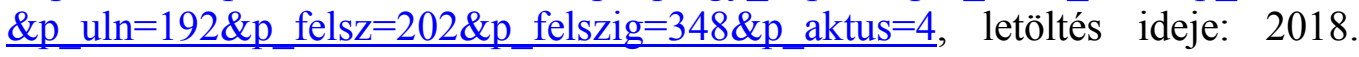
május 24.

„A határon túli magyar politikai vezetők nyilatkozata a Magyarországgal szomszédos államokban élő magyarokról szóló törvény hatályba lépése alkalmából". In: Kántor Zoltán (szerk.): A státustörvény: dokumentumok, tanulmányok, publicisztika. Budapest: Teleki László Alapítvány.

„A Kormány 1079/1999. (VII. 7.) Korm. határozata a határon túli magyarokkal kapcsolatos feladatok végrehajtását szolgáló szakértői bizottságok létrehozásáról”. Magyar Közlöny, 62. szám, 1999. július 7.

„A Külügyminisztérium nyilatkozata Románia Kormányának a magyar kedvezménytörvénnyel kapcsolatos 2001. október 29-i nyilatkozatával összefüggésben". In: Magyar Külpolitikai Évkönyv. Budapest: Külügyminisztérium. 
„A Külügyminisztérium tájékoztatója - a szóvivője útján - a kedvezménytörvénnyel kapcsolatos magyar-román tárgyalás folytatására tett magyar javaslatról, 2001. december 12." 2001. In: Magyar Külpolitikai Évkönyv. Budapest: Külügyminisztérium.

„A magyar állampolgárságról szóló 1993. évi LV. törvény módosításáról és a külföldiek beutazásáról és tartózkodásáról szóló 2001. évi XXXIX. törvény módosításáról szóló törvényjavaslat általános vitája”. Országgyülés, 2005. május 3. https://www.parlament.hu/internet/plsql/ogy naplo.ulnap felszo?p lista $=\mathrm{f} \& \mathrm{p} \_\mathrm{n}$ $a p=221 \& p \_c k l=37 \& p \_s t i l u s=$, letöltés ideje: 2018 . május 24 .

„A magyar állampolgárságról szóló 1993. évi LV. törvény módosításáról és a külföldiek beutazásáról és tartózkodásáról szóló 2001. évi XXXIX. törvény módosításáról szóló törvényjavaslat részletes vitája”. Országgyülés, 2005. május 17. https://www.parlament.hu/internet/plsql/ogy_naplo.naplo_fadat_aktus?p_ckl=37 $\& p$ uln $=225 \& p$ felsz $=353 \& p$ felszig $=370 \& p$ aktus $=39$, letöltés ideje: 2018. május 24.

„A magyar állampolgárságról szóló 1993. évi LV. törvény módosításáról és a külföldiek beutazásáról és tartózkodásáról szóló 2001. évi XXXIX. törvény módosításáról szóló törvényjavaslat zárószavazása". Országgyülés, 2005. június 6. https://www.parlament.hu/internet/plsql/ogy naplo.naplo_szoveg?P_CKL=37\& p_uln=233\&p_felsz=178\&p_szoveg=\&p_stilus=, letöltés ideje: 2018 . május 24 .

„A Magyar Állandó Értekezlet V. ülésének zárónyilatkozata”. 2002. In: Magyar külpolitikai évkönyv. Budapest: Külügyminisztérium.

„A Magyar Állandó Értekezlet VI. ülésének Zárónyilatkozata (Budapest, 2002. November 17.)". In: Magyar Külpolitikai Évkönyv, 376-380. Budapest: Külügyminisztérium.

„A Magyar Állandó Értekezlet VII. ülésének Zárónyilatkozata (2003. május 24.)”. https://bgazrt.hu/wp-content/uploads/2019/03/9.-A-M\%C3\%81\%C3\%89RTVII.- \%C3\%BCl\%C3\%A9s\%C3\%A9nek-Z\%C3\%A1r\%C3\%B3nyilatkozata2003.05.24..pdf, letöltés ideje: 2018. március 7.

„A Magyar Állandó Értekezlet harmadik ülésének Zárónyilatkozata”. In: Kántor Zoltán (szerk.): A státustörvény: dokumentumok, tanulmányok, publicisztika. Budapest: Teleki László Alapítvány.

„A Magyar Állandó Értekezlet második ülésének Zárónyilatkozata”. In: Kántor Zoltán (szerk.): A státustörvény: dokumentumok, tanulmányok, publicisztika, 166-69. Budapest: Teleki László Alapítvány.

„A magyar-magyar csúcstalálkozó közös nyilatkozata”. 1996. Magyar Kisebbség, V. évf., 1 (15). szám.

„A Medgyessy Péter miniszterelnök által beterjesztett és az Országgyülés által elfogadott Kormányprogram külpolitikai része, 2002. május 25.” In: Magyar Külpolitikai Évkönyv. Budapest: Külügyminisztérium.

„A Nemzeti Megmentési Front nyilatkozata a romániai nemzeti kisebbségek jogairól (január 6.)." Romániai Magyar Szó, 1990. január 7. 12. szám, 1-2.

„A Romániai Magyar Demokrata Szövetség Elnökségének nyilatkozata, 1990. március 20.” 2009. In: Húszéves az RMDSZ 1989-2009: Eseménynaptár, dokumentumok, 394-95. Kolozsvár: RMDSZ Elnöki Hivatal-Ügyvezető Elnökség.

„A Romániai Magyar Demokrata Szövetség Ideiglenes Intéző Bizottságának kiáltványa. Bukarest, 1989. december 25". 2009. In: Húszéves az RMDSZ 1989-2009: Eseménynaptár, dokumentumok. Kolozsvár: RMDSZ Elnöki Hivatal-Ügyvezető Elnökség. 
„A Romániai Magyar Demokrata Szövetség VIII. Kongresszusán elfogadott dokumentumok. 1. számú Határozat a kedvezménytörvény módosításával kapcsolatban. Elfogadta az RMDSZ VII. Kongresszusa Szatmárnémeti, 2003. február 2.” 2009. In: Húszéves az RMDSZ 1989-2009: Eseménynaptár, dokumentumok. Kolozsvár: RMDSZ Elnöki Hivatal-Ügyvezető Elnökség.

„A schengeni térség és együttműködés”. 2009. EUR-LEX. http://eurlex.europa.eu/legal-content/HU/TXT/?uri=LEGISSUM\%3Al33020, letöltés ideje: 2018. január 24.

„A Szenátus külügyi bizottságának jelentése az állampolgársági törvény módosításáról. Raport la Proiectul de lege pentru aprobarea Ordonanței de urgență a Guvernului nr. 36/2009 pentru modificarea și completarea Legii cetățeniei române nr. 21/1991 republicată, cu modificările și completările ulterioare.” Szenátus, 2009. május 27. https://www.senat.ro/Legis/PDF/2009/09L121CR.pdf, letöltés ideje: 2018. június 8 .

„A szomszédos államokban élő magyarokról szóló törvényjavaslat általános vitája." Országgyülés, $2001 . \quad$ április 19. https://www.parlament.hu/internet/plsql/ogy naplo.naplo fadat aktus?p ckl=36 $\underline{\& p}$ uln=202\&p_felsz=1\&p_felszig=39\&p_aktus $=2$, letöltés ideje: 2018. március 18.

„A szomszédos államokban élő magyarokról szóló törvényjavaslat részletes vitája”. Országgyűlés, 2001. május 29. https://www.parlament.hu/internet/plsql/ogy naplo.naplo fadat aktus?p ckl=36 $\underline{\& p} u \ln =210 \& p$ felsz $=23 \& p$ felszig $=125 \& p$ aktus $=8$, letöltés ideje: 2018. március 18.

„A szomszédos államokban élő magyarokról szóló törvényjavaslat részletes vitájának folytatása és lezárása". Országgyülés, 2001. május 29. 2001. https://www.parlament.hu/internet/plsql/ogy naplo.naplo_szoveg?P_CKL=36\& p_uln=210\&p_felsz=431\&p_szoveg $=\& p \_$stilus $=$, letöltés ideje: 2018. március 18 .

„A szomszéd államokban élő magyarokról szóló törvényjavaslat általános vitájának folytatása és lezárása”. Országgyülés, 2001. május 29. https://www.parlament.hu/internet/plsql/ogy naplo.naplo fadat aktus?p_ckl=36 $\& p$ uln $=206 \& p$ felsz=344\&p felszig $=445 \& p$ aktus $=6$, letöltés ideje: 2018. március 18.

„A szomszédos államokban élő magyarokról szóló törvényjavaslat záróvitája és zárószavazása”. $\quad$ Országgyülés, $\quad 2001 . \quad$ június 19. https://www.parlament.hu/internet/plsql/ogy_naplo.naplo_fadat_aktus?p_ckl=36 $\underline{\& p} u \ln =217 \& p$ felsz $=58 \& p$ felszig $=74 \& p \_$aktus $=13$, letöltés ideje: 2018. március 18.

„A Szövetségi Képviselők Tanácsa és a Szövetségi Egyeztető Tanács Nyilatkozata, Marosvásárhely 1996. szeptember 6". In: Húszéves az RMDSZ 1989-2009: Eseménynaptár, dokumentumok. Kolozsvár: RMDSZ Elnöki Hivatal-Ügyvezető Elnökség.

„A Szövetségi Képviselők Tanácsának határozata a magyar-román alapszerződés kérdésében, 1995. február 26, Marosvásárhely." In: Húszéves az RMDSZ 19892009: Eseménynaptár, dokumentumok. Kolozsvár: RMDSZ Elnöki Hivatal-Ügyvezetö Elnökség.

„A Szülőföld Alapról szóló 2005. évi II. törvény módosításáról szóló törvényjavaslat általános vitája”. Országgyülés, 2005. március 21. http://www.parlament.hu/internet/plsq1/ogy_naplo.naplo_fadat_aktus?p_ckl=37 


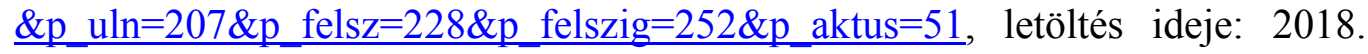
május 24.

„A Tanács 539/2001/EK rendelete a külső határok átlépésekor vízumkötelezettség alá eső, illetve az e kötelezettség alól mentes harmadik országbeli állampolgárok országainak felsorolásáról”. Európai Unió Tanácsa, 2001. március 15. http://eurlex.europa.eu/legalcontent/HU/TXT/HTML/?uri=CELEX:32001R0539\&from=EN, letöltés ideje: 2018. január 24.

„Abandonarea Transilvaniei. Moţiunii cu privire la consecinţele asupra siguranţei naţionale a României pe care le are aplicarea Memorandumului de înţelegere între Guvernul României şi Guvernul Republicii Ungare privind Legea maghiarilor din statele vecine Ungariei şi chestiuni legate de cooperarea bilaterală, semnat la 22 decembrie", 2002.

„Acord din 20.10.2006 între Guvernul Republicii Moldova şi Guvernul României privind călătoriile reciproce ale cetăţenilor", 2006. Ministerul Afacerilor Externe, Republica

Moldova. http://lex.justice.md/index.php?action=view\&view=doc\&lang=1\&id=357004, letöltés ideje: 2018. május 20.

„Acord între Guvernul României și Guvernul Republicii Ungaria privind stabilirea unui regim de Cer Deschis". 1991.

„Agenda 2000: Commission Opinion on Hungary’s Application for Membership of the European Union". 1997. European Commission.

„Agenda 2000: Commission Opinion on Romania's Application for Membership of the European Union". 1997. European Commission.

„Annual Report of European Commission for Democracy Through Law (Venice Commission)". 2002. Council of Europe.

„Az EBEÉ emberi dimenzióval foglalkozó koppenhágai konferenciájának dokumentuma (Koppenhága, 1990. június 29.)”. In: Bíró Anna-Maria (szerk.): Kisebbségvédelem és a nemzetközi szervezetek. Budapest: Teleki László Alapítvány.

„Az erdélyi magyarok röntgenképe 2003. október”. Erdélyi vonatkozású társadalomtudományi kutatások adatbankja. http://kutatasok.adatbank.transindex.ro/adatlap.php?adID=27, letöltés ideje: 2018 . március 9.

„Az Országos Választási Bizottság 108/2004. (VIII. 12.) határozata”. Országos Választási Bizottság. http://www.parlament.hu/irom37/10960/10960.pdf, február 20.

„Az RMDSZ állásfoglalása a magyar-román alapszerződés tárgyában. 1994. augusztus 26." In: Húszéves az RMDSZ 1989-2009: Eseménynaptár, dokumentumok. Kolozsvár: RMDSZ Elnöki Hivatal-Ügyvezető Elnökség.

„Az RMDSZ Operatív Tanácsának álláspontja a véglegesítés előtt álló magyar-román alapszerződésről". In: Húszéves az RMDSZ 1989-2009: Eseménynaptár, dokumentumok. Kolozsvár: RMDSZ Elnöki Hivatal-Ügyvezető Elnökség.

„Az SZDSZ a népszavazási kérdésekről”. 2004. november. https://web.archive.org/web/20050108045245/http://www.deszdsz.hu/nepszavaz as.htm, letöltés ideje: 2018 . május 10.

„Balladur terv” (1993): http://www.cvce.eu/content/publication/1999/1/1/83dcbde9a916-478c-a977-b1116ed83c56/publishable en.pdf, letöltés ideje: 2017. november 3.

„Bozeni/Bolzanói Ajánlások a nemzeti kisebbségekről az államközi kapcsolatokban”. In: Szarka László-Vizi Balázs-Tóth Norbert-Kántor Zoltán-Majtényi Balázs 
(szerk.) 2009: Etnopolitikai modellek a gyakorlatban. Budapest: Gondolat, 30124.

„Regionális vagy kisebbségi nyelvek európai chartája (1992. október 2)”. In: Bíró Anna-Maria (szerk.): Kisebbségvédelem és a nemzetközi szervezetek. Budapest: Teleki László Alapítvány.

„Camera Deputatilor: Proiectul de Lege pentru ratificarea Tratatului de înţelegere, cooperare şi bună vecinătate între România şi Republica Ungară, semnat la Timişoara la data de 16 septembrie 1996". Képviselőház, 1996. október 3. http://www.cameradeputatilor.ro/pls/steno/steno.stenograma? ids=591\&idm=3\&i $\underline{\mathrm{dl}=1}$, letöltés ideje: 2017 . november 26.

"Convention on the Reduction of Cases of Multiple Nationality and on Military Obligations in Cases of Multiple Nationality". 1963. Council of Europe. https://rm.coe.int/168006b659, letöltés ideje: 2018. április 15.

Curierul Naţional (2004): „Năstase: România nu va accepta dubla cetățenie pe criterii etnice", 2004. december 2. https://curierulnational.ro/old/Opinii/2004-1202/Nastase $\% 3 \mathrm{~A}+$ Romania + nu $+v a+$ accepta + dubla + cetatenie + pe + criterii + etnice, letöltés ideje: 2018. május 19.

„Das Gruber-De-Gasperi-Abkommen (Pariser Abkommen)”. 1946. szeptember 5. http://www.provinz.bz.it/pariservertrag/vertrag/vertrag.asp, letöltés ideje: 2018. január 13.

„Declaraţie de presă a preşedintelui Traian Băsescu la finalul şedinţei CSAT”. 2007. Departamentul de Comunicare Publică, Președintele României. http://www.old.presidency.ro/pdf/date/9146_ro.pdf, letöltés ideje: 2018. május 20.

Deutsche Welle (2009): „EU Worried about Romanian offer of Citizenship to Moldovans". $\quad$ http://www.dw.com/en/eu-worried-about-romanian-offer-ofcitizenship-to-moldovans/a-4185592, letöltés ideje: 2018. május 21.

„Dr. Horn Gyula külügyminiszter levele a román külügyminiszterhez.” 1990. In: Magyar Külpolitikai Évkönyv. Budapest: Külügyminisztérium.

„Dr. Horn Gyulának, Az MSZP elnöksége tagjának, a Magyar Köztársaság Külügyminiszterének Nyilatkozata romániai látogatása után”. 1989. In: Magyar külpolitikai évkönyv. Budapest: Külügyminisztérium Dokumentációs Főosztálya.

„Egyetértési Nyilatkozat a Magyar Köztársaság Kormánya és Románia Kormánya között A szomszédos államokban élö magyarokról szóló törvényröl és $\mathrm{s}$ kétoldalú együttműködés egyéb kérdéseiről”. 2001. In: Magyar Külpolitikai Évkönyv. Budapest: Külügyminisztérium.

„Egyezmény a Magyar Népköztársaság és a Román Szocialista Köztársaság között a kettős állampolgárság eseteinek megoldásáról és megelőzéséről”. 1979. http://magyarkisebbseg.ro/index.php?action=cimek\&lapid=12\&cikk=m990211. htm, letöltés ideje: 2018. május 7.

Ekéus, Rolf (2001): „Sovereignty, Responsibility, and National Minorities: Statement by OSCE Minorities Commissioner". OSCE High Commissioner on National Minorities. http://www.osce.org/hcnm/53936, letöltés ideje: 2018. február 10.

„Etnikumközi kapcsolatok barométere”, 2000-2003. Etnokulturális Kisebbségek Forrásközpontja. http:/www.edrc.ro/projects.jsp?project_id=19, letöltés ideje: 2018. március 16.

Európa Tanács Parlamenti Közgyülése (1993): „1201/1993. számú ajánlás az Emberi Jogok Európai Egyezménye Kiegészítő Jegyzőkönyvére a nemzeti kisebbségek jogairól”. Magyar Kisebbség, 1. évf., 1. szám 
European Commission (2001): „Regular Report on Hungary's Progress Towards Accession, SEC (2001) 1748".

European Commission for Democracy through Law (Venice Commission) (2001): „The Official Position of the Romanian Government on the Law on Hungarians Living in Neighbouring Countries".

Evenimentul Zilei (2009): „Voronin: România se află în spatele revoltei de la Chişinău”. 2009. április. http://evz.ro/voronin-romania-se-afla-in-spatelerevoltei-de-la-chisinau-video-846610.html, letöltés ideje: 2018. május 21.

„Felmérés a népszavazásról. Temetni fogjuk, nem dicsérni?” Medián. 2007. november 7. http://www.median.hu/object.c224b172-ca48-4d22-a3bc-e6a2490441b3.ivy, letöltés ideje: 2018. május 12.

„Günter Verheugen's Letter to Hungarian Prime Minister Péter Medgyessy (5 December 2002)". In: Kántor Zoltán-Vizi Balázs-Majtényi Balázs-Halász István-Ieada Osamu (szerk.) The Hungarian Status Law: Nation Building and/or Minority Protection, 585-87. Sapporo: Slavic Research Center of Hokkaido University.

„Gyurcsány Ferenc levele a MÁÉRT tagjaihoz”. 2005. http://kisebbsegkutato.tk.mta.hu/kettosallampolgarsag/allasfoglalasok/allasfogl 77.html, letöltés ideje: 2018. május 12.

„Gyurcsány Ferenc Miniszterelnök beszéde a Magyar Állandó Értekezlet (MÁÉRT) VIII. ülésén (Budapest, 2004. november 12.)". 2004. In: Magyar Külpolitikai Évkönyv. Budapest: Külügyminisztérium.

„Hágai Egyezmény (1930): Convention on Certain Questions Relating to the Conflict of Nationality Law". League of Nations. http://www.refworld.org/docid/3ae6b3b00.html, letöltés ideje: 2018. április 15.

„Határozati javaslat a Magyar Köztársaság és Románia között kötendő alapszerződés ügyében, (Országgyülési napló)”. 1996. szeptember 3. http://www.parlament.hu/iromany/02834ir.htm, letöltés ideje: 2017. 11. 26.

„Hotărâre pentru aprobarea Protocolului dintre Guvernul României și Guvernul Republicii Ungare privind crearea Comisiei mixte interguvernamentale de colaborare și parteneriat activ între România și Republica Ungarã, semnat la Budapesta la 12 martie 1997”. Publicat în Monitorul Oficial nr. 100 din data: 06/26/97.

Húszéves az RMDSZ 1989-2009: Eseménynaptár, dokumentumok. 2009. Kolozsvár: RMDSZ Elnöki Hivatal-Ügyvezető Elnökség.

Iliescu, Ion (1995): „Expunerea Presedintelui României, domnul Ion Iliescu, la Simpozionul National »România în vara anului 1940 sub impactul politicii de forță. 55 de ani după Dictatul de la Viena - București, 30 august 1995". Președintele României. http://old.presidency.ro/pdf/date arhiva/514_ro.pdf, letöltés ideje: 2017 . november 21.

IRES (2011): „Barometrul relaţiilor interetnice în România”. http://www.ires.com.ro/articol/144/barometrul-relatiilor-interetnice-in-romania, letöltés ideje: 2018. június 10 .

(2013): „Prieteni și duşmani. Percepţii asupra relaţiilor interetnice din România".

http://www.ires.com.ro/uploads/articole/ires_perceptii_asupra_relatiilor_interetn ice raport.pdf, letöltés ideje: 2018. június 10 .

„Iromány módosító: T/4070 A szomszédos államokban élő magyarokról (státus tv.)”. 2001. 
„J/2204. számú Jelentés a határon túli magyarokra vonatkozó politikai feladatok végrehajtásáról, különös tekintettel a Magyar Állandó Értekezlet ajánlásaira”. 2000 .

https://www.parlament.hu/internet/plsql/ogy naplo.naplo fadat aktus?p ckl=36 \&p uln=126\&p felsz=46\&p felszig=193\&p aktus=13, letöltés ideje: 2018. január 29.

„Jelentés a nemzeti kisebbségek számára az anyaállamok által biztosított kedvezményes bánásmódról. Jóváhagyta a Velencei Bizottság 48. Plenáris Ülése”. 2001. http://adattar.adatbank.transindex.ro/nemzetkozi/velence.htm, letöltés ideje: 2016. február 16.

„Képviselőházi vita jegyzőkönyve. Dezbaterea Proiectului de Lege privind aprobarea Ordonanţei de urgenţă a Guvernului nr.36/2009 pentru modificarea şi completarea Legii cetățeniei române nr.21/1991”. 2009. http://www.cdep.ro/pls/steno/steno.stenograma?ids=6716\&idm $=5$, letöltés ideje: 2018. május 24.

„Képviselőházi vita. Stenograma ședinței Camerei Deputaţilor din 3 octombrie 1996. Proiectul de Lege pentru ratificarea Tratatului de înţelegere, cooperare şi bună vecinătate între România şi Republica Ungară, semnat la Timişoara la data de 16 septembrie 1996". http://www.cameradeputatilor.ro/pls/steno/steno.stenograma?ids=591\&idm=3\&i $\underline{\mathrm{dl}=1}$, letöltés ideje: 2016 . március 15 .

„Keretegyezmény a nemzeti kisebbségek védelméről (1995. február 1.)”. In: Bíró AnnaMaria (szerk.): Kisebbségvédelem és a nemzetközi szervezetek. Budapest: Teleki László Alapítvány.

„Kisebbségi vonatkozású romániai jogszabályok - MinLex”. 2011. Nemzeti Kisebbségkutató Intézet. http://www.ispmn.gov.ro/page/minlex, letöltés ideje: 2017. január 19.

„Kormánynyilatkozat a romániai magyarellenes cselekményekkel kapcsolatban”. 1990. In: Magyar Külpolitikai Évkönyv. Budapest: Külügyminisztérium.

„Kovács László külügyminiszter beszéde a Magyar Állandó Értekezlet ötödik ülésén”. 2002. In: Magyar Külpolitikai Évkönyv. Budapest: Külügyminisztérium.

„Közlemény a kettős állampolgárságról”. 2004. In: Húszéves az RMDSZ 1989-2009: Eseménynaptár, dokumentumok. Kolozsvár: RMDSZ Elnöki Hivatal-Ügyvezető Elnökség.

„Központi Választási Hivatal”. 1998, http://www.valasztas.hu/ujweb/index.htm, letöltés ideje: 2018. július 21.

Központi Választási Iroda, BEC (2009a): „Rezultatele alegerilor pentru Președintele României, turul I." $2009 . \quad$ november 22. http://www.bec2009p.ro/Documente\%20PDF/Rezultate/Rezultate $\% 20$ finale $\% 20$ turul $\% 20 \mathrm{I} / \mathrm{P} /$ statistici/p strainatate 2.txt, letöltés ideje: 2018 . május 21.

(2009b): „Rezultatele alegerilor pentru Președintele României, turul II.” 2009. december

http://www.bec2009p.ro/Documente $\% 20 \mathrm{PDF} /$ Rezultate/Rezultate $\% 20$ finale $\% 20$ turul\%20II/tur2_strainatate.txt, letöltés ideje: 2018. május 21.

(2012): „Rezultatele finale ale referendumului național pentru demiterea Președintelui României 29 iulie 2012”. 2012. július. http://www.becreferendum2012.ro/DOCUMENTE\%20BEC/Rezultate/rezultat.p df, letöltés ideje: 2018. május 21. 
(2014): „Rezultatele alegerilor pentru Președintele României din anul 2014”. 2014. november. http://www.bec2014.ro/rezultate/index.html, letöltés ideje: 2018. május 22.

„Külügyminiszteri találkozó. Întrevederea ministrului Afacerilor Externe, Teodor Baconschi, cu ministrul Afacerilor Externe al Republicii Ungare, János Martonyi”. 2010. június 29. https://www.mae.ro/node/2673, letöltés ideje: 2018. június 10 .

„Lege Nr. 33 din 29 aprilie 1995 pentru ratificarea Convenției-cadru pentru protecția minorităților naționale, încheiată la Strasbourg la 1 februarie 1995.”. Megjelent a Hivatalos Közlöny 1995-ös év 82/4-es számában.

„Lege Nr. 273 din 07.12.2007 pentru modificarea şi completarea unor acte legislative”. Moldova Köztársaság Parlamentje, 2007. http://lex.justice.md/md/327797/, letöltés ideje: 2018. május 20.

„Lege nr. 373 din 24 septembrie 2004 pentru alegerea Camerei Deputaţilor şi a Senatului”. Románia Parlamentje 2004. http://www.cdep.ro/pls/legis/legis_pck.htp_act text?idt=58521, letöltés ideje: 2018. május 20.

„Lege Nr. 596 din 05.06.1991 cu privire la cetăţenia Republicii Moldova”. Moldova Köztársaság Parlamentje, 1991. http://lex.justice.md/index.php?action=view\&view=doc\&lang=1\&id=311903, letöltés ideje: 2018 . május 8 .

„Ljubljanai útmutató a sokszínü társadalmak integrálásához”. 2012. EBESZ Kisebbségi Föbiztos. https://www.osce.org/hu/hcnm/110502?download=true, letöltés ideje: 2018. április 29.

„Mádl Ferenc köztársasági elnök beszéde a MÁÉRT VIII. tanácskozásán (Budapest, 2004. November 12.)”. 2004. In: Magyar Külpolitikai Évkönyv. Budapest: Külügyminisztérium.

„Madrid Declaration on Euro-Atlantic Security and Cooperation”. 1997. https://www.nato.int/docu/pr/1997/p97-081e.htm, letöltés ideje: 2017. december 3.

„Magyar külpolitika az uniós elnökség után”. 2011. Külügyminisztérium. http://eu.kormany.hu/download/4/c6/20000/kulpolitikai_strategia_20111219.pdf , letöltés ideje: 2016. február 21.

Magyar külpolitikai évkönyv 1968-2010. Szerkesztette a Külügyminisztérium Dokumentációs Főosztálya. Budapest: Külügyminisztérium.

„Magyar nemzetpolitika. A nemzetpolitikai stratégiai kerete”. 2011. Közigazgatási és Igazságügyi

Minisztérium.

http://www.nemzetiregiszter.hu/download/9/a2/00000/Magyar\%20nemzetpolitik a\%20A4.pdf, letöltés ideje: 2016. február 21.

„Magyarország

Alaptörvénye".

2011. https://net.jogtar.hu/jr/gen/hjegy doc.cgi?docid=A1100425.ATV, letöltés ideje: 2017. február 24-én.

„Magyarország Alkotmánya. A Magyar Közlöny 1990. évi 84. számában (1990. augusztus 24.) egységes szerkezetbe foglalt szöveg". http://ki.oszk.hu/sites/ki.oszk.hu/files/dokumentumok/1949.pdf, letöltés ideje: 2017. november 26.

„»Magyarország és a határon túli magyarság - 1999 «konferencia nyilatkozat”. Magyar Kisebbség, 5. évf., (1999/1), 148-150.

Magyarország Kormánya (1998): „Az új évezred küszöbén. Kormányprogram a polgári Magyarországért”. http://www.parlament.hu/irom36/0021/0021.htm, letöltés ideje: 2018. január 23. 
„Magyarország megítélése a szomszéd államokhoz. (Nézőpont Intézet, 2017. január).” http://nezopontintezet.hu/analysis/minden-szomszedos-orszaggal-

szimpatizalnak-magyarok/, letöltés ideje: 2018. március 14.

„Megállapodás a Magyar Köztársaság Kormánya és Románia Kormánya között (Bukarest, 2003. szeptember 23.)”. In: Magyar Külpolitikai Évkönyv, Budapest: Külügyminisztérium.

„Mesajul preşedintelui României, Traian Băsescu, în faţa Camerelor reunite ale Parlamentului". $2009 . \quad$ április. http://www.old.presidency.ro/? RID $=$ det $\&$ tb $=$ date\&id=10876\&_PRID $=a g$, letöltés ideje: 2018 . május 21.

„Motion for a resolution presented by Mr Prisăcaru”. 2001. Európa Tanács Parlamenti Közgyülése. $\quad$ http://www.assembly.coe.int/nw/xml/XRef/X2H-XrefViewHTML.asp?FileID=9378\&lang=EN, letöltés ideje: 2018 . február 8.

NATO (1995): „Study on NATO Enlargement”. http://www.nato.int/cps/en/natohq/official texts_24733.htm, letöltés ideje: 2015. február 2.

„Németh Zsoltnak, a Külügyminisztérium Politikai Államtitkárának beszéde a Magyar Állandó Értekezlet II. ülésén (Budapest, 1999. November 11.)”. In: Magyar Külpolitikai Évkönyv. Budapest: Külügyminisztérium.

„Nemzetpolitikai eredmények 2010-2018”. 2018. Miniszterelnökség - Nemzetpolitikai Államtitkárság.

Népszava (2011): „Markó Béla egyelőre nem igényel magyar állampolgárságot”. Népszava, 2011. január 4. http://nepszava.hu/cikk/380701-marko-bela-egyelorenem-igenyel-magyar-allampolgarsagot, letöltés ideje: 2018. június 9.

„Nyilatkozat a kettős állampolgárságról”. MÁÉRT, 2004. november 12. http://kisebbsegkutato.tk.mta.hu/kettosallampolgarsag/allasfoglalasok/allasfogl 39.html, letöltés ideje: 2018. május 10

„Nyilatkozat a magyar-román stratégiai partnerségi kapcsolatokról és együttmüködésről. Európáért a XXI. században”. 2002. In: Magyar Külpolitikai Évkönyv. Budapest: Külügyminisztérium.

„Országos népszavazás: A 2004. december 5-i népszavazás végleges eredménye”. Országos Választási Bizottság. http://www.valasztas.hu/nepszav04/main_hu.html, letöltés ideje: 2018. május 28.

„Országgyülési napló. 197. ülésnap a Magyar Köztársaság és Románia között kötendő Alapszerződés ügyében”. Országgyülés 1996. szeptember 3 http://www.parlament.hu/naplo35/197/197tart.htm, letöltés ideje: 2016. november 26.

„Paper Containing the Position of the Hungarian Government in Relation to the Act on Hungarians Living in Neighbouring Countries". 2001. European Commission for Democracy through Law (Venice Commission).

„Percepţia opiniei publice din România asupra politicii externe şi a relaţiilor internaţionale”. 2005. Bucureşti: Institutul pentru Politici Publice.

„Preferential Treatment of National Minorities by their Kin-State: Collection of Laws". 2001. European Commission for Democracy through Law (Venice Commission).

http://www.venice.coe.int/webforms/documents/?pdf=CDL(2001)096-e, letöltés ideje: 2018. január 20.

„Propunere legislativă nr. 359/2001 privind reglementarea efectelor Legii privind maghiarii care trăiesc în statele învecinate pe teritoriul României". 
Képviselőház,

2001.

június

21.

http://www.cdep.ro/pls/proiecte/upl_pck2015.proiect?cam=2\&idp=2528, letöltés ideje: 2018. február 6.

„Protocol of the IV Meeting of the Joint Committee on National Minorities of the Joint Intergovernmental Commission on Cooperation and Active Partnership between Romania and Hungary". 2001.

„Regulamentul de funcționare a Comisiei mixte interguvernamentale de colaborare și parteneriat activ între România și Republica Ungară”. 1997.

„Resolution 910 (1988): Rural policy in Romania”. Európa Tanács, 1988. október 8. http://www.assembly.coe.int/nw/xml/XRef/Xref-XML2HTMLen.asp?fileid=16321\&lang=en, letöltés ideje: 2017 . július 19

„Resolution 1335 (2003) Preferential treatment of national minorities by the kin-state: the case of the Hungarian law of 19 June 2001 on Hungarians living in neighbouring countries (»Magyars«)”. ET PKGY, 2003. június 25. http://www.assembly.coe.int/nw/xml/XRef/Xref-XML2HTMLen.asp?fileid=17121\&lang=en, letöltés ideje: 2018 . március 7.

„Részlet az RMDSZ Ideiglenes Intéző Bizottságának Szándéknyilatkozatából, 1990. január 13." In: Húszéves az RMDSZ 1989-2009: Eseménynaptár, dokumentumok. Kolozsvár: RMDSZ Elnöki Hivatal-Ügyvezető Elnökség.

„RMDSZ Újratervezés CD-ROM”. 2015.

„Románia Alkotmánya”. 2003. Romániai Magyar Jogtudományi Közlöny 2003/1.

Szabad Demokraták Szövetsége (1989): „A rendszerváltás programja”. http://nezopontintezet.hu/files/2012/03/A-Rendszerv\%C3\%A11t\%C3\%A1sprogramja-1989.pdf, letöltés ideje: 2018. március 25.

„Szenátusi vita jegyzőkönyve. Dezbaterea şi adoptarea Proiectului de lege privind aprobarea Ordonanţei de urgenţă a Guvernului nr. 36/2009 pentru modificarea şi completarea Legii cetăţeniei române nr. 21/1991 (L121/2009)". 2009. http://www.cdep.ro/pls/steno/steno.stenograma?ids=6669\&idm $=12$, letöltés ideje: 2018. május 24.

„Szenátusi vita jegyzőkönyve. Stenograma Şedinţei Senatului din 7 martie 2002 Prezentarea, dezbaterea şi respingerea Moţiunii cu privire la consecinţele asupra siguranţei naţionale a României pe care le are aplicarea Memorandumului de înţelegere între Guvernul României şi Guvernul Republicii Ungare privind Legea maghiarilor din statele vecine Ungariei şi chestiuni legate de cooperarea bilaterală, semnat la 22 decembrie 2001 ”. http://www.cdep.ro/pls/steno/steno.stenograma?ids=5238\&idm=4\&idl=1, letöltés ideje: 2018. március 18.

„Szerződés a Magyar Köztársaság és Románia között a megértésről, az együttmüködésről és a jószomszédságról és a vonatkozó nemzetközi dokumentumok”. 1997. Magyar Köztársaság: Miniszterelnöki Hivatal.

„T/4070. számú törvényjavaslat a szomszédos államokban élő magyarokról”. 2001. Magyarország Kormánya. https://www.parlament.hu/internet/plsql/ogy_irom.irom_adat?p_ckl=36\&p_izon $=4070$, letöltés ideje 2018. január 29

„T/10896. A magyar állampolgárságról szóló 1993. évi LV. törvény módosításáról”. 2009.

http://www.parlament.hu/internet/plsql/ogy irom.irom adat?p ckl=38\&p izon= 10896, letöltés ideje 2018. június 9.

„Törvény a román állampolgárságról. Románia Hivatalos Közlönye, III. évfolyam, 44. szám, 1991. március 6.” In: Magyar Kisebbség, V. évf., 1999/2-3 (16-17) szám. 
„Transfrontier co-operation in preserving the identity of national minorities. Motion for a resolution presented by Mr van der Linden and others". ET PKGY, 2001. július $\quad 3 . \quad$ http://assembly.coe.int/nw/xml/XRef/X2H-XrefViewHTML.asp?FileID=9389\&lang=EN, letöltés ideje: 2018. július 3.

Udvardy Frigyes: „A romániai magyar kisebbség történeti kronológiája, 1990-2009.” http://udvardy.adatbank.transindex.ro, letöltés ideje: 2014. január 20.

„Új magyar nemzetpolitika belföldön és külföldön”. Országgyülés, 2004. november 17. https://www.parlament.hu/internet/plsql/ogy_irom.irom_adat?p_ckl=37\&p_izon =12451, letöltés ideje: 2018 . május 24

„U.S. Department of State: Daily Press Briefing”. 1996. U.S. Department of State. Federal Depository Library at the Richard J. Daley Library. http://dosfan.lib.uic.edu/ERC/briefing/daily_briefings/1996/9607/960717db.htm 1, letöltés ideje: 2017. november 24

Velencei Bizottság (2011): „A Velencei Bizottság véleménye Magyarország új Alaptörvényéröl, CDL-AD(2011)016".

„Verfassungen der Welt. Gegenwärtige und historische nationale und internationale Verfassungstexte". http://www.verfassungen.de, letöltés ideje: 2018. március 16.

„Vertrag über die Grundlagen der Beziehungen zwischen der Bundesrepublik Deutschland und der Deutschen Demokratischen Republik". 1972. december 21. http://www.documentarchiv.de/brd/grundlvertr.html, letöltés ideje: 2017. október 29.

„Vita a Magyarok Világszövetsége által kezdeményezett országos népszavazásról”. 2004.

Országgyülés. http://www.parlament.hu/internet/plsql/ogy naplo.naplo fadat aktus?p_ckl=37 $\underline{\& p \_u l n=163 \& p \_f e l s z=195 \& p \_f e l s z i g=213 \& p \_ \text {aktus }=39}$, letöltés ideje: 2018. május 24.

\section{Szakkönyvek, tanulmányok}

„A kettős állampolgárságról". Magyar Kisebbség, V. évf., (1999/2-3 (16-17.) szám)”. „A nemzeti kisebbségek helyzete: A magyarok”. Magyar Kisebbség XIII. évf., (2008/12): $20-51$.

„A romániai nemzeti kisebbségek integrációját célzó állampolitikák”. Magyar Kisebbség XIII. évf. (2008/3-4(49-50.)).

Alcántara, Cynthia H.- Ghai, Dharam (1994): „Globalization and Social Integration: Patterns and Processes". UN Research Institute for Social Development, Occasional Paper no. 2.

Aliboni, Roberto-Greco, Ettore (1996): „Foreign Policy Re-Nationalization and Internationalism in the Italian Debate". International Affairs 72 (1), 43-51. DOI: https://doi.org/10.2307/2624748.

Andreescu, Gabriel (1998): „A történelmi emlékezet és a román-magyar megbékélési modell”. Európai Szemmel, 1-2. sz., 50-60.

(2001): Pages from the Romanian-Hungarian Reconciliation, 1989-1999: The Role of Civic Organizations. Washington, D.C: International Human Rights Internship Program.

Antal Árpád-Tamás Sándor (2013): „A kettős állampolgárság következményei és hatásai a külhoni magyar nemzetközösségek helyzetére és megítélésére". Magyar Kisebbség XVIII évf., (3-4(69-70)): 156-62. 
Arp, Björn (2008): International Norms and Standards for the Protection of National Minorities: Bilateral and Multilateral Texts with Commentary. Leiden - Boston: Martinus Nijhoff Publishers.

„Az új magyar külkapcsolati stratégia előmunkálatai”. Magyar Kisebbség X. évf., (2006/3-4(41-42)).

Bakk Miklós (1999): „Az RMDSZ mint az erdélyi magyarság önmeghatározási kerete”. REGIO. Kisebbség Kultúra Politika Társadalom, 2. sz., 81-116.

(2004a): „Az autonómia-tervek két szakasza Erdélyben 1989 után”. Magyar Kisebbség 31-32(1-2) sz., 39-60.

(2004b): „Modellek peremén: az autonómia Erdélyben”. Élő Jászkunság 1. évf., http://epa.niif.hu/00100/00187/00001/pdf/011.pdf, letöltés ideje: 2015. február 2.

Baldwin, David A. (2013): „Power and International Relations”. In: Carlsnaes, WalterRisse-Kappen, Thomas- Simmons, Beth A. (szerk.): Handbook of international relations. Second edition, Los Angeles: SAGE, 273-297.

Bárdi Nándor (2004a.):»A mumusok és a kék madár« Mi történt? Miről beszél(t)ünk? Györgyi Annamária interjúja Bárdi Nándorral”. Regio - Kisebbség, politika, társadalom, 4. sz., 51-84.

(2004b): Tény és való. A budapesti kormányzatok és a határon túli magyarság kapcsolattörténete. Pozsony: Kaligramm.

(2013a): „Magyarország és a kisebbségi magyar közösségek 1989 után”. Metszetek, 2-3. sz., 40-79.

(2013b): Otthon és haza: tanulmányok a romániai magyar kisebbség történetéröl. Spectrum Hungarologicum. University of Jyväskylä.

Bárdi Nándor-Gidó Attila-Novák Csaba Zoltán (2014): Együtt és külön: az erdélyi magyarok önszervezödése (1989-1990). Kolozsvár: Nemzeti Kisebbségkutató Intézet.

Bárdi Nándor-Misovicz Tibor (2010): „A kisebbségi magyar közösségek támogatásának politikája". In: Botond Bitskey (szerk.): Határon túli magyarság a 21. században: Konferencia-sorozat a Sándor-palotában. Budapest: Köztársasági Elnöki Hivatal.

Bauböck, Rainer (2007): „Stakeholder Citizenship and Transnational Political Participation: A Normative Evaluation of External Voting". Fordham Law Review 75 (5): 2393-2447.

(szerk.) 2010: „Dual citizenship for transborder minorities? How to respond to the Hungarian-Slovak tit-for-tat". EUDO Citizenship Observatory. European University Institute-Robert Schuman Centre for Advanced Studies. http://cadmus.eui.eu/bitstream/handle/1814/14625/RSCAS 2010 75.corr.pdf?se quence $=3 \&$ isAllowed $=y$, letöltés ideje: 2018 . április 15 .

(2014): „Érdekeltség-alapú állampolgárság és transznacionális politikai részvétel: a külhoni szavazás normatív értékelése". REGIO. Kisebbség Kultúra Politika Társadalom 22 (1): 5-35.

Bauböck, Rainer-Perchinig, Bernhard-Sievers, Wiebke (szerk.) 2009: Citizenship Policies in the New Europe. Expanded and updated ed. IMISCOE Research. Amsterdam: Amsterdam University Press.

Bauer Tamás (2013) „Cukor a sebbe”. Magyar Kisebbség XVIII évf. (3-4(69-70)): 16371.

Baumann, Rainer-Rittberger, Volker-Wagner, Wolfgang (1999): „Macht und Machtpolitik. Neorealistische Außenpolitiktheorie und Prognosen über die 
deutsche Außenpolitik nach der Vereinigung". Zeitschrift für Internationale Beziehungen 6 (2): 245-86.

Baylis, John (1998): „European Security in the Post-cold War Era: The Continuing Struggle between Realism and Utopianism”. European Security 7 (3): 14-27. DOI: https://doi.org/10.1080/09662839808407370.

Beissinger, Mark-Kotkin, Stephen (2014): Historical Legacies of Communism in Russia and Eastern Europe. Cambridge University Press.

Békés Csaba (2004): Európából Európába. Magyarország konfliktusok kereszttüzében, 1945-1990. Budapest: Gondolat Kiadó.

Bellamy, Alex J. (2007): „The English School”. In: Griffiths, Martin (szerk.): International Relations Theory for the Twenty-first Century: An Introduction, London; New York: Routledge, 75-87.

Benoît-Rohmer, Florence (1996a): The Minority Question in Europe: Towards a Coherent System of Protection for National Minorities. Council of Europe.

(1996b): „The Pact for Stability in Europe”. In The Minority Question in Europe: Towards a Coherent System of Protection for National Minorities, Council of Europe, 81-84.

Bidder, Benjamin (2010): „Romanian Passports For Moldovans: Entering the EU Through the Back Door". Spiegel Online, 2010. július 13. http://www.spiegel.de/international/europe/romanian-passports-for-moldovansentering-the-eu-through-the-back-door-a-706338.html, letöltés ideje: 2018. május 21.

Bienen, Derk-Freund, Corinna-Rittberger, Volker (1999): Gesellschaftliche Interessen und Außenpolitik: die Außenpolitiktheorie des utilitaristischen Liberalismus. Tübinger Arbeitspapiere zur Internationalen Politik und Friedensforschung 33. Tübingen: Instituts für Politikwissenschaft.

Bíró, Anna-Mária (1996): „The international relations of the DAHR 1989-1996”. Berghof Occasional Paper, 5. sz. http://www.berghoffoundation.org/fileadmin/redaktion/Publications/Papers/Occasional_Papers/boc5 e.pdf, letöltés ideje: 2015. február 21.

Bíró, Gáspár (1999): „Bilateral Treaties between Hungary and Its Neighbors after 1989”. In: Romsics Ignác-Király K. Béla (szerk.): Geopolitics in the Danube Region: Hungarian Reconciliation Efforts, 1848-1998, Budapest: Central European University Press, 347-87.

Bogdán, Andrea-Cãlușer, Monica-Moșteanu, Olimpia-Salat Levente (2008): „Implementarea prevederilor privind drepturile minorităţilor naţionale la nivelul instituţiilor publice”. In: Salat Levente (szerk.): Politici de integrare a minorităţilor naţionale din România. Aspecte legale şi instituţionale într-o perspectivă comparată. Cluj-Napoca: CRDE.

Bognár Zoltán (2006): „Romániai magyar autonómiakoncepciók. Az 1989 és 2006 között kidolgozott törvénytervezetek”. In: Törzsök Erika (szerk.): Autonómia, liberalizmus, szociáldemokrácia, Budapest: Európai Összehasonlító Kisebbségkutatások Közalapítvány, 85-117.

Borbély Imre (1991): „Merre vigyük végzetünk?” Hitel 4 (13-14).

(1999) „Külhoni állampolgárság vagy státustörvény? Az elszakított nemzetrészek magyarországi jogállásának rendezési lehetőségei”. Magyar Kisebbség V. évf., (4 (18). szám).

Borbély Zsolt Attila (2013): „A magyar állampolgárság kiterjesztésének nemzetpolitikai vetületei”. Magyar Kisebbség XVIII. évf., (3-4(69-70)): 172-84. 
Börzel, Tanja A.-Risse, Thomas (2000) „When Europe Hits Home: Europeanization and Domestic Change". European Integration Online Papers 4 (15): 1-24.

Bredow, Wilfried von (2001): „Re-nationalization of military strategy?” Society 38 (6): 25-30. DOI: https://doi.org/10.1007/BF02712588.

Brody, Reed-Weissbrodt, David (1989): „Major Developments at the 1989 Session of the UN Commission on Human Rights". Human Rights Quarterly 11 (4): 586611.

Brubaker, Rogers (1996): Nationalism Reframed: Nationhood and the National Question in the New Europe. Cambridge-New York: Cambridge University Press. (2006a): Nacionalizmus új keretek között. Budapest: L'Harmattan - Atelier. 2006b) „Nemzeti kisebbségek, nemzetiesítő államok és anyaországok az új Európában”. Regio-Kisebbség, politika, társadalom, 3. sz., 3-30.

(2011): „Nationalizing States Revisited: Projects and Processes of Nationalization in Post-Soviet States". Ethnic and Racial Studies 34 (11): 17851814. DOI: https://doi.org/10.1080/01419870.2011.579137.

Brubaker, Rogers-Feischmidt, Margit-Fox, John-Grancea, Liana (2011): Nacionalista politika és hétköznapi etnicitás egy erdélyi városban. Budapest: L'Harmattan.

Brzezinski, Zbigniew (1989): „Post-Communist Nationalism”. Foreign Affairs 68 (5): 1. DOI: https://doi.org/10.2307/20044197.

Bull, Hedley (2002): The Anarchical Society: A Study of Order in World Politics. 3. Columbia University Press.

Buquicchio, Gianni (2016): „The International Conference "20 Years of Framework Convention for the Protection of National Minorities - 20 Years of Interculturalism, Cultural Diversity, Tolerance, Integration" Cluj-Napoca, 30 April 2015". Romanian Journal of International Law June-December (16): 14-19.

Burchill, Scott (szerk.) 2005: Theories of International Relations. 3rd ed. Houndmills, Basingstoke, Hampshire; New York: Palgrave Macmillan.

Buzan, Barry (2014): An Introduction to the English School of International Relations. The Societal Approach. Cambridge: Polity Press.

Carothers, Thomas (1996): Assessing Democracy Assistance: The Case of Romania. New York: Brookings Institution Press.

Cartner, Holly (1991): Since the Revolution: Human Rights in Romania. Vienna: Helsinki Watch.

Ceaușescu, Nicolae (1971): Propuneri de măsuri pentru îmbunătățirea activității politico-ideologice, de educare marxist-leninistă a membrilor de partid, a tuturor oamenilor muncii. București: Editura Politică.

Checkel, Jeffrey T. (2000): „Book review: Thomas Risse, Stephen Ropp, and Kathryn Sikkink (Eds.): The Power of Human Rights: International Norms and Domestic Change. Cambridge, UK: Cambridge University Press". Comparative Political Studies 33 (10): 1337-43. DOI: https://doi.org/10.1177/0010414000033010004.

Chiriac, Marian (2005): „O lege pentru (același) status quo? Raport privind efectele aplicării Legii pentru maghiarii din statele vecine Ungariei”. In Provocările diversitătii: politici publice privind minoritățile naționale și religioase în România, 59-91. Seria Diversitate etnoculturală în România. Cluj: Centrul de Resurse pentru Diversitate Etnoculturală.

Clinton, William J. (1997): „Remarks to the Citizens of Bucharest”. https://clintonwhitehouse4.archives.gov/textonly/WH/new/Spain/1997071415453.html, letöltés ideje: 2017 . december 3. 
Collyer, Michael (2014): „A Geography of Extra-Territorial Citizenship: Explanations of External Voting". Migration Studies 2 (1): 55-72. DOI: https://doi.org/10.1093/migration/mns008.

Commercio, Michele E. (2004): „Exit in the Near Abroad: The Russian Minorities in Latvia and Kyrgyzstan". Problems of Post-Communism 51 (6): 23-32. DOI: https://doi.org/10.1080/10758216.2004.11052185.

(2010): Russian Minority Politics in Post-Soviet Latvia and Kyrgyzstan: The Transformative Power of Informal Networks. Philadelphia: University of Pennsylvania Press. DOI: https://doi.org/10.9783/9780812204704.

Cordell, Karl-Wolff, Stefan (2005): Germany's Foreign Policy towards Poland and the Czech Republic Ostpolitik Revisited. London; New York, NY: Routledge.

Culic, Irina (2005): „Magyarság Erdélyben: a mienk, az övék, senkié? avagy hogyan értelmezzük a kettős állampolgárságról szóló népszavazást és a hozzá kapcsolódó reakciókat". Erdélyi Társadalom, 1. sz., 127-48.

(2006): „Dilemmas of Belonging: Hungarians from Romania”. Nationalities Papers 34 (2): 175-200. DOI: https://doi.org/10.1080/00905990600617839.

(2009): „Dual Citizenship Policies in Central and Eastern Europe”. ISPMN Working Papers, 15. sz.

(2013): „Az állampolgárság visszaállításától a kedvezményes (vissza)honosításig: a kettős állampolgárság politikájának kiterjedése Romániában 1989 után”. Magyar Kisebbség 18. évf., (3-4.(69-70)): 96-128.

Császár Melinda (2009): „Nemzet - jog - identitás. A státustörvény végrehajtásának szociológiai vonatkozásai”. Budapest: Budapesti Corvinus Egyetem, Szociológia Doktori Iskola, http://phd.lib.uni-corvinus.hu/457/1/csaszar_melinda.pdf, letöltés ideje: 2018. március 9.

Csergo, Zsuzsa-Goldgeier, James M. (2004) „Nationalist Strategies and European Integration". Perspectives on Politics 2 (01): 21-37. DOI: https://doi.org/10.1017/S153759270400060X.

Csergő, Zsuzsa-Regelmann, Ada-Charlotte (2017): „Europeanization and Collective Rationality in Minority Voting: Lessons from Central and Eastern Europe". Problems of Post-Communism 64 (5): 291-310. DOI: https://doi.org/10.1080/10758216.2017.1330659.

Csigó Péter-Kovács Éva (2000): „Európai integráció vagy/és kisebbségpolitika? A magyar-román alapszerződés sajtóvitája". In: Sík Endre-Tóth Judith (szerk.): Diskurzusok a vándorlásról. Budapest: Nemzetközi Migrációs és Menekültügy Kutatóközpont, 252-279.

Dick, C.J.-Dunn, J.F.J.-Lough, B.K. (1993): „Potential Sources of Conflict in Post-communist Europe". European Security 2 (3): 386-406. DOI: https://doi.org/10.1080/09662839308407131.

Dinger, Dörte (2013): From Friends to Collaborators: A Constructivist Analysis of Changes in Italo-German relations with the End of the Cold War. Internationale Beziehungen, vol. 19. Baden-Baden: Nomos.

Diószegi, László-Süle R. Andrea (szerk.) 1990: Hetven év. A romániai magyarság története 1919-1989. Erdélyi Honismereti könyvtár, Budapest: Magyarságkutató Intézet.

Dobre, Ana-Maria (2003): „EU Conditionality Building and Romanian Minority Rights Policy: Towards the Europeanisation of the Candidate Countries". Perspectives on European Politics and Society 4 (1): 55-83. DOI: https://doi.org/10.1080/15705850308438853. 
Donnelly, Jack (2000): Realism and International Relations. Cambridge-New York: Cambridge University Press.

Dumbrava, Costica (2013): „Rolling Back History: The Romanian Policy of Restoration of Citizenship to Former Citizens". CITSEE Stories, University of Edinburgh. 2013. http://www.citsee.eu/citsee-story/rolling-back-history-romanian-policyrestoration-citizenship-former-citizens, letöltés ideje: 2018. május 8.

(2014a): „External Citizenship in EU Countries”. Ethnic and Racial Studies 37 (13): 2340-60. DOI: https://doi.org/10.1080/01419870.2013.826812.

(2014b): Nationality, Citizenship and Ethno-Cultural Belonging. London: Palgrave Macmillan UK. DOI: https://doi.org/10.1057/9781137382085.

(2018): „The Ethno-Demographic Impact of Co-Ethnic Citizenship in Central and Eastern Europe”. Journal of Ethnic and Migration Studies, március, 1-17. DOI: https://doi.org/10.1080/1369183X.2018.1440490.

Dunay, Pál (1995): „Whence the threat to peace in Europe”. In: A Lasting Peace in Central Europe?, Challiot Papers 20. Institute for Security Studies, Western European Union.

(2000): „A Magyar Köztársaság szomszédságpolitikája a külpolitika rendszerében 1990-1999. Doktori disszertáció”. Budapest: BKÁE.

(2004): „Az átmenet magyar külpolitikája”. In: Kiss J. László-Gazdag Ferenc (szerk.): Magyar külpolitika a 20. században. Budapest: Zrínyi Kiadó, 221-43.

(2005): „Nem értünk egyet”. Külügyi Szemle, 2-3. sz., 281-89.

Dunne, Tim (2013): „The English School”. In: Dunne, Tim-Kurki, Milja-Smith, Steve (szerk.): International Relations Theories: Discipline and Diversity. Third edition, Oxford: Oxford University Press.

Durandin, Catherine-Petre, Zoe (2010): România post 1989. Iaşi: Institutul European.

Egry Gábor (2013): „Válaszok híján”. Magyar Kisebbség XVIII (3-4(69-70)): 195-205.

Egyed Péter (2000) „Autonómia az RMDSZ-programokban”. Korunk 11 (1): 40-43.

Eiler Ferenc (2008): „A népszövetségi nemzetközi kisebbségvédelmi rendszer működése az első években". In: Bárdi Nándor-Fedinec Csilla-Szarka László (szerk.): Kisebbségi magyar közösségek a 20. században. Budapest: MTA Kisebbségkutató Intézet.

Ellis, Andrew-Wall, Alan (szerk.) 2007: Voting from Abroad: The International IDEA Handbook. International Institute for Democracy and Electoral Assistance-Instituto Federal Electoral (Mexico). Stockholm, Sweden - Mexico City, Mexico, International IDEA, Federal Electoral Institute of Mexico.

Epstein, Rachel A.- Sedelmeier, Ulrich (2008): „Beyond Conditionality: International Institutions in Postcommunist Europe after Enlargement". Journal of European $\begin{array}{lllll}\text { Public } & \text { Policy } & 15 & \text { (6): }\end{array}$ https://doi.org/10.1080/13501760802196465.

Faist, Thomas-Gerdes, Jürgen-Rieple, Beate (2006): „Dual Citizenship as a PathDependent Process". International Migration Review 38 (3): 913-44. DOI: https://doi.org/10.1111/j.1747-7379.2004.tb00224.x.

Featherstone, Kevin (2003): „Introduction: In the Name of »Europe«”. In: Featherstone, Kevin-Radaelli, Claudio M. (szerk.): The Politics of Europeanization. OxfordNew York: Oxford University Press.

Finnemore, Martha-Sikkink, Kathryn (1998): „International Norm Dynamics and Political Change". International Organization 42 (4): 887-917. DOI: https://doi.org/10.1162/002081898550789. 
Fowler, Brigid (2006): „Fuzzing Citizenship, Nationalising Political Space: A Framework for Interpreting the Hungarian 'Status Law' as a New Form of Kinstate Policy in Central and Eastern Europe". In: Ieda, Osamu-Kántor Zoltán, Majtényi Balázs-Vizi Balázs-Halász István (szerk.): Beyond Sovereignty: From Status Law to Transnational Citizenship? Sapporo: Slavic Research Center, Hokkaido University, 177-238.

Földes György (2007): Magyarország, Románia és a nemzeti kérdés 1956-1989. Budapest: Napvilág Kiadó.

Fukuyama, Francis (1989): „The end of history?” National Interest, Summer: 3-18.

Gál Kinga (1999): „Bilateral Agreements in Central and Eastern Europe: A New InterState Framework for Minority Protection?" European Centre for Minority Issues Working Papers No. 4.

Galbreath, David (2003): „The Politics of European Integration and Minority Rights in Estonia and Latvia". Perspectives on European Politics and Society 4 (1): 35 53. DOI: https://doi.org/10.1080/15705850308438852.

(2005): Nation-Building and Minority Politics in Post-Socialist States: Interests, Influence and Identities in Estonia and Latvia. Columbia University Press.

Galbreath, David (2006): „From Nationalism to Nation-Building: Latvian Politics and Minority Policy". Nationalities Papers 34 (4): 383-406. DOI: https://doi.org/10.1080/00905990600841918.

Galbreath, David-McEvoy, Joanne (2010): „European Integration and the Geopolitics of National Minorities". Ethnopolitics 9 (3-4): 357-77. DOI: https://doi.org/10.1080/17449051003791700.

Gallagher, Tom (1997): „Danube Détente. Romania's Reconciliation With Hungary After 1996". Balkanologie. Revue d'études pluridisciplinaires 1 (2). http://balkanologie.revues.org/222.

Geoană, Mircea (1997): „Romania: Euro-Atlantic Integration and Economic Reform”. Fordham International Law Journal 21 (1): 12.

Grabbe, Heather (2001): „How Does Europeanization Affect CEE Governance? Conditionality, Diffusion and Diversity". Journal of European Public Policy 8 (6): 1013-31. DOI: https://doi.org/10.1080/13501760110098323.

(2006): The EU's Transformative Power Europeanization Through Conditionality in Central and Eastern Europe. Basingstoke: Palgrave Macmillan.

Griffiths, Stephen Iwan (1993): Nationalism and Ethnic Conflict: Threats to European Security. SIPRI Research Report, no. 5. Oxford, England; New York: Oxford University Press.

Győri Szabó Róbert (2000): „A parlamenti pártok és alapszerződések (1994-1997)”. Magyar Kisebbség VI. évf., (4. (22.) Szám).

Haas, Peter M. (1992): „Epistemic Communities and International Policy Coordination". International Organization, Knowledge, Power, and International Policy, Vol. 46 (No. 1): 1-35. DOI: https://doi.org/10.1017/S0020818300001442.

Halász, Iván. 2006. „Models of Kin Minority Protection in Central and Eastern Europe”. In: Ieda, Osamu-Kántor Zoltán-Majtényi Balázs-Vizi Balázs-Halász István (szerk.): Beyond Sovereignty: From Status Law to Transnational Citizenship? Sapporo: Slavic Research Center, Hokkaido University, 255-79.

(2009): Állampolgárság, migráció és integráció. A modern politikai közösségek dilemmái az Európai Unióban. Budapest: MTA Jogtudományi Intézet. 
Halász Iván-Majtényi Balázs (2002): „A magyar státustörvény a kelet-közép-európai jogi szabályozás tükrében". In: Kovács Nóra-Szarka László (szerk.): Tér és terep: tanulmányok az etnicitás és az identitás kérdésköréböl. Az MTA Kisebbségkutató Intézetének évkönyve. Budapest: Akadémiai Kiadó, 391-407.

Halász Iván-Majtényi Balázs (2001): „A magyar és a szomszédos államok „státustörvényei"”. Kisebbségkutatás 11 (3): 470-79.

Halász, Iván-Majtényi, Balázs-Vizi, Balázs (2004): „A New Regime of Minority Protection? Preferential Treatment of Kin minorities under National and International Law”. In: Kántor Zoltán-Vizi Balázs-Majtényi Balázs-Halász István-Ieda Osamu (szerk.): The Hungarian Status Law: Nation Building and/or Minority Protection. Sapporo: Slavic Research Center, Hokkaido University, 328-49.

Harnisch, Sebastian (2010): „Sozialer Konstruktivismus”. In: Masala, Carlo-Sauer, Frank-Wilhelm, Andreas (szerk.): Handbuch der internationalen Politik, Wiesbaden: VS Verlag für Sozialwissenschaften, 102-116.

Harris, Erika (2007): „Moving Politics Beyond the State: The Hungarian Minority in Slovakia”. Perspectives 28 (Summer): 43-62.

Herner-Kovács Eszter (2017): „Válogatás a Committee for Human Rights in Rumania történetének első dokumentumaiból". Archív Net - 20. századi történeti források 17 (2). http://archivnet.hu/valogatas-a-committee-human-rights-rumaniatortenetenek-elso-dokumentumaibol, letöltés ideje: 2017. szeptember 12.

Herner-Kovács, Eszter (2013): „Challenging the Conventional Wisdom on Ethnic lobby Success in the united States: the Case of HHRF". Minority Studies 15: 199-223.

Herner-Kovács Eszter-Illyés Gergely-Rákóczi Krisztián (2014): „Külhoni szavazatok a 2014-es magyar országgyülési választásokon”. Kisebbségkutatás 2 (2): 7-19.

Herz, John H. (1950): „Idealist Internationalism and the Security Dilemma”. World Politics 2 (2): 157-80. DOI: https://doi.org/10.2307/2009187.

Hill, Christopher (2016): Foreign Policy in the Twenty-First Century. Second edition. London - New York: Palgrave Macmillan.

Horváth, István (2002): „Facilitating Conflict Transformation: Implementation of the Recommendations of the OSCE High Commissioner on National Minorities to Romania, 1993-2001”. CORE Working Paper 8. http://edoc.vifapol.de/opus/volltexte/2008/603/, letöltés ideje: 2015. február 1.

Höhn, Christiane (2005): Zwischen Menscenrechten und Konfliktprävention: Die Minderheitenschutz im Rahmen der Organisation für Sicherheit und Zusammenarbeit in Europa (OSZE). Berlin-Heidelberg-New York: Springer Science and Business Media.

Huntington, Samuel P. (1973): „Transnational Organizations in World Politics”. World Politics Vol. 25, No. 3 (April): 333-68.

Hurd, Ian (2008): „Constructivism”. In: Reus-Smit, Christian-Snidal, Duncan (szerk.): The Oxford Handbook of International Relations. Oxford-New York: Oxford University Press, 298-316.

Ieda, Osamu. 2004. „Post-communist Nation Building and the Status Law Syndrome in Hungary”. In: Kántor, Zoltán-Vizi, Balázs- Majtényi, Balázs - Halász, István Ieda, Osamu (szerk.): The Hungarian Status Law: Nation Building and/or Minority Protection. Sapporo: Slavic Research Center of Hokkaido University, $3-57$.

Iordachi, Constantin (2000): „Állampolgárság és nemzeti identitás Romániában”. Regio - Kisebbség, politika, társadalom 11 (3): 27-57. 
(2001): „The Romanian-Hungarian Reconciliation Process, 1994-2001: From Conflict to Cooperation." Romanian Journal of Political Science 1 (3-4).

(2002): „A nemzet újrarajzolt határai: a magyar" státustörvény" és Románia kettős állampolgárságra vonatkozó politikája a Moldovai Köztársaságban”. In: Kántor Zoltán (szerk): A státustörvény, elözmények és következmények. Budapest: Teleki László Alapítvány.

(2004a): „Dual Citizenship and Policies toward Kin minorities in East-Central Europe: A Comparison between Hungary, Romania and the Republic of Moldova". In: Kántor, Zoltán-Vizi, Balázs- Majtényi, Balázs - Halász, István Ieda, Osamu (szerk.): The Hungarian Status Law: Nation Building and/or Minority Protection, Sapporo: Slavic Research Center of Hokkaido University, 239-69.

(2004b): „Entangled Histories:" Re-thinking the History of Central and Southeastern Europe from a Relational Perspective". Regio-Minorities, Politics, Society-English Edition 7 (1): 113-147.

(2009): „Politics of citizenship in post-communist Romania: Legal traditions, restitution of nationality and multiple memberships". In: Bauböck, RainerPerchinig, Bernhard-Sievers, Wiebke (szerk.): Citizenship Policies in the New Europe.IMISCOE Research. Amsterdam: Amsterdam University Press, 177209.

(2013): „Country Report: Romania”. EUDO Citizenship Observatory. European University Institute, Florence Robert Schuman Centre for Advanced Studies.

Iordachi, Constantin-Leonescu, Ștefan-Toderită, Alexandra-Silaghi, Claudiu-Ghinea, Cristian (szerk.) 2012: Redobândirea cetățeniei române: perspective istorice, comparative şi aplicate. Bucureşti: Curtea Veche.

Ivan, Ruxandra (2010): „Relațiile dintre România și Ungaria, 1990-2006”. In: Motoc Iulia-Cioculescu, Șerban Filip (szerk.): Manual de analiză a politicii externe. Iași: Polirom, 394-417.

(2012): „România și Republica Moldova: un bilanț al relațiilor bilaterale”. Institutul diplomatic Roman - Policy Brief, 40. szám.

Jackson, Robert H.- Sørensen, Georg (2013): Introduction to International Relations: Theories and Approaches. Fifth edition. Oxford: Oxford University Press.

Jakab Albert Zsolt- Peti Lehel (2005): „Átszerveződő identitások a kettős állampolgárság kudarca folytán”. Korunk XVI (1): 118-21.

Jenne, Erin K. (2007): Ethnic Bargaining: The Paradox of Minority Empowerment. Ithaca: Cornell University Press.

Jeszenszky Géza (2000): „Magyarország kétoldalú szerződései a szomszédos országokkal és a kisebbségi kérdés". In: Ars boni et aequi. Tanulmányok az ezredvég nemzetközi rendszeréröl. Bokorné Szegö Hanna 75. születésnapjára. Budapest: BKÁE Nemzetközi Kapcsolatok Tanszék, 450-469.

(2005a): „Antall József, a nemzetpolitikus”. Valóság XLVIII (1, január).

(2005b): „Tanulmányok a szuverén Magyarország külpolitikájáról”. Külügyi Szemle 4 (1-2): 274-90.

(2005c): „Tanulmányok a szuverén Magyarország külpolitikájáról”. Külügyi Szemle 4 (1-2).

(2005d): „Válasz egy doktrinernek”. Külügyi Szemle, 4 (2-3): 290-93.

(2015): Kisérlet a trianoni trauma orvoslására. Magyarország szomszédsági politikája a rendszerváltozás éveiben. Budapest: Osiris Kiadó. 
(2012): „Antall a külpolitikus”. Magyar Szemle, Új folyam XXI. évf., 3-4. szám.

Jetschke, Anja- Liese Andrea (2013): „The Power of Human Rights a Decade After”. In: Risse, Thomas-Ropp, Stephen C.-Sikkink, Kathryn (szerk.): The Persistent Power of Human Rights, 26-42. Cambridge: Cambridge University Press. DOI: https://doi.org/10.1017/CBO9781139237161.004.

Johns, Michael (2003): „"Do as I Say, Not as I Do”: The European Union, Eastern Europe and Minority Rights". East European Politics and Societies: And Cultures 17 (4): 682-99. DOI: https://doi.org/10.1177/0888325403258291.

Kaiser, Karl (1969): „Transnationale Politik”. In: Czempiel, Ernst-Otto (szerk.): Die anachronistische Souveränität. Zum Verhältnis von Innen- und Außenpolitik. Wiesbaden: VS Verlag für Sozialwissenschaften, 80-109.

Kántor Zoltán (2001): „A konszociáció Erdélyben. Folyamatok és modellek”. Provincia $2(4(12))$.

(szerk.) 2002a: „A magyar nemzetpolitika és a státustörvény”. In: Uő (szerk): $A$ státustörvény: dokumentumok, tanulmányok, publicisztika. Budapest: Teleki László Alapítvány, 291-307.

(2002f): „Státustörvény és nemzetpolitika: elméleti szempontok”. In: Kántor Zoltán (szerk.): A státustörvény: elözmények és következmények Budapest: Teleki László Alapítvány, 18-28.

(2010): „A státustörvény módosítása”. In: Borsi Kálmán Béla-Filep Tamás Gusztáv-Zelei Miklós (szerk.): A mérték. Egybegyüjtött irások töle és róla. Budapest: Kisebbségekért - Pro Minoritate Alapítvány, Méry Ratio Kiadó, 48496.

(2014a.) A nemzet intézményesülése a rendszerváltás utáni Magyarországon. Budapest: Osiris Kiadó.

(2014b): „Slovak-Hungarian relations: A theoretical account (emphasis on the issue of dual citizenship)".

(2015): „Nemzetpolitika és állampolgárság”. Pro Minoritate, sz. 4: 36-48.

Kántor Zoltán-Bárdi Nándor (2000): „Az RMDSZ a romániai kormányban, 19962000”. Regio - Kisebbség, politika, társadalom 11 (4): 150-86.

Kántor Zoltán-Majtényi Balázs (2005): „A »kettős állampolgárság« - népszavazás, politikai vita, érvek." In: Romániai Magyar Évkönyv 2004/2005. Temesvár: Szórvány Alapítvány-Marineasa Kiadó, 213-228.

Kardos Gábor (2006): „Role for the Kin-states?” In: Ieda, Osamu-Kántor Zoltán, Majtényi Balázs-Vizi Balázs-Halász István (szerk.): Beyond Sovereignty: From Status Law to Transnational Citizenship? Sapporo: Slavic Research Center, Hokkaido University.

Kárpáti Ferenc (2000): „A román forradalom és Magyarország, 1989. Egy volt miniszter emlékezése". História 22 (4): 26-29.

Kaszás Veronika (2013): „Erdélyi menekültek Magyarországon 1988-89-ben. Út a menekültkérdés tagadásától az 1951. évi genfi menekültügyi konvencióhoz való csatlakozásig”. Budapest: Eötvös Loránd Tudományegyetem Bölcsészettudományi Kar. http://doktori.btk.elte.hu/hist/kaszasveronika/diss.pdf, letöltés ideje: 2017. október 8 .

Kelley, Judith G. (2004): Ethnic Politics in Europe: The Power of Norms and Incentives. Princeton University Press.

Kemp, Walter (2006): „The Triadic Nexus: Lessons Learned from the Status Law”. Beyond Sovereignty: From Status Law to Transnational Citizenship, 109-126. 
Kemp, Walter (szerk.) 2001: Quiet Diplomacy in Action: The OSCE High Commissioner on National Minorities. Leiden - Boston: Martinus Nijhoff Publishers.

Keohane, Robert O. (1984): After Hegemony: Cooperation and Discord in the World Political Economy. Princeton, N.J: Princeton University Press.

Khalilzad, Zalmay-Lesser, Ian O. (szerk.): 1998. Sources of Conflict in the 21st Century. http://www.rand.org/pubs/monograph_reports/MR897.html.

Kiss, J. László (2004): „A kádárizmustól az EU-tagságig: a magyar külpolitika metamorfózisa”. In: Kiss J. László-Gazdag Ferenc: Magyar külpolitika a 20. században. Budapest: Zrínyi Kiadó, 45-78.

(2009): Változó utak a külpolitika elméletében és elemzésében. Budapest: Osiris Kiadó.

Kiss, Tamás (2013): „Nemzetdiskurzusok hálójában. Az állampolgárság-politika, mint a magyar nemzetre vonatkozó klasszifikációs küzdelem epizódja és eszköze". Magyar Kisebbség XVIII (34 (69-70)): 7-95.

(2015a): „Etnikai hegemónia és transznacionalizmus? A román közvélemény viszonya az erdélyi magyar etnopolitikai célkitüzésekhez és a magyar nemzetpolitikához". Pro Minoritate, sz. Tavasz: 3-35.

(2015b): „Marginalizáció, etnikai párhuzamosság és aszimmetrikus akkomodáció. Az erdélyi magyar közösséget érintő társadalmi és politikai folyamatok". Magyar Kisebbség XX ((75-76)): 30-64.

Kiss Tamás-Barna, Gergő (2013): „Az erdélyi magyarok a romániai és magyarországi politikai térben". Nemzeti Kisebbségkutató Intézet.

Kiss Tamás- Barna Gergő-Székely István Gergő (2013) „A társadalomépítéstől a klientúra-építésig. Az RMDSZ és a magyar választók közötti kapcsolódás átalakulása". Magyar Kisebbség XVIII. évf., (68.) szám (2): 7-40.

Kiss, Tamás - István Gergő Székely - Tibor Toró - Nándor Bárdi - István Horváth (szerk.) 2018: Unequal Accommodation of Minority Rights. Hungarians in Transylvania. Palgrave Politics of Identity and Citizenship Series. UK: Palgrave Macmillan.

Kivisto, Peter-Faist, Thomas (2008): Citizenship: Discourse, Theory, and Transnational Prospects. Key Themes in Sociology. Malden: Blackwell Publishing.

Knigth, Gregory D. (1987): „The Nationality Question in Contemporary Hungarian-Romanian Relations". Nationalities Papers 15 (2): 215-27. DOI: https://doi.org/10.1080/00905998708408056.

Korhecz Tamás (2013): „A kettős állampolgárságról vajdasági szemmel”. Magyar Kisebbség XVIII (3-4(69-70)): 212-18.

Kostecki, Wojciech (2002): „Prevention of ethnic conflict: Lessons from Romania”. Berghof Occasional Paper, 19. sz.

Kovács Éva-Misovicz Tibor-Bárdi Nándor (1998): „Politikai attitűdök az erdélyi magyarság körében. A román-magyar alapszerződés és az RMDSZ koalíciós részvételének megítélése 1997-ben”. Regio - Kisebbség, politika, társadalom 9 (1): 81-108.

Kovács Mária M. (2006): „The Politics of Dual Citizenship in Hungary”. Citizenship Studies 10 (4): 431-51. DOI: https://doi.org/10.1080/13621020600858088.

Kovács Péter (2002): „A státustörvény mint köztes megoldás”. In: Kántor Zoltán (szerk.): A státustörvény: dokumentumok, tanulmányok, publicisztika. Budapest: Teleki László Alapítvány, 238-249. 
(2011): Nemzetközi közjog. 2. kiad. Budapest: Osiris Kiadó.

Körösényi András (2015): „A magyar demokrácia három szakasza és az Orbán-rezsim”. In: Körösényi András (szerk.): A magyar politikai rendszer - negyedszázad után. Budapest: Osiris Kiadó-MTA Társadalomtudományi Kutatóközpont Politikatudományi Intézet.

Krotz, Ulrich-Schild, Joachim (2013a): „Embedded Bilateralism: Deutsch-französische Beziehungen in der europäischen Politik". In: Seidendorf, Stefan (szerk.): Frankreich Jahrbuch 2012: Deutsch-Französische Beziehungen: Entwicklungslinien und Fungkionswandel. Ludwigsburg-Wiesbaden: DeutschFranzösisches Institut-Springer Fachmedien Wiesbaden, 33-48. DOI: https://doi.org/10.1007/978-3-658-01622-7.

(2013b): Shaping Europe: France, Germany, and Embedded Bilateralism from the Elysée Treaty to Twenty-First Century Politics. OUP Oxford.

Kubicek, Paul (1997): „Ethnic Conflict and Three-Level Games: Turks, Kurds, and Foreign Actors". International Negotiation 2 (1): 79-101. DOI: https://doi.org/10.1163/15718069720847870.

Kuzio, Taras (2001): ,„»Nationalising States « or Nation-Building? A Critical Review of the Theoretical Literature and Empirical Evidence". Nations and Nationalism 7 (2): 135-54. DOI: https://doi.org/10.1111/1469-8219.00009.

„Külpolitika. A magyar Külügyi Intézet elméleti és politikai folyóirata.” 1989. Külügyi Intézet XVI (2).

Kyriazi, Anna (2014):. „Externally Induced Policy-Making in the Education of National Minorities in Eastern and Central European Countries: Limits and Possibilities". Paper Presented at the 2014 SISP Annual Conference. https://www.sisp.it/files/papers/2014/anna-kyriazi-1915.pdf, letöltés ideje: 2019. április 10 .

Lantschner, Emma-Medda-Windischer, Roberta (2001): „Protection of Minorities trough Bilateral Agreements in South Eastern Europe". In: European Yearbook of Minority Issues, I:534-61. The Hague; New York: Kluwer Law International.

Lappin, Richard (2016): „The Right to Vote for Non-Resizent Citizens in Europe”. International and Comparative Law Quarterly 65 (4): 859-94. DOI: https://doi.org/10.1017/S0020589316000336.

László Márton-Novák Csaba Zoltán (2012): A szabadság terhe: Marosvásárhely, 1990. március 16-21. Csíkszereda: Pro-Print.

Lijphart, Arend (1977): Democracy in Plural Societies: A Comparative Exploration. New Haven and London: Yale University Press.

Linden, Ronald H. (2000): „Putting on Their Sunday Best: Romania, Hungary, and the Puzzle of Peace”. International Studies Quarterly 44 (1): 121-145. DOI: https://doi.org/10.1111/0020-8833.00151.

Linklater, Andrew (1998): The Transformation of Political Community: Ethical Foundations of the Post-Westphalian Era. Cambridge: Polity Press.

(2007): „Citizenship and Sovereignty in the Post-Westphalian State”. In: Critical Theory and World Politics: Citizenship, Sovereignty and Humanity, 90108. London: Routledge.

Lőrincz Csaba (2008): „A szomszédos államokban élő magyarokat megillető egyes kedvezményekről szóló törvény koncepciója”. Pro Minoritate, sz. 2: 32-39. (2010a.): A mérték. Egybegyüjtött irások tőle és róla. Budapest: Kisebbségekért - Pro Minoritate Alapítvány, Méry Ratio Kiadó.

(2010b.): „A schengeni megállapodás, Magyarország és a határon túli magyarok. Javaslat a határon túli magyar nemzeti kisebbségi közösségekhez 
tartozó egyének vízummentes közlekedésére a schengeni megállapodáshoz csatlakozott államok és azon államok között, melyeknek az állampolgárai, ha az utóbb említett államok nem csatlakoztak a schengeni megállapodáshoz." In: Borsi Kálmán Béla-Filep Tamás Gusztáv-Zelei Miklós (szerk.): A mérték. Egybegyüjtött irások töle és róla. Budapest: Kisebbségekért - Pro Minoritate Alapítvány, Méry Ratio Kiadó, 299-302.

(2010c): „Nemzeti érdekek érvényesítése Magyarország csatlakozása során az euro-atlanti államok közösségéhez”. In: Borsi Kálmán Béla-Filep Tamás Gusztáv-Zelei Miklós (szerk.): A mérték. Egybegyüjtött irások töle és róla. Budapest: Kisebbségekért - Pro Minoritate Alapítvány, Méry Ratio Kiadó, 275302.

Ludányi, Andrew (1990): „Hungarian Lobbying Efforts for the Human Rights of Minorities in Rumania: The CHRR/HHRF as a Case Study". Hungarian Studies 6 (1). http://www.epa.hu/01400/01462/00010/pdf/077-090.pdf, letöltés ideje: 2017. szeptember 12.

Majtényi Balázs-Vizi Balázs (szerk.) 2003: A kisebbségi jogok nemzetközi okmányai. Dokumentumgyüjtemény. Budapest: Gondolat Kiadó - MTA Jogtudományi Intézet - MTA Kisebbségkutató Intézet.

Markó Béla (2011): Álompolgárok. Élet és Irodalom, LV. évf. 32. szám, 2011. https://www.es.hu/cikk/2011-08-14/marko-bela/alompolgarok.html. .

Marshall, Thomas H. (1950): Citizenship and Social Class and Other Essays. Cambridge: Cambridge University Press.

Marton Péter (2013): A külpolitika elemzése. Fogalmak és módszerek a külpolitika forrásainak feltárására. Budapest: Antall József Tudásközpont.

McGarry, John-Keating, Michael (szerk.) 2006: European Integration and the Nationalities Question. London-New York: Routledge.

McMahon, Patrice C. (2007): Taming Ethnic Hatred: Ethnic Cooperation and Transnational Networks in Eastern Europe. New York: Syracuse University Press.

Mearsheimer, John (1990): „Back to the Future: Instability in Europe after the Cold War". International Security 15 (1): 5-56. DOI: https://doi.org/10.2307/2538981.

Medianu, Narcisa (2002): „Analysing Political Exchanges between Minority and Majority Leaders in Romania". Global Review of Ethnopolitics 1 (4): 28-41. DOI: https://doi.org/10.1080/14718800208405111.

Meleșcanu, Teodor (1993): „Security in Central Europe: A positive-sum game”. NATO Review 41 (5): 12-18.

Mihailescu, Mihaela (2005): „Dampening the Powder Keg: Understanding Interethnic Cooperation in Post-Communist Romania (1990-96)". Nationalism and Ethnic Politics 11 (1): 25-59. DOI: https://doi.org/10.1080/13537110590927647.

Milton, Andrew K.-O'Neil, Patrick H. (2002): „The Conservative Peace: An Institutional Explanation of Post-Cold War Stability". International Politics 39 (3): 293-310. DOI: https://doi.org/10.1057/palgrave.ip.8897454.

„Moldova. Country Reports on Human Rights Practices”. 2010, U.S. Department of State. http://www.state.gov/j/drl/rls/hrrpt/2009/eur/136046.htm, letöltés ideje: 2018. május 21.

Molnár Gusztáv (1997): „Az erdélyi kérdés”. Magyar Kisebbség 3 (3-4 (9-10)): 208232.

(2000): „A konszociációs demokrácia esélyei Erdélyben”. Provincia 1 (6): 1-2. 
Moravcsik, Andrew (1997): „Taking Preferences Seriously: A Liberal Theory of International Politics". International Organization 51 (4): 513-53. DOI: https://doi.org/10.1162/002081897550447.

Morgenthau, Hans J. (1948): Politics among Nations. The Struggle for Power and Peace. New York: A. A. Knopf.

Morin, Jean-Frédéric (2010): „The Two-Level Game of Transnational Networks”. International Interactions $36 \quad$ (4): 309-34. DOI: https://doi.org/10.1080/03050629.2010.523656.

Năstase, Adrian-Miga-Beșteliu, Raluca-Aurescu, Bogdan-Donciu, Irina (szerk.) 2002: Protecting Minorities in the Future Europe. Between Political Interest and International Law. Bucureşti: Regia Autonomă „Monitorul Oficial”.

Nelson, Daniel (1992): „In the Wake of Revolution: Eastern Europe in the 1990s”. European Security 1 (1): 84-100. https://doi.org/10.1080/09662839208407070.

Nelson, Daniel N. (1991): „Europe’s Unstable East”. Foreign Policy, 82. szám. DOI: https://doi.org/10.2307/1148645.

Nohlen, Dieter-Grotz, Florian (2000): „External Voting: Legal Framework and Overview of Electoral Legislation". Boletín Mexicano de Derecho Comparado 33 (99): 1115-46.

Novák Csaba Zoltán (é. n.): Holtvágányon: A Ceaușescu-rendszer magyarságpolitikája II. (1975-1989). Kézirat. http://real.mtak.hu/27249/1/Ceausecu\%20magyarsagpolitikaja.pdf, letöltés ideje: 2017. szeptember 13.

Nye, Joseph S. (1990): „Soft Power”. Foreign Policy, sz. 80, Twentieth Anniversary: 153-71. DOI: https://doi.org/10.2307/1148580.

(2012): Viitorul puterii. Iași: Polirom.

Nye Jr, Joseph S.-Keohane, Robert O. (szerk.) 1971a: „Transnational Relations and World Politics". International Organization Vol. 25, No. 3, 329-758.

(1971b.): „Transnational Relations and World Politics: An Introduction”. International Organization Vol. 25, No. 3, (Transnational Relations and World Politics): $329-49$.

Olsen, Johan P. (2002): „The Many Faces of Europeanization”. Journal of Common Market Studies 40 (5): 921-952. DOI: https://doi.org/10.1111/1468-5965.00403.

Panainte, Sergiu-Nedelciuc, Victoria-Voicu, Ovidiu (2014): „Redombândirea cetățeniei române: o politică ce capătă viziune?" Fundatia Soros.

Papadimitriou, Dimitris-Phinnemore, David (2008): Romania and the European Union: From Marginalisation to Membership. London - New York: Routledge.

Patrubány Miklós (2005): Gyújtatlan gyulladjék. Gondolatok a 2004. december 5-i népszavazási kisérletröl. Budapest - Kolozsvár.

Patterson, Lee Ann (1997): „Agricultural Policy Reform in the European Community: A Three-Level Game Analysis”. International Organization 51 (1): 135-65. DOI: https://doi.org/10.1162/002081897550320.

Pettai, Vello (2006): „Explaining Ethnic Polit ics in the Balt ic States: Reviewing the Triadic Nexus Model". Journal of Baltic Studies 37 (1): 124-36. DOI: https://doi.org/10.1080/01629770500000291.

Pogonyi Szabolcs (2013): „Nemzetpolitika a határon túli szavazati jog fogságában”. Magyar Kisebbség XVIII (3-4(69-70)): 219-25.

(2014): „Four Patterns of Non-Resident Voting Rights”. Ethnopolitics 13 (2): 122-40. DOI: https://doi.org/10.1080/17449057.2013.846041. 
(2017a): Extra-Territorial Ethnic Politics, Discourses and Identities in Hungary. Palgrave Studies in Citizenship Transitions, Cham: Palgrave Macmillan.

(2017b.): „Europeanization of Kin-Citizenship and the Dynamics of KinMinority Claim-Making: The Case of Hungary". Problems of Post-Communism 64 (5): 242-56. DOI: https://doi.org/10.1080/10758216.2017.1329630.

Pogonyi, Szabolcs-Kovács, M. Mária-Körtvélyesi, Zsolt (2010): „The Politics of External Kin-State Citizenship in East Central Europe”. EUDO Citizenship Observatory, Comparative Report, RSCAS/EUDO-CIT-Comp. 2010/6. http://cadmus.eui.eu/bitstream/handle/1814/19576/EastCentralEurope.pdf?seque nce $=1 \&$ is Allowed $=y$, letöltés ideje: 2018 . április 14 .

Putnam, Robert D. (1988): „Diplomacy and Domestic Politics: The Logic of Two-Level Games". International Organization 42 (3): 427-460. DOI: https://doi.org/10.1017/S0020818300027697.

Reus-Smit, Christian (2005): „Constructivism”. In: Burchill, Scott (szerk.): Theories of International Relations. 3rd ed. Houndmills, Basingstoke, Hampshire; New York: Palgrave Macmillan.

Ripsman, Norrin M.-Taliaferro, Jeffrey W.-Lobell, Steven E. (2016): Neoclassical Realist Theory of International Politics. New York, NY: Oxford University Press.

Risse, Thomas (2013): „Transnational Actors and World Politics”. In: Carlsnaes, Walter -Risse-Kappen, Thomas-Simmons, Beth A. (szerk): Handbook of international relations. Second edition, Los Angeles: SAGE, 426-52.

Risse, Thomas-Sikkink, Kathryn (1999): „The Socialization of International Human Rights Norms into Domestic Practices: Introduction". In: Risse-Kappen, Thomas- Ropp, Steve C.-Sikkink, Kathryn (szerk.): The Power of Human Rights: International Norms and Domestic Change. Cambridge Studies in International Relations 66. New York: Cambridge University Press.

Risse-Kappen, Thomas (szerk.) 1995: Bringing Transnational Relations Back In: NonState Actors, Domestic Structures, and International Institutions. Cambridge Studies in International Relations. Cambridge - New York: Cambridge University Press.

Rittberger, Volker (2001): German Foreign Policy Since Unification: Theories and Case Studies. Manchester University Press.

Rose, Gideon (1998): „Neoclassical Realism and Theories of Foreign Policy”. World $\begin{array}{llll}\text { Politics } & 51 & \text { (1/October): }\end{array}$ https://doi.org/10.1017/S0043887100007814.

Rosenau, James N. (1980): The Study of Global Interdependence: Essays on the Transnationalization of World Affairs. London: Frances Pinter.

Saideman, Stephen M.-Ayres, R. William (2008): For Kin or Country: Xenophobia, Nationalism, and War. Columbia University Press.

Salat, Levente (2013a): „A Rapprochement without Reconciliation: Romanian-Hungarian Relations in the Post-Communist Era". In: Blomqvist, Anders-Iordachi, Constantin-Balázs, Trencsényi (szerk.): Hungary and Romania beyond National Narratives: Comparisons and Entanglements. Oxford: Peter Lang AG, Internationaler Verlag der Wissenschaften, 655-90. (2001) Etnopolitika - a konfliktustól a méltányosságig. Marosvásárhely: Mentor kiadó.

(2004) „A román-magyar kapcsolatok alakulásának kilátásai és a francia-német megbékélési modell”. In: Salat Levente-Smaranda Enache (szerk.): Relațiile 
româno-maghiare și modelul de reconciliere franco-german =: A románmagyar kapcsolatok és a francia-német megbékélési model = RomanianHungarian relaitons and the French-German reconciliation. Seria Diversitate etnoculturală în România 9. Cluj: Liga Pro Europa: Centrul de Resurse pentru Diversitate Etnoculturală.

(2009): „A román-magyar kapcsolatok”. Budapesti Könyvszemle-BUKSZ, 4. sz., 347-352.

(2011): „A politikai közösség kérdése a többség-kisebbség viszonyának a nézőpontjából”. Magyar Kisebbség XVI (3-4(61-62)): 159-90.

(2013b): „A könnyített honosítás látható és várható következményeiről. Válaszok a Magyar Kisebbség kérdéseire”. Magyar Kisebbség XVIII (3-4(6970)): $226-40$.

(2014): „The Chances of Ethnic Autonomy in Romania - between Theory and Practice". In: Kántor, Zoltán (szerk.): Autonomies in Europe: Solutions and Challenges. Budapest: L'Harmattan, 123-138.

(2003): „Kisebbségi magyar jövőképek esélyei és buktatói Erdélyben”. Kisebbségkutatás 12. évf., 3. sz.

Salat, Levente-Smaranda Enache (szerk.) 2004: Relațiile româno-maghiare și modelul de reconciliere franco-german $=:$ A román-magyar kapcsolatok és a francianémet megbékélési model = Romanian-Hungarian relaitons and the FrenchGerman reconciliation. Seria Diversitate etnoculturală în România 9. Cluj: Liga Pro Europa : Centrul de Resurse pentru Diversitate Etnoculturală.

Salat, Levente- Novák, Csaba Zoltán (2015): „Ethnicity, Nationalism, and the Minority Regime”. In: Stan, Lavinia-Vance, Diane (szerk.): Post-Communist Romania at Twenty-Five: Linking Past, Present, and Future. Lanham, Maryland: Lexington Books, 63-83.

Sata, Róbert (2006): „Multicultural Pluralism. Towards a Normative Theory of Ethnic Relations". Budapest: Central European University.

Schimmelfennig, Frank (2005): „Strategic calculation and international socialization: Membership incentives, party constellations, and sustained compliance in Central and Eastern Europe". International Organization 59 (04): 827-860. DOI: https://doi.org/10.1017/S0020818305050290.

Schimmelfennig, Frank-Engert, Stefan-Knobel, Heiko (2003): „Europäisierung in Osteuropa: Reaktionen auf die demokratische Konditionalität". Österreichische Zeitschrift für Politikwissenschaft 32 (3): 321-337. DOI: https://doi.org/10.15203/ozp.839.vol32iss3.

(2006): International Socialization in Europe. European Organizations, Political Conditionality and Democratic Change. Basingstoke; New York: Palgrave Macmillan.

Schimmelfennig, Frank-Sedelmeier, Ulrich (2004): „Governance by Conditionality: EU Rule Transfer to the Candidate Countries of Central and Eastern Europe". Journal of European Public Policy 11 (4): 661-79. DOI: https://doi.org/10.1080/1350176042000248089.

Schneckener, Urlich (2002): Auswege aus dem Bürgerkrieg. Modelle yur Regulierung ethno-nationalistischer Konflikte in Europa. Frankfurt am Main: Suhrkamp.

Schoppa, Leonard J. (1993): „Two-Level Games and Bargaining Outcomes: Why Gaiatsu Succeeds in Japan in Some Cases but Not Others". International $\begin{array}{llll}\text { Organization } & 47 & \text { (3): } & 353-86 .\end{array}$ https://doi.org/10.1017/S0020818300027995. 
Schöpflin, George (1987): „The Hungarians of Rumania”. Minority Rights Group Reports No. 37.

Schöpflin, George-Poulton, Hugh (1990): Romania's Ethnic Hungarians. London: Minority Rights Group.

Sedelmeier, Urlich (2005): „Eastern Enlargement: Towards a European EU?” In: Wallace, Helen-Wallace, William-Pollack, Mark A. (szerk.): Policy-making in the European Union, 5th ed, The new European Union series. Oxford - New York: Oxford University Press, 401-27.

Sevel Okszana (2011): „Diaszpóra-törvények a poszt-kommunista térségben. Túl a jón és rosszon, avagy meghaladható-e a polgári/etnikai nacionalizmus dichotómiája". Pro Minoritate, Tavasz: 3-37.

Severin, Adrian-Andreescu, Gabriel (2000): Locurile unde se construieste Europa. Adrian Severin in dialog cu Gabriel Andreescu. Iași: Polirom.

Singer, David J. (1961): „The level-of-analysis problem in international relations”. World Politics 14 (01): 77-92.

Smith, David J. (2002): „Framing the National Question in Central and Eastern Europe: A Quadratic Nexus?" The Global Review of Ethnopolitics 2 (1): 3-16. DOI: https://doi.org/10.1080/14718800208405119ch.

Snyder, Jack (1990): „Averting Anarchy in the New Europe”. International Security 14 (4): 5. DOI: https://doi.org/10.2307/2538749.

Soltész István (szerk.) 2010: Az Országgyülés. Az Országgyülés szervezete, feladatai és müködése 1990-2010. 4. átdolgozott és bővített kiadás. Budapest: Parlamenti Módszertani Iroda.

Sommer, Jan-Philipp (2015): Normen als Grund bilateraler Außenpolitik. Wiesbaden: Springer Fachmedien Wiesbaden. https://doi.org/10.1007/978-3-658-10124-4.

Szabó Tamás (2014): „Magyarország, Románia és az RMDSZ kapcsolatrendszere az alapszerződés aláírásának időszakában (1992-1996)" Külügyi Szemle, 4: 77-108. (2015a): „A magyar-román alapszerződés parlamenti vitája. Összehasonlító elemzés". Többlet 3: 96-136.

(2015b.): „Az RMDSZ külpolitikájának intézményesülése”. Magyar Kisebbség XX (1-2 (75-76)): 117-46.

Szarka László (2006): „Bevezető a nemzetpolitikai előtanulmányokhoz. Az új magyar külkapcsolati stratégia előmunkálatai”. Magyar Kisebbség X (3-4 (41-42.) szám): 7-10.

Székely István (2002): „A kedvezménytörvény romániai végrehajtásának dilemmái”. In: Státustörvény: elözmények és következmények, 141-48. Budapest: Teleki László Alapítvány.

Székely István Gergő (2009): „Egyéni választókörzetes többségi rendszer arányos kimenetellel. Románia új választási rendszere”, Pro Minoritate 2. sz., 7-33.

(2011): Democraţie consociaţionistă sau împărţirea puterii în societăţi multietnice. Cadru teoretic şi patru studii de caz. Cluj-Napoca: Nemzeti Kisebbségkutató Intézet \& Kriterion.

Székely, István Gergő-Horváth, István (2014): „Diversity Recognition and Minority Representation in Central and Southeast Europe: A Comparative Analysis". Nationalities $\quad$ Papers $42 \quad$ (3): $426-48 . \quad$ DOI: https://doi.org/10.1080/00905992.2014.916660.

Székely Kriszta (1999): „Különleges státus a határon túli magyaroknak.” Szabadság, november. 
Szele Áron-Tófalvi Zselyke (2011): „A nemzettest formálása. Állampolgárság és szavazati jog Romániában". Pro Minoritate, Tavasz: 61-69.

Szokai Imre-Tabajdi Csaba (1988): „Mai politikánk és a nemzetiségi kérdés”. In: Bárdi Nándor-Éger György (szerk.) 1999: Útkeresés és integráció. Határon túli magyar érdekvédelmi szervezetek dokumentumai 1989-2000.Budapest: Teleki László Alapítvány, 647-59.

Tabajdi Csaba (2006): „A kedvezménytörvény és a szocialisták”. In: Uö. (szerk.): Keletröl nyugatra Európa közepén. Magyarország és a magyar nemzet az új Közép- és Kelet-Európában. Budapest: Codex Print Kft., pp. 619-627.

Takács Ferenc (1998): „Románia Erdély-politikája 1989 után”. Magyar Kisebbség 4 (34).

Tálas Péter (2008a): „Az aszimmetrikus szlovák-magyar viszonyról”. Nemzet és Biztonság 1 (11): 73-80.

(2008b): „Kelet-Közép-Európa az integrációk szorításában”. Nemzet és Biztonság 1 (3): 65-76.

Tesser, Lynn M. (2003): „The Geopolitics of Tolerance: Minority Rights Under EU Expansion in East-Central Europe". East European Politics and Societies: And Cultures 17 (3): 483-532. DOI: https://doi.org/10.1177/0888325403255310.

Tilly, Charles (1975a): „Reflection on the History of European State-Making”. In: Uo” (szerk.): The Formation of National States is Western Europe. Princeton: Princeton University Press, 3-83.

(szerk.) 1975b: The Formation of National States is Western Europe. Princeton: Princeton University Press.

Tismăneanu, Vladimir-Dobrincu Dorin-Vasile, Cristian (szerk.) 2007: Comisia prezidențială pentru analiza dictaturii comuniste din România. Raport final. București: Humanitas.

Toró Tibor (2013a.): „A határon túli magyar közösségek a könnyített honosítás bevezetése után. Ankét a kettős állampolgárság témaköréről". Magyar Kisebbség XVIII (3-4(69-70)): 152-55.

(2013b.): „A romániai magyar nyilvánosság alakulásának diskurzusa politikai filozófiai megközelítésben”. Doktori dolgozat, Kolozsvár: Babeș-Bolyai Tudományegyetem.

Tóth Judit (2000): „A diaszpóra a jogszabályok tükrében”. In: Tóth Judit-Sík Endre: Diskurzusok a vándorlásról. Budapest: Nemzetközi Migrációs és Menekültügyi Kutatóközpont-MTA Politikai Tudományok Intézete, 185-217.

(2004): „Hogyan vélekednek az állampolgárságról a parlamentben?” Regio, 4. sz., 36-50.

(2011): „Menekültügy Magyarországon”. In: Sík Endre: A migráció szociológiája 2. E-könyv. Budapest: ELTE Társadalomtudományi Kar. http://www.tankonyvtar.hu/hu/tartalom/tamop425/0010_2A_15_Sik_Endre Mig racio_szociologiaja_ 2 Valogatta es szerk Sik Endre/index.html, letöltés ideje: 2017. október 8.

(2014): „A honosítás jogintézményének alakulása az elmúlt húsz évben”. Regio-Kisebbség-Kultúra-Politika-Társadalom 22 (1): 74-90. DOI: https://doi.org/10.17355/rkkpt.v22i1.6.

Tóth Károly (2000): Ellenpontok 1982. Múltunk Könyvek. Csíkszereda: Pro-Print.

Tőkés László (1996): „Román-magyar alternatív megbékélési kezdeményezés. Nyílt levél Göncz Árpád magyar és Ion Iliescu román államelnökökhöz”. In: Uö: Temesvár szellemében. Nagyvárad: Királyhágómelléki Református Egyházkerület. 
Vădean, Mihai-Romulus (2011): Relațiile româno-ungare în contextul integrării în structurile europene și euroatlantice: 1989-2010. Iaşi: Lumen.

Valeriu, Ioan-Franc (szerk.) 2000: „A snagovi nyilatkozat. In: Din lucrările Comisiei de la Snagov". Centrul de Infromare și Documentare Economică.

Valki, László (1992): „Security Concerns in Central Europe”. European Security 1 (4): 1-14. DOI: https://doi.org/10.1080/09662839208407095.

Van Oudenaren, John (1998): „Sources of Conflict in Europe and the Former Soviet Union". In: Sources of Conflict in Europe. http://www.rand.org/dam/rand/pubs/monograph_reports/MR897/MR897.chap5. pdf, letöltés ideje: 2017. január 23.

Varga Attila (2014): „A román alkotmányos demokrácia eltelt huszonöt éve. Észrevételek a politikai rendszer kialakulásáról és változásairól." Pro Minoritate, 4. sz., 178-209.

Vass Ágnes (2013): „Szlovák-magyar kettős állampolgárok szlovák állampolgárság nélkül”. Magyar Kisebbség XVIII (3-4(69-70)): 129-51.

Verdery, Katherine (1991): National Ideology under Socialism. Identity and Cultural Politics in Ceaussescu's Romania. California: California University Press.

Vermeersch, Peter (2004): „Minority Policy in Central Europe: Exploring the Impact of the EU's Enlargement Strategy". Global Review of Ethnopolitics 3 (2): 3-19. DOI: https://doi.org/10.1080/14718800408405162.

Vincze Gábor (2003): Történeti kényszerpályák - kisebbségi reálpolitikák II. (Dokumentumok a romániai magyar kisebbség történetének tanulmányozásához 1944-1989). Magyar Kisebbség Könyvtára. Csíkszereda: Jakabffy Elemér Alapítvány, Teleki László Intézet, Pro-Print Könyvkiadó. http://www.adatbank.ro/cedula.php?kod=39, letöltés ideje: 2016. március 29.

(2006): „Lăncrănjantól Lăncrănjanig Fejezet a magyar-román kapcsolatok nyolcvanas évekbeli történetéböl”. Magyar Kisebbség X. évf., (3-4 (41-42)): 262-352.

Vizi, Balázs (2006): „The Evaluation of the 'Status Law' in the European Union”. In: Ieda, Osamu-Kántor Zoltán, Majtényi Balázs-Vizi Balázs-Halász István (szerk.): Beyond Sovereignty: From Status Law to Transnational Citizenship? Sapporo: Slavic Research Center, Hokkaido University.

Waltz, Kenneth N. (1979): Theory of International Politics. Reading, Massachusetts: Addison-Wesley Publishing Company.

Waltz, Kenneth N. (2001): Man, the State, and War: A Theoretical Analysis. Columbia University Press.

Waterbury, Myra A. (2010): Between State and Nation: Diaspora Politics and Kin-state Nationalism in Hungary. New York: Palgrave Macmillan.

(2014): „Making Citizens Beyond the Borders: Nonresident Ethnic Citizenship in Post-Communist Europe". Problems of Post-Communism 61 (4): 36-49. DOI: https://doi.org/10.2753/PPC1075-8216610403.

(2016): „National Minorities in an Era of Externalization: Kin-State Citizenship, European Integration, and Ethnic Hungarian Minority Politics". Problems of Post-Communism 6 (5): 228-41. DOI: https://doi.org/10.1080/10758216.2016.1251825.

Wendt, Alexander (1992): „Anarchy is what States make of it: The Social Construction of Power Politics". International Organization 46 (02): 391-425. DOI: https://doi.org/10.1017/S0020818300027764.

(1995): „Constructing International Politics”. International Security 20 (1): 7181. DOI: https://doi.org/10.2307/2539217. 
(1999): Social Theory of International Politics. Cambridge studies in international relations 67. Cambridge, UK; New York: Cambridge University Press.

Wetzel Tamás (2013): „Válasz a Magyar Kisebbség folyóirat szerkesztősége által megfogalmazott kérdésekre”. Magyar Kisebbség XVIII (3-4(69-70)): 268-72.

Wittenberg, Jason (2015): „Conceptualizing historical legacies”. East European Politics $\begin{array}{lllll}\text { and } & \text { Societies } & 29 & (2): & 366-378 .\end{array}$ https://doi.org/10.1177/0888325415577864.

Zaharia, Dragoș (2014): Politica externa a Romaniei de la izolare la inceperea negocierilor de aderare la Uniunea Europeana. Târgoviște: Cetatea de Scaun.

Zellner, Wolfgang (1999): „On the Effectiveness of the OSCE Minority Regime”. Comparative Case Studies on Implementation of the Recommendations of the High Commissioner on National Minorities of the OSCE, Hamburg. http://ifsh.de/pdf/publikationen/hb/hb111e.pdf, letöltés ideje: 2017. március 4.

Zellner, Wolfgang-Dunay Pál (1998): Ungarns Ausenpolitik 1990-1997: zwischen Westintegration, Nachbarschafts-und Minderheitenpolitik. 118. köt. Baden-Baden: Nomos Verlaggesellschaft.

\section{Sajtóanyagok, kronológiák}

Krónika, Kolozsvár

Romániai Magyar Szó, Bukarest

Szabadság, Kolozsvár

MTI Hírarchívum 1988-2017: http://archiv1988-2005.mti.hu/Pages/HirSearch.aspx.

Kuszálik Péter: Az RMDSZ tizenöt éve a sajtó tükrében c. kronológiája: http://rmdszkronologia.adatbank.transindex.ro.

Udvardy Frigyes: A romániai magyar kisebbség történeti kronológiája: http://udvardy.adatbank.transindex.ro/.

\section{Adatbázisok:}

CIA: The World Factbook: https://www.cia.gov/library/publications/resources/theworld-factbook/.

Global Citizenship Observatory (GLOBALCIT), 2017: http://globalcit.eu/acquisitioncitizenship/.

Központi Választási Hivatal: http://www.valasztas.hu/ujweb/index.htm.

Nemzetközi Valutaalap (IMF) idősoros adatai:

http://www.imf.org/external/datamapper/datasets/WEO/1.

SIPRI Military Expenditure Database (1949-2017):

https://www.sipri.org/databases/milex. 


\section{A doktori értekezés témájában született publikációk}

1. Szabó Tamás (2015): A magyar-román alapszerződés parlamenti vitája. Összehasonlító elemzés. Többlet, 3. szám, pp. 96-136.

2. Szabó Tamás (2015): Az RMDSZ külpolitikájának intézményesülése. Magyar Kisebbség, 1-2. szám, pp.117-146.

3. Toró Tibor - Szabó Tamás (2015): A romániai magyar politikatudomány helyzete a 2002-2013-as periódusban - szakterületi szintézis. In: Péntek János Salat Levente - Szikszai Mária (szerk.): Magyar tudományosság Romániában 2002-2013 között. Ábel Kiadó: Kolozsvár, II. kötet, pp. 335-388.

4. Szabó Tamás (2014): Magyar-román államközi viszony és az RMDSZ kapcsolatai az alapszerződés tárgyalásának időszakában 1992-1996. In: Fedinec Csilla - Szoták Szilvia (szerk): Közösség és identitás a Kárpát-medencében. Határhelyzetek VII. Balassi Intézet Márton Áron Szakkollégium, Budapest, pp. 385-411.

5. Szabó Tamás (2014): Magyarország, Románia és az RMDSZ kapcsolatai az alapszerződés tárgyalásának időszakában. Külügyi Szemle, 4. szám, pp. 77-108.

6. Szabó Tamás (2015): Az RMDSZ külpolitikájának kronológiája (1989-1996). Magyar Kisebbség, 1-2. szám, pp. 147-220. 